JESNER SERENI ILDEFONSO

\title{
ANÁLISE DA VIABILIDADE TÉCNICA DA UTILIZAÇÃO DO COPOLÍMERO ETILENO ACETATO DE VINILA (EVA) DESCARTADO PELA INDÚSTRIA CALÇADISTA EM MISTURAS ASFÁLTICAS (PROCESSO SECO)
}

Dissertação apresentada à Escola de Engenharia de São Carlos, da Universidade de São Paulo, como parte dos requisitos para a obtenção do Título de Mestre em Engenharia Civil: Transportes.

Orientador: Prof. Dr. José Leomar Fernandes Jr.

São Carlos 


\section{AUTORIZO A REPRODUÇÃO E DIVULGAÇÃO TOTAL OU PARCIAL DESTE TRABALHO, POR QUALQUER MEIO CONVENCIONAL OU ELETRÔNICO, PARA FINS DE ESTUDO E PESQUISA, DESDE QUE CITADA A FONTE}

Ficha catalográfica preparada pela Seção de Tratamento da Informação do Serviço de Biblioteca - EESC/USP

\footnotetext{
127a Análise da viabilidade técnica da utilização do copolímero etileno acetato de vinila (EVA) descartado pela indústria calçadista em misturas asfálticas (processo seco) / Jesner Sereni Ildefonso ; orientador José Leomar Fernandes Jr. -- São Carlos, 2007.

Dissertação (Mestrado - Programa de Pós-Graduação em Engenharia de Transportes e Área de Concentração em Infra-Estrutura de Transportes) -- Escola de Engenharia de São Carlos da Universidade de São Paulo.

1. Infra-estrutura de transporte. 2. Misturas asfálticas. 3. Etileno acetato de vinila. 4. Processo seco. 5. Ensaios mecânicos. Método Bailey. 7. Envelhecimento. I. Título.
} 


\section{FOLHA DE JULGAMENTO}

Candidato: Engenheiro JESNER SERENI ILDEFONSO

Dissertação defendida e julgada em 07-02-2007 perante a Comissão Julgadora:
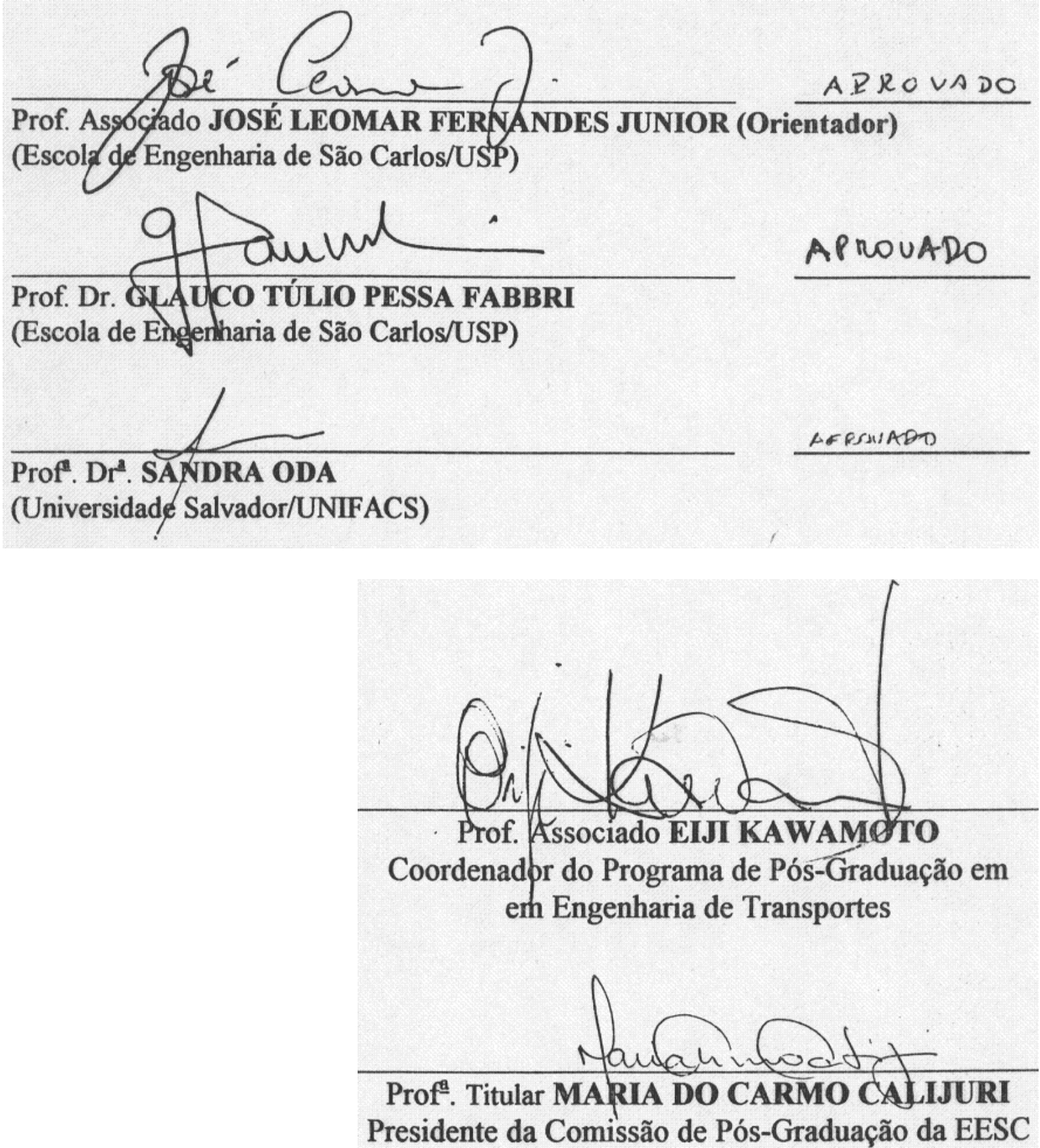



\section{DEDICATÓRIA}

Aos meus pais, Élcio e Iracy, pelos ensinamentos, apoio e incentivo. 

Pessoas entram em nossa vida por acaso, mas não é por acaso que elas permanecem.

(Lílian Tonet)

\section{AGRADECIMENTOS}

À Deus, por ter me dado forças para realizar este trabalho.

Ao professor Dr. José Leomar Fernandes Jr., pela orientação, apoio e colaboração ao longo da pesquisa.

Aos professores do Departamento de Transportes da USP de São Carlos pelos ensinamentos, em especial aos Drs. Glauco Túlio Pessa Fabbri e Alexandre Benetti Parreira.

Aos técnicos do laboratório e meus amigos, Antônio Carlos Gigante, Paulo VTNC Toyama e João D. Pereira Filho, pelo apoio, auxílio, companheirismo e amizade ao longo desses anos.

Aos professores do Departamento de Engenharia Civil da UNESP de Ilha Solteira, Jairo Salim Pinheiro, Dib Gebara, Luzenira Brasileiro e Jair Camacho, pela recomendação e o incentivo para iniciar o mestrado. 
Aos amigos, Fábio Zanchetta, Marcos Bottene Cunha, Jorge Escalante, Fábio Iwanaga, Vivian Bardini, Frederico Klein e Ana Paula Furlan que auxiliaram diretamente na pesquisa.

Aos colegas e amigos de departamento, pelos ótimos momentos passados no STT e em São Carlos, Zanca, Dú Caramuru, Giga, Japonês, Fábio, Markito, Weslley "Mineiro", Mateus Araújo, André, Lute, João, Fred, Idalíria, Stella, Reginaldo, Diogo, Jorge, Bruneco, Karênina, Celane, Serginho, Camilla Carrara, Camila Modenese, Leandro, Samuca, Lobão, Dani Andolfato, Andréa Júlia, Andréa Castro, Gú, Bia, Rogério, Cida, Cira, Shirley, Lia, Ana Furlan, Ana Larocca, Gauchinha, Vivian Bardine, Vivian Mantovani, Deise, Léo Hotta, Adalberto, Daniel, Nei, Marcelinha, Marcão, Eduardo, Pablo, Josi, Lilian, Kakuda, Manoel Lucas, Giovane, Vivianne, Dinato, Caróides e Simone.

Aos funcionários Zé Toco, Heloísa, Beth, Magali, Zé Vicente, Alexandre e Paulinho pela colaboração, apoio e amizade.

Aos meus amigos de vida, Eduardo "Duzão" Moreira, Mauro "Carecão" Gattamorta, Marcelo "Coroca" Gonsales, Ricardo "Bardal" Bardalati, Denise "Dê" Yamassake e Renata "Rê" Fiorini pelo apoio, incentivo, amizade e companheirismo.

À Daniela Andresa Mortari, por todo amor, carinho, alegria, respeito e paciência em todos os momentos.

À Coordenadoria de Aperfeiçoamento de Pessoal de Nível Superior - CAPES, pela bolsa de estudo concedida.

À pedreira Bandeirantes e à Ipiranga Asfaltos, pelos materiais concedidos para a realização da pesquisa. 
Em últimos na ordem, mas não no coração:

Aos meus familiares, tia Sueli, tio Toninho, Diogo, Diana e tio Celso por sempre acreditarem em mim e me apoiarem incondicionalmente, pelo amor, carinho e incentivo.

À minha avó, e segunda mãe, Olívia, que eu amo de paixão, por tudo o que representa na minha vida; e meu avô Orlando (in memorian).

Aos meus irmãos Dinho e Binho, meus amigos, companheiros e parceiros, por me trazerem alegrias todos os dias da minha vida, pelo amor e apoio.

Aos meus pais, Élcio Ildefonso e Iracy Sereni Ildefonso, minha inspiração, meu porto seguro, pessoas que admiro, respeito e amo, por tudo o que são e tudo o que fizeram para que eu chegasse até aqui, pelo amor, carinho e ensinamentos de vida. 



\section{RESUMO}

ILDEFONSO, J.S. Análise da viabilidade técnica da utilização do copolímero etileno acetato de vinila (EVA) descartado pela indústria calçadista em misturas asfálticas (processo seco). 2007. 331 f. Dissertação (Mestrado) - Escola de Engenharia de São Carlos, Universidade de São Paulo, São Carlos, 2007.

A presente dissertação teve por objetivo analisar o comportamento de misturas asfálticas modificadas, pelo processo seco, com o copolímero Etileno Acetato de Vinila (EVA), resíduo sólido descartado pela indústria calçadista. Em razão das características do EVA, acredita-se que ele possa melhorar as características mecânicas de misturas asfálticas e a resistência ao desgaste. A maioria dos pesquisadores tem direcionado seus esforços em estudos de misturas asfálticas modificadas pelo processo úmido, porém, devido à natureza do resíduo analisado neste trabalho, optou-se pelo processo seco, que demanda menos energia por não necessitar de moagem do material. A pesquisa compreendeu o estudo de amostras de misturas asfálticas não envelhecidas e com envelhecimento de duas e quatro horas em estufa, com moldagem de corpos-de-prova para realização dos ensaios de resistência à tração por compressão diametral estática, módulo de resiliência por compressão diametral, fluência por compressão uniaxial estática e dinâmica, vida de fadiga e desgaste por abrasão (ensaio Cantabro). Os resultados mostram que a utilização deste resíduo aumentou a resistência das misturas à fadiga e ao desgaste de forma significativa, porém as misturas tornaram-se mais susceptíveis à deformação permanente. $O$ tempo de envelhecimento de curto prazo se mostrou importante, pois aumentou a resistência das misturas à fadiga e à deformação permanente.

Palavras-chave: Misturas asfálticas. Etileno acetato de vinila. Processo seco. Ensaios mecânicos. Método Bailey. Envelhecimento. 


\section{ABSTRACT}

ILDEFONSO, J.S. Analysis of the technical feasibility of the use of the ethylene vinyl acetate copolymer (EVA) discarded for the footwear industry in asphalt mixtures (dry process). 2007. 331 p. Master thesis (Mastering) - Escola de Engenharia de Sao Carlos, Universidade de São Paulo, Sao Carlos, 2007.

The main purpose of the present master thesis was to analyze the behavior of modified hot-mix asphalt, through the dry process, with the copolymer Ethylene Vinyl Acetate (EVA) discarded by the footwear industry. Since the EVA characteristics, it is believed that it can improve hot-mix asphalt mechanic characteristics and the wear and tear resistance. Most of the researchers have been addressing efforts in studies on modified hot-mix asphalt by the wet process, however, due to the nature of the solid residue analyzed in this work, the dry process will demand less energy for not needing of grinding. The research evolved the study of samples of asphalt mixtures not aged and with aging of two and four hours in oven, submitted to indirect tension test, resilient modulus, static and dynamic creep, fatigue life and loss due to abrasion (Cantabro test). The results show that the use of this residue increased the resistance of the mixtures to the fatigue and loss of mass due to abrasion, however the mixtures became more susceptible to the permanent deformation. The short-time aging was shown important, because it increased the resistance of the mixtures to the fatigue and the permanent deformation.

Keywords: Asphalt mixtures. Ethylene vinyl acetate. Dry process. Mechanical tests. Bailey method. Aging. 


\section{LISTA DE FIGURAS}

Figura 2.1. Exemplos de deformação permanente encontrada nas trilhas de roda.

Figura 2.2. Gráficos típicos da deformação em função do tempo para o ensaio de fluência por compressão uniaxial estática.

Figura 2.3. Curva típica de deformação pelo número de ciclos no ensaio de fluência por compressão uniaxial.

Figura 2.4. Curvas características do ensaio de vida de fadiga por tensão controlada.

Figura 2.5. Curvas características do ensaio de vida de fadiga por deformação controlada.

Figura 2.6. Eixo de coordenadas do programa ELSYM5. .73

Figura 2.7. Estrutura molecular do copolímero EVA. .80

Figura 2.8. Consumo mundial de materiais para solados. .83

Figura 2.9. Produção brasileira de calçados em milhões de pares.. .83

Figura 2.10. Resíduos das placas de EVA gerados na confecção de palmilhas......84

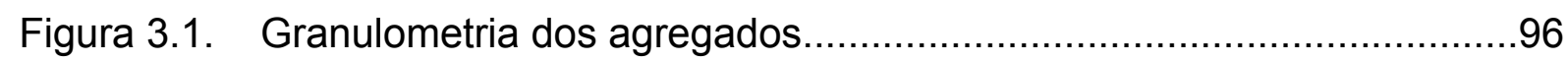

Figura 3.2. Secagem superficial do agregado graúdo........................................97

Figura 3.3. Preparação da amostra para o ensaio de massa específica do agregado fino. .99

Figura 3.4. Secagem da amostra para o ensaio de massa específica do agregado fino.

Figura 3.5. Verificação da condição saturada seca superficialmente do agregado fino.

Figura 3.6. Retirada das bolhas de ar da amostra para o ensaio de massa específica do agregado fino.........................................................101

Figura 3.7. Curva de calibração do kitassato modificado......................................101

Figura 3.8. Máquina de abrasão "Los Angeles"................................................104

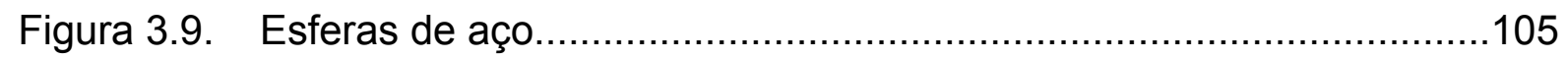


Figura 3.10. EVA cortado. 106

Figura 3.11. Cilindro com agregado graúdo para determinação da massa específica solta.

Figura 3.12. Cilindro com agregado fino para determinação da massa específica compactada...... 114

Figura 3.13. Viscosidade Saybolt-Furol versus temperatura.............................125

Figura 3.14. Molde utilizado na compactação Marshall........................................128

Figura 3.15. Panela utilizada para misturar os corpos-de-prova...........................128

Figura 3.16. Compactador Marshall.........................................................129

Figura 3.17. Soquete

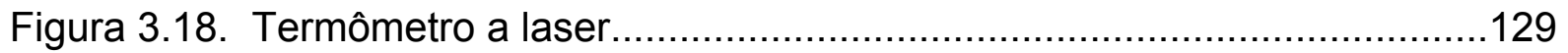

Figura 3.19. Verificação da massa ao ar e massa imersa dos corpos-de-

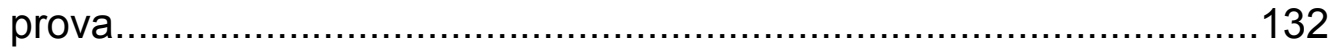

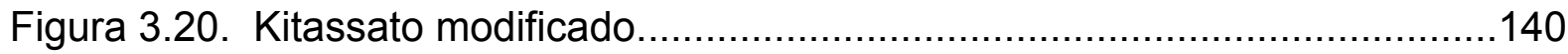

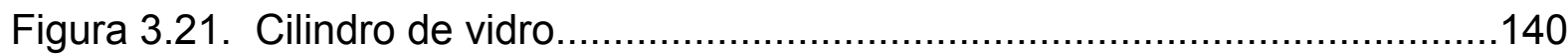

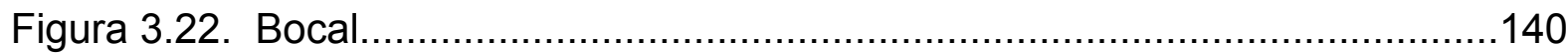

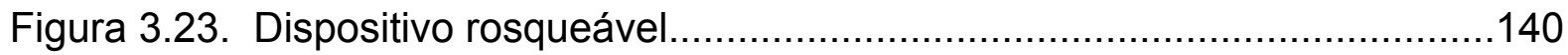

Figura 3.24. Montagem do cilindro de vidro no bocal.........................................141

Figura 3.25. Montagem dos corpos-de-prova no suporte para o ensaio de RT......148

Figura 3.26. Fixação do suporte para o ensaio de RT........................................148

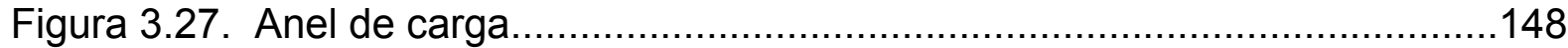

Figura 3.28. Montagem dos corpos-de-prova no suporte para o ensaio de MR.....151

Figura 3.29. Esquema de fixação do suporte na prensa......................................152

Figura 3.30. Deformações instantânea e total no ensaio de MR versus tempo (AASHTO TP31-94 apud SANTANNA-GRECO (2004))...................153

Figura 3.31. Tela do programa utilizado para aquisição dos dados de MR............154

Figura 3.32. Detalhe dos pulsos do ensaio de MR............................................154

Figura 3.33. Tela do programa utilizado para processamento dos dados de MR...155 
Figura 3.34. Corpo-de-prova lixado para o ensaio de fluência por compressão uniaxial estática.

Figura 3.35. Preparação do corpo-de-prova para o ensaio de fluência por compressão uniaxial estática. 156

Figura 3.36. Conjunto para o ensaio de fluência por compressão uniaxial estática.

Figura 3.37. Condicionamento do corpo-de-prova no ensaio de fluência por compressão uniaxial estática. 158

Figura 3.38. Tela do programa utilizado para aquisição dos dados de fluência por compressão uniaxial estática. 158

Figura 3.39. Tela do programa utilizado para processamento dos dados de fluência por compressão uniaxial estática. 159

Figura 3.40. Tela do programa utilizado para aquisição dos dados de fluência por compressão uniaxial dinâmica. 160

Figura 3.41. Tela do programa utilizado para processamento dos dados de fluência por compressão uniaxial dinâmica.

Figura 3.42. Prensa e suporte de fixação do LVDT para o ensaio de vida de fadiga. 162

Figura 4.1. Dosagem Marshall - Volume de vazios em função do teor de CAP..173

Figura 4.2. Dosagem Marshall - Densidade aparente da mistura em função do teor de CAP......

Figura 4.3. Dosagem Marshall - Vazios no agregado mineral em função do teor de CAP.

Figura 4.4. Dosagem Marshall - Relação betume-vazios em função do teor de CAP. 175

Figura 4.5. Dosagem Marshall - Fluência em função do teor de CAP................176

Figura 4.6. Dosagem Marshall - Estabilidade em função do teor de CAP. 176

Figura 4.7. Ensaios exploratórios - RT em função do teor de EVA. 178

Figura 4.8. Ensaios exploratórios - MR em função do teor de EVA. 178

Figura 4.9. Ensaios exploratórios - Relação MR/RT em função do teor de EVA.179

Figura 4.10. Programa Experimental - Módulo de resiliência em função do teor de EVA para 0 hora de envelhecimento. 181

Figura 4.11. Programa Experimental - Módulo de resiliência em função do teor de EVA para 2 horas de envelhecimento. 
Figura 4.12. Programa Experimental - Módulo de resiliência em função do teor de EVA para 4 horas de envelhecimento.

Figura 4.13. Programa experimental - Módulos de resiliência em função do teor de EVA e do tempo de envelhecimento.

Figura 4.14. Programa Experimental - Modelo de módulo de resiliência em função do teor de EVA e do tempo de envelhecimento, para significância de $0,1 \%$. 183

Figura 4.15. Programa experimental - Resistência à tração em função do teor de EVA para 0 hora de envelhecimento. 184

Figura 4.16. Programa experimental - Resistência à tração em função do teor de EVA para 2 horas de envelhecimento. 185

Figura 4.17. Programa experimental - Resistência à tração em função do teor de EVA para 4 horas de envelhecimento. 185

Figura 4.18. Programa experimental - Resistência à tração em função do teor de EVA e do tempo de envelhecimento. 186

Figura 4.19. Programa Experimental - Modelo de resistência à tração em função do teor de EVA e do tempo de envelhecimento, para significância de $0,5 \%$ 187

Figura 4.20. Programa experimental - Relação MR/RT do teor de EVA e do tempo de envelhecimento. 188

Figura 4.21. Programa experimental - Número de ciclos em função da diferença de tensões em corpos-de-prova com 0\% de EVA e 0 hora de envelhecimento. 190

Figura 4.22. Programa experimental - Número de ciclos em função da deformação resiliente em corpos-de-prova com $0 \%$ de EVA e 0 hora de envelhecimento. 190

Figura 4.23. Programa experimental - Número de ciclos em função da diferença de tensões em corpos-de-prova com $1 \%$ de EVA e 0 hora de envelhecimento. 191

Figura 4.24. Programa experimental - Número de ciclos em função da deformação resiliente em corpos-de-prova com $1 \%$ de EVA e 0 hora de envelhecimento. 192

Figura 4.25. Programa experimental - Número de ciclos em função da diferença de tensões em corpos-de-prova com $2 \%$ de EVA e 0 hora de envelhecimento. 193

Figura 4.26. Programa experimental - Número de ciclos em função da deformação resiliente em corpos-de-prova com $2 \%$ de EVA e 0 hora de envelhecimento. 
Figura 4.27. Programa experimental - Número de ciclos em função da diferença de tensões em corpos-de-prova com 3\% de EVA e 0 hora de envelhecimento.

Figura 4.28. Programa experimental - Número de ciclos em função da deformação resiliente em corpos-de-prova com 3\% de EVA e 0 hora de envelhecimento.

Figura 4.29. Programa experimental - Número de ciclos em função da diferença de tensões em corpos-de-prova com 0\% de EVA e 2 horas de envelhecimento. 196

Figura 4.30. Programa experimental - Número de ciclos em função da deformação resiliente em corpos-de-prova com $0 \%$ de EVA e 2 horas de envelhecimento. 196

Figura 4.31. Programa experimental - Número de ciclos em função da diferença de tensões em corpos-de-prova com 1\% de EVA e 2 horas de envelhecimento

Figura 4.32. Programa experimental - Número de ciclos em função da deformação resiliente em corpos-de-prova com 1\% de EVA e 2 horas de envelhecimento.

Figura 4.33. Programa experimental - Número de ciclos em função da diferença de tensões em corpos-de-prova com $2 \%$ de EVA e 2 horas de envelhecimento 199

Figura 4.34. Programa experimental - Número de ciclos em função da deformação resiliente em corpos-de-prova com 2\% de EVA e 2 horas de envelhecimento. 199

Figura 4.35. Programa experimental - Número de ciclos em função da diferença de tensões em corpos-de-prova com 3\% de EVA e 2 horas de envelhecimento. 200

Figura 4.36. Programa experimental - Número de ciclos em função da deformação resiliente em corpos-de-prova com 3\% de EVA e 2 horas de envelhecimento. 201

Figura 4.37. Programa experimental - Número de ciclos em função da diferença de tensões em corpos-de-prova com $0 \%$ de EVA e 4 horas de envelhecimento. 202

Figura 4.38. Programa experimental - Número de ciclos em função da deformação resiliente em corpos-de-prova com 0\% de EVA e 4 horas de envelhecimento. 202

Figura 4.39. Programa experimental - Número de ciclos em função da diferença de tensões em corpos-de-prova com $1 \%$ de EVA e 4 horas de envelhecimento 
Figura 4.40. Programa experimental - Número de ciclos em função da deformação resiliente em corpos-de-prova com 1\% de EVA e 4 horas de envelhecimento. 204

Figura 4.41. Programa experimental - Número de ciclos em função da diferença de tensões em corpos-de-prova com 2\% de EVA e 4 horas de envelhecimento. 205

Figura 4.42. Programa experimental - Número de ciclos em função da deformação resiliente em corpos-de-prova com 2\% de EVA e 4 horas de envelhecimento. 205

Figura 4.43. Programa experimental - Número de ciclos em função da diferença de tensões em corpos-de-prova com $3 \%$ de EVA e 4 horas de envelhecimento. 206

Figura 4.44. Programa experimental - Número de ciclos em função da deformação resiliente em corpos-de-prova com 3\% de EVA e 4 horas de envelhecimento. 207

Figura 4.45. Programa experimental - Número de ciclos em função da diferença de tensões em corpos-de-prova com 0 hora de envelhecimento 208

Figura 4.46. Programa experimental - Número de ciclos em função da deformação resiliente em corpos-de-prova com 0 hora de envelhecimento.... 208

Figura 4.47. Programa experimental - Número de ciclos em função da diferença de tensões em corpos-de-prova com 2 horas de envelhecimento. 209

Figura 4.48. Programa experimental - Número de ciclos em função da deformação resiliente em corpos-de-prova com 2 horas de envelhecimento........209

Figura 4.49. Programa experimental - Número de ciclos em função da diferença de tensões em corpos-de-prova com 4 horas de envelhecimento .210

Figura 4.50. Programa experimental - Número de ciclos em função da deformação resiliente em corpos-de-prova com 4 horas de envelhecimento........210

Figura 4.51. Esquema do pavimento hipotético 212

Figura 4.52. Vida de fadiga para cada condição experimental de acordo com as tensões geradas pelo programa ELSYM5 para a estrutura 1

Figura 4.53. Vida de fadiga para cada condição experimental de acordo com as tensões geradas pelo programa ELSYM5 para a estrutura 2. 215

Figura 4.54. Programa experimental - Deformações totais medidas no ensaio de fluência por compressão uniaxial estática. 217

Figura 4.55. Programa experimental - Deformações recuperáveis medidas no ensaio de fluência por compressão uniaxial estática. 
Figura 4.56. Programa experimental - Deformações permanentes medidas no ensaio de fluência por compressão uniaxial estática.

Figura 4.57. Programa experimental - Recuperações medidas no ensaio de fluência por compressão uniaxial estática.

Figura 4.58. Programa experimental - Módulos de fluência medidos aos 3600 segundos no ensaio de fluência por compressão uniaxial estática....219

Figura 4.59. Programa experimental - Módulos de fluência medidos aos 4500 segundos no ensaio de fluência por compressão uniaxial estática....220

Figura 4.60. Programa experimental - Inclinações das curvas no ensaio de fluência por compressão uniaxial estática. 220

Figura 4.61. Programa Experimental - Modelo de deformação total do ensaio de fluência por compressão uniaxial estática em função do teor de EVA e do tempo de envelhecimento, para significância de $5 \%$ 222

Figura 4.62. Programa Experimental - Modelo de deformação recuperável do ensaio de fluência por compressão uniaxial estática em função do teor de EVA e do tempo de envelhecimento, para significância de 5\%...223

Figura 4.63. Programa Experimental - Modelo de deformação recuperável do ensaio de fluência por compressão uniaxial estática em função do teor de EVA e do tempo de envelhecimento, para significância de 5\%....224

Figura 4.64. Programa Experimental - Modelo de módulo de fluência aos $3600 \mathrm{~s}$ do ensaio de fluência por compressão uniaxial estática em função do teor de EVA e do tempo de envelhecimento, para significância de 5\%...225

Figura 4.65. Programa Experimental - Modelo de módulo de fluência aos $4500 \mathrm{~s}$ do ensaio de fluência por compressão uniaxial estática em função do teor de EVA e do tempo de envelhecimento, para significância de 5\%...226

Figura 4.66. Programa Experimental - Modelo de inclinação da curva no estágio secundário do ensaio de fluência por compressão uniaxial estática em função do teor de EVA e do tempo de envelhecimento, para significância de $2,5 \%$.

Figura 4.67. Programa experimental - Deformações totais medidas no ensaio de fluência por compressão uniaxial dinâmica. 229

Figura 4.68. Programa experimental - Módulos de fluência medidos no ensaio de fluência por compressão uniaxial dinâmica 229

Figura 4.69. Programa experimental - Inclinações das curvas no ensaio de fluência por compressão uniaxial dinâmica. 230

Figura 4.70. Programa Experimental - Modelo de deformação total do ensaio de fluência por compressão uniaxial dinâmica em função do teor de EVA e do tempo de envelhecimento, para significância de $5 \%$. 
Figura 4.71. Programa Experimental - Modelo de módulo de fluência do ensaio de fluência por compressão uniaxial dinâmica em função do teor de EVA e do tempo de envelhecimento, para significância de 2,5\% 233

Figura 4.72. Programa Experimental - Modelo de inclinação da curva no estágio secundário do ensaio de fluência por compressão uniaxial dinâmica em função do teor de EVA e do tempo de envelhecimento, para significância de $2,5 \%$....................................................................234

Figura 4.73. Desgaste por abrasão em função do teor de EVA e do tempo de envelhecimento

Figura 4.74. Programa Experimental - Modelo de desgaste por abrasão do ensaio Cantabro em função do teor de EVA e do tempo de envelhecimento, para significância de $2,5 \%$. 236

Figura A.1. Curva granulométrica determinada através do método Bailey.... 262

Figura B.1. Curva viscosidade versus temperatura do ligante asfáltico 266 


\section{LISTA DE TABELAS}

Tabela 2.1 - Fatores que influem na deformação permanente em concretos asfálticos.

Tabela 2.2 - Zona de restrição e pontos de controle para DMN 9,5 mm .53

Tabela 2.3 - Critério para controle da deformação através de valores obtidos no ensaio de fluência.

Tabela 2.4 - Critério do módulo de fluência para 1 hora de carregamento. 62

Tabela 2.5 - Vantagens e desvantagens dos ensaios de fluência por compressão uniaxial estática e dinâmica.

Tabela 2.6 - Histórico de previsão de deformação permanente através do ensaio de fluência por compressão uniaxial estática do departamento de transportes da USP - São Carlos.

Tabela 2.7 - Histórico de previsão de deformação permanente através do ensaio de fluência por compressão uniaxial dinâmica do departamento de transportes da USP - São Carlos

Tabela 2.8 - Influência de alguns fatores na vida de fadiga das misturas asfálticas.

Tabela 2.9 - Materiais disponíveis para a fabricação de calçados no decorrer das décadas

Tabela 2.10 - Métodos de avaliação de envelhecimento acelerado em laboratório. .88

Tabela 3.1 - Resultados dos ensaios de caracterização do CAP 50/70...... .94

Tabela 3.2 - Granulometria dos agregados. .96

Tabela 3.3 - Especificações para o ensaio de Abrasão "Los Angeles"..... 104

Tabela 3.4 - Resultado do ensaio de abrasão "Los Angeles". 104

Tabela 3.5 - Propriedades físico-químicas do EVA............................................106

Tabela 3.6 - Intervalo recomendado para PAG, PGAF e PFAF...........................123

Tabela 3.7 - Temperaturas de mistura e compactação........................................124

Tabela 3.8 - VAM mínimo segundo o SUPERPAVE (COMINSKY et al., 1998)..136 
Tabela 3.9 - Fatores que influenciam nos VAM..............................................136

Tabela 3.10 - Fatores de graduação............................................................137

Tabela 3.11 - Valores mínimos de VAM de acordo com a norma DNIT 031-2004-

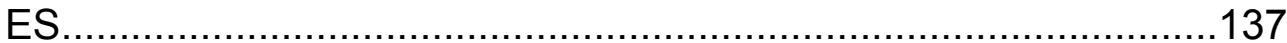

Tabela 3.12 - Valores limite da RBV segundo a especificação SUPERPAVE.......138

Tabela 4.1 - Modelos estatísticos - Equações polinomiais.................................170

Tabela 4.2 - Dosagem Marshall - Características volumétricas e mecânicas das

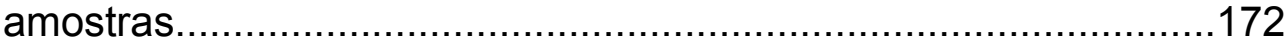

Tabela 4.3 - Absorção de ligante...........................................................173

Tabela 4.4 - Resultados dos ensaios exploratórios...........................................177

Tabela 4.5 - Programa experimental - Módulos de resiliência em função do teor de EVA e do tempo de envelhecimento........................................180

Tabela 4.6 - Programa experimental - Resistência à tração em função do teor de EVA e do tempo de envelhecimento............................................184

Tabela 4.7 - Análise da variância da resistência à tração, para significância de $0,5 \%$ 187

Tabela 4.8 - Programa experimental - Relação MR/RT em função do teor de EVA e do tempo de envelhecimento....................................................188

Tabela 4.9 - Programa experimental - Resultados dos ensaios de fadiga em corpos-de-prova com 0\% de EVA e 0 hora de envelhecimento......189

Tabela 4.10 - Programa experimental - Resultados dos ensaios de fadiga em corpos-de-prova com $1 \%$ de EVA e 0 hora de envelhecimento......191

Tabela 4.11 - Programa experimental - Resultados dos ensaios de fadiga em corpos-de-prova com 2\% de EVA e 0 hora de envelhecimento......192

Tabela 4.12 - Programa experimental - Resultados dos ensaios de fadiga em corpos-de-prova com 3\% de EVA e 0 hora de envelhecimento......194

Tabela 4.13 - Programa experimental - Resultados dos ensaios de fadiga em corpos-de-prova com 0\% de EVA e 2 horas de envelhecimento.....195

Tabela 4.14 - Programa experimental - Resultados dos ensaios de fadiga em corpos-de-prova com 1\% de EVA e 2 horas de envelhecimento.....197

Tabela 4.15 - Programa experimental - Resultados dos ensaios de fadiga em corpos-de-prova com 2\% de EVA e 2 horas de envelhecimento.....198

Tabela 4.16 - Programa experimental - Resultados dos ensaios de fadiga em corpos-de-prova com 3\% de EVA e 2 horas de envelhecimento.....200 
Tabela 4.17 - Programa experimental - Resultados dos ensaios de fadiga em corpos-de-prova com $0 \%$ de EVA e 4 horas de envelhecimento.....201

Tabela 4.18 - Programa experimental - Resultados dos ensaios de fadiga em corpos-de-prova com 1\% de EVA e 4 horas de envelhecimento.....203

Tabela 4.19 - Programa experimental - Resultados dos ensaios de fadiga em corpos-de-prova com $2 \%$ de EVA e 4 horas de envelhecimento.....204

Tabela 4.20 - Programa experimental - Resultados dos ensaios de fadiga em corpos-de-prova com 3\% de EVA e 4 horas de envelhecimento.....206

Tabela 4.21 - Estruturas hipotéticas para análise das tensões através do programa ELSYM5........

Tabela 4.22 - Vida de fadiga para cada condição experimental de acordo com as tensões geradas pelo programa ELSYM5 para a estrutura $1 \ldots \ldots \ldots . .213$

Tabela 4.23 - Vida de fadiga para cada condição experimental de acordo com as tensões geradas pelo programa ELSYM5 para a estrutura 2.........214

Tabela 4.24 - Programa experimental - Resultados dos ensaios de fluência por compressão uniaxial estática.

Tabela 4.25 - Análise da variância da deformação total medida no ensaio de fluência por compressão uniaxial estática, para significância de $5 \%$. 222

Tabela 4.26 - Análise da variância da deformação recuperável medida no ensaio de fluência por compressão uniaxial estática, para significância de $2,5 \%$. 223

Tabela 4.27 - Análise da variância da deformação permanente medida no ensaio de fluência por compressão uniaxial estática, para significância de $1 \%$. 224

Tabela 4.28 - Análise da variância do módulo de fluência medido aos $3600 \mathrm{~s}$ no ensaio de fluência por compressão uniaxial estática, para significância de $5 \%$ 225

Tabela 4.29 - Análise da variância do módulo de fluência medido aos 4500 s no ensaio de fluência por compressão uniaxial estática, para significância de $1 \%$ 226

Tabela 4.30 - Análise da variância da inclinação da curva medida no estágio secundário do ensaio de fluência por compressão uniaxial estática, para significância de $2,5 \%$. 227

Tabela 4.31 - Programa experimental - Resultados dos ensaios de fluência por compressão uniaxial dinâmica. 
Tabela 4.32 - Análise da variância da deformação total medida no ensaio de fluência por compressão uniaxial dinâmica, para significância de $5 \%$.

Tabela 4.33 - Análise da variância do módulo de fluência medido no ensaio de fluência por compressão uniaxial dinâmica, para significância de $2,5 \%$ 232

Tabela 4.34 - Análise da variância da inclinação da curva medida no estágio secundário do ensaio de fluência por compressão uniaxial dinâmica, para significância de $2,5 \%$ 233

Tabela 4.35 - Desgaste médio por abrasão das misturas asfálticas em função do tempo de envelhecimento e do teor de EVA

Tabela 4.36 - Análise da variância dos resultados do ensaio de desgaste, para

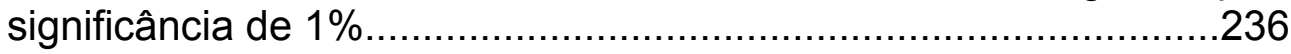

Tabela A.1 - Granulometria dos agregados utilizados na pesquisa...................256

Tabela A.2 - Massa específica compactada do pó de pedra..............................256

Tabela A.3 - Massa específica solta do pedrisco......................................257

Tabela A.4 - Massa específica compactada do pedrisco...............................257

Tabela A.5 - Massa específica solta do pedrisco..........................................257

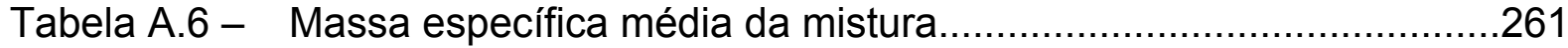

Tabela A.7 - Curva granulométrica determinada através do método Bailey........261

Tabela B.1 - Composição dos corpos-de-prova para a dosagem Marshall..........265

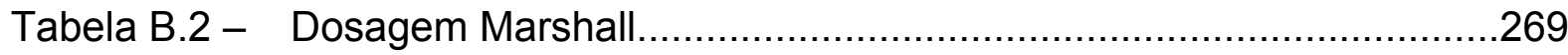

Tabela C.1 - Absorção de asfalto para as diferentes etapas de envelhecimento.273

Tabela D.1 - Dosagem Marshall - Diâmetro e altura dos corpos-de-prova..........276

Tabela D.2 - Dosagem Marshall - Massas, volumes, densidades e volume de

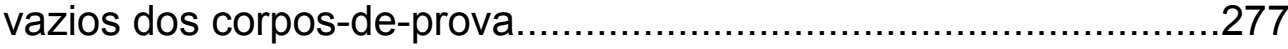

Tabela D.3 - Ensaios Exploratórios - Diâmetro e altura dos corpos-de-prova.....278

Tabela D.4 - Ensaios exploratórios - Massas, volumes, densidades e volume de vazios dos corpos-de-prova....................................................279

Tabela D.5 - Programa Experimental - Diâmetro e altura dos CPs com 0\% de

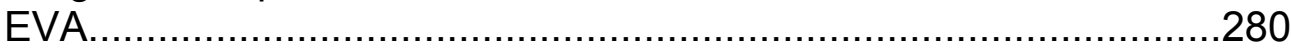

Tabela D.6 - Programa Experimental - Diâmetro e altura dos CPs com 1\% de EVA .....................................................................................281 
Tabela D.7 - Programa Experimental - Diâmetro e altura dos CPs com 2\% de EVA.

Tabela D.8 - Programa Experimental - Diâmetro e altura dos CPs com 3\% de EVA.

Tabela D.9 - Programa Experimental - Massas, volumes, densidades e Vv dos corpos-de-prova com $0 \%$ de EVA...........................................284

Tabela D.10 - Programa Experimental - Massas, volumes, densidades e Vv dos corpos-de-prova com $1 \%$ de EVA............................................285

Tabela D.11 - Programa Experimental - Massas, volumes, densidades e Vv dos corpos-de-prova com $2 \%$ de EVA............................................286

Tabela D.12 - Programa Experimental - Massas, volumes, densidades e Vv dos corpos-de-prova com 3\% de EVA ..........................................287

Tabela E.1 - Ensaios Exploratórios - Resultado dos ensaios...........................291

Tabela F.1 - Programa experimental - Dados do ensaio de MR para 0\% de EVA e 0 hora de envelhecimento.......................................................294

Tabela F.2 - Programa experimental - Dados do ensaio de MR para 0\% de EVA e 2 horas de envelhecimento.........................................................295

Tabela F.3 - Programa experimental - Dados do ensaio de MR para 0\% de EVA e 4 horas de envelhecimento.......................................................295

Tabela F.4 - Programa experimental - Dados do ensaio de MR para 1\% de EVA e 0 hora de envelhecimento.......................................................296

Tabela F.5 - Programa experimental - Dados do ensaio de MR para 1\% de EVA e 2 horas de envelhecimento......................................................296

Tabela F.6 - Programa experimental - Dados do ensaio de MR para 1\% de EVA e 4 horas de envelhecimento......................................................297

Tabela F.7 - Programa experimental - Dados do ensaio de MR para 2\% de EVA e 0 hora de envelhecimento......................................................297

Tabela F.8 - Programa experimental - Dados do ensaio de MR para 2\% de EVA e 2 horas de envelhecimento......................................................298

Tabela F.9 - Programa experimental - Dados do ensaio de MR para 2\% de EVA e 4 horas de envelhecimento...................................................298

Tabela F.10 - Programa experimental - Dados do ensaio de MR para 3\% de EVA e 0 hora de envelhecimento.. 299

Tabela F.11 - Programa experimental - Dados do ensaio de MR para 3\% de EVA e 2 horas de envelhecimento.. .299 
Tabela F.12 - Programa experimental - Dados do ensaio de MR para 3\% de EVA e 4 horas de envelhecimento. 300

Tabela F.13 - Programa experimental - Tratamento estatístico para o ensaio de MR em corpos-de-prova com $0 \%$ de EVA e 0 hora de envelhecimento. 301

Tabela F.14 - Programa experimental - Tratamento estatístico para o ensaio de MR em corpos-de-prova com $0 \%$ de EVA e 2 horas de envelhecimento. 303

Tabela F.15 - Programa experimental - Tratamento estatístico para o ensaio de MR em corpos-de-prova com $0 \%$ de EVA e 4 horas de envelhecimento. 303

Tabela F.16 - Programa experimental - Tratamento estatístico para o ensaio de MR em corpos-de-prova com $1 \%$ de EVA e 0 hora de envelhecimento.......................................................................304

Tabela F.17 - Programa experimental - Tratamento estatístico para o ensaio de MR em corpos-de-prova com $1 \%$ de EVA e 2 horas de envelhecimento 304

Tabela F.18 - Programa experimental - Tratamento estatístico para o ensaio de MR em corpos-de-prova com $1 \%$ de EVA e 4 horas de envelhecimento. 305

Tabela F.19 - Programa experimental - Tratamento estatístico para o ensaio de MR em corpos-de-prova com $2 \%$ de EVA e 0 hora de envelhecimento 305

Tabela F.20 - Programa experimental - Tratamento estatístico para o ensaio de MR em corpos-de-prova com $2 \%$ de EVA e 2 horas de envelhecimento. 306

Tabela F.21 - Programa experimental - Tratamento estatístico para o ensaio de MR em corpos-de-prova com $2 \%$ de EVA e 4 horas de envelhecimento. 306

Tabela F.22 - Programa experimental - Tratamento estatístico para o ensaio de MR em corpos-de-prova com $3 \%$ de EVA e 0 hora de envelhecimento. 307

Tabela F.23 - Programa experimental - Tratamento estatístico para o ensaio de MR em corpos-de-prova com $3 \%$ de EVA e 2 horas de envelhecimento. 307

Tabela F.24 - Programa experimental - Tratamento estatístico para o ensaio de MR em corpos-de-prova com $3 \%$ de EVA e 4 horas de envelhecimento......................................................................308

Tabela G.1 - Programa Experimental - Dados do ensaio de RT. 311 
Tabela H.1 - Programa experimental - Deformações totais medidas no ensaio de fluência por compressão uniaxial estática.

Tabela H.2 - Programa experimental - Deformações recuperáveis medidas no ensaio de fluência por compressão uniaxial estática.....................316

Tabela H.3 - Programa experimental - Deformações permanente medidas no ensaio de fluência por compressão uniaxial estática.....................317

Tabela H.4 - Programa experimental - Recuperações medidas no ensaio de fluência por compressão uniaxial estática....................................318

Tabela H.5 - Programa experimental - Módulo de fluência em MPa medidos aos 3600 segundos no ensaio de fluência por compressão uniaxial estática.

Tabela H.6 - Programa experimental - Módulo de fluência em MPa medidos aos 4500 segundos no ensaio de fluência por compressão uniaxial estática. 320

Tabela H.7 - Programa experimental - Inclinação das curvas medidas no estágio secundário no ensaio de fluência por compressão uniaxial estática. 321

Tabela I.1 - Programa experimental - Deformações totais medidas no ensaio de fluência por compressão uniaxial dinâmica. 325

Tabela I.2 - Programa experimental - Módulos de fluência, em MPa, medidos no ensaio de fluência por compressão uniaxial dinâmica.. 326

Tabela I.3 - Programa experimental - Inclinação das curvas medidas no estágio secundário no ensaio de fluência por compressão uniaxial dinâmica. 327

Tabela J.1 - Programa experimental - Desgastes por abrasão medidos no ensaio Cantabro. 



\section{LISTA DE ABREVIATURAS, SIGLAS E SÍMBOLOS}

a

Porcentagem passada na peneira $0,30 \mathrm{~mm}$ e retida na peneira 0,075 $\mathrm{mm}$

A Massa da amostra seca; Porcentagem passada na peneira $4,76 \mathrm{~mm}$ e retida na peneira $0,30 \mathrm{~mm}$; Desgaste das misturas asfálticas por abrasão

AASHTO American Association of State Highway and Transportation Officials

Aabs

Porcentagem de asfalto absorvido por massa de agregado

Abicaçados Associação Brasileira das Indústrias de Calçados

ABNT Associação Brasileira de Normas Técnicas

$\mathrm{Abs}_{\mathrm{af}} \quad$ Absorção de água pelo agregado fino

Abs $_{a g} \quad$ Absorção de água pelo agregado graúdo

$\mathrm{AF}_{\mathrm{d}} \quad$ Contribuição do pó de pedra

$\mathrm{AF}_{\mathrm{f}} \quad$ Quantidade corrigida de pó de pedra na mistura

$\mathrm{AFi} \quad$ Quantidade de pó de pedra na mistura

$A G_{1 f} \quad$ Quantidade corrigida de pedra 1 na mistura

$\mathrm{AG}_{2 f} \quad$ Quantidade corrigida de pedrisco na mistura

$\mathrm{AG}_{\mathrm{d} 1} \quad$ Contribuição da pedra 1

$\mathrm{AG}_{\mathrm{d} 2} \quad$ Contribuição do pedrisco

AGi Quantidade de agregado graúdo na mistura

$\mathrm{AGi}_{1} \quad$ Quantidade de pedra 1 na mistura

$\mathrm{AGi}_{2} \quad$ Quantidade de pedrisco na mistura

$A G_{p} \quad$ Quantidade de agregados na mistura

APA Asphalt Pavement Analyzer 
Assintecal Associação Brasileira de Empresas de Componentes para Couros, Calçados e Artefatos

ASTM American Society for Testing and Materials

atm Atmosfera(s)

$\mathrm{a}_{\mathrm{x}} \quad$ Número de níveis do fator $\mathrm{x}$

BRP Borracha Reciclada de Pneus

C Massa da amostra submersa

$\mathrm{CAF}_{\mathrm{t}} \quad$ Contribuição total dos agregados finos na mistura

$\mathrm{CAG}_{\mathrm{t}} \quad$ Contribuição total dos agregados graúdos na mistura

CAP Cimento Asfáltico de Petróleo

$\mathrm{CAP}_{\mathrm{p}} \quad$ Quantidade de ligante na mistura

cm Centímetro(s)

CNT Confederação Nacional dos Transportes

D Diâmetro médio do corpo-de-prova; Massa do kitassato cheio de água obtida da curva de calibração

DAP Densidade Aparente do corpo-de-prova

DAPsss Densidade Aparente do corpo-de-prova na condição Saturado Seco Superficialmente

DC Deformação Controlada

DMM Densidade Máxima Medida da mistura

DMN Diâmetro Máximo Nominal

DMT Densidade Máxima Teórica

DNER Departamento Nacional de Estradas de Rodagem

DNIT Departamento Nacional de Infra-estrutura de Transportes

DP Desvio Padrão

DP $P_{\mathrm{CE}} \quad$ Deformação Permanente medida no ensaio de "Creep" Estático

$\mathrm{DR}_{\mathrm{CE}} \quad$ Deformação Recuperável medida no ensaio de "Creep" Estático

DT 

$\mathrm{DT}_{\mathrm{CE}} \quad$ Deformação Total medida no ensaio de "Creep" Estático
$d_{x} \quad$ Distância entre os níveis do fator quantitativo $x$
E Estabilidade; Massa da amostra + kitassato modificado completo com água; Tempo de envelhecimento da mistura
EE $\quad$ Estimativa de Erro do Desvio Padrão
EESC Escola de Engenharia de São Carlos
ELSYM5 Elastic Layer System
ES Especificação de Serviço
ESALS Número equivalente de operações do eixo padrão
EVA Etileno Acetato de Vinila
f Porcentagem passada na peneira $0,075 \mathrm{~mm}$
F Fluência; Carga de ruptura; Carga vertical repetida aplicada diametralmente no corpo-de-prova
$\mathrm{F}_{0} \quad$ Valor de $\mathrm{F}$ para a variável analisada
FC Fator de Controle
FCL Fator Campo-Laboratório
FHWA Federal Highway Administration
FN Número de Fluência
FORTRAN Formula Translator
FT Tempo de Fluência
g Grama(s); Porcentagem passada na peneira $9,52 \mathrm{~mm}$ e retida na peneira $4,76 \mathrm{~mm}$
G Porcentagem retida na peneira $9,52 \mathrm{~mm}$
GL $\quad$ Grau(s) de Liberdade
$\mathrm{G}_{\mathrm{sb} 1} \quad$ Massa específica da pedra 1
$\mathrm{G}_{\mathrm{sb2}} \quad$ Massa específica do pedrisco
h Hora(s)
H Altura média do corpo-de-prova 
IDOT Departamento de Transportes de Illinois

I Inclinação da curva no estágio secundário de "creep" dinâmico

I Inclinação da curva no estágio secundário de "creep" estático

kg Quilograma

kgf Quilograma-força

LVDT Linear Variable Differential Transformers

m Metro(s); Módulo de riqueza em asfalto

M Massa inicial do corpo-de-prova

M' Massa final do corpo-de-prova

Ma Massa do agregado

MA Massa ao Ar do corpo-de-prova

MAsss Massa ao $\mathrm{Ar}$ do corpo-de-prova na condição Seco Saturado Superficialmente

$\mathrm{M}_{\mathrm{c}} \quad$ Massa do Cilindro

M $\quad$ Massa total de asfalto

M MAP,abs Massa de asfalto absorvido

$\mathrm{M}_{\mathrm{cc}} \quad$ Massa do cilindro com agregado

$\mathrm{M}_{\mathrm{cf}} \quad$ Massa do cilindro com agregado fino

$\mathrm{M}_{\mathrm{cv}} \quad$ Massa do cilindro vazio

ME Metodologia de Ensaio

MEC Massa Específica Compactada do agregado fino

$\mathrm{MEE}_{\mathrm{f}} \quad$ Massa Específica Escolhida para o agregado fino

MEE $_{g} \quad$ Massa Específica Escolhida para o agregado graúdo

MEM Massa específica da mistura

MES Massa Especifica Solta

MES $_{d} \quad$ Massa Especifica Solta Desejada

$\mathrm{MF}_{3600} \quad$ Módulo de Fluência medido aos 3600 segundos no ensaio de "creep" estático 


\begin{tabular}{|c|c|}
\hline $\mathrm{MF}_{4500}$ & $\begin{array}{l}\text { Módulo de Fluência medido aos } 4500 \text { segundos no ensaio de "creep" } \\
\text { estático }\end{array}$ \\
\hline $\mathrm{MF}_{\mathrm{CD}}$ & Módulo de Fluência medido no ensaio de "creep" dinâmico \\
\hline MI & Índice de Fluidez; Massa Imersa do corpo-de-prova \\
\hline $\min$ & Minuto(s) \\
\hline $\mathrm{mm}$ & Milímetro(s) \\
\hline $\mathrm{MPa}$ & Mega Pascal \\
\hline MR & Módulo de Resiliência por compressão diametral \\
\hline $\mathrm{MR}_{\text {inst }}$ & Módulo de Resiliência Instantâneo \\
\hline $\mathrm{MR}_{\text {total }}$ & Módulo de Resiliência Total \\
\hline Mtm & Massa total da mistura \\
\hline $\mathrm{n}$ & Número de amostras analisadas \\
\hline $\mathrm{N}$ & Número de ciclos do eixo padrão \\
\hline NBR & Norma Brasileira \\
\hline $\mathrm{Nf}$ & Vida de fadiga \\
\hline Ns & Vida de serviço \\
\hline PAG & Proporção dos agregados graúdos \\
\hline PC & Policarbonato \\
\hline$P_{\text {ca }}$ & Porcentagem de cimento asfáltico \\
\hline PCP & Peneira de Controle Primário \\
\hline $\mathrm{PCP}_{\mathrm{p}}$ & Quantidade passada na peneira de controle primário \\
\hline PCS & Peneira de Controle Secundário \\
\hline $\mathrm{PCS}_{\mathrm{p}}$ & Peneira de controle secundário \\
\hline PCT & Peneira de Controle Terciário \\
\hline $\mathrm{PCT}_{\mathrm{p}}$ & Peneira de controle terciário \\
\hline PE & Polietileno \\
\hline PET & Poli(Tereftalato de Etileno) \\
\hline PFAF & Proporção fina dos agregados finos \\
\hline
\end{tabular}




\begin{tabular}{|c|c|}
\hline $\mathrm{PFG}_{1}$ & Quantidade de finos na pedra 1 \\
\hline $\mathrm{PFG}_{2}$ & Quantidade de finos no pedrisco \\
\hline PGAF & Proporção graúda dos agregados finos \\
\hline PGF & Quantidade de graúdos no agregado fino \\
\hline$P_{1}(E)$ & Equação polinomial linear correspondente ao fator $\mathrm{E}$ \\
\hline$P_{1}(T)$ & Equação polinomial linear correspondente ao fator $T$ \\
\hline PM & Peneira Média \\
\hline PMMA & Poli(Metilmetacrilato) \\
\hline $\mathrm{PM}_{\mathrm{p}}$ & Quantidade passada na peneira média \\
\hline pol & Polegada(s) \\
\hline PP & Polipropileno \\
\hline$P_{q}(E)$ & Equação polinomial quadrática correspondente ao fator $E$ \\
\hline$P_{q}(T)$ & Equação polinomial quadrática correspondente ao fator $T$ \\
\hline PS & Poliestireno \\
\hline psi & Libra(s) por polegada \\
\hline PU & Poliuretano \\
\hline PVC & Poli(Cloreto de Vinila) \\
\hline QAF & Quantidade de pó de pedra retida na PCP \\
\hline $\mathrm{QAG}_{1}$ & Quantidade de pedra 1 passante na PCP \\
\hline $\mathrm{QAG}_{2}$ & Quantidade de pedrisco passante na PCP \\
\hline QM & Quadrado Médio \\
\hline $\mathrm{R}^{2}$ & Coeficiente de determinação \\
\hline RASF & Resíduo Asfáltico de Petróleo \\
\hline RBV & Relação Betume-Vazios \\
\hline REVAP & Refinaria Henrique Lage \\
\hline RLCT & Repeated-Load Creep Test \\
\hline rpm & Rotações Por Minuto \\
\hline
\end{tabular}


RT Resistência à Tração por compressão diametral estática

RTFOT Rolling Thin Film Oven Test

$\mathrm{S}$

Segundo(s)

S

Massa da amostra na condição saturada seca superficialmente; Superfície específica do agregado

SBR Borracha Estireno Butadieno

SBS Estireno Butadieno Estireno

SQ Soma dos Quadrados

sSF Segundos Saybolt-Furol

SSS Saturado Superfície Seca

SST Superpave Shear Tester

T Temperatura; Teor de EVA na mistura

TC Tensão Controlada

$\mathrm{T}_{\mathrm{ca}} \quad$ Teor de cimento asfáltico em relação à massa do agregado mineral

T' $\quad$ Teor de cimento asfáltico corrigido

TFOT Thin Film Oven Test

TPU Poliuretano Termoplástico

USP Universidade de São Paulo

VA $\quad$ Acetato de Vinila

VAG Vazios no Agregado Graúdo

VAM Vazios do Agregado Mineral

$\mathrm{V}_{\mathrm{ap}} \quad$ Volume aparente do agregado

$\mathrm{V}_{\mathrm{c}} \quad$ Volume do cilindro

$V_{\text {cap }} \quad$ Volume de vazios preenchido pelo cimento asfáltico

$\mathrm{V}_{\mathrm{CAP}, \mathrm{abs}} \quad$ Volume de asfalto absorvido

VCP Volume do Corpo-de-prova

$V_{\text {ef }} \quad$ Volume efetivo do agregado

Vtm Volume total da mistura 


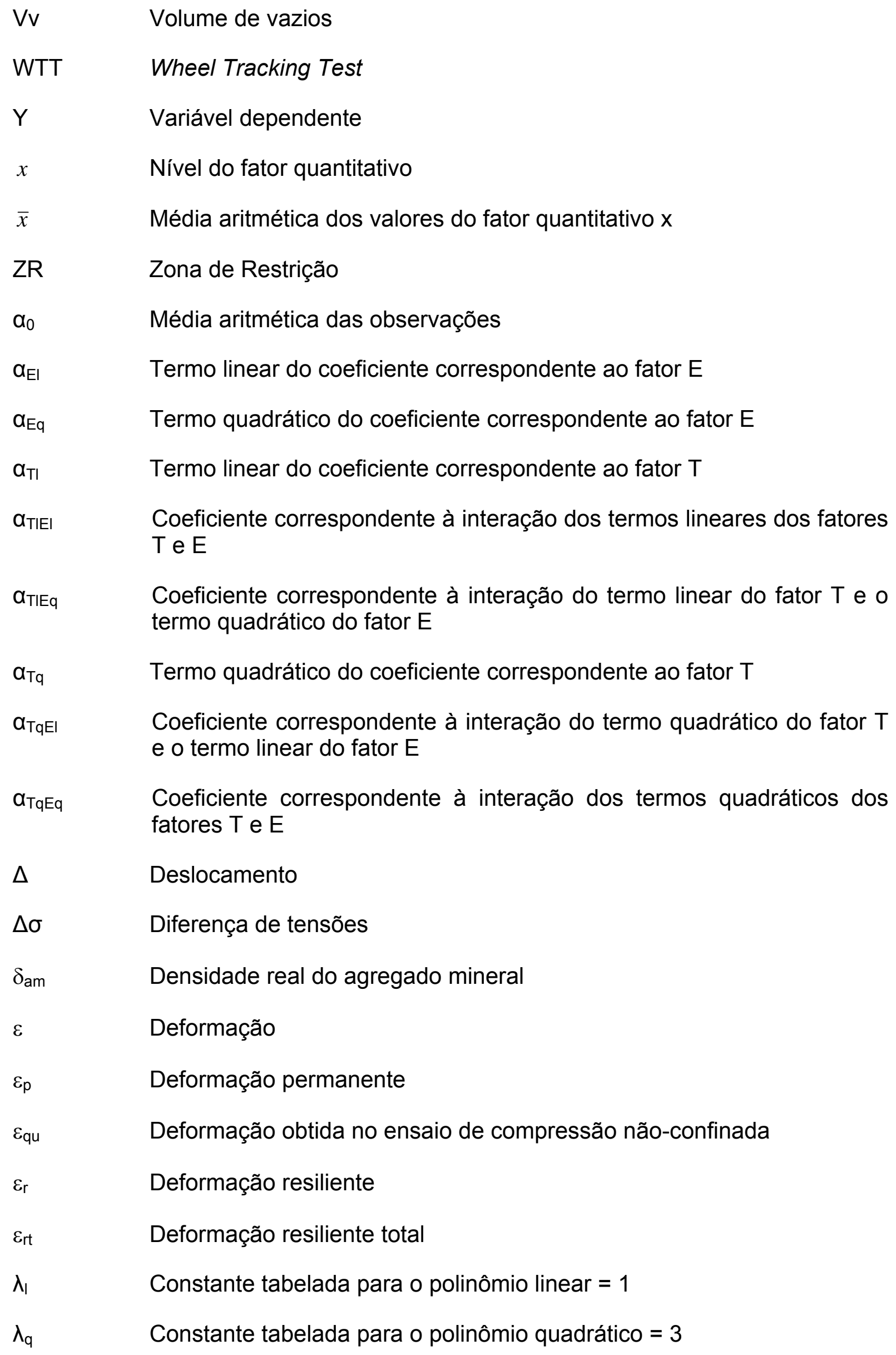




$\begin{array}{ll}\mu & \text { Coeficiente de Poisson } \\ \pi & \mathrm{Pi}=3,141593 \\ \rho_{\mathrm{af}} & \text { Massa específica real do agregado fino } \\ \rho_{\mathrm{ag}} & \text { Massa específica real do agregado graúdo } \\ \rho_{\text {água }} & \text { Massa específica da água na temperatura do ensaio } \\ \rho_{\mathrm{ap}} & \text { Massa específica aparente do agregado } \\ \rho_{\mathrm{ap}, \text { af }} & \text { Massa específica aparente do agregado fino } \\ \rho_{\mathrm{CAP}} & \text { Massa específica do ligante asfáltico } \\ \rho_{\mathrm{ef}} & \text { Massa específica efetiva do agregado } \\ \sigma & \text { Tensão } \\ \sigma_{\mathrm{c}} & \text { Tensão de compressão } \\ \sigma_{\mathrm{t}} & \text { Tensão de tração; Resistência à tração } \\ { }^{\circ} \mathrm{C} & \text { Graus Celsius }\end{array}$





\section{SUMÁRIO}

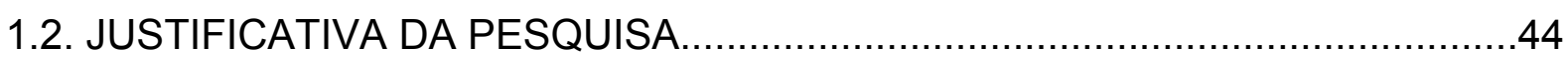

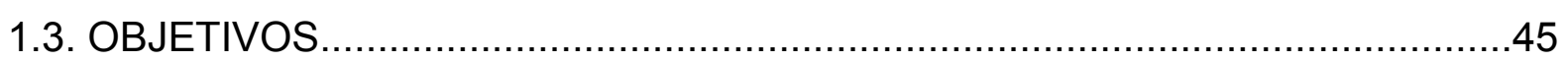

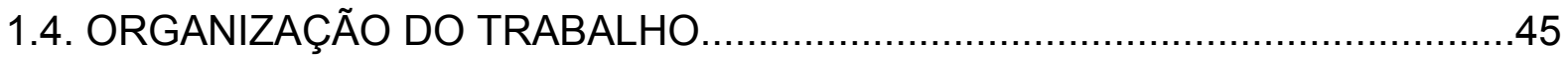

2. REVISÃO BIBLIOGRÁFICA

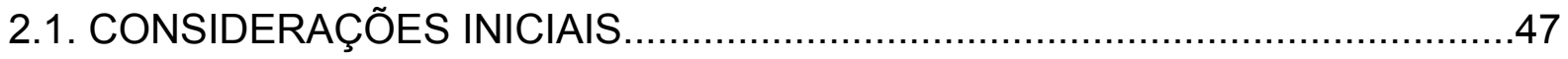

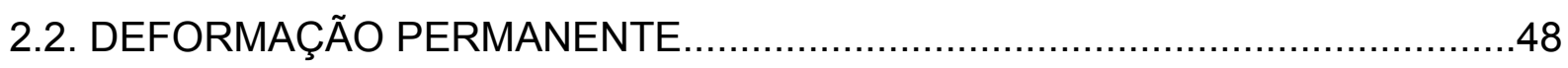

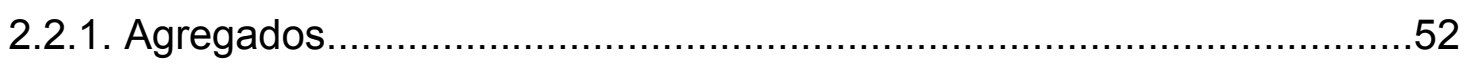

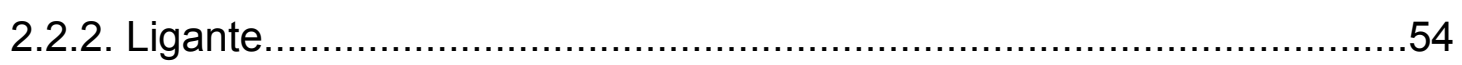

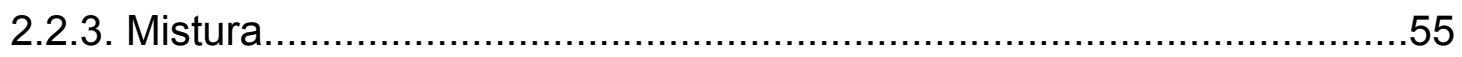

2.2.4. Métodos de ensaios para avaliar deformação permanente....................56

2.2.4.1. Fluência por compressão uniaxial...............................................57

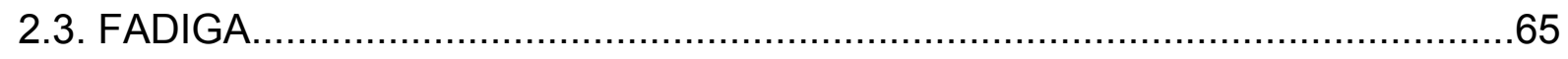

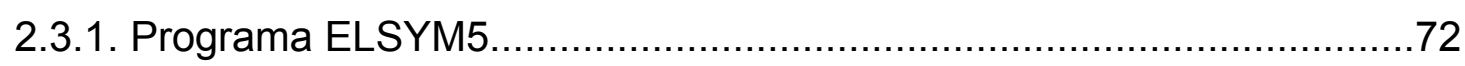

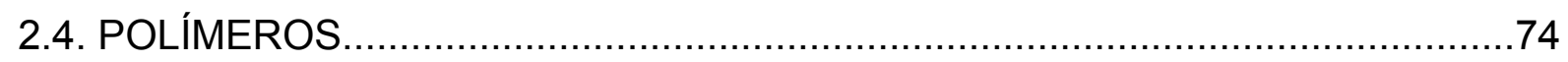

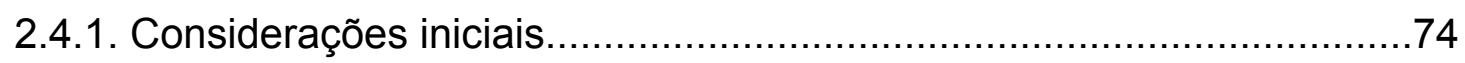

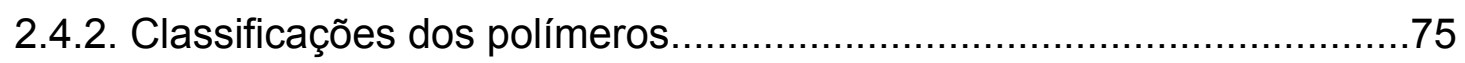

2.4.2.1. Quanto à disposição dos meros...........................................76

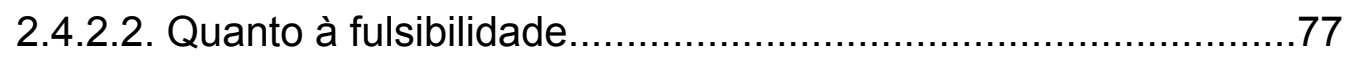

2.4.2.3. Quanto ao comportamento mecânico.....................................77

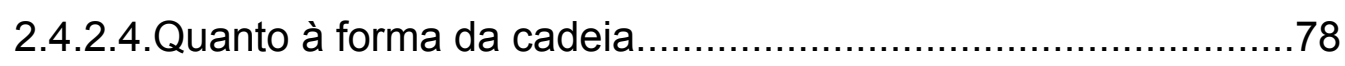

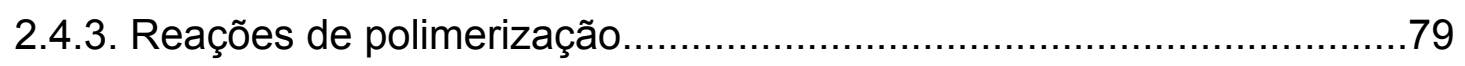

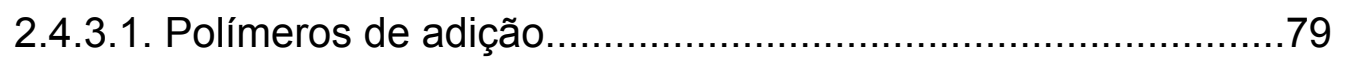

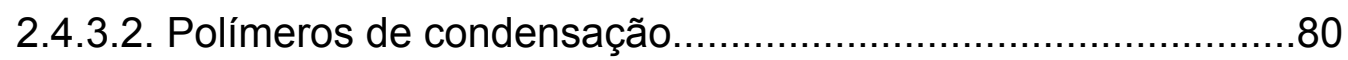




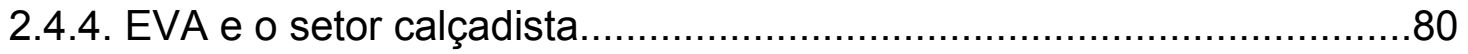

2.5. MÉTODO BAILEY DE SELEÇÃO GRANULOMÉTRICA.................................84

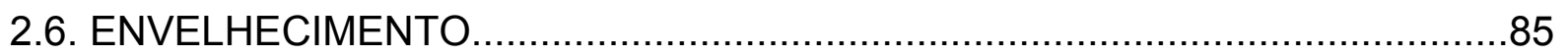

3. MATERIAIS E MÉTODOS 93

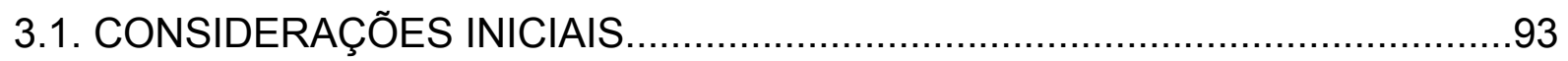

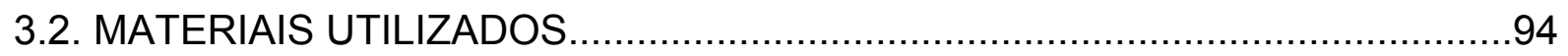

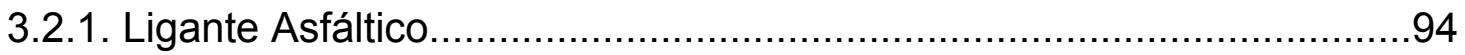

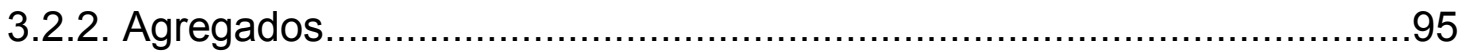

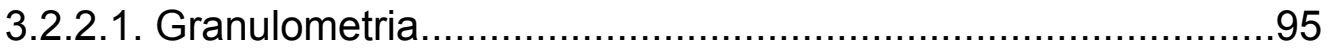

3.2.2.2. Absorção e massa específica do agregado graúdo.................96

3.2.2.3. Absorção e massa específica do agregado fino......................97

3.2.2.4. Ensaio de abrasão "Los Angeles".........................................103

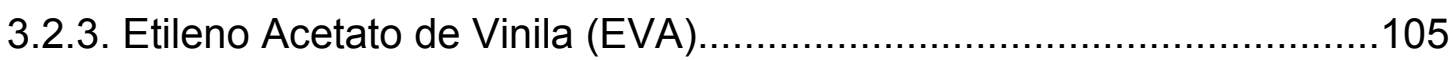

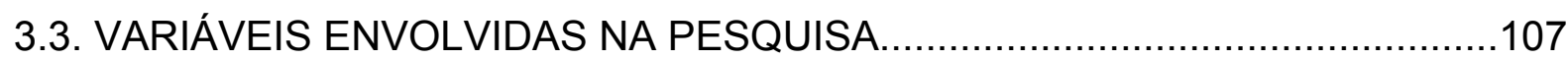

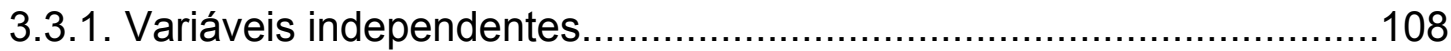

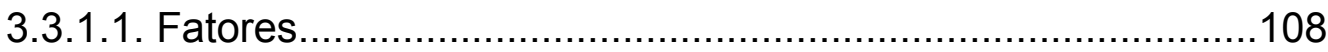

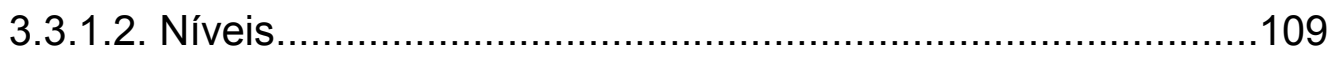

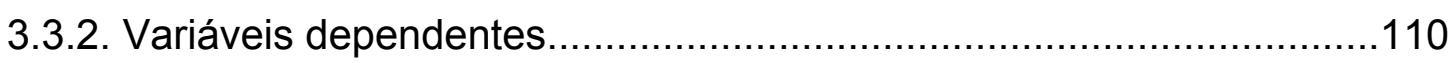

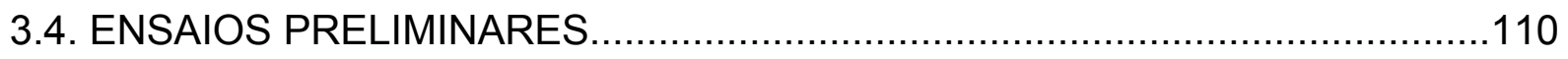

3.4.1. Método Bailey de seleção granulométrica........................................111

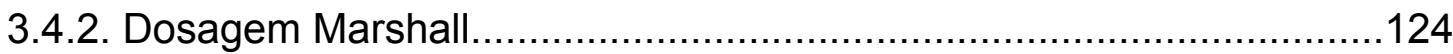

3.4.2.1. Temperatura de mistura e compactação..............................124

3.4.2.2. Determinação do teor ótimo provável de ligante asfáltico.....125

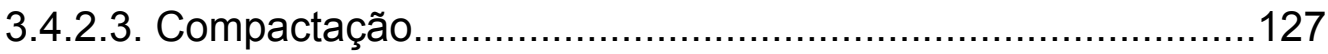

3.4.2.4. Densidade aparente dos corpos-de-prova............................131

3.4.2.5. Densidade máxima teórica da mistura..................................132

3.4.2.6. Volume de vazios.......................................................132

3.4.2.7. Vazios preenchidos com cimento asfáltico...........................134

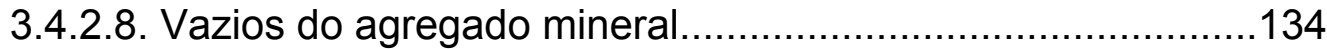

3.4.2.9. Relação betume-vazios..................................................137

3.4.3. Densidade máxima medida e absorção de misturas asfálticas...........139 
3.4.3.1. Preparação das amostras. 139

3.4.3.2. Determinação da densidade máxima medida. 139

3.4.3.3. Determinação da densidade efetiva do agregado. 142

3.4.3.4. Determinação da absorção 144

3.5. ENSAIOS PARA A DETERMINAÇÃO DE PROPRIEDADES MECÂNICAS....146

3.5.1. Resistência à tração por compressão diametral estática. 146

3.5.2. Módulo de resiliência por compressão diametral... 149

3.5.3. Fluência por compressão uniaxial estática ("creep" estático). 155

3.5.4. Fluência por compressão uniaxial dinâmica ("creep" dinâmico). 159

3.5.5. Vida de fadiga. 161

3.5.6. Desgaste por abrasão no ensaio Cantabro. 164

3.6. RESUMO DA PROGRAMAÇÃO EXPERIMENTAL 165

4.1. CONSIDERAÇÕES INICIAIS 167

4.2. MODELOS DE REGRESSÃO. 168

4.3. DOSAGEM MARSHALL.

4.4. ENSAIOS EXPLORATÓRIOS 176

4.5. PROGRAMA EXPERIMENTAL. 179

4.5.1. Módulo de resiliência por compressão diametral dinâmica 179

4.5.1.1. Análise da variância e modelo estatístico do módulo de resiliência.

4.5.2. Resistência à tração por compressão diametral estática 183

4.5.2.1. Análise da variância e modelo estatístico de resistência à tração. 186

4.5.3. Relação MR/RT. 187

4.5.4. Vida de Fadiga. 189

4.5.5.1. Simulação de tensões utilizando o programa ELSYM5

4.5.5. Fluência por compressão uniaxial estática.

4.5.4.1. Análise da variância no ensaio de fluência por compressão uniaxial estática.

4.5.5. Fluência por compressão uniaxial dinâmica. 
4.5.4.2. Análise da variância e modelos estatísticos para os parâmetros do ensaio de fluência por compressão uniaxial dinâmica.....231

4.5.6. Desgaste por abrasão (Cantabro) ...........................................234

4.5.4.2. Análise da variância e modelo estatístico do desgaste por abrasão. 236

5.1. CONSIDERAÇÕES INICIAIS 237

5.2. MÓDULO DE RESILIÊNCIA POR COMPRESSÃO DIAMETRAL...................238

5.3. RESISTÊNCIA À TRAÇÃO POR COMPRESSÃO DIAMETRAL ESTÁTICA...239

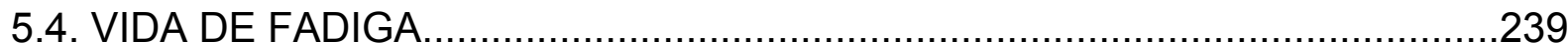

5.5. FLUÊNCIA POR COMPRESSÃO UNIAXIAL ESTÁTICA ...........................240

5.6. FLUÊNCIA POR COMPRESSÃO UNIAXIAL DINÂMICA ..............................241

5.7. DESGASTE POR ABRASÃO NO ENSAIO CANTABRO $\ldots \ldots \ldots \ldots \ldots \ldots \ldots \ldots \ldots . . . . . . . . . . . . . . . . . .242$

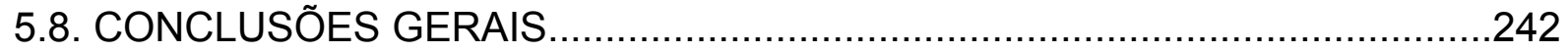

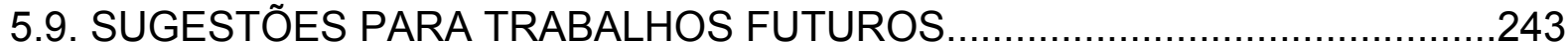

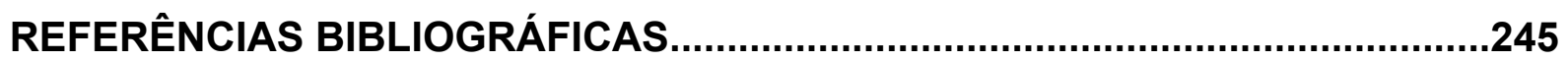

APÊNDICE A. Método Bailey .....................................................................255

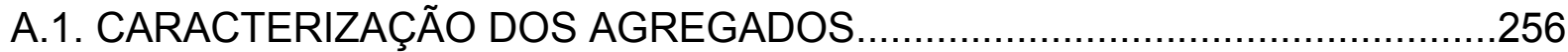

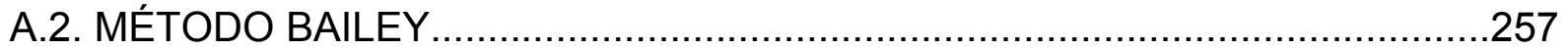

A.2.1. Massas específicas escolhidas...............................................257

A.2.2. Contribuição inicial dos agregados...........................................258

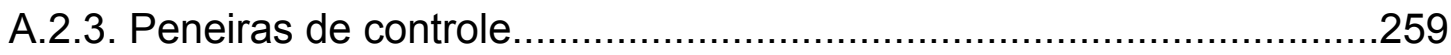

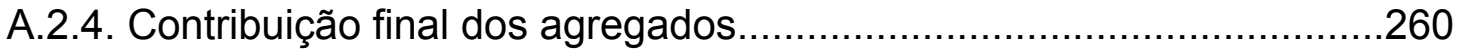

A.2.5. Curva granulométrica...............................................................261

A.2.6. Parâmetros de controle ............................................................262 


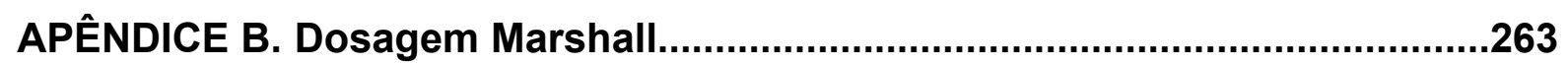

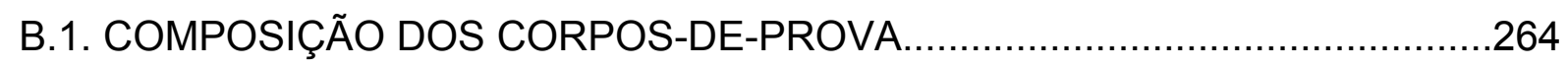

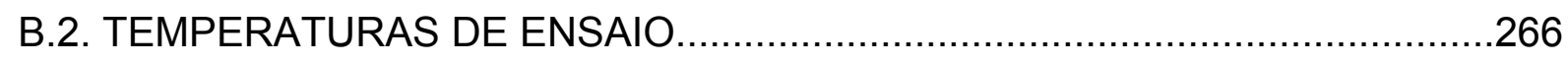

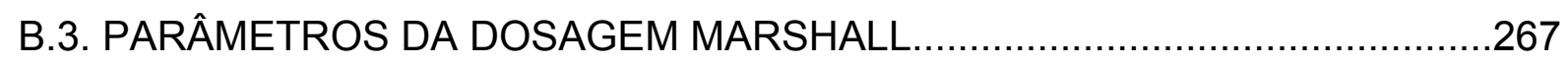

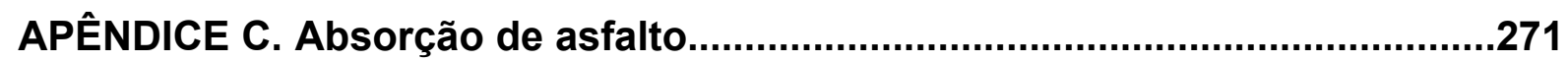

APÊNDICE D. Características volumétricas dos corpos-de-

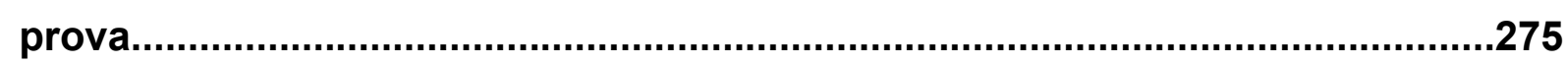

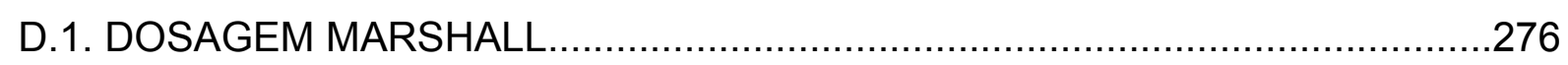

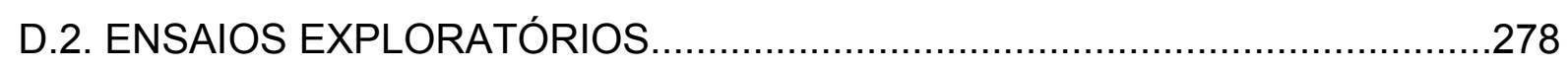

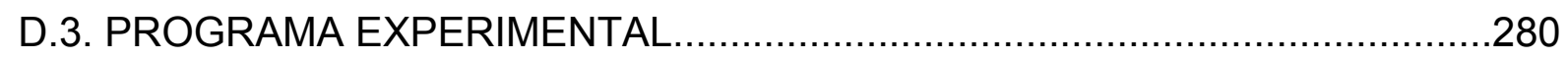

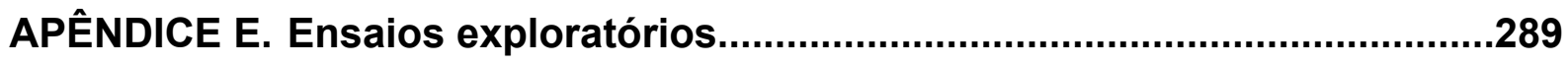

APÊNDICE F. Módulos de resiliência por compressão diametral......................293

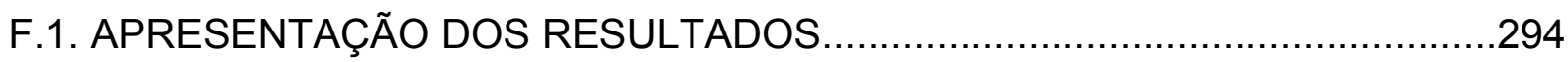

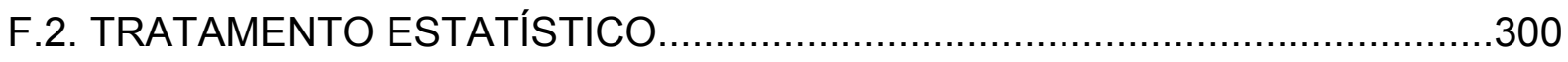

APÊNDICE G. Resistência à tração por compressão diametral

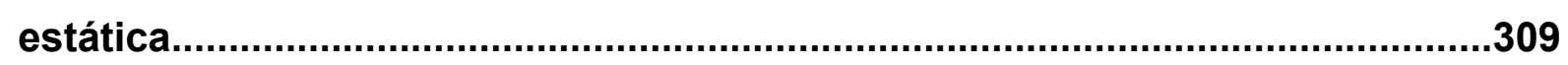

APÊNDICE H. Fluência por compressão uniaxial estática...............................313

APÊNDICE I. Fluência por compressão uniaxial dinâmica................................323

APÊNDICE J. Desgaste por abrasão no ensaio Cantabro. 

O degrau de uma escada não serve simplesmente para que alguém permaneça em cima dele, destina-se a sustentar o pé de um homem pelo tempo suficiente para que ele coloque o outro um pouco mais alto.

(Thomas Huxley)

\section{INTRUDUÇÃo}

A malha rodoviária nacional segundo uma pesquisa da Confederação Nacional dos Transportes (CNT) de 2005, em seus diversos níveis (federal, estadual e municipal), é de aproximadamente 1,6 milhão de quilômetros, porém somente 180 mil quilômetros estão pavimentados, ou seja, pouco mais que $10 \%$ do total, valor írisório perto dos verificados em países desenvolvidos, como por exemplo a Alemanha, onde aproximadamente $98 \%$ de suas rodovias são pavimentadas. Outro agravante é a condição atual da malha rodoviária, que tem mais de $70 \%$ de sua extensão classificada como deficiente, ruim ou péssima, com relação ao pavimento, sinalização e geometria. Já que as rodovias brasileiras respondem por $46,6 \%$ do volume total de cargas transportadas e $61,1 \%$ do total de toneladas-quilômetro e, 
considerando a pesquisa da CNT e também que a maior parte dessas cargas transportadas se dá através de rodovias pavimentadas, fica evidenciado o déficit qualitativo e quantitativo.

A expansão da indústria automobilística, por volta da década de 50 , juntamente com os baixos preços dos derivados de petróleo, fez com que a modalidade rodoviária de transporte de cargas fosse escolhida como o principal meio de transporte no Brasil, sendo quase exclusiva até a década de 70 . A partir da década de 80 , o investimento público em setores como o de transportes foi indiscriminadamente diminuído devido, principalmente, ao aumento do preço do petróleo e políticas de combate à inflação e de redução da dívida externa, resultando não só no adiamento de projetos, mas também na não manutenção e conservação das rodovias existentes, justificados através da necessidade de cortes no orçamento.

Para que um pavimento tenha um bom desempenho, ou seja, suporte as ações do tráfego e intempéries durante o seu período de vida de projeto, são necessários o conhecimento das características dos materiais que o compõe, a utilização de um bom método de dimensionamento e um trabalho de conservação e manutenção preventivo e corretivo ao longo do tempo. Por estudos laboratoriais pode-se conhecer o comportamento dos materiais e, então, criar modelos que os represente da melhor maneira possível, permitindo um dimensionamento mais preciso e, por conseguinte, uma redução nos custos.

Com o intuito de melhorar a camada de concreto asfáltico dos pavimentos, para prevenir ou postergar o aparecimento de defeitos, aumentando assim a vida útil do 
pavimento, tem-se estudado não somente os materiais que comumente compõem uma mistura asfáltica (pedra, fíler mineral e ligante asfáltico), mas também modificadores, que podem ser materiais termoplásticos ou termorrígidos, borracha, elastômeros, entre outros.

A utilização de modificadores tem a finalidade de melhorar características do concreto asfáltico, como a suscetibilidade térmica, a coesão, a elasticidade e a resistência à fadiga e ao desgaste.

Os métodos de inserção desses modificadores nas misturas asfáltica são basicamente dois:

i. Processo úmido: o modificador, na forma de partículas muito pequenas, é incorporado ao ligante;

ii. Processo seco: o modificador é incorporado à mistura como parte dos agregados, portanto, em partículas de maior tamanho.

O processo seco demanda menos energia (menor custo), pois o modificador utilizado não necessita de moagem, porém as pesquisas têm sido direcionadas, em sua maioria, às misturas asfálticas modificadas pelo processo úmido, com destaque para os modificadores borracha reciclada de pneus (BRP), estireno butadieno estireno (SBS), borracha estireno butadieno (SBR) e etileno acetato de vinila (EVA). 


\subsection{JUSTIFICATIVA DA PESQUISA}

Um dos maiores problemas da humanidade é o descarte do lixo. A cada dia, toneladas e mais toneladas são descartadas de forma inadequada, causando sérios problemas ao meio ambiente. O desenvolvimento sustentável deve ser tomado como meta para que um país possa crescer, evoluir e mesmo assim garantir uma vida adequada às gerações futuras. Com base no conceito de desenvolvimento sustentável e da utilização de técnicas de reuso e reciclagem, muito dos rejeitos, outrora considerados lixo, tornaram-se matéria-prima, o que fez com que a exploração dos recursos naturais e o montante de resíduos depositados no meio ambiente diminuíssem.

O EVA provindo de resíduos das placas expandidas utilizadas pela indústria calçadista na confecção de palmilhas é direcionado aos aterros sanitários e/ou lixões e, embora não seja um material tóxico, ele não apresenta características biodegradáveis e é descartado em grande quantidade, já que cerca de $15 \%$ a $20 \%$ das placas expandidas são desperdiçadas na forma de aparas.

Visto o potencial de pavimentação que o Brasil possui e devido ao destino inadequado dos rejeitos de EVA das placas expandidas, houve a motivação para o estudo de sua inserção, utilizando-se o processo seco, em misturas asfálticas com o intuito de dar um destino adequado aos rejeitos, bem como melhorar as características mecânicas das misturas. 


\subsection{OBJETIVOS}

O objetivo geral deste trabalho consiste em estudar a influência da adição do copolímero EVA em misturas asfálticas, pelo processo seco, com relação às propriedades mecânicas e a resistência ao desgaste.

Os objetivos específicos deste trabalho são:

- estudar o efeito da porcentagem de resíduos a ser utilizada, em volume, em substituição ao agregado;

- quantificar as propriedades mecânicas de misturas asfálticas modificadas com EVA e comparar com misturas asfálticas "convencionais";

- analisar a influência do tempo de envelhecimento de curto prazo ("tempo de digestão");

- verificar se há vantagens resultantes da utilização do copolímero EVA em misturas asfálticas quanto à diminuição do passivo ambiental.

\subsection{ORGANIZAÇÃO DO TRABALHO}

Este trabalho está dividido em cinco capítulos. No Capítulo 2, encontra-se a revisão bibliográfica acerca dos principais tipos de defeitos em estudo na pesquisa (deformação permanente e fadiga) e como os materiais que compõem uma mistura asfáltica os afetam. Também se encontram revisões acerca: dos métodos de ensaio propostos por outros pesquisadores; do programa ELSYM5; de polímeros; do EVA e 
a indústria calçadista; do método Bailey de seleção granulométrica e; do envelhecimento.

O Capítulo 3 trata: da obtenção, preparação, classificação e caracterização dos materiais utilizados na pesquisa (ligante asfáltico, agregados e resíduo), das variáveis envolvidas na pesquisa (fatores e níveis); dos ensaios para determinação dos teores de resíduo a serem incorporados nas misturas asfálticas; da composição da curva granulométrica através do método Bailey; da dosagem e compactação pelo método Marshall; dos ensaios realizados (resistência à tração por compressão diametral estática, módulo de resiliência por compressão diametral, fluência por compressão uniaxial estática e dinâmica, vida de fadiga e desgaste por abrasão) e; um resumo do programa experimental.

No Capítulo 4 são apresentados os resultados dos ensaios, propostos modelos estatísticos calibrados com os parâmetros significantes do teste $F$ e são feitos breves comentários acerca dos resultados.

No Capítulo 5 encontram-se as conclusões e constatações decorrentes das análises dos resultados e as sugestões para os trabalhos futuros. 
A maior parte do tempo de um escritor é passado na leitura, para depois escrever: uma pessoa revira metade de uma biblioteca para fazer um só livro.

(Samuel Jhonson)

\section{REVISÃO BIBLIOGRÁFICA}

\subsection{CONSIDERAÇÕES INICIAIS}

Este capítulo traz uma revisão acerca dos principais defeitos em pavimentos asfálticos, método de seleção granulométrica dos agregados, polímeros e envelhecimento de misturas asfálticas.

A função de um pavimento é proporcionar economia, segurança e conforto ao usuário da via, porém esses parâmetros ficam comprometidos à medida que surgem defeitos no pavimento, reduzindo o seu desempenho ou serventia. 
Os principais defeitos nos pavimentos são as deformações permanentes encontradas nas trilhas de roda e as trincas por fadiga, cada um associado principalmente a uma etapa de vida do pavimento. As deformações permanentes geralmente aparecem nos primeiros anos de vida do pavimento, o qual está mais sujeito à consolidação e às deformações cisalhantes plásticas. Por outro lado, as trincas por fadiga aparecem normalmente quando o pavimento asfáltico está mais envelhecido e, após ser submetido às cargas cíclicas, já não oferece boa resposta. Apesar de muitos fatores influenciarem esses tipos de defeitos, as deformações permanentes estão mais relacionadas às propriedades dos agregados e da seleção granulométrica, enquanto que a fadiga está relacionada à flexibilidade das camadas do pavimento.

\subsection{DEFORMAÇÃO PERMANENTE}

O pavimento flexível apresenta uma deformação ao ser submetido a uma carga. Quando essa deformação é plástica, recebe o nome de deformação permanente. Esse tipo de defeito causa grande preocupação quando aparece de forma prematura e excessiva.

Diversos autores, entre eles Motta e Pinto (1994), relatam que a deformação permanente é um dos principais mecanismos que determinam a vida útil de um pavimento.

Coelho (1996) cita dois problemas com relação às deformações permanentes: (i) a configuração de um quadro de aquaplanagem, quando a camada superficial do 
pavimento é impermeável e no canal formado pelas trilhas de roda há uma lâmina d'água; (ii) os veículos leves têm uma pior dirigibilidade nos casos de deformações permanentes excessivas, havendo, portanto, redução na segurança, além do comprometimento da estética ou até da estrutura do pavimento.

A deformação permanente ocorre por consolidação (ou densificação) e por deformação cisalhante. A consolidação é a compactação que ocorre no pavimento, pelo tráfego, após a sua construção, devido ao fato do teor de vazios da mistura asfáltica compactada ser maior que o de projeto, dessa forma, a ação de um tráfego canalizado faz com que haja uma densificação nas áreas das trilhas de roda, reduzindo o teor de vazios ao de projeto e completando, assim, a compactação (ROBERTS et al., 1991).

De acordo com diversos autores, a deformação permanente pode se dar por movimentação plástica, por consolidação ou por deformação mecânica. A deformação permanente causada pela movimentação plástica apresenta uma depressão no centro da aplicação das cargas pelos veículos com elevações de ambos os lados e ocorre geralmente quando o volume de vazios é menor que $4 \%$ e/ou a temperatura ambiente é muito alta, fazendo com que o ligante atue como um lubrificante. A deformação permanente ocorrida por consolidação tem como característica as depressões nas trilhas de roda e, normalmente, ocorre quando o volume de vazios da mistura é maior que $8 \%$, ocasionando a compactação da camada asfáltica pelo tráfego. Já a deformação permanente ocasionada por deformação mecânica apresenta o afundamento de outras camadas do pavimento além da capa asfáltica e aparece juntamente com trincas de tração na parte inferior 
da capa asfáltica, geralmente em pavimentos com estrutura mal dimensionada para o tráfego ao qual deve suportar.

A Figura 2.1a mostra um exemplo de deformação permanente causada pela compactação pós-construção e a Figura 2.1b mostra um exemplo de deformação permanente causada pelo rompimento das camadas do pavimento. (adaptado de THIESSEN; SHALABY; KAVANAGH; 2000).

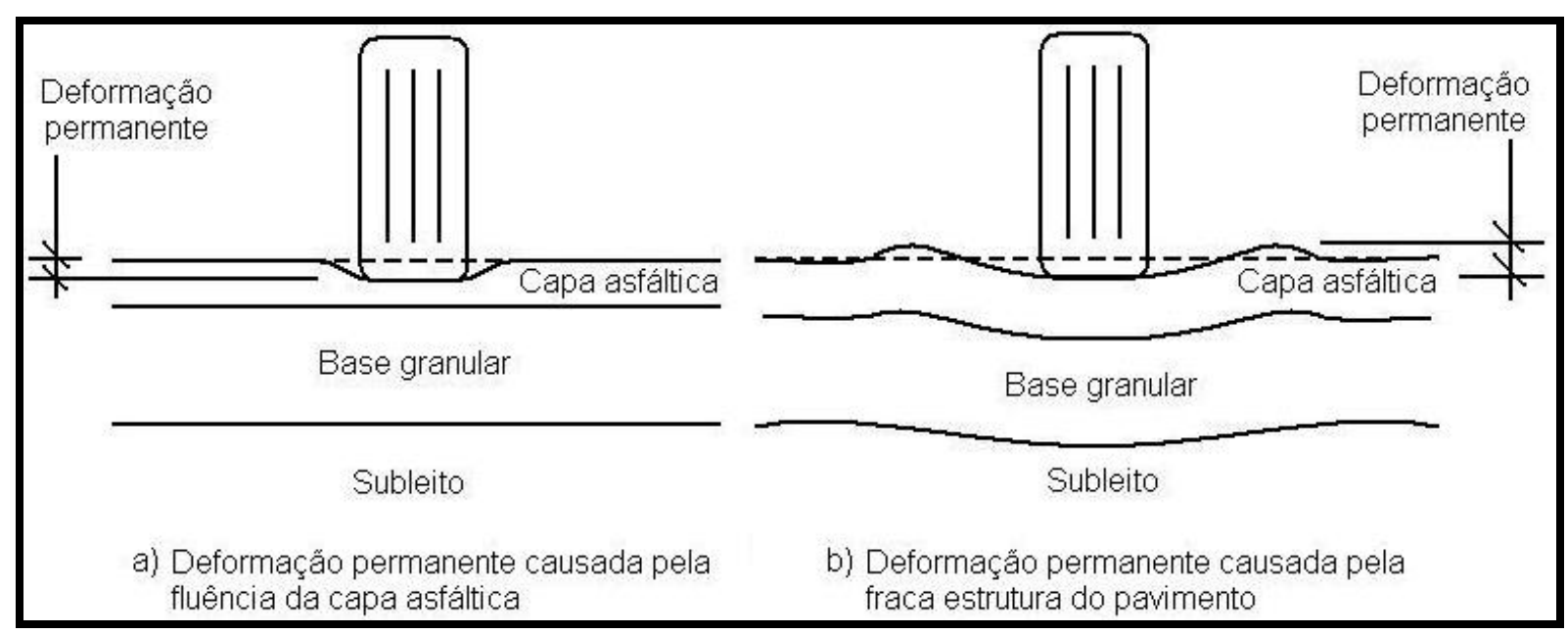

FONTE: Adaptado de Thiessen, Shalaby e Kavanagh, 2000.

Figura 2.1. Exemplos de deformação permanente encontrada nas trilhas de roda.

A Tabela 2.1, adaptada de Souza, Craus e Monismith (1991), mostra como a mudança de alguns fatores influi nas deformações permanentes. 
Tabela 2.1 - Fatores que influem na deformação permanente em concretos asfálticos.

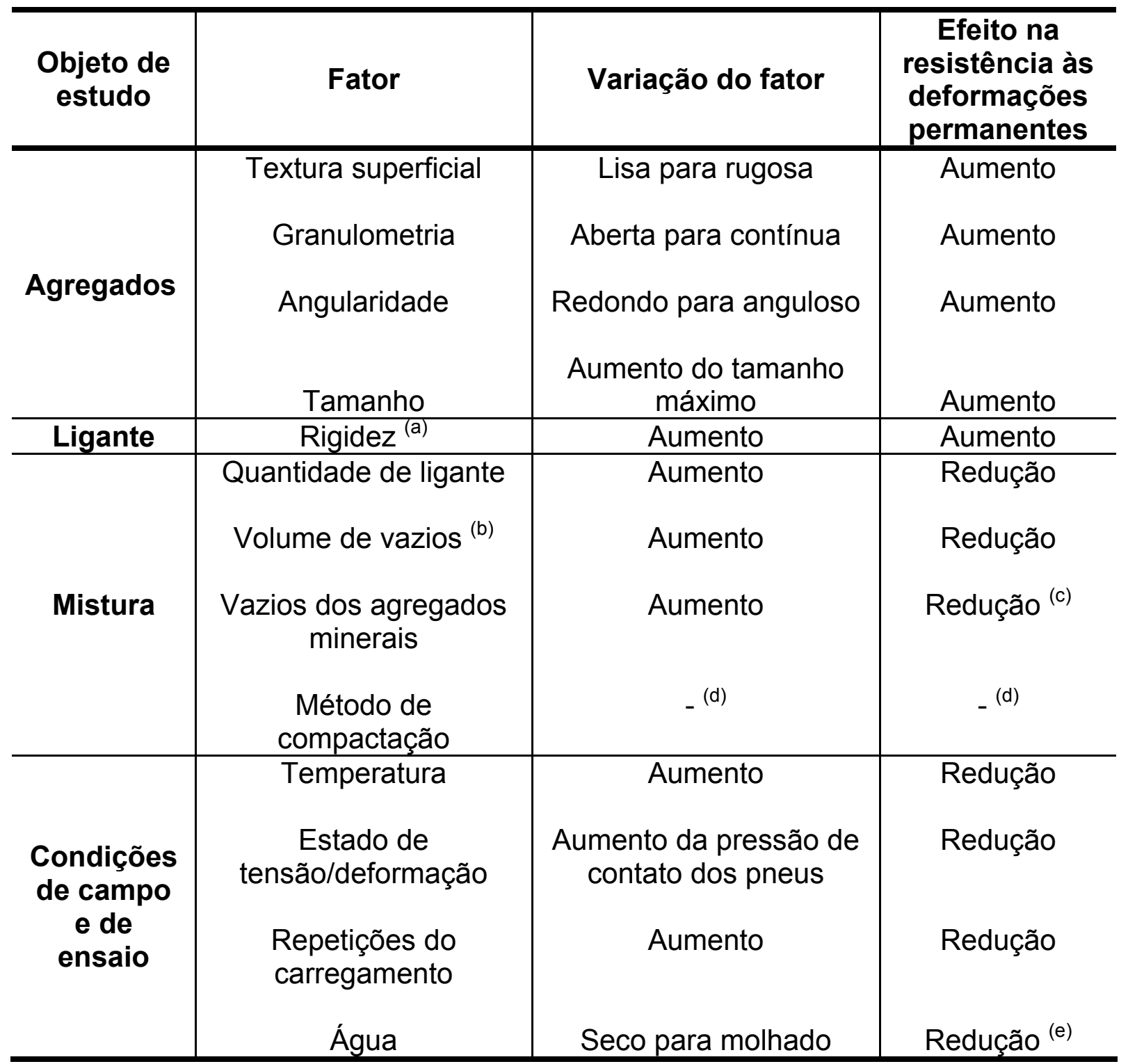

(a) Refere-se à rigidez na temperatura em que a propensão às deformações permanentes está sendo determinada. A adição de produtos modificadores das características do ligante pode ser usada para aumentar a rigidez do material nas temperaturas críticas.

(b) Quando o volume de vazios for inferior a 3\%, a propensão às deformações permanentes aumenta.

(c) Valores de VAM muito baixos ( $<10 \%)$ devem ser evitados.

(d) O método de compactação, tanto no campo quanto em laboratório, pode influenciar na estrutura do material e, portanto, na sua propensão às deformações permanentes.

(e) Se a mistura for sensível à água. 
Souza, Craus e Monismith (1991) relataram que, embora a densificação das misturas asfálticas (mudança de volume) tenham algum efeito sobre as deformações permanentes, a principal causa para esse defeito são as repetitivas deformações cisalhantes causadas pelos carregamentos do tráfego. Os mesmos autores ainda citaram que entre os principais fatores que afetam as deformações permanentes estão a magnitude do carregamento aplicado pela pressão dos pneus, o volume de tráfego, o ambiente térmico e as variações das propriedades da mistura, como as características dos agregados (especificamente textura superficial, angularidade e graduação) e o teor e a rigidez do ligante.

\subsubsection{Agregados}

Muitos dos esforços realizados para solucionar o problema de deformação permanente estão focados no estudo dos agregados, visto que a experiência tem demonstrado que este é o fator mais relevante ao se tratar desse tipo de defeito. Estudos realizados por Button, Perdomo e Lytton (1990) mostram que as misturas asfálticas que contêm areia natural (arredondada) se deformam plasticamente mais rapidamente que misturas asfálticas que contêm partículas britadas (angulares), sob a ação de cargas estáticas ou dinâmicas. A deformação permanente pode ser minimizada utilizando-se agregados de maior diâmetro máximo nominal (DMN), de forma angular e textura rugosa (ROBERTS et al., 1991).

Nas especificações SUPERPAVE há uma região da curva granulométrica conhecida como zona de restrição (ZR), que varia de acordo com $\mathrm{DMN}$ e serve de guia para assegurar que não seja usada muita areia natural na mistura, como também 
assegura o valor mínimo de VAM requerido. Porém, há alguns tipos de agregados que podem ter sua graduação passando através da zona de restrição e, mesmo assim, apresentar um bom resultado, como citou Gouveia (2002): “Agregados que não possuem excessiva quantidade de partículas arredondadas e que satisfaçam o VAM mínimo podem passar através da zona de restrição e, ainda assim, apresentar desempenho satisfatório". As especificações SUPERPAVE também prevêem alguns limites, denominados pontos de controle, dentro dos quais deve passar a curva granulométrica. A Tabela 2.2, extraída de Motta et al. (1996), mostra os valores de controle volumétrico indicados pelo SUPERPAVE para o DMN de 9,5 mm, que corresponde à composição granulométrica utilizada na pesquisa, para diferentes DMN deve-se utilizar outras tabelas.

Tabela 2.2 - Zona de restrição e pontos de controle para DMN 9,5 mm.

\begin{tabular}{c|c|c|c|c}
\cline { 2 - 5 } Peneira (mm) & \multicolumn{4}{c}{ Porcentagem retida acumulada } \\
\cline { 2 - 5 } & Mónimo & Máximo & Mínimo & Máximo \\
\hline 12,5 & 100,0 & 100,0 & - & - \\
9,5 & 100,0 & 100,0 & - & - \\
4,75 & - & 90,0 & - & - \\
2,36 & 32,0 & 67,0 & 47,2 & 47,2 \\
1,18 & - & - & 31,6 & 37,6 \\
0,60 & - & - & 23,5 & 27,5 \\
0,30 & - & - & 18,7 & 18,7 \\
0,15 & - & - & - & - \\
0,075 & 2,0 & 10,0 & - & - \\
\hline
\end{tabular}

Kandhal e Mallik (2001) realizaram um estudo sobre a zona de restrição na curva granulométrica introduzida pelo SUPERPAVE, utilizando um "Asphalt Pavement Analyzer" (APA), para agregados de origem calcária, cascalhos e granitos. Ao se estudar os agregados de origem calcária e os granitos, os autores verificaram que a 
graduação que passou abaixo da zona de restrição geralmente apresentou maior quantidade de deformação permanente, a que passou através da zona de restrição apresentou as menores quantidades de deformação permanente, enquanto que a graduação que passou acima da zona de restrição apresentou uma quantidade intermediária de deformação permanente. Ao se utilizar cascalho, os autores verificaram que as graduações que passaram abaixo, acima e através da zona de restrição apresentaram deformação permanente menores, maiores e intermediárias, respectivamente.

Ao utilizar o "Superpave Shear Tester" (SST), os autores concluíram que, em termos de pico de deformação cisalhante, não havia diferenças significativas entre as graduações que passaram abaixo, através ou acima da zona de restrição, ao se utilizar granito. No caso do agregado de origem calcária, a curva granulométrica que passou abaixo teve o maior pico de deformação cisalhante (indicativo de potencial de deformação permanente). Já no caso do cascalho, o maior pico se deu na curva que passou acima e o menor valor foi encontrado na curva que passou através da zona de restrição. Os autores da pesquisa deixam a ressalva que o SST não aparenta ser tão sensível às diferentes graduações quanto o APA.

\subsubsection{Ligante}

Embora o ligante não seja o principal fator de importância com relação à deformação permanente, muitos autores, como Mahboub e Little (1988) apud Little, Button e 
Youssef $(1993)^{1}$, citam que a utilização de ligante com maior rigidez minimiza o aparecimento de deformações permanentes. Santanna-Greco (2004) concluiu que misturas envelhecidas apresentam maiores valores de módulo de fluência e menores valores de deformação total, o que indica que um aumento na rigidez do ligante faz com que haja uma redução no potencial de deformação permanente.

\subsubsection{Mistura}

O uso excessivo de ligante diminui o volume de vazios da mistura, porém o volume diminuído é o mesmo que é preenchido pelo ligante e este atua como um lubrificante entre as partículas, o que reduz o atrito interno na mistura e, portanto, aumenta o potencial de deformação permanente.

Zhu, Liu e Fwa (2002) realizaram ensaios em laboratório para prever deformação permanente através do "Wheel Tracking Test" (WTT) e do "Repeated-Load Creep Test” (RLCT). Em ambos os equipamentos os testes foram realizados a $28^{\circ} \mathrm{C}, 40^{\circ} \mathrm{C}$ e $60^{\circ} \mathrm{C}$. As misturas apresentaram maiores tendências à deformação permanente com o aumento da temperatura, como também resistiram menos à deformação permanente com o aumento de carga aplicada. Foram encontradas maiores deformações permanentes no ensaio utilizando o WTT nas menores velocidades, justificadas pelos autores que maiores períodos de carregamentos permitem o desenvolvimento de maior deformação viscosa. Também concluíram que as misturas que utilizaram agregados com superfície mais angular e textura superficial

\footnotetext{
${ }^{1}$ LITTLE, D.N.; BUTTON, J.W.; YOUSSEF, H. (1993). Development of criteria to evaluate uniaxial creep data and asphalt concrete permanent deformation potential. Transportation Research Record, n.1417, p.49-57.
} 
mais rugosa apresentaram maior resistência à deformação permanente, assim como as misturas que utilizaram ligante com ponto de amolecimento mais alto.

\subsubsection{Métodos de ensaios para avaliar deformação permanente}

Segundo Brown, Khandal e Zhang (2001), numerosos métodos de ensaio têm sido usados com o intuito de caracterizar as respostas dos materiais de um pavimento à deformação permanente, podendo ser classificados assim:

i. Ensaios fundamentais:

- Ensaios uniaxial e triaxial: não confinado (uniaxial) e confinado (triaxial);

- Ensaios de cisalhamento;

- Ensaios diametrais: corpos-de-prova cilíndricos (“creep”).

ii. Ensaios empíricos:

- Marshall;

- Hveen;

- Máquina de ensaios giratórios do "Corps of Engineering";

- Indicador de pressão lateral.

iii. Ensaios simulativos:

- "Asphalt Pavement Analyzer" (nova geração do "Georgia Loaded Wheel Tester");

- "Hamburg Wheel-Tracking Device";

- "French Rutting Tester" (“LCPC Wheel Tracker"); 
- "Purdue University Laboratory Wheel Tracking Device";

- "Model Mobile Load Simulator";

- "Dry Wheel Tracker" (“Wessex Engineering”);

- “Rotary Loaded Wheel Tester” (“Rutmeter").

Nessa pesquisa foram utilizados os ensaios de fluência por compressão uniaxial estática e dinâmica e as características desses ensaios estão descritas a seguir.

\subsubsection{Fluência por compressão uniaxial}

O ensaio de fluência por compressão uniaxial, seja confinado ou não, tem sido usado por muitos órgãos para prever deformação permanente. Van de Loo (1976) descreveu o ensaio, explicando que o corpo-de-prova utilizado deve ter as faces paralelas, planas, lisas e bem lubrificadas, a fim de garantir uma tensão uniforme e evitar tensões cisalhantes. O corpo-de-prova deve ser colocado entre dois pratos metálicos, sendo um fixo e o outro móvel. Os deslocamentos são medidos através de dois LVDTs (Linear Variable Differential Transformers) como sendo função do tempo. A temperatura durante o ensaio deve ser mantida constante. $\mathrm{O}$ autor afirmou que quando o resultado do ensaio é expresso com relação à deformação (medida da mudança na altura dividida pela altura original), independe a forma do corpo-deprova e a taxa de variação da altura pelo diâmetro, mantidas as condições de faces paralelas, planas e bem lubrificadas.

Diversos sistemas de carregamento podem ser utilizados para medir a resposta da mistura aos carregamentos repetidos, porém o mais comum é o sistema pneumático 
(SOUZA; CRAUS; MONISMITH; 1991). Esse sistema pode incluir também uma câmara de controle de temperatura.

A Figura 2.2 mostra os gráficos de tensão e deformação do ensaio de fluência por compressão uniaxial estática.

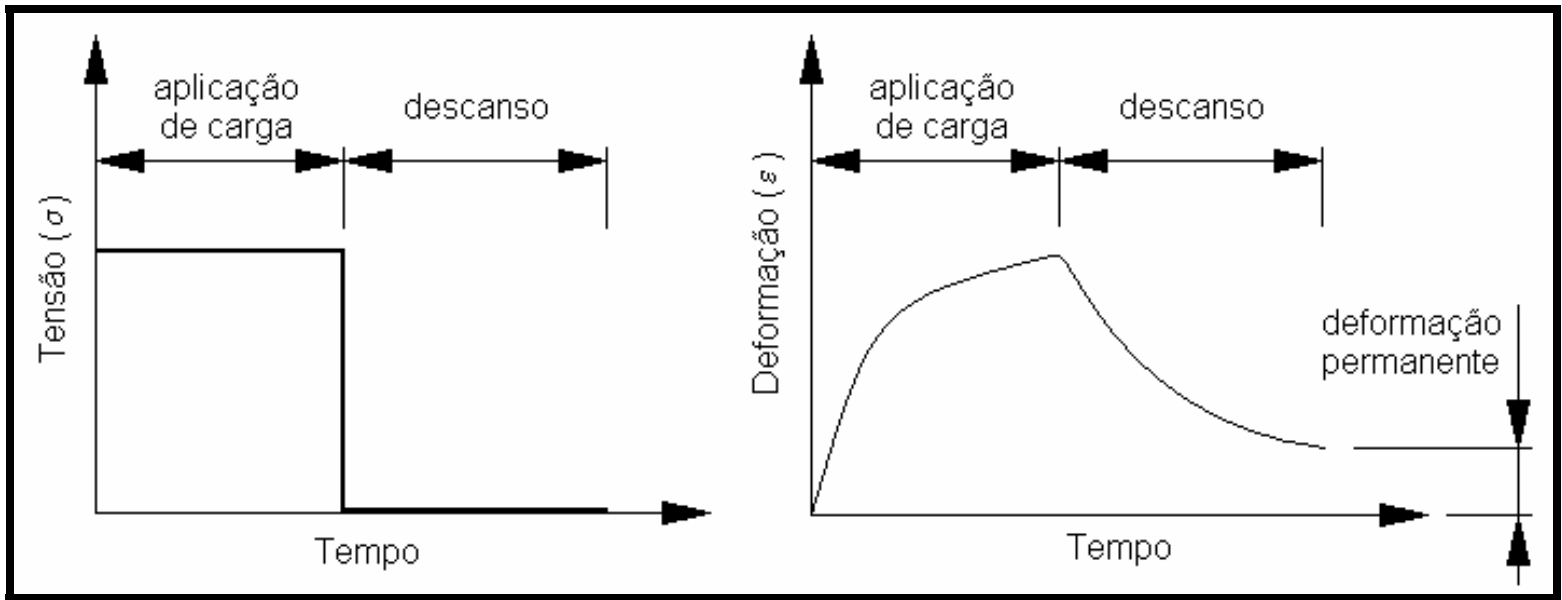

Figura 2.2. Gráficos típicos da deformação em função do tempo para o ensaio de fluência por compressão uniaxial estática.

Van de Loo (1974) recomenda que sejam usados baixos níveis de tensão nos ensaio de fluência, para que possam ser comparados os resultados do ensaio com as deformações causadas nas trilhas de roda, procurando-se manter o comportamento linear do material.

Segundo Witczak et al. (2002), em um ensaio de fluência por compressão uniaxial, uma relação total tempo-deformação para uma mistura é medida em laboratório sobre condições confinadas ou não confinadas, usando um ciclo de carregamentodescarregamento ou ciclos de incremento de carga e descarregamento. Dessa forma é possível obter informações suficientes para determinar o componente 
elástico instantâneo (recuperável) e o componente plástico (irrecuperável), como também os componentes viscoelásticos e viscoplásticos (que são funções do tempo) de resposta do material.

A Figura 2.3 mostra as características de uma curva típica do ensaio de fluência por compressão uniaxial, seja carregamento estático ou dinâmico, quando levado até a ruptura. A conformidade total pode ser dividida em três zonas. A zona primária é a parte na qual as taxas de deformações decrescem com o tempo de carregamento, a zona secundária corresponde a parte na qual as deformações são constantes e na zona terciária a taxa de deformações cresce com o tempo de carregamento. À zona terciária correspondem as deformações plásticas do material e o ponto onde essas deformações começam chama-se número de fluência (FN) ou tempo de fluência (FT). O parâmetro de intercepto "a" representa a deformação permanente correspondente ao número de ciclos igual a 1 e o parâmetro "b" representa a taxa de mudança da deformação permanente como uma função da taxa de carregamento e ambos os parâmetros estão relacionados à zona secundária da conformidade da fluência por compressão uniaxial. Um modelo clássico, que representa matematicamente o comportamento dessa zona, é dado pela Equação 2.1. Fica claro que as constantes de regressão "a" e "b" ignoram a zona terciária de deformação do material. 


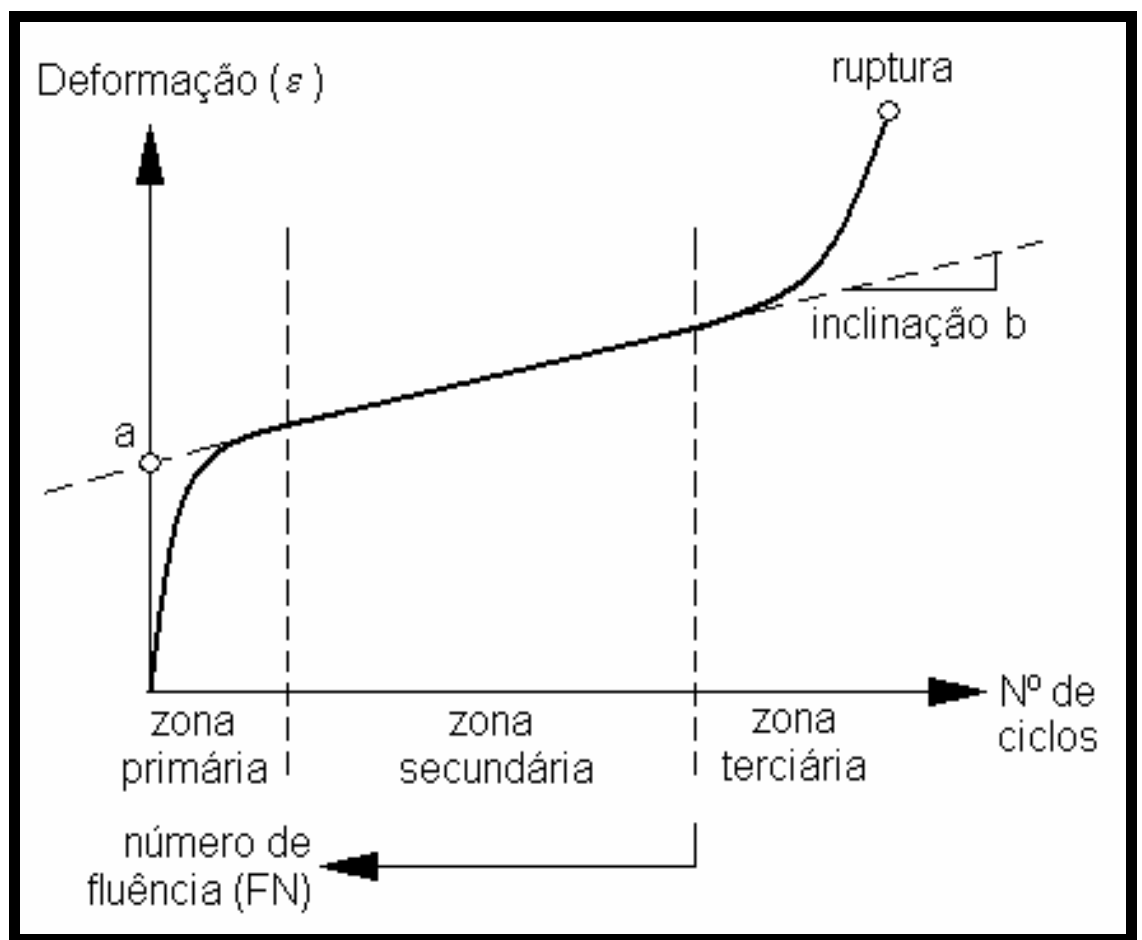

Figura 2.3. Curva típica de deformação pelo número de ciclos no ensaio de fluência por compressão uniaxial.

$$
\varepsilon=a \times N^{b}
$$

em que,

$\varepsilon \quad$ : $\log$ da deformação;

a : parâmetro de intercepto para $\mathrm{N}=1$;

$N \quad$ : número de ciclos;

b $\quad$ : inclinação referente à zona secundária.

Little, Button, e Youssef (1993) propuseram o ensaio de fluência por compressão uniaxial estática com a utilização do tempo de carregamento de uma hora a uma temperatura de $40^{\circ} \mathrm{C}$. A análise dos resultados fica em função da deformação total aos 3600 segundos, da inclinação da curva de fluência no estágio da zona secundária e do módulo de fluência. Os autores apresentam as Tabelas 2.3 e 2.4 
como critérios a serem seguidos, em função dos resultados do ensaio. A Tabela 2.3 foi criada a partir de dados gerados com ensaios utilizando 0,69 MPa de tensão.

Tabela 2.3 - Critério para controle da deformação através de valores obtidos no ensaio de fluência.

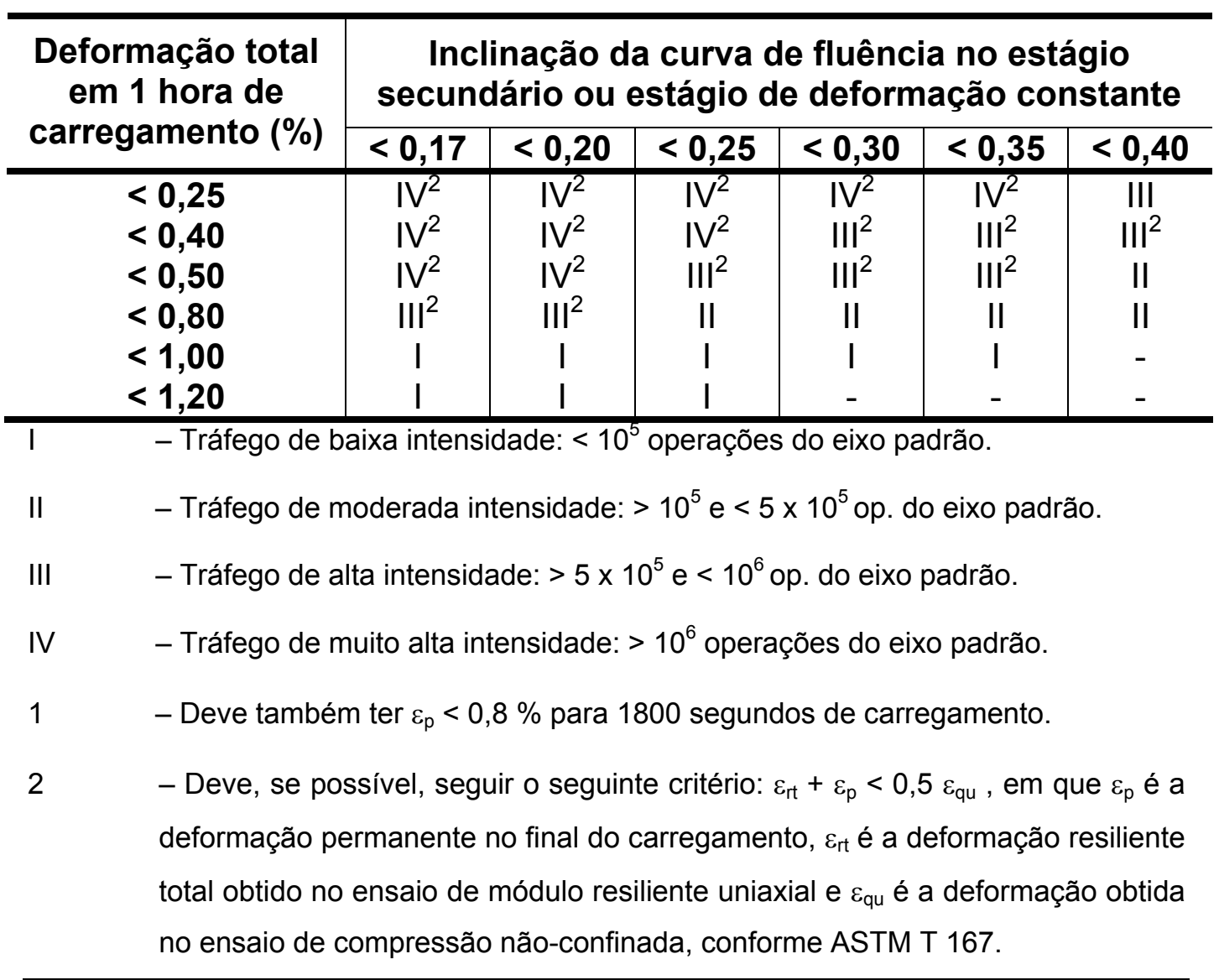

Fonte: Adaptação de Little, Button e Youssef (1993). 
Tabela 2.4 - Critério do módulo de fluência para 1 hora de carregamento.

\begin{tabular}{c|c|ccc}
\hline Resistência à & Nível de & \multicolumn{3}{c}{ Módulo de fluência mínimo (MPa) } \\
\cline { 3 - 5 } formação de trilhas & Intensidade & \multicolumn{3}{|c}{ Tensão de ensaio (MPa) } \\
de rodas & de Tráfego & $\mathbf{0 , 2 0 7}$ & $\mathbf{0 , 3 4 5}$ & $\mathbf{0 , 4 8 3}$ \\
\hline \multirow{3}{*}{ Alta } & IV & 103,4 & 120,7 & 155,1 \\
& III & 48,3 & 69,0 & 96,5 \\
& II & 34,5 & 44,8 & 60,3 \\
& I & 20,7 & 27,6 & 41,4 \\
\hline \multirow{3}{*}{ Moderada } & IV & 51,7 & 69,0 & 96,5 \\
& III & 34,5 & 50,0 & 96,0 \\
& II & 24,1 & 41,4 & 51,7 \\
& I & 17,2 & 20,7 & 27,6 \\
\hline
\end{tabular}

Fonte: Adaptação de Little, Button e Youssef (1993).

Mugayar (2004), após analisar os resultados dos ensaios de fluência por compressão uniaxial estática através da variância, concluiu que os valores de deformação final e total mostraram-se sensíveis às variações de tensão de ensaio e da distribuição granulométrica, porém não se mostraram sensíveis quanto à mudança no tipo de asfalto. Já o ensaio de fluência por compressão uniaxial dinâmica, foi capaz de detectar diferenças no comportamento de misturas asfálticas com diferentes tipos de ligantes.

Brown, Kandhal e Zhang (2001), após longo estudo sobre os métodos de previsão de deformação permanente utilizando quatro amostras com desempenhos relativamente conhecidos, determinaram as vantagens e desvantagens dos métodos estático e dinâmico. A Tabela 2.5. apresenta as conclusões dos autores com relação aos ensaios uniaxiais estáticos e dinâmicos. 
Tabela 2.5 - Vantagens e desvantagens dos ensaios de fluência por compressão uniaxial estática e dinâmica.

\begin{tabular}{|c|c|c|c|}
\hline Método de ensaio & $\begin{array}{l}\text { Dimensões dos } \\
\text { corpos-de-prova }\end{array}$ & Vantagens & Desvantagens \\
\hline $\begin{array}{c}\text { Compressão } \\
\text { uniaxial estática }\end{array}$ & $\begin{array}{c}4 \text { pol. de diâmetro } x \\
2 \text { pol. de altura }\end{array}$ & $\begin{array}{ll}\text { - } & \text { Facilidade de } \\
\text { realização do } \\
\text { ensaio; } \\
\text { - Equipamento } \\
\text { disponível na } \\
\text { maioria dos } \\
\text { laboratórios; } \\
\text { - Corpo-de-prova } \\
\text { facilmente } \\
\text { moldado. }\end{array}$ & $\begin{array}{ll}\text { - } & \text { Habilidade em } \\
\text { prever } \\
\text { deformação } \\
\text { permanente } \\
\text { questionável; } \\
\text { - } \quad \text { A temperatura } \\
\text { de ensaio } \\
\text { restrita e os } \\
\text { níveis de carga } \\
\text { não simulam as } \\
\text { condições de } \\
\text { campo; } \\
\text { Não simula os } \\
\text { fenômenos } \\
\text { dinâmicos de } \\
\text { campo. }\end{array}$ \\
\hline $\begin{array}{c}\text { Compressão } \\
\text { uniaxial dinâmica }\end{array}$ & $\begin{array}{c}4 \text { pol. de diâmetro } x \\
2 \text { pol. de altura }\end{array}$ & $\begin{array}{l}\text { - Simula melhor } \\
\text { as condições de } \\
\text { tráfego. }\end{array}$ & $\begin{array}{ll}\text { - } & \text { Equipamento } \\
\text { mais complexo; } & \text { A temperatura } \\
\text { - } & \text { de ensaio } \\
\text { restrita e os } \\
\text { níveis de carga } \\
\text { não simulam as } \\
\text { condições de } \\
\text { campo. }\end{array}$ \\
\hline
\end{tabular}

FONTE: Adaptação de Brown, Kandhal e Zhang (2001).

Apesar das desvantagens apresentadas pelos autores, os ensaios de fluência por compressão uniaxial estática e dinâmica foram utilizados nesta pesquisa pelo fato de serem os únicos métodos disponíveis no laboratório do Departamento de Transportes do campus de São Carlos da Universidade de São Paulo e pela facilidade na execução do ensaio. Outros pesquisadores do mesmo departamento realizaram ensaios semelhantes e suas características estão apresentadas na Tabela 2.6 e 2.7 . 
Tabela 2.6 - Histórico de previsão de deformação permanente através do ensaio de fluência por compressão uniaxial estática do departamento de transportes da USP -

São Carlos.

\begin{tabular}{c|c|c|c|c}
\hline Pesquisador & $\begin{array}{c}\text { Tempo de } \\
\text { carregam. } \\
(\mathbf{s})\end{array}$ & $\begin{array}{c}\text { Tempo de } \\
\text { recuper. } \\
\text { (s) }\end{array}$ & $\begin{array}{c}\text { Tensão de } \\
\text { carregam. } \\
\text { (MPa) }\end{array}$ & $\begin{array}{c}\text { Temp. de } \\
\left.\text { ensaio ( }{ }^{\circ} \mathbf{C}\right)\end{array}$ \\
\hline Coelho (1996) & 3600 & 900 & 0,4 & 40 \\
Foretti (1999) & 3600 & 900 & 0,4 & 40 \\
Silveira (1999) & 3600 & 900 & 0,4 & 40 \\
Amaral (2000) & 3600 & 900 & 0,1 & 40 \\
Taira (2001) & 3600 & 900 & 0,$1 ; 0,4 ; 0,7$ & 40 \\
Faxina (2002) & 3600 & 900 & $04 ; 0,7$ & 40 \\
Cunha (2004) & 3600 & 900 & 0,1 & 40 \\
Mugayar (2004) & 3600 & 900 & 0,$1 ; 0,4 ; 0,7$ & 40 \\
Santanna-Greco (2004) & 3600 & 900 & 0,1 & 40 \\
\hline
\end{tabular}

Tabela 2.7 - Histórico de previsão de deformação permanente através do ensaio de fluência por compressão uniaxial dinâmica do departamento de transportes da USP - São Carlos.

\begin{tabular}{c|c|c|c|c|c}
\hline Pesquisador & $\begin{array}{c}\text { Tempo de } \\
\text { carregam. } \\
(\mathbf{s})\end{array}$ & $\begin{array}{c}\text { Tempo de } \\
\text { recuper. } \\
(\mathbf{s})\end{array}$ & $\begin{array}{c}\text { Tensão de } \\
\text { carregam. } \\
\text { (MPa) }\end{array}$ & $\begin{array}{c}\mathbf{N}^{\circ} \text { de } \\
\text { ciclos }\end{array}$ & $\begin{array}{c}\text { Temp. de } \\
\text { ensaio } \\
\left({ }^{\circ} \mathbf{C}\right)\end{array}$ \\
\hline Silveira (1999) & 0,2 & 0,8 & 0,1 & 5000 & 40 \\
Taira (2001) & 0,2 & 1,8 & 0,1 & 5000 & 40 \\
Mugayar (2004) & 0,1 & 0,9 & 0,$1 ; 0,4 ; 0,7$ & 5000 & 40 \\
Santanna-Greco (2004) & 0,1 & 0,9 & 0,4 & 5000 & 40 \\
\hline
\end{tabular}




\subsection{FADIGA}

De acordo com informações apresentadas por Fernandes Jr. (1994),

fadiga é o fenômeno estrutural, progressivo e localizado, que sofre um material submetido a tensões ou deformações repetidas, inferiores à sua resistência última, podendo culminar na fissuração ou ruptura completa do material após um número suficiente de solicitações. O processo de fadiga modifica as propriedades do material a cada ciclo de carga, provocando, geralmente, uma redução na sua capacidade de suporte.

Trincas por fadiga nos concretos asfálticos é um dos mais importantes defeitos que afetam o desempenho de um pavimento flexível e, segundo Motta e Pinto (1994), é o principal defeito e o principal mecanismo que leva um pavimento à ruptura no Brasil. A resistência à fadiga de uma mistura asfáltica pode ser definida como a capacidade que esta mistura apresenta de resistir aos esforços repetitivos de flexão (esforço cíclico) sem se romper.

Quando uma mistura asfáltica está sujeita a carregamentos (ou tensões) cíclicos, a resposta do material na tração e na compressão consiste de três componentes de deformação principais: elástica, viscoelástica e plástica. As trincas por fadiga ocorrem devido à componente de deformação plástica, ou seja, se a mistura fosse completamente elástica, não ocorreria fadiga (KHATTAK e BALADI, 2001). Segundo Roberts et al. (1991) esse problema se torna mais grave quando não há um sistema de drenagem adequado, pois permite que as camadas do pavimento sejam saturadas por água e percam resistência. 
O Manual de Identificação de Defeitos (FHWA, 2003) classifica as trincas por fadiga em três níveis: baixo, moderado e alto. No nível baixo, na área de trincas, encontram-se poucas ou nenhuma delas se conectando, as trincas não precisam ser seladas e o bombeamento não é evidente. No nível moderado, a área de trincas interconectadas forma um padrão completo, as trincas podem ser seladas e o bombeamento ainda não é evidente. Já no nível alto, a área apresenta-se moderada ou severamente fragmentada por trincas interconectadas e alguns trechos não podem mais estar sujeitos às ações do tráfego, as trincas podem ser seladas e o bombeamento pode ser evidente. Si, Little e Lytton (2002) dividiram as trincas por fadiga em três estágios: início de microtrincas e crescimento, propagação de macrotrincas e ruptura final.

O local para o aparecimento das trincas por fadiga é na base da camada de concreto asfáltico e diretamente abaixo do ponto de aplicação da carga, pois neste ponto o estado de tensões apresenta componentes de tração nas direções transversal e longitudinal e de compressão na direção vertical (WEN e KIM, 2002).

Diversos são os fatores que influenciam na vida de fadiga de um pavimento (número de solicitações que o pavimento resiste antes de se romper), entre eles se encontram as características do tráfego, do pavimento e condições climáticas. Como característica do pavimento, há a influência do ligante (viscosidade e teor utilizado com relação à massa total de agregados), do agregado (distribuição granulométrica, textura e forma), da mistura (com relação ao volume de vazios) e da espessura da camada. 
Tangella et al. (1990) afirmaram que, para mistura de graduação densa, os dois primeiros fatores que influenciam na vida de fadiga são o teor de asfalto e o teor de vazios na mistura. O teor de asfalto deve ser o mais alto possível, porém ter como limite a estabilidade da mistura, e o teor de vazios deve ser de $4 \%$. Segundo o autor, altas temperaturas diminuem a vida de fadiga no caso de pavimentos espessos, mas aumenta a vida de fadiga para pavimentos esbeltos.

Um aumento na viscosidade do ligante faz com que a rigidez da mistura aumente. Se o pavimento possuir uma camada de concreto asfáltico esbelta e alta rigidez ele se torna propenso às trincas por fadiga, porém se o pavimento for espesso e projetado para resistir a altos carregamentos, este deve ter uma rigidez elevada (SANTANNA-GRECO, 2004).

Segundo Kim, Y.R., Kim, N. e Khosla (1992), misturas contendo agregados com textura superficial rugosa são mais resistentes à fadiga, pois estes promovem uma melhor interface de união agregado-ligante. Kim, Little e Song (2003), através de um modelo de previsão mecânica de fadiga, utilizaram a teoria da viscosidade e concluíram que a fração fíler do agregado mineral aumenta a resistência às microtrincas devido a mais baixa taxa de evolução e mais alta acumulação de dano total. A Tabela 2.8 mostra como alguns fatores influenciam na vida de fadiga das misturas asfálticas. 
Tabela 2.8 - Influência de alguns fatores na vida de fadiga das misturas asfálticas.

\begin{tabular}{|c|c|c|c|c|}
\hline \multirow[b]{2}{*}{ Fator } & \multirow[b]{2}{*}{ Variação } & \multicolumn{3}{|c|}{ Efeito da variação } \\
\hline & & Rigidez & $\begin{array}{l}\text { Vida de fadiga } \\
\text { (TC) }\end{array}$ & $\begin{array}{l}\text { Vida de fadiga } \\
\text { (DC) })^{(\mathbf{b})}\end{array}$ \\
\hline $\begin{array}{c}\text { Viscosidade do } \\
\text { ligante }\end{array}$ & Aumento & Aumento & Aumento & Diminuição \\
\hline Teor de ligante & Aumento & Aumento & Aumento & Aumento \\
\hline $\begin{array}{c}\text { Distribuição } \\
\text { granulométrica do } \\
\text { agregado }\end{array}$ & $\begin{array}{c}\text { Aberta } \\
\text { para } \\
\text { contínua }\end{array}$ & Aumento & Aumento & Diminuição \\
\hline Volume de vazios & Diminuição & Aumento & Aumento & Aumento \\
\hline
\end{tabular}

(a) Ensaio de tensão controlada.

(b) Ensaio de deformação controlada.

FONTE: Adaptação de Tangella et al.,1990.

O ensaio de fadiga tem o objetivo de verificar o número de solicitações que uma determinada carga leva para conduzir uma mistura asfáltica à ruptura. São três os critérios de ruptura comumente utilizados:

- Redução da rigidez inicial da mistura a um determinado valor (geralmente $50 \%$ do valor inicial);

- Surgimento da primeira fissura;

- Ruptura total do corpo-de-prova.

O ensaio pode ser realizado com tensão controlada (TC) ou deformação controlada (DC). No ensaio de tensão controlada, a tensão permanece constante ao longo do ensaio e a deformação aumenta no decorrer deste. Já no ensaio de deformação controlada ocorre o contrário, a deformação é mantida constante e a tensão varia ao longo do ensaio. No primeiro ensaio, o resultado é a vida de fadiga (Nf) da mistura asfáltica e no segundo ensaio o resultado é a vida de serviço (Ns) (PINTO, 1991). 
Segundo Medina (1997), os revestimentos asfálticos espessos e/ou muito mais rígidos que a estrutura subjacente do pavimento controlam a magnitude das deformações, ao resistirem às cargas aplicadas, e estão sujeitos à tensão controlada. Os pavimentos mais esbeltos estão sujeitos à deformação controlada, pois há uma contribuição maior das subcamadas na absorção das tensões.

As Figuras 2.4 e 2.5, extraídas de Pinto (1991), apresentam as curvas características dos ensaios de tensão controlada e deformação controlada, respectivamente.

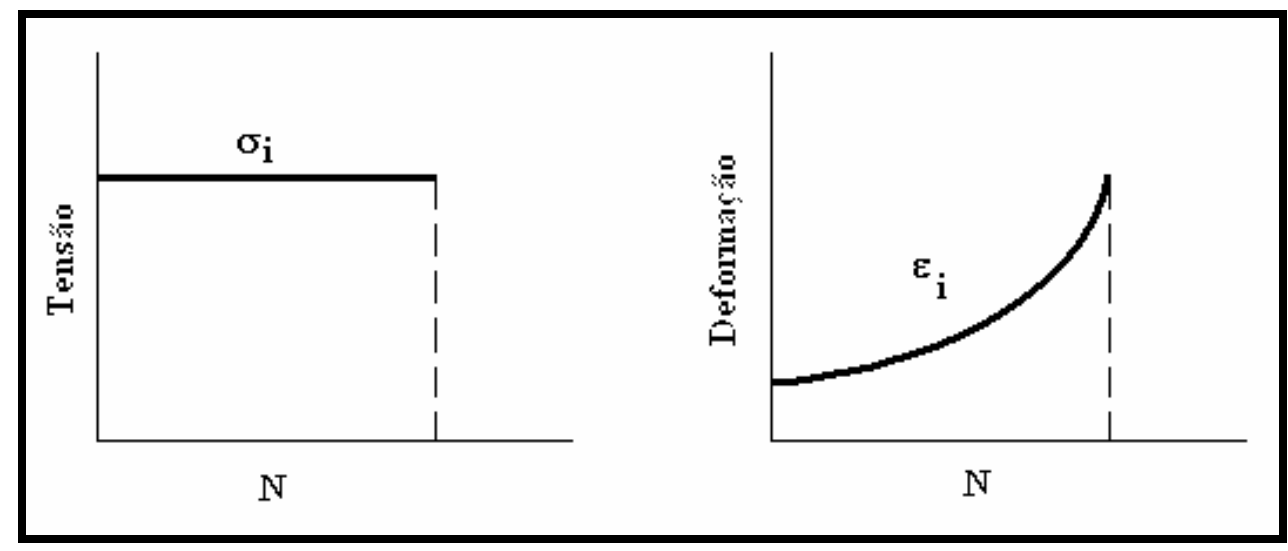

Figura 2.4. Curvas características do ensaio de vida de fadiga por tensão controlada.
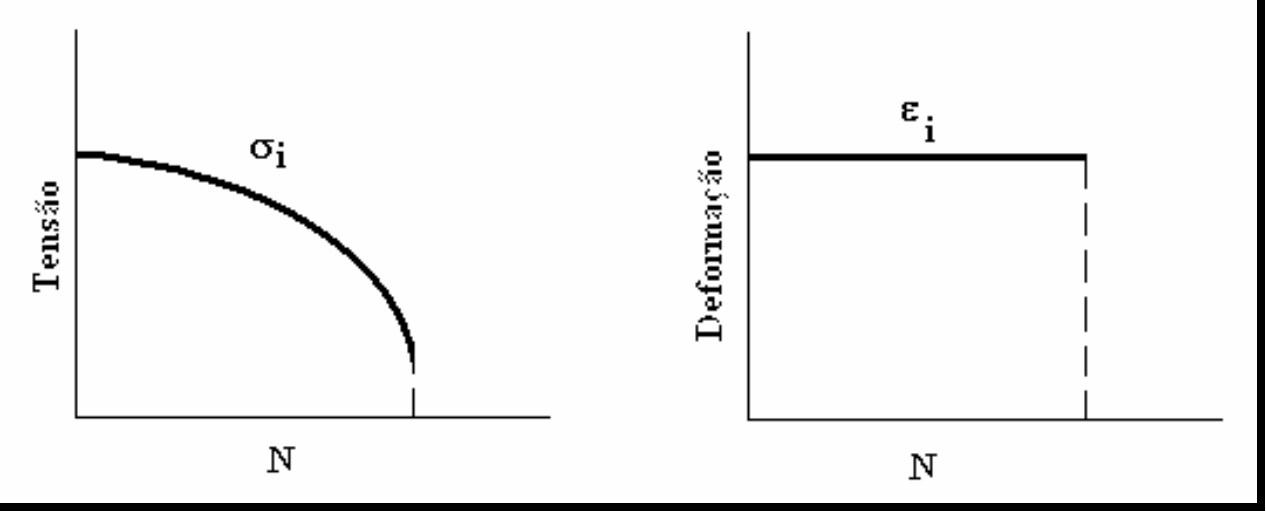

Figura 2.5. Curvas características do ensaio de vida de fadiga por deformação controlada. 
Segundo Santos (2005), no Brasil, a adoção do critério de tensão controlada, utilizando-se a diferença de tensões $(\Delta \sigma)$, é o mais usual.

Balbo (2000) citou que o corpo-de-prova, em um ensaio de compressão diametral, está submetido a um estado biaxial de tensões. No plano paralelo à aplicação da carga, está solicitado à compressão, e no plano normal à aplicação da carga, está solicitado à tração. A diferença de tensões é dada pela diferença entre a tensão de tração e a tensão de compressão do corpo-de-prova, medidas no ensaio de resistência à tração por compressão diametral.

Tangella et al. (1990) apresentaram as vantagens e desvantagens em se utilizar o método de compressão diametral para a previsão de deformação permanente:

- Vantagens:

i. Facilidade de ensaio;

ii. O projeto da mistura e do pavimento adequado à fadiga é possível, em princípio, utilizando a resposta de fadiga medida pelo ensaio juntamente com a correlação de campo;

iii. O equipamento pode ser usado em outros ensaios, como módulo de resiliência e resistência à tração;

iv. As trincas se iniciam na região de relativa tensão de tração uniforme;

v. O estado biaxial de tensões existente, possivelmente, representa melhor as condições de campo;

vi. O ensaio pode ser realizado não somente em corpos-de-prova moldados em laboratório, mas também em corpos-de-prova extraídos em campo. 
- Desvantagens:

i. Embora um estado de tensões biaxiais exista no centro do corpo-de-prova, é impossível variar a taxa das componentes vertical e horizontal e, daí, replicar o estado de tensões dos locais críticos em um pavimento in-situ;

ii. O método subestima significantemente a vida de fadiga se a tensão de tração principal for utilizada como o fator de determinação do dano. Mesmo quando a diferença de tensões é utilizada, o método ainda subestima a vida de fadiga relativamente a outros métodos de laboratório;

iii. Há possibilidade de ausência de tensão reversa e acúmulo de deformação permanente.

De acordo com Ghile (2006), o motivo pelo qual os ensaios laboratoriais prevêem que o rompimento da mistura asfáltica por fadiga ocorre antes do que realmente acontece, deve-se ao fato da vida de fadiga ser função da distribuição de tensões e das condições limites, as quais são diferentes para as condições de laboratório e de campo. Entretanto, o autor citou que o ensaio de vida de fadiga permite fazer comparações entre o desempenho de várias misturas diferentes.

Diversos autores recomendam a utilização de um fator campo-laboratório (FCL), visando corrigir a severidade e as condições extremas a que os corpos-de-prova estão sujeitos em laboratório. Medina e Motta (2005) recomendam o uso do FCL de $10^{4}$ para o ensaio com tensão controlada e de $10^{5}$ para o ensaio com deformação controlada. 


\subsubsection{Programa ELSYM5}

O programa ELSYM5 (Elastic Layered System) foi desenvolvido na Universidade de Berkeley na Califórnia, Estados Unidos da América, em linguagem FORTRAN (Formula Translator) para computadores de grande porte na década de 1970 e adaptado a microcomputadores por Kopperman et al. em 1985 (FERREIRA, 2000).

O programa utiliza como modelo as diferenças finitas, fundamentada nas equações generalizadas por Burmister em 1943, possibilitando o cálculo de tensões, deformações e deslocamentos de até cinco camadas consideradas homogêneas, isotrópicas, elásticas e sem o peso próprio (PEREIRA, 2002). As camadas são consideradas infinitas na horizontal e finitas na vertical, com exceção da última camada, que é considerada ou infinita na vertical ou sobreposta sobre placa rígida de espessura finita (BENEVIDES, 2000).

A estrutura pode ser submetida a um ou mais carregamentos uniformes (até um máximo de dez), que são distribuídos em uma área circular, permitindo avaliar o feito de rodas duplas.

Todos os parâmetros de entrada do programa são constantes e divididos em três etapas: 
i. Referentes aos carregamentos: quantidade (1 a 10), valor (carga ou pressão) e coordenadas $(\mathrm{x}, \mathrm{y})$;

ii. Referentes às camadas e materiais: quantidade (1 a 5), espessura, coeficiente de Poisson e módulo de elasticidade;

iii. Referentes às respostas: coordenadas $(x, y, z)$ dos pontos.

O referencial é o sistema cartesiano de coordenas e está disposto como apresentado na Figura 2.6.

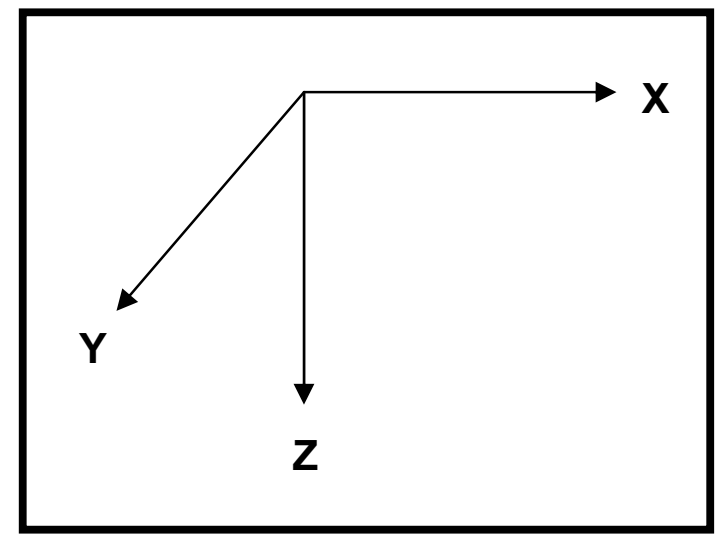

Figura 2.6. Eixo de coordenadas do programa ELSYM5.

Os dados de saída do programa são: os deslocamentos, as tensões normais, cisalhantes e principais e as deformações normais, cisalhantes e principais.

De posse das tensões calculadas pelo programa é possível determinar a vida de fadiga do revestimento asfáltico, analisando-se a diferença de tensões na fibra inferior do material e o seu respectivo modelo constitutivo, obtido em laboratório. 


\subsection{POLÍMEROS}

\subsubsection{Considerações iniciais}

O termo polímero vem do grego e significa muitas partes $($ poli $=$ muitas e mero $=$ partes), porém é indefinido, no sentido de que o menor comprimento ou tamanho das moléculas não é especificado. Por outro lado, este termo é aceito como significando uma molécula muito maior, de tal modo que as suas propriedades se tornam evidentes (MANO, 1988).

Polímeros contêm milhares de milhões de átomos em uma molécula muito grande e são também conhecidos por macromoléculas (CHANDA e ROY, 1998).

Segundo Mano (1998), os polímeros são constituídos da união de moléculas de baixo peso molecular, denominadas monômeros, através de reações químicas. O peso molecular de um polímero é maior quanto maior for o grau de polimerização (reação química que forma o polímero), termo utilizado primeiramente por Berthelot, em 1866, quando da obtenção de um poliestireno gelatinoso. Os que possuem peso molecular elevado são chamados de altos polímeros, enquanto os de baixo peso molecular são conhecidos como oligômeros (poucas partes, do grego).

O primeiro relato de material polimérico que se tem notícia foi criado por Charles Goodyear, em 1830, que descobriu que ao se aquecer uma mistura de borracha natural (extraída de seringueira) com enxofre, as propriedades mecânicas dessa macromolécula eram modificadas, ou seja, um material que inicialmente era mole e 
pegajoso a baixas temperaturas e rígido e áspero a temperaturas mais elevadas, se tornou seco e flexível em qualquer temperatura. Entretanto a estrutura química das moléculas era desconhecida. Em 1877, Friedrick A. Kekulé propôs a primeira hipótese da existência de macromoléculas, que foi reafirmada por Emil Fisher, em 1893, ao sugerir que a estrutura da celulose natural era formada por cadeias constituídas por unidades de celulose, enquanto que os polipeptídeos eram longas cadeias de poliaminoácidos unidas.

\subsubsection{Classificações dos polímeros}

Um polímero que possua apenas um tipo de mero em sua cadeia é um homopolímero e um polímero que possua mais de um tipo mero em sua cadeia é chamado de copolímero. Os monômeros que dão origem aos copolímeros são chamados de comonômeros, que é uma classificação quanto ao número de meros diferentes presentes em sua estrutura química.

Homopolímeros são compostos da unidade repetidora de um monômero, que formam uma cadeia molecular com seqüência do tipo: $A A A A A$, a partir da homopolimerização. Já os copolímeros são compostos de duas ou mais unidades repetidoras diferentes, formando uma cadeia polimérica a partir da reação dessas unidades.

Os copolímeros podem ser classificados de diferentes maneiras, como a disposição dos meros, fulsibilidade, comportamento mecânico ou forma da cadeia. 


\subsubsection{Quanto à disposição dos meros}

\section{i. Aleatórios}

Neste caso os meros são dispostos de forma desordenada na cadeia:

$$
-\mathrm{A} A \mathrm{~B} A \mathrm{~B} B \mathrm{~A} A \mathrm{~B}-
$$

\section{ii. Alternados}

Nesse tipo de copolímero os meros estão ordenados de forma alternada na cadeia:

$$
- \text { A B A B A B A - }
$$

\section{iii. Em blocos}

Esses copolímeros são formados por seqüências de meros iguais de comprimentos variados:

$$
\text { - A A A B B B A A A A - }
$$

\section{iv. Grafitizados ou enxertados}

Nesse caso a cadeia principal é formada por um tipo de unidade repetida, enquanto outro mero forma a cadeia lateral (enxertada).

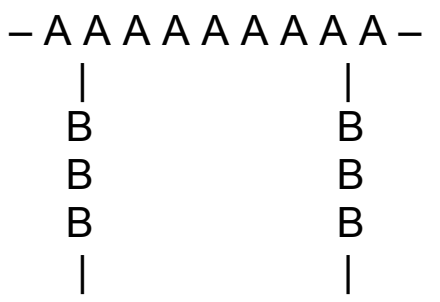




\subsubsection{Quanto à fulsibilidade}

\section{i. Termoplásticos}

Se fundem ao serem aquecidos e se solidificam ao serem resfriados, podendo, alguns, serem dissolvidos em vários solventes, possibilitando a reciclagem. Podem ser maleáveis, rígidos ou frágeis à temperatura ambiente. Exemplos: polietileno (PE), polipropileno (PP), poli(tereftalato de etileno) (PET), policarbonato (PC), poliestireno (PS), poli(cloreto de vinila) (PVC), poli(metilmetacrilato) (PMMA).

\section{ii. Termorrígidos}

Fazem ligações cruzadas ao serem aquecidos, tornando-se insolúveis e infusíveis. Pelo fato de se decomporem antes de se fundirem, fazem com que sua reciclagem seja complicada. Podem ser rígidos ou frágeis e são muito estáveis à temperatura ambiente. Exemplos: Baquelite e Poliéster.

\subsubsection{Quanto ao comportamento mecânico}

Em sua aplicação, estes termos envolvem a expressão resina. Resina é uma substância amorfa ou uma mistura, de peso molecular intermediário ou alto, insolúvel em água, mas solúvel em alguns solventes orgânicos, e que, à temperatura ordinária, é sólida ou um liquido muito viscoso, que amolece gradualmente por aquecimentos. Todas as resinas naturais são solúveis e fusíveis e todos os

polímeros sintéticos que obedecem às condições acima apontadas são também chamados de resinas sintéticas (MANO, 1988). 


\section{i. Plásticos}

Plásticos são materiais que contêm, como componente principal, um polímero orgânico sintético e se caracterizam porque, embora sólidos à temperatura ambiente em seu estado final, em alguns estágios de seu processamento, tornam-se fluídos e possíveis de serem moldados, por ação isolada ou conjunta de calor e pressão. Esse ingrediente polimérico é chamado de resina sintética. Exemplos: polipropileno e poliestireno.

\section{ii. Elastômeros ou borrachas}

Borrachas ou elastômeros são materiais macromoleculares que exibem elasticidade em longa faixa, à temperatura ambiente. Por não serem fusíveis, são de difícil reciclagem. Exemplos: polibutadieno, borracha nítrica.

\section{iii. Fibras}

Fibra é um corpo que tem uma elevada razão entre o comprimento e as dimensões laterais e é composto, principalmente, de macromoléculas lineares, orientadas longitudinalmente. Exemplos: poliésteres, poliamidas, poliacrilonitrila.

\subsubsection{Quanto à forma da cadeia}

\section{i. Linear}

A cadeia do polímero não possui ramificações.

\section{ii. Ramificada}

O copolímero apresenta pequenas cadeias laterais 


\section{iii. Reticulada}

Os polímeros apresentam uma estrutura tridimensional e as cadeias estão unidas por ligações químicas (cruzadas).

\subsubsection{Reações de polimerização}

\subsubsection{Polímeros de adição}

De acordo com Chanda e Roy (1998), os polímeros de adição são produzidos em maior escala dentre os polímeros industriais. Seus mais importantes monômeros são etileno, propileno e butadieno. Eles são baseados nos produtos de baixo custo do petróleo ou gás natural e são produzidos pela quebra ou refino de óleo cru.

São conhecidos quatro processos de polimerização para os polímeros de adição: polimerização de corrente por radical-livre-iniciado, polimerização aniônica, polimerização catiônica e polimerização por coordenação.

Dentre os polímeros de adição se encontram os polímeros de vinila, que constituem um importante seguimento da indústria de plásticos. Um dos mais comuns polímeros de vinila é o poli-(acetato de vinila), este que, por sua vez, se divide em dois grupos principais de copolímeros para as indústrias de plásticos: o copolímero etileno acetato de vinila e o copolímero cloreto de vinila - acetato de vinila. 


\subsubsection{Polímeros de condensação}

Polímeros de condensação são formados de monômeros bi- ou polifuncionais pela reação que envolve eliminação de algumas moléculas menores. Em um polímero de condensação, os heteroátomos $(\mathrm{O}, \mathrm{N}, \mathrm{S}, \mathrm{Si})$ estão presentes no esqueleto do polímero, diferentemente dos polímeros de adição, em que a cadeia principal consiste inteiramente de correntes C-C (CHANDA e ROY, 1998).

\subsubsection{EVA e o setor calçadista}

O copolímero etileno acetato de vinila - EVA (Figura 2.7) é um composto microporoso, formado por resina de poli-(etileno-co-vinil acetato), agente de expansão, agente reticulante, cargas ativadoras e auxiliares de processo, além de outros polímeros, como a borracha. Sua formação se dá pela polimerização do etileno com acetato de vinila, via radicais livres, em reatores de alta pressão e pode apresentar propriedades diferentes de acordo com a porcentagem de acetato de vinila utilizado na polimerização, podendo ser utilizado como termoplástico ou elastômero. A redução do teor de acetato de vinila aumenta o módulo de rigidez desses copolímeros e a temperatura de amolecimento.

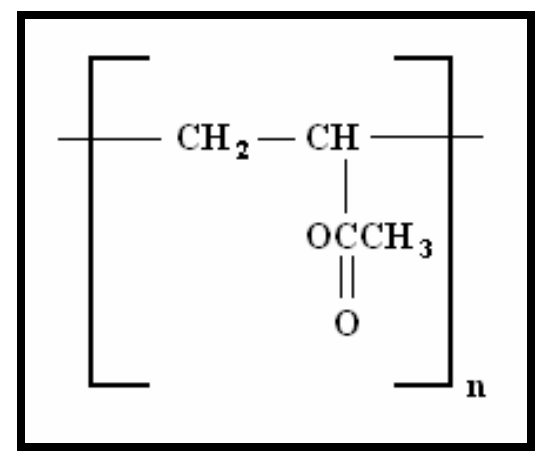

Figura 2.7. Estrutura molecular do copolímero EVA. 
O EVA apresenta, de modo geral, boa processabilidade, estabilidade térmica, boa resistência ao impacto, à fadiga, resiliência, tenacidade e flexibilidade e tem uma densidade variando de 0,922 a 0,945 .

O setor calçadista trabalha com resinas de EVA que contêm de $2 \%$ a $28 \%$ de acetato de vinila (VA) e índices de fluidez (MI) na faixa de 0,3 a $150 \mathrm{~g} / 10 \mathrm{~min}$. A combinação destes dois parâmetros determina as propriedades da resina formada e, portanto, o seu campo de aplicação. Aumentando-se o valor de VA, para um mesmo MI, conseguem-se maiores densidade, transparência e resistência ao ozônio e às baixas temperaturas. Por outro lado, mantendo-se o teor de VA constante e diminuindo o valor do Ml, conseguem-se maiores resistências mecânicas, maior temperatura de amolecimento e ligeira elevação na dureza e densidade.

O EVA é uma substância orgânica e não oferece riscos à saúde humana em seu estado normal. Apesar de ser um material atóxico e ser classificado pela NBR 10004/04 (ABNT, 2004) como resíduo sólido não perigoso, o EVA não é biodegradável e não há reutilização dos resíduos provindos da indústria calçadista. O seu descarte deve ser feito de acordo com regulamentações federais, estaduais ou locais, que recomendam que sejam aterrados ou incinerados, neste último caso com o risco de liberação de gases tóxicos, como $\mathrm{CO}_{2}, \mathrm{CO}$, fumaça, hidrocarbonetos e possibilidade de traços de acroleina.

O copolímero EVA é amplamente utilizado pela indústria calçadista na confecção de saltos, solas e palmilhas. É o material mais leve e macio para a fabricação de solas, 
além de possuir boa resistência ao desgaste. A Tabela 2.9 mostra os principais materiais e a data em que começaram a ser utilizados na confecção de calçados.

Tabela 2.9 - Materiais disponíveis para a fabricação de calçados no decorrer das décadas.

\begin{tabular}{|c|c|c|c|c|c|c|c|c|}
\hline \multirow{2}{*}{ Material } & \multicolumn{8}{|c|}{ Década } \\
\hline & 1930 & 1940 & 1950 & 1960 & 1970 & 1980 & 1990 & 2000 \\
\hline \multirow{3}{*}{\multicolumn{9}{|c|}{$\begin{array}{c}\text { Couro } \\
\text { Borracha não vulcanizada } \\
\text { Borracha vulcanizada }\end{array}$}} \\
\hline & & & & & & & & \\
\hline & & & & & & & & \\
\hline \multirow{5}{*}{$\begin{array}{c}\text { PVC } \\
\text { PU } \\
\text { Borracha termoplástica } \\
\text { Poliuretano termoplástico } \\
\text { EVA }\end{array}$} & & & & & & & & \\
\hline & & & & & & & & \\
\hline & & & & & & & & \\
\hline & & & & & & & & \\
\hline & & & & & & & & \\
\hline
\end{tabular}

A Figura 2.8 representa, em peso, a participação mundial de cada material utilizado na produção de solados. Dados da Associação Brasileira de Empresas de Componentes para Couros, Calçados e Artefatos (Assintecal) mostram que, só em 1999, a indústria brasileira produziu 499 milhões de pares de sapatos, sendo que 369 milhões desses pares foram para o mercado interno. Os dados de um estudo realizado em 2001, pela mesma entidade, mostram que o consumo de pares de sapato no Brasil foi de 2,3 por habitante por ano e, no mundo, de 6,5 por habitante, indicando o grande potencial da produção nacional. Uma pesquisa realizada pela Associação Brasileira das Indústrias de Calçados (Abicalçados) mostra produção de calçados brasileiros nos últimos anos, como apresenta a Figura 2.9. 


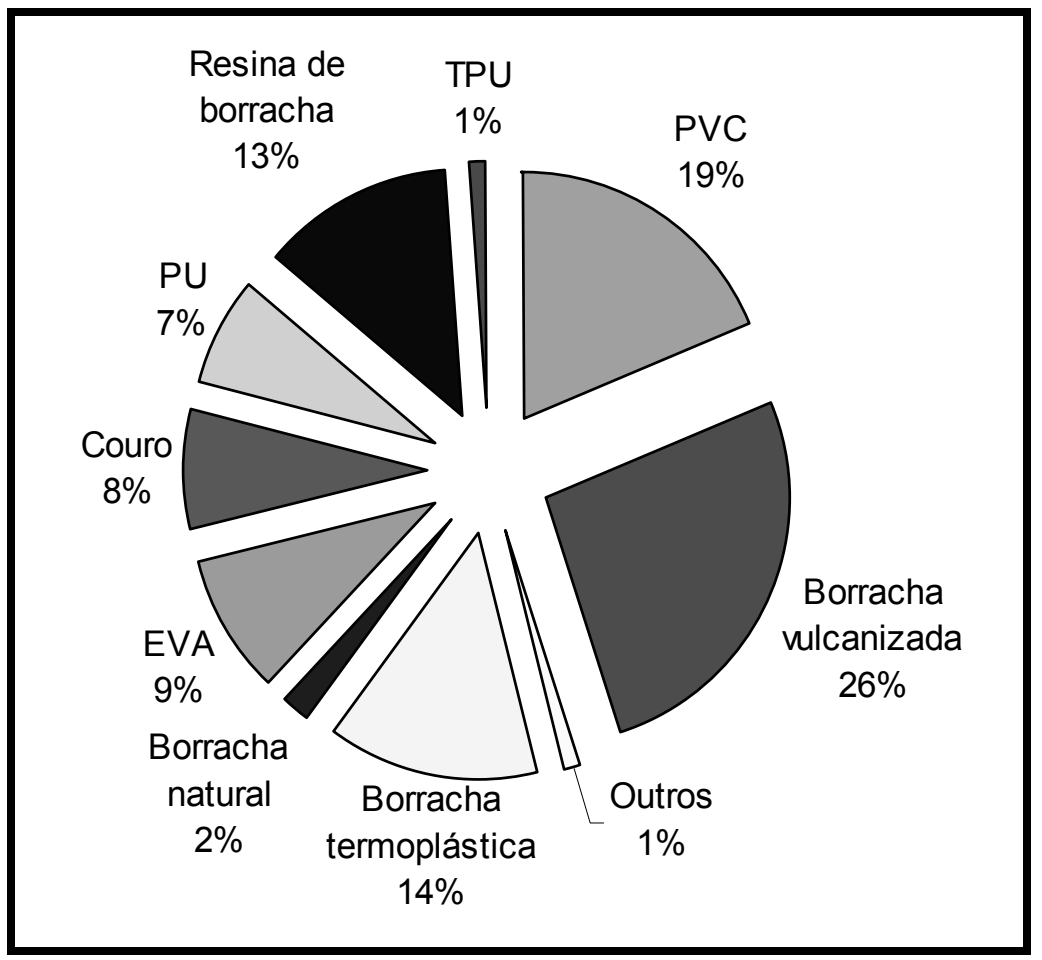

Fonte: Assintecal (1999).

Figura 2.8. Consumo mundial de materiais para solados.

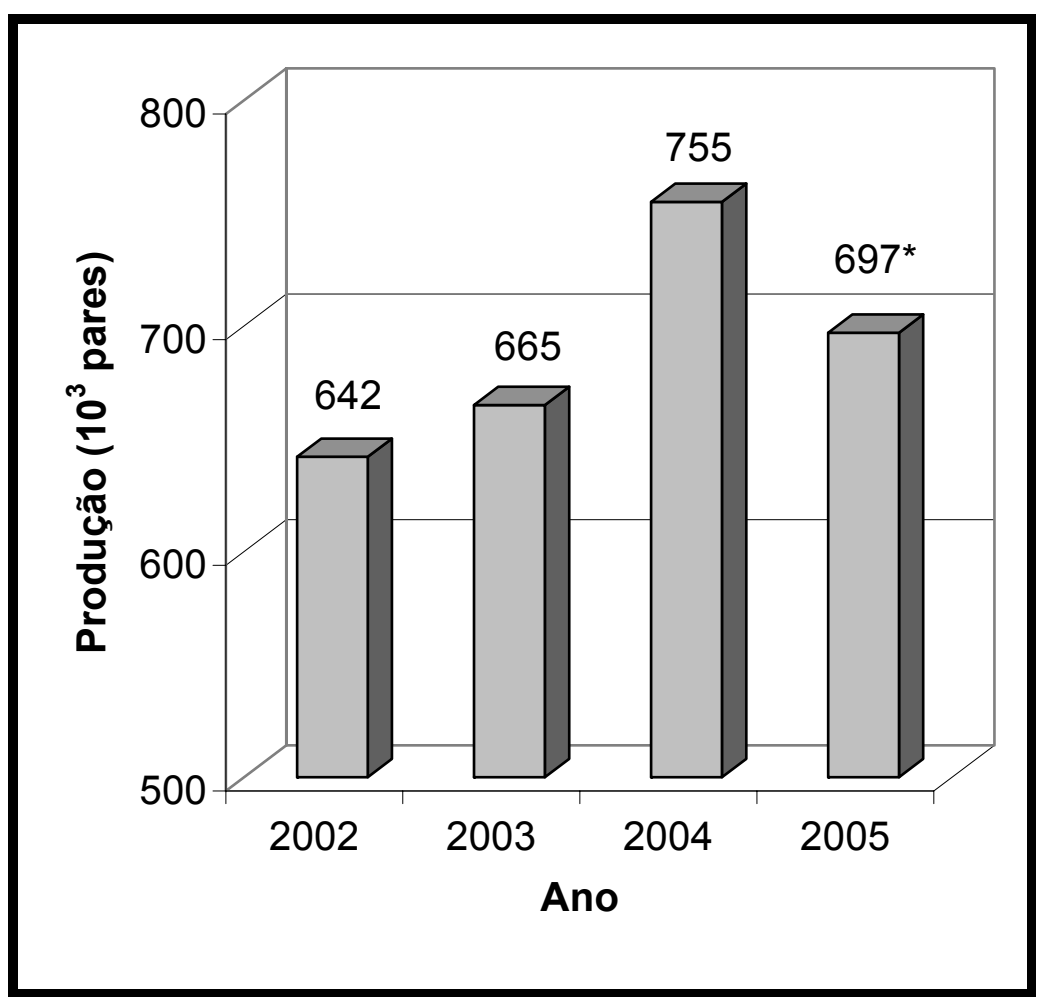

Fontes: Abicalçados (2005),

*Revista Química e Derivados (2006).

Figura 2.9. Produção brasileira de calçados em milhões de pares. 
Os resíduos das placas expandidas de EVA, objeto de estudo desta pesquisa, gerados pela indústria calçadista, são em forma de aparas devido à confecção de palmilhas, como mostra a Figura 2.10.

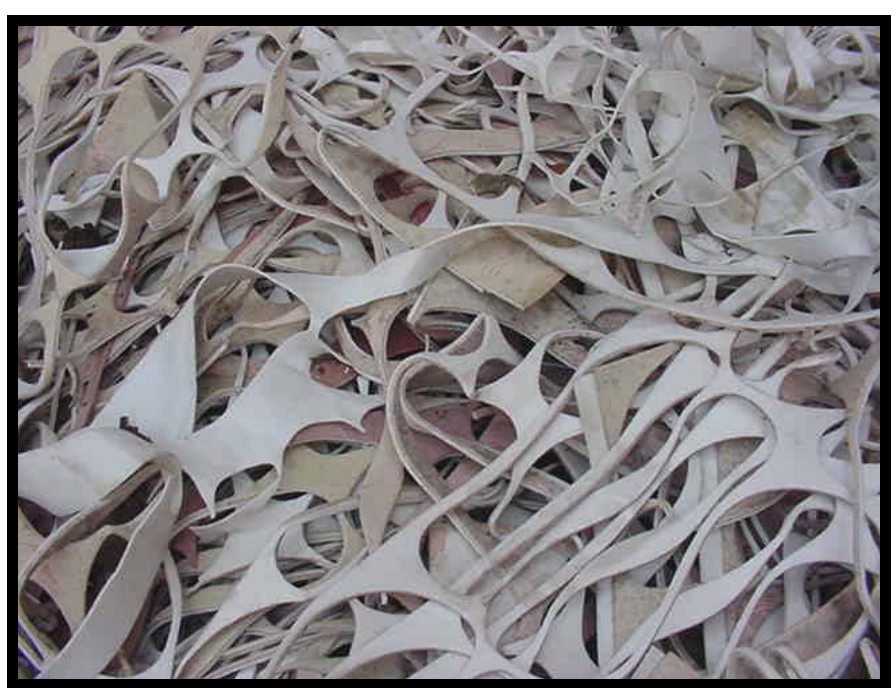

Figura 2.10. Resíduos das placas de EVA gerados na confecção de palmilhas.

\subsection{MÉTODO BAILEY DE SELEÇÃO GRANULOMÉTRICA}

O método Bailey de seleção granulométrica de agregados foi desenvolvido por Robert Bailey, do Departamento de Transportes de Illinois (IDOT), e vem sendo utilizado desde a década de 80 . Este método faz a seleção granulométrica dos agregados por volume, o que proporciona um forte esqueleto de agregado.

Por ser um método que define agregado graúdo e miúdo mais precisamente, de acordo com o diâmetro máximo nominal (DMN) do agregado, ele permite ajustes na quantidade de vazios da mistura, de modo a aumentar o intertravamento dos agregados e, portanto, a resistência à deformação permanente. Segundo Vavrik et al. (2002), o método Bailey, além de garantir a resistência à deformação 
permanente, também garante a resistência ao desgaste através da utilização de um maior teor de ligante graças ao correto volume de vazios.

As misturas feitas pelo método Bailey apresentam valores maiores de vazios do agregado mineral e de relação betume-vazios do que os das misturas convencionais, o que é um indicativo de misturas menos propensas às deformações permanentes e potencialmente mais resistentes às trincas por fadiga. Também apresentam melhores resultados nos ensaios de módulo de resiliência e resistência à tração (CUNHA, 2004).

\subsection{ENVELHECIMENTO}

O fenômeno de envelhecimento do asfalto é representado por seu enrijecimento, aumento de viscosidade e por se apresentar de forma mais quebradiça, portanto mais sujeito às trincas e a deterioração devido ao desgaste e à umidade (BELL; WIEDER; FELLIN; 1994).

Os ligantes asfálticos apresentam uma composição química que pode ser fracionada em compostos saturados, aromáticos, resinas e asfaltenos. O processo de envelhecimento se caracteriza, normalmente, pela diminuição do teor de aromáticos, que são transformados em resinas e estas, por sua vez, em parte se transformam em asfaltenos (partes insolúveis em n-heptano do asfalto), aumentando sua consistência (TONIAL, 2001). 
O envelhecimento de misturas asfálticas ocorre em duas etapas. A primeira quando a mistura asfáltica é preparada, ou seja, durante a usinagem, transporte, espalhamento e compactação, que recebe o nome de envelhecimento de curto prazo. A segunda é conhecida como envelhecimento de longo prazo e acontece após a construção do pavimento, quando a mistura asfáltica fica sujeita às ações climáticas e do tráfego.

No processo de envelhecimento de curto prazo a mistura sofre mudanças reológicas bruscas, como aumento de viscosidade e diminuição de penetração, através da oxidação pelo ar quente e perda de componentes voláteis. Já no processo de envelhecimento de longo prazo, as mudanças continuam, porém a uma taxa menor e cada vez mais lenta, sendo mais perceptível entre os dois ou três primeiros anos. Podem-se citar, também, como causas de envelhecimento, a oxidação do asfalto pela luz (radiação ultravioleta especialmente), polimerização, tixotropia, sinerese e separação dos óleos constituintes (ROBERTS et al., 1991).

Santanna-Greco (2004) simulou o envelhecimento de curto prazo, coletando a mistura asfáltica em dois momentos: logo após o processo de mistura e após 4 horas de envelhecimento da mistura em estufa com ventilação forçada a $135^{\circ} \mathrm{C}$. A mistura envelhecida por 4 horas foi disposta em um recipiente de tal maneira que formasse uma camada de $25 \mathrm{~mm}$ a $50 \mathrm{~mm}$ e foi revolvida a cada $60 \pm 5$ minutos, para manter a uniformidade da mistura. A autora simulou o processo de envelhecimento de longo prazo de dois modos: em estufa, com ventilação forçada por 5 dias, a uma temperatura de $135^{\circ} \mathrm{C}$; em exposição da mistura compactada por quatro meses ao ar livre, sendo que foram invertidos e girados $90^{\circ}$ semanalmente. A 
autora concluiu que ambos os envelhecimentos enrijeceram as misturas, refletindo em maiores módulos de resiliência e menor susceptibilidade à deformação permanente. Também verificou que as misturas apresentaram menores valores de recuperação elástica, ou seja, tornaram-se menos resistentes à fadiga. As misturas expostas ao tempo sofreram um envelhecimento mais acelerado que a simulação em estufa, o que concluiu ser em razão do fator radiação ultravioleta.

Magalhães (2004) estudou misturas com ligantes virgens e modificados com SBS, EVA e RASF (Resíduo Asfáltico de Petróleo), simulando envelhecimento de curto e de longo prazos e sem envelhecimento. As misturas sem envelhecimento foram compactadas logo após o processo de usinagem. O envelhecimento de curto prazo foi simulado mantendo-se a mistura em estufa por 2 horas, na temperatura de compactação. No envelhecimento de longo prazo, a mistura compactada foi mantida na estufa por 5 dias, a uma temperatura de $85^{\circ} \mathrm{C}$. Em todos os casos o autor verificou um aumento no módulo de resiliência.

A Tabela 2.10 mostra um resumo de alguns processos de envelhecimento de misturas asfálticas utilizados ao longo dos anos e o método de avaliação dos resultados (BELL, 1989). 
Tabela 2.10 - Métodos de avaliação de envelhecimento acelerado em laboratório.

\begin{tabular}{|c|c|c|c|}
\hline Data & Investigador(es) & $\begin{array}{c}\text { Método de } \\
\text { envelhecimento }\end{array}$ & Método de avaliação \\
\hline 1903 & Dow & $\begin{array}{l}18,24 \mathrm{~h}, 163^{\circ} \mathrm{C} \\
30 \mathrm{~min}, 149^{\circ} \mathrm{C}\end{array}$ & $\begin{array}{c}\text { Mudança no peso, penetração } \\
\text { de resíduo } \\
\text { Recuperação do asfalto - } \\
\text { mudança na penetração }\end{array}$ \\
\hline \multirow{3}{*}{1937} & Nicholson & $\begin{array}{c}\text { Ventilação forçada, } \\
15 \mathrm{~min}, 229^{\circ} \mathrm{C} \\
\end{array}$ & Penetração, ductilidade \\
\hline & $\begin{array}{l}\text { Rasching e } \\
\text { Doyle }\end{array}$ & $\begin{array}{c}\text { Ventilação forçada, } \\
15 \mathrm{~min}, 204^{\circ} \mathrm{C}\end{array}$ & Mudança na penetração \\
\hline & $\begin{array}{l}\text { Hubbard e } \\
\text { Gollomb }\end{array}$ & $\begin{array}{l}\text { Envelhecimento de } \\
\text { mistura de areia de } \\
\text { Ottawa, variação de } \\
\text { tempo e temperatura }\end{array}$ & $\begin{array}{l}\text { Recuperação do asfalto - } \\
\text { mudança na penetração }\end{array}$ \\
\hline \multirow[t]{3}{*}{1939} & Lang e Thomas & $\begin{array}{l}\text { Mistura arenosa de } \\
\text { Ottawa, } \\
\text { envelhecimento em } \\
\text { estufa, exposição ao } \\
\text { tempo }\end{array}$ & $\begin{array}{c}\text { Mudança nas propriedades da } \\
\text { mistura, abrasão, resistência, } \\
\text { etc. }\end{array}$ \\
\hline & Shattuck & $\begin{array}{l}\text { Envelhecimento da } \\
\text { mistura em estufa, } \\
30 \text { min, } 163^{\circ} \mathrm{C}\end{array}$ & $\begin{array}{c}\text { Recuperação do asfalto - } \\
\text { penetração, ductilidade, ponto } \\
\text { de amolecimento }\end{array}$ \\
\hline & Lewis e Welborn & $\begin{array}{c}\text { Ensaio de } \\
\text { envelhecimento de } \\
\text { filme de } 1 / 8 \text { pol, } 5 \mathrm{~h} \text {, } \\
163^{\circ} \mathrm{C}-\text { TFOT }\end{array}$ & $\begin{array}{c}\text { Mudança no peso, penetração, } \\
\text { ductilidade }\end{array}$ \\
\hline 1946 & Lewis e Halstead & $\begin{array}{c}\text { Ensaio de } \\
\text { envelhecimento de } \\
\text { filme de } 1 / 8 \text { pol, } 5 \mathrm{~h} \text {, } \\
163^{\circ} \mathrm{C}-\text { TFOT }\end{array}$ & $\begin{array}{c}\text { Mudança no peso, penetração, } \\
\text { ductilidade }\end{array}$ \\
\hline 1952 & Pauls e Welborn & $\begin{array}{l}\text { Envelhecimento em } \\
\text { estufa de mistura de } \\
\text { areia de Ottawa, } \\
163^{\circ} \mathrm{C} \text { - TFOT }\end{array}$ & $\begin{array}{l}\text { Resistência à compressão, } \\
\text { recuperação do asfalto, } \\
\text { resíduo do TFOT }\end{array}$ \\
\hline 1955 & $\begin{array}{l}\text { Griffin, Miles e } \\
\quad \text { Penther }\end{array}$ & $\begin{array}{c}\text { Ensaio de microfilme } \\
\text { da Shell, filme de } \\
5 \text { micra, } \\
2 \mathrm{~h} \\
\end{array}$ & $\begin{array}{l}\text { Viscosidade antes e depois do } \\
\text { envelhecimento - índice de } \\
\text { envelhecimento }\end{array}$ \\
\hline \multirow[t]{2}{*}{1957} & $\begin{array}{l}\text { Vallerga, } \\
\text { Monismith e } \\
\text { Granthem }\end{array}$ & $\begin{array}{l}\text { Exposição aos raios } \\
\text { ultravioletas e } \\
\text { infravermelhos }\end{array}$ & $\begin{array}{l}\text { Penetração, ponto de } \\
\text { amolecimento, ductilidade }\end{array}$ \\
\hline & $\begin{array}{c}\text { Brown, Sparks e } \\
\text { Smith }\end{array}$ & $\begin{array}{l}\text { Resfriamento rápido } \\
\text { de amostras de asfalto }\end{array}$ & Ensaio de tração \\
\hline
\end{tabular}


Tabela 2.10 - Continuação.

\begin{tabular}{|c|c|c|c|}
\hline 1958 & $\begin{array}{l}\text { Heithaus e } \\
\text { Johnson }\end{array}$ & $\begin{array}{l}\text { Pista de ensaio } \\
\text { Envelhecimento em } \\
\quad \text { laboratório } \\
\text { Ensaio de microfilme }\end{array}$ & $\begin{array}{l}\text { Recuperação do asfalto } \\
\text { Índice de envelhecimento de } \\
\text { microfilme }\end{array}$ \\
\hline \multirow{2}{*}{1961} & Traxler & $\begin{array}{l}\text { TFOT e filme de } 15 \\
\text { micra, } 2 \mathrm{~h}, 107^{\circ} \mathrm{C}\end{array}$ & $\begin{array}{l}\text { Comparação da } \\
\text { microviscosidade a } \\
25^{\circ} \mathrm{C}\end{array}$ \\
\hline & $\begin{array}{l}\text { Halstead e } \\
\text { Zenewits }\end{array}$ & $\begin{array}{l}\text { TFOT e filme de } 15 \\
\text { micra, } 2 \mathrm{~h}, 107^{\circ} \mathrm{C}\end{array}$ & $\begin{array}{c}\text { Comparação da } \\
\text { microviscosidade a } \\
25^{\circ} \mathrm{C} \text {, taxa de } 0,05 \mathrm{~s}^{-1}\end{array}$ \\
\hline 1963 & $\begin{array}{l}\text { Hveen, Zube e } \\
\text { Skog }\end{array}$ & $\begin{array}{l}\text { Ensaio modificado de } \\
\text { microfilme da Shell, } \\
\text { filme de } 20 \text { micra, } \\
24 \mathrm{~h}, 99^{\circ} \mathrm{C} \\
\text { RTFOT e TFOT, } \\
163^{\circ} \mathrm{C} \\
50 \text { min } \\
\text { Ensaio de coesígrafo }\end{array}$ & $\begin{array}{c}\text { Comparação da } \\
\text { microviscosidade a } \\
25^{\circ} \mathrm{C} \text { antes e depois do } \\
\text { envelhecimento } \\
\text { Comparação das viscosidades } \\
\text { do RTFOT, TFOT e } \\
\text { recuperação do asfalto }\end{array}$ \\
\hline 1968 & Lee & $\begin{array}{c}\text { TFOT, } 163^{\circ} \mathrm{C} \\
\mathrm{POB}, 65^{\circ} \mathrm{C}, 24 \mathrm{~h}, 48 \mathrm{~h}, \\
96 \mathrm{~h} \text { e } 240 \mathrm{~h}, 29 \text { psig e } \\
132 \text { psig } \\
\text { Misturas asfálticas e } \\
\text { areia-asfalto }\end{array}$ & $\begin{array}{c}\text { Microviscosidade a } 25^{\circ} \mathrm{C}, \\
\text { limitando a viscosidade, tempo } \\
\text { de endurecimento até } 30 \\
\text { megapoise, índice de } \\
\text { cisalhamento } \\
\text { Conteúdo de asfaltenos }\end{array}$ \\
\hline 1969 & $\begin{array}{l}\text { Schimidt e } \\
\text { Santucci }\end{array}$ & $\begin{array}{l}\text { Ensaio de microfilme } \\
\text { giratório, filme de } 20 \\
\text { micra, } 99^{\circ} \mathrm{C}\end{array}$ & Microviscosidade do resíduo \\
\hline 1973 & Lee & $\begin{array}{c}\text { TFOT } \\
\text { POB, } 65^{\circ} \mathrm{C}, 20 \mathrm{~atm} \\
\text { Recuperação dos } \\
\text { materiais envelhecidos } \\
\text { em campo }\end{array}$ & $\begin{array}{c}\text { Microviscosidade a } 25^{\circ} \mathrm{C} \\
\text { Viscosidade por capilaridade a } \\
62^{\circ} \mathrm{C} \\
\text { Microductilidade, Ensaio } \\
\text { Fraass } \\
\text { Conteúdo de asfaltenos e } \\
\text { porcentagem de oxigênio } \\
\text { Análise Rostler }\end{array}$ \\
\hline \multirow[b]{2}{*}{1976} & Benson & $\begin{array}{c}\text { TFOT } \\
\text { Atuação da luz } \\
\text { Misturas expostas ao } \\
\text { tempo }\end{array}$ & $\begin{array}{l}\text { Microviscosidade a } 25^{\circ} \mathrm{C} \\
\text { Penetração a } 25^{\circ} \mathrm{C}\end{array}$ \\
\hline & $\begin{array}{c}\text { Plancher, Green } \\
\text { e Petersen }\end{array}$ & $\begin{array}{c}\text { RTFOT, RMFO } \\
\text { Oxidação de coluna } \\
\text { Envelhecimento em } \\
\text { estufa, } 5 \mathrm{~h}, 150^{\circ} \mathrm{C} \\
\text { Misturas virgens e com } \\
\text { cal }\end{array}$ & $\begin{array}{c}\text { Microviscosidade a } 25^{\circ} \mathrm{C} \\
\text { Determinação dos asfaltenos } \\
\text { Análise química } \\
\text { Módulo de resiliência }\end{array}$ \\
\hline
\end{tabular}


Tabela 2.10 - Continuação.

\begin{tabular}{|c|c|c|c|}
\hline 1977 & Kumar e Goetz & $\begin{array}{c}\text { Permeação de ar a } \\
60^{\circ} \mathrm{C} \text { em uma película } \\
\text { de } 0,5 \mathrm{~mm} \text { de água por } \\
1,2,4,6 \text { e } 10 \text { dias }\end{array}$ & $\begin{array}{c}\text { Ensaio de fluência por } \\
\text { compressão uniaxial estática a } \\
21^{\circ} \mathrm{C} \pm 2^{\circ} \mathrm{C} \text {, condicionamento } \\
\text { por repetição de carga, } 5 \text { psi, } \\
5 \text { min } \\
\text { Uso da declividade e do } \\
\text { intercepto da curva de fluência } \\
\text { indicam oxidação progressiva } \\
\text { Taxa de declividade ou } \\
\text { intercepto a "x" dias pela } \\
\text { declividade inicial = índice de } \\
\text { durabilidade }\end{array}$ \\
\hline \multirow[t]{2}{*}{1981} & $\begin{array}{l}\text { Kemp e } \\
\text { Predoehl }\end{array}$ & $\begin{array}{c}\text { Ensaio de ação da luz } \\
\text { e do tempo. Ensaio de } \\
\text { microfilme giratório. } \\
\text { Envelhecimento de } \\
\text { mistura de areia de } \\
\text { Ottawa. Ensaio } \\
\text { modificado de } \\
\text { microfilme da Shell. } \\
\text { Misturas expostas ao } \\
\text { tempo em campo. }\end{array}$ & $\begin{array}{c}\text { Penetração a } 25^{\circ} \mathrm{C} \\
\text { Ductilidade a } 25^{\circ} \mathrm{C} \\
\text { Módulo de resiliência } \\
\text { Microviscosidade a } 25^{\circ} \mathrm{C} \\
\text { Viscosidade por capilaridade a } \\
60^{\circ} \mathrm{C}\end{array}$ \\
\hline & $\begin{array}{l}\text { Santucci, } \\
\text { Goodrich e } \\
\text { Sundberg }\end{array}$ & $\begin{array}{l}\text { Ensaio de durabilidade } \\
\text { em forno inclinado, } \\
113^{\circ} \mathrm{C} \text { por } 168 \mathrm{~h} \mathrm{e} \\
115^{\circ} \mathrm{C} \text { por } 100 \mathrm{~h}\end{array}$ & $\begin{array}{c}\text { Viscosidade a } 60^{\circ} \mathrm{C} \text { e } 135^{\circ} \mathrm{C} \\
\text { Penetração a } 4^{\circ} \mathrm{C} \text { e a } 25^{\circ} \mathrm{C} \\
\text { Ductilidade a } 25^{\circ} \mathrm{C}\end{array}$ \\
\hline 1983 & McHattie & $\begin{array}{l}\text { RTFOT estendido, } \\
100 \mathrm{~h}, 115^{\circ} \mathrm{C}\end{array}$ & $\begin{array}{c}\text { Penetração a } 25^{\circ} \mathrm{C} \\
\text { Viscosidade cinemática a } \\
135^{\circ} \mathrm{C} \\
\text { Módulo de resiliência } \\
\text { Vida EAL (carga equivalente } \\
\text { de eixo) }\end{array}$ \\
\hline \multirow[t]{2}{*}{1985} & Edler et al. & $\begin{array}{l}\text { RTFOT, filme de } 100 \\
\text { micra, estendido até } \\
8 \mathrm{~h} \text {. Oxidação por } \\
\text { pressão por } 96 \mathrm{~h}, \\
65^{\circ} \mathrm{C}, 300 \text { psi. TFOT } \\
\text { modificado, filme de } \\
100 \text { micra, } 24 \mathrm{~h}\end{array}$ & $\begin{array}{c}\text { Viscosidade a } 45^{\circ} \mathrm{C} \text { pelo } \\
\text { microviscosímetro de placa a } \\
\text { uma taxa de cisalhamento de } \\
0,05 \mathrm{~s}^{-1} \\
\text { Nível de oxidação - espectro } \\
\text { infravermelho } \\
\text { Constituintes de alto peso } \\
\text { molecular }\end{array}$ \\
\hline & Hugo e Kennedy & $\begin{array}{c}\text { Envelhecimento da } \\
\text { mistura em estufa, } \\
100^{\circ} \mathrm{C} \text {. Exposição da } \\
\text { mistura aos raios } \\
\text { ultravioletas, } 54 \text { h e } 14 \\
\text { dias }\end{array}$ & $\begin{array}{l}\text { Microviscosidade a } 25^{\circ} \mathrm{C} \\
\text { Redução da mistura em forma } \\
\text { de viga }\end{array}$ \\
\hline
\end{tabular}


Tabela 2.10 - Continuação.

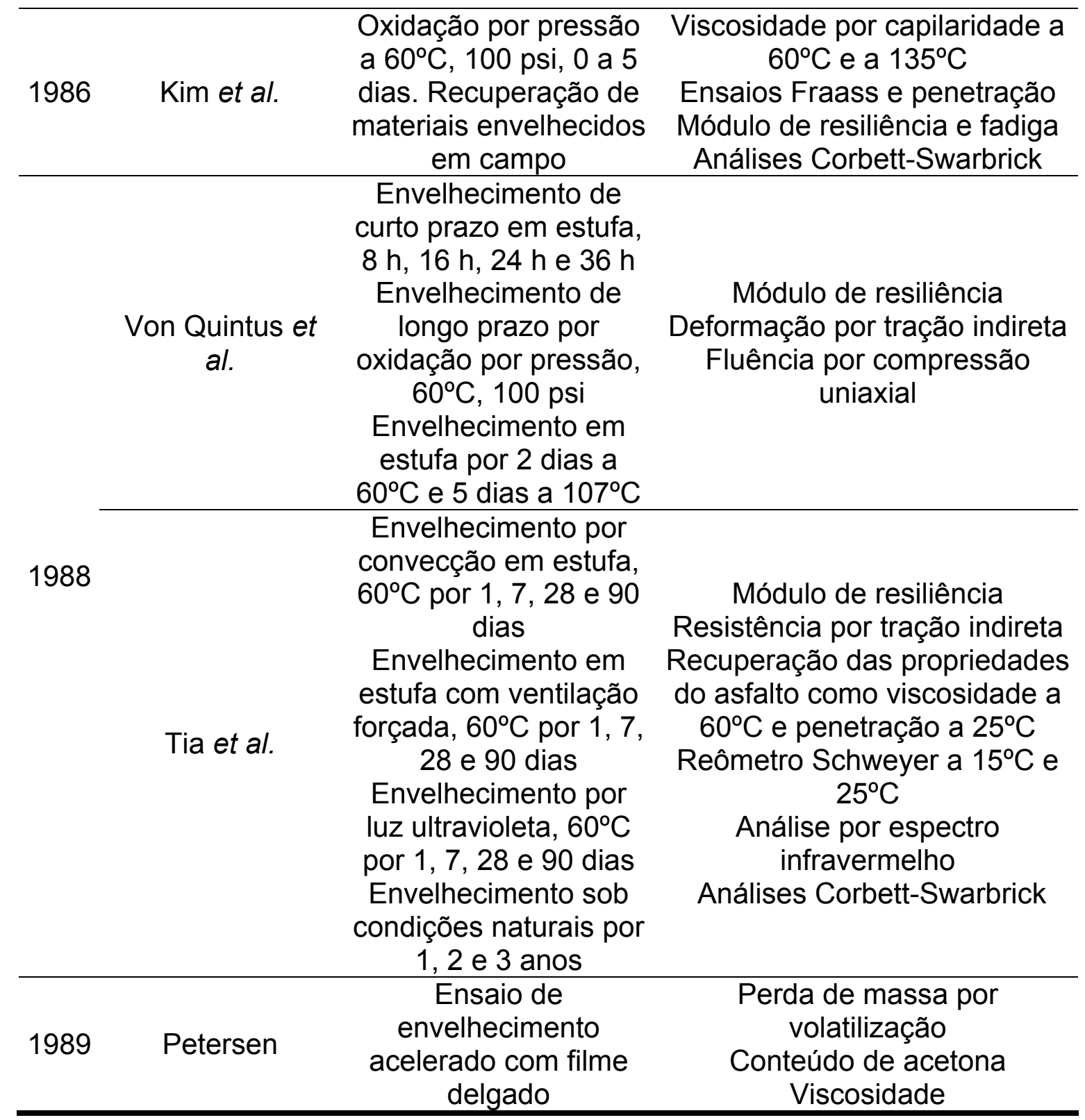


Ninguém comete maior erro do que não fazer nada porque só pode fazer pouco.

\section{MATERIAIS E MÉTODOS}

\subsection{CONSIDERAÇÕES INICIAIS}

O programa experimental dessa pesquisa foi dividido em três partes. A primeira parte refere-se à preparação e caracterização dos materiais envolvidos (agregado, ligante asfáltico e resíduo). A segunda parte foi denominada de ensaios exploratórios e serviu para a determinação dos teores de resíduos que foram utilizados na pesquisa. Por fim, a última parte detalha os ensaios realizados. À descrição dos materiais e métodos de ensaio foi dada grande importância, pois somente desse modo pode-se reproduzir futuramente os ensaios realizados nesta pesquisa. 


\subsection{MATERIAIS UTILIZADOS}

A primeira parte laboratorial da pesquisa teve o intuito de obter, preparar, classificar e caracterizar os materiais utilizados. Os resultados servem não somente para esta pesquisa, mas também permitem a repetição dos experimentos apresentados nos itens a seguir.

\subsubsection{Ligante Asfáltico}

O ligante asfáltico utilizado na pesquisa foi o CAP 50/70 proveniente da refinaria Henrique Lage (REVAP). Os resultados dos ensaios de caracterização do ligante foram fornecidos pela Ipiranga Asfaltos S/A e são apresentadas na Tabela 3.1.

Tabela 3.1 - Resultados dos ensaios de caracterização do CAP 50/70.

\begin{tabular}{l|c}
\hline Característica & Resultado \\
\hline Penetração - $25^{\circ} \mathrm{C}, 5 \mathrm{~s}, 100 \mathrm{~g}(\mathrm{~mm})$ & 5,7 \\
Ponto de amolecimento $\left({ }^{\circ} \mathrm{C}\right)$ & 48,6 \\
Ponto de fulgor $\left({ }^{\circ} \mathrm{C}\right)$ & 252 \\
Índice de susceptibilidade térmica & $-1,25$ \\
Viscosidade absoluta a $60^{\circ} \mathrm{C}(\mathrm{Poise})$ & 2065 \\
Viscosidade Saybolt Furol a $135^{\circ} \mathrm{C}(\mathrm{s})$ & 162 \\
Viscosidade Saybolt Furol a $150^{\circ} \mathrm{C}(\mathrm{s})$ & 73,2 \\
Viscosidade Saybolt Furol a $177^{\circ} \mathrm{C}(\mathrm{s})$ & 28 \\
Ductilidade a $25^{\circ} \mathrm{C}(\mathrm{cm})$ & 110 \\
RTFOT - perda de massa (\%) & 0,105 \\
RTFOT - relação de penetração & 0,5 \\
\hline \multicolumn{2}{|c}{ Fonte: Fornecido por Ipiranga Asfaltos S/A. }
\end{tabular}




\subsubsection{Agregados}

Nesta pesquisa utilizou-se agregado de origem basáltica, proveniente da pedreira Bandeirantes, localizada na cidade de São Carlos/SP. Este material foi escolhido pelo fato de ser muito utilizado em obras de pavimentação no interior de São Paulo, pela facilidade de sua obtenção e por apresentar boas características em misturas asfálticas, segundo a bibliografia consultada.

\subsubsection{Granulometria}

As granulometrias dos agregados utilizados nessa pesquisa foram determinadas utilizando as peneiras recomendadas pelo SUPERPAVE (peneiras com malhas de abertura $0,075 \mathrm{~mm}, 0,15 \mathrm{~mm}, 0,30 \mathrm{~mm}, 0,60 \mathrm{~mm}, 1,18 \mathrm{~mm}, 2,36 \mathrm{~mm}, 4,75 \mathrm{~mm}, 9,5$ $\mathrm{mm}, 12,5 \mathrm{~mm}$ e $19,1 \mathrm{~mm})$. O peneiramento dos materiais foi feito totalmente de maneira manual, com a finalidade minimizar o erro por peneira e, portanto, produzir corpos-de-prova com características mais semelhantes possível. Os dados resultantes são apresentados na Tabela 3.2 e na Figura 3.1. 
Tabela 3.2 - Granulometria dos agregados.

\begin{tabular}{c|c|c|c}
\hline \multicolumn{3}{c}{ QUANTIDADE PASSADA ACUMULADA (\%) } \\
\hline Peneira (mm) & Pedra 1 & Pedrisco & Pó de pedra \\
\hline 19,1 & 100,00 & 100,00 & 100,00 \\
12,5 & 78,67 & 100,00 & 100,00 \\
9,5 & 27,38 & 99,01 & 100,00 \\
4,75 & 0,00 & 37,05 & 99,86 \\
2,36 & 0,00 & 6,11 & 89,33 \\
1,18 & 0,00 & 1,69 & 66,60 \\
0,60 & 0,00 & 0,26 & 48,14 \\
0,30 & 0,00 & 0,20 & 33,90 \\
0,15 & 0,00 & 0,13 & 20,12 \\
0,075 & 0,00 & 0,11 & 9,91 \\
\hline
\end{tabular}

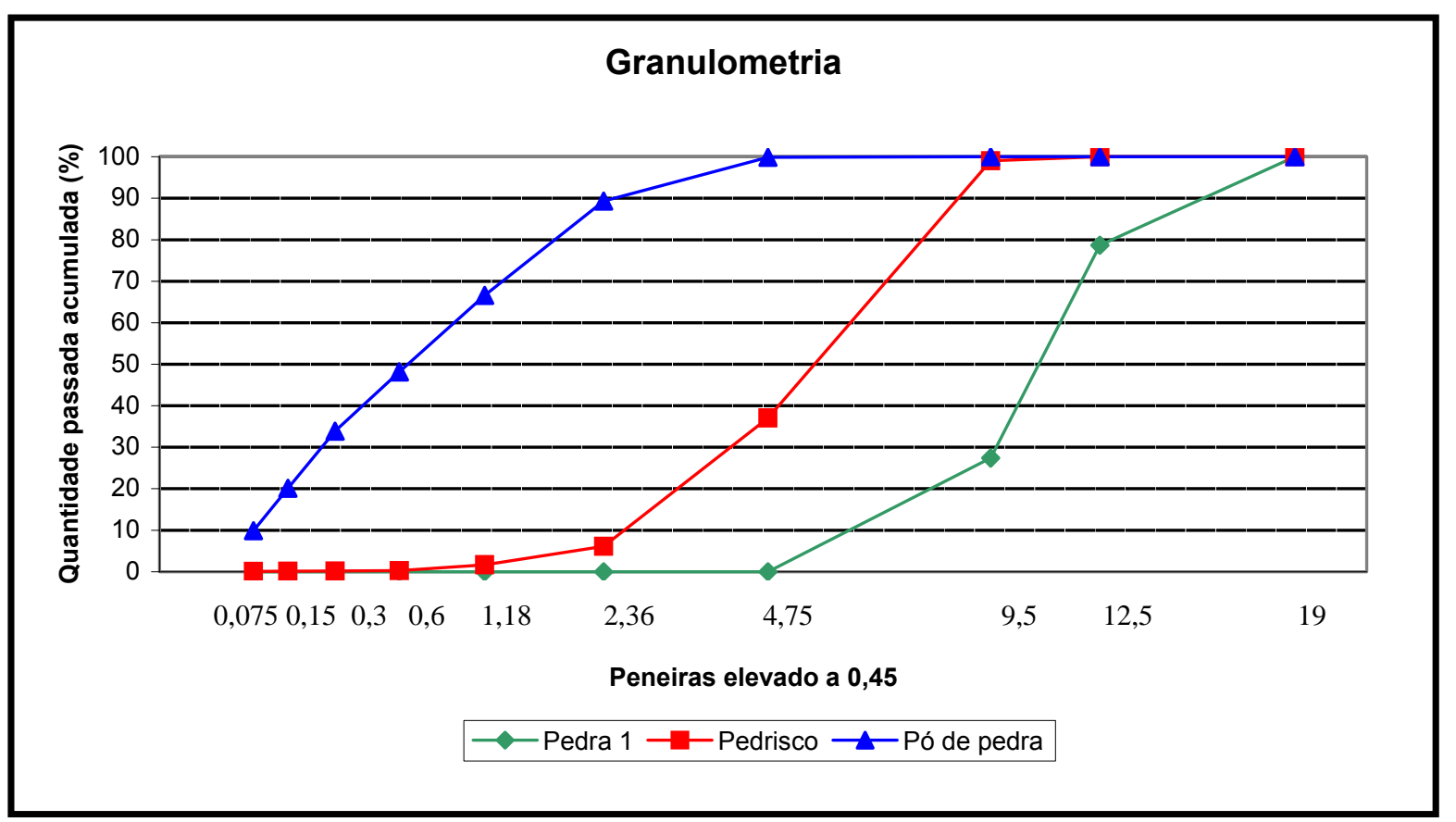

Figura 3.1. Granulometria dos agregados.

\subsubsection{Absorção e massa específica do agregado graúdo}

A determinação da absorção e da massa específica do agregado graúdo foi realizada de acordo com a norma DNER-ME 081/98 (DNER, 1998a). Os agregados graúdos utilizados em toda a pesquisa foram primeiramente lavados, para que 
fossem retirados o pó e as impurezas, seco em estufa a $110^{\circ} \mathrm{C}$ por 4 horas, resfriado à temperatura ambiente e guardado em sacos plásticos para evitar umidade.

Uma amostra de cerca de 2000 gramas foi separada e colocada em imersão em água à temperatura ambiente, por 24 horas. O material foi retirado e colocado em um pano para que fosse seco superficialmente, para então ser verificada sua massa (Figura 3.2). Imediatamente após isso, a amostra foi colocada em uma cesta para a verificação da massa imersa. Em seguida, o material foi seco em estufa a $110^{\circ} \mathrm{C}$, por um período de 4 horas, resfriado à temperatura ambiente por 2 horas e verificada sua massa seca.

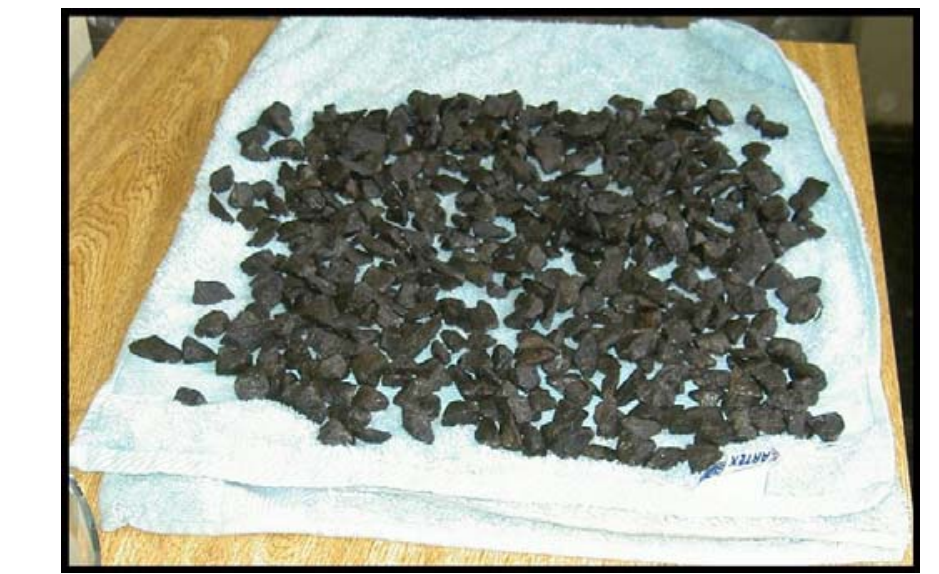

Figura 3.2. Secagem superficial do agregado graúdo.

A massa específica aparente do agregado graúdo foi determinada a partir da Equação 3.1.

$$
\rho_{\text {ap.ag }}=\frac{A}{S-C}
$$


em que:
$\rho_{\text {ap,ag }}:$ massa específica aparente do agregado graúdo $\left(\mathrm{g} / \mathrm{cm}^{3}\right)$;
A : massa da amostra seca (g);
S : massa da amostra na condição saturada seca superficialmente (g);
C : massa da amostra submersa (g).

A Equação 3.2 fornece a massa específica real do agregado graúdo.

$$
\rho_{a g}=\frac{A}{A-C}
$$

em que:

$$
\rho_{a g} \quad \text { : massa específica real do agregado graúdo }\left(\mathrm{g} / \mathrm{cm}^{3}\right) \text {. }
$$

A absorção foi determinada através da Equação 3.3.

$$
A b s_{a g}=\frac{S-A}{A} \times 100
$$

em que:

$A b s_{a g}:$ absorção de água pelo agregado graúdo (\%).

\subsubsection{Absorção e massa específica do agregado fino}

O ensaio para a determinação da massa específica do agregado fino foi feito de acordo com a ASTM C 128 (ASTM, 1993). A amostra foi preparada lavando-se $1000 \mathrm{~g}$ de agregado fino (passado na peneira de malha 2,36 $\mathrm{mm}$ e retido na peneira 
de malha $0,075 \mathrm{~mm}$ ) na peneira de malha $0,075 \mathrm{~mm}$. O material lavado ficou em repouso por 24 horas, submerso com 3,0 cm de água acima do nível superior do agregado (Figura 3.3).

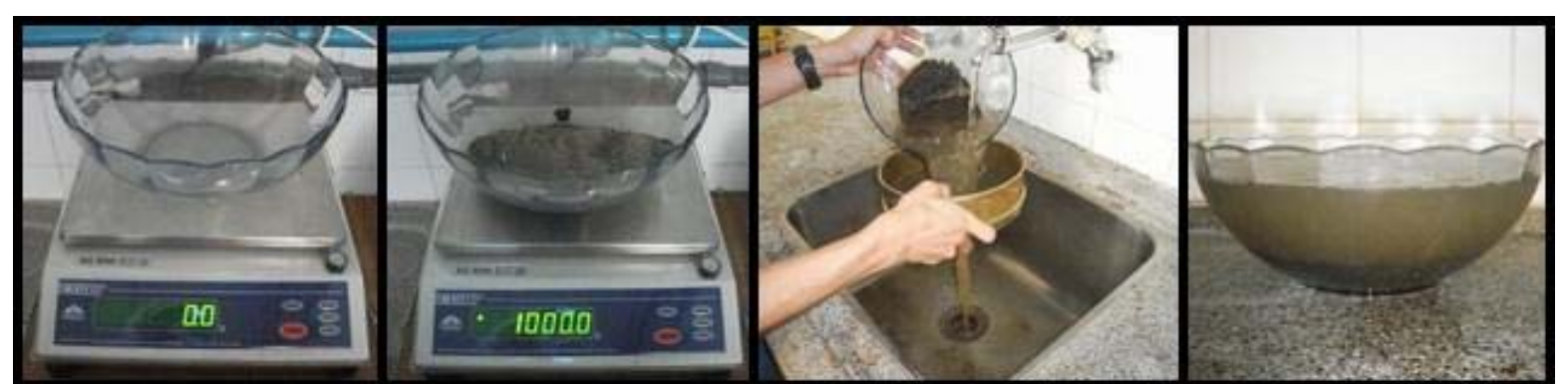

Figura 3.3. Preparação da amostra para o ensaio de massa específica do agregado fino.

Após o prazo de repouso, retirou-se o excesso de água com cuidado para que não houvesse perda de material e este foi colocado, em camada bem fina, dentro de uma bandeja. A seguir, iniciou-se processo de secagem com uma corrente de ar aquecido e revirando-se o agregado com uma espátula (Figura 3.4).

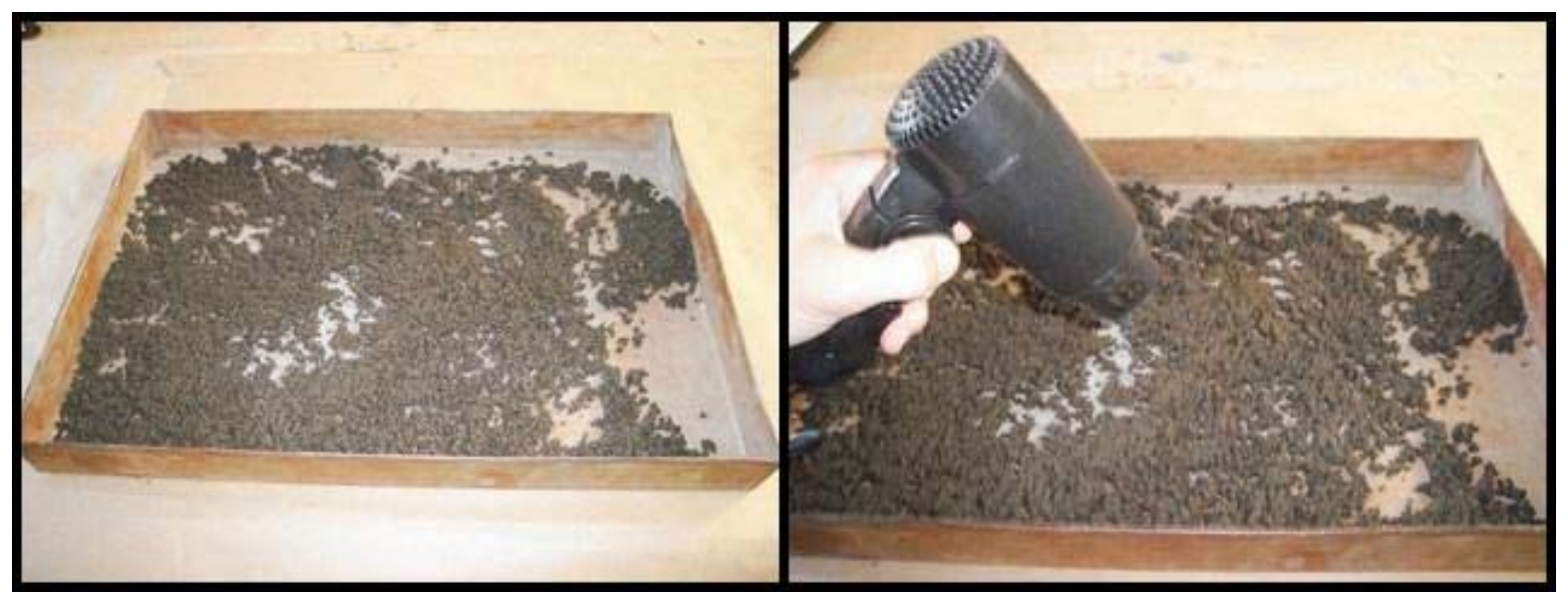

Figura 3.4. Secagem da amostra para o ensaio de massa específica do agregado fino. 
No momento em que foi observada mudança na cor do agregado, uma parte da amostra foi retirada e colocada dentro do cone metálico, em cima de uma placa de vidro lisa e plana, até a borda superior, e compactada com 25 golpes do soquete, com queda de $5 \mathrm{~mm}$ acima da superfície do agregado. Em seguida, retirou-se o cone metálico com cuidado para que não ocorressem movimentos horizontais e verificou-se a condição do agregado compactado. A condição saturada seca superficialmente se dá quando parte ou todo o cone desmorona. O procedimento de secagem foi feito até que esta condição fosse atingida (Figura 3.5).

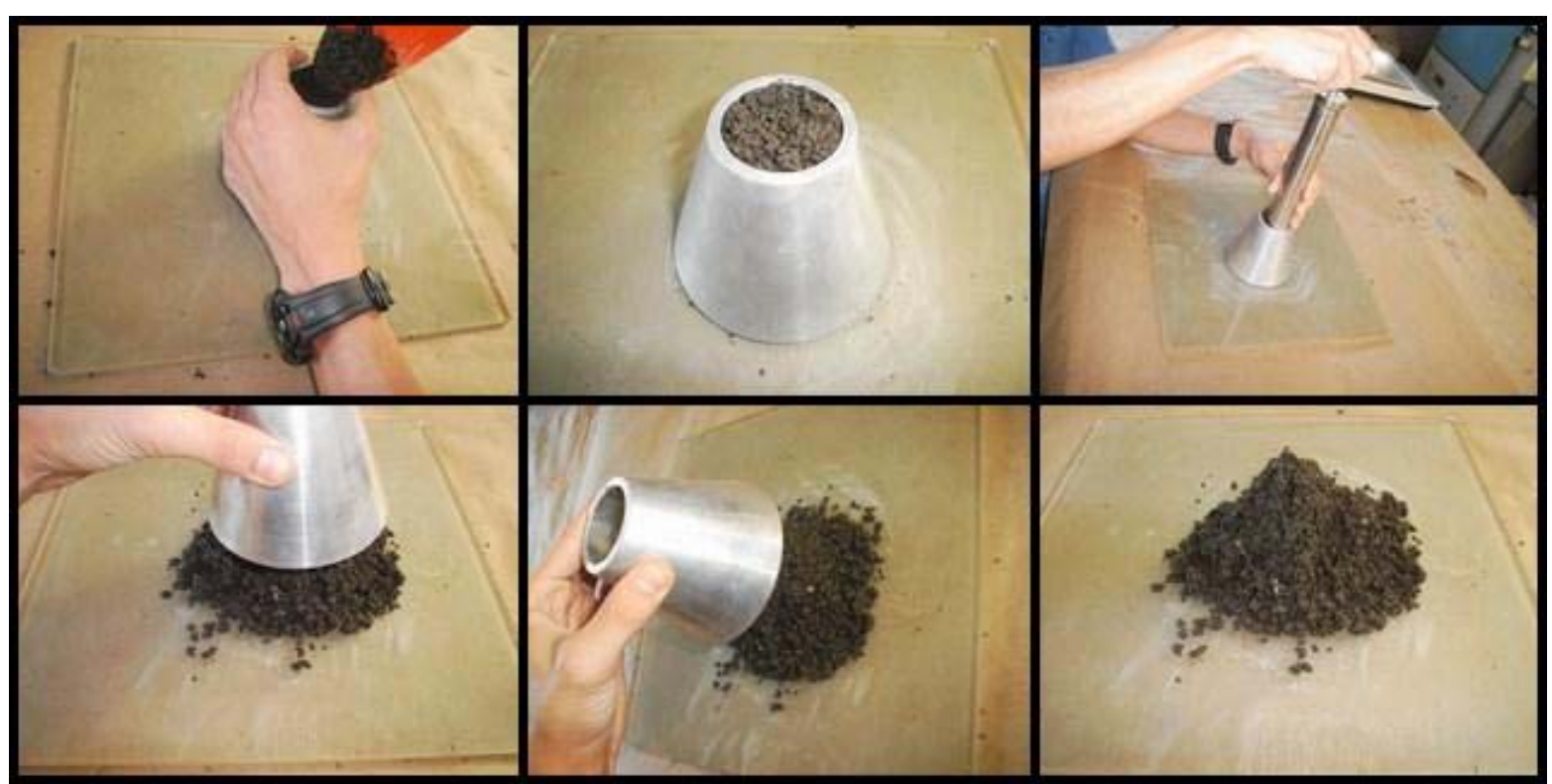

Figura 3.5. Verificação da condição saturada seca superficialmente do agregado fino.

Atingida a condição saturada seca superficialmente do agregado, retirou-se aproximadamente 500 gramas do material, que foi colocado no kitassato modificado para verificação da massa do conjunto (amostra + recipiente). Feito isso, adicionouse água (destilada e fervida por 1 hora) no kitassato até atingir um nível de água de, aproximadamente, $4 \mathrm{~cm}$ acima da superfície do agregado e então foi aplicado um 
vácuo parcial por 20 minutos, com o intuito de retirar as bolhas de ar. Completou-se o kitassato com água e anotou-se a temperatura, para então se verificar a massa do conjunto (amostra + recipiente + água), como mostra a Figura 3.6.

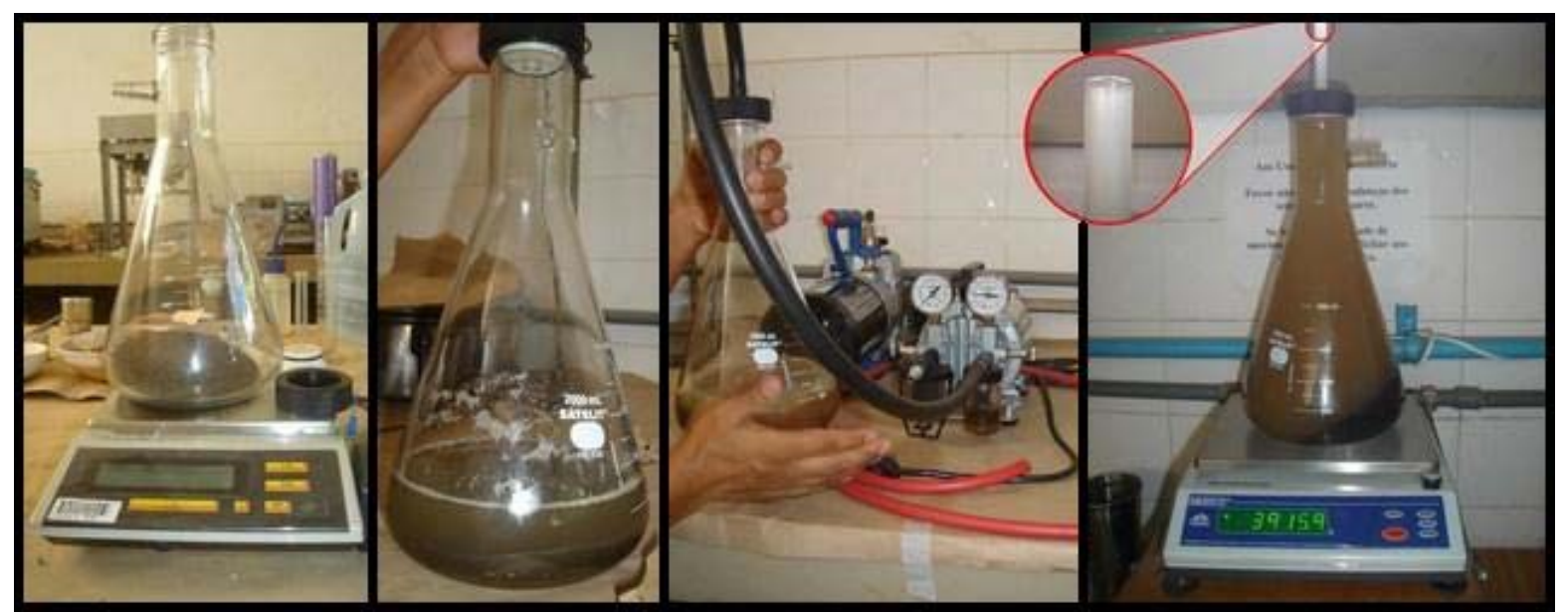

Figura 3.6. Retirada das bolhas de ar da amostra para o ensaio de massa específica do agregado fino.

Em seguida, o material foi retirado e levado em estufa a $100^{\circ} \mathrm{C}$, até atingir a condição seca, e então anotada a massa da amostra. A massa do kitassato modificado, cheio de água, foi retirada de uma curva de calibração (Figura 3.7).

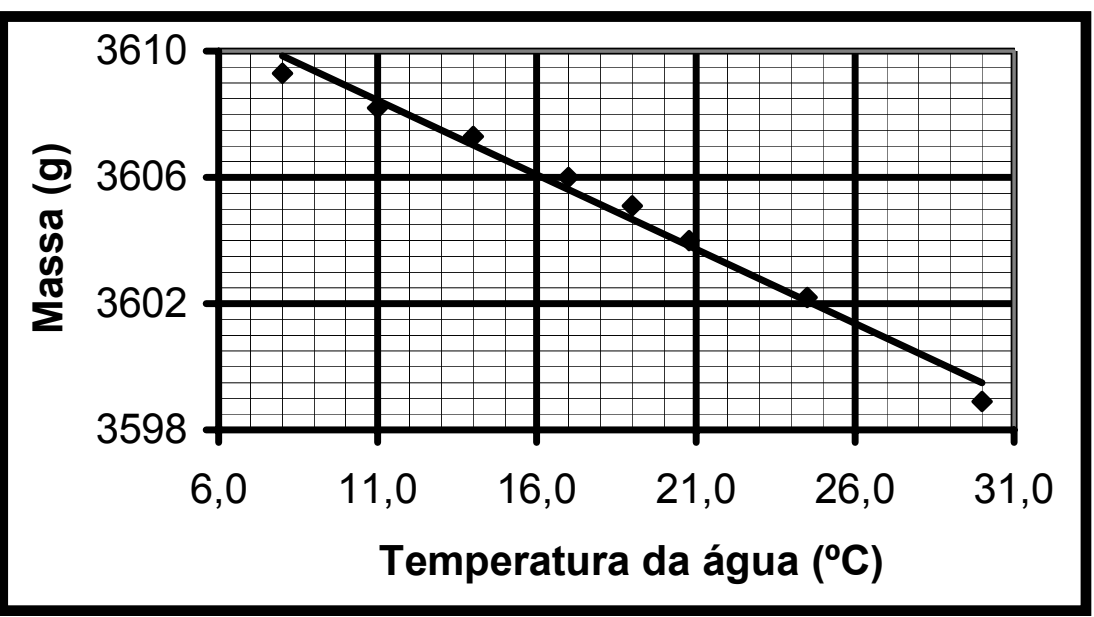

Figura 3.7. Curva de calibração do kitassato modificado. 
A Equação 3.4 fornece a massa específica do agregado fino.

$$
\rho_{\text {ap }, a f}=\frac{A}{S+D-E} \times \rho_{\text {agua }}
$$

em que:

$$
\begin{array}{ll}
\rho_{\text {ap,af }} & \text { : massa específica aparente do agregado fino }\left(\mathrm{g} / \mathrm{cm}^{3}\right) ; \\
\rho_{\text {água }} & \text { : massa específica da água na temperatura do ensaio }\left(\mathrm{g} / \mathrm{cm}^{3}\right) ; \\
A & : \text { massa da amostra seca }(\mathrm{g}) ; \\
D \quad & : \text { massa do kitassato, cheio de água, obtida da curva de calibração }(\mathrm{g}) ; \\
E & : \text { massa da amostra + kitassato modificado completo com água }(\mathrm{g}) ; \\
S & : \text { massa da amostra na condição saturada seca superficialmente }(\mathrm{g}) .
\end{array}
$$

A massa específica real foi determinada através da Equação 3.5.

$$
\rho_{a f}=\frac{A}{A+D-E} \times \rho_{\text {agua }}
$$

em que:

$$
\begin{aligned}
& \rho_{a f} \quad \text { : massa específica real do agregado fino }\left(\mathrm{g} / \mathrm{cm}^{3}\right) ; \\
& \rho_{\text {água }} \text { : massa específica da água na temperatura do ensaio }\left(\mathrm{g} / \mathrm{cm}^{3}\right) ; \\
& A \quad: \text { massa da amostra seca }(\mathrm{g}) ; \\
& D \quad \text { : massa do kitassato, cheio de água, obtida da curva de calibração }(\mathrm{g}) ; \\
& \text { E : massa da amostra + kitassato modificado completo com água }(\mathrm{g}) .
\end{aligned}
$$


O valor de absorção de água pelo agregado fino foi determinada pela Equação 3.6.

$$
A b s_{a f}=\frac{S-A}{A} \times 100
$$

em que:

$$
\begin{aligned}
& A b S_{a f} \text { : absorção de água pelo agregado fino (\%); } \\
& S \quad \text { : massa da amostra na condição saturada seca superficialmente }(\mathrm{g}) \text {; } \\
& \text { A } \quad \text { : massa da amostra seca }(\mathrm{g}) .
\end{aligned}
$$

\subsubsection{Ensaio de abrasão "Los Angeles"}

O ensaio de abrasão "Los Angeles" foi realizado em conformidade com a metodologia de ensaio DNER-ME 035/98 (DNER, 1998b), com o intuito de verificar a perda de massa por desgaste do agregado. A Tabela 3.3 apresenta as especificações para as graduações A a G do DNER.

material foi lavado e posteriormente seco em estufa a $105^{\circ} \mathrm{C}$. A preparação das amostras se deu por peneiramento manual. O material foi pesado e colocado no tambor (Figura 3.8) junto com as esferas de aço (Figura 3.9) e submetido a 500 rotações a $33 \mathrm{rpm}$. A amostra ensaiada foi lavada na peneira de malha 1,68 $\mathrm{mm} \mathrm{e}$ seca em estufa a $105^{\circ} \mathrm{C}$ por 6 horas. A Tabela 3.4 mostra a perda de massa em porcentagem. 
Tabela 3.3 - Especificações para o ensaio de Abrasão "Los Angeles".

\begin{tabular}{|c|c|c|c|c|c|c|c|c|}
\hline \multicolumn{2}{|c|}{ Peneiras (mm) } & \multicolumn{7}{|c|}{$\begin{array}{c}\text { Amostra } \\
\text { Massa parcial }(\mathrm{g})\end{array}$} \\
\hline Pass. & Retido & $\begin{array}{c}\text { Grad. } \\
\text { A }\end{array}$ & $\begin{array}{c}\text { Grad. } \\
\text { B }\end{array}$ & $\begin{array}{c}\text { Grad. } \\
\text { C }\end{array}$ & $\begin{array}{l}\text { Grad. } \\
\text { D }\end{array}$ & $\begin{array}{c}\text { Grad. } \\
\text { E }\end{array}$ & $\begin{array}{l}\text { Grad. } \\
\quad \text { F }\end{array}$ & $\begin{array}{c}\text { Grad. } \\
\text { G }\end{array}$ \\
\hline 76 & 63 & - & - & - & - & $\begin{array}{l}2500 \pm \\
50\end{array}$ & - & - \\
\hline 63 & 50 & - & - & - & - & $\begin{array}{l}2500 \pm \\
50\end{array}$ & - & - \\
\hline 50 & 38 & - & - & - & - & $\begin{array}{l}5000 \pm \\
50\end{array}$ & $\begin{array}{c}5000 \pm \\
50\end{array}$ & - \\
\hline 38 & 25 & $\begin{array}{c}1250 \pm \\
25\end{array}$ & - & - & - & - & $\begin{array}{l}5000 \pm \\
25\end{array}$ & $\begin{array}{c}5000 \pm \\
25\end{array}$ \\
\hline 25 & 19 & $\begin{array}{c}1250 \pm \\
25\end{array}$ & - & - & - & - & 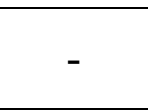 & $\begin{array}{c}5000 \pm \\
25\end{array}$ \\
\hline 19 & 12,5 & $\begin{array}{c}1250 \pm \\
10\end{array}$ & $\begin{array}{c}2500 \pm \\
10\end{array}$ & - & - & - & - & - \\
\hline 12,5 & 9,5 & $\begin{array}{c}1250 \pm \\
10\end{array}$ & $\begin{array}{c}2500 \pm \\
10\end{array}$ & - & - & - & - & - \\
\hline 9,5 & 6,3 & - & - & $\begin{array}{c}2500 \pm \\
10\end{array}$ & - & - & - & - \\
\hline 6,3 & 4,8 & - & - & $\begin{array}{c}2500 \pm \\
10\end{array}$ & - & - & - & - \\
\hline 4,8 & 2,4 & - & - & - & $\begin{array}{c}5000 \pm \\
10\end{array}$ & - & - & - \\
\hline \multicolumn{2}{|c|}{$\begin{array}{c}\text { Massas totais } \\
(\mathrm{g})\end{array}$} & $\begin{array}{c}5000 \pm \\
10 \\
\end{array}$ & $\begin{array}{c}5000 \pm \\
10\end{array}$ & $\begin{array}{c}5000 \pm \\
10\end{array}$ & $\begin{array}{c}5000 \pm \\
10\end{array}$ & $\begin{array}{l}10000 \\
\pm 100 \\
\end{array}$ & $\begin{array}{c}10000 \\
\pm 75 \\
\end{array}$ & $\begin{array}{c}10000 \\
\pm 50 \\
\end{array}$ \\
\hline \multicolumn{2}{|c|}{$\begin{array}{c}\text { Rotações do } \\
\text { tambor }\left(n^{\circ}\right)\end{array}$} & 500 & 500 & 500 & 500 & 1000 & 1000 & 1000 \\
\hline \multicolumn{2}{|c|}{ Esferas $\left(n^{0}\right)$} & 12 & 11 & 8 & 6 & 12 & 12 & 12 \\
\hline \multicolumn{2}{|c|}{$\begin{array}{l}\text { Massa das } \\
\text { esferas }(g)\end{array}$} & $\begin{array}{c}5000 \pm \\
25\end{array}$ & $\begin{array}{c}4584 \pm \\
25\end{array}$ & $\begin{array}{c}3330 \pm \\
20\end{array}$ & $\begin{array}{c}2500 \pm \\
15\end{array}$ & $\begin{array}{c}5000 \pm \\
25\end{array}$ & $\begin{array}{c}5000 \pm \\
25\end{array}$ & $\begin{array}{c}5000 \pm \\
25 \\
\end{array}$ \\
\hline
\end{tabular}

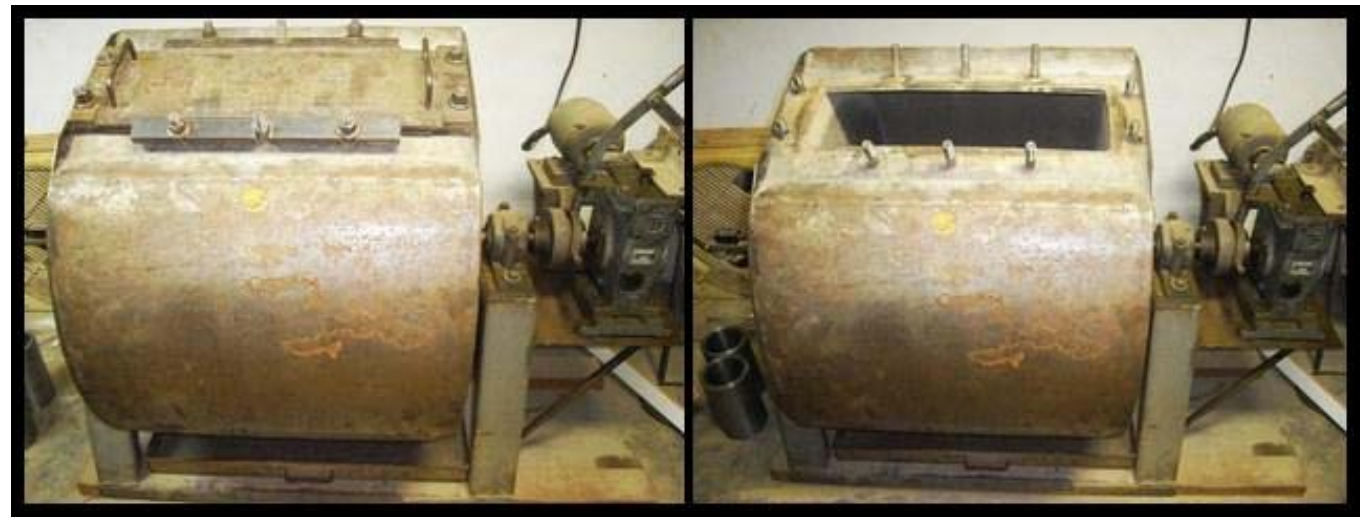

Figura 3.8. Máquina de abrasão "Los Angeles". 


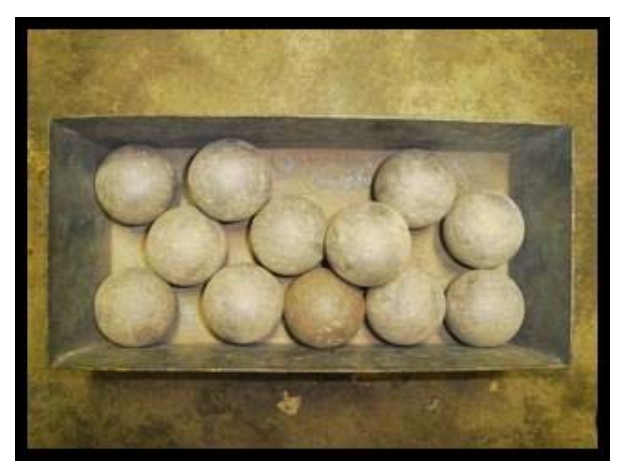

Figura 3.9. Esferas de aço.

Tabela 3.4 - Resultado do ensaio de abrasão "Los Angeles".

\begin{tabular}{c|c|c|c|c}
\hline \multirow{2}{*}{ Desgaste (\%) } & Amostra 1 & Amostra 2 & Amostra 3 & Amostra 4 \\
\cline { 2 - 5 } & 24,31 & 23,99 & 24,25 & 24,17 \\
\hline Média (\%) & \multicolumn{4}{|c}{24,18} \\
\hline Desvio Padrão & \multicolumn{4}{|c}{0,14} \\
\hline
\end{tabular}

\subsubsection{Etileno Acetato de Vinila (EVA)}

O EVA utilizado na pesquisa é oriundo de resíduos da fabricação de palmilhas para calçados das indústrias da cidade de Jaú/SP. O material bruto apresenta-se na forma de aparas e foi fornecido colado a aparas de papelão, próprias das placas expandidas de EVA oferecidas comercialmente. As aparas foram colocadas em um tanque com água para a retirada do papelão, pois a cola é solúvel em água.

O material foi seco à temperatura ambiente e posteriormente cortado em forma de cubos (Figura 3.10), de tal forma que duas de suas arestas tivessem tamanhos aproximados e ficassem entre as peneiras $4,76 \mathrm{~mm}$ e $9,5 \mathrm{~mm}$, sempre procurando 
manter o tamanho no centro dessa faixa. A terceira aresta dependeu exclusivamente da espessura da placa de EVA, que é de aproximadamente $2 \mathrm{~mm}$.

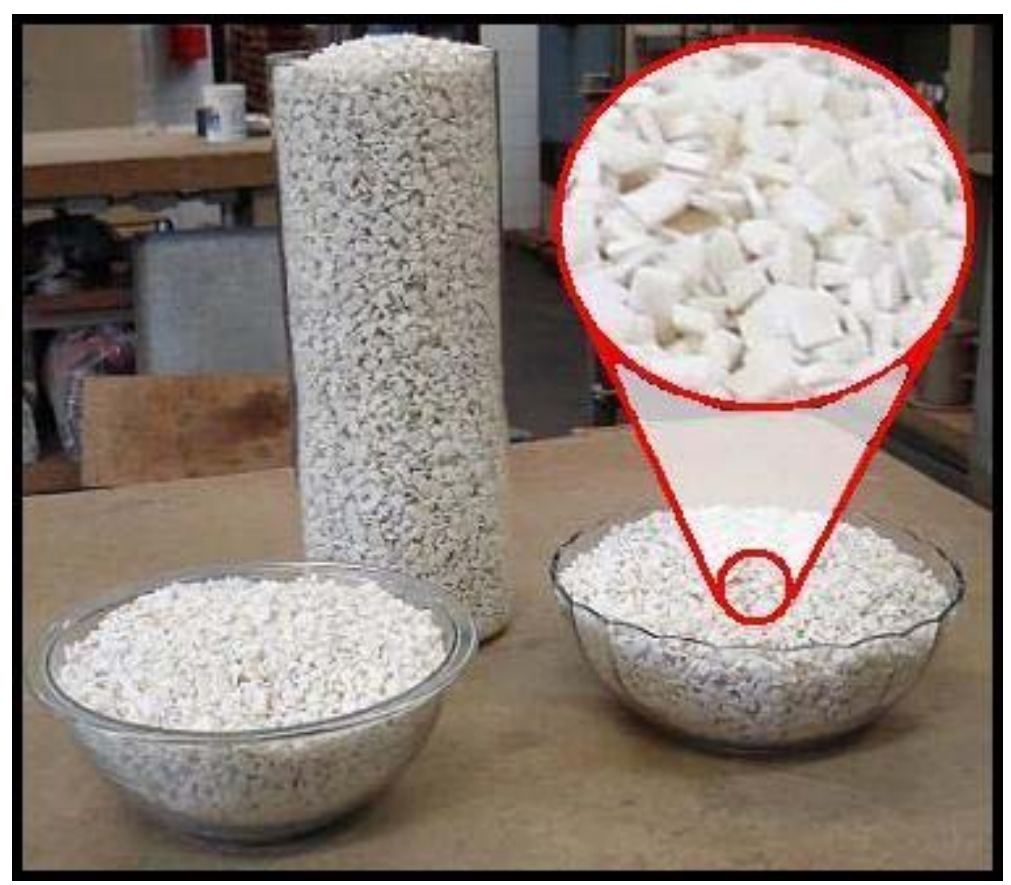

Figura 3.10. EVA cortado.

A Tabela 3.5 apresenta algumas características do EVA, extraídas da folha de segurança da empresa Polietilenos União S/A.

Tabela 3.5 - Propriedades físico-químicas do EVA.

\begin{tabular}{c|c}
\hline Característica & Resultado \\
\hline Estado físico & Sólido \\
\hline Temperatura de amolecimento $\left({ }^{\circ} \mathrm{C}\right)$ & $50-90$ \\
\hline Temperatura de auto-ignição $\left({ }^{\circ} \mathrm{C}\right)$ & 340 \\
\hline Densidade $\left(\mathrm{g} / \mathrm{cm}^{3}\right)$ & $0,922-0,945$ \\
\hline Solubilidade & Insolúvel \\
\hline
\end{tabular}

A densidade dos resíduos das placas expandidas de EVA, adotada nesta pesquisa, foi de 0,927 . 


\subsection{VARIÁVEIS ENVOLVIDAS NA PESQUISA}

Diversos são os fatores envolvidos no comportamento de misturas asfálticas, portanto, para que se possa ter conhecimento e compreensão acerca desse comportamento, faz-se necessário o estudo de todas as variáveis envolvidas, em seus vários níveis. São considerados fatores todos os parâmetros que possam influenciar o resultado de um experimento, podendo cada um destes assumir diversos valores, os quais são conhecidos por níveis. Para que uma variável independente seja considerada um fator é necessário que ela possua mais de um nível.

Há diversos métodos de investigação para um experimento como, por exemplo, a experimentação clássica e a experimentação fatorial. Na primeira, cada fator é estudado separadamente, sendo que todos os outros fatores permanecem constantes. A conclusão do fenômeno resultante é feita mediante análise da variação de cada fator. A falha desse método é não considerar o possível efeito que possa haver da interação entre os fatores envolvidos, o que não ocorre na experimentação fatorial, pois além de cada fator ser estudado isoladamente, também se verifica a interação entre todos os fatores, ou seja, têm-se todas as possibilidades de combinações dos fatores de um experimento com um número muito menor de ensaios quando comparado à experimentação clássica.

A significância que cada fator - bem como da interação entre esses fatores - tem no experimento, ou o quanto o experimento se mostra sensível à mudança dos fatores, deve ser estimada através de análise estatística dos resultados obtidos. 
Para caracterizar as misturas asfálticas modificadas com EVA foi escolhido o método de experimentação fatorial, pois este é mais completo e rápido que o método de experimentação clássico, dado o número de variáveis independentes e dependentes envolvidas.

\subsubsection{Variáveis independentes}

\subsubsection{Fatores}

Há diversos fatores envolvidos no processo de misturas asfálticas, como o teor e o tipo de ligante asfáltico, a granulometria do agregado, o tempo de envelhecimento, a energia de compactação, a granulometria e o teor de resíduo, entre outros. Porém, para que o experimento fosse exeqüível, fez-se necessário considerar apenas os fatores mais importantes e, portanto, a partir de estudos realizados em misturas asfálticas por outros pesquisadores, foram selecionados os fatores teor de resíduo e tempo de envelhecimento.

\section{i. Teor de resíduo}

Essa variável teve como objetivo verificar a quantidade de EVA a ser incorporada na mistura asfáltica. 


\section{ii. Tempo de envelhecimento de curto prazo (tempo de digestão)}

A escolha desse fator teve como objetivo simular o envelhecimento que a mistura asfáltica sofre durante as fases de mistura e compactação.

\subsubsection{Níveis}

Os fatores indicados no item anterior foram estudados em quatro e três níveis, respectivamente. Os critérios de escolha estão descritos a seguir.

\section{i. Teor de resíduo}

O objetivo principal desta pesquisa é avaliar a possibilidade de se utilizar os resíduos de EVA gerados pela indústria calçadista em misturas asfálticas. Para decidir sobre o teor de resíduos utilizados foi necessário testar a sensibilidade das propriedades mecânicas e da resistência ao desgaste das misturas asfálticas com o aumento da quantidade de EVA.

\section{ii. Tempo de envelhecimento de curto prazo}

Para simular o processo de envelhecimento de curto prazo a mistura foi submetida ao condicionamento em estufa com circulação forçada de ar na temperatura de compactação $\left(137^{\circ} \mathrm{C}\right)$ por zero, duas e quatro horas, sendo os dois últimos tempos de envelhecimento em conformidade com a AASHTO PP2 (AASHTO, 2001). 


\subsubsection{Variáveis dependentes}

As variáveis dependentes são as afetadas por mudanças nas variáveis independentes. Nesta pesquisa, as variáveis dependentes são:

- Resistência à tração por compressão diametral estática;

- Módulo de resiliência por compressão diametral;

- Fluência por compressão uniaxial estática ("creep" estático);

- Fluência por compressão uniaxial dinâmica ("creep” dinâmico);

- Vida de fadiga;

- Desgaste por abrasão (ensaio Cantabro).

Todos os ensaios foram realizados no Laboratório de Estradas do Departamento de Transportes da Escola de Engenharia de São Carlos (EESC-USP), em corpos-deprova moldados pelo método Marshall de acordo com a NBR 12891/93 (ABNT, 1993),

\subsection{ENSAIOS PRELIMINARES}

Esta pesquisa utilizou resíduos de EVA inseridos em misturas asfálticas através do processo seco e, como não foram encontrados estudos publicados acerca desse assunto, houve a necessidade de alguns ensaios para determinar os teores de resíduo a serem utilizados na pesquisa. 
A determinação do teor ótimo de ligante foi dada pela dosagem Marshall, para um volume de vazios de $4 \%$, tendo sido feita a análise da estabilidade $(E)$, fluência $(F)$, relação betume-vazios (RBV) e vazios do agregado mineral (VAM) para o teor ótimo. O teor de trabalho de ligante foi fixado, para todas as diferentes misturas estudadas, como sendo o teor ótimo determinado através da dosagem Marshall mais a absorção de ligante pelo agregado, ocorrida durante as duas primeiras horas de envelhecimento em estufa.

A idéia inicial era avaliar o comportamento de misturas asfálticas dosadas pelo método Marshall, envelhecidas duas horas, através dos ensaios de módulo de resiliência por compressão diametral (MR), resistência à tração por compressão diametral (RT) e a relação entre esses dois parâmetros (MR/RT), ao se incrementar o teor de EVA. Porém, o fator limitante ao teor de EVA máximo foi a desagregação da mistura ao não aceitar compactação quando da substituição de $10 \%$ do material retido na peneira $4,75 \mathrm{~mm}$ (pouco mais que $3 \%$ em relação à mistura total) por resíduos. Desse modo, o fator teor de resíduos teve os níveis de $0 \%, 1 \%, 2 \%$ e $3 \%$ em relação à mistura total.

\subsubsection{Método Bailey de seleção granulométrica}

Este item foi baseado nos estudos de Vavrik et al. (2002) e na dissertação de mestrado de Cunha (2004) e mostra como foram feitos os cálculos para a composição da curva granulométrica utilizada na pesquisa. Os dados completos encontram-se no Apêndice A. 
O primeiro passo foi a determinação da massa específica solta (MES) dos agregados graúdos e da massa específica compactada (MEC) do agregado fino, de acordo com a norma AASHTO T-19/T 19M (AASHTO, 1997). A amostra de material foi obtida através de separação de $10 \mathrm{~kg}$ de cada agregado (pedra 1, pedrisco e pó de pedra) por quarteamento.

A massa específica solta representa a massa, relativa a um determinado volume, que os agregados apresentam, sem qualquer esforço de compactação. Inicialmente, mediu-se a massa do cilindro vazio $\left(M_{v}\right)$ e, com a utilização de uma pequena pá, colocou-se os agregados no recipiente, em camadas, cuidadosamente para que não houvesse compactação. $\mathrm{O}$ excesso de material foi retirado manualmente até que a superfície livre dos agregados estivesse relativamente plana e no limite da boca do cilindro, como mostra a Figura 3.11. Verificou-se a massa do conjunto e, através da Equação 3.7, determinou-se a massa específica solta da pedra 1 e do pedrisco.

$$
M E S=\frac{M_{c c}-M_{c v}}{V_{c}}
$$

em que:

MES : massa específica solta do agregado graúdo $\left(\mathrm{kg} / \mathrm{m}^{3}\right)$;

$M_{c c} \quad$ : massa do cilindro com agregado $(\mathrm{kg})$;

$M_{c v} \quad$ : massa do cilindro vazio $(\mathrm{kg})$

$V_{c} \quad$ : volume do cilindro $\left(\mathrm{m}^{3}\right)$ 


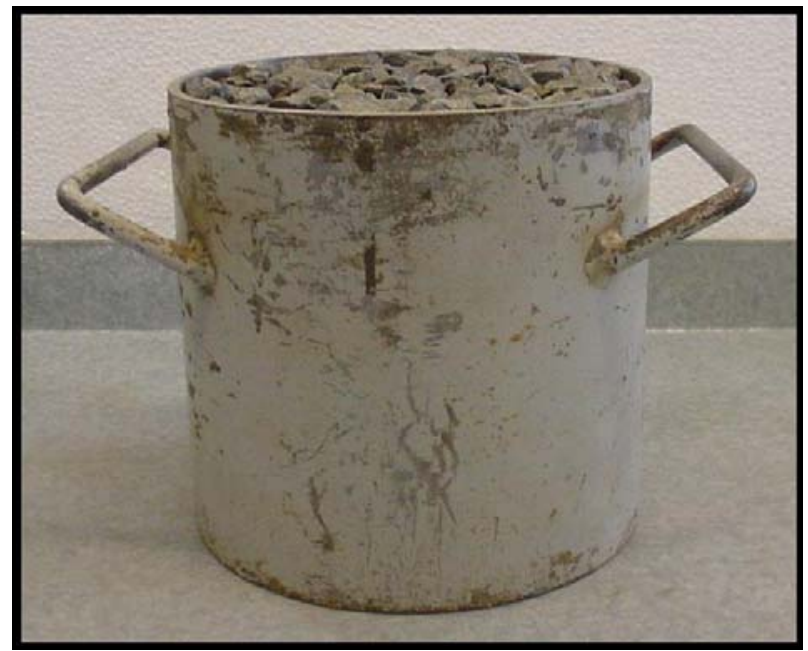

Figura 3.11. Cilindro com agregado graúdo para determinação da massa específica solta.

A massa específica compactada do agregado fino foi determinada utilizando-se o mesmo cilindro, com o material sendo disposto em três camadas, cada uma delas recebendo 25 golpes de uma haste metálica caindo a $5 \mathrm{~cm}$ da superfície livre do agregado. O excesso de material foi rasado com auxílio de uma régua metálica, com o cuidado de não causar uma pós-compactação, até que ficasse no nível da boca do cilindro (Figura 3.12). A massa específica compactada foi determinada através da Equação 3.8.

$$
M E C=\frac{M_{c f}-M_{c v}}{V_{c}}
$$

em que:

MEC : massa específica compactada do agregado fino $\left(\mathrm{kg} / \mathrm{m}^{3}\right)$;

$M_{c f} \quad$ : massa do cilindro com agregado fino $(\mathrm{kg})$; 
114

$M_{c v} \quad$ : massa do cilindro vazio $(\mathrm{kg})$;

$V_{c} \quad$ : volume do cilindro $\left(\mathrm{m}^{3}\right)$

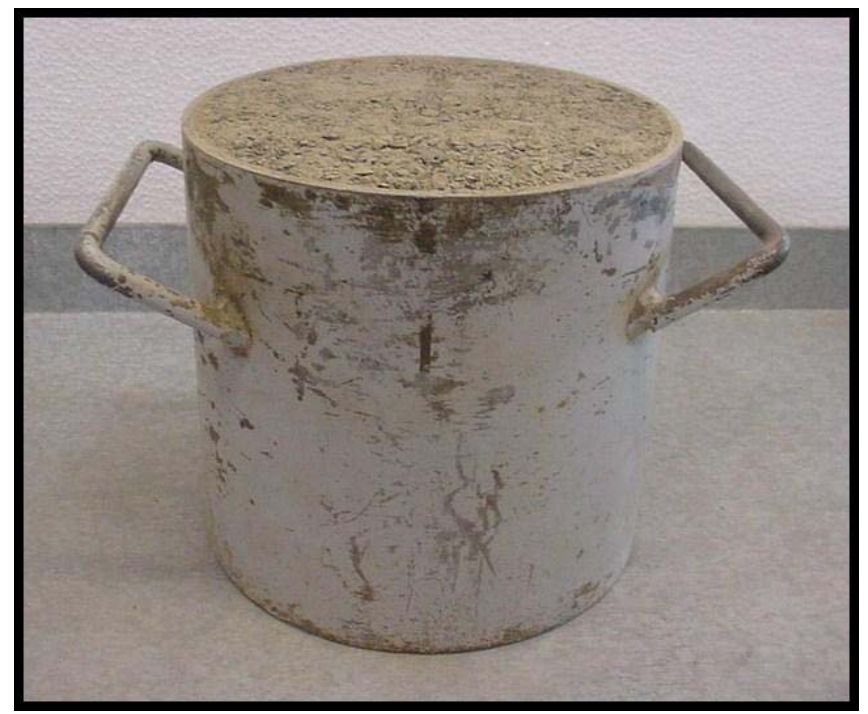

Figura 3.12. Cilindro com agregado fino para determinação da massa específica compactada.

O passo seguinte foi a determinação da massa específica escolhida para o agregado fino $\left(\mathrm{MEE}_{\mathrm{f}}\right)$ e a massa específica escolhida para o agregado graúdo $\left(\mathrm{MEE}_{\mathrm{g}}\right) . \mathrm{A} \mathrm{MEE}_{\mathrm{f}}$, neste caso, é igual à massa específica compactada do agregado fino, pois só foi utilizado um agregado fino na pesquisa. $A M^{\prime} E_{g}$ foi determinada através da MES de cada um dos dois agregados graúdos e está em função da porcentagem desejada da massa específica solta $\left(M E S_{d}\right)$. Esse fator, que varia de $95 \%$ a $105 \%$, indica como a mistura trabalhará, pois a escolha do menor valor indica que a mistura trabalhará mais com as propriedades dos agregados finos e viceversa. Nesta pesquisa, optou-se por trabalhar mais as propriedades dos agregados finos, assim foi escolhido o valor de 95\%. A massa específica escolhida do agregado graúdo foi, então, dada pela Equação 3.9. 


$$
M E E_{g}=M E S \times M E S_{d}
$$

em que:

$$
\begin{aligned}
& M E E_{g}: \text { massa específica escolhida de cada agregado graúdo }\left(\mathrm{kg} / \mathrm{m}^{3}\right) \text {; } \\
& M E S \text { : massa específica solta de cada agregado graúdo }\left(\mathrm{kg} / \mathrm{m}^{3}\right) ; \\
& M E S_{d}: \text { massa específica solta desejada }(\%) \text {. }
\end{aligned}
$$

Em seguida determinou-se a massa específica contribuinte dos agregados graúdos, que foi de $10 \%$ para a pedra 1 e $90 \%$ para o pedrisco, através da Equação 3.10 . Esta composição visou um melhor enquadramento dos valores das proporções dos agregados nos intervalos recomendados pelo método, explicado mais adiante (Tabela 3.6).

$$
C A G_{t}=M E E_{g 1} \times A G_{d 1}+M E E_{g 2} \times A G_{d 2}
$$

em que:

$C A G_{t}:$ contribuição total dos agregados graúdos na mistura $\left(\mathrm{kg} / \mathrm{m}^{3}\right)$;

$M E E_{g 1}:$ massa específica escolhida da pedra $1\left(\mathrm{~kg} / \mathrm{m}^{3}\right)$;

$A G_{d 1}$ : contribuição da pedra $1(\%)$

$M E E_{g 2}$ : massa específica escolhida do pedrisco $\left(\mathrm{kg} / \mathrm{m}^{3}\right)$;

$A G_{d 2}$ : contribuição do pedrisco (\%). 
O próximo passo foi a determinação dos vazios no agregado graúdo (VAG) ou os vazios que são preenchidos pelos agregados finos, através da Equação 3.11.

$$
V A G=\left(1-\frac{M E E_{g 1}}{G_{s b 1}}\right) \times A G_{d 1}+\left(1-\frac{M E E_{g 2}}{G_{s b 2}}\right) \times A G_{d 2}
$$

em que:

$$
\begin{aligned}
& V A G \text { : vazios no agregado graúdo }(\%) ; \\
& M E E_{g 1}: \text { massa específica escolhida da pedra } 1\left(\mathrm{~kg} / \mathrm{m}^{3}\right) ; \\
& G_{s b 1}: \text { massa específica da pedra } 1\left(\mathrm{~kg} / \mathrm{m}^{3}\right) ; \\
& A G_{d 1}: \text { contribuição da pedra } 1(\%) ; \\
& M E E_{g 2}: \text { massa específica escolhida do pedrisco }\left(\mathrm{kg} / \mathrm{m}^{3}\right) ; \\
& G_{s b 2}: \text { massa específica do pedrisco }\left(\mathrm{kg} / \mathrm{m}^{3}\right) ; \\
& A G_{d 2}: \text { contribuição do pedrisco }(\%) .
\end{aligned}
$$

A contribuição dos agregados finos é dada em função do VAG e foi determinada através da Equação 3.12 .

$$
C A F_{t}=M E E_{f} \times A F_{d} \times V A G
$$


em que:

$C A F_{t}$ : contribuição total dos agregados finos na mistura $\left(\mathrm{kg} / \mathrm{m}^{3}\right)$;

$M E E_{f}$ : massa específica escolhida do agregado fino $\left(\mathrm{kg} / \mathrm{m}^{3}\right)$;

$A F_{d}$ : contribuição do pó de pedra (\%).

Neste caso, a contribuição do pó de pedra foi de $100 \%$, pois foi utilizado somente um agregado fino.

A massa específica da mistura foi, então, dada pela soma da contribuição de cada uma das massas específicas dos agregados utilizados na pesquisa e está representada na Equação 3.13.

$$
M E M=C A G_{t}+C A F_{t}
$$

em que:

MEM : massa específica da mistura $\left(\mathrm{kg} / \mathrm{m}^{3}\right)$;

$C A G_{t}$ : contribuição total dos agregados graúdos na mistura $\left(\mathrm{kg} / \mathrm{m}^{3}\right)$;

$C A F_{t}$ : contribuição total dos agregados finos na mistura $\left(\mathrm{kg} / \mathrm{m}^{3}\right)$.

Com a massa específica da mistura e a contribuição de cada agregado, calculou-se a estimativa inicial de cada agregado na mistura. 
118

$$
\begin{gathered}
A G i_{1}=\frac{C A G_{1}}{M E M} \\
A G i_{2}=\frac{C A G_{2}}{M E M} \\
A G i=A G i_{1}+A G i_{2} \\
A F i=\frac{C A F_{t}}{M E M}
\end{gathered}
$$

em que:

$A G i_{1}$ : quantidade de pedra 1 na mistura (\%);

$A G i_{2}$ : quantidade de pedrisco na mistura (\%);

AGi : quantidade de agregado graúdo na mistura (\%);

AFi : quantidade de pó de pedra na mistura (\%);

MEM : massa específica da mistura $\left(\mathrm{kg} / \mathrm{m}^{3}\right)$;

$C A G_{t}$ : contribuição da pedra 1 na mistura $\left(\mathrm{kg} / \mathrm{m}^{3}\right)$;

$C A G_{2}$ : contribuição do pedrisco na mistura $\left(\mathrm{kg} / \mathrm{m}^{3}\right)$;

$C A F_{t}$ : contribuição do pó de pedra na mistura $\left(\mathrm{kg} / \mathrm{m}^{3}\right)$. 
O passo seguinte foi a divisão dos agregados graúdos dos finos, através da peneira de controle primário (PCP), dada pela multiplicação do diâmetro máximo nominal do agregado (DMN) pelo fator de controle (FC). O método também prevê a utilização da peneira média (PM), que é a peneira de abertura mais próxima da metade do DMN, para controlar melhor a compactação do agregado graúdo.

$$
P C P=D M N \times F C
$$

em que:

$$
\begin{aligned}
& P C P \text { : peneira de controle primário }(\mathrm{mm}) \\
& \text { DMN : diâmetro máximo nominal dos agregados }(\mathrm{mm}) \text {; } \\
& \text { FC : fator de controle }(0,22) \text {. }
\end{aligned}
$$

Para separar a fração graúda da fração fina do agregado fino, utilizou-se a peneira de controle secundário (PCS) e para o estudo da fração fina do agregado fino utilizou-se a peneira de controle terciário (PCT), determinadas através das Equações 3.19 e 3.20 respectivamente.

$$
\begin{aligned}
& P C S=P C P \times F C \\
& P C T=P C S \times F C
\end{aligned}
$$


em que:

$$
\begin{aligned}
& P C S \text { : peneira de controle secundário }(\mathrm{mm}) \text {; } \\
& P C P \quad \text { : peneira de controle primário }(\mathrm{mm}) ; \\
& F C \quad \text { : fator de controle }(0,22) ; \\
& P C T \quad \text { : peneira de controle terciário }(\mathrm{mm}) \text {. }
\end{aligned}
$$

O valor da PCP permitiu a quantificação de material passante na peneira $2,36 \mathrm{~mm}$ para a pedra $1\left(\mathrm{QAG}_{1}\right)$ e para o pedrisco $(\mathrm{QAG})$ e o retido, no caso do pó de pedra (QAF). Com esses dados calculou-se a quantidade de finos no agregado graúdo (PFG) e a quantidade de graúdos no agregado fino (PGF), através das Equações $3.21,3.22$ e 3.23 respectivamente.

$$
\begin{gathered}
P F G_{1}=A G_{1} \times Q A G_{1} \\
P F G_{2}=A G_{2} \times Q A G_{2} \\
P G F=A F \times Q A F
\end{gathered}
$$

em que:

$P F G_{1}$ : quantidade de finos na pedra $1(\%)$ $A G_{1}$ : quantidade de pedra 1 na mistura (\%); 
$Q A G_{1}$ : quantidade de pedra 1 passante na PCP $(\%)$

$P F G_{2}$ : quantidade de finos no pedrisco (\%);

$A G_{2} \quad$ : quantidade de pedrisco na mistura (\%);

$Q A G_{2}$ : quantidade de pedrisco passante na PCP (\%);

PGF : quantidade de graúdos no agregado fino (\%);

AF : quantidade de pó de pedra na mistura (\%);

QAF : quantidade de pó de pedra retida na PCP (\%).

A partir desses resultados foram ajustadas as porcentagens iniciais da pedra 1 $\left(A G_{1 f}\right)$, do pedrisco $\left(A G_{2 f}\right)$ e do pó de pedra $\left(A F_{f}\right)$ na mistura, através das Equações $3.24,3.25$ e 3.26 respectivamente.

$$
\begin{gathered}
A G_{1 f}=A G_{1}+P F G_{1}-\left(\frac{A G_{1} \times P G F_{t}}{A G}\right) \\
A G_{2 f}=A G_{2}+P F G_{2}-\left(\frac{A G_{2} \times P G F_{2}}{A G}\right) \\
A F_{f}=A F i+P G F-\left(\frac{A F_{i} \times P G F}{A F_{i}}\right)
\end{gathered}
$$


em que:

$A G_{1 f}$ : quantidade corrigida de pedra 1 na mistura (\%);

$A G_{1}$ : quantidade de pedra 1 na mistura (\%);

$P F G_{1}$ : quantidade de finos na pedra $1(\%) ;$

AG : quantidade de agregado graúdo na mistura (\%);

$A G_{2 f}$ : quantidade corrigida de pedrisco na mistura (\%);

$A G_{2}$ : quantidade de pedrisco na mistura (\%);

$P F G_{2}$ : quantidade de finos no pedrisco (\%);

$A F_{f} \quad$ : quantidade corrigida de pó de pedra na mistura (\%);

AFi : quantidade de pó de pedra na mistura (\%);

PGF : quantidade de graúdos no agregado fino (\%).

A partir das curvas granulométricas da pedra 1, do pedrisco e do pó de pedra foi calculada a curva granulométrica, somando-se a multiplicação de cada quantidade retida em cada peneira pela quantidade corrigida de cada material. Nesta pesquisa não foi utilizado fíler mineral, pois a quantidade de material passante na peneira $0,075 \mathrm{~mm}$ se enquadrou no intervalo recomendado pelo método.

O método recomenda que a proporção dos agregados graúdos (PAG), a proporção graúda dos agregados finos (PGAF) e a proporção fina dos agregados finos (PFAF) fiquem dentro de intervalos (Tabela 3.6), de acordo com o DMN, para que a mistura 
apresente bons resultados. Esses parâmetros foram calculados através Equações 3.27 a 3.29 .

Tabela 3.6 - Intervalo recomendado para PAG, PGAF e PFAF.

\begin{tabular}{c|c|c|c}
\hline DMN (mm) & PAG & PGAF & PFAF \\
\hline 37,5 & $0,80-0,95$ & $0,35-0,50$ & $0,35-0,50$ \\
25,0 & $0,70-0,85$ & $0,35-0,50$ & $0,35-0,50$ \\
19,0 & $0,60-075$ & $0,35-0,50$ & $0,35-0,50$ \\
12,5 & $0,50-0,65$ & $0,35-0,50$ & $0,35-0,50$ \\
9,5 & $0,40-0,55$ & $0,35-0,50$ & $0,35-0,50$ \\
4,75 & $0,30-0,45$ & $0,35-0,50$ & $0,35-0,50$ \\
\hline
\end{tabular}

$$
P A G=\frac{P M_{p}-P C P_{p}}{1-P M_{p}}
$$

$$
P G A F=\frac{P C S_{p}}{P C P_{p}}
$$

$$
P F A F=\frac{P C T_{p}}{P C S_{p}}
$$

em que:

PAG : proporção dos agregados graúdos (\%);

$P M_{p} \quad$ : quantidade passada na peneira média (\%);

$P C P_{p}$ : quantidade passada na peneira de controle primário (\%);

PGAF : proporção graúda dos agregados finos (\%); 
$P C S_{p}$ : peneira de controle secundário (\%);

PFAF : proporção fina dos agregados finos (\%);

$P C T_{p}$ : peneira de controle terciário.

\subsubsection{Dosagem Marshall}

\subsubsection{Temperatura de mistura e compactação}

A determinação das temperaturas de mistura (aquecimento do ligante asfáltico) e compactação deu-se através da curva viscosidade-temperatura, traçada a partir dos dados encontrados na Tabela 3.7.

3.7 - Temperaturas de mistura e compactação.

\begin{tabular}{ccc}
\hline & $\begin{array}{c}\text { Viscosidade Saybolt-Furol } \\
\text { recomendada (sSF) }\end{array}$ & $\begin{array}{c}\text { Temperatura } \\
\text { adotada }\left({ }^{\circ} \mathbf{C} \text { ) }\right.\end{array}$ \\
\hline Mistura & $125-155$ & 149 \\
\hline Compactação & $75-95$ & 137 \\
\hline
\end{tabular}

A especificação de serviço DNER-ES 313/97 (DNER, 1997) estabelece que a mistura deva ser compactada a uma temperatura que apresente viscosidade entre 75 e 150 sSF, com preferência para viscosidade entre 85 e 95 sSF; no entanto, essa temperatura não pode ser inferior a $107^{\circ} \mathrm{C}$ nem superior a $177^{\circ} \mathrm{C}$. Com relação à mistura, a especificação recomenda que sejam utilizados valores que apresentem viscosidade entre $140 \pm 15 \mathrm{sSF}$. A NBR 12891/1993 (ABNT, 1993) estabelece a realização da compactação na temperatura que corresponde a viscosidade $85 \pm 10$ sSF. A Figura 3.13 mostra a viscosidade Saybolt-Furol em função da temperatura, 
para o CAP 50/70 desse trabalho. No Apêndice B encontra-se o detalhamento dos cálculos realizados.

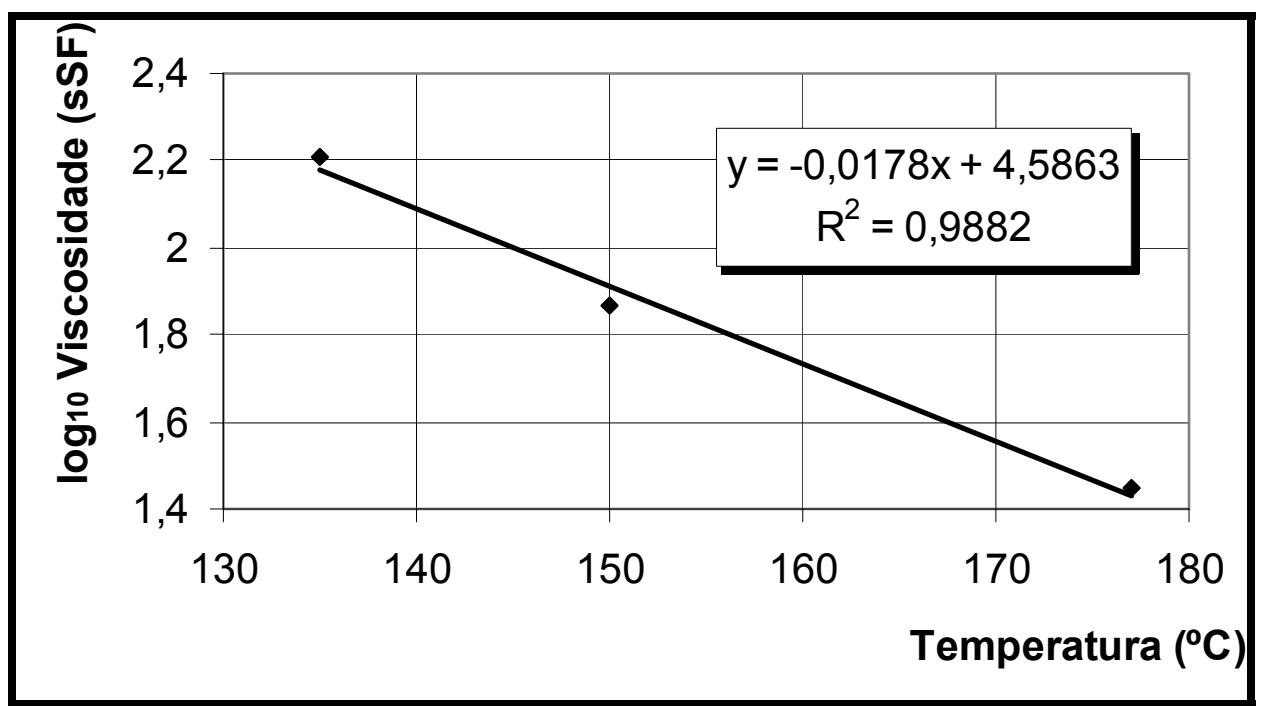

Figura 3.13. Viscosidade Saybolt-Furol versus temperatura.

\subsubsection{Determinação do teor ótimo provável de ligante asfáltico}

A partir da curva granulométrica definida pelo método de seleção granulométrica Bailey, foi calculada a superfície específica dos agregados, com a Equação 3.30, e o teor ótimo provável de ligante, com a Equação 3.31.

$$
S=\frac{0,17 \times G+0,33 \times g+2,30 \times A+12,00 \times a+135,00 \times f}{100}
$$

em que:

$S \quad$ : superfície específica do agregado $\left(\mathrm{m}^{2} / \mathrm{kg}\right)$;

G : porcentagem retida na peneira $9,5 \mathrm{~mm}$; 
126

$g$ : porcentagem passada na peneira $9,5 \mathrm{~mm}$ e retida na peneira 4,76 $\mathrm{mm}$;

A : porcentagem passada na peneira $4,76 \mathrm{~mm}$ e retida na peneira 0,30 $\mathrm{mm}$;

a : porcentagem passada na peneira $0,30 \mathrm{~mm}$ e retida na peneira 0,075 $\mathrm{mm}$;

$f \quad$ : porcentagem passada na peneira $0,075 \mathrm{~mm}$.

$$
T_{c a}=m \sqrt[5]{S}
$$

em que:

$T_{c a} \quad$ : teor de cimento asfáltico em relação à massa do agregado mineral $(\%)$;

$m$ : módulo de riqueza em asfalto, variável de 3,75 a 4,00 para pavimentos rodoviários (adota-se 3,75 quando se exige nas capas de rolamento máxima resistência à deformação por compressão e 4,00 para capas que necessitam ter maior flexibilidade).

Corrigiu-se o teor de cimento asfáltico em função da densidade real do agregado mineral, através da Equação 3.32 .

$$
T_{c a}^{\prime}=\frac{2,65 \times T_{c a}}{\delta_{a m}}
$$


em que:

$T_{c a}^{\prime} \quad$ : teor de cimento asfáltico corrigido (\%);

$\delta_{\mathrm{am}} \quad$ : densidade real do agregado mineral.

Em relação à massa da mistura, a porcentagem de cimento asfáltico foi dada pela Equação 3.33.

$$
P_{c a}=\frac{100 \times T_{c a}^{\prime}}{100+T_{c a}^{\prime}}
$$

em que:

$$
\begin{aligned}
& P_{c a}: \text { porcentagem de cimento asfáltico (\%); } \\
& T_{c a}^{\prime} \quad \text { : teor de cimento asfáltico corrigido (\%). }
\end{aligned}
$$

Para a dosagem Marshall foram escolhidos dois teores abaixo e três teores acima do teor ótimo provável. Os cálculos e resultados detalhados obtidos encontram-se no Apêndice B.

\subsubsection{Compactação}

O primeiro passo foi colocar os moldes (Figura 3.14) na estufa, na temperatura de compactação, conservando, assim, a temperatura da mistura na compactação. 


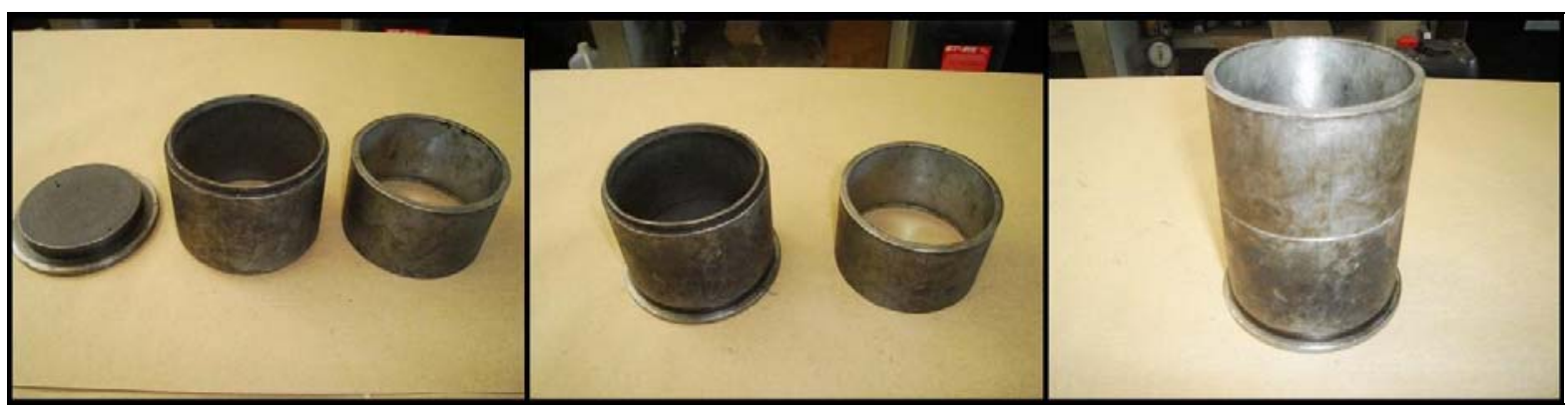

Figura 3.14. Molde utilizado na compactação Marshall.

Após isso o ligante foi aquecido em estufa à temperatura de $149^{\circ} \mathrm{C}$ por duas horas. Em seguida, os agregados referentes a 18 corpos-de-prova (três corpos-de-prova por teor de ligante), compostos previamente, foram colocados na estufa por 2 horas, à temperatura de $162^{\circ} \mathrm{C}$.

Utilizou-se uma panela de aço (Figura 3.15) para misturar os agregados e o ligante, enquanto o molde era colocado no compactador (Figura 3.16). No caso das misturas modificadas, o resíduo foi colocado após uma pré-mistura do agregado com o ligante. Dentro do molde foram colocados papéis filtro na base e em cima da mistura, para evitar a perda de material. Seguindo-se a isso foram dados 75 golpes, com o soquete (Figura 3.17), por face do corpo-de-prova.

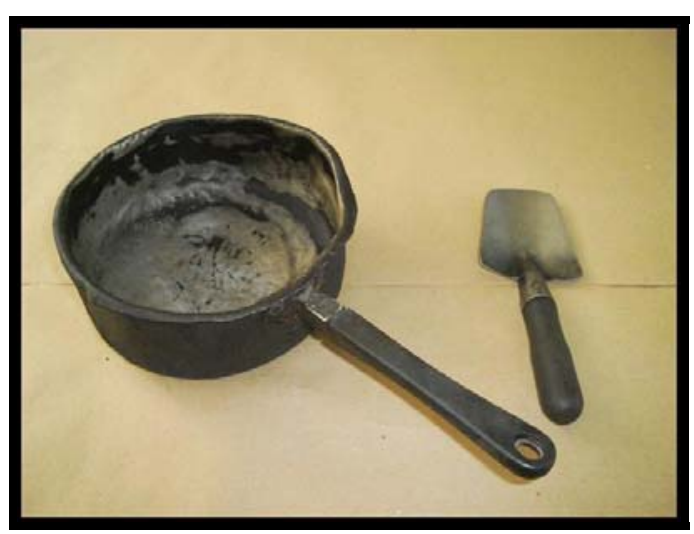

3.15. Panela utilizada para misturar os corpos-de-prova. 


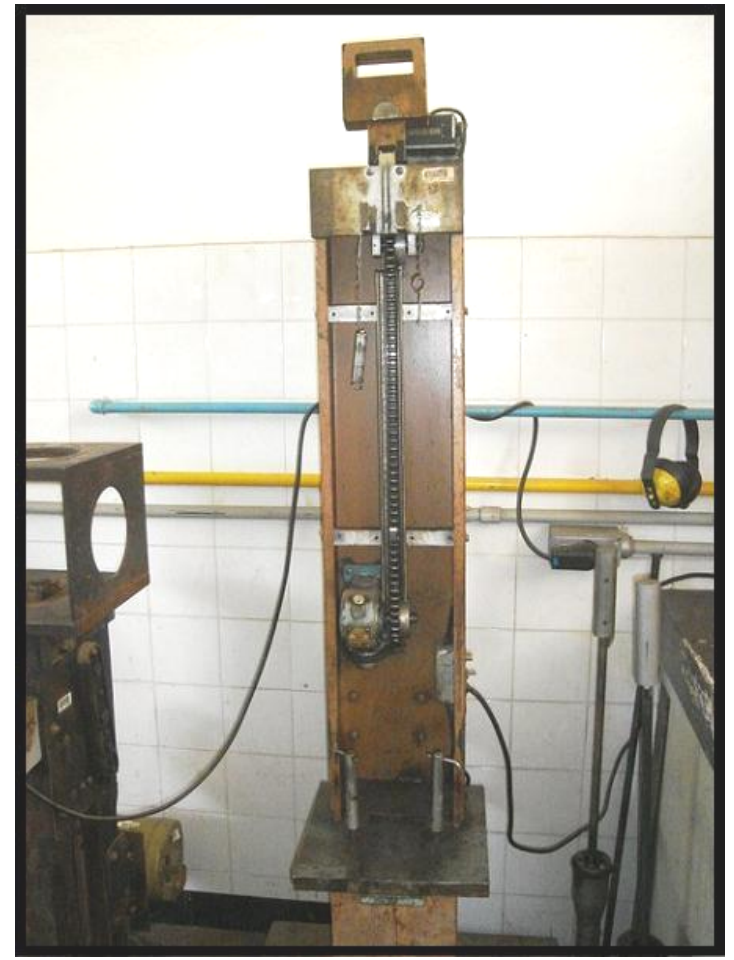

Figura 3.16. Compactador Marshall.

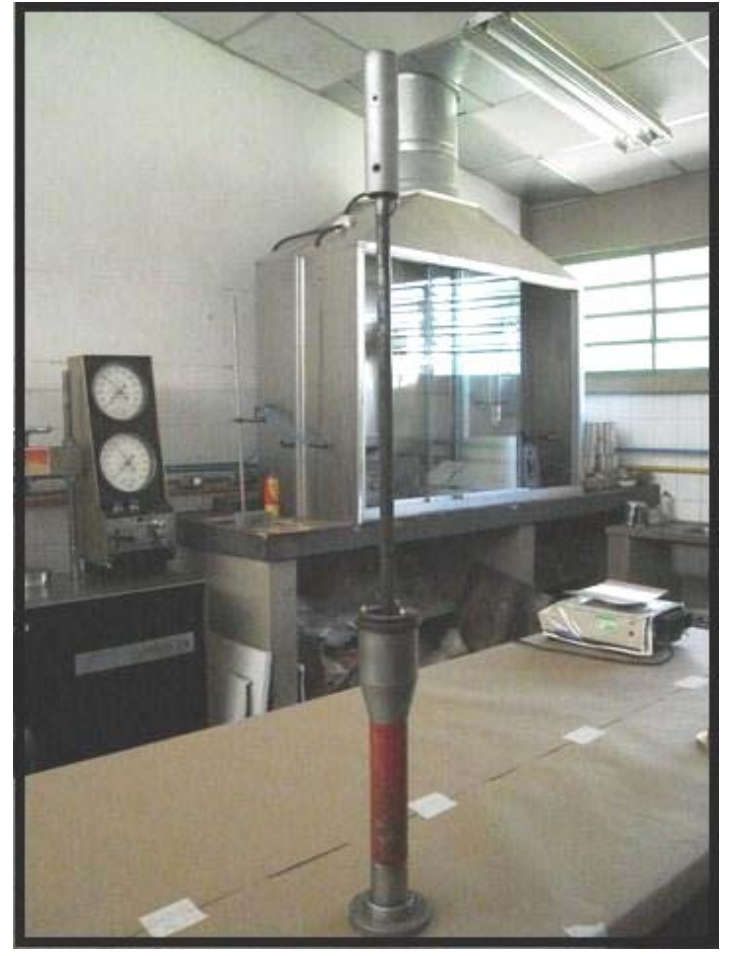

Figura 3.17. Soquete.

Durante a compactação foi verificada a temperatura da mistura com um termômetro a laser (Figura 3.18), com a finalidade de garantir que a mistura estava sendo compactada na temperatura correta.

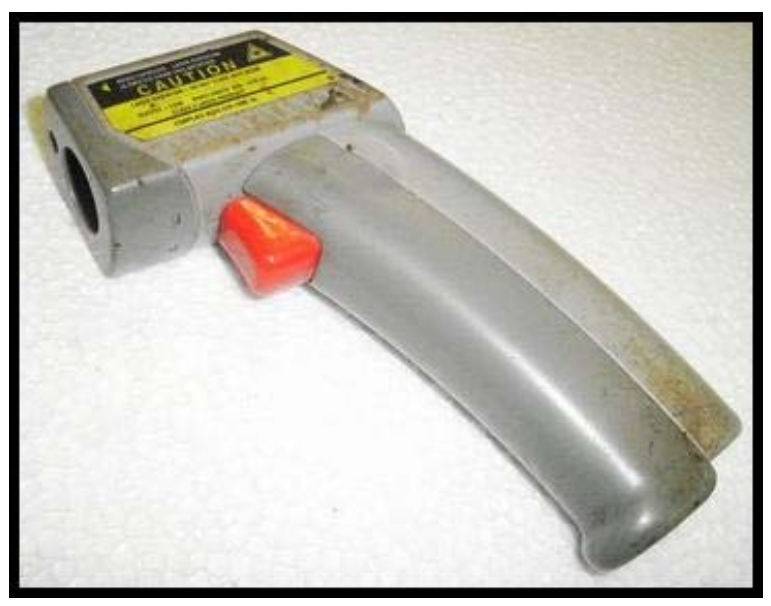

Figura 3.18. Termômetro a laser. 
Os corpos-de-prova ficaram descansando nos moldes por 6 horas antes de serem extraídos e 24 horas sobre uma superfície plana.

Verificou-se a massa ao ar (MA) e a massa imersa (MI) dos corpos-de-prova (Figura 3.19) para a determinação do seu volume (VCP) através da Equação 3.34. Considerou-se a massa específica da água como sendo $1 \mathrm{~g} / \mathrm{cm}^{3}$, desse modo a densidade aparente de cada corpo-de-prova se iguala, em valor absoluto, à sua massa específica e $1 \mathrm{~g}$ de massa de água deslocada equivale a um volume de $1 \mathrm{~cm}^{3}$.

$$
V C P=M A-M I
$$

em que:

VCP : volume do corpo-de-prova $\left(\mathrm{cm}^{3}\right)$;

MA : massa ao ar do corpo-de-prova (g);

MI : massa imersa do corpo-de-prova (g).

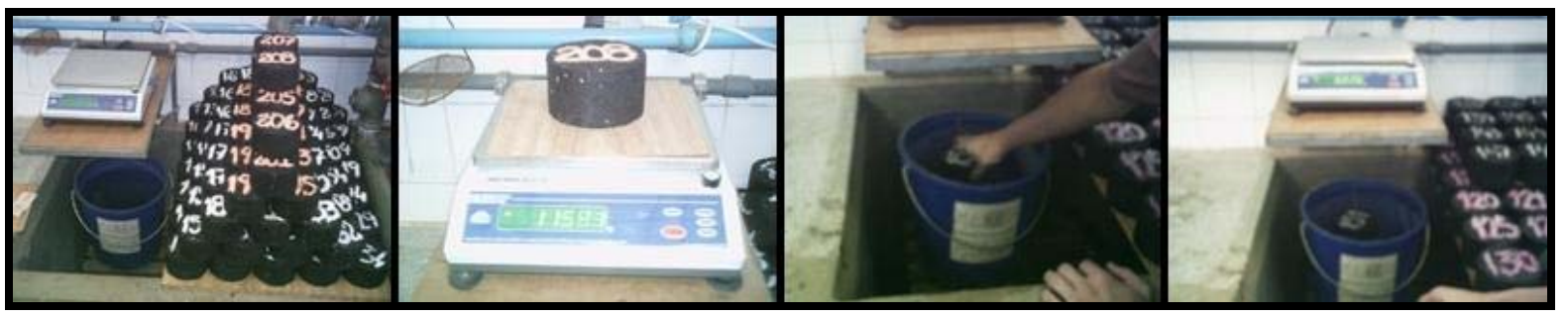

Figura 3.19. Verificação da massa ao ar e massa imersa dos corpos-de-prova. 


\subsubsection{Densidade aparente dos corpos-de-prova}

De posse das MA e das MI foram calculadas as densidades aparentes dos corposde-prova (DAP), com a Equação 3.35.

$$
D A P=\frac{M A}{M A-M I}
$$

em que:

$D A P$ : densidade aparente do corpo-de-prova;

MA : massa ao ar do corpo-de-prova (g);

MI : massa imersa do corpo-de-prova (g).

A DAP pode, também, ser obtida considerando-se o corpo-de-prova na condição saturado superfície seca (SSS), deste modo, a equação 3.35 fica:

$$
D A P_{S S S}=\frac{M A}{M A_{S S S}-M I}
$$

em que:

$D A P_{S S S}$ : densidade aparente do corpo-de-prova saturado e com a superfície seca;

MAsss : massa ao ar do corpo-de-prova saturado e com a superfície seca (g). 
Nesta pesquisa optou-se por utilizar a DAP ao invés da DAPsss, que o procedimento recomendado pelo DNIT (DNER-ME 117/87).

\subsubsection{Densidade máxima teórica da mistura}

A densidade máxima teórica da mistura (DMT) foi calculada utilizando-se as massas específicas e as porcentagens na mistura de ligante e agregados.

$$
D M T=\frac{1}{\left(\frac{C A P_{p}}{\rho_{C A P}}+\frac{A G_{p}}{\rho_{A G}}\right) \times \rho_{\text {ăgua }}}
$$

em que,

$D M T$ : densidade máxima teórica da mistura;

$C A P_{p}:$ quantidade de ligante na mistura (\%);

$\rho_{\text {CAP }} \quad$ : massa específica do ligante $\left(\mathrm{g} / \mathrm{cm}^{3}\right)$;

$A G_{p} \quad$ : quantidade de agregados na mistura (\%);

$\rho_{A G} \quad$ : massa específica dos agregados $\left(\mathrm{g} / \mathrm{cm}^{3}\right)$;

Págua : massa específica da água $\left(\mathrm{g} / \mathrm{cm}^{3}\right)=1$ (adotada).

\subsubsection{Volume de vazios}

Os espaços existentes entre as partículas de agregados cobertos por uma película de asfalto são conhecidos por volume de vazios (Vv), como mostra a Equação 3.37. 


$$
V v=\left(1-\frac{D A P}{D M T}\right) \times 100
$$

em que:

$$
\begin{aligned}
& \text { VV : volume de vazios (\%); } \\
& D A P \quad: \text { densidade aparente da mistura compactada; } \\
& D M T: \text { densidade máxima teórica. }
\end{aligned}
$$

Segundo Gouveia (2002), a utilização tanto da densidade aparente quanto da densidade real dos agregados gera erros no cálculo do $\mathrm{V} v$ das misturas asfálticas. $\mathrm{O}$ uso da densidade aparente implica em considerar que nenhuma quantidade de asfalto será absorvida pelos poros existentes no agregado, ou seja, o volume dos vazios preenchidos pelo asfalto está incluído como parte do volume da película do agregado, isso dá como resultado uma mistura com $\mathrm{Vv}$ menor do que ela realmente possui. Já a utilização da densidade real dos agregados leva em conta somente o volume da massa sólida do agregado, desse modo os poros permeáveis à água passam a fazer parte do $\mathrm{V} v$ da mistura, resultando em um valor de $\mathrm{V} v$ maior do que a mistura apresenta realmente. A autora cita que a utilização da densidade efetiva do agregado é que leva a resultados mais precisos, pois esta considera a absorção de asfalto pelos poros existentes nos agregados.

Diversos autores mostram que valores muito baixos de $\mathrm{V} v$ podem ocasionar deformação permanente e exsudação, pois o ligante acaba trabalhando como uma espécie de lubrificante, enquanto que valores muito altos de $\mathrm{V} v$ indicam propensão ao desgaste. A especificação SUPERPAVE recomenda a utilização de um Vv de $4 \%$. 


\subsubsection{Vazios preenchidos com cimento asfáltico}

O volume de vazios que foi preenchido pelo cimento asfáltico foi encontrado através da Equação 3.38.

$$
V_{\text {cap }}=\frac{D A P \times C A P_{p}}{\rho_{\text {CAP }}} \times \rho_{\text {água }}
$$

em que:

$V_{\text {cap }} \quad$ : volume de vazios preenchido pelo cimento asfáltico (\%);

DAP : densidade aparente do corpo-de-prova;

$C A P_{p}:$ quantidade de ligante na mistura (\%);

$\rho_{\text {CAP }}:$ massa específica do ligante $\left(\mathrm{g} / \mathrm{cm}^{3}\right)$;

fágua : massa específica da água $\left(\mathrm{g} / \mathrm{cm}^{3}\right)=1$ (adotada).

\subsubsection{Vazios do agregado mineral}

O conceito de vazios do agregado mineral (VAM) é fundamental no dimensionamento de pavimentos, pois define a porção da mistura, em porcentagem do volume, que não está preenchida com agregado. A definição SUPERPAVE para VAM é a quantidade de vazios na mistura compactada que é preenchida por ar ou ligante efetivo, ou seja, que não é absorvido.

$$
V A M=100-\left(1-\frac{D A P \times\left(1-C A P_{p}\right)}{\rho_{A G}} \times \rho_{\text {água }}\right) \times 100
$$


ou

$$
V A M=V v+V_{c a}
$$

em que:

VAM : vazios do agregado mineral (\%);

$D A P$ : densidade aparente da mistura;

$C A P_{p}:$ quantidade de ligante na mistura (\%)

$\rho_{A G} \quad$ : massa específica dos agregados $\left(\mathrm{g} / \mathrm{cm}^{3}\right)$;

คágua : massa específica da água $\left(\mathrm{g} / \mathrm{cm}^{3}\right)=1$ (adotada);

Vv : Volume de vazios (\%);

$V_{c a} \quad$ : volume de vazios preenchido pelo cimento asfáltico (\%).

De acordo com o DMN da mistura, é recomendada uma porcentagem mínima de VAM para garantir que a mistura não esteja com uma quantidade deficiente de ligante, comprometendo a sua durabilidade (KHANDAL e CHAKRABORTY, 1996). A Tabela 3.8 mostra os valores mínimos de VAM segundo a especificação SUPERPAVE. De acordo com Cominsky et al. (1998), os vazios do agregado mineral de uma mistura estão relacionados não só com a curva granulométrica, mas também com o grau de compactação, a forma, a textura e a angularidade dos agregados. 
Tabela 3.8 - VAM mínimo segundo o SUPERPAVE (COMINSKY et al., 1998).

\begin{tabular}{c|c}
\hline DMN (mm) & VAM mínimo (\%) \\
\hline 9,5 & 15 \\
12,5 & 14 \\
19,0 & 13 \\
25,0 & 12 \\
37,5 & 11 \\
50,0 & 10,5 \\
\hline
\end{tabular}

A Tabela 3.9 mostra alguns fatores que influenciam nos VAM, segundo Chadbourn et al. (2000).

Tabela 3.9 - Fatores que influenciam nos VAM.

\begin{tabular}{c|c|c}
\hline Fator & Tipo & $\begin{array}{c}\text { Efeito nos } \\
\text { VAM }\end{array}$ \\
\hline Graduação do agregado & Densas & Diminuição \\
Forma do agregado & Arredondados & Diminuição \\
Textura do agregado & Lisos ou polidos & Diminuição \\
Absorção de asfalto & Diminuição & Aumento \\
Presença de pó & Diminuição & Aumento \\
Finos & Diminuição & Aumento \\
Temperatura de produção da mistura em usina & Mais elevada & Diminuição \\
Temperatura durante a pavimentação & Mais elevada & Diminuição \\
Tempo de transporte da mistura & Maior & Diminuição \\
Degradação do agregado & Maior & Diminuição \\
\hline
\end{tabular}

Fonte: Chadbourn et al. (2000).

Khandal, Foo e Mallick (1998) recomendam uma modificação nos valores mínimos de VAM das especificações SUPERPAVE, pois misturas com graduação mais grossa, que passam abaixo da zona de restrição, podem ter valores de VAM menores e ainda apresentarem bons resultados mecânicos e ao desgaste, basta garantir uma película mínima de asfalto de $8 \mu \mathrm{m}$. A Tabela 3.10 apresenta os valores que devem ser subtraídos dos indicados pela especificação SUPERPAVE, denominados fatores de graduação pelos autores. 
Tabela 3.10 - Fatores de graduação.

\begin{tabular}{l|l|l|l|l|l}
\hline DMN (mm) & 37,5 & 25,0 & 19,0 & 12,5 & 9,5 \\
\hline Fator de graduação & 0,5 & 1,0 & 1,5 & 1,5 & 2,0 \\
\hline \multicolumn{5}{r}{ Fonte: Khandal, Foo e Mallick (1998). }
\end{tabular}

O Departamento Nacional de Infra-estrutura Terrestre (DNIT) recomenda, em sua Especificação de Serviço DNIT 031-2004 - ES (DNIT, 2004), alguns valores mínimos de VAM, apresentados na Tabela 3.11.

Tabela 3.11 - Valores mínimos de VAM de acordo com a norma DNIT 031-2004 ES.

\begin{tabular}{c|c|c}
\hline \multicolumn{3}{c}{ VAM - Vazios do Agregado Mineral } \\
\cline { 1 - 2 } Tamanho Nominal Máximo dos Agregados & VAM mínimo \\
\cline { 1 - 2 } \# & $\mathbf{m m}$ & 13 \\
\hline $11 / "$ & 38,1 & 14 \\
$1 "$ & 25,4 & 15 \\
$3 / 4 "$ & 19,1 & 16 \\
$1 / 2 "$ & 12,7 & 18 \\
$3 / 8 "$ & 9,5 & \\
\hline
\end{tabular}

\subsubsection{Relação betume-vazios}

A relação betume-vazios (RBV) é definida como a porcentagem de VAM que contém asfalto, ou seja, a porcentagem de vazios que é preenchida por ligante e que representa o volume efetivo de ligante.

$$
R B V=\frac{1-V_{C A P}}{V A M}
$$


em que:

RBV : Relação betume-vazios (\%);

VAM : Vazios do agregado mineral (\%);

$V_{C A P}:$ Volume de asfalto (\%).

É necessário que a RBV se enquadre numa faixa para garantir que a mistura asfáltica tenha boa durabilidade e que não esteja suscetível à deformação permanente, exsudação ou fadiga. Isso normalmente é conseguido controlando-se os vazios do agregado mineral e mantendo-se a mistura com $4 \%$ de $V v$ e, deste modo, assegurando uma correta espessura de película de asfalto envolvendo o agregado.

A Tabela 3.12 mostra os limites recomendados pela especificação SUPERPAVE, de acordo com o nível de tráfego e a espessura da camada de rolamento, para um projeto de pavimento de 20 anos.

Tabela 3.12 - Valores limite da RBV segundo a especificação SUPERPAVE.

\begin{tabular}{c|c|c}
\hline \multirow{2}{*}{$\begin{array}{c}\text { ESALS } \\
\left(\mathbf{x 1 0 ^ { 6 }}\right)\end{array}$} & \begin{tabular}{c} 
RBV (\%) \\
\cline { 2 - 3 }
\end{tabular} & $\begin{array}{c}\text { Capa asfáltica }>\mathbf{1 0 0} \mathbf{~ m m ~ e} \\
\text { acostamento }\end{array}$ \\
\hline$\leq 0,3$ & $70-80$ & $75-85$ \\
$0,3 \leq 3$ & $65-78$ & $70-83$ \\
$>3$ & $65-75^{(1)}$ & $70-80^{(2)}(3)$ \\
\hline (1) Para mistura com DMN de $9,5 \mathrm{~mm}$ o limite superior é $76 \%$. \\
(2) Para mistura com DMN de 9,5 mm o limite superior é $82 \%$. \\
(3) Para mistura com DMN de $12,5 \mathrm{~mm}$ o limite superior é $81 \%$. \\
\hline
\end{tabular}

O DNIT (DNIT, 2004) recomenda os limites da RBV no intervalo de $75 \%$ a $82 \%$ para a camada de rolamento e $65 \%$ a $72 \%$ para a camada de ligação ("binder"). 


\subsubsection{Densidade máxima medida e absorção de misturas asfálticas}

\subsubsection{Preparação das amostras}

As amostras para a determinação das densidades máximas medidas (DMM) foram preparadas de acordo com a curva granulométrica e o teor de trabalho de asfalto. $\mathrm{O}$ procedimento de mistura da amostra foi semelhante ao de preparação dos corposde-prova Marshall, exceto pela ausência da compactação. Para que houvesse a absorção do asfalto pelo agregado foi necessário que cada amostra permanecesse durante 2 horas ou 4 horas em estufa ventilada na temperatura de compactação, em conformidade com a AASHTO PP2. Após ter sido retirada da estufa, a amostra foi resfriada manualmente com a utilização de uma espátula para evitar a formação grumos.

\subsubsection{Determinação da densidade máxima medida}

Após o resfriamento, verificou-se a massa seca da amostra, colocada dentro de um recipiente. Com a finalidade de garantir a precisão do ensaio, o recipiente utilizado neste ensaio foi um kitassato modificado, no qual foi feita uma rosca em sua boca e também foi fechado o seu dispositivo de nivelamento lateral (Figura 3.20). 


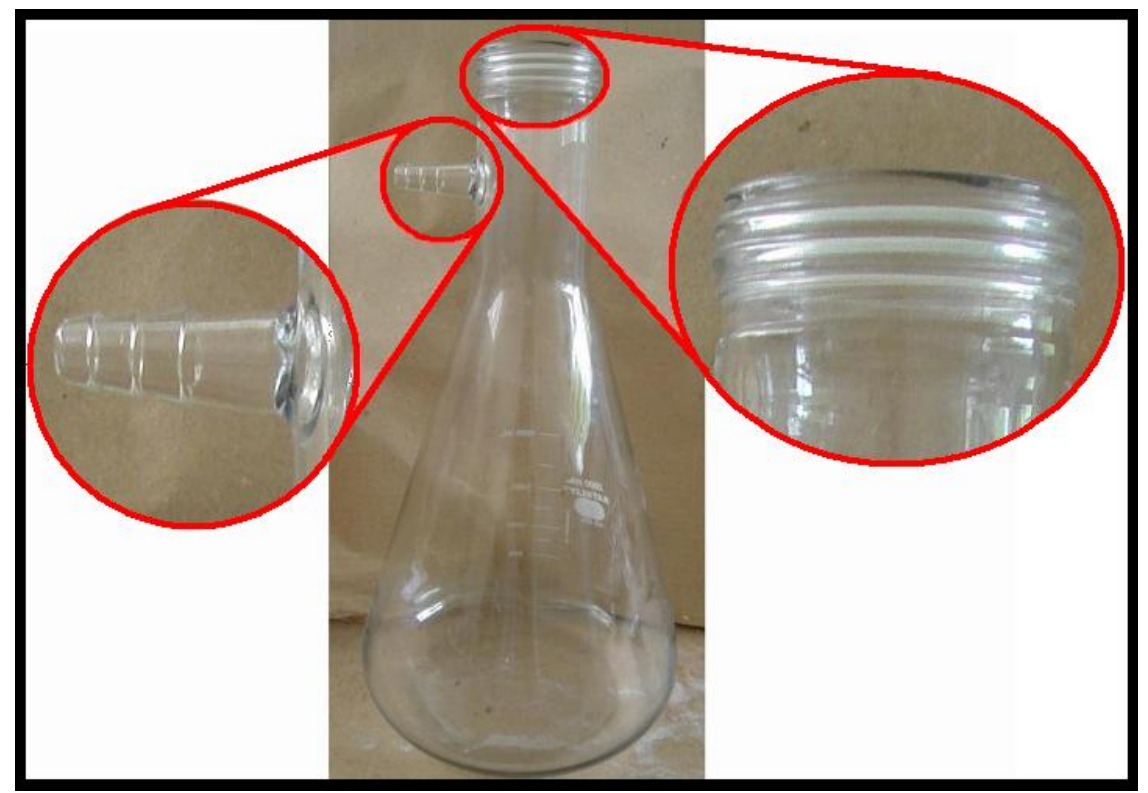

Figura 3.20. Kitassato modificado.

Esse equipamento também é composto por um cilindro de vidro (Figura 3.21), um bocal (Figura 3.22) e um dispositivo rosqueável para prender o bocal (Figura 3.23), o qual contém um anel de borracha na parte interna para evitar que haja vazamento de água. A finalidade do cilindro de vidro foi proporcionar uma maior precisão ao se encher o kitassato com água.

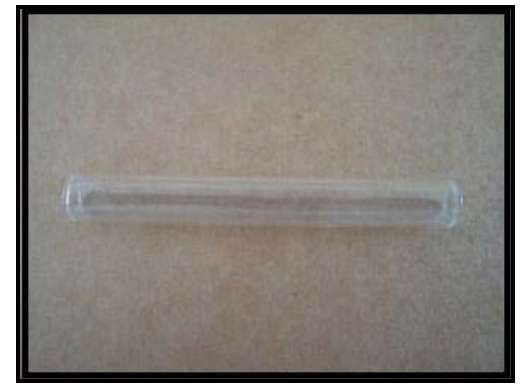

Figura 3.21. Cilindro de vidro.

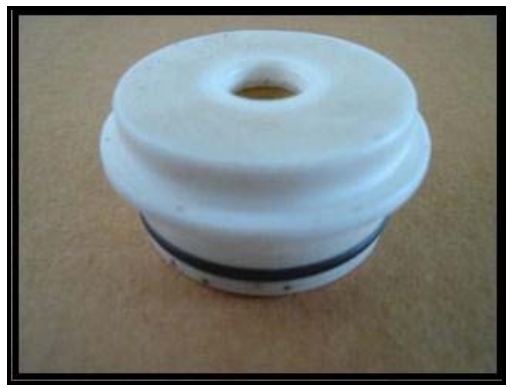

Figura 3.22. Bocal.

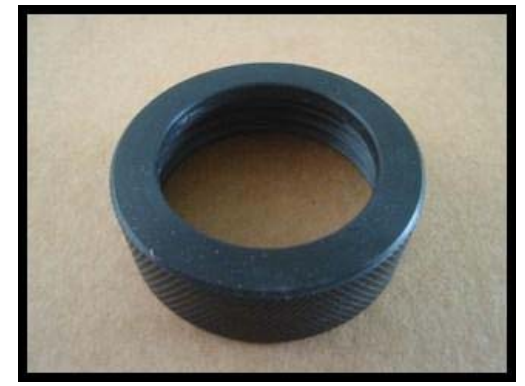

Figura 3.23. Dispositivo rosqueável.

Em seguida à determinação da massa seca, adicionou-se água fervida no kitassato até que a amostra ficasse $4 \mathrm{~cm}$ abaixo da superfície. A água foi fervida durante uma 
hora, para que tivesse uma menor oxigenação, e esperou-se a temperatura estabilizar-se à temperatura ambiente.

Após isso, conectou-se o kitassato modificado à bomba de vácuo parcial, durante um período 15 a 20 minutos, ou até que não houvesse mais bolhas de ar se desprendendo da mistura.

Extraídas as bolhas, completou-se o kitassato com água fervida, com cuidado para não haver oxigenação da água e verificou-se a massa do conjunto. Tomou-se o cuidado de manter a parte inferior do cilindro de vidro no mesmo nível do bocal (Figura 3.24). Por fim, mediu-se a temperatura da água dentro do kitassato modificado, procurando-se manter o termômetro sempre na mesma altura.

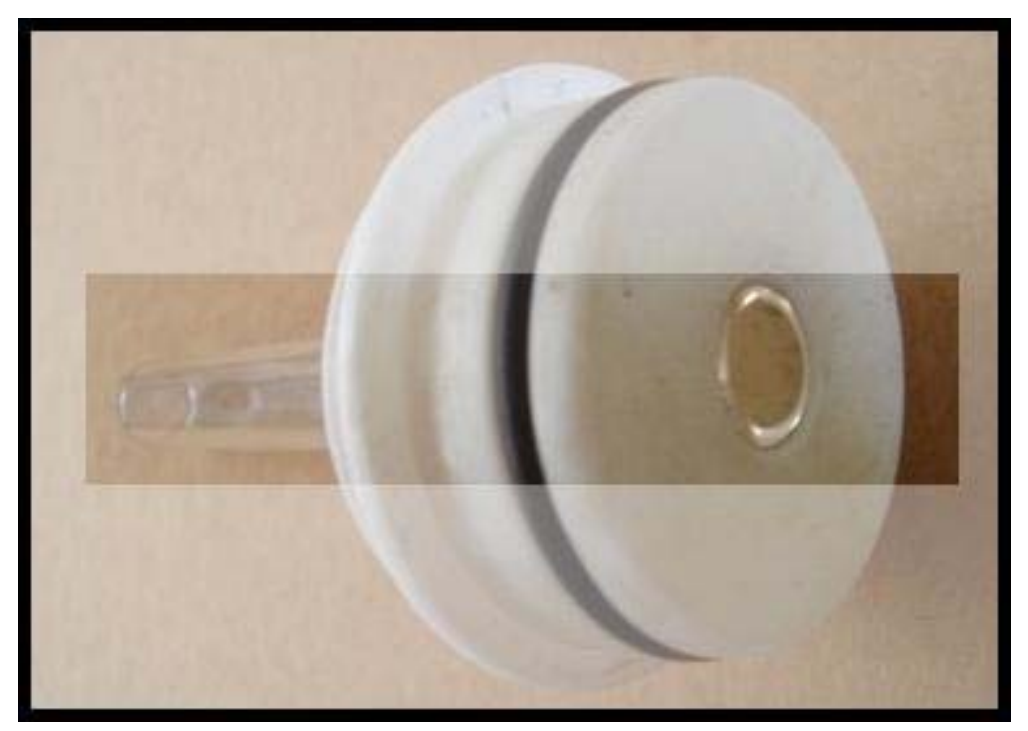

Figura 3.24. Montagem do cilindro de vidro no bocal. 
Com as massas secas do conjunto (kitassato modificado, água e amostra) e com a curva de calibração do kitassato modificado em função da temperatura da água (Figura 3.7), foi possível calcular a DMM de cada mistura asfáltica através da Equação 3.42 .

$$
D M M=\frac{A}{A+D-E}
$$

em que,

$D M M$ : densidade máxima medida da mistura;

A : : massa da amostra seca $(\mathrm{g})$;

D : massa do kitassato modificado preenchido com água em função da temperatura (curva de calibração) (g);

E : massa do conjunto (kitassato modificado, água, amostra) (g).

\subsubsection{Determinação da massa específica efetiva do agregado}

Tem-se, por definição, que a massa específica efetiva do agregado ( $\left.\rho_{\mathrm{ef}}\right)$ é correspondente à relação entre a massa do agregado $(\mathrm{Ma})$ e o seu volume efetivo $\left(\mathrm{V}_{\mathrm{ef}}\right)$ :

$$
\rho_{e f}=\frac{M a}{V_{e f}}
$$


Sabendo-se que a massa de agregado é igual a diferença entre massa total da mistura (Mtm) e a massa total de asfalto (Mb), que é a porcentagem de asfalto na mistura $(\mathrm{Pb})$ multiplicada pela massa total da mistura, e que o volume efetivo de agregado é a diferença entre o volume total da mistura (Vtm) e o volume de ligante asfáltico (Vb), a Equação 3.43 pode ser expressa por:

$$
\rho_{e f}=\frac{M t m-\left(C A P_{p} \times M t m\right)}{V t m-V_{C A P}}
$$

Substituindo-se os volumes:

$$
\rho_{e f}=\frac{M t m-\left(C A P_{p} \times M t m\right)}{\frac{1}{\rho_{\text {água }}} \times \frac{M t m}{D M M}-\frac{M_{C A P}}{\rho_{\text {CAP }}}}
$$

Simplificando:

$$
\rho_{\text {ef }}=\frac{1-C A P_{p}}{\frac{1}{\rho_{\text {água }}} \times \frac{1}{D M M}-\frac{C A P_{p}}{\rho_{\text {CAP }}}}
$$


em que:

Ma : massa do agregado $(\mathrm{g})$;

$M_{C A P}:$ massa total de asfalto $(\mathrm{g})$;

Mtm : massa total da mistura $(\mathrm{g})$;

$V_{\text {ef }} \quad$ : volume efetivo do agregado $\left(\mathrm{cm}^{3}\right) ;$

$V_{C A P}:$ volume de asfalto $\left(\mathrm{cm}^{3}\right)$;

Vtm : volume total da mistura $\left(\mathrm{cm}^{3}\right)$;

$\rho_{\text {ef }} \quad$ : massa específica efetiva do agregado $\left(\mathrm{g} / \mathrm{cm}^{3}\right)$;

$\rho_{\text {água }}:$ massa específica da água $=1$ (adotada) $\left(\mathrm{g} / \mathrm{cm}^{3}\right)$;

$\rho_{\text {CAP }}:$ massa específica do ligante asfáltico $\left(\mathrm{g} / \mathrm{cm}^{3}\right)$;

$D M M$ : densidade máxima medida da mistura;

$C A P_{p}$ : quantidade de asfalto na mistura (\%).

\subsubsection{Determinação da absorção}

Por definição, tem-se que a absorção de ligante pelo agregado $\left(\mathrm{A}_{\mathrm{abs}}\right)$ é dada pela relação entre a massa de asfalto absorvida ( $\left.\mathrm{M}_{\mathrm{CAP}, \mathrm{abs}}\right)$ pela massa do agregado da mistura (Ma).

$$
A_{a b s}=\frac{M_{C A P, a b s}}{M a} \times 100
$$


Sabendo-se que massa é a relação de multiplicação entre volume e a massa específica de um determinado material, tem-se:

$$
A_{a b s}=\frac{V_{C A P, a b s} \times \rho_{C A P}}{M a} \times 100
$$

Sendo o volume de asfalto absorvido a diferença entre o volume aparente do agregado $\left(V_{a p}\right)$ e o volume efetivo do agregado $\left(V_{e f}\right)$, a Equação 3.48 fica:

$$
A_{a b s}=\frac{\left(V_{a p}-V_{e f}\right) \times \rho_{C A P}}{M a} \times 100
$$

Substituindo os volumes pela relação de massa por massa específica, tem-se a Equação 3.50 .

$$
A_{a b s}=\frac{\left(\frac{M a}{\rho_{a p}}-\frac{M a}{\rho_{e f}}\right) \times \rho_{C A P}}{M a} \times 100
$$

Simplificando:

$$
A_{a b s}=\left(\frac{\rho_{e f}-\rho_{a p}}{\rho_{e f} \times \rho_{a p}} \times \rho_{C A P}\right) \times 100
$$


em que:

$A_{a b s}$ : porcentagem de asfalto absorvido por massa de agregado (\%);

$\mathrm{M}_{\mathrm{CAP}, \text { abs: }}$ : massa de asfalto absorvido (g);

Ma : massa de agregado $(\mathrm{g})$;

$V_{C A P, \text { abs }}$ : volume de asfalto absorvido $\left(\mathrm{cm}^{3}\right)$

$V_{a p} \quad$ : volume aparente do agregado $\left(\mathrm{cm}^{3}\right) ;$

$V_{\text {ef }} \quad$ : volume efetivo do agregado $\left(\mathrm{cm}^{3}\right)$;

$\rho_{\text {CAP }} \quad$ : massa específica do asfalto $\left(\mathrm{g} / \mathrm{cm}^{3}\right)$;

$\rho_{\text {ef }} \quad$ : massa específica efetiva do agregado $\left(\mathrm{g} / \mathrm{cm}^{3}\right)$;

$\rho_{\text {ap }} \quad$ : massa específica aparente do agregado $\left(\mathrm{g} / \mathrm{cm}^{3}\right)$.

\subsection{ENSAIOS PARA A DETERMINAÇÃO DE PROPRIEDADES MECÂNICAS}

\subsubsection{Resistência à tração por compressão diametral estática}

O ensaio de resistência à tração foi realizado através de compressão diametral estática, em conformidade com a norma DNER-ME 138/94 (DNER, 1994a). Inicialmente foram anotadas as alturas dos corpos-de-prova, medidas nas quatro posições diametralmente opostas e também quatro leituras do diâmetro, sendo duas em uma face e duas em outra face dos corpos-de-prova, opostas $90^{\circ} \mathrm{em}$ cada face. 
Os valores adotados foram as médias aritméticas das quatro medidas para alturas e os diâmetros.

Os corpos-de-prova ficaram em uma sala com temperatura controlada de $25^{\circ} \mathrm{C}$ por, no mínimo 24 horas, para que estabilizassem a temperatura para o ensaio. Cada corpo-de-prova foi colocado em um suporte (Figura 3.25) com friso de fixação de $12,5 \mathrm{~mm}$, e levado à prensa. Em seguida, ajustaram-se os pratos até que o suporte ficasse preso (Figura 3.26). A carga foi aplicada progressivamente pela prensa, a uma velocidade constante de $0,8 \mathrm{~mm} / \mathrm{s}$, até que fosse verificada a ruptura do corpode-prova. O valor lido no anel de carga (Figura 3.27) foi multiplicado pela sua constante e, assim, determinado o valor da carga de ruptura de cada corpo-deprova. 


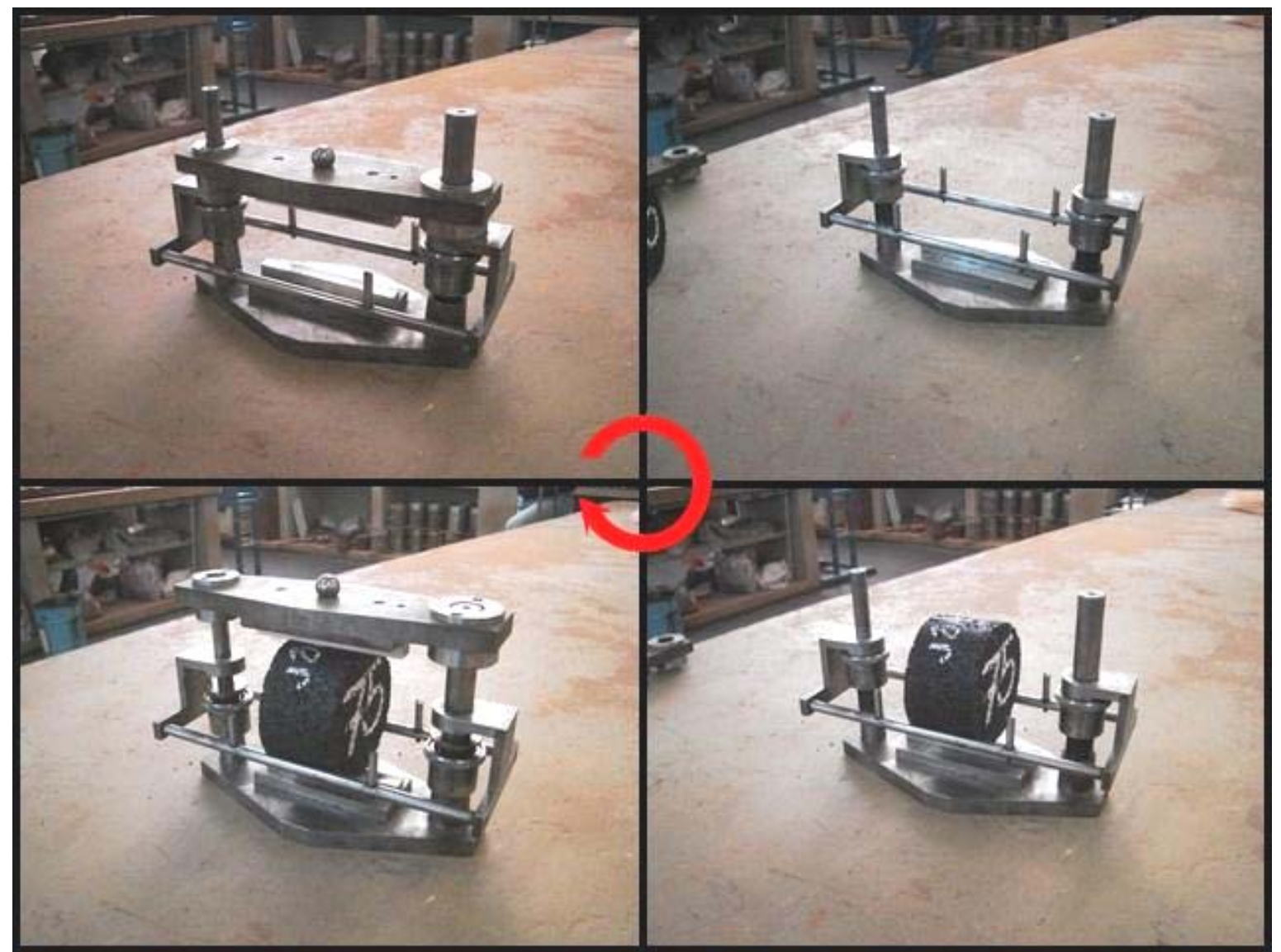

Figura 3.25. Montagem dos corpos-de-prova no suporte para o ensaio de RT.

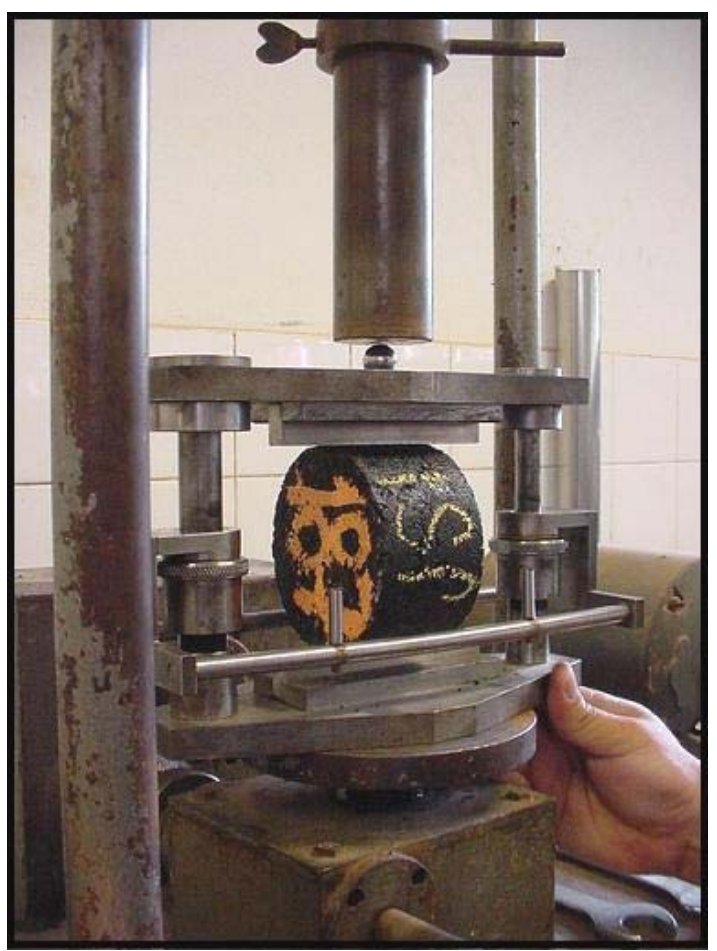

Figura 3.26. Fixação do suporte para o ensaio de RT.

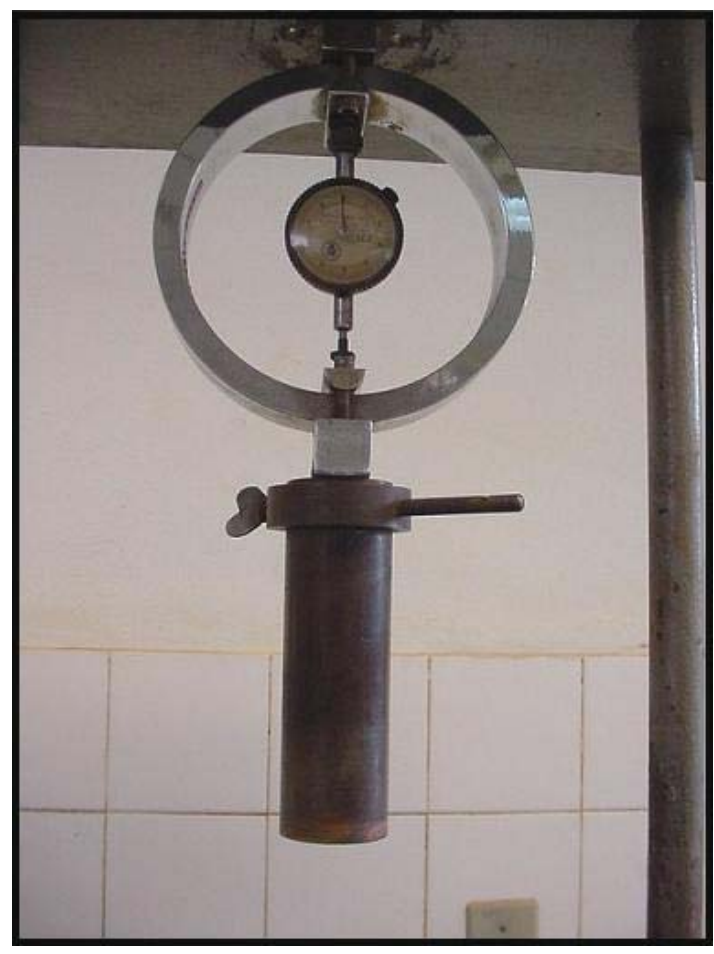

Figura 3.27. Anel de carga. 
A Equação 3.52 forneceu o valor da resistência à tração de cada corpo-de-prova.

$$
\sigma_{t}=\frac{2 \times F}{\pi \times D \times H}
$$

em que:

$$
\begin{array}{ll}
\sigma_{t} & : \text { resistência à tração }\left(\mathrm{kgf} / \mathrm{cm}^{2}\right) ; \\
F & : \text { carga de ruptura }(\mathrm{kgf}) ; \\
D & : \text { diâmetro médio do corpo-de-prova }(\mathrm{cm}) ; \\
H & : \text { altura média do corpo-de-prova }(\mathrm{cm}) .
\end{array}
$$

\subsubsection{Módulo de resiliência por compressão diametral}

O módulo de resiliência (MR) de misturas asfálticas é a relação entre a tensão de tração $\left(\sigma_{t}\right)$, aplicada repetidamente no plano vertical de uma amostra cilíndrica de mistura asfáltica, e a deformação específica recuperável $\left(\varepsilon_{t}\right)$, correspondente à tensão aplicada, numa dada temperatura (T). A norma DNER-ME 133/94 (DNER, 1994b) recomenda a Equação 3.53 para o cálculo de módulo de resiliência por compressão diametral.

$$
M R=\left(\frac{F}{\Delta \times H}\right) \times(0,9976 \times \mu+0,2692)
$$

em que:

MR : módulo de resiliência $\left(\mathrm{kgf} / \mathrm{cm}^{2}\right)$; 
150

F : carga vertical repetida aplicada diametralmente no corpo de prova (kgf);

$\Delta \quad$ : deformação $(\mathrm{cm})$

H : altura do corpo-de-prova (cm);

$\mu \quad$ : coeficiente de Poisson (adimensional).

Todos os corpos-de-prova da pesquisa foram submetidos a este ensaio, com exceção dos moldados para a dosagem Marshall e os compostos para determinação da absorção, e ficaram em sala com temperatura controlada de $25^{\circ} \mathrm{C}$ por no mínimo 24 horas para a estabilização da temperatura.

Para a realização do ensaio, cada corpo-de-prova foi colocado em um suporte e, então, fixou-se o medidor de deslocamento do tipo LVDT, como mostra a Figura 3.28. O conjunto foi levado à prensa e fixado, tomando-se o cuidado de manter o LVDT centralizado com relação à altura do corpo-de-prova, com o intuito de medir o deslocamento médio, como mostra a Figura 3.29. 


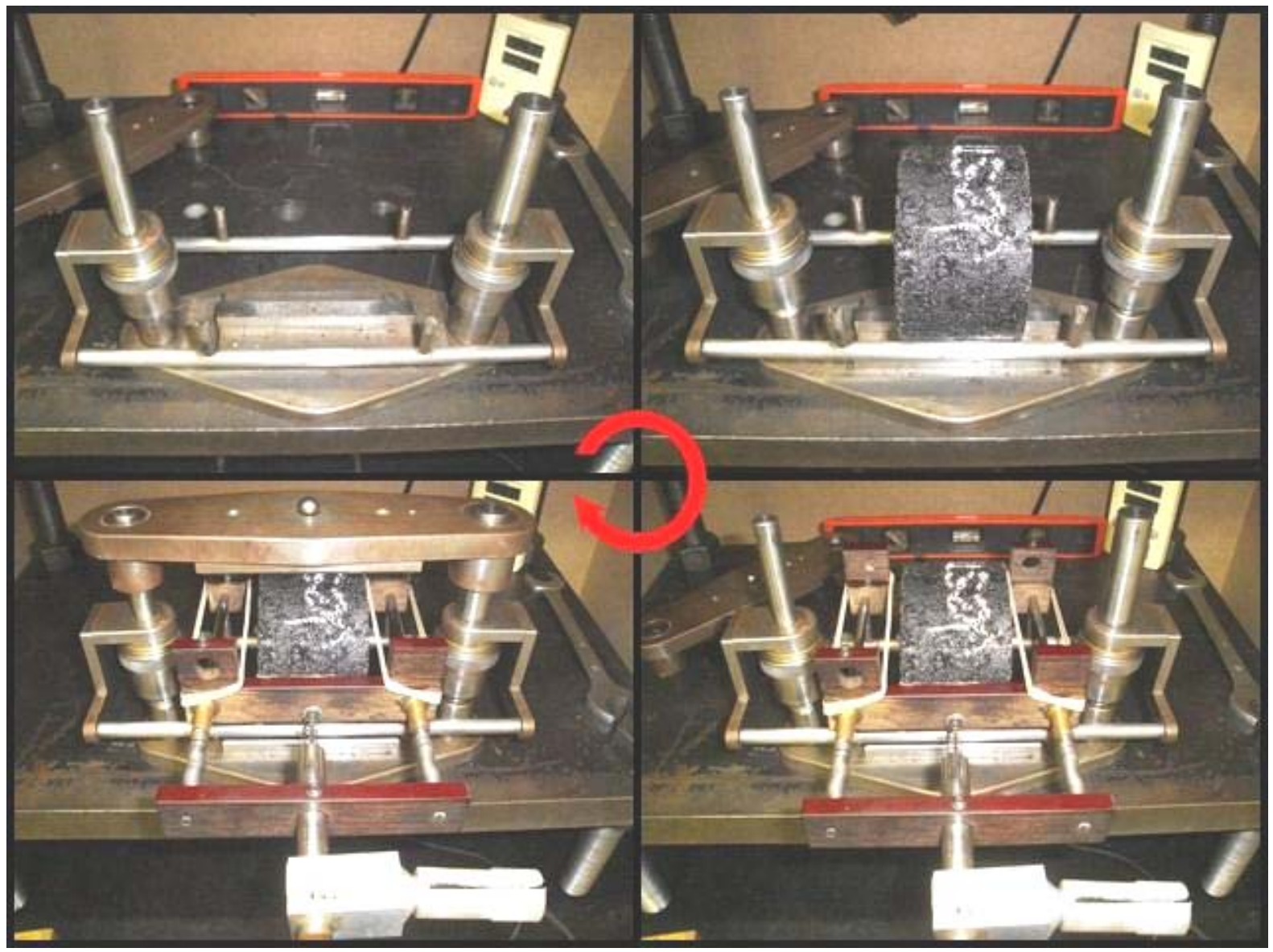

Figura 3.28. Montagem dos corpos-de-prova no suporte para o ensaio de MR. 


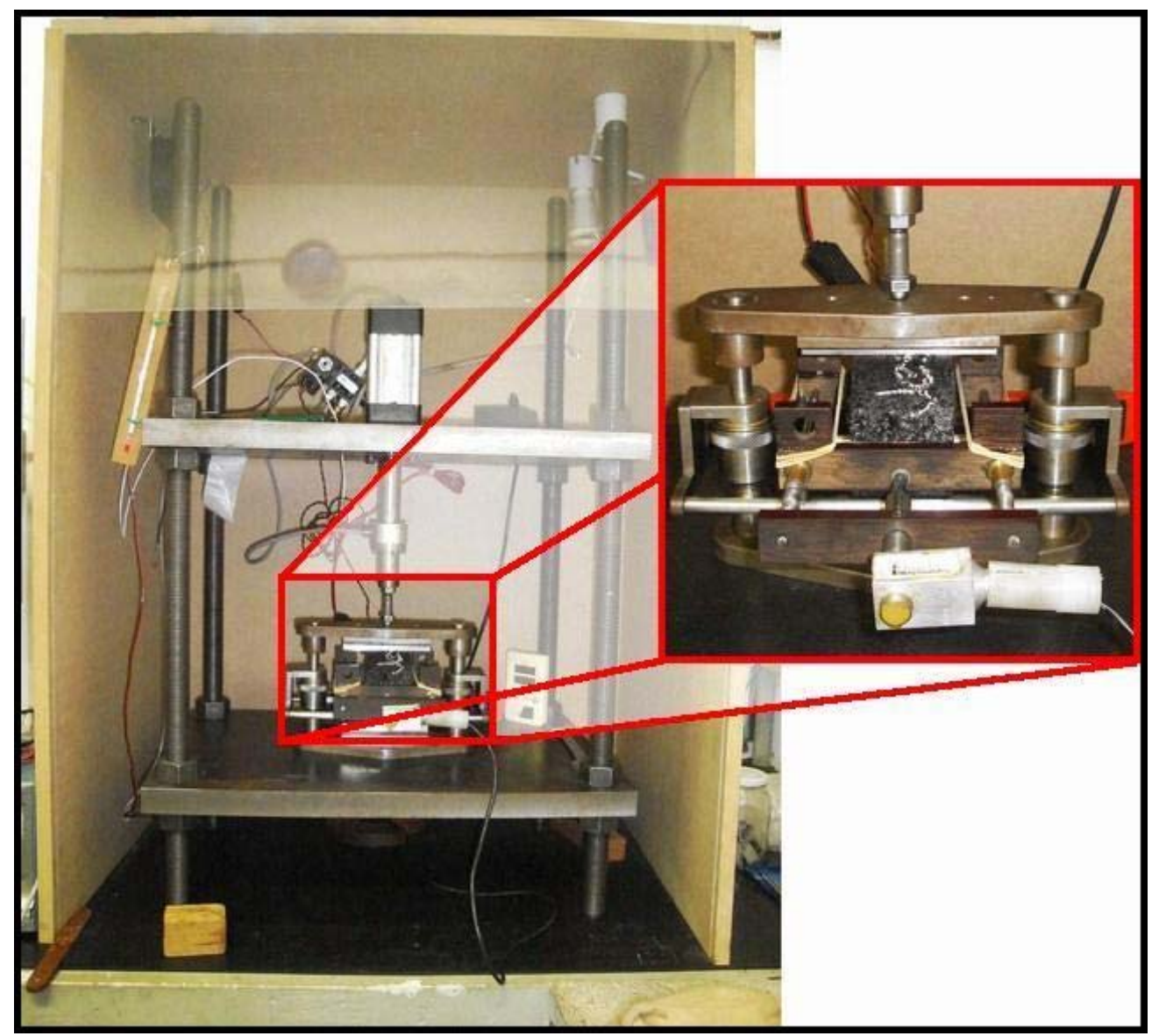

Figura 3.29. Esquema de fixação do suporte na prensa.

Os carregamentos aplicados pela prensa foram controlados para que os deslocamentos de cada corpo-de-prova ficassem no intervalo de $0,0020 \mathrm{~mm}$ a 0,0030 mm em cada ciclo de carga, com 0,1 segundo de carregamento e 0,9 segundo de recuperação.

A Figura 3.30 mostra um exemplo das deformações instantânea e total ocorridas durante um ciclo de carregamento. O ensaio de módulo de resiliência por compressão diametral foi realizado com a aplicação de 100 ciclos de carregamento. As Figuras 3.31, 3.32 e 3.33 mostram as telas dos programas de aquisição desenvolvidos em LabView, detalhe dos pulsos e do processamento dos dados, respectivamente. 


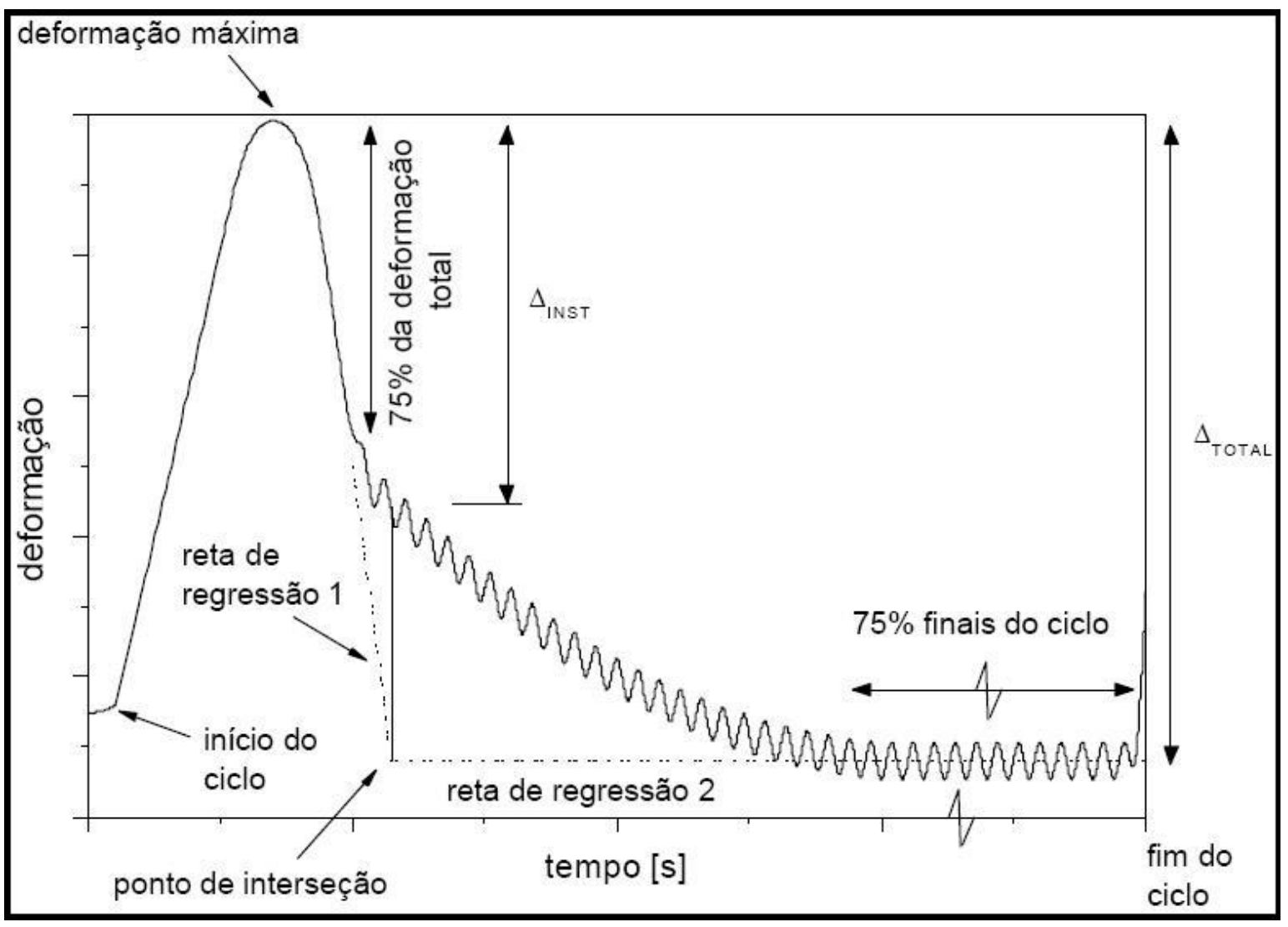

Figura 3.30. Deformações instantânea e total no ensaio de MR versus tempo (AASHTO TP31-94² apud SANTANNA-GRECO (2004)). 


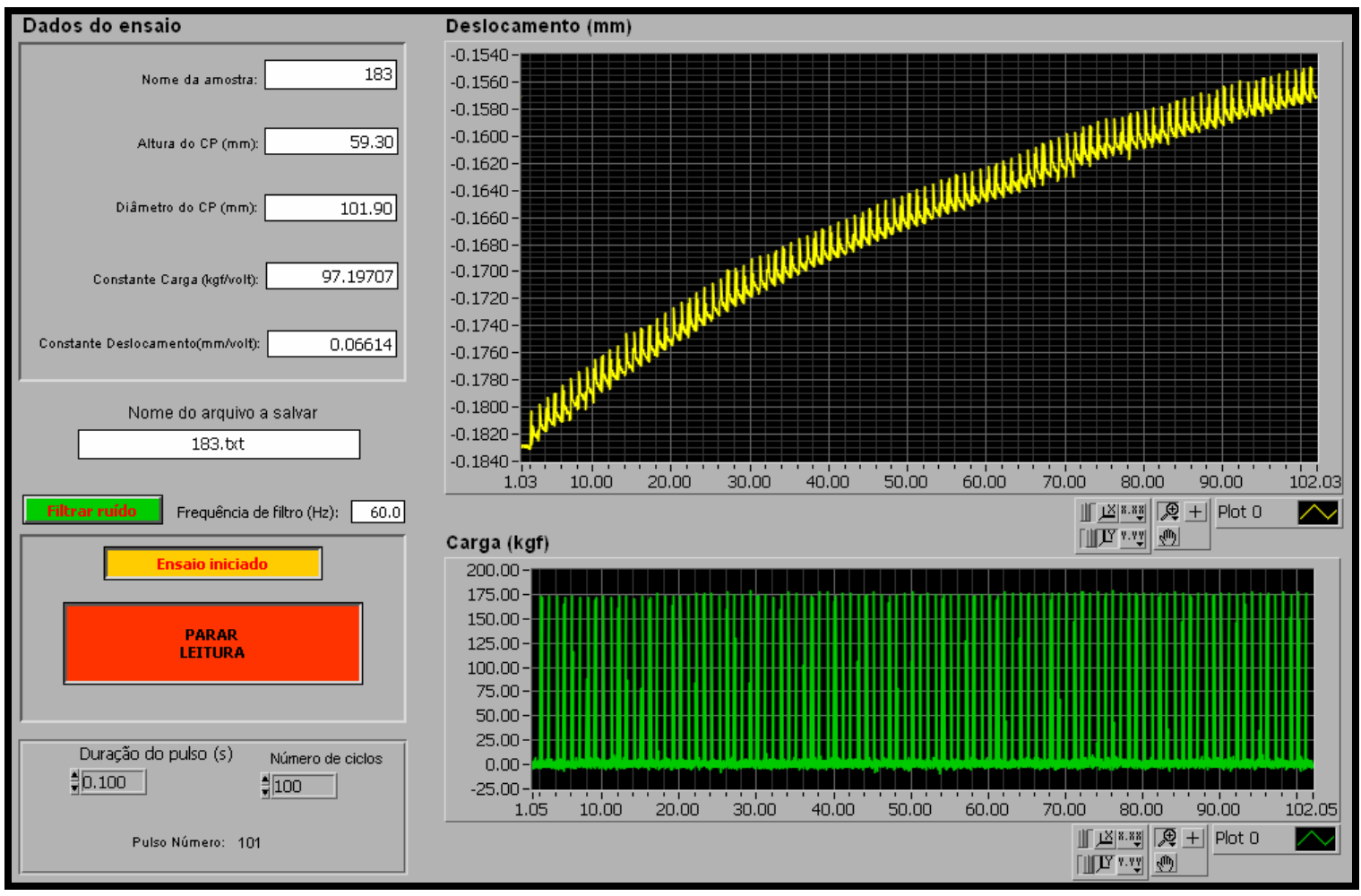

Figura 3.31. Tela do programa utilizado para aquisição dos dados de MR.

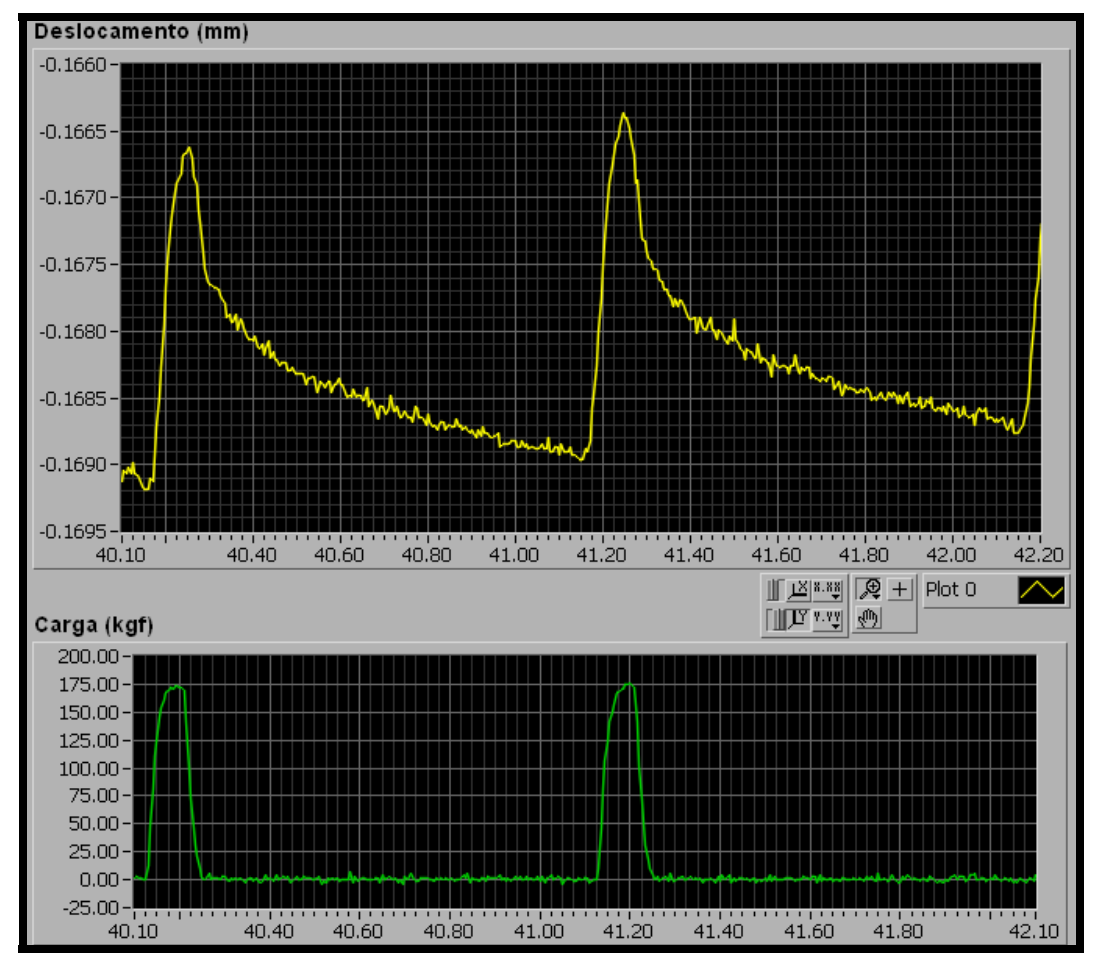

Figura 3.32. Detalhe dos pulsos do ensaio de MR. 


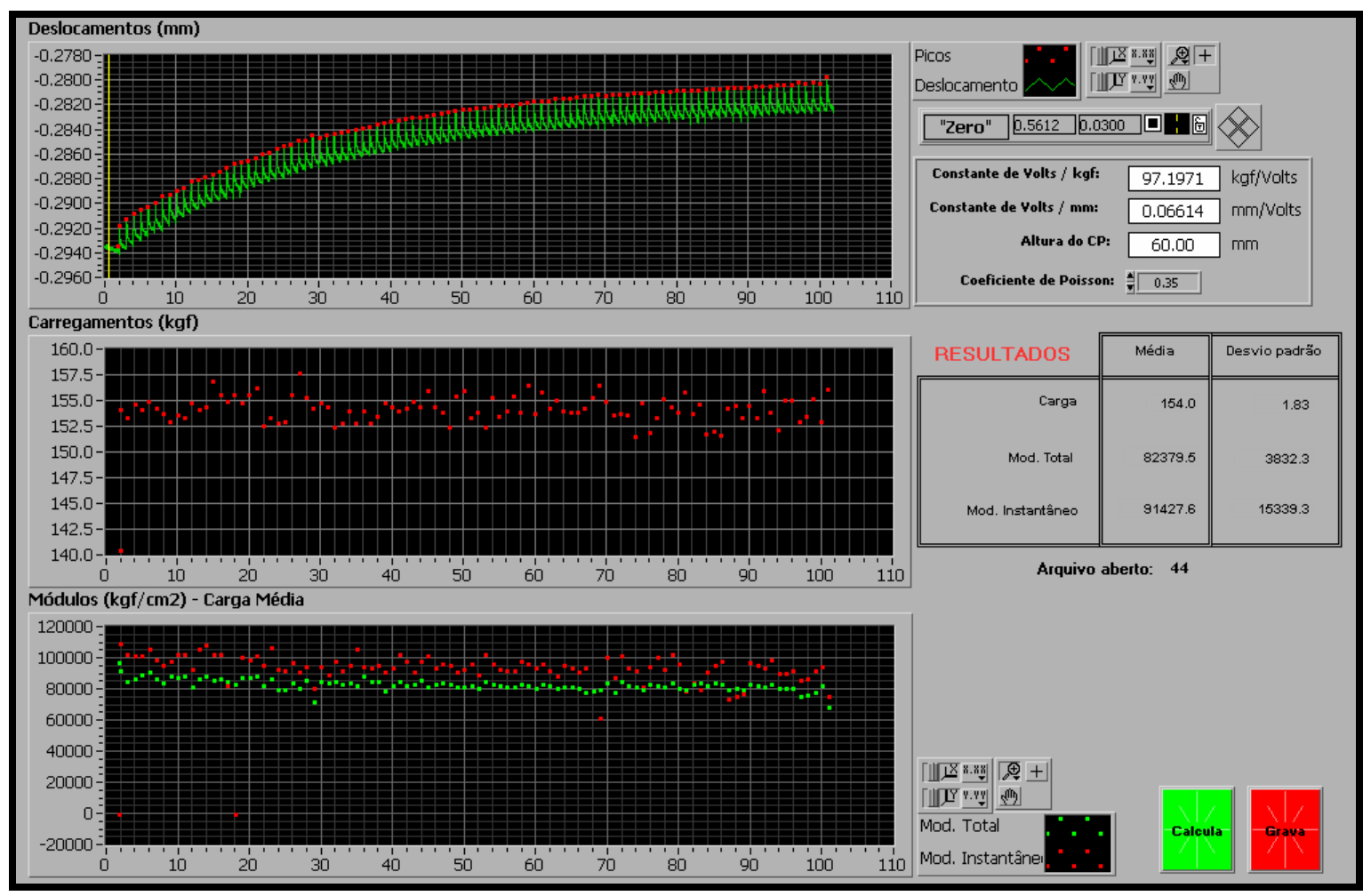

Figura 3.33. Tela do programa utilizado para processamento dos dados de MR.

\subsubsection{Fluência por compressão uniaxial estática ("creep" estático)}

O ensaio consistiu na aplicação, axialmente, de uma carga estática de 0,4 $\mathrm{MPa}$

$\left(4 \mathrm{~kg} / \mathrm{cm}^{2}\right)$ num corpo-de-prova cilíndrico, o que segundo Little, Button e Youssef (1993) representa a tensão média no centro de uma camada asfáltica do pavimento em serviço. Foi realizado a $40^{\circ} \mathrm{C}$, com 1 hora de aplicação de carga e 15 minutos de recuperação. As faces dos corpos-de-prova foram lixadas (Figura 3.34) para que ficassem mais planas quanto possível e a tensão aplicada pela prensa fosse homogênea em toda a superfície. 


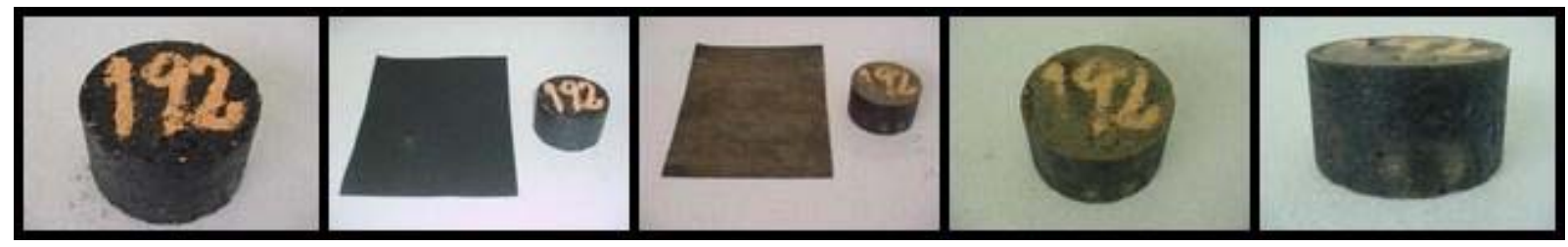

Figura 3.34. Corpo-de-prova lixado para o ensaio de fluência por compressão uniaxial estática.

Os corpos-de-prova, colocados em sacos plásticos e lacrados, permaneceram em estufa a $40^{\circ} \mathrm{C}$ por 10 horas para que a temperatura em toda a sua massa ficasse homogênea na hora do ensaio. Antes do ensaio, as faces de cada corpo-de-prova foram lubrificadas (Figura 3.35), seguindo-se o seu posicionamento no interior do suporte para fixação do LVDT, tomando-se o cuidado de observar o perfeito assentamento do pistão de carga e dos cabeçotes no corpo-de-prova. Estabilizou-se a temperatura da câmara a $40^{\circ} \mathrm{C} \pm 1^{\circ} \mathrm{C}$, antes de colocar os corpos-de-prova para o ensaio. A Figura 3.36 mostra o conjunto utilizado para realização do ensaio.

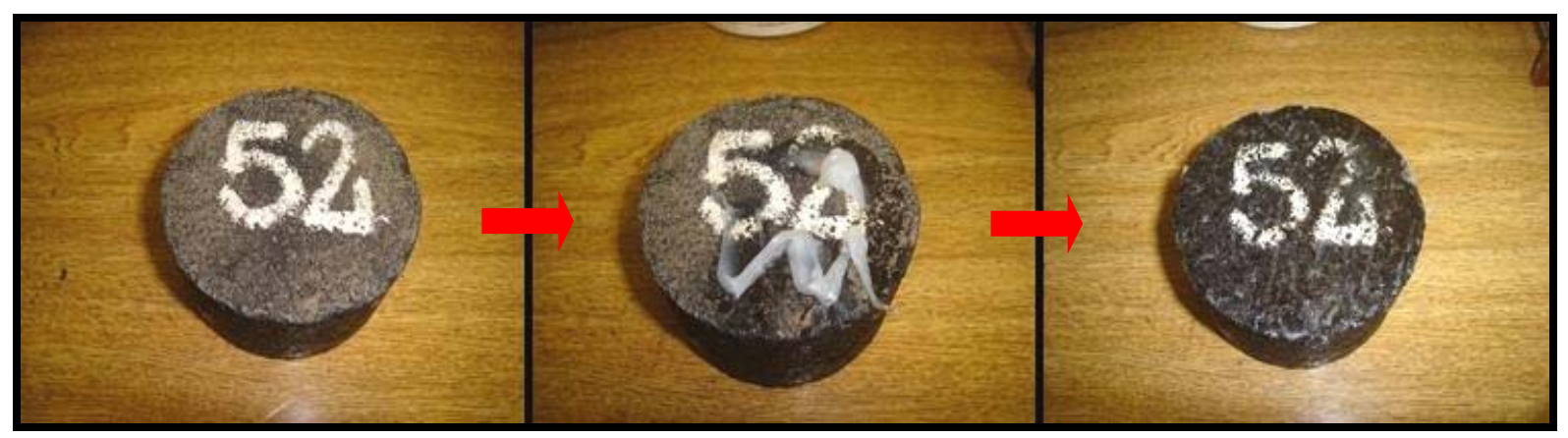

Figura 3.35. Preparação do corpo-de-prova para o ensaio de fluência por compressão uniaxial estática. 


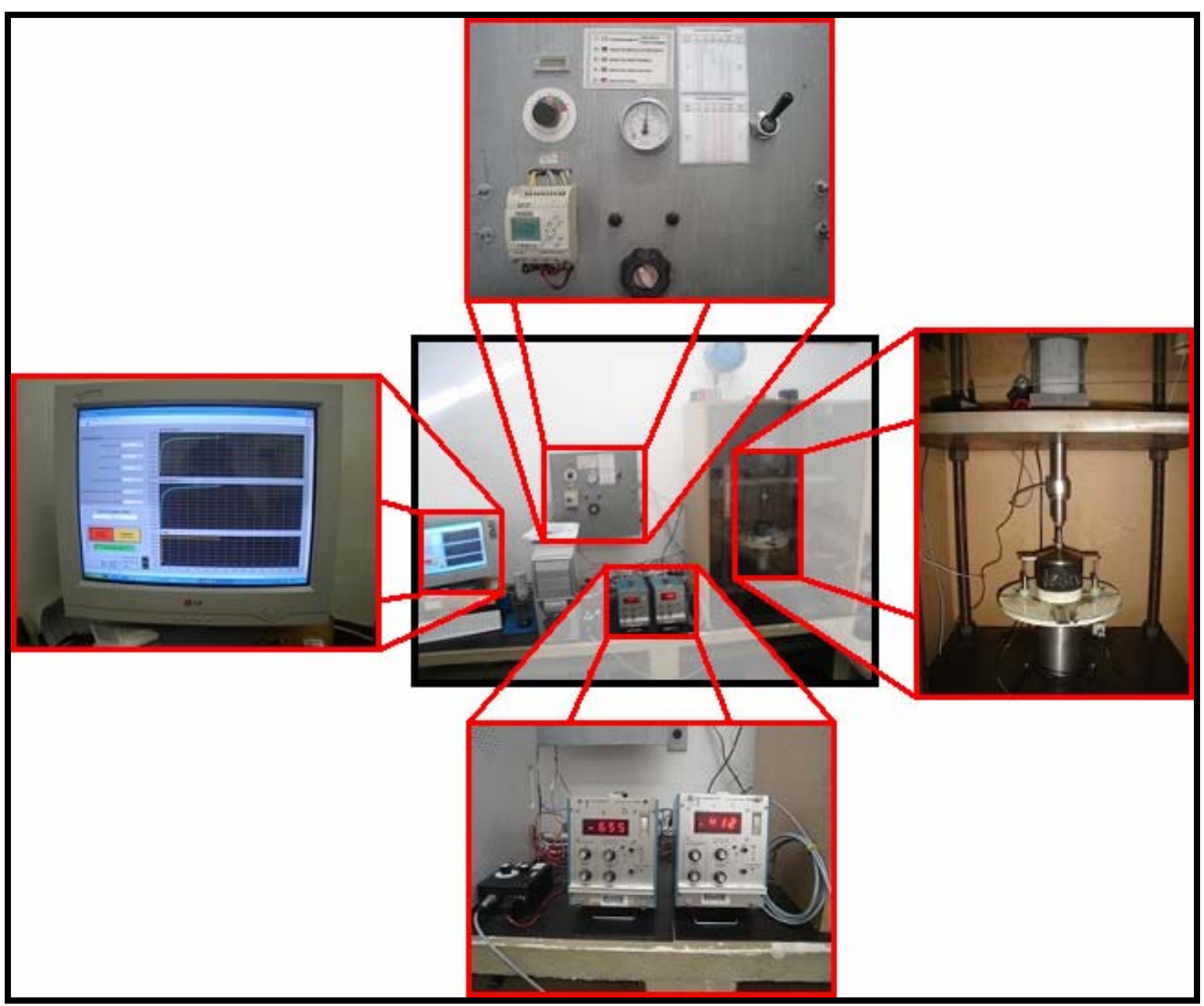

Figura 3.36. Conjunto para o ensaio de fluência por compressão uniaxial estática.

Uma fase de pré-condicionamento, que é dada através da aplicação da carga de ensaio por 5 minutos, foi feita e seguiu-se um período de um descanso (recuperação) de 5 minutos (Figura 3.37). O tempo de ensaio foi de 60 minutos de carregamento, mais 15 minutos de recuperação. Através de programas desenvolvidos em Labview foram feitos a aquisição - leituras ao longo do tempo dos deslocamentos axiais e da carga - e o processamento dos dados (Figuras 3.38 e 3.39). 


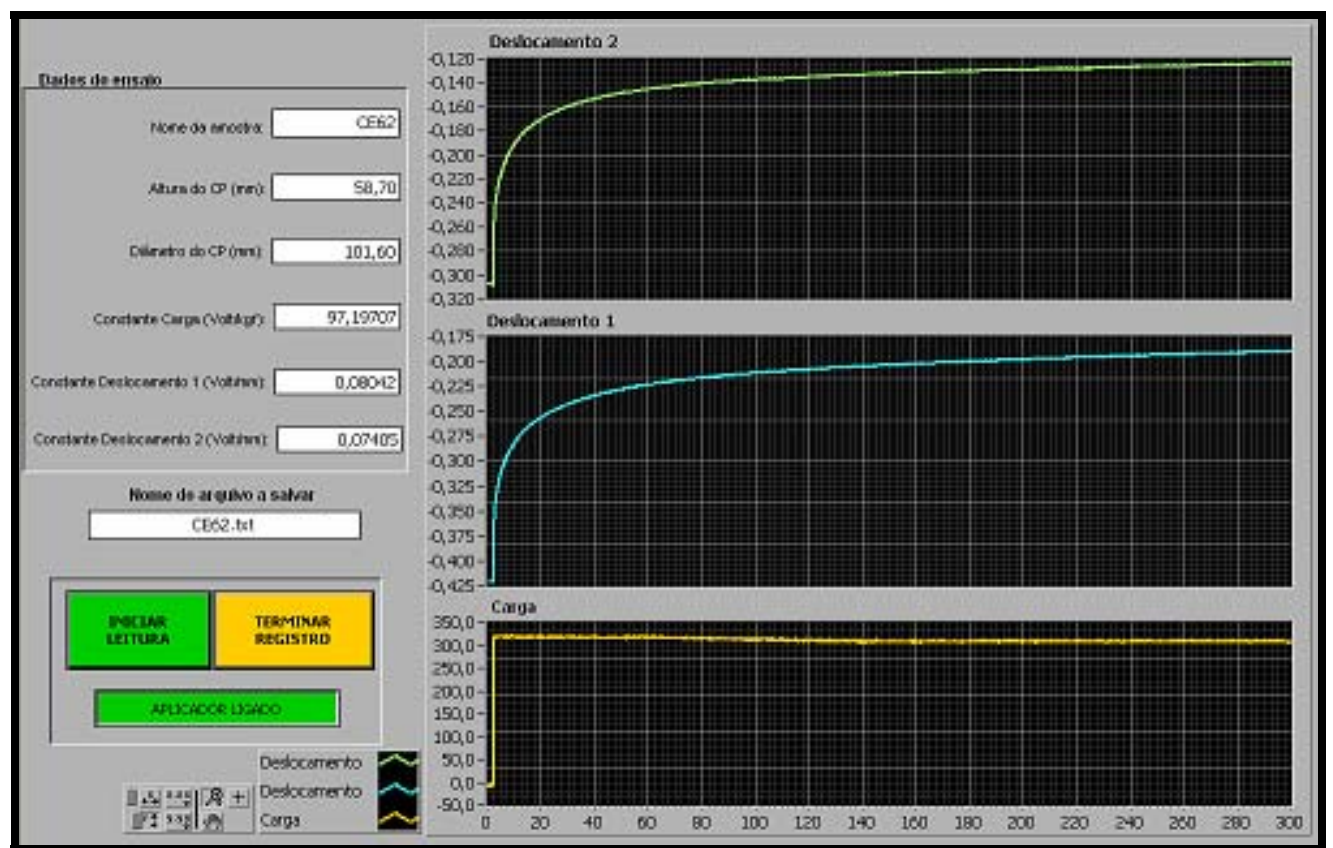

Figura 3.37. Condicionamento do corpo-de-prova no ensaio de fluência por

compressão uniaxial estática.

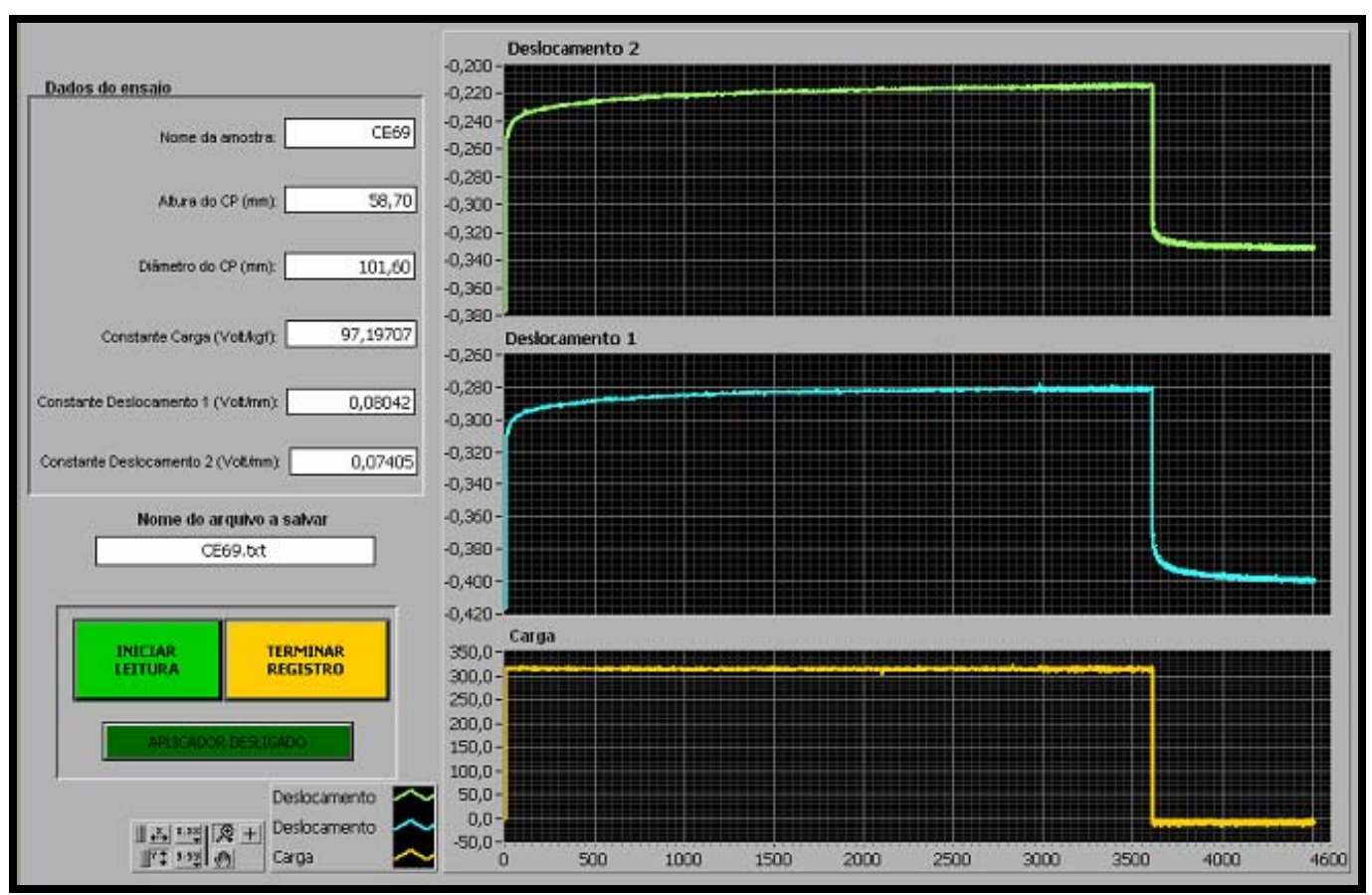

Figura 3.38. Tela do programa utilizado para aquisição dos dados de fluência por

compressão uniaxial estática. 


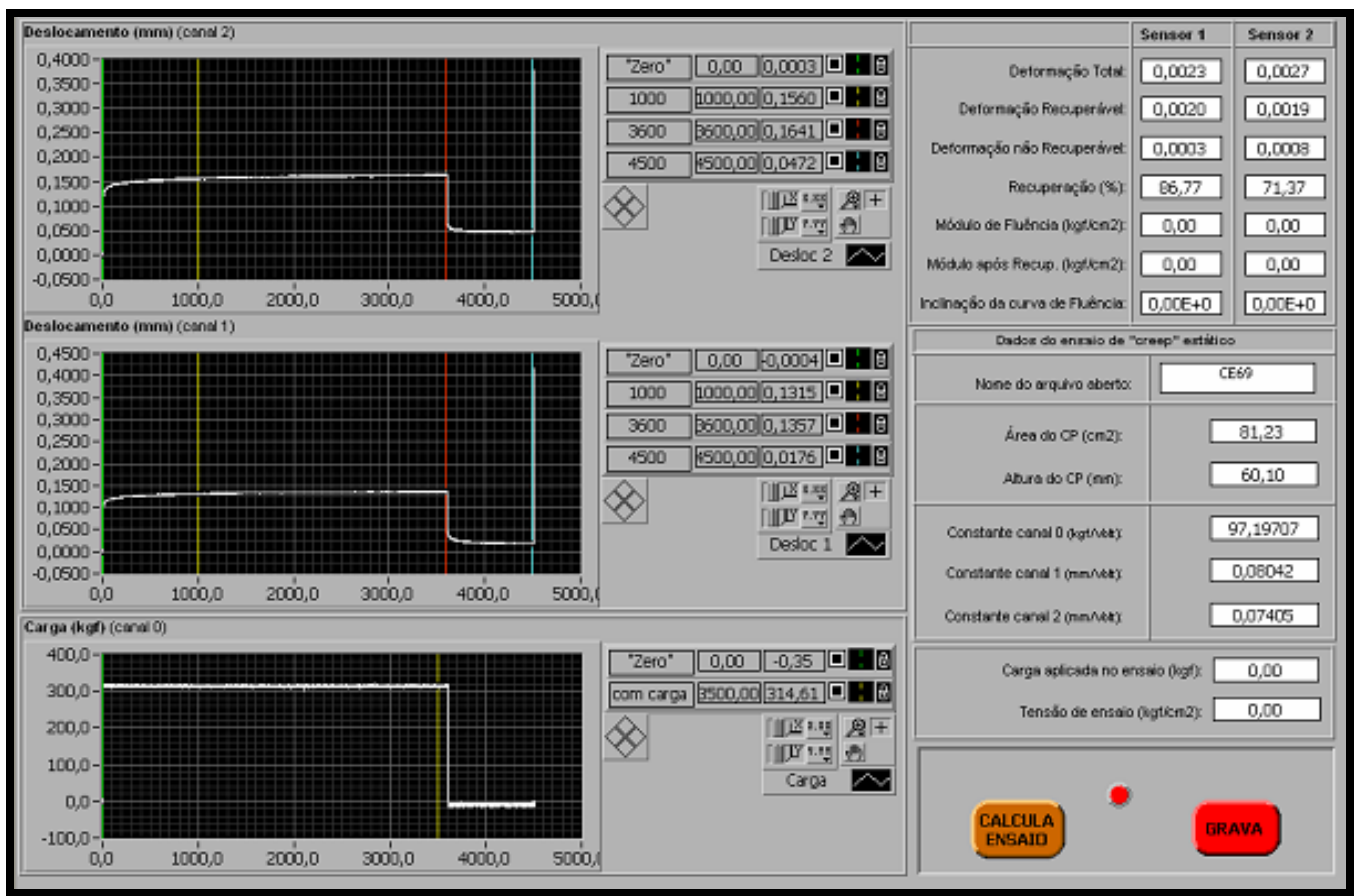

Figura 3.39. Tela do programa utilizado para processamento dos dados de fluência por compressão uniaxial estática.

As respostas geradas pelo programa de cálculo são: a deformação total, a deformação recuperável, a deformação não recuperável, a recuperação, o módulo de rigidez à fluência aos 3600 segundos e aos 4500 segundos, a inclinação da curva no estágio secundário de deformação e a carga média aplicada.

\subsubsection{Fluência por compressão uniaxial dinâmica ("creep" dinâmico)}

O ensaio consistiu na aplicação repetitiva de um ciclo cargas de compressão de curta duração seguidas por um descanso em corpos-de-prova cilíndricos a uma temperatura de $40^{\circ} \mathrm{C}$. As etapas de lixar faces dos corpos-de-prova e de estabilizar a 
temperatura foram executadas como no ensaio de fluência por compressão uniaxial estática (Figura 3.34). A tensão utilizada no ensaio foi de $0,4 \mathrm{MPa}\left(4 \mathrm{kgf} / \mathrm{cm}^{2}\right)$.

Cada ciclo teve duração de 1 segundo, sendo 0,1 segundo de carregamento e 0,9 segundo de recuperação. Antes da realização do ensaio houve uma fase de précondicionamento, onde foram aplicados 200 ciclos com a mesma carga e temperatura de ensaio.

Durante o ensaio foram aplicados 5000 ciclos e a aquisição e processamento dos dados foi semelhante ao ensaio de fluência por compressão uniaxial estática. As Figuras 3.40 e 3.41 mostram as telas dos programas utilizados para aquisição e processamento dos dados, respectivamente.

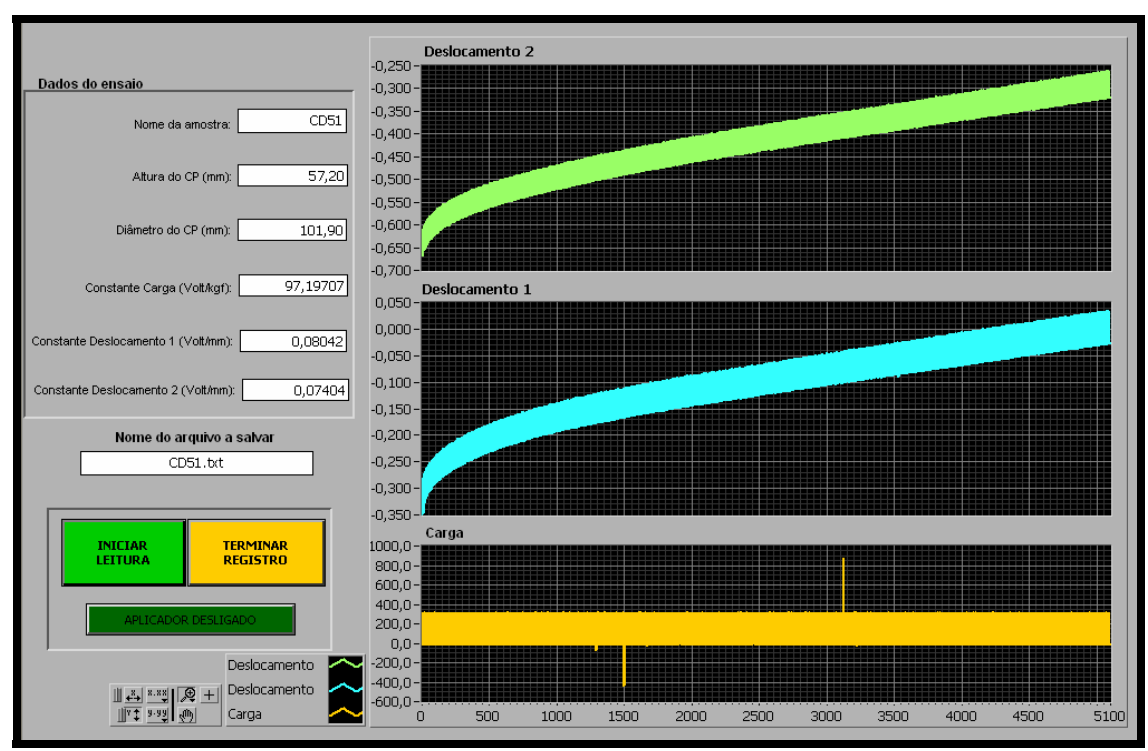

Figura 3.40. Tela do programa utilizado para aquisição dos dados de fluência por compressão uniaxial dinâmica. 


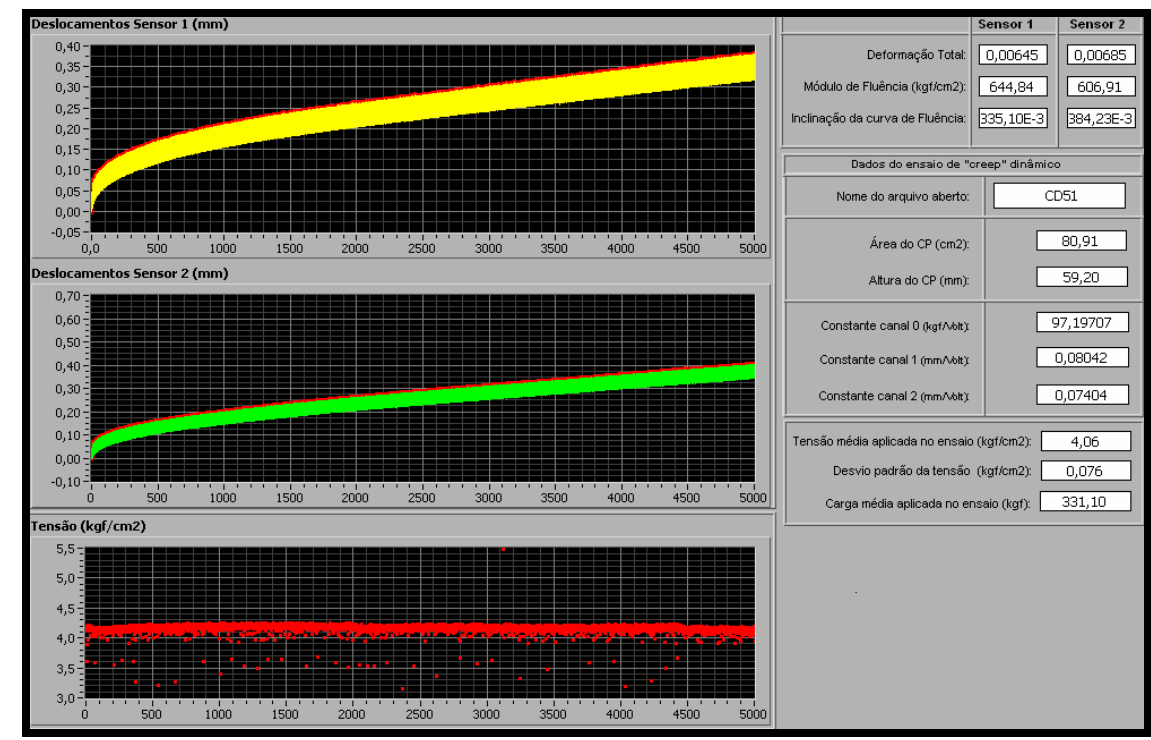

Figura 3.41. Tela do programa utilizado para processamento dos dados de fluência por compressão uniaxial dinâmica.

\subsubsection{Vida de fadiga}

O ensaio consistiu na aplicação de carregamentos cíclicos, com duração de 0,1 segundo e com recuperação 0,9 segundo, intervalo escolhido para representar o tempo de aplicação de carga entre uma roda e outra, até a ruptura ou deslocamento de $6 \mathrm{~mm}$ do corpo-de-prova, que está sujeito a um estado bi-axial de tensões.

A carga a ser aplicada dependeu exclusivamente da resistência à tração da mistura de controle, determinada no ensaio de resistência à tração por compressão diametral estática. O ensaio foi realizado com 10\%, 20\%, 30\% e $40 \%$ da RT da mistura de controle. Optou-se por usar somente os valores de RT da mistura de controle para normalizar os valores de todas e misturas e assim permitir uma comparação da vida de fadiga das diferentes misturas utilizando-se a mesma carga de aplicação. 
O ensaio foi realizado a $25^{\circ} \mathrm{C}$ e os corpos-de-prova ficaram acondicionados na temperatura de ensaio, por pelo menos 24 horas. O posicionamento do corpo-deprova no suporte deu-se como no ensaio de RT (Figura 3.25). Uma barra metálica dobrada (Figura 3.42) foi utilizada para permitir a aquisição dos deslocamentos com o uso de um LVDT. Os dados foram captados e armazenados em um computador com o uso de um programa desenvolvido em LabView.

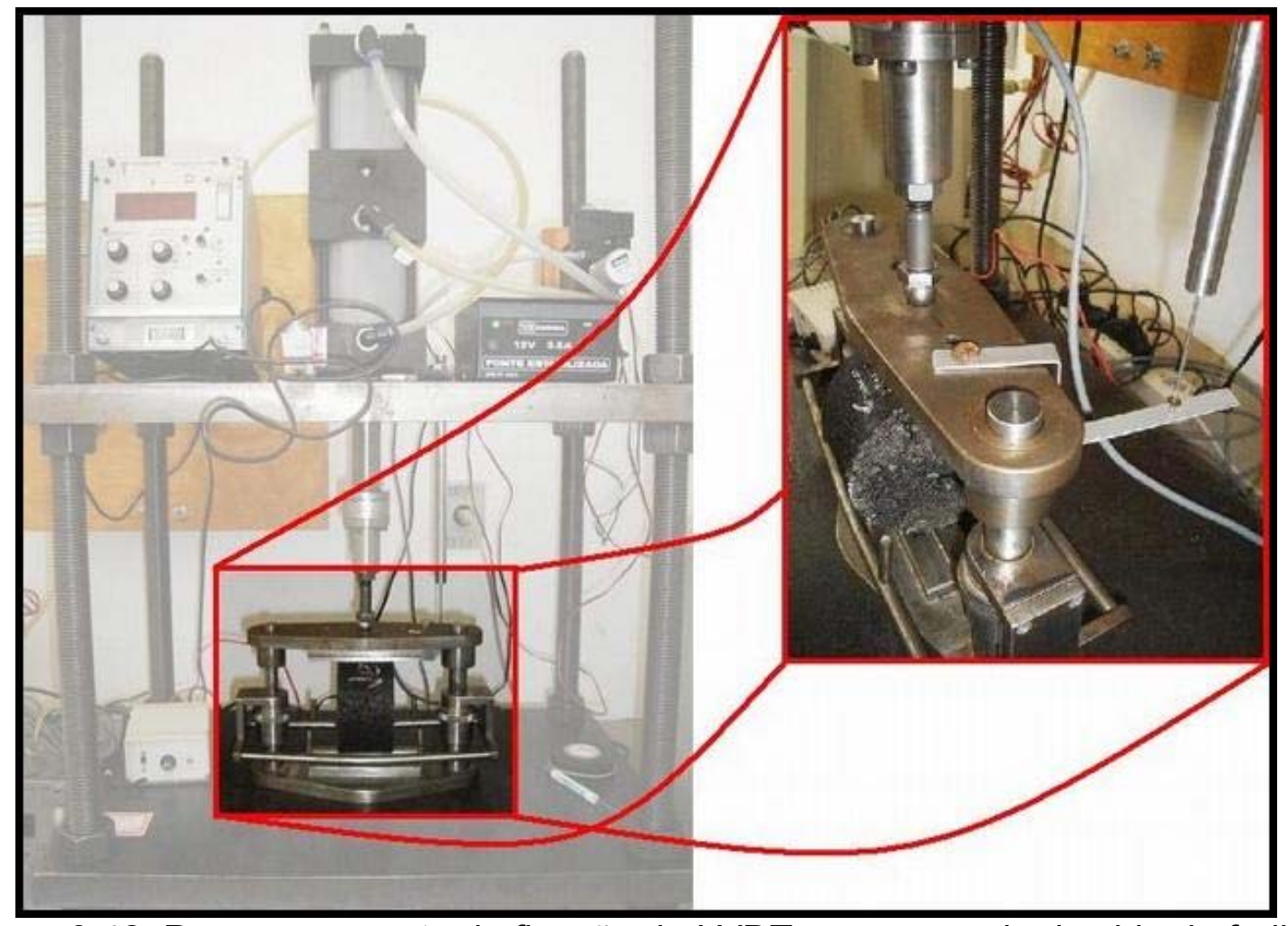

Figura 3.42. Prensa e suporte de fixação do LVDT para o ensaio de vida de fadiga.

As tensões encontradas no centro do corpo-de-prova são:

$$
\begin{aligned}
& \sigma_{t}=\frac{2 \times F}{100 \times \pi \times D \times H} \\
& \sigma_{c}=\frac{-6 \times F}{100 \times \pi \times D \times H}
\end{aligned}
$$




$$
\Delta \sigma=\frac{8 \times F}{100 \times \pi \times D \times H}
$$

em que:

$$
\begin{array}{ll}
\sigma_{t} & : \text { tensão de tração (MPa); } \\
\sigma_{c} & : \text { tensão de compressão (MPa); } \\
\Delta \sigma & : \text { diferença de tensões }(\mathrm{MPa}) ; \\
F & : \text { carga aplicada }(\mathrm{N}) ; \\
D & : \text { diâmetro médio do corpo-de-prova }(\mathrm{cm}) ; \\
H & : \text { altura média do corpo-de-prova }(\mathrm{cm}) .
\end{array}
$$

A resposta do ensaio pôde ser expressa em função da diferença de tensões e da deformação resiliente $\left(\varepsilon_{r}\right)$, que é função do módulo de resiliência e da tensão aplicada.

$$
\varepsilon_{r}=\frac{\% R T}{M R}
$$

em que:

$\varepsilon_{r} \quad$ : deformação resiliente;

$\% R T$ : tensão aplicada referente a porcentagem da RT (MPa);

MR : módulo de resiliência (MPa).

$$
N_{T}=k_{1} \times\left(\frac{1}{\Delta \sigma}\right)^{k_{2}}
$$




$$
N_{D}=k_{3} \times\left(\frac{1}{\varepsilon_{r}}\right)^{k_{2}}
$$

em que:

$$
\begin{aligned}
& \mathrm{N}_{\mathrm{T}} \quad \text { : número de ciclos em função da diferença de tensões; } \\
& \mathrm{N}_{\mathrm{D}} \quad \text { : número de ciclos em função da deformação resiliente; } \\
& \mathrm{k}_{1}, \mathrm{k}_{2}, \mathrm{k}_{3} \text { : constantes determinadas por regressão no ensaio de vida } \\
& \text { de fadiga. }
\end{aligned}
$$

\subsubsection{Desgaste por abrasão no ensaio Cantabro}

O ensaio foi realizado conforme a norma DNER-ME 383/99 (DNER, 1999), visando avaliar a coesão e a resistência à desintegração das misturas asfálticas. Os corposde-prova ficaram acondicionados à temperatura de $25^{\circ} \mathrm{C}$ por pelo menos 24 horas antes do ensaio e, então, foram pesados e colocados individualmente na máquina de abrasão "Los Angeles", sem as cargas abrasivas. Foram realizadas 300 revoluções a 33 rpm, após as quais foram verificadas as massas dos corpos-deprova. O desgaste das misturas asfálticas é dado pela seguinte equação:

$$
A(\%)=\frac{M-M^{\prime}}{M} \times 100
$$

em que:

$$
\begin{aligned}
& \text { A } \quad \text { desgaste das misturas asfálticas por abrasão (\%); } \\
& M \quad \text { : massa inicial do corpo-de-prova }(\mathrm{g}) ; \\
& M^{\prime} \quad \text { : massa final do corpo-de-prova }(\mathrm{g}) .
\end{aligned}
$$




\subsection{RESUMO DA PROGRAMAÇÃO EXPERIMENTAL}

Com 4 teores de resíduo $(0 \%, 1 \%, 2 \%$ e 3\%) e 3 etapas de envelhecimento $(0$ h, 2 h e 4 h), têm-se 4 × 3 = 12 combinações possíveis, ou seja, para que o experimento completo fosse realizado foram necessárias 12 condições experimentais.

Os ensaios de resistência à tração por compressão diametral, fluência por compressão uniaxial estática e Cantabro foram realizados em 3 corpos-de-prova para cada condição experimental. Para os ensaios de fluência por compressão uniaxial estática e Cantabro foram utilizados os mesmos corpos-de-prova, seguindose essa seqüência.

O ensaio de fadiga foi realizado com 8 corpos-de-prova para cada condição experimental, sendo que o ensaio foi feito em dois corpos-de-prova para cada tensão $(10 \%, 20 \%, 30 \%$ e $40 \%$ da RT da mistura de controle).

Os ensaios de módulo de resiliência foram realizados em todos os corpos-de-prova, já que não se trata de um ensaio destrutivo, com a finalidade de submeter todos os corpos-de-prova às mesmas condições.

Para os ensaios exploratórios foram utilizados 40 corpos-de-prova, sendo 18 para a dosagem Marshall, 6 para absorção $(0 h, 2 h$ e $4 h)$ e 16 para os ensaios preliminares (MR e RT). Para a pesquisa foram compostos um total de 208 corposde-prova, sendo as características de cada um apresentadas no Apêndice D. 
Se o conhecimento pode trazer problemas, não é através da ignorância que podemos solucioná-los.

(Isaac Asimov)

$4 \begin{aligned} & \text { APRESENTAÇÃO E ANÁLISE } \\ & \text { DOS RESULTADOS }\end{aligned}$

\subsection{CONSIDERAÇÕES INICIAIS}

Neste capítulo são apresentados os resultados da dosagem Marshall, que serviu para a determinação do teor ótimo (ou de projeto) de ligante asfáltico, dos ensaios de módulo de resiliência por compressão diametral, resistência à tração por compressão diametral estática, vida de fadiga, fluência por compressão uniaxial estática, fluência por compressão uniaxial dinâmica e Cantabro. Seguindo-se à apresentação dos resultados foram feitos breves comentários acerca dos resultados dos ensaios e propostos modelos estatísticos gerados a partir do teste $\mathrm{F}$ de Snedecor para o módulo de resiliência, a resistência à tração e o desgaste. O ensaio 
de vida de fadiga já proporciona modelos em função do nível de tensão para cada condição experimental.

\subsection{MODELOS DE REGRESSÃO}

Os modelos obtidos através de regressão múltipla dos resultados dos ensaios aparecem na forma polinomial em função dos dois fatores envolvidos na pesquisa (teor de EVA e tempo de envelhecimento) e apresenta a forma geral:

$Y=\alpha_{0}+\alpha_{T I} \times P_{l}(T)+\alpha_{T q} \times P_{q}(T)+\alpha_{E I} \times P_{I}(E)+\alpha_{E q} \times P_{q}(E)+\alpha_{T I E I} \times P_{I}(E) \times$

$x P_{l}(T)+\alpha_{T q E I} \times P_{q}(T) \times P_{l}(E)+\alpha_{T I E q} \times P_{l}(T) \times P_{q}(E)+\alpha_{T q E q} \times P_{q}(T) \times P_{q}(E)$

em que:

Y $\quad$ : variável dependente;

$T, E$ : variável independente;

$T \quad$ : teor de EVA na mistura (\%);

E : tempo de envelhecimento da mistura (h);

$\alpha_{0} \quad$ : média aritmética das observações;

$\alpha_{T I} \quad$ : termo linear do coeficiente correspondente ao fator T;

$\alpha_{T q} \quad$ : termo quadrático do coeficiente correspondente ao fator T;

$\alpha_{E I} \quad$ : termo linear do coeficiente correspondente ao fator $\mathrm{E}$;

$\alpha_{E q} \quad$ : termo quadrático do coeficiente correspondente ao fator $\mathrm{E}$; 
$\alpha_{T I E I}$ : coeficiente correspondente à interação dos termos lineares dos fatores T e E;

$\alpha_{T q E I}:$ coeficiente correspondente à interação do termo quadrático do fator $\mathrm{T}$ e o termo linear do fator $E$;

$\alpha_{T I E q}:$ coeficiente correspondente à interação do termo linear do fator $\mathrm{T} e$ o termo quadrático do fator $\mathrm{E}$;

$\alpha_{T q E q}:$ coeficiente correspondente à interação dos termos quadráticos dos fatores T e E;

$P_{l}(T)$ : equação polinomial linear correspondente ao fator $\mathrm{T}$;

$P_{q}(T)$ : equação polinomial quadrática correspondente ao fator $\mathrm{T}$;

$P_{l}(E)$ : equação polinomial linear correspondente ao fator $E$;

$P_{q}(E)$ : equação polinomial quadrática correspondente ao fator $\mathrm{E}$.

As equações polinomiais lineares e quadráticas apresentadas na Equação 4.1 podem ser expressas, de forma geral, como as Equações 4.2 e 4.3.

$$
\begin{gathered}
P_{l}(x)=\lambda_{l} \times\left(\frac{x-\bar{x}}{d_{x}}\right) \\
P_{q}(x)=\lambda_{q} \times\left[\left(\frac{x-\bar{x}}{d_{x}}\right)^{2}-\left(\frac{a_{x}{ }^{2}-1}{12}\right)\right]
\end{gathered}
$$


em que:

$$
\begin{aligned}
& \lambda_{l} \quad \text { : constante tabelada para o polinômio linear }=1 ; \\
& \lambda_{q} \quad \text { : constante tabelada para o polinômio quadrático = } 3 ; \\
& x \quad \text { : nível do fator quantitativo; } \\
& \bar{x} \quad \text { : média aritmética dos valores do fator quantitativo } \mathrm{x} ; \\
& d_{x} \quad \text { : distância entre os níveis do fator quantitativo } \mathrm{x} ; \\
& a_{x} \quad \text { : número de níveis do fator } \mathrm{x} .
\end{aligned}
$$

\begin{tabular}{|c|c|c|c|}
\hline Fator & Equação polinomial & Variável representativa & Condição \\
\hline \multirow{3}{*}{ Teor de EVA } & \multirow{3}{*}{$P(T)=$} & -1 & $1 \%$ de EVA \\
\hline & & 0 & $2 \%$ de EVA \\
\hline & & 1 & $3 \%$ de EVA \\
\hline \multirow{3}{*}{$\begin{array}{c}\text { Tempo de } \\
\text { envelhecimento }\end{array}$} & \multirow{3}{*}{$P(E)=$} & -1 & 0 hora \\
\hline & & 0 & 2 horas \\
\hline & & 1 & 4 horas \\
\hline
\end{tabular}

As equações polinomiais são definidas através dos níveis de cada fator e podem ser representadas como na Tabela 4.1.

Tabela 4.1 - Modelos estatísticos - Equações polinomiais.

A construção de cada modelo foi feita a partir da análise da variância efetuada nos dados dos ensaios, considerando-se apenas os efeitos significativos, que foram determinados através do teste $\mathrm{F}$ de Snedecor. Trata-se de um teste que fornece a soma dos quadrados (SQ) dos fatores e suas interações, que por sua vez estão relacionadas com as variações dos níveis de cada fator e suas respectivas interações. Supondo-se que tratamentos (termos) são equivalentes, o quadrado 
médio (QM) para os tratamentos é uma estimativa da variância, da mesma forma que o quadrado médio do resíduo (GOMES, 1973).

As tabelas do teste F (GOMES, 1973; LEABO, 1972) podem ser usadas para comparar as estimativas de cada parâmetro dentro de cada significância ou probabilidade. Por exemplo, para um nível de significância de 5\%, o valor da resposta do modelo tem $5 \%$ de probabilidade de ter sido ao acaso. A qualidade com que cada modelo representa o comportamento do material pode ser dada em função do coeficiente de determinação $\left(R^{2}\right)$, que é calculado de acordo com a Equação 4.4. Quanto mais próximo de 1 estiver $\circ \mathrm{R}^{2}$, mais próximo o modelo proposto está de representar a realidade. Os modelos incluem apenas os fatores e interações significantes, de acordo com o teste F. A significância com que cada modelo foi construído $(0,1 \%, 1 \%, 2,5 \%$ e $5 \%)$ difere um do outro, pois foi utilizado para cada modelo a significância de menor valor e que apresentasse resposta mais próxima dos valores de ensaio, por exemplo, para modelos construídos com significância $0,1 \%, 1 \%, 2,5 \%$ e $5 \%$ e $\mathrm{R}^{2}$ de $0,7,0,75,0,8,0,8$ e 0,8 , respectivamente, utilizou-se o modelo que apresenta significância de 2,5\%.

$$
R^{2}=\frac{S Q_{\mathrm{mod}}}{S Q_{\text {total }}}
$$

\subsection{DOSAGEM MARSHALL}

O intuito de se realizar a dosagem Marshall foi obter o teor ótimo de ligante para compor os corpos-de-prova da pesquisa. Os parâmetros obtidos na dosagem, que 
são a densidade aparente da mistura (Dap), os vazios do agregado mineral (VAM), a relação betume-vazios (RBV), a fluência $(F)$ e a estabilidade $(E)$ foram verificados para o teor de ligante que corresponde ao volume de vazios de $4 \%$. A Tabela 4.2 mostra as médias dos parâmetros encontrados na dosagem Marshall, sendo os dados completos apresentados no Apêndice B.

Tabela 4.2 - Dosagem Marshall - Características volumétricas e mecânicas das amostras.

\begin{tabular}{ccccccccc}
\hline $\begin{array}{c}\text { CAP } \\
(\mathbf{\%})\end{array}$ & Dap & $\begin{array}{c}\text { Vv } \\
(\mathbf{\%})\end{array}$ & $\begin{array}{c}\text { Vol. CAP } \\
(\mathbf{\%})\end{array}$ & $\begin{array}{c}\text { VAM } \\
(\mathbf{\%})\end{array}$ & $\begin{array}{c}\text { RBV } \\
(\mathbf{\%})\end{array}$ & $\begin{array}{c}\mathbf{F} \\
(\mathbf{m m})\end{array}$ & $\begin{array}{c}\mathbf{E} \\
(\mathbf{N})\end{array}$ & $\begin{array}{c}\text { E/F } \\
(\mathbf{N} / \mathbf{m m})\end{array}$ \\
\hline $\mathbf{4 , 5}$ & 2,428 & 8,25 & 10,84 & 19,09 & 56,78 & 2,62 & 11636 & 4433 \\
$\mathbf{5 , 0}$ & 2,445 & 6,83 & 12,13 & 18,96 & 63,96 & 2,79 & 12604 & 4511 \\
$\mathbf{5 , 5}$ & 2,476 & 4,85 & 13,51 & 18,36 & 73,58 & 2,88 & 13861 & 4815 \\
$\mathbf{6 , 0}$ & 2,490 & 3,52 & 14,82 & 18,34 & 80,83 & 3,13 & 14403 & 4598 \\
$\mathbf{6 , 5}$ & 2,492 & 2,63 & 16,07 & 18,70 & 85,94 & 3,39 & 13139 & 3880 \\
$\mathbf{7 , 0}$ & 2,486 & 2,05 & 17,27 & 19,31 & 89,40 & 3,64 & 12074 & 3317 \\
\hline
\end{tabular}

As Figuras 4.1 a 4.6 representam graficamente as médias correspondentes aos valores dos parâmetros da dosagem apresentados na Tabela 4.2. De acordo com os dados representados na Figura 4.1, o teor ótimo de ligante, para $4 \%$ de volume de vazios, se dá em aproximadamente $5,78 \%$ de ligante. 


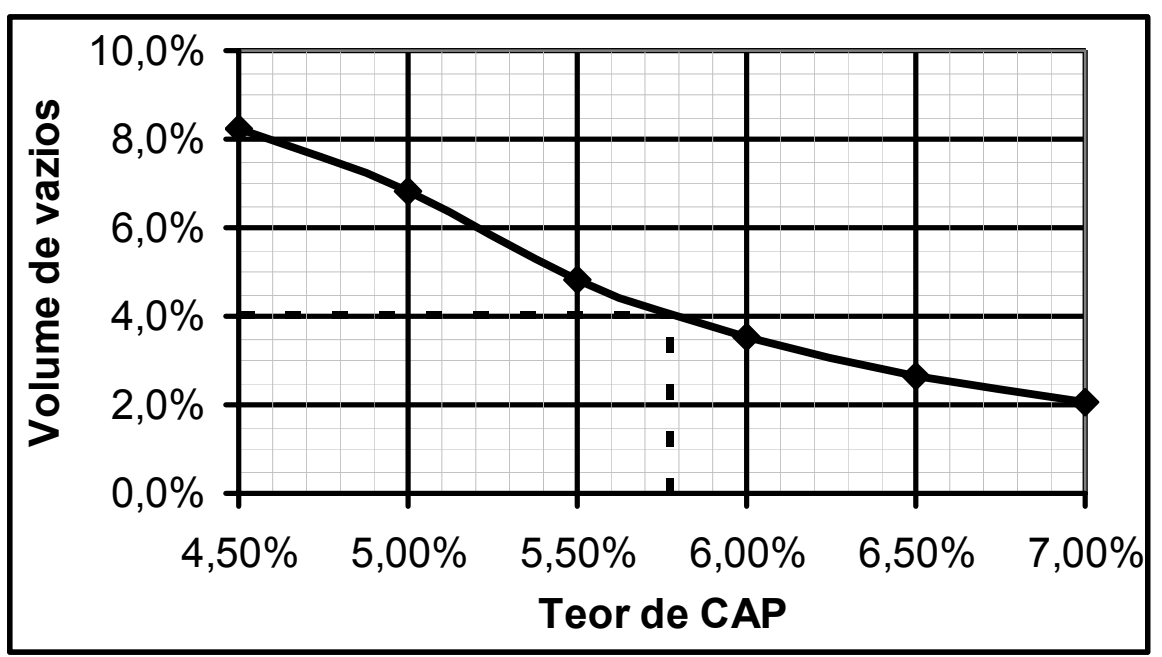

Figura 4.1. Dosagem Marshall - Volume de vazios em função do teor de CAP.

A Tabela 4.3 apresenta os resultados das médias da absorção de ligante pelo agregado em função do tempo de envelhecimento em estufa com ventilação forçada, para a mistura de controle no teor de projeto. Os cálculos estão apresentados no Apêndice C.

Tabela 4.3 - Absorção de ligante.

\begin{tabular}{cc}
\hline Envelhecimento (h) & Absorção (\%) \\
\hline $\mathbf{0}$ & 0,001 \\
\hline $\mathbf{2}$ & 0,023 \\
\hline $\mathbf{4}$ & 0,123 \\
\hline
\end{tabular}

Nesta pesquisa foi adotado o teor de ligante calculado mais a absorção de 2 horas para todas as misturas, desse modo o teor de ligante utilizado nas misturas foi de $5,83 \%$, porém o teor efetivo de ligante foi de $5,78 \%$, portanto todos os parâmetros apresentados a seguir são baseados no teor efetivo de ligante. De acordo com a Figura 4.2 , para $5,78 \%$ de ligante, tem-se uma densidade aparente da mistura de 2,486. A Figura 4.3 mostra um teor de vazios no agregado mineral de $18,3 \%$, valor 
maior que o mínimo recomendado pela especificação SUPERPAVE (COMINSKY et al., 1998) e pelo DNIT (DNIT, 2004).

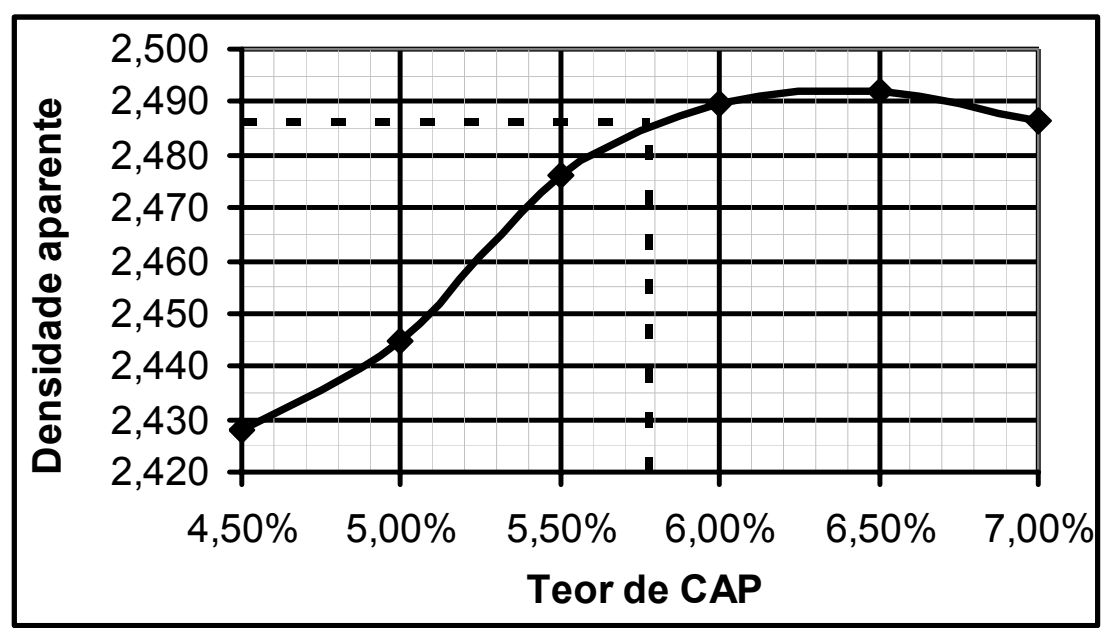

Figura 4.2. Dosagem Marshall - Densidade aparente da mistura em função do teor de CAP.

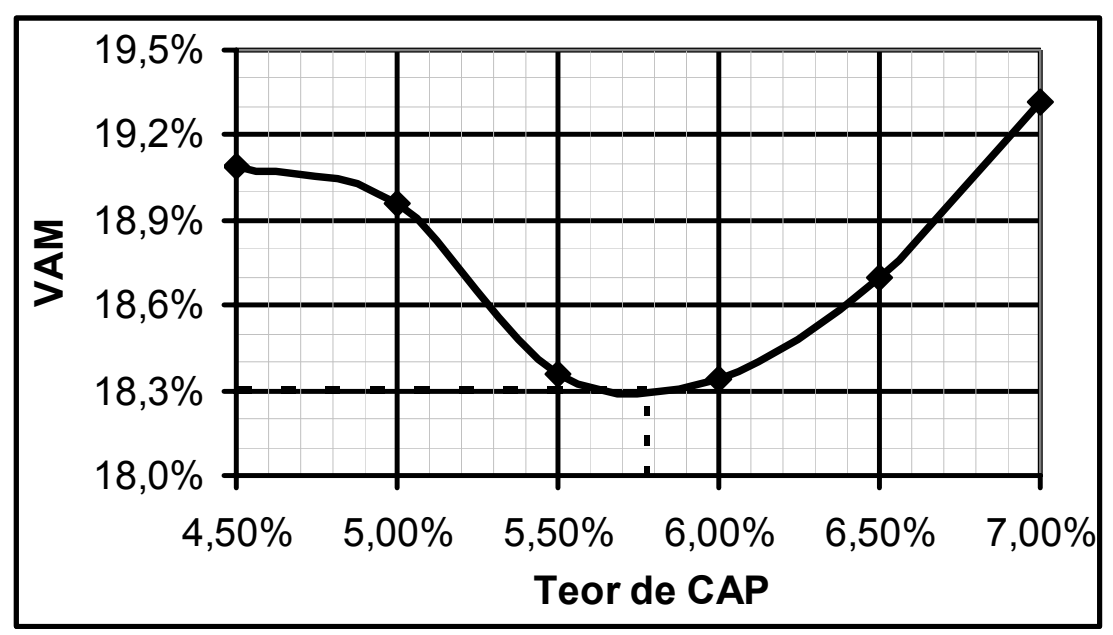

Figura 4.3. Dosagem Marshall - Vazios no agregado mineral em função do teor de CAP. 
Analisando-se a Figura 4.4, encontra-se a relação betume-vazios, para o teor de ligante de projeto, de aproximadamente $78 \%$, valor que se encontra no intervalo recomendado pelo DNIT (DNIT, 2004) para camada de rolamento. A Figura 4.5 indica uma fluência de 3,02 mm, sendo que o DNER (DNER, 1997) recomenda que a fluência da camada de rolamento se encontre no intervalo de 2,0 a $4,5 \mathrm{~mm}$. Segundo a norma DNER-ES 313/97 a estabilidade mínima para misturas asfálticas compactadas, segundo o método Marshall, com 75 golpes, é de 350 kgf. Analisando-se a Figura 4.6, tem-se uma estabilidade de $14320 \mathrm{~N}$ ou 1432 kgf, valor muito acima do mínimo recomendado.

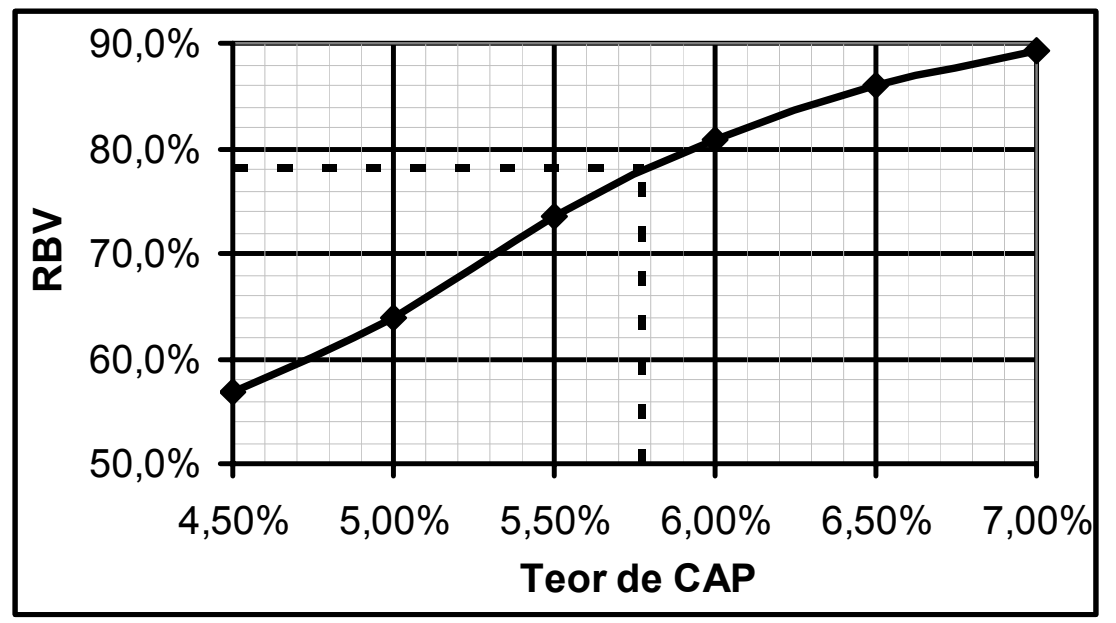

Figura 4.4. Dosagem Marshall - Relação betume-vazios em função do teor de CAP. 


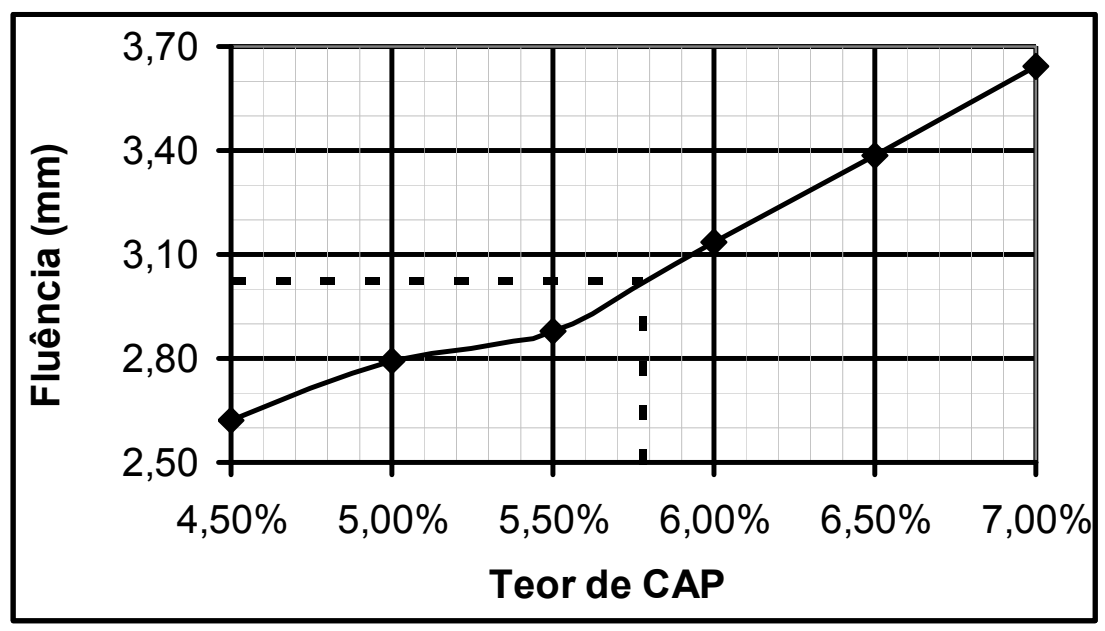

Figura 4.5. Dosagem Marshall - Fluência em função do teor de CAP.

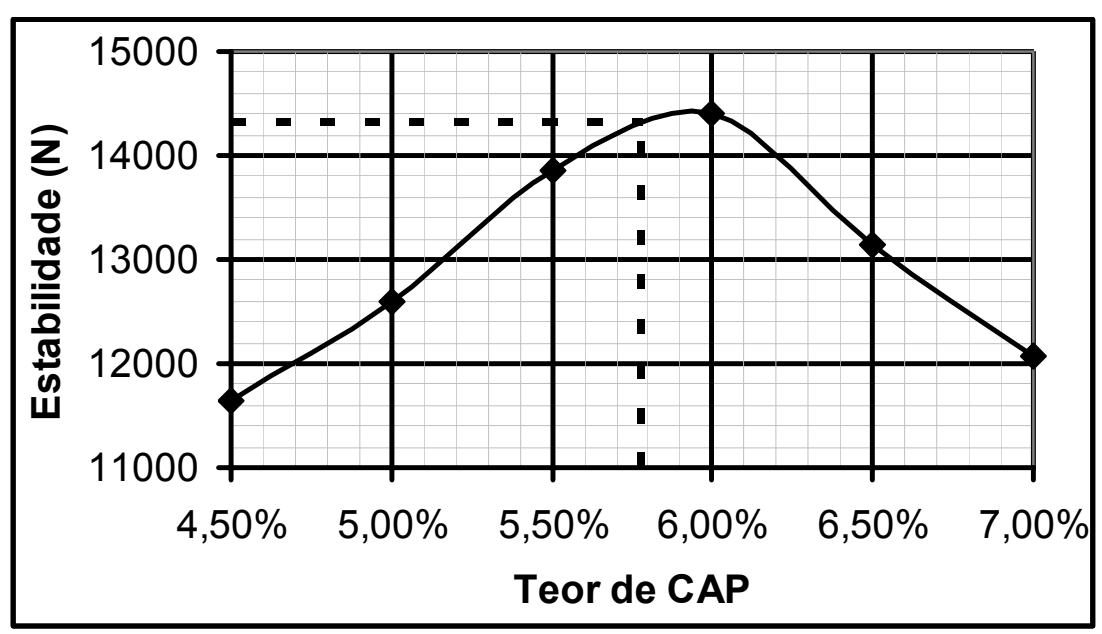

Figura 4.6. Dosagem Marshall - Estabilidade em função do teor de CAP.

\subsection{ENSAIOS EXPLORATÓRIOS}

A etapa inicial da pesquisa teve como objetivo determinar o teor de EVA que substituiria os agregados. A análise seria feita através dos ensaios de resistência à tração por compressão diametral estática (RT), módulo de resiliência por compressão diametral (MR) e pela relação $M R / R T$, ao se substituir parte dos 
agregados retidos na peneira $4,75 \mathrm{~mm}$ pelo EVA. A substituição foi feita até um máximo de $10 \%$ do material, com 4 intervalos espaçados em 2,5\%. A porcentagem da massa de agregados $(2,5 \%, 5 \%, 7,5 \%$ e $10 \%)$ foi convertida em volume utilizando-se a massa específica dos agregados e, usando a massa específica do resíduo, convertido novamente em massa, para determinar a quantidade de EVA a ser utilizada. Notou-se, entretanto, que a mistura começou a apresentar problema de desagregação quando da utilização de $10 \%$ de material substituído, por esse motivo optou-se por limitar a quantidade máxima de substituição em $3 \%$ de material com relação à massa total de agregados que corresponde a pouco menos que $10 \%$ da massa de agregados retidos na peneira $4,75 \mathrm{~mm}$. Os níveis intermediários de teor de EVA foram igualmente espaçados com intervalo de $1 \%$ da massa total de agregados da mistura.

Os ensaios foram realizados com duas horas de envelhecimento, para simular o tempo de mistura, transporte e compactação em campo, e as médias dos resultados são apresentadas na Tabela 4.4 e nas Figuras 4.7 a 4.9.

Tabela 4.4 - Resultados dos ensaios exploratórios.

\begin{tabular}{cccc}
\hline $\begin{array}{c}\text { Teor de EVA com relação } \\
\text { à peneira 4,75 } \mathbf{~ m m ~ ( \% )}\end{array}$ & $\begin{array}{c}\text { RT } \\
(\mathbf{M P a})\end{array}$ & $\begin{array}{c}\text { MR } \\
(\mathbf{M P a})\end{array}$ & MR/RT \\
\hline 2,5 & 1,228 & 6033 & 4914 \\
5,0 & 1,142 & 6686 & 5856 \\
7,5 & 1,066 & 6585 & 6180 \\
10,0 & 0,972 & 3013 & 3102 \\
\hline
\end{tabular}




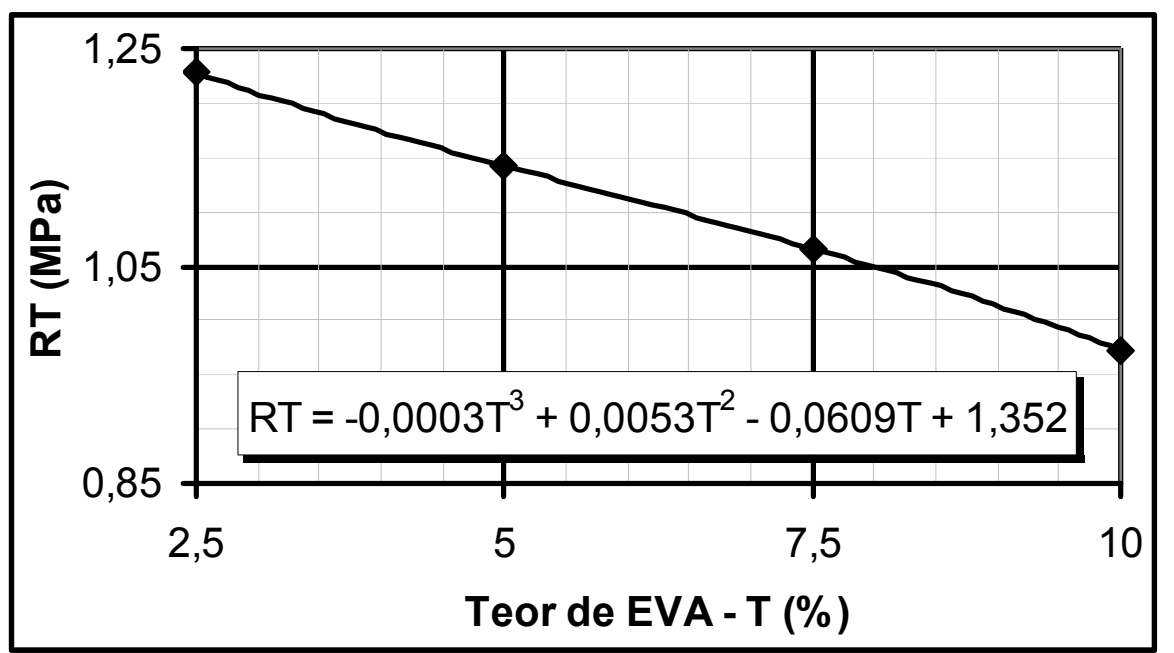

Figura 4.7. Ensaios exploratórios - RT em função do teor de EVA.

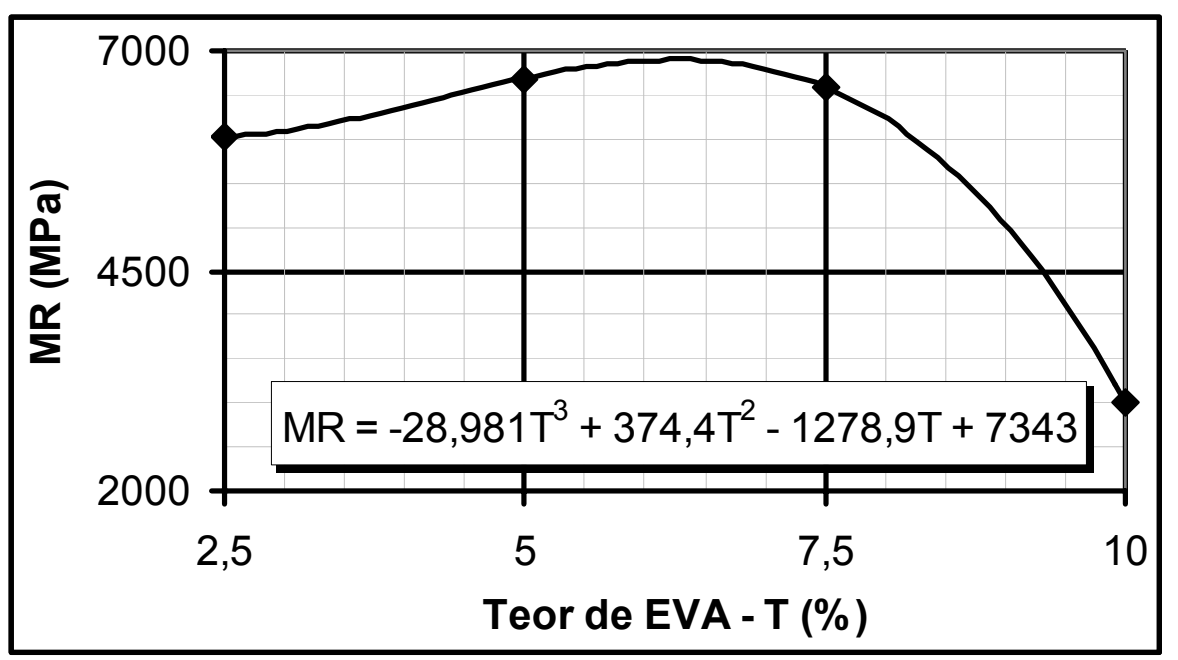

Figura 4.8. Ensaios exploratórios - MR em função do teor de EVA. 


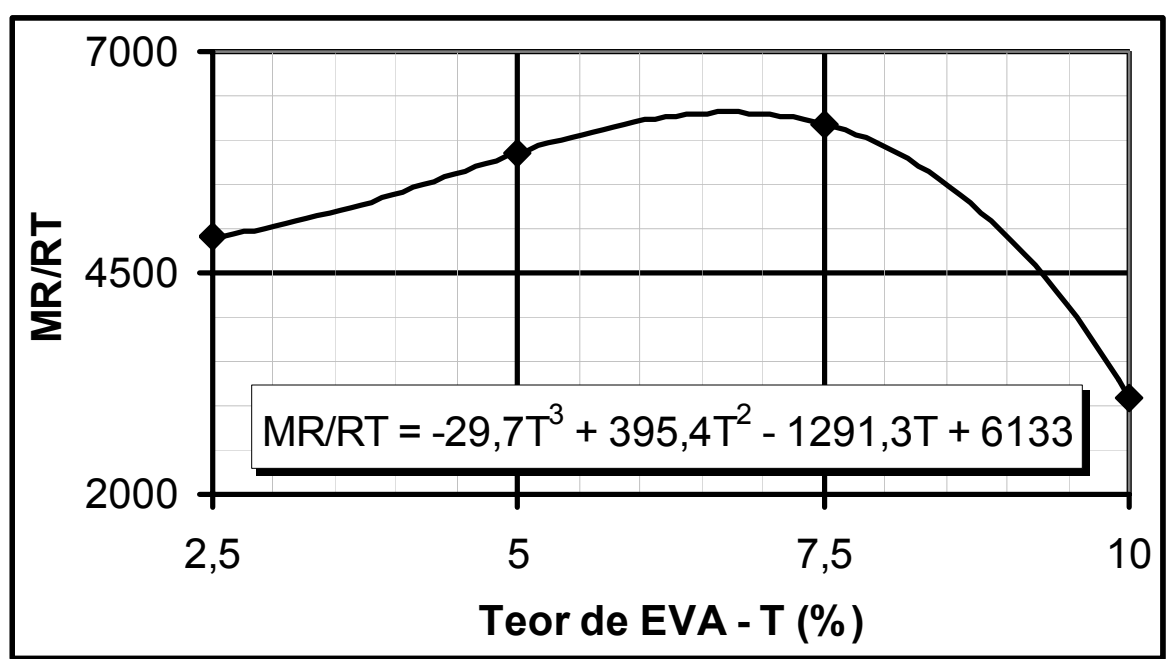

Figura 4.9. Ensaios exploratórios - Relação MR/RT em função do teor de EVA.

Ao se analisar as Figuras 4.7 e 4.8 notou-se que a resistência à tração e o módulo de resiliência das misturas caíram significantemente com a substituição de $10 \%$ do volume de agregados retidos na peneira de malha $4,75 \mathrm{~mm}$ por EVA. Entretanto a relação MR/RT (Figura 4.9) ficou mais próxima a 3000, o que, segundo grande parte da literatura consultada, é um indicativo de misturas proporcionalmente com melhores resistências à fadiga e às deformações permanentes.

\subsection{PROGRAMA EXPERIMENTAL}

\subsubsection{Módulo de resiliência por compressão diametral}

Todos os corpos-de-prova da pesquisa, com exceção dos destinados à dosagem e à absorção, num total de 184, foram submetidos ao ensaio de módulo de resiliência. 
Os dados apresentados na Tabela 4.5 referem-se às médias dos módulos de resiliência totais, após análise estatística (Apêndice F).

Tabela 4.5 - Programa experimental - Módulos de resiliência em função do teor de EVA e do tempo de envelhecimento.

\begin{tabular}{cccc}
\hline \multirow{2}{*}{ Teor de EVA (\%) } & Envelhecimento $(\mathbf{h})$ & \multicolumn{2}{c}{ Módulo de Resiliência } \\
\cline { 3 - 4 } & Média (MPa) & Desvio Padrão (\%) \\
\hline \multirow{2}{*}{$\mathbf{0}$} & $\mathbf{0}$ & 7363 & 2,80 \\
& $\mathbf{2}$ & 7534 & 2,68 \\
\multirow{2}{*}{$\mathbf{1}$} & $\mathbf{4}$ & 7493 & 3,58 \\
\hline \multirow{2}{*}{$\mathbf{2}$} & $\mathbf{0}$ & 5660 & 3,76 \\
& $\mathbf{2}$ & 6014 & 1,71 \\
& $\mathbf{4}$ & 8036 & 4,84 \\
\hline \multirow{2}{*}{$\mathbf{3}$} & $\mathbf{0}$ & 5057 & 2,98 \\
& $\mathbf{2}$ & 6831 & 1,79 \\
& $\mathbf{4}$ & 5990 & 2,56 \\
\hline $\mathbf{0}$ & $\mathbf{2}$ & 4191 & 4,04 \\
& $\mathbf{4}$ & 4413 & 1,90 \\
\end{tabular}

As Figuras 4.10, 4.11 e 4.12 mostram o comportamento do módulo de resiliência total das misturas com o incremento de EVA para 0, 2 e 4 horas, e as respectivas equações. A Figura 4.13 mostra as médias dos módulos de resiliência para 0, 2 e 4 horas, nos grupos com $0 \%, 1 \%, 2 \%$ e $3 \%$ de EVA. 


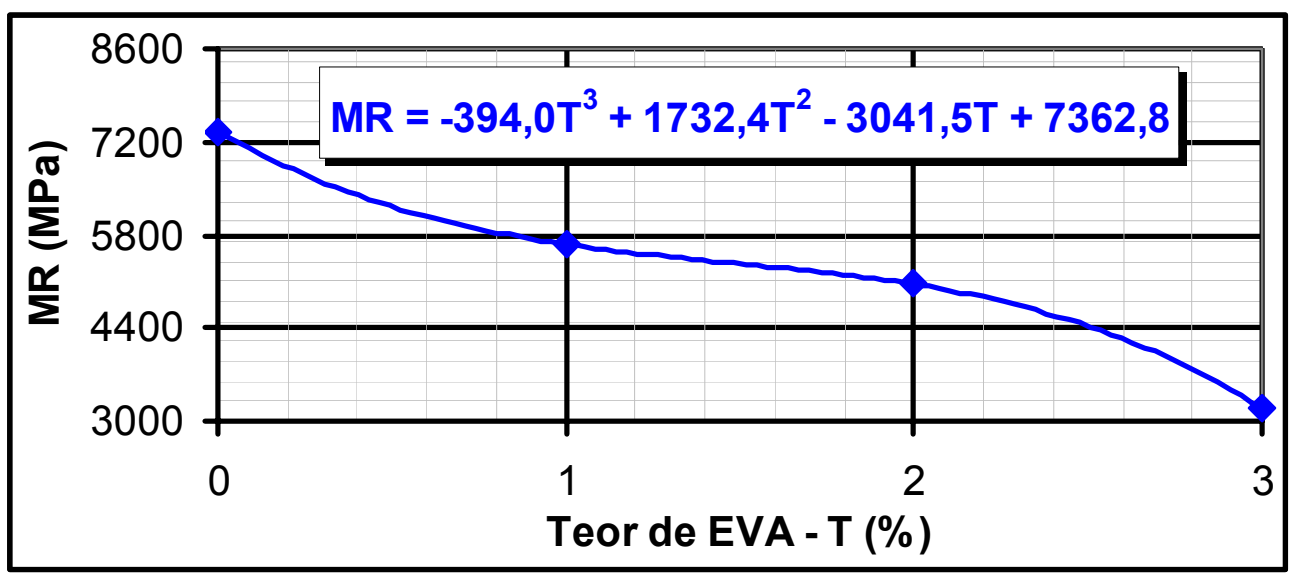

Figura 4.10. Programa Experimental - Módulo de resiliência em função do teor de EVA para 0 hora de envelhecimento.

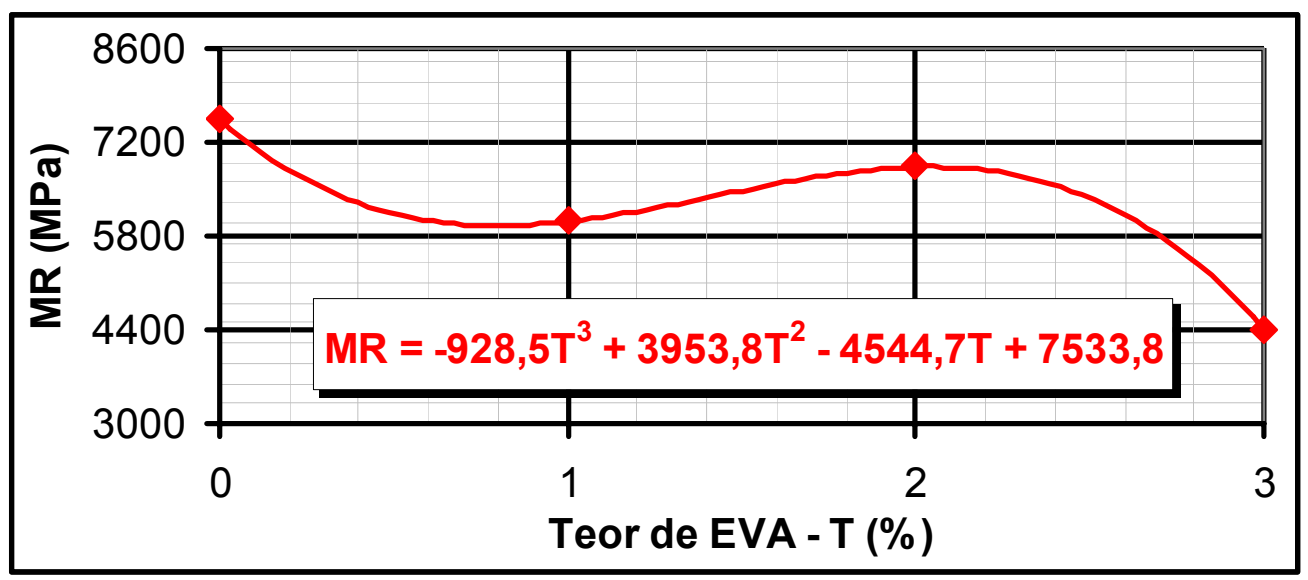

Figura 4.11. Programa Experimental - Módulo de resiliência em função do teor de EVA para 2 horas de envelhecimento.

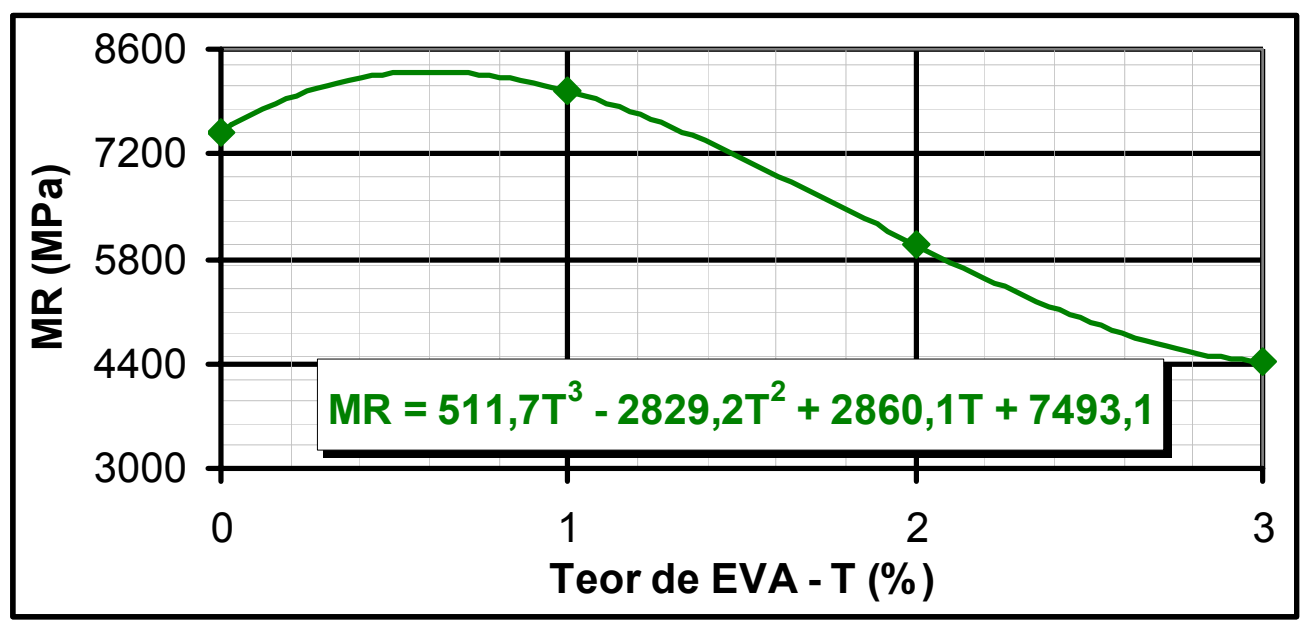

Figura 4.12. Programa Experimental - Módulo de resiliência em função do teor de EVA para 4 horas de envelhecimento. 


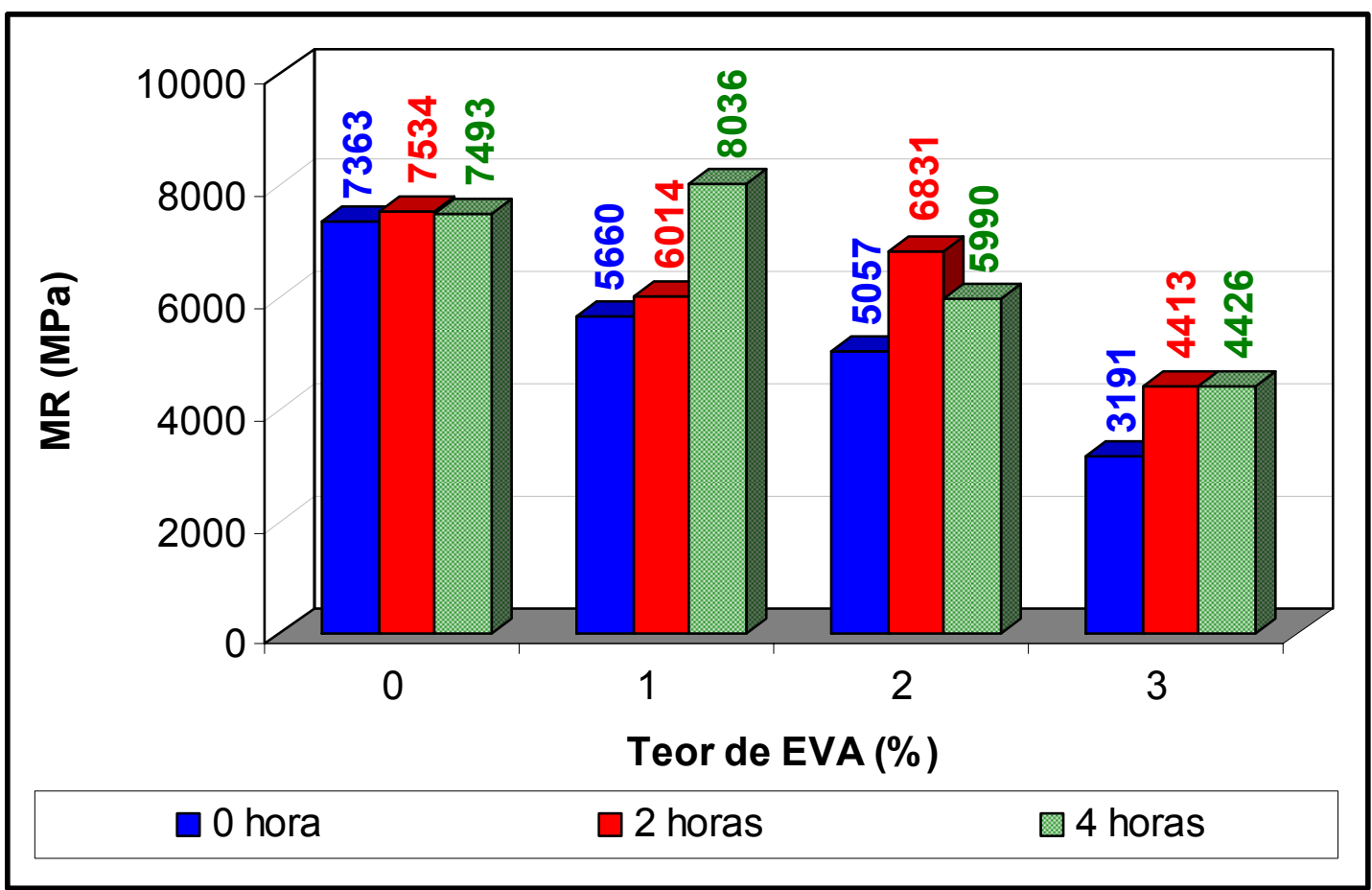

Figura 4.13. Programa experimental - Módulos de resiliência em função do teor de EVA e do tempo de envelhecimento.

Com exceção das misturas com $0 \%$ de EVA, que se mostraram praticamente estáveis com o envelhecimento, e das misturas com 2\% de EVA e 2 horas de envelhecimento, os módulos de resiliência aumentaram.

\subsubsection{Análise da variância e modelo estatístico do módulo de resiliência}

Para a construção do modelo estatístico (Equação 4.5) do módulo de resiliência, com significância de $0,1 \%$ e $\mathrm{R}^{2}$ de 0,987 , utilizou-se a média aritmética após tratamento com o teste $t \pm$ desvio padrão, para homogeneizar as amostras para cada condição experimental. Como os valores obtidos foram homogeneizados, todos os 
fatores foram significantes. A Figura 4.14 apresenta os gráficos gerados pela Equação 4.5.

$$
\begin{aligned}
& M R=5513-1238 \times P_{l}(T)-223 \times P_{q}(T)+757 \times P_{l}(E)-120 \times P_{q}(E)-285 \times P_{l}(T) \times \\
& \times P_{l}(E)-240 \times P_{l}(T) \times P_{q}(E)+145 \times P_{q}(T) \times P_{l}(E)+158 \times P_{q}(T) \times P_{q}(E)
\end{aligned}
$$

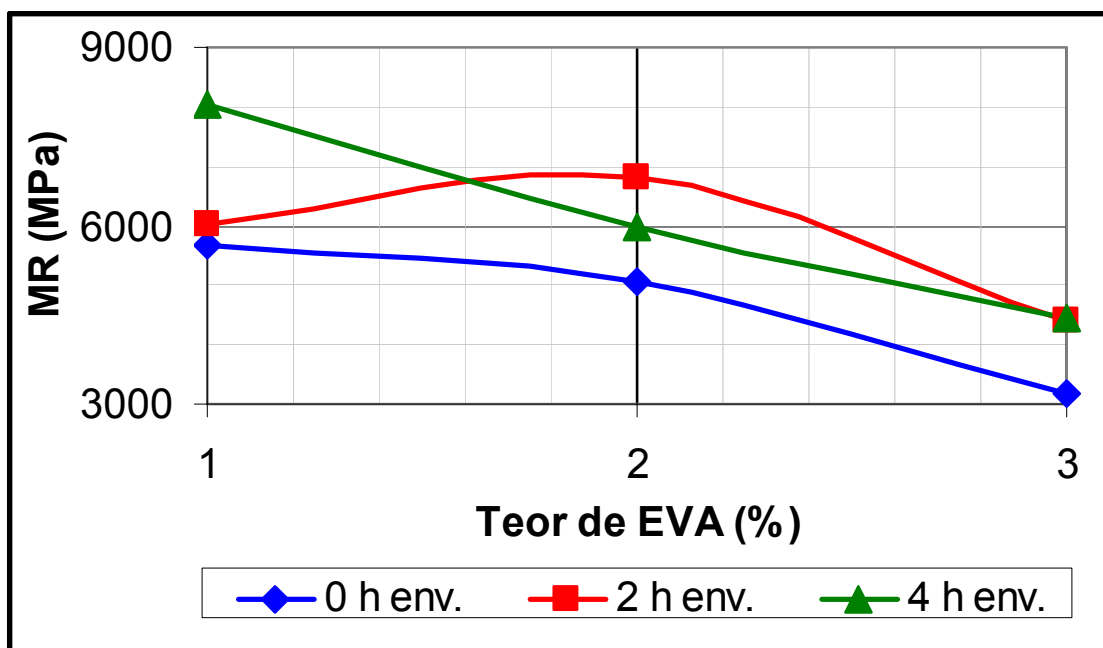

Figura 4.14. Programa Experimental - Modelo de módulo de resiliência em função do teor de EVA e do tempo de envelhecimento, para significância de 0,1\%.

\subsubsection{Resistência à tração por compressão diametral estática}

A Tabela 4.6 apresenta os resultados das médias dos ensaios de resistência à tração, realizado conforme a norma DNER-ME 138/94 (DNER, 1994a), as Figuras 4.15 a 4.17 representam graficamente os dados e fornecem as respectivas equações que regem as curvas e a Figura 4.18 um resumo com os dados do ensaio. 
Tabela 4.6 - Programa experimental - Resistência à tração em função do teor de EVA e do tempo de envelhecimento.

\begin{tabular}{cccc}
\hline \multirow{2}{*}{ Teor de EVA (\%) } & Envelhecimento $(\mathrm{h})$ & \multicolumn{2}{c}{ Resistência à Tração } \\
\cline { 3 - 4 } & $\mathbf{0}$ & 1,234 & Mesvio Padrão (\%) \\
\hline \multirow{2}{*}{$\mathbf{0}$} & $\mathbf{2}$ & 1,259 & 0,09 \\
& $\mathbf{4}$ & 1,289 & 0,51 \\
\multirow{2}{*}{$\mathbf{1}$} & $\mathbf{0}$ & 1,036 & 4,30 \\
\hline \multirow{2}{*}{$\mathbf{2}$} & $\mathbf{4}$ & 1,211 & 4,50 \\
& $\mathbf{4}$ & 1,268 & 1,44 \\
& $\mathbf{0}$ & 0,946 & 4,65 \\
\hline \multirow{2}{*}{$\mathbf{3}$} & $\mathbf{2}$ & 1,102 & 0,65 \\
& $\mathbf{4}$ & 1,240 & 2,09 \\
& $\mathbf{0}$ & 0,826 & 1,23 \\
\hline $\mathbf{2}$ & 1,050 & 6,56 \\
& $\mathbf{4}$ & 1,119 & 3,18 \\
\hline
\end{tabular}

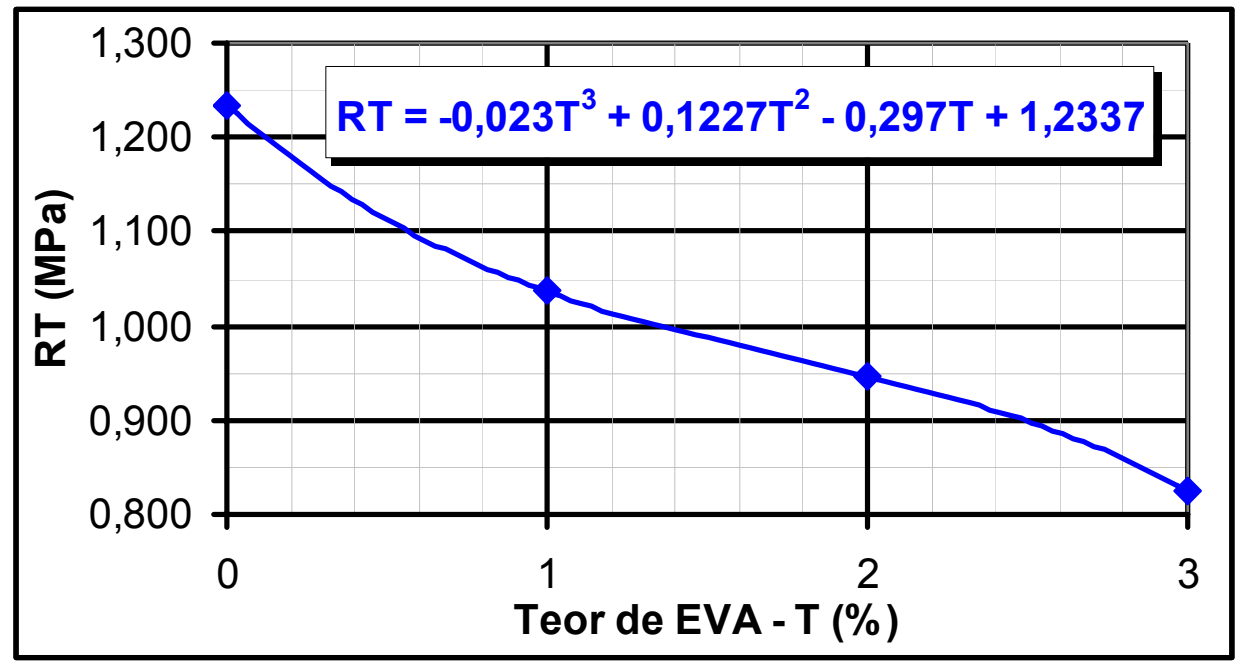

Figura 4.15. Programa experimental - Resistência à tração em função do teor de EVA para 0 hora de envelhecimento. 


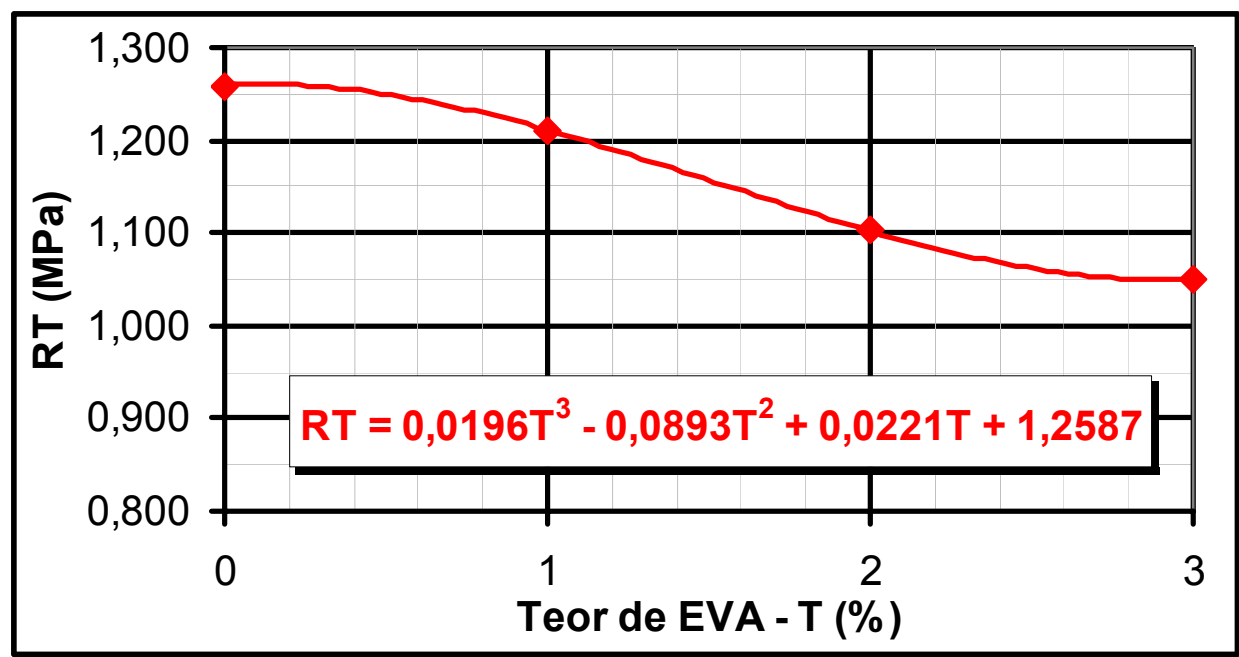

Figura 4.16. Programa experimental - Resistência à tração em função do teor de EVA para 2 horas de envelhecimento.

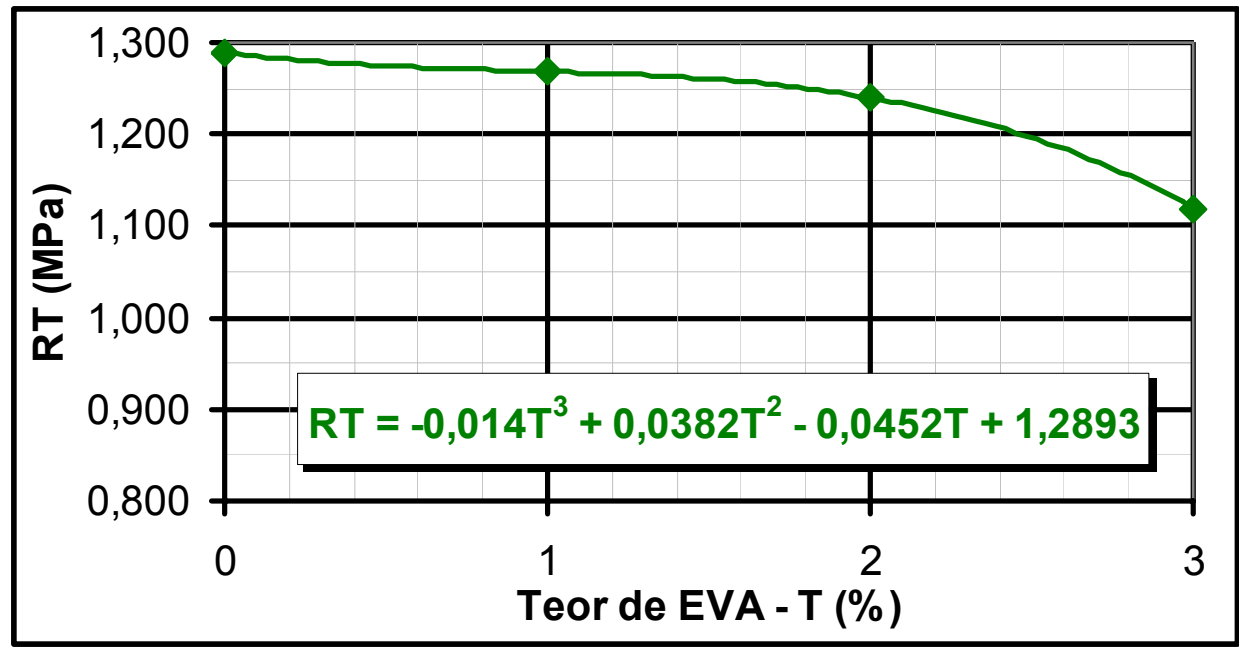

Figura 4.17. Programa experimental - Resistência à tração em função do teor de EVA para 4 horas de envelhecimento. 


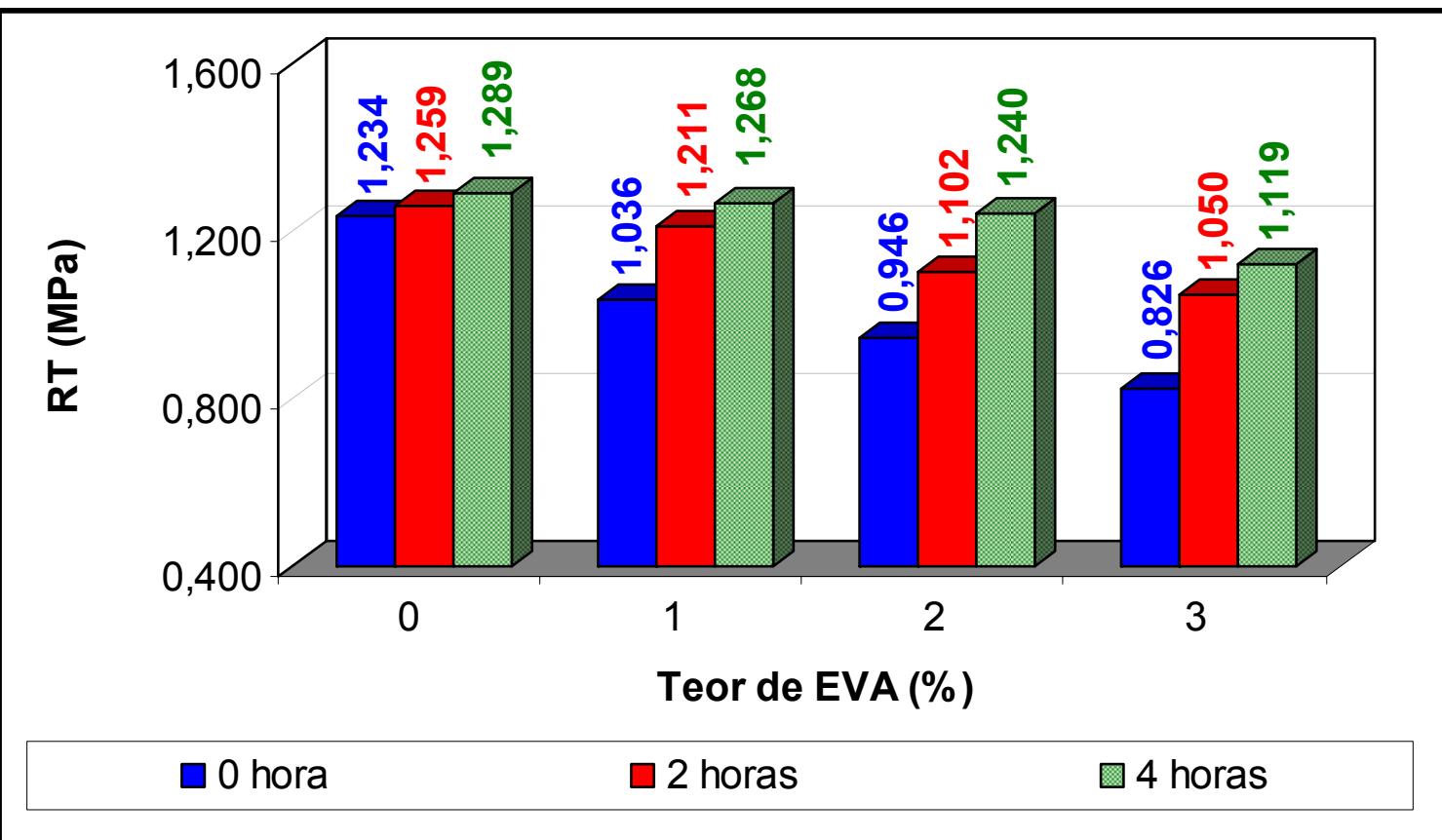

Figura 4.18. Programa experimental - Resistência à tração em função do teor de EVA e do tempo de envelhecimento.

Todas as misturas apresentaram ganho na resistência à tração com o envelhecimento e diminuição com o incremento do teor de EVA.

\subsubsection{Análise da variância e modelo estatístico de resistência à tração}

A Tabela 4.7 mostra o modelo estatístico e o $R^{2}$, obtidos com análise de variância. $A$ Figura 4.19 mostra o gráfico gerado com o modelo estatístico desenvolvido com significância de 0,5\%. 
Tabela 4.7 - Análise da variância da resistência à tração, para significância de 0,5\%.

\begin{tabular}{|c|c|c|c|c|c|c|c|}
\hline Parâmetro & GL & SQ & QM & Coeficiente & $F_{0}$ & $\mathbf{F}_{\text {crítico }}$ & Signif.? \\
\hline Total & 26 & 0,5180 & 0,0199 & 1,089 & 15,20 & 3,36 & Sim \\
\hline $\mathrm{T}_{1}$ & 1 & 0,1354 & 0,1354 & $-0,087$ & 103,25 & 10,22 & Sim \\
\hline $\mathrm{T}_{\mathrm{q}}$ & 1 & 0,0007 & 0,0007 & $-0,004$ & 0,55 & 10,22 & Não \\
\hline $\mathrm{E}_{1}$ & 1 & 0,3354 & 0,3354 & 0,137 & 255,81 & 10,22 & Sim \\
\hline $\mathrm{E}_{\mathrm{q}}$ & 1 & 0,0142 & 0,0142 & $-0,016$ & 10,81 & 10,22 & Sim \\
\hline $\mathrm{T}_{1} \mathrm{E}_{1}$ & 1 & 0,0029 & 0,0029 & 0,015 & 2,18 & 10,22 & Não \\
\hline $\mathrm{T}_{j} \mathrm{E}_{\mathrm{q}}$ & 1 & 0,0004 & 0,0004 & $-0,003$ & 0,28 & 10,22 & Não \\
\hline$T_{q} E_{l}$ & 1 & 0,0009 & 0,0009 & $-0,005$ & 0,71 & 10,22 & Não \\
\hline $\mathrm{T}_{\mathrm{q}} \mathrm{E}_{\mathrm{q}}$ & 1 & 0,0046 & 0,0046 & $-0,007$ & 3,53 & 10,22 & Não \\
\hline Resíduo & 18 & 0,0236 & 0,0013 & - & - & - & - \\
\hline Modelo & \multicolumn{6}{|c|}{$R T(M P a)=1,089-0,087 \times P_{l}(T)+0,137 \times P_{l}(E)-0,016 \times P_{q}(E)$} & $R^{2}=0,936$ \\
\hline
\end{tabular}

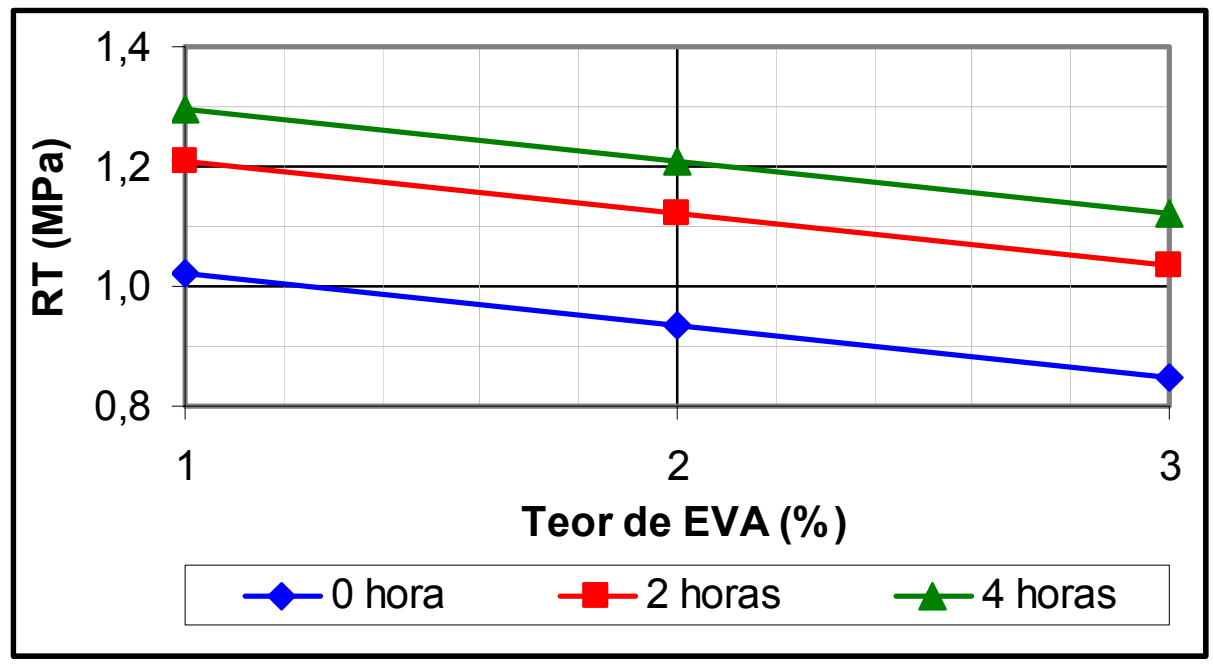

Figura 4.19. Programa Experimental - Modelo de resistência à tração em função do teor de EVA e do tempo de envelhecimento, para significância de 0,5\%.

\subsubsection{Relação MR/RT}

A Tabela 4.8 e a Figura 4.20 apresentam os resultados da relação MR/RT, para diferentes valores de EVA e tempo de envelhecimento. 
Tabela 4.8 - Programa experimental - Relação MR/RT em função do teor de EVA e do tempo de envelhecimento.

\begin{tabular}{ccc}
\hline Teor de EVA (\%) & Envelhecimento $(\mathrm{h})$ & Relação MR/RT \\
\hline \multirow{2}{*}{$\mathbf{0}$} & $\mathbf{2}$ & 5968 \\
& $\mathbf{4}$ & 5986 \\
\multirow{3}{*}{$\mathbf{1}$} & $\mathbf{0}$ & 5812 \\
& $\mathbf{2}$ & 5461 \\
\multirow{2}{*}{$\mathbf{2}$} & $\mathbf{4}$ & 4966 \\
& $\mathbf{0}$ & 6336 \\
\hline \multirow{2}{*}{$\mathbf{3}$} & $\mathbf{2}$ & 5344 \\
& $\mathbf{4}$ & 6197 \\
& $\mathbf{0}$ & 4832 \\
\hline
\end{tabular}

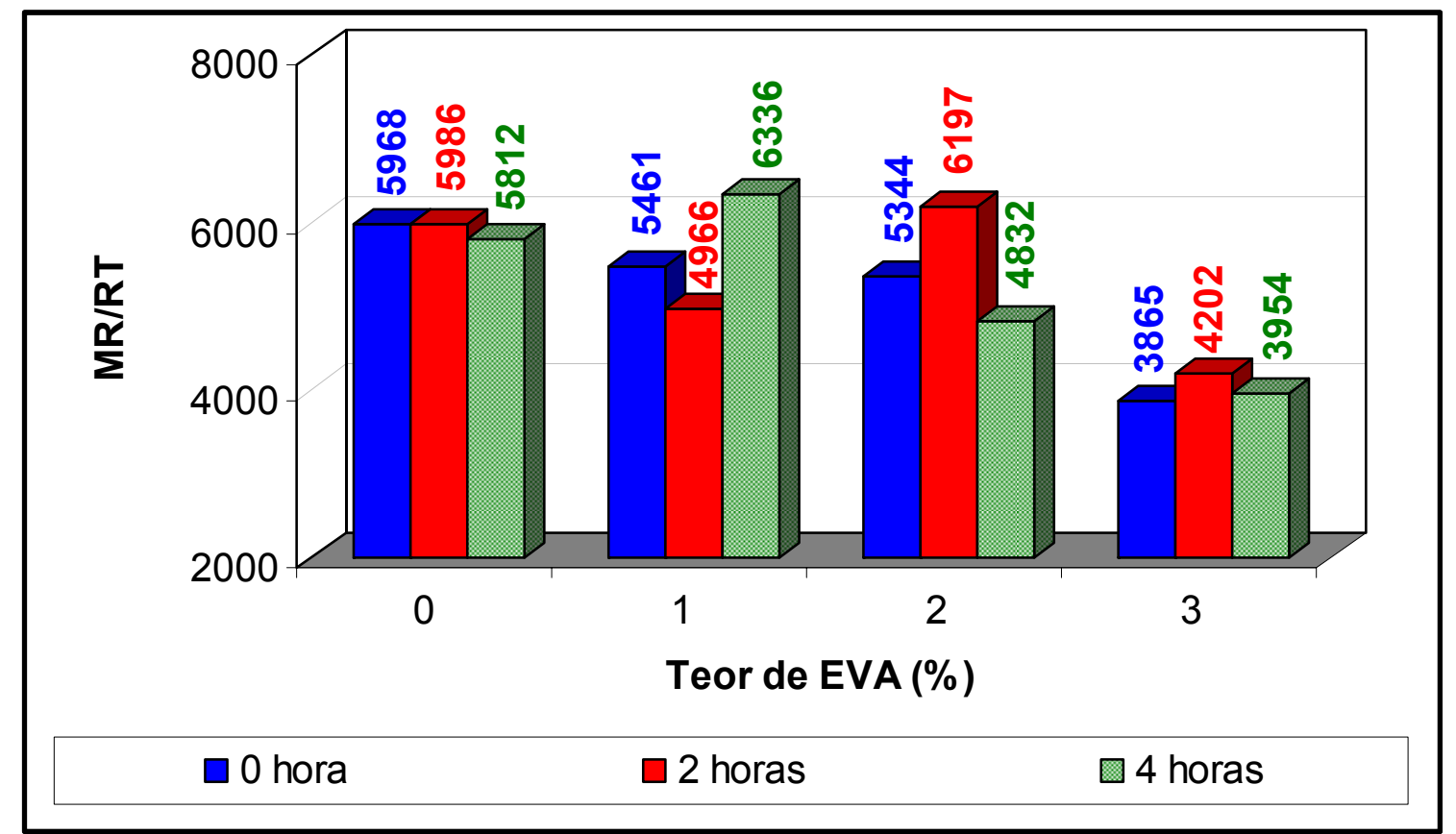

Figura 4.20. Programa experimental - Relação MR/RT do teor de EVA e do tempo de envelhecimento. 
As misturas sem EVA mostraram-se menos sensíveis ao envelhecimento que as misturas com EVA, que, por sua vez, não apresentam um padrão de comportamento com o envelhecimento e o aumento do teor de EVA do resíduo.

\subsubsection{Vida de Fadiga}

O ensaio de vida de fadiga foi conduzido utilizando-se tensão controlada. Os valores de carga aplicados foram de 10\%, 20\%, 30\% e 40\% da RT da mistura de controle para cada tempo de envelhecimento (0,2 e 4 horas). Os resultados estão apresentados nas Tabelas 4.9 a 4.20 . Os modelos de fadiga apresentados foram calibrados com o uso das curvas dos ensaios de fadiga (Figuras 4.21 a 4.44).

Tabela 4.9 - Programa experimental - Resultados dos ensaios de fadiga em corposde-prova com $0 \%$ de EVA e 0 hora de envelhecimento.

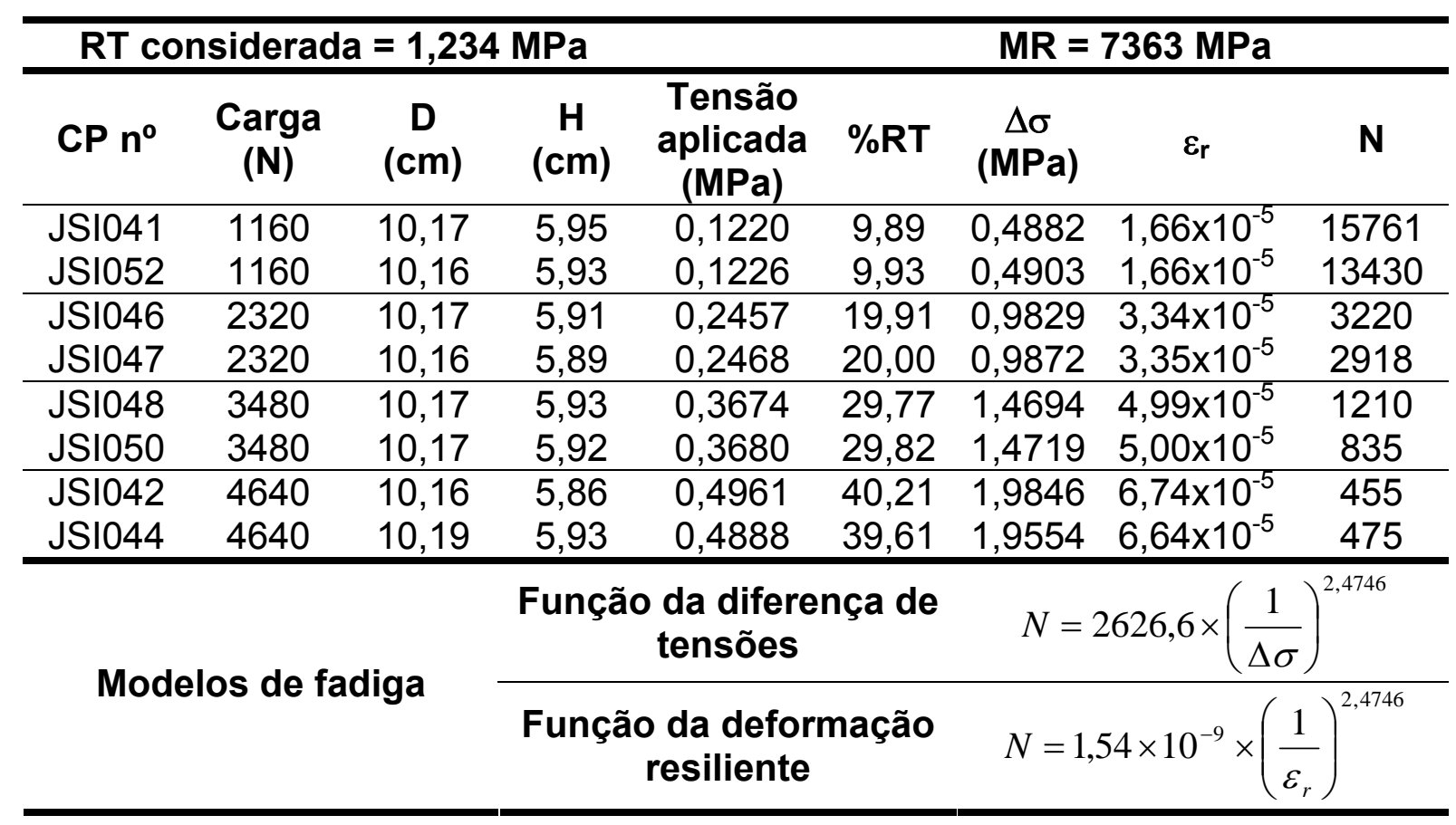




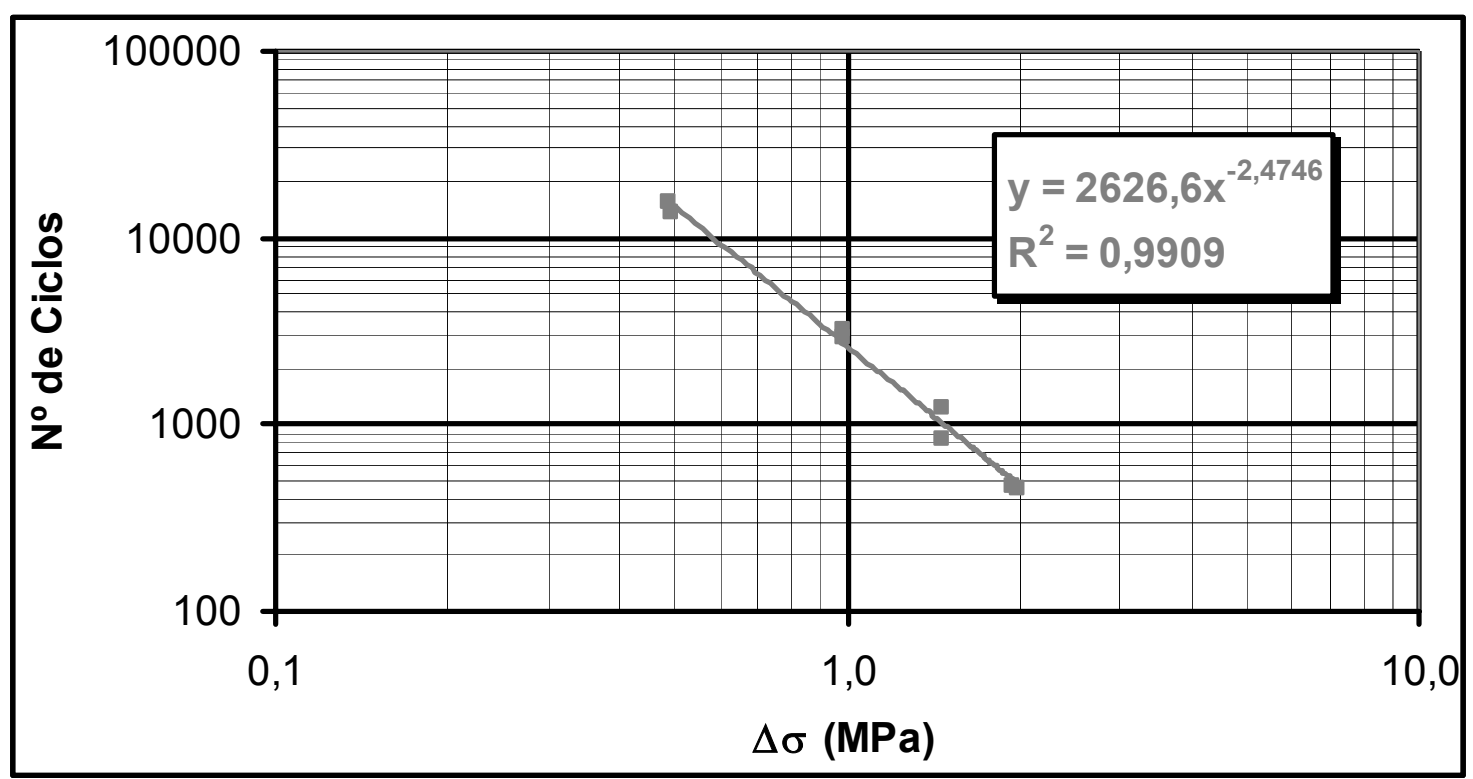

Figura 4.21. Programa experimental - Número de ciclos em função da diferença de tensões em corpos-de-prova com 0\% de EVA e 0 hora de envelhecimento.

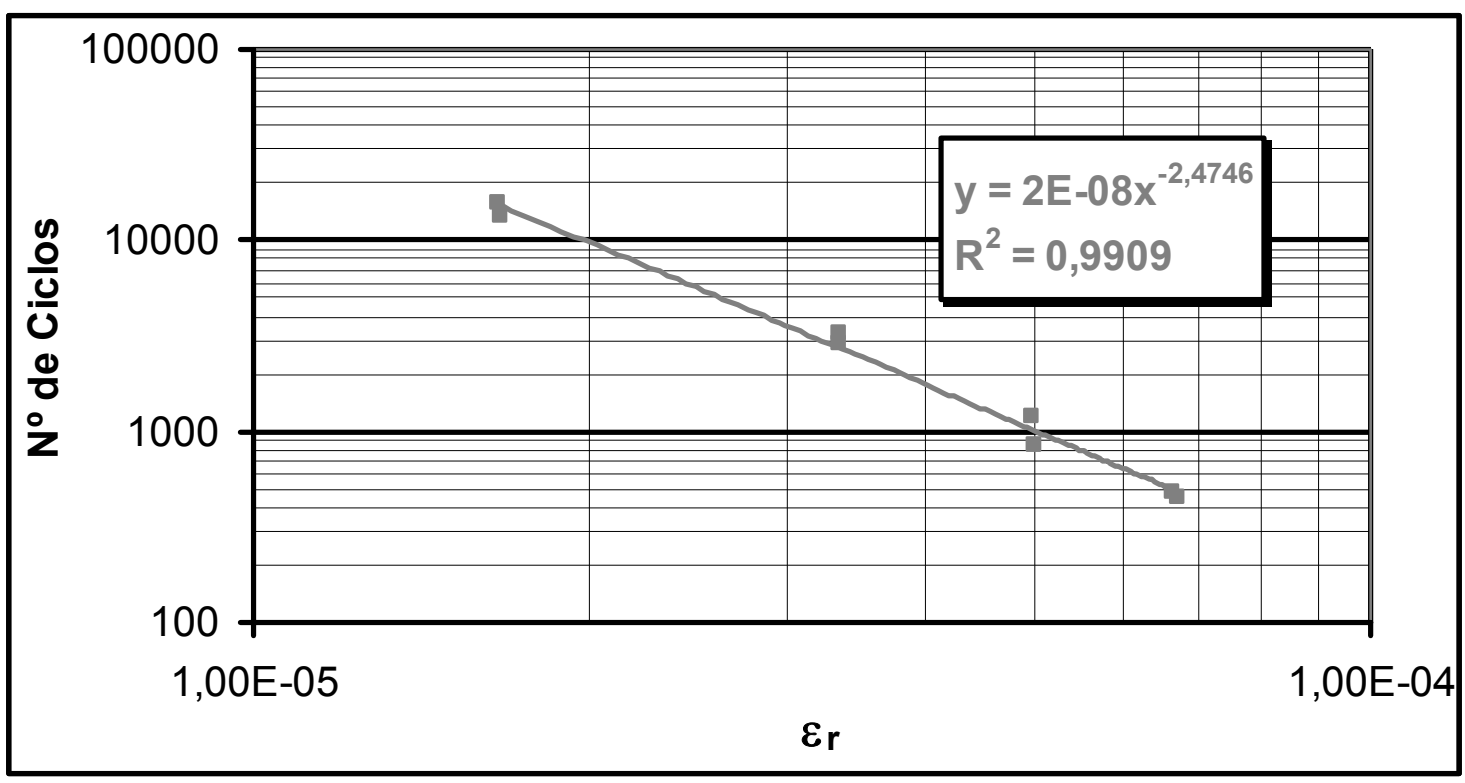

Figura 4.22. Programa experimental - Número de ciclos em função da deformação resiliente em corpos-de-prova com 0\% de EVA e 0 hora de envelhecimento. 
Tabela 4.10 - Programa experimental - Resultados dos ensaios de fadiga em corpos-de-prova com $1 \%$ de EVA e 0 hora de envelhecimento.

\begin{tabular}{|c|c|c|c|c|c|c|c|c|}
\hline \multicolumn{4}{|c|}{ RT considerada $=1,234 \mathrm{MPa}$} & & \multicolumn{4}{|c|}{$\mathrm{MR}=5660 \mathrm{MPa}$} \\
\hline CP $n^{\circ}$ & $\begin{array}{c}\text { Carga } \\
(\mathrm{N})\end{array}$ & $\begin{array}{c}D \\
(\mathrm{~cm})\end{array}$ & $\begin{array}{c}\mathrm{H} \\
(\mathrm{cm})\end{array}$ & $\begin{array}{l}\text { Tensão } \\
\text { aplicada } \\
\text { (MPa) }\end{array}$ & $\%$ RT & $\begin{array}{c}\Delta \sigma \\
(\mathrm{MPa})\end{array}$ & $\varepsilon_{r}$ & $\mathbf{N}$ \\
\hline JSI083 & 1160 & 10,17 & 5,95 & 0,1220 & 9,89 & 0,4882 & $2,16 \times 10^{-5}$ & 22156 \\
\hline JSI089 & 1160 & 10,17 & 5,87 & 0,1237 & 10,02 & 0,4948 & $2,19 \times 10^{-5}$ & 23939 \\
\hline JSI087 & 2320 & 10,18 & 5,84 & 0,2484 & 20,13 & 0,9937 & $4,39 \times 10^{-5}$ & 3410 \\
\hline JSI095 & 2320 & 10,18 & 5,88 & 0,2467 & 20,00 & 0,9870 & $4,36 \times 10^{-5}$ & 3169 \\
\hline JSI088 & 3480 & 10,18 & 5,82 & 0,3739 & 30,30 & 1,4957 & $6,61 \times 10^{-5}$ & 1213 \\
\hline JSI092 & 3480 & 10,18 & 5,91 & 0,3682 & 29,84 & 1,4729 & $6,51 \times 10^{-5}$ & 1067 \\
\hline JSI086 & 4640 & 10,17 & 5,83 & 0,4982 & 40,37 & 1,9928 & $8,80 \times 10^{-5}$ & 485 \\
\hline JSI091 & 4640 & 10,17 & 5,83 & 0,4982 & 40,37 & 1,9928 & $8,80 \times 10^{-5}$ & 481 \\
\hline \multirow{2}{*}{\multicolumn{3}{|c|}{ Modelos de fadiga }} & \multicolumn{3}{|c|}{$\begin{array}{c}\text { Função da diferença de } \\
\text { tensões }\end{array}$} & \multicolumn{2}{|c|}{$N=3261,7 \times$} & \\
\hline & & & \multicolumn{3}{|c|}{$\begin{array}{c}\text { Função da deformação } \\
\text { resiliente }\end{array}$} & \multicolumn{2}{|c|}{$N=3,57 \times 10^{-9} \times$} & \\
\hline
\end{tabular}

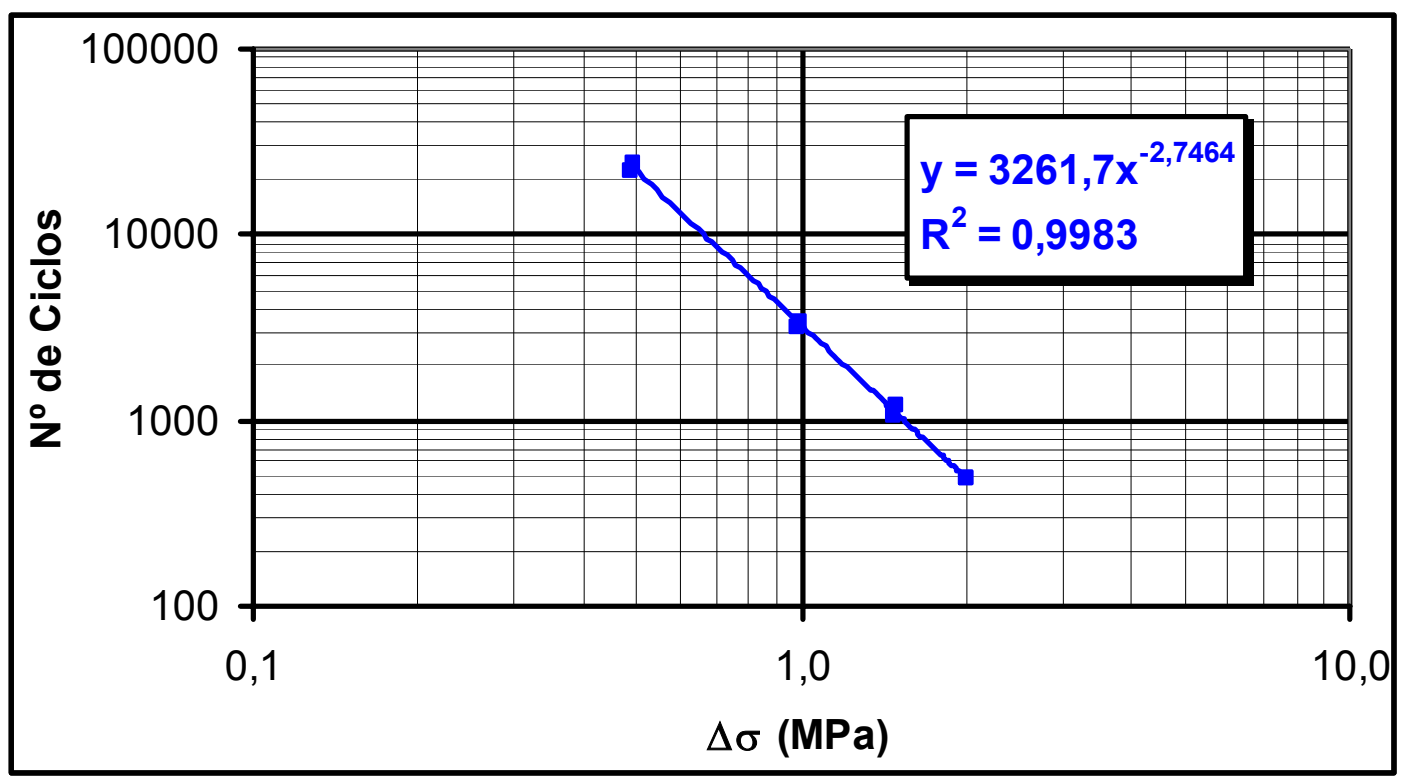

Figura 4.23. Programa experimental - Número de ciclos em função da diferença de tensões em corpos-de-prova com 1\% de EVA e 0 hora de envelhecimento. 


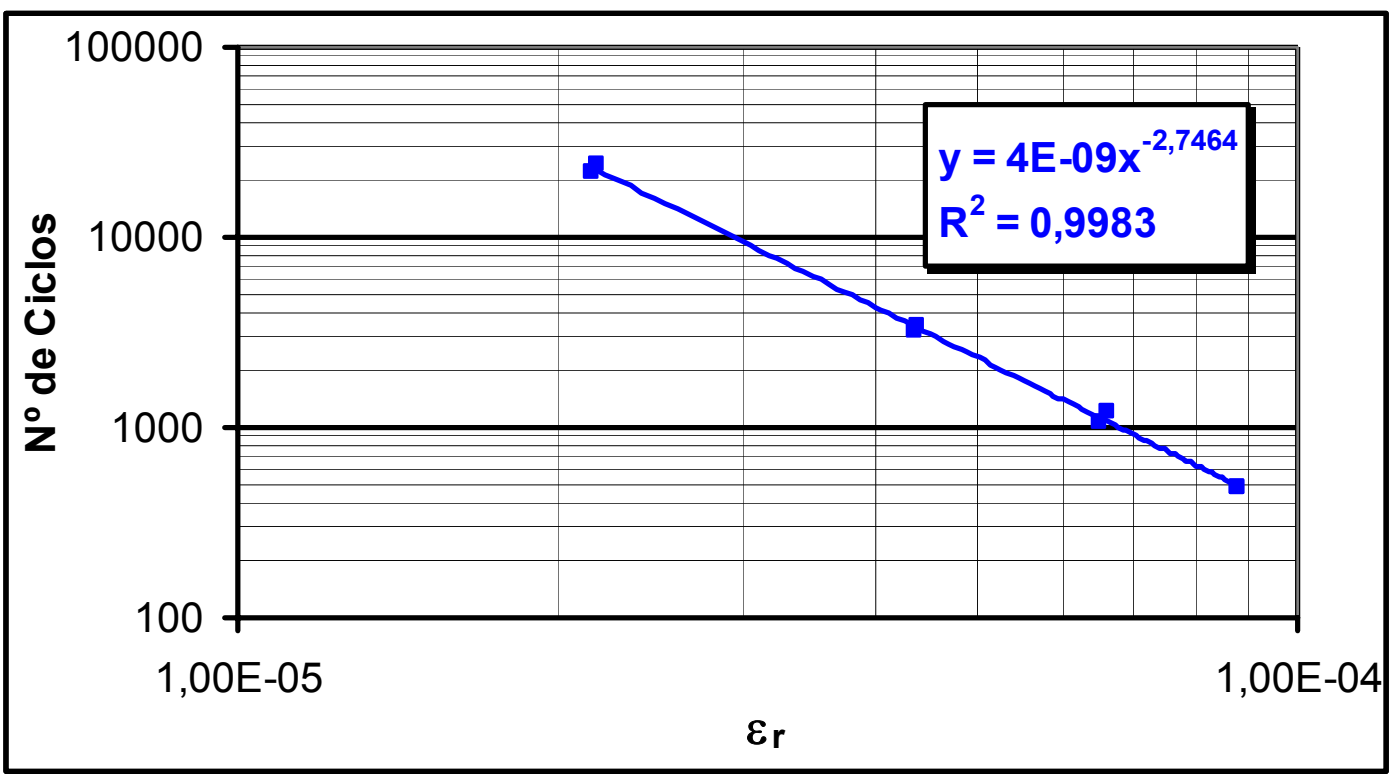

Figura 4.24. Programa experimental - Número de ciclos em função da deformação resiliente em corpos-de-prova com $1 \%$ de EVA e 0 hora de envelhecimento.

Tabela 4.11 - Programa experimental - Resultados dos ensaios de fadiga em corpos-de-prova com $2 \%$ de EVA e 0 hora de envelhecimento.

\begin{tabular}{|c|c|c|c|c|c|c|c|c|}
\hline \multicolumn{5}{|c|}{ RT considerada $=1,234 \mathrm{MPa}$} & \multicolumn{4}{|c|}{$\mathrm{MR}=5657 \mathrm{MPa}$} \\
\hline$C P n^{\circ}$ & $\begin{array}{l}\text { Carga } \\
\text { (N) }\end{array}$ & $\begin{array}{c}D \\
(\mathrm{~cm})\end{array}$ & $\begin{array}{c}\mathrm{H} \\
(\mathrm{cm})\end{array}$ & $\begin{array}{l}\text { Tensão } \\
\text { aplicada } \\
\text { (MPa) }\end{array}$ & $\%$ RT & $\begin{array}{c}\Delta \sigma \\
(\mathrm{MPa})\end{array}$ & $\varepsilon_{\mathbf{r}}$ & $\mathbf{N}$ \\
\hline JSI126 & 1160 & 10,19 & 6,17 & 0,1175 & 9,52 & 0,4698 & $2,32 \times 10^{-5}$ & 22287 \\
\hline JSI131 & 1160 & 10,15 & 5,98 & 0,1217 & 9,86 & 0,4867 & $2,41 \times 10^{-5}$ & 25160 \\
\hline JSi125 & 2320 & 10,19 & 6,22 & 0,2330 & 18,88 & 0,9321 & $4,61 \times 10^{-5}$ & 3380 \\
\hline JSI127 & 2320 & 10,16 & 6,05 & 0,2403 & 19,47 & 0,9611 & $4,75 \times 10^{-5}$ & 2589 \\
\hline JSI129 & 3480 & 10,19 & 5,98 & 0,3636 & 29,46 & 1,4543 & $7,19 \times 10^{-5}$ & 811 \\
\hline JSI132 & 3480 & 10,17 & 6,04 & 0,3607 & 29,23 & 1,4427 & $7,13 \times 10^{-5}$ & 885 \\
\hline JSI130 & 4640 & 10,18 & 5,94 & 0,4885 & 39,59 & 1,9540 & $9,66 \times 10^{-5}$ & 427 \\
\hline JSI137 & 4640 & 10,19 & 5,89 & 0,4922 & 39,88 & 1,9687 & $9,73 \times 10^{-5}$ & 489 \\
\hline \multirow{2}{*}{\multicolumn{3}{|c|}{ Modelos de fadiga }} & \multicolumn{3}{|c|}{$\begin{array}{c}\text { Função da diferença de } \\
\text { tensões }\end{array}$} & \multicolumn{2}{|c|}{$N=2760,7 \times$} & \\
\hline & & & \multicolumn{3}{|c|}{$\begin{array}{l}\text { Função da deformação } \\
\text { resiliente }\end{array}$} & \multicolumn{2}{|c|}{$N=1,54 \times 10^{-9} \times$} & \\
\hline
\end{tabular}




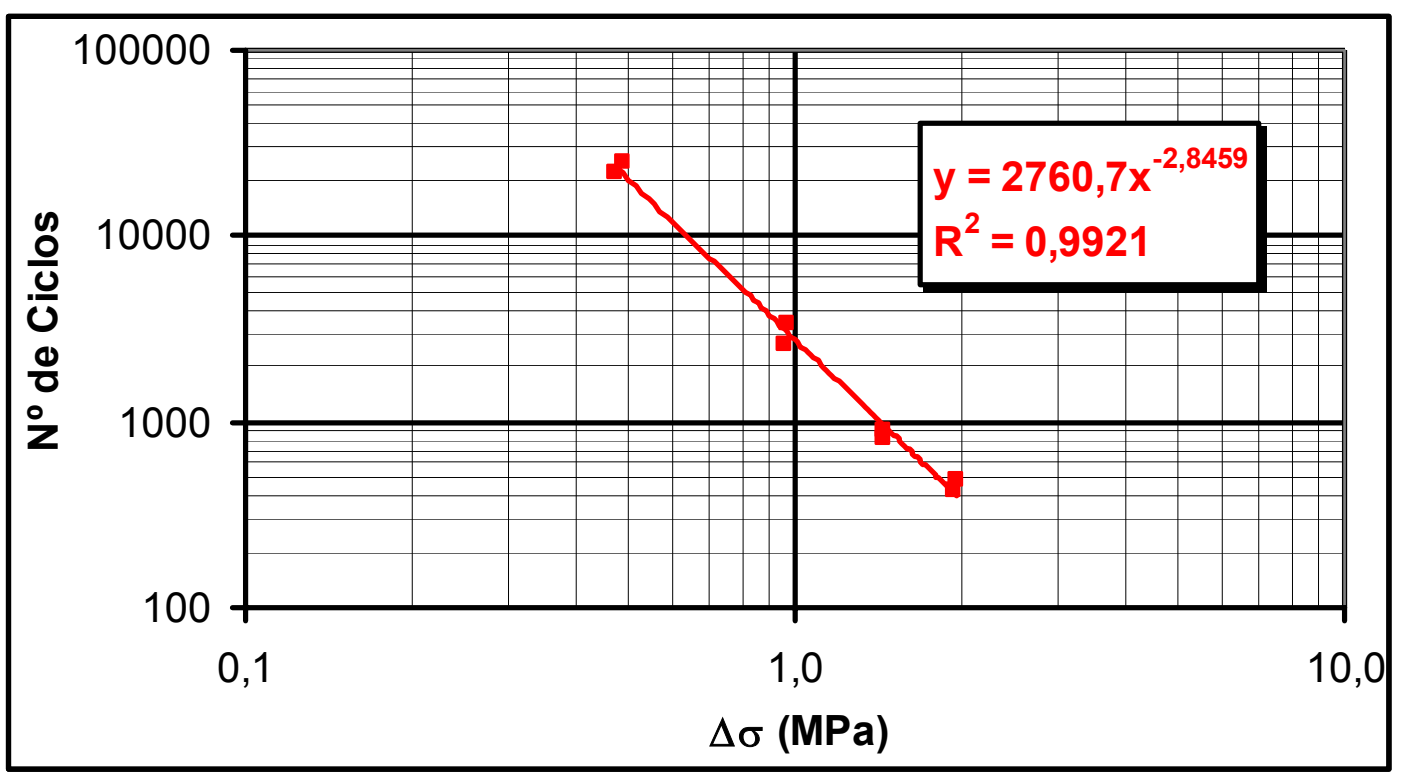

Figura 4.25. Programa experimental - Número de ciclos em função da diferença de tensões em corpos-de-prova com 2\% de EVA e 0 hora de envelhecimento.

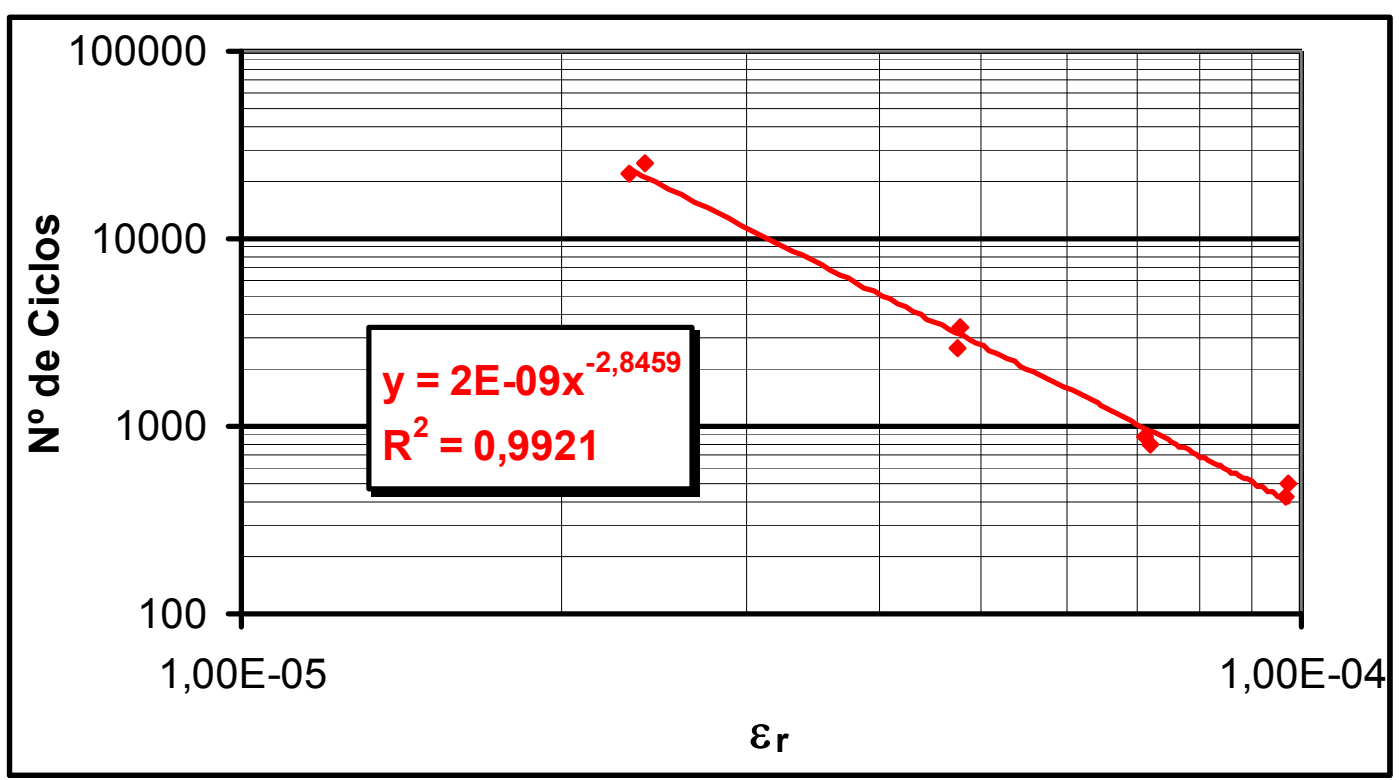

Figura 4.26. Programa experimental - Número de ciclos em função da deformação resiliente em corpos-de-prova com $2 \%$ de EVA e 0 hora de envelhecimento. 
Tabela 4.12 - Programa experimental - Resultados dos ensaios de fadiga em corpos-de-prova com 3\% de EVA e 0 hora de envelhecimento.

\begin{tabular}{|c|c|c|c|c|c|c|c|c|}
\hline \multicolumn{5}{|c|}{$\mathrm{RT}$ considerada $=1,234 \mathrm{MPa}$} & \multicolumn{4}{|c|}{ MR $=3191 \mathrm{MPa}$} \\
\hline $\mathrm{CP}^{\circ}$ & $\begin{array}{l}\text { Carga } \\
\text { (N) }\end{array}$ & $\begin{array}{c}D \\
(\mathrm{~cm})\end{array}$ & $\underset{(\mathrm{cm})}{\mathrm{H}}$ & $\begin{array}{c}\text { Tensão } \\
\text { aplicada } \\
\text { (MPa) }\end{array}$ & $\% R T$ & $\begin{array}{c}\Delta \sigma \\
(\mathrm{MPa})\end{array}$ & $\varepsilon_{r}$ & $\mathbf{N}$ \\
\hline JSI174 & 1160 & 10,18 & 6,01 & 0,1207 & 9,78 & 0,4828 & $3,78 \times 10^{-5}$ & 8709 \\
\hline JSI179 & 1160 & 10,16 & 08 & 0,1195 & 9,69 & 0,4782 & $3,75 \times 10^{-5}$ & 10709 \\
\hline JSI171 & 2320 & 10,19 & 6,22 & 0,2330 & 18,88 & 0,9321 & $7,30 \times 10^{-5}$ & 2145 \\
\hline JSI180 & 2320 & 10,19 & 6,26 & 0,2315 & 18,76 & 0,9261 & $7,26 \times 10^{-5}$ & 1866 \\
\hline JSI173 & 3480 & 10,17 & 6,18 & 0,3525 & 28,57 & 1,4100 & $1,10 \times 10^{-4}$ & 679 \\
\hline JSI176 & 3480 & 10, & 6,22 & 0,3495 & 28,33 & 1,3982 & $1,10 \times 10^{-4}$ & 652 \\
\hline JSI169 & 4640 & 10,18 & 6,15 & 0,4718 & 38,23 & 1,8873 & $1,48 \times 10^{-4}$ & 264 \\
\hline JSI172 & 4640 & 10,16 & 6,17 & 0,4712 & 38,19 & 1,8849 & $1,48 \times 10^{-4}$ & 291 \\
\hline \multirow{2}{*}{\multicolumn{3}{|c|}{ Modelos de fadiga }} & \multicolumn{3}{|c|}{$\begin{array}{c}\text { Função da diferença de } \\
\text { tensões }\end{array}$} & \multicolumn{3}{|c|}{$N=1530,6 \times\left(\frac{1}{\Delta \sigma}\right)$} \\
\hline & & & \multicolumn{3}{|c|}{$\begin{array}{l}\text { Função da deformação } \\
\text { resiliente }\end{array}$} & \multicolumn{2}{|c|}{$N=3,86 \times 10^{-8} \times$} & \\
\hline
\end{tabular}

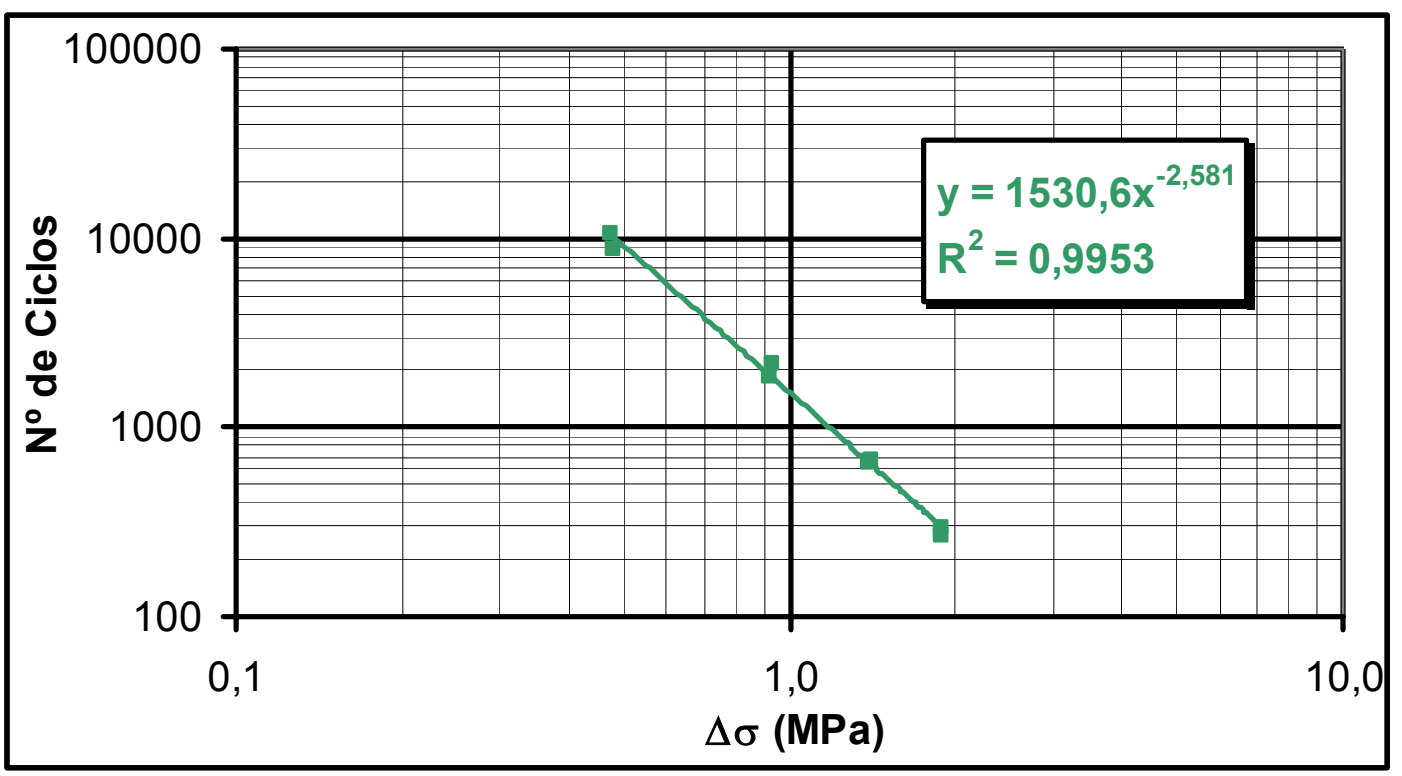

Figura 4.27. Programa experimental - Número de ciclos em função da diferença de tensões em corpos-de-prova com 3\% de EVA e 0 hora de envelhecimento. 


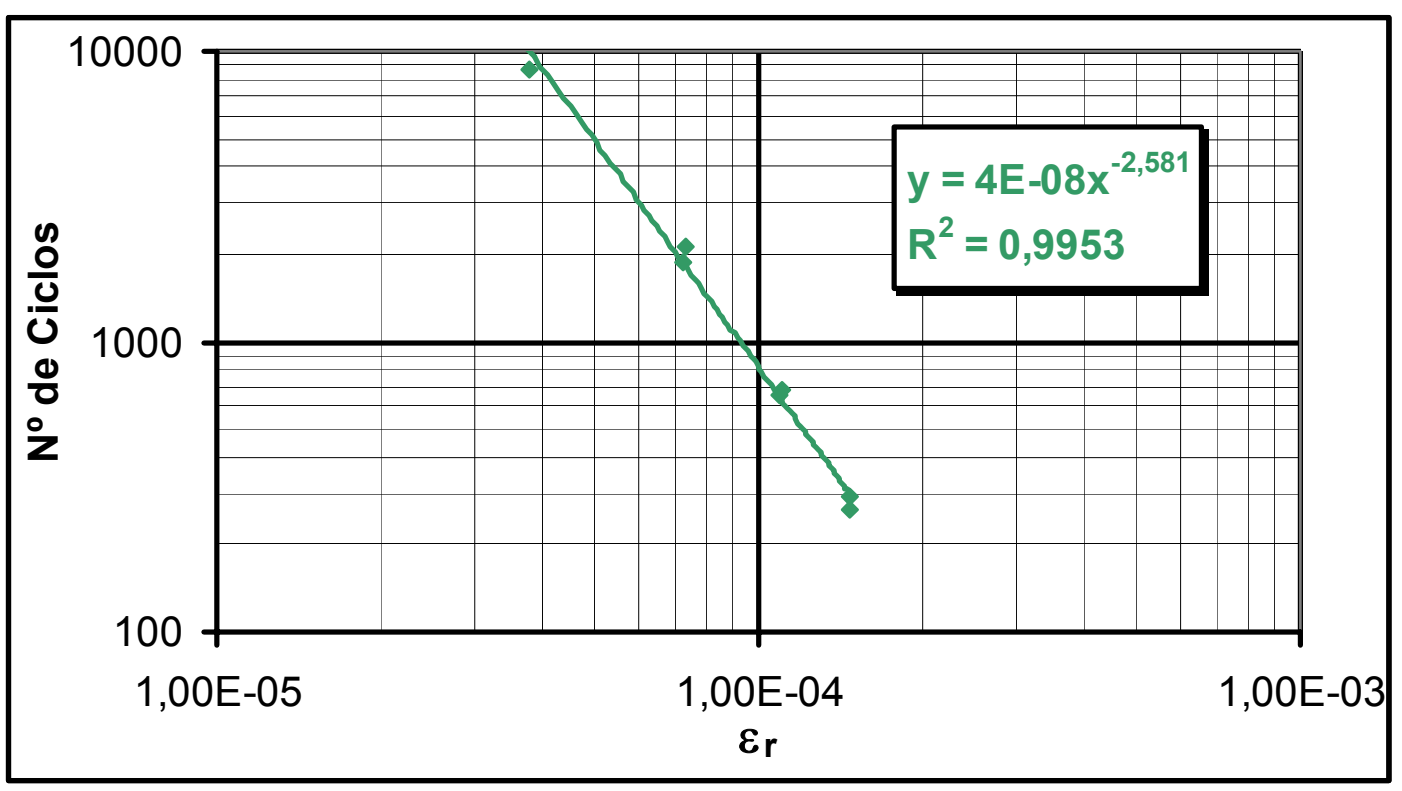

Figura 4.28. Programa experimental - Número de ciclos em função da deformação resiliente em corpos-de-prova com 3\% de EVA e 0 hora de envelhecimento.

Tabela 4.13 - Programa experimental - Resultados dos ensaios de fadiga em corpos-de-prova com 0\% de EVA e 2 horas de envelhecimento.

\begin{tabular}{|c|c|c|c|c|c|c|c|c|}
\hline \multicolumn{4}{|c|}{ RT considerada $=1,260 \mathrm{MPa}$} & & \multicolumn{4}{|c|}{$\mathrm{MR}=7534 \mathrm{MPa}$} \\
\hline$C P n^{\circ}$ & $\begin{array}{l}\text { Carga } \\
\text { (N) }\end{array}$ & $\begin{array}{c}D \\
(\mathrm{~cm})\end{array}$ & $\begin{array}{c}\mathrm{H} \\
(\mathrm{cm})\end{array}$ & $\begin{array}{c}\text { Tensão } \\
\text { aplicada } \\
\text { (MPa) }\end{array}$ & $\% R T$ & $\begin{array}{c}\Delta \sigma \\
(\mathrm{MPa})\end{array}$ & $\varepsilon_{r}$ & $\mathbf{N}$ \\
\hline JSI062 & 1200 & 10,17 & 5,98 & 0,1256 & 9,97 & 0,5025 & $1,67 \times 10^{-5}$ & 18795 \\
\hline JSI065 & 1200 & 10,15 & 6,01 & 0,1252 & 9,94 & 0,5009 & $1,66 \times 10^{-5}$ & 20478 \\
\hline JSI063 & 2410 & 10,17 & 5,97 & 0,2527 & 20,06 & 1,0108 & $3,35 \times 10^{-5}$ & 4215 \\
\hline JSI064 & 2410 & 10,17 & 6,00 & 0,2514 & 19,96 & 1,0057 & $3,34 \times 10^{-5}$ & 3594 \\
\hline JSI060 & 3610 & 10,19 & 5,99 & 0,3765 & 29,88 & 1,5061 & $5,00 \times 10^{-5}$ & 1526 \\
\hline JSI066 & 3610 & 10,17 & 5,98 & 0,3779 & 29,99 & 1,5116 & $5,02 \times 10^{-5}$ & 1640 \\
\hline JSI059 & 4810 & 10,18 & 5,97 & 0,5039 & 39,99 & 2,0154 & $6,69 \times 10^{-5}$ & 717 \\
\hline JSI061 & 4810 & 10,16 & 5,99 & 0,5032 & 39,93 & 2,0126 & $6,68 \times 10^{-5}$ & 736 \\
\hline \multirow{2}{*}{\multicolumn{3}{|c|}{ Modelos de fadiga }} & \multicolumn{3}{|c|}{$\begin{array}{c}\text { Função da diferença de } \\
\text { tensões }\end{array}$} & \multicolumn{2}{|c|}{$N=3939,5 \times$} & \\
\hline & & & \multicolumn{3}{|c|}{$\begin{array}{c}\text { Função da deformação } \\
\text { resiliente }\end{array}$} & \multicolumn{2}{|c|}{$N=1,19 \times 10^{-7} \times$} & \\
\hline
\end{tabular}




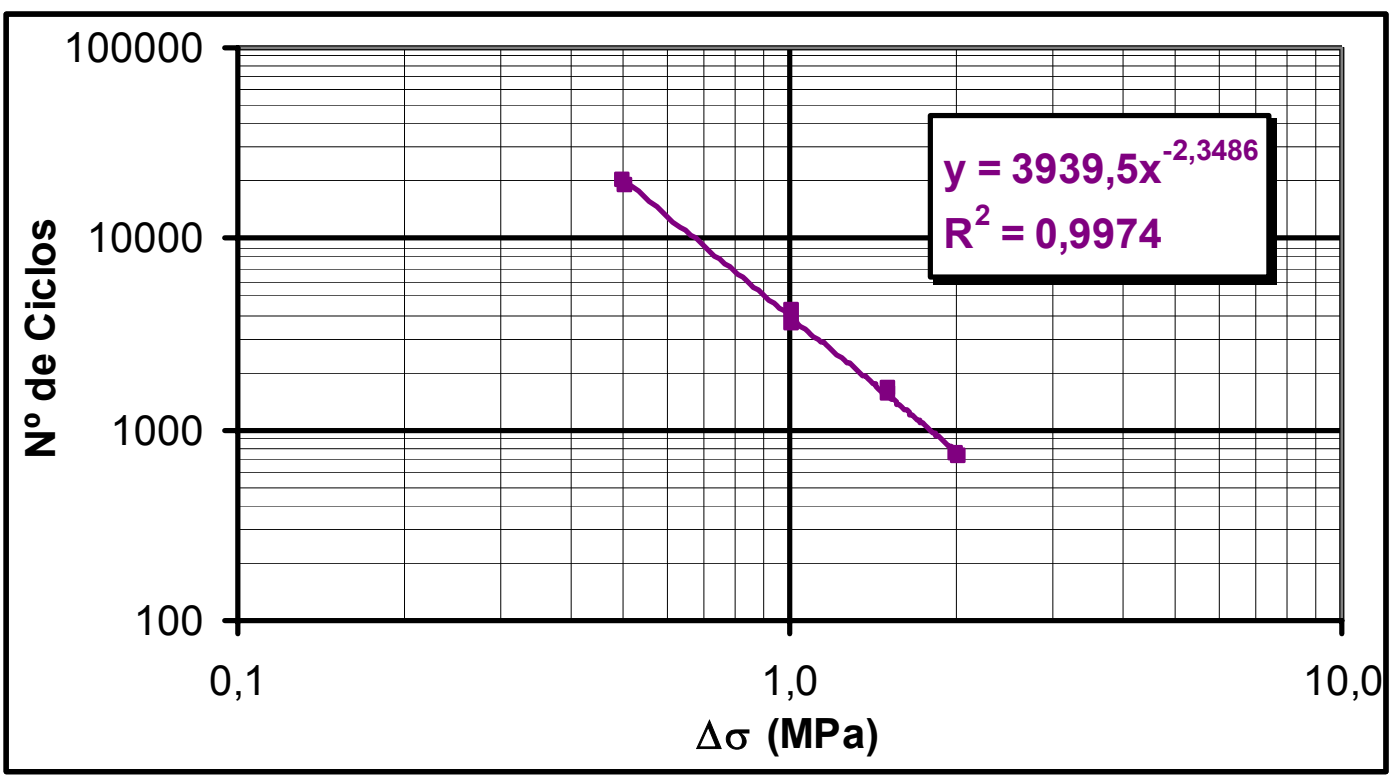

Figura 4.29. Programa experimental - Número de ciclos em função da diferença de tensões em corpos-de-prova com 0\% de EVA e 2 horas de envelhecimento.

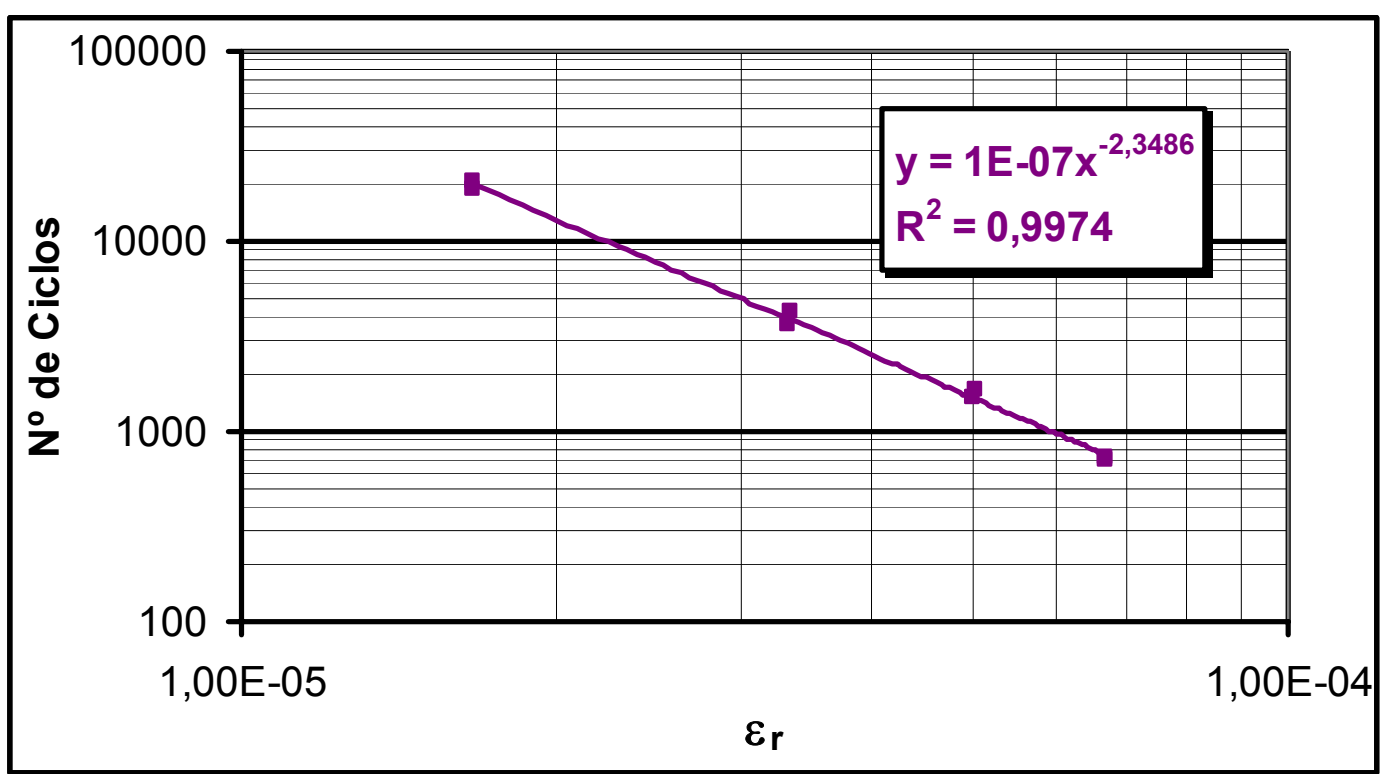

Figura 4.30. Programa experimental - Número de ciclos em função da deformação resiliente em corpos-de-prova com 0\% de EVA e 2 horas de envelhecimento. 
Tabela 4.14 - Programa experimental - Resultados dos ensaios de fadiga em corpos-de-prova com $1 \%$ de EVA e 2 horas de envelhecimento.

\begin{tabular}{|c|c|c|c|c|c|c|c|c|}
\hline \multicolumn{5}{|c|}{ RT considerada $=1,260 \mathrm{MPa}$} & \multicolumn{4}{|c|}{$\mathrm{MR}=6014 \mathrm{MPa}$} \\
\hline CP no & $\begin{array}{c}\text { Carga } \\
\text { (N) }\end{array}$ & $\begin{array}{c}D \\
(\mathrm{~cm})\end{array}$ & $\begin{array}{c}\mathrm{H} \\
(\mathrm{cm})\end{array}$ & $\begin{array}{c}\text { Tensão } \\
\text { aplicada } \\
\text { (MPa) }\end{array}$ & $\%$ RT & $\begin{array}{c}\Delta \sigma \\
(\mathrm{MPa})\end{array}$ & $\varepsilon_{\mathbf{r}}$ & $\mathbf{N}$ \\
\hline JSI100 & 1200 & 10,18 & 5,91 & 0,1270 & 10,08 & 0,5079 & $2,11 \times 10^{-5}$ & 34115 \\
\hline JSI110 & 1200 & 10,18 & 5,93 & 0,1265 & 10,04 & 0,5062 & $2,10 \times 10^{-5}$ & 29512 \\
\hline JSI098 & 2410 & 10,17 & 5,98 & 0,2523 & 20,02 & 1,0091 & $4,19 \times 10^{-5}$ & 4808 \\
\hline JSI101 & 2410 & 10,17 & 5,93 & 0,2544 & 20,19 & 1,0176 & $4,23 \times 10^{-5}$ & 4859 \\
\hline JSI097 & 3610 & 10,16 & 6,04 & 0,3745 & 29,72 & 1,4980 & $6,23 \times 10^{-5}$ & 1432 \\
\hline JSI102 & 3610 & 10,18 & 5,92 & 0,3813 & 30,27 & 1,5254 & $6,34 \times 10^{-5}$ & 1374 \\
\hline JSI103 & 4810 & 10,18 & 5,93 & 0,5073 & 40,26 & 2,0290 & $8,43 \times 10^{-5}$ & 777 \\
\hline JSI105 & 4810 & 10,17 & 5,94 & 0,5069 & 40,23 & 2,0276 & $8,43 \times 10^{-5}$ & 641 \\
\hline \multirow{2}{*}{\multicolumn{3}{|c|}{ Modelos de fadiga }} & \multicolumn{3}{|c|}{$\begin{array}{c}\text { Função da diferença de } \\
\text { tensões }\end{array}$} & \multicolumn{2}{|c|}{$N=4814,2 \times$} & \\
\hline & & & \multicolumn{3}{|c|}{$\begin{array}{l}\text { Função da deformação } \\
\text { resiliente }\end{array}$} & \multicolumn{2}{|c|}{$N=3,18 \times 10^{-9} \times$} & \\
\hline
\end{tabular}

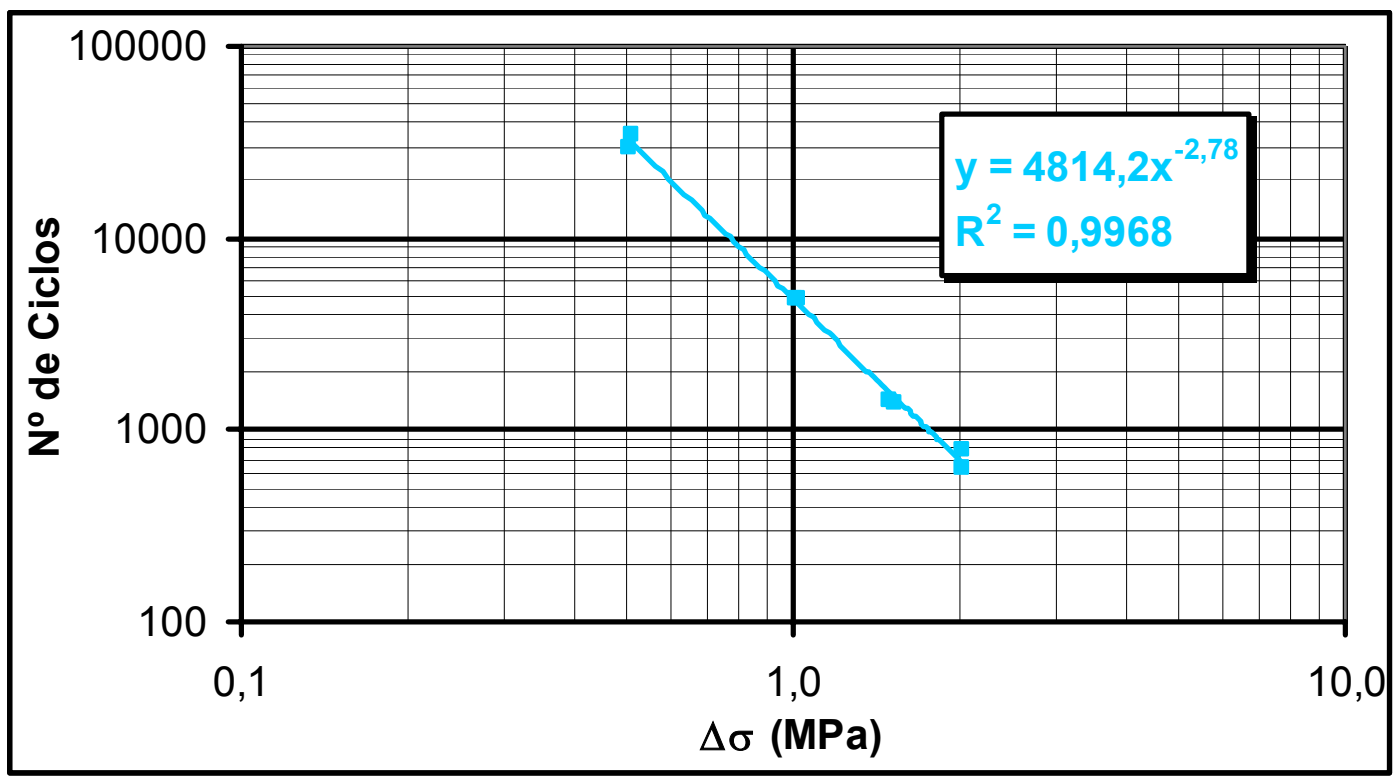

Figura 4.31. Programa experimental - Número de ciclos em função da diferença de tensões em corpos-de-prova com 1\% de EVA e 2 horas de envelhecimento. 


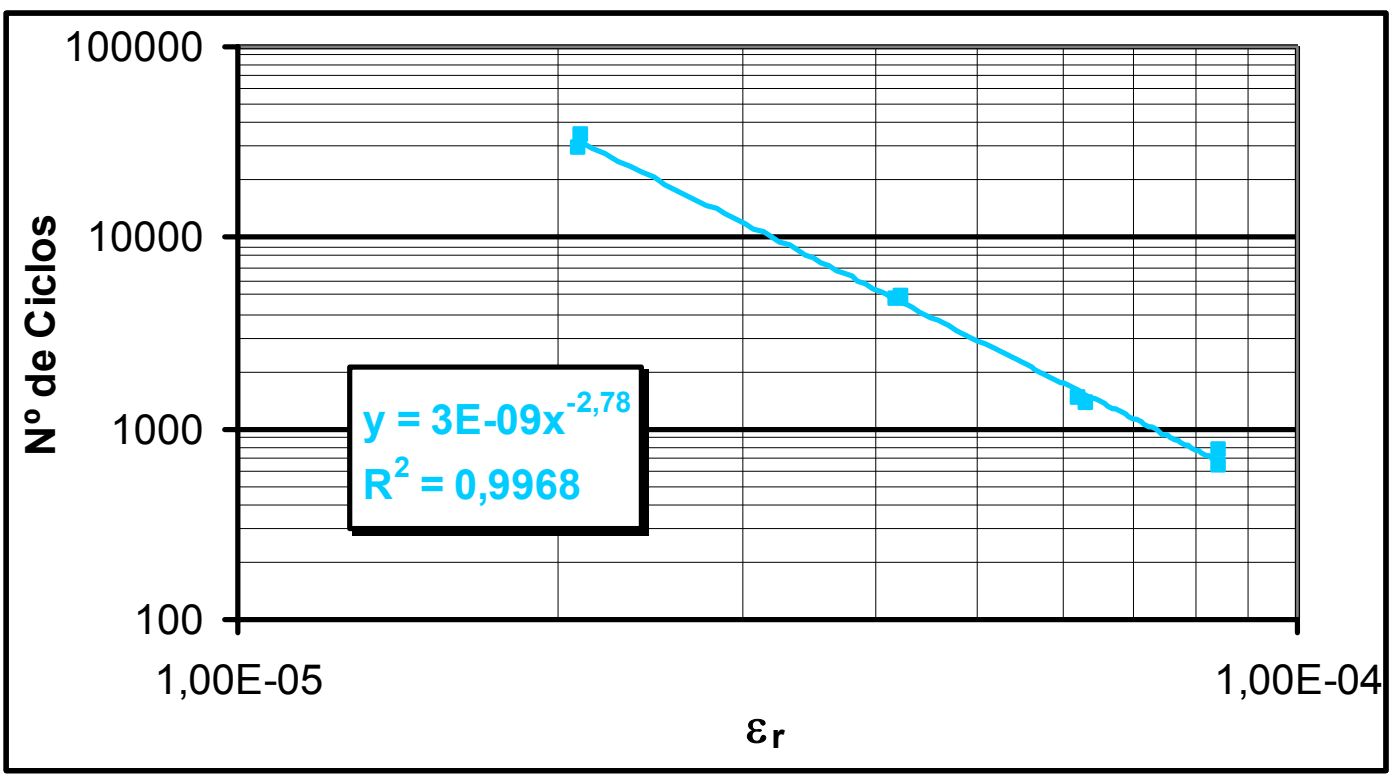

Figura 4.32. Programa experimental - Número de ciclos em função da deformação resiliente em corpos-de-prova com 1\% de EVA e 2 horas de envelhecimento.

Tabela 4.15 - Programa experimental - Resultados dos ensaios de fadiga em corpos-de-prova com $2 \%$ de EVA e 2 horas de envelhecimento.

\begin{tabular}{|c|c|c|c|c|c|c|c|c|}
\hline \multicolumn{5}{|c|}{ RT considerada $=1,260 \mathrm{MPa}$} & \multicolumn{4}{|c|}{$\mathrm{MR}=6831 \mathrm{MPa}$} \\
\hline$C P n^{\circ}$ & $\begin{array}{l}\text { Carga } \\
\text { (N) }\end{array}$ & $\begin{array}{c}D \\
(\mathrm{~cm})\end{array}$ & $\begin{array}{c}\mathrm{H} \\
(\mathrm{cm})\end{array}$ & $\begin{array}{l}\text { Tensão } \\
\text { aplicada } \\
\text { (MPa) }\end{array}$ & $\%$ RT & $\begin{array}{c}\Delta \sigma \\
(\mathrm{MPa})\end{array}$ & $\varepsilon_{\mathbf{r}}$ & $\mathbf{N}$ \\
\hline JSI145 & 1200 & 10,18 & 6,01 & 0,1249 & $10,12 \%$ & 0,4995 & $1,83 \times 10^{-5}$ & 34698 \\
\hline JSI152 & 1200 & 10,17 & 6,00 & 0,1252 & $10,15 \%$ & 0,5008 & $1,83 \times 10^{-5}$ & 32594 \\
\hline JSI140 & 2410 & 10,18 & 6,03 & 0,2499 & $20,25 \%$ & 0,9998 & $3,66 \times 10^{-5}$ & 3906 \\
\hline JSI141 & 2410 & 10,17 & 5,98 & 0,2523 & $20,44 \%$ & 1,0091 & $3,69 \times 10^{-5}$ & 4607 \\
\hline JSI146 & 3610 & 10,17 & 6,00 & 0,3766 & $30,52 \%$ & 1,5065 & $5,51 \times 10^{-5}$ & 1356 \\
\hline JSI147 & 3610 & 10,19 & 5,91 & 0,3816 & $30,93 \%$ & 1,5265 & $5,59 \times 10^{-5}$ & 1525 \\
\hline JSI143 & 4810 & 10,18 & 6,04 & 0,4980 & $40,36 \%$ & 1,9921 & $7,29 \times 10^{-5}$ & 671 \\
\hline JSI150 & 4810 & 10,18 & 5,97 & 0,5039 & $40,83 \%$ & 2,0154 & $7,38 \times 10^{-5}$ & 736 \\
\hline \multirow{2}{*}{\multicolumn{3}{|c|}{ Modelos de fadiga }} & \multicolumn{3}{|c|}{$\begin{array}{c}\text { Função da diferença de } \\
\text { tensões }\end{array}$} & \multicolumn{2}{|c|}{$N=4654,5 \times$} & \\
\hline & & & \multicolumn{3}{|c|}{$\begin{array}{l}\text { Função da deformação } \\
\text { resiliente }\end{array}$} & \multicolumn{2}{|c|}{$N=1,92 \times 10^{-9} \times$} & \\
\hline
\end{tabular}




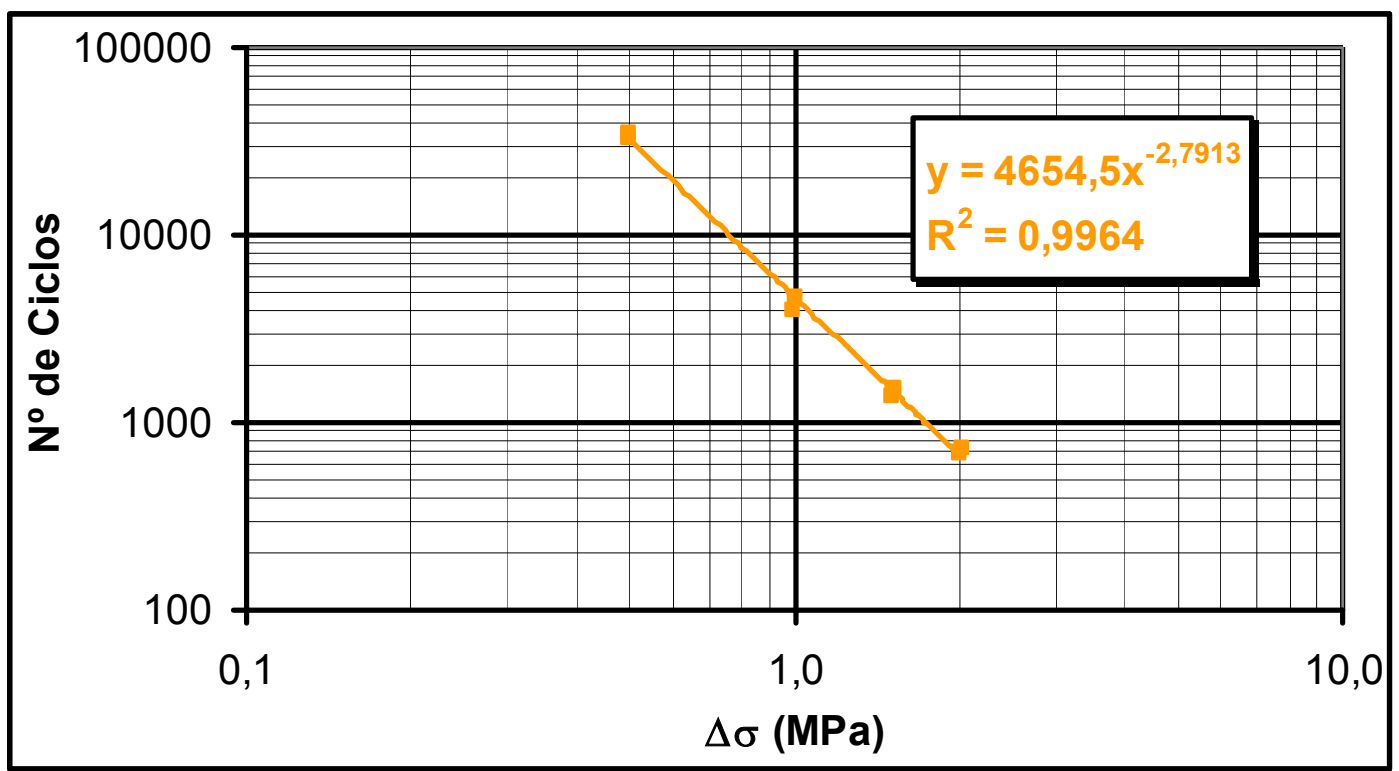

Figura 4.33. Programa experimental - Número de ciclos em função da diferença de tensões em corpos-de-prova com $2 \%$ de EVA e 2 horas de envelhecimento.

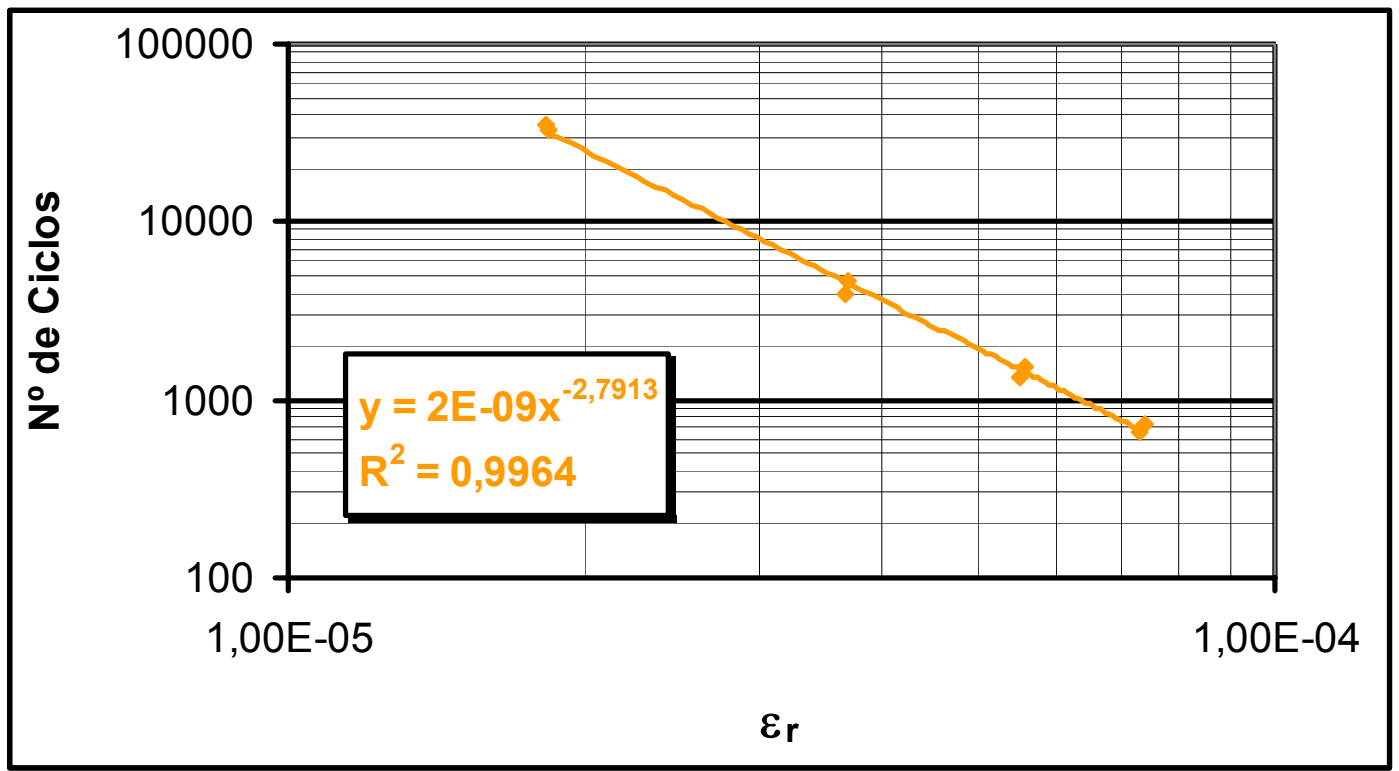

Figura 4.34. Programa experimental - Número de ciclos em função da deformação resiliente em corpos-de-prova com 2\% de EVA e 2 horas de envelhecimento. 
Tabela 4.16 - Programa experimental - Resultados dos ensaios de fadiga em corpos-de-prova com 3\% de EVA e 2 horas de envelhecimento.

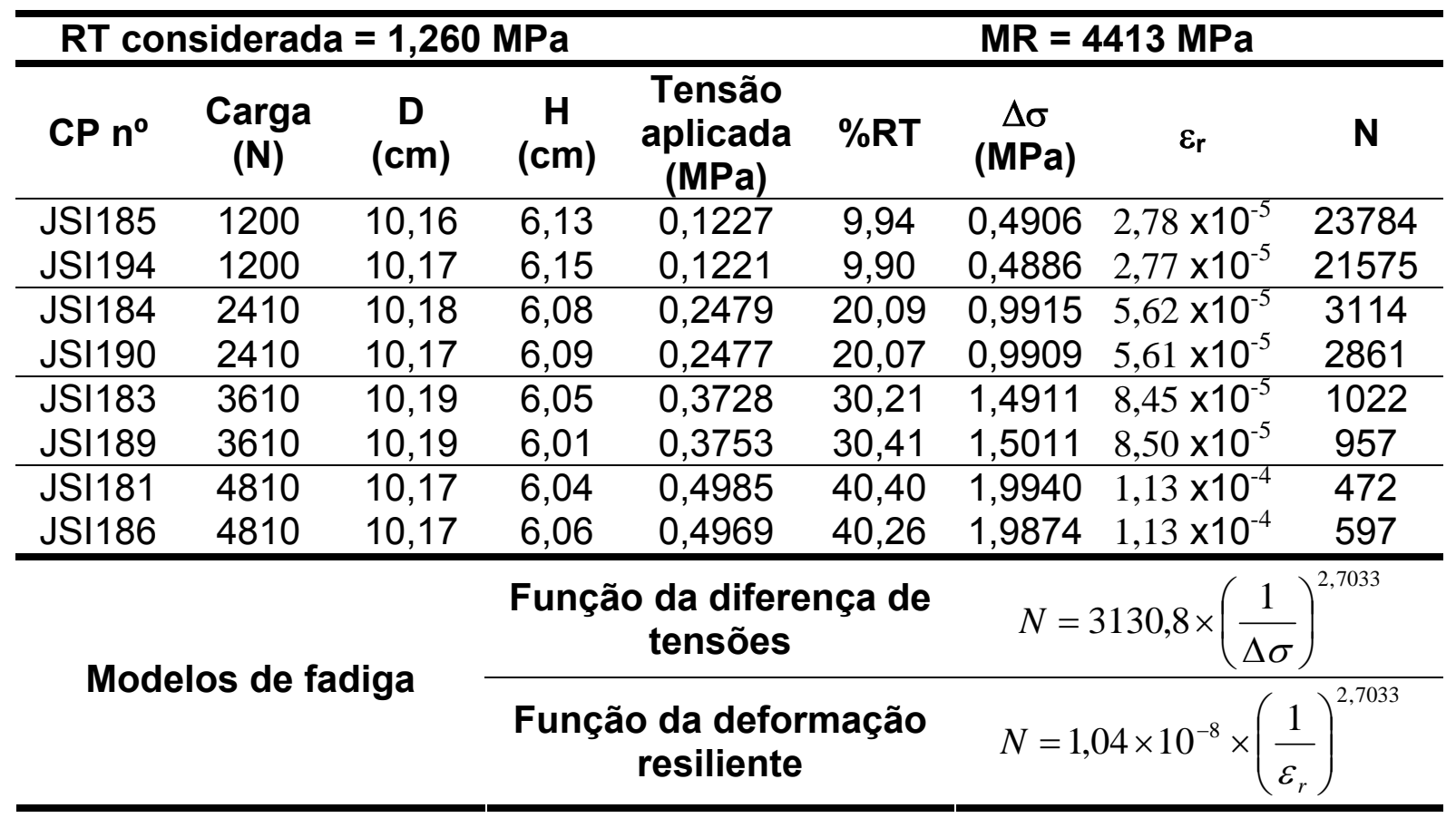

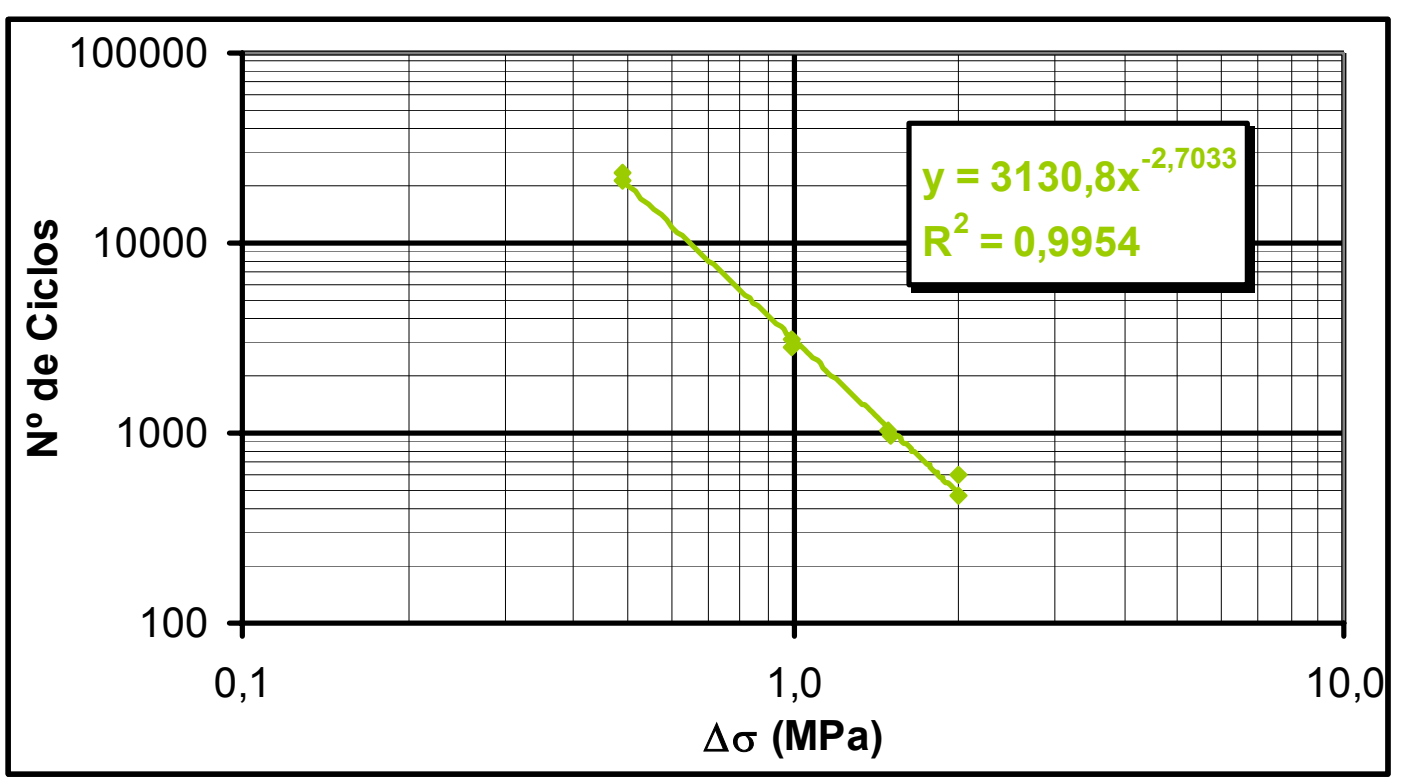

Figura 4.35. Programa experimental - Número de ciclos em função da diferença de tensões em corpos-de-prova com 3\% de EVA e 2 horas de envelhecimento. 


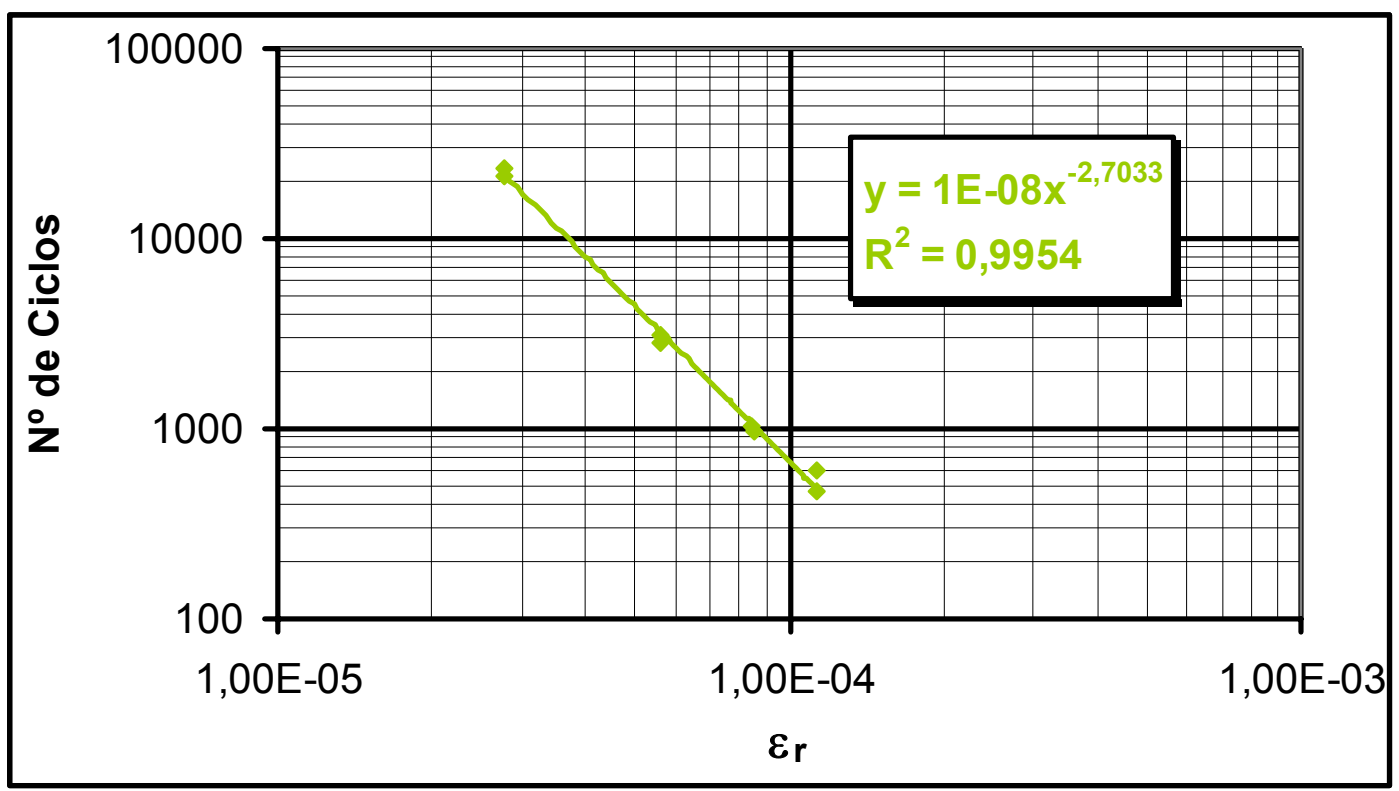

Figura 4.36. Programa experimental - Número de ciclos em função da deformação resiliente em corpos-de-prova com 3\% de EVA e 2 horas de envelhecimento.

Tabela 4.17 - Programa experimental - Resultados dos ensaios de fadiga em corpos-de-prova com $0 \%$ de EVA e 4 horas de envelhecimento.

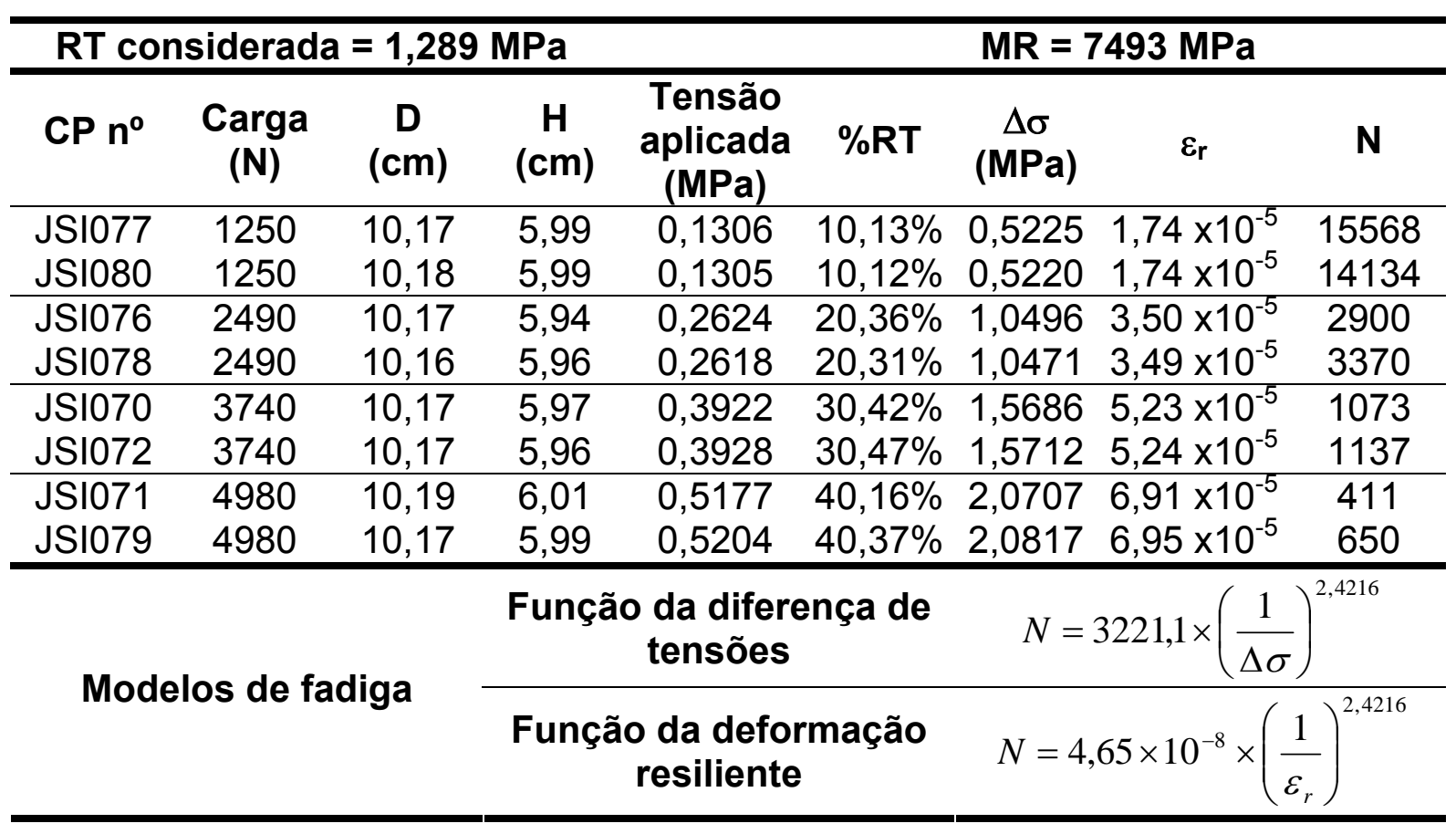




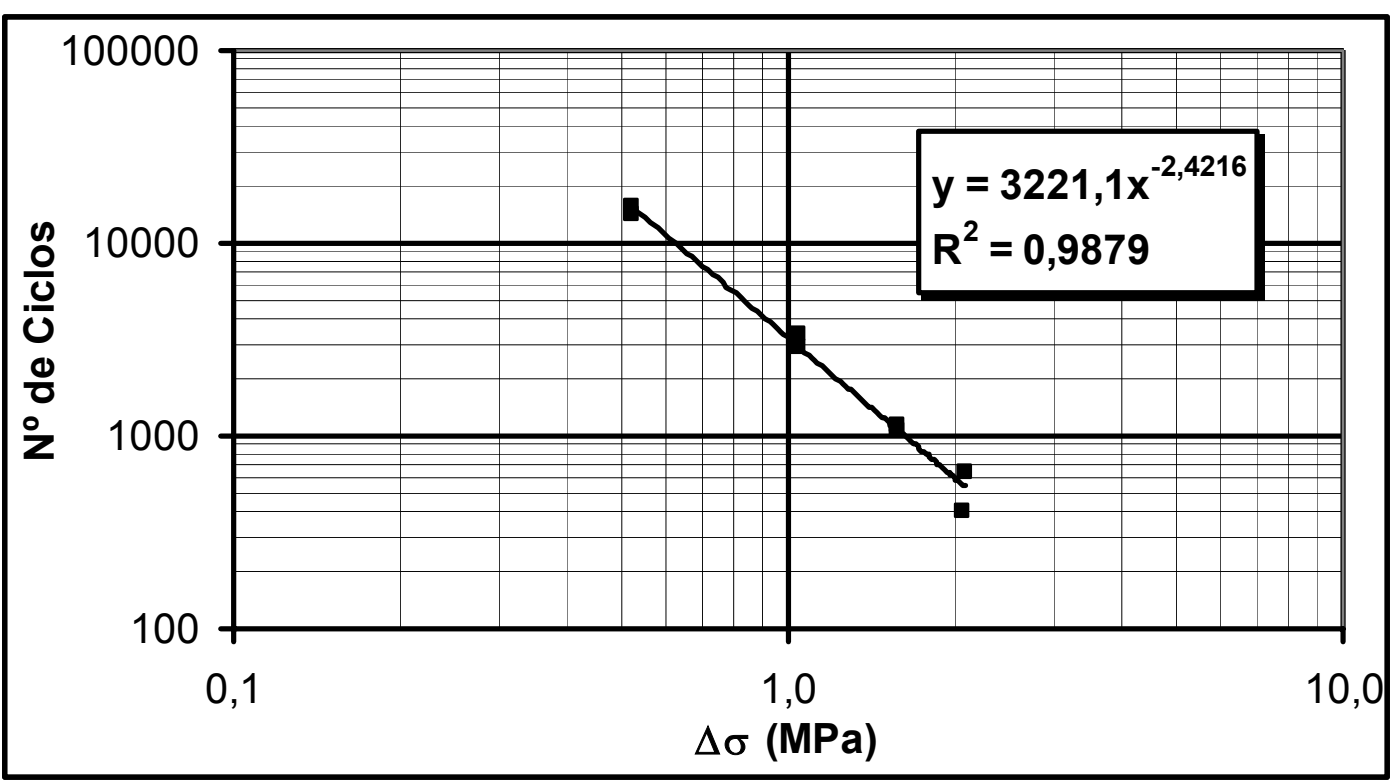

Figura 4.37. Programa experimental - Número de ciclos em função da diferença de tensões em corpos-de-prova com 0\% de EVA e 4 horas de envelhecimento.

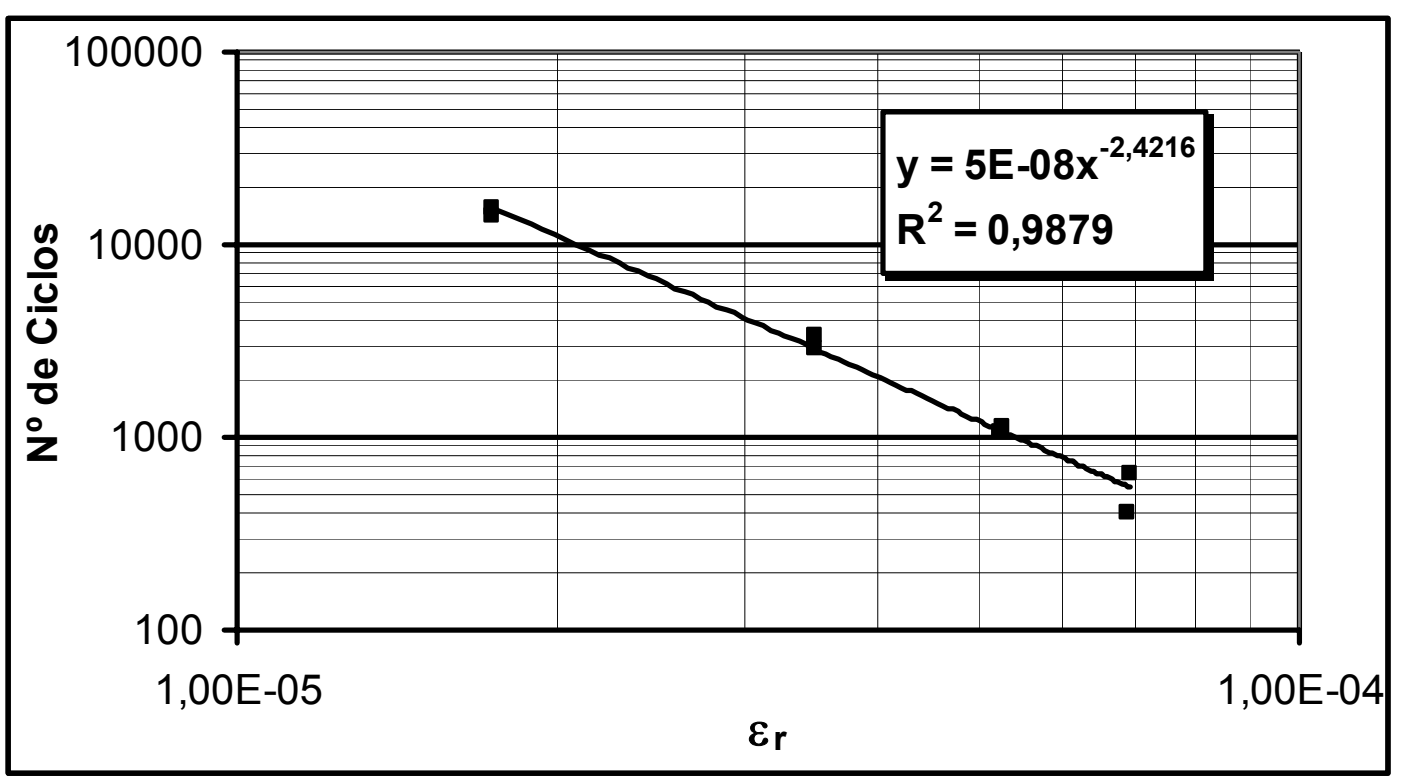

Figura 4.38. Programa experimental - Número de ciclos em função da deformação resiliente em corpos-de-prova com 0\% de EVA e 4 horas de envelhecimento. 
Tabela 4.18 - Programa experimental - Resultados dos ensaios de fadiga em corpos-de-prova com 1\% de EVA e 4 horas de envelhecimento.

\begin{tabular}{|c|c|c|c|c|c|c|c|c|}
\hline \multicolumn{5}{|c|}{ RT considerada $=1,289 \mathrm{MPa}$} & \multicolumn{4}{|c|}{ MR = $8036 \mathrm{MPa}$} \\
\hline$C P n^{\circ}$ & $\begin{array}{l}\text { Carga } \\
\text { (N) }\end{array}$ & $\begin{array}{c}D \\
(\mathrm{~cm})\end{array}$ & $\begin{array}{c}\mathrm{H} \\
(\mathrm{cm})\end{array}$ & $\begin{array}{l}\text { Tensão } \\
\text { aplicada } \\
\text { (MPa) }\end{array}$ & $\%$ RT & $\begin{array}{c}\Delta \sigma \\
(\mathrm{MPa})\end{array}$ & $\varepsilon_{\mathbf{r}}$ & $\mathbf{N}$ \\
\hline JSI114 & 1250 & 10,17 & 5,99 & 0,1306 & 0,1013 & 0,5225 & $1,63 \times 10^{-5}$ & 39038 \\
\hline JSI118 & 1250 & 10,18 & 5,97 & 0,1309 & 0,1016 & 0,5238 & $1,63 \times 10^{-5}$ & 37290 \\
\hline JSi113 & 2490 & 10,16 & 6,01 & 0,2596 & 0,2014 & 1,0384 & $3,23 \times 10^{-5}$ & 4160 \\
\hline JSI116 & 2490 & 10,17 & 5,99 & 0,2602 & 0,2019 & 1,0409 & $3,24 \times 10^{-5}$ & 4858 \\
\hline JSI119 & 3740 & 10,18 & 5,90 & 0,3964 & 0,3075 & 1,5857 & $4,93 \times 10^{-5}$ & 1881 \\
\hline JSI124 & 3740 & 10,17 & 5,95 & 0,3935 & 0,3053 & 1,5739 & $4,90 \times 10^{-5}$ & 1697 \\
\hline JSI111 & 4980 & 10,17 & 6,01 & 0,5187 & 0,4024 & 2,0748 & $6,45 \times 10^{-5}$ & 609 \\
\hline JSI117 & 4980 & 10,19 & 5,95 & 0,5229 & 0,4057 & 2,0916 & $6,51 \times 10^{-5}$ & 1029 \\
\hline \multirow{2}{*}{\multicolumn{3}{|c|}{ Modelos de fadiga }} & \multicolumn{3}{|c|}{$\begin{array}{c}\text { Função da diferença de } \\
\text { tensões }\end{array}$} & \multicolumn{2}{|c|}{$N=5907,1 \times$} & \\
\hline & & & \multicolumn{3}{|c|}{$\begin{array}{l}\text { Função da deformação } \\
\text { resiliente }\end{array}$} & \multicolumn{2}{|c|}{$N=1,91 \times 10^{-9} \times$} & \\
\hline
\end{tabular}

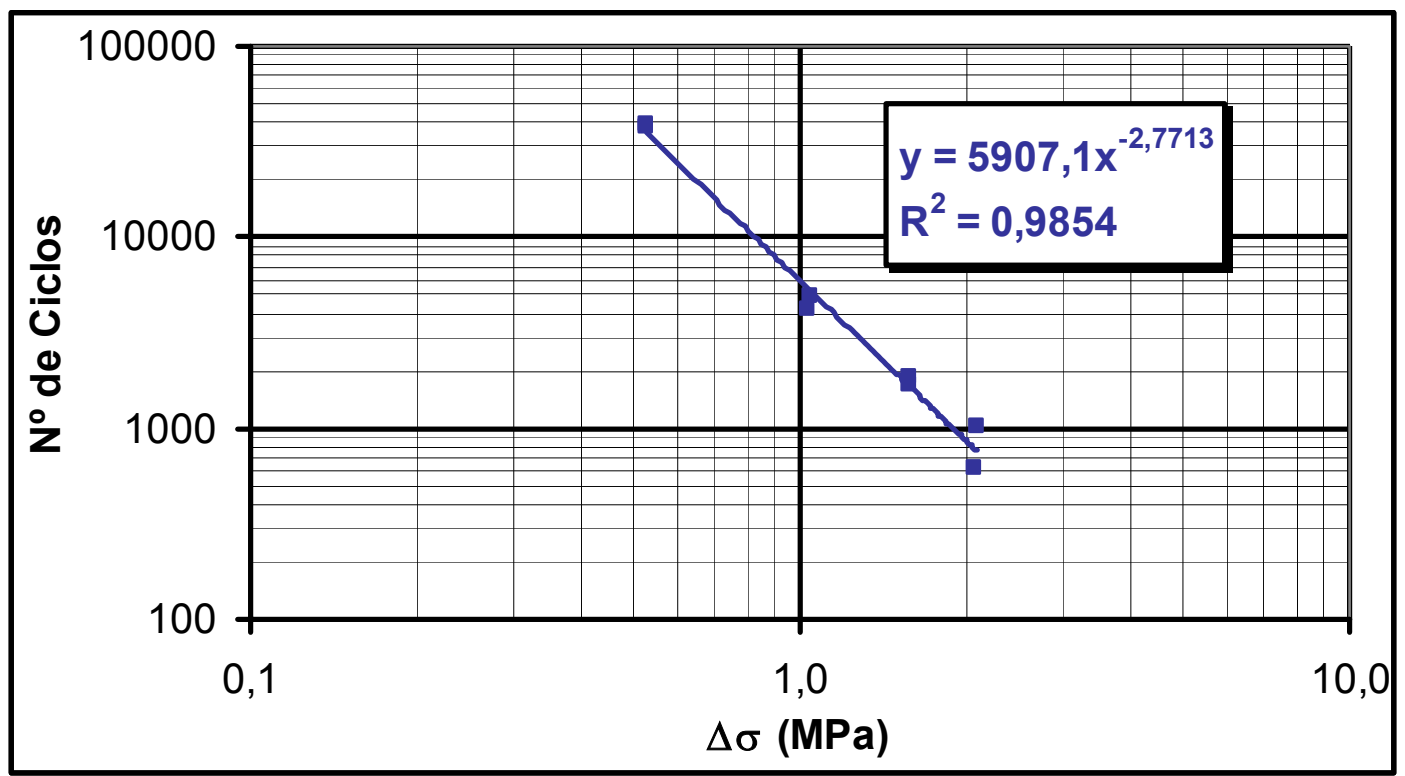

Figura 4.39. Programa experimental - Número de ciclos em função da diferença de tensões em corpos-de-prova com 1\% de EVA e 4 horas de envelhecimento. 


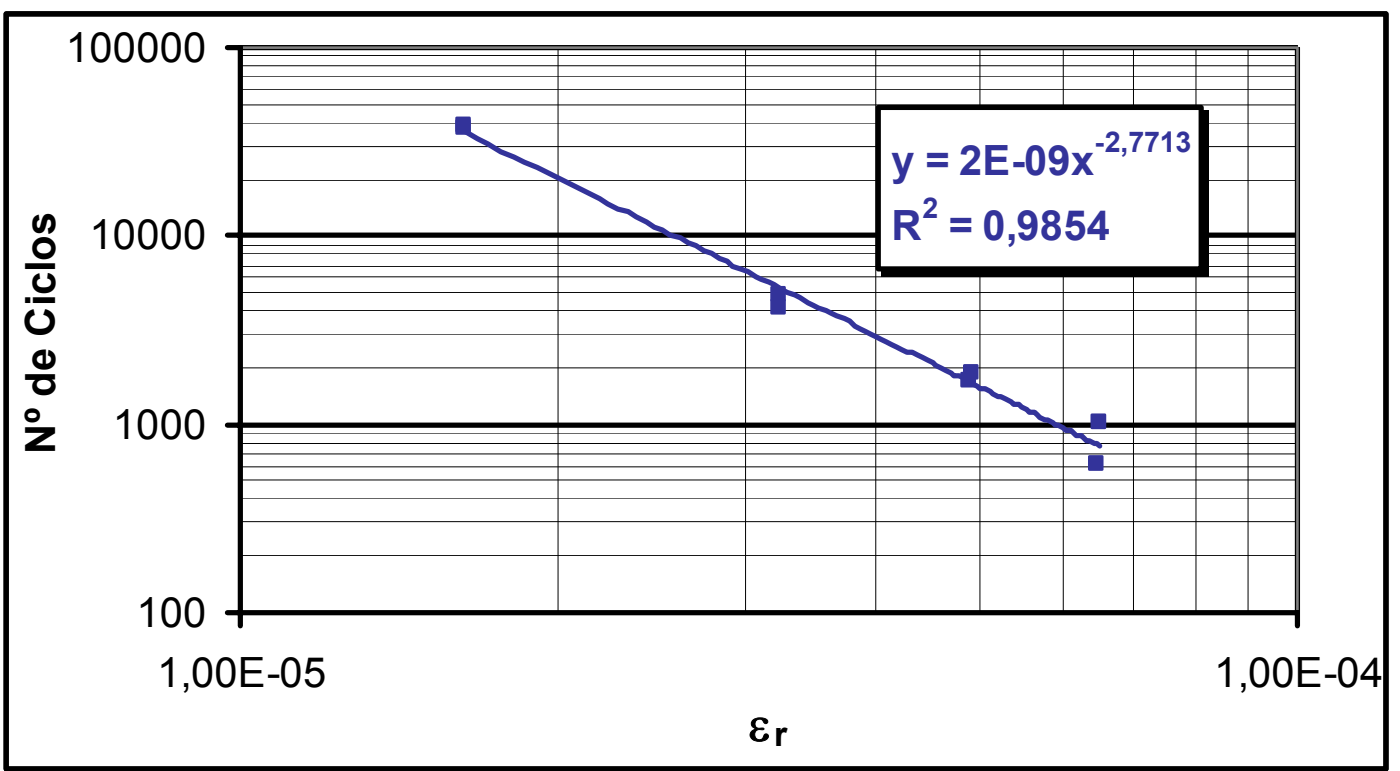

Figura 4.40. Programa experimental - Número de ciclos em função da deformação resiliente em corpos-de-prova com 1\% de EVA e 4 horas de envelhecimento.

Tabela 4.19 - Programa experimental - Resultados dos ensaios de fadiga em corpos-de-prova com $2 \%$ de EVA e 4 horas de envelhecimento.

\begin{tabular}{|c|c|c|c|c|c|c|c|c|}
\hline \multicolumn{5}{|c|}{$\mathrm{RT}$ considerada $=1,289 \mathrm{MPa}$} & \multicolumn{4}{|c|}{$\mathrm{MR}=5990 \mathrm{MPa}$} \\
\hline $\mathrm{CP}^{\circ}{ }^{\circ}$ & $\begin{array}{l}\text { Carga } \\
\text { (N) }\end{array}$ & $\begin{array}{c}D \\
(\mathbf{c m})\end{array}$ & $\begin{array}{c}\mathrm{H} \\
(\mathrm{cm})\end{array}$ & $\begin{array}{c}\text { Tensão } \\
\text { aplicada } \\
\text { (MPa) }\end{array}$ & $\%$ RT & $\Delta \sigma(\mathrm{MPa})$ & $\varepsilon_{r}$ & $\mathbf{N}$ \\
\hline JSI160 & 1250 & 10,16 & 5,98 & 0,1310 & 0,1016 & 0,5239 & $2,19 \times 10^{-5}$ & 36950 \\
\hline JSI166 & 1250 & 10,16 & 6,05 & 0,1295 & 0,1004 & 0,5178 & $2,16 \times 10^{-5}$ & 35163 \\
\hline JSI153 & 2490 & 10,18 & 6,02 & 0,2587 & 0,2007 & 1,0347 & $4,32 \times 10^{-5}$ & 4336 \\
\hline JSI155 & 2490 & 10,17 & 6,04 & 0,2581 & 0,2002 & 1,0322 & $4,31 \times 10^{-5}$ & 4879 \\
\hline JSI156 & 3740 & 10,16 & 6,00 & 0,3906 & 0,3030 & 1,5623 & $6,52 \times 10^{-5}$ & 1368 \\
\hline JSI162 & 3740 & 10,18 & 5,96 & 0,3924 & 0,3044 & 1,5697 & $6,55 \times 10^{-5}$ & 1672 \\
\hline JSI158 & 4980 & 10,18 & 6,00 & 0,5191 & 0,4027 & 2,0762 & $8,67 \times 10^{-5}$ & 624 \\
\hline JSI161 & 4980 & 10,18 & 5,95 & 0,5234 & 0,4061 & 2,0937 & $8,74 \times 10^{-5}$ & 767 \\
\hline \multirow{2}{*}{\multicolumn{3}{|c|}{ Modelos de fadiga }} & \multicolumn{3}{|c|}{$\begin{array}{l}\text { Função da diferença } \\
\text { de tensões }\end{array}$} & \multicolumn{2}{|c|}{$N=5422,4 \times$} & \\
\hline & & & \multicolumn{3}{|c|}{$\begin{array}{l}\text { Função da deformação } \\
\text { resiliente }\end{array}$} & \multicolumn{2}{|c|}{$N=1,82 \times 10^{-9} \times$} & \\
\hline
\end{tabular}




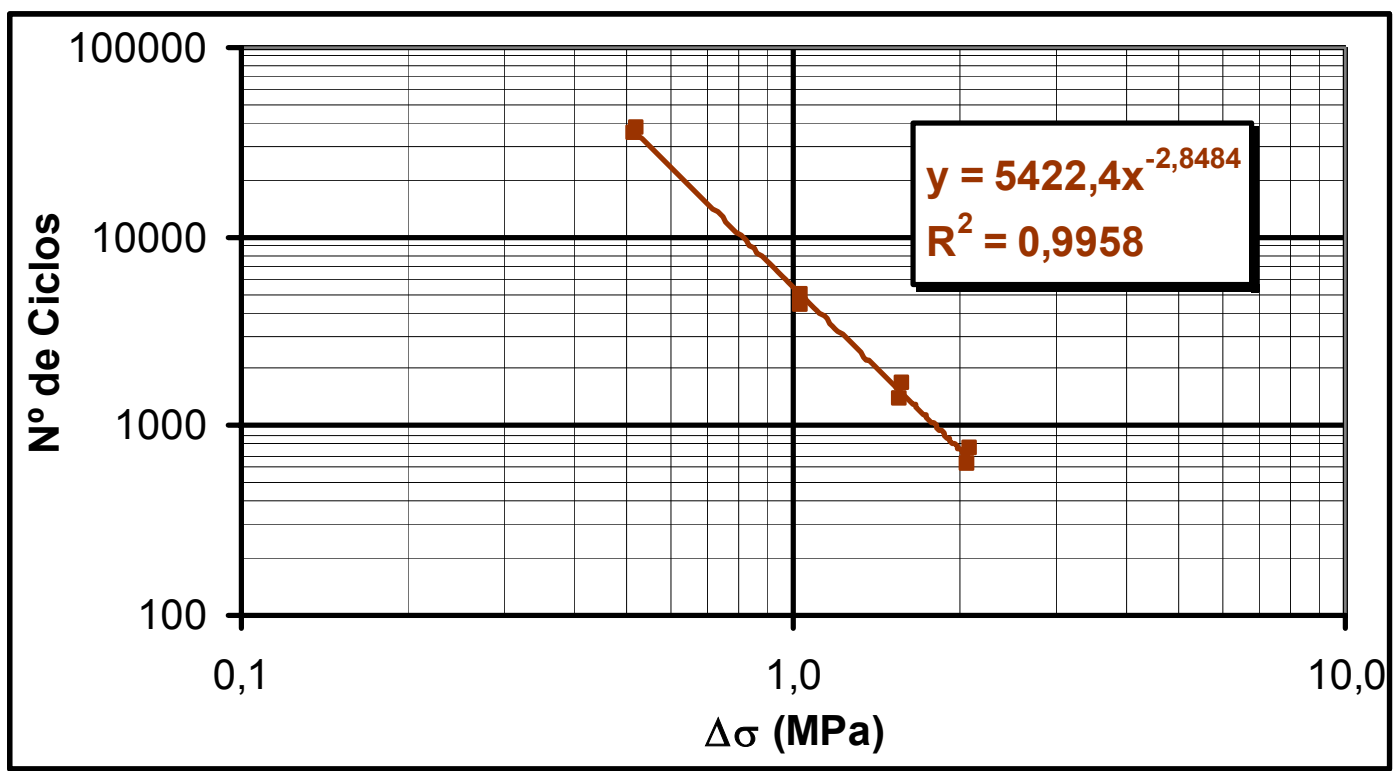

Figura 4.41. Programa experimental - Número de ciclos em função da diferença de tensões em corpos-de-prova com $2 \%$ de EVA e 4 horas de envelhecimento.

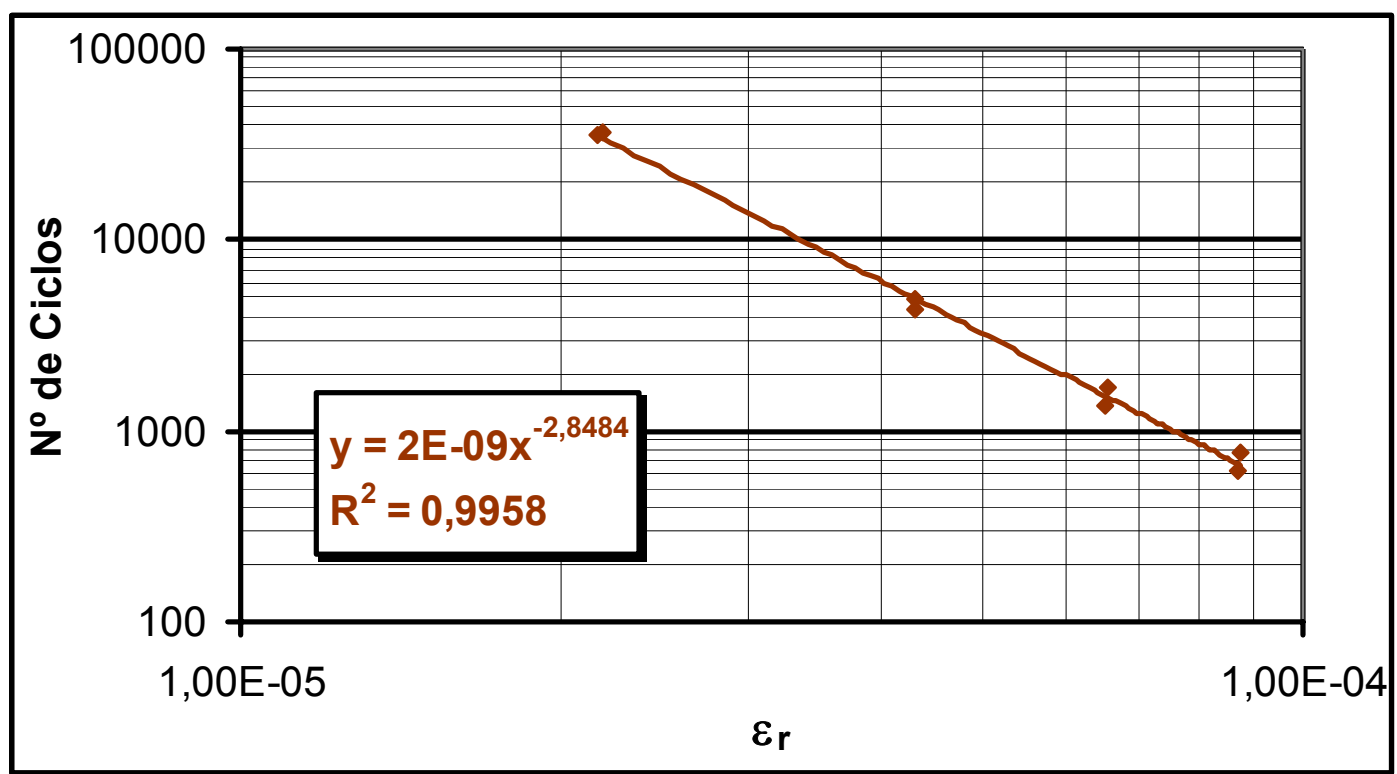

Figura 4.42. Programa experimental - Número de ciclos em função da deformação resiliente em corpos-de-prova com 2\% de EVA e 4 horas de envelhecimento. 
Tabela 4.20 - Programa experimental - Resultados dos ensaios de fadiga em corpos-de-prova com 3\% de EVA e 4 horas de envelhecimento.

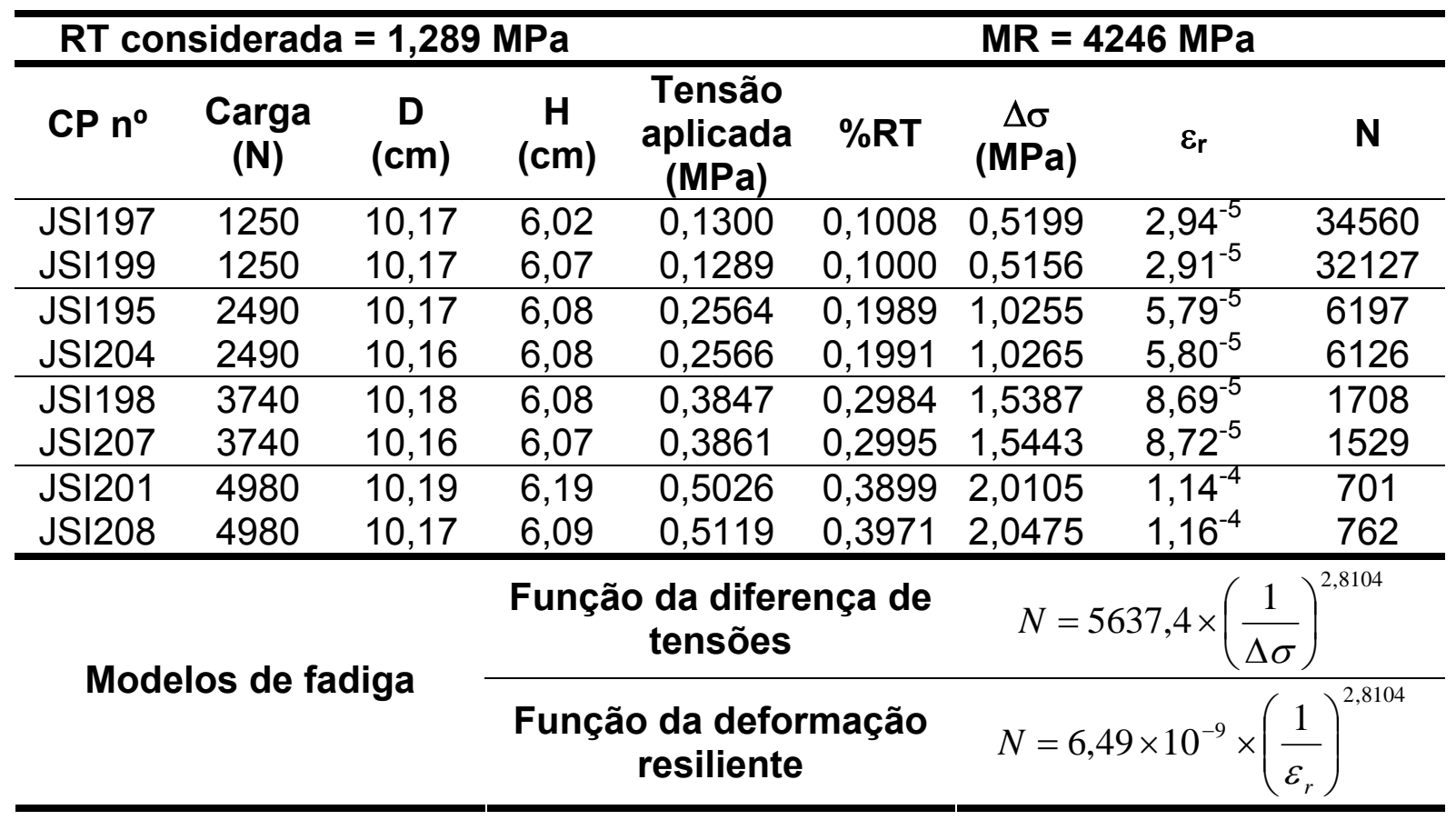

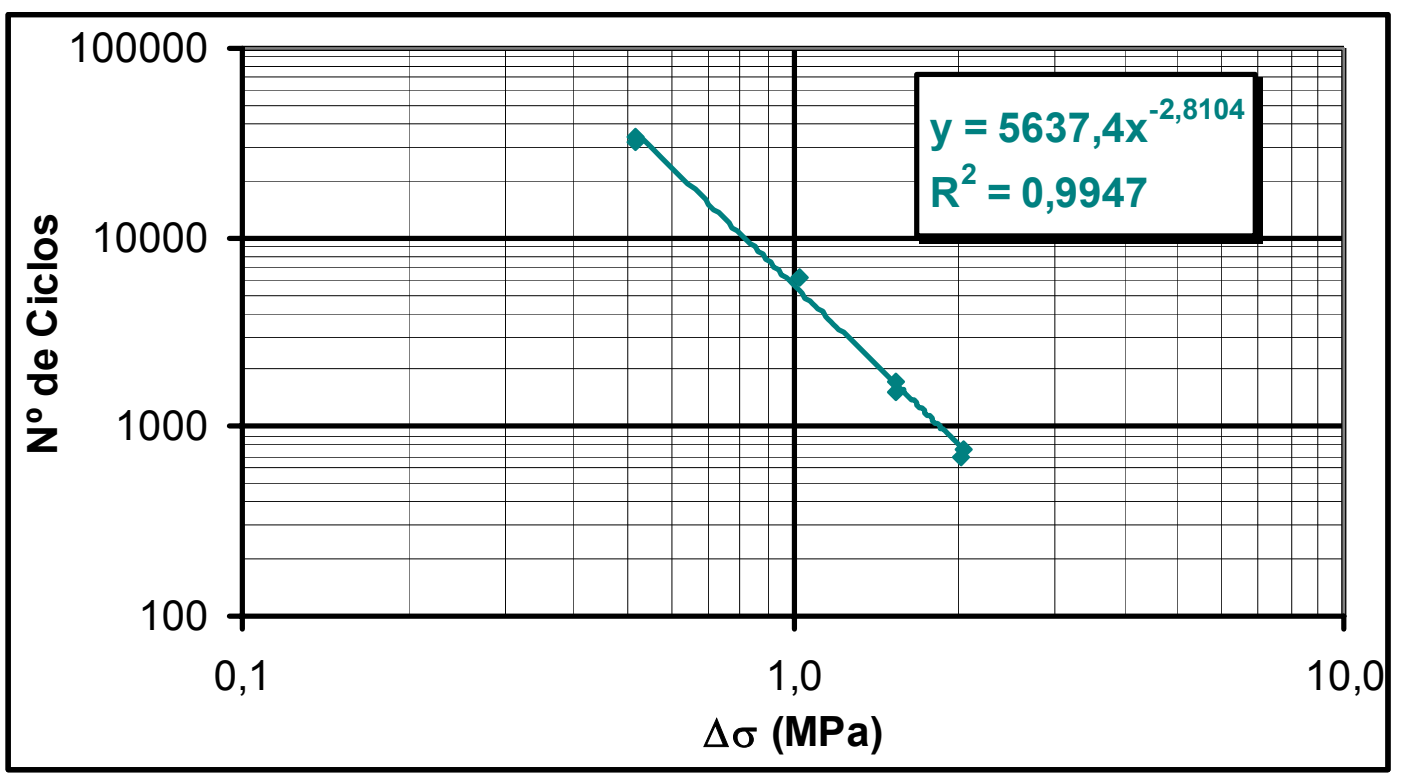

Figura 4.43. Programa experimental - Número de ciclos em função da diferença de tensões em corpos-de-prova com 3\% de EVA e 4 horas de envelhecimento. 


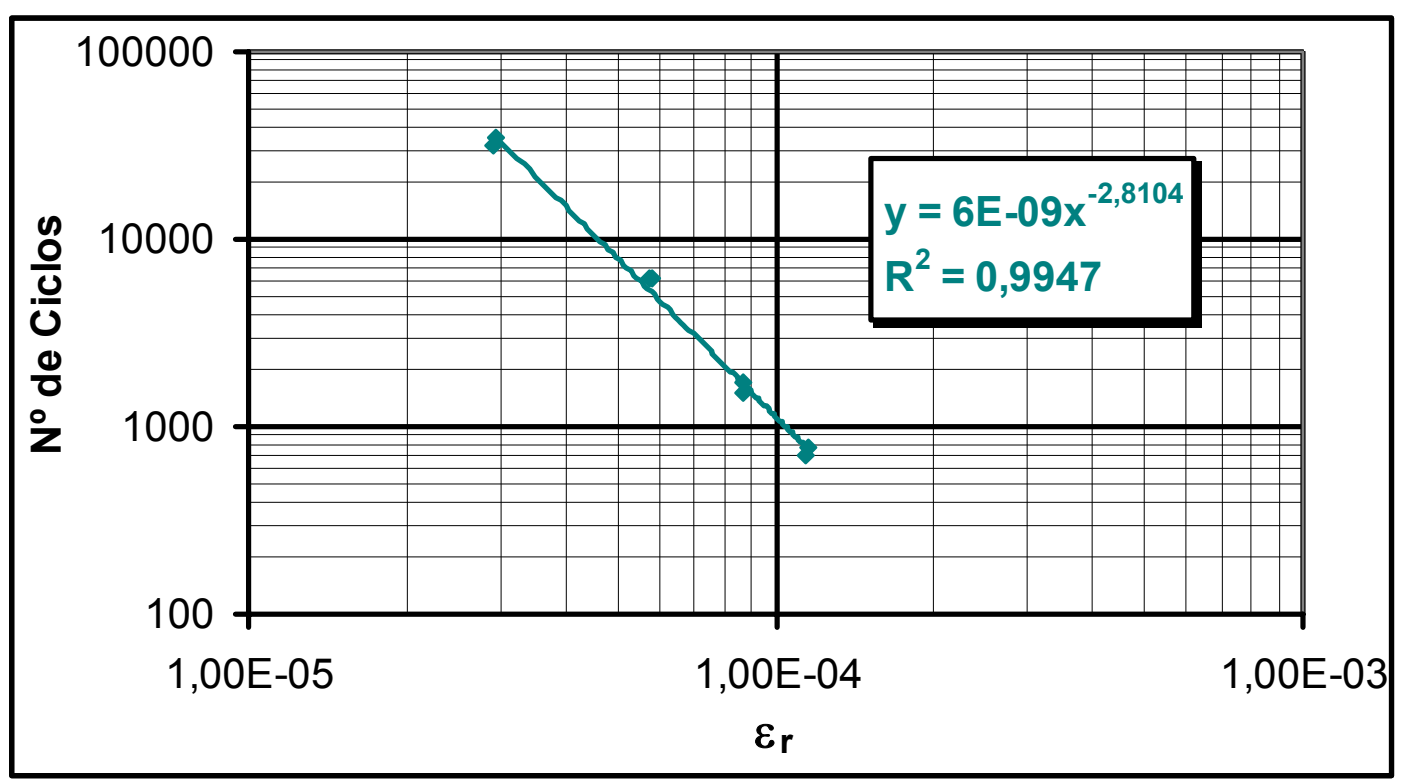

Figura 4.44. Programa experimental - Número de ciclos em função da deformação resiliente em corpos-de-prova com 3\% de EVA e 4 horas de envelhecimento.

As Figuras 4.45 a 4.47 mostram o comportamento das curvas como sendo o número de ciclos em função da diferença de tensões e as Figuras 4.48 a 4.50 mostram o comportamento das curvas como sendo o número de ciclos em função da deformação resiliente. Pode-se verificar que as curvas das misturas com adição de resíduo apresentam inclinações parecidas, diferentemente das curvas das misturas sem EVA, para um mesmo tempo de envelhecimento. 


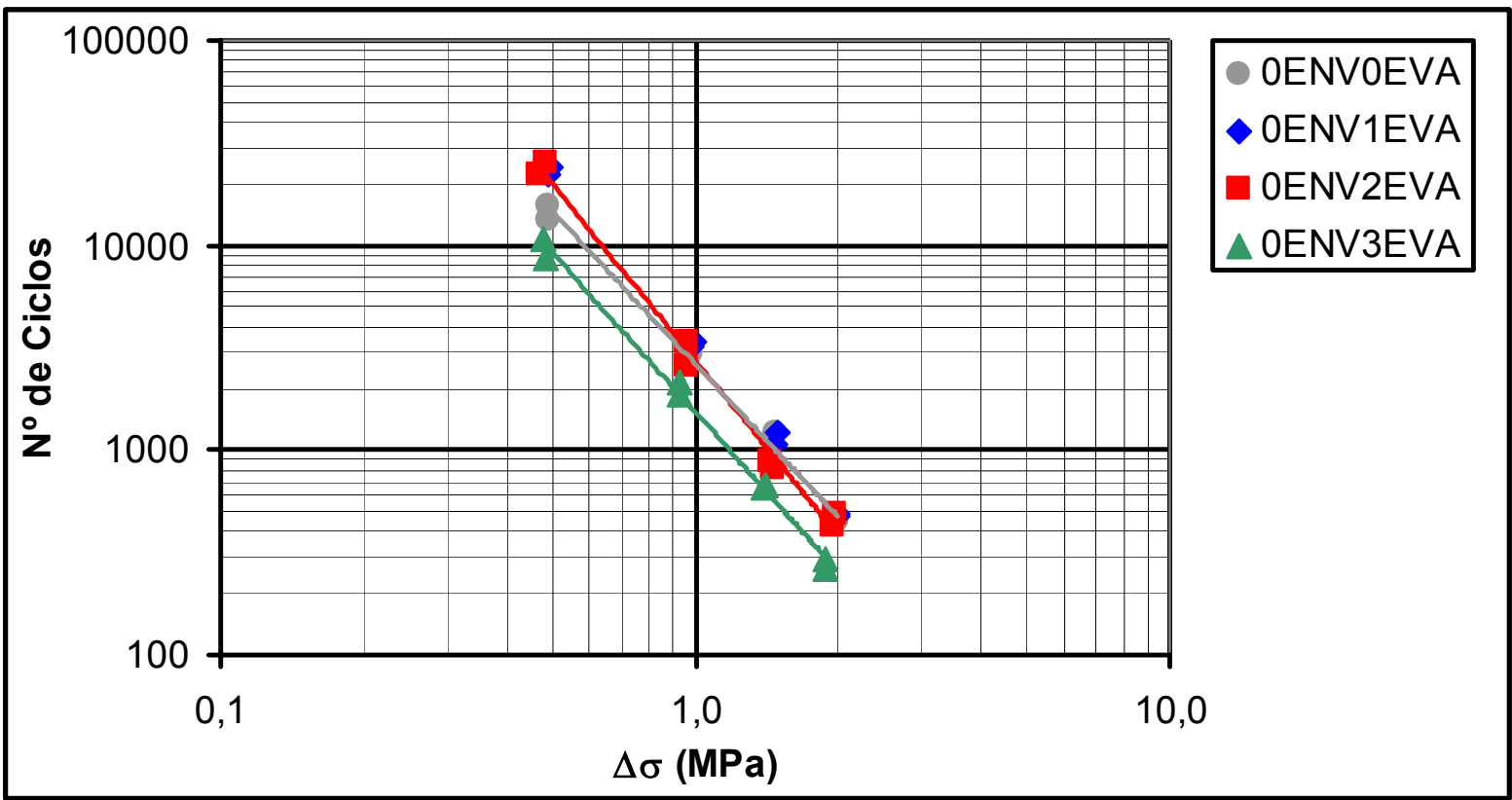

Figura 4.45. Programa experimental - Número de ciclos em função da diferença de tensões em corpos-de-prova com 0 hora de envelhecimento.

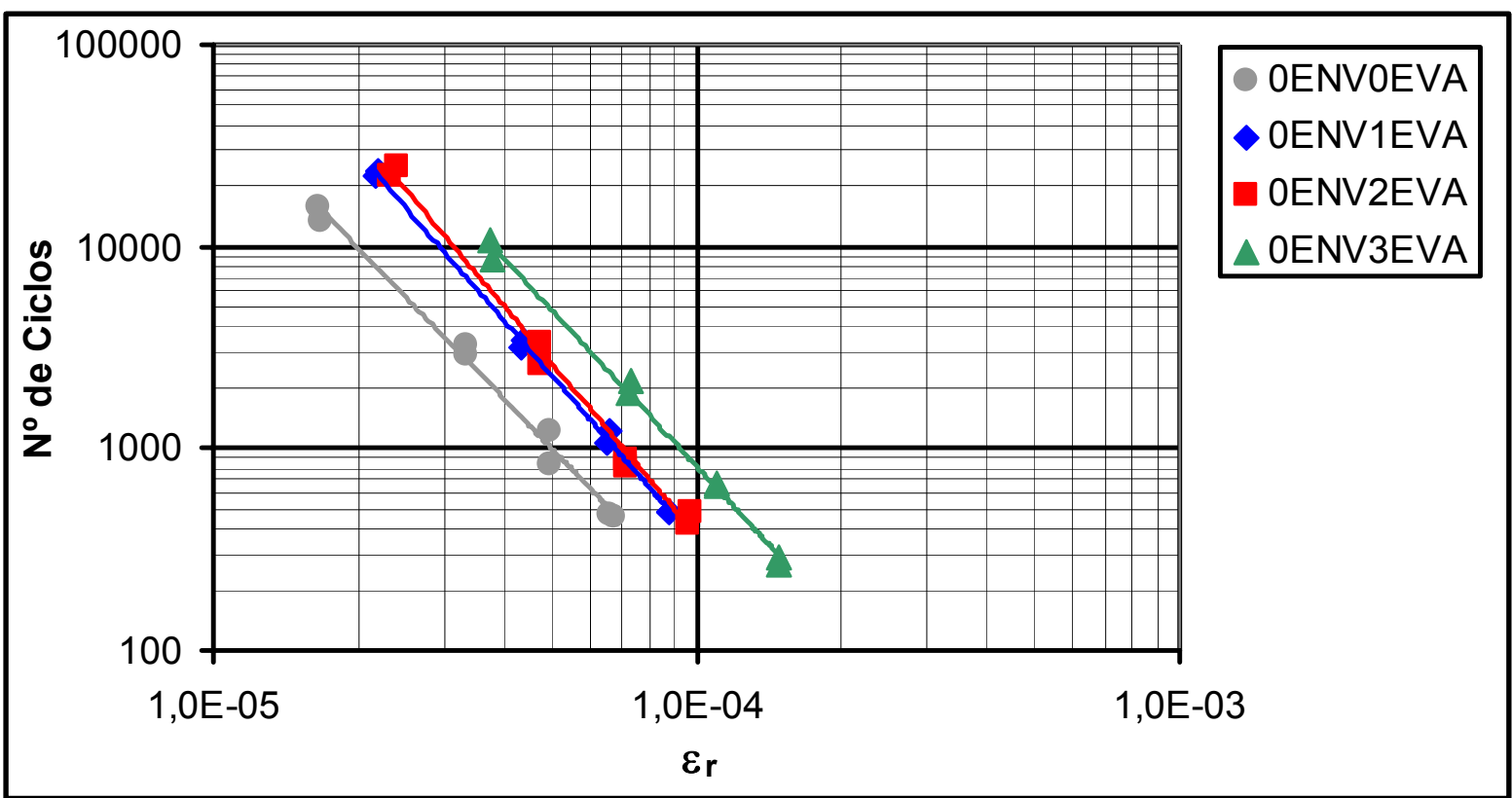

Figura 4.46. Programa experimental - Número de ciclos em função da deformação resiliente em corpos-de-prova com 0 hora de envelhecimento. 


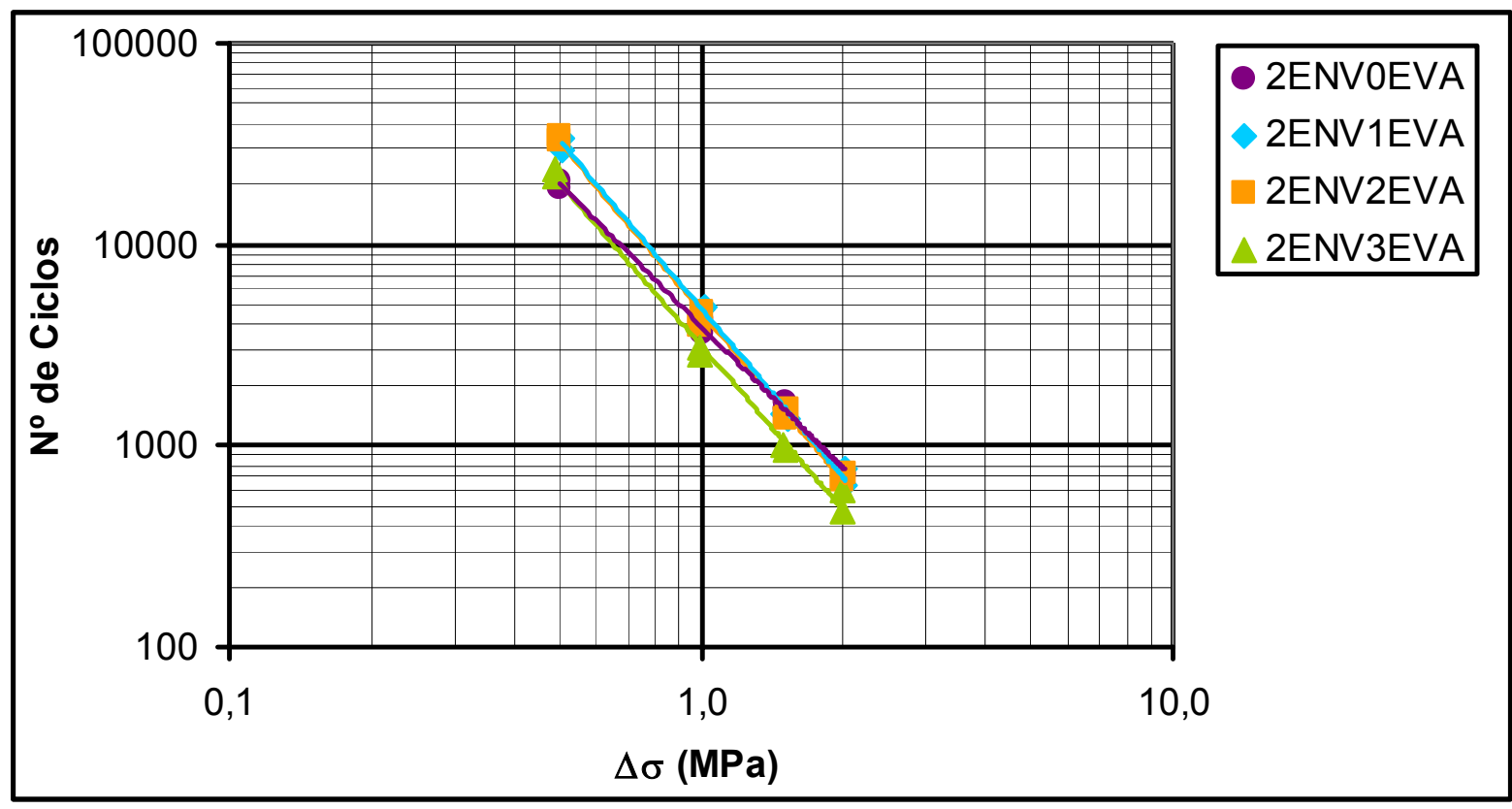

Figura 4.47. Programa experimental - Número de ciclos em função da diferença de tensões em corpos-de-prova com 2 horas de envelhecimento.

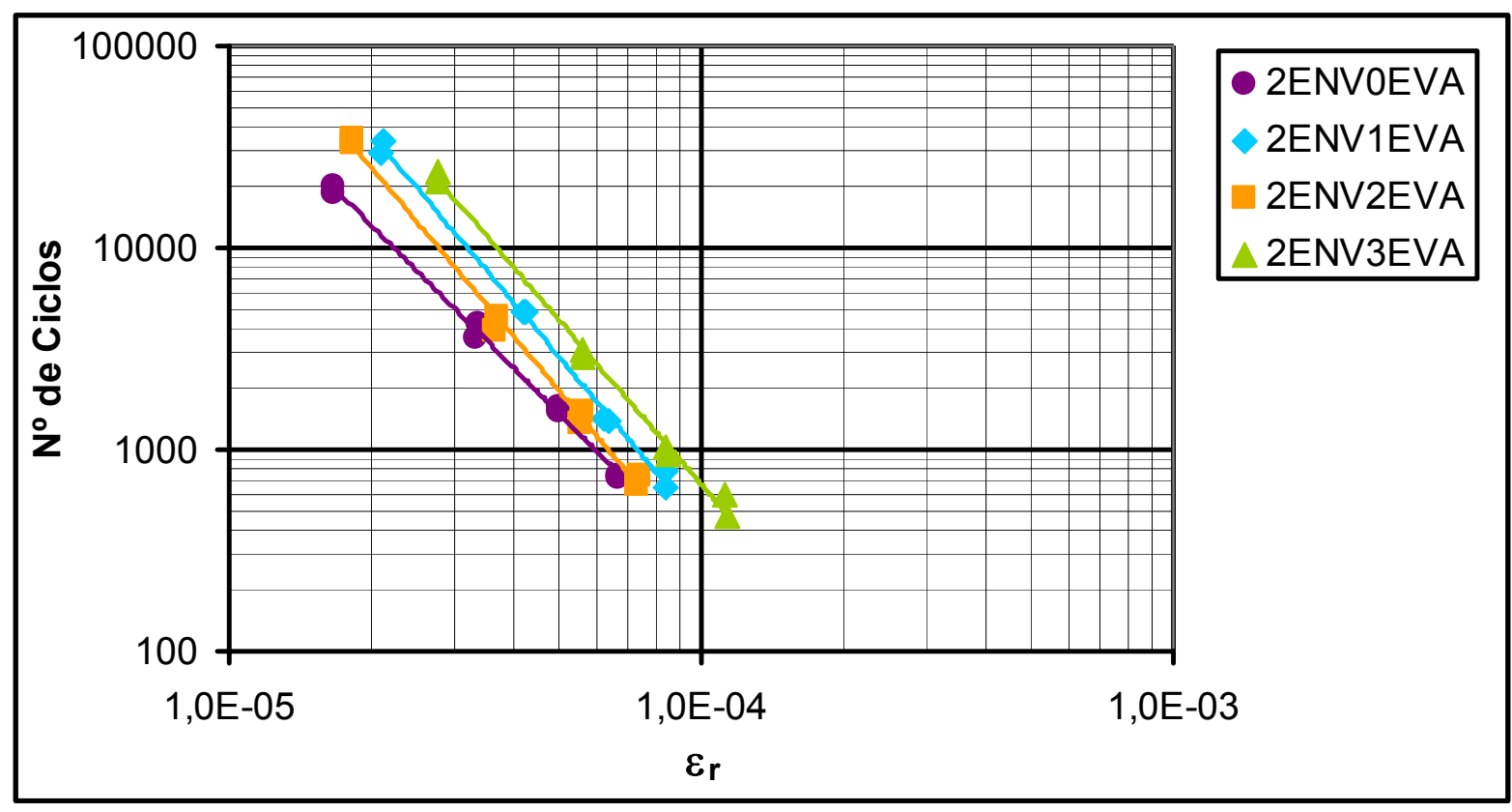

Figura 4.48. Programa experimental - Número de ciclos em função da deformação resiliente em corpos-de-prova com 2 horas de envelhecimento. 


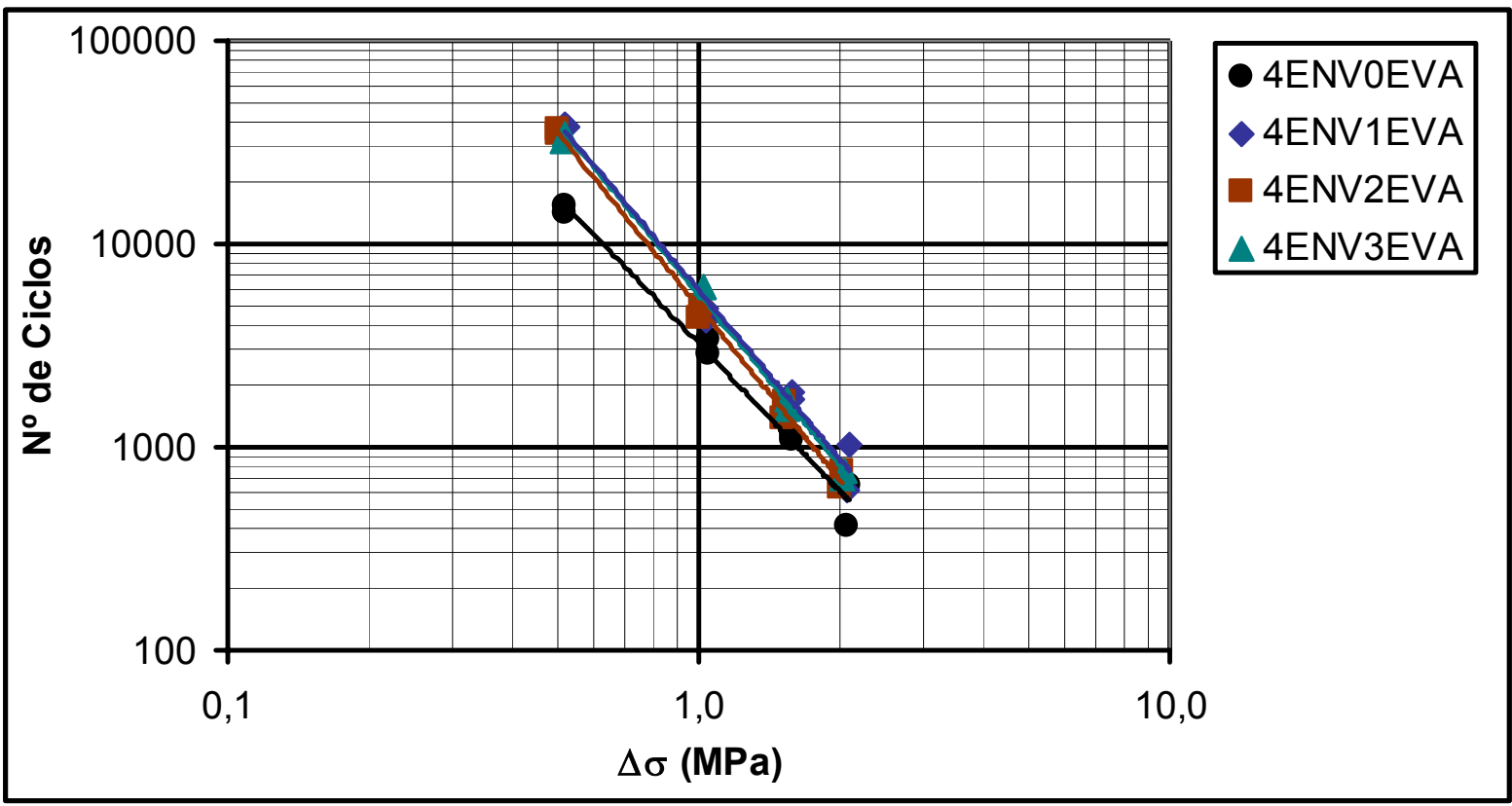

Figura 4.49. Programa experimental - Número de ciclos em função da diferença de tensões em corpos-de-prova com 4 horas de envelhecimento.

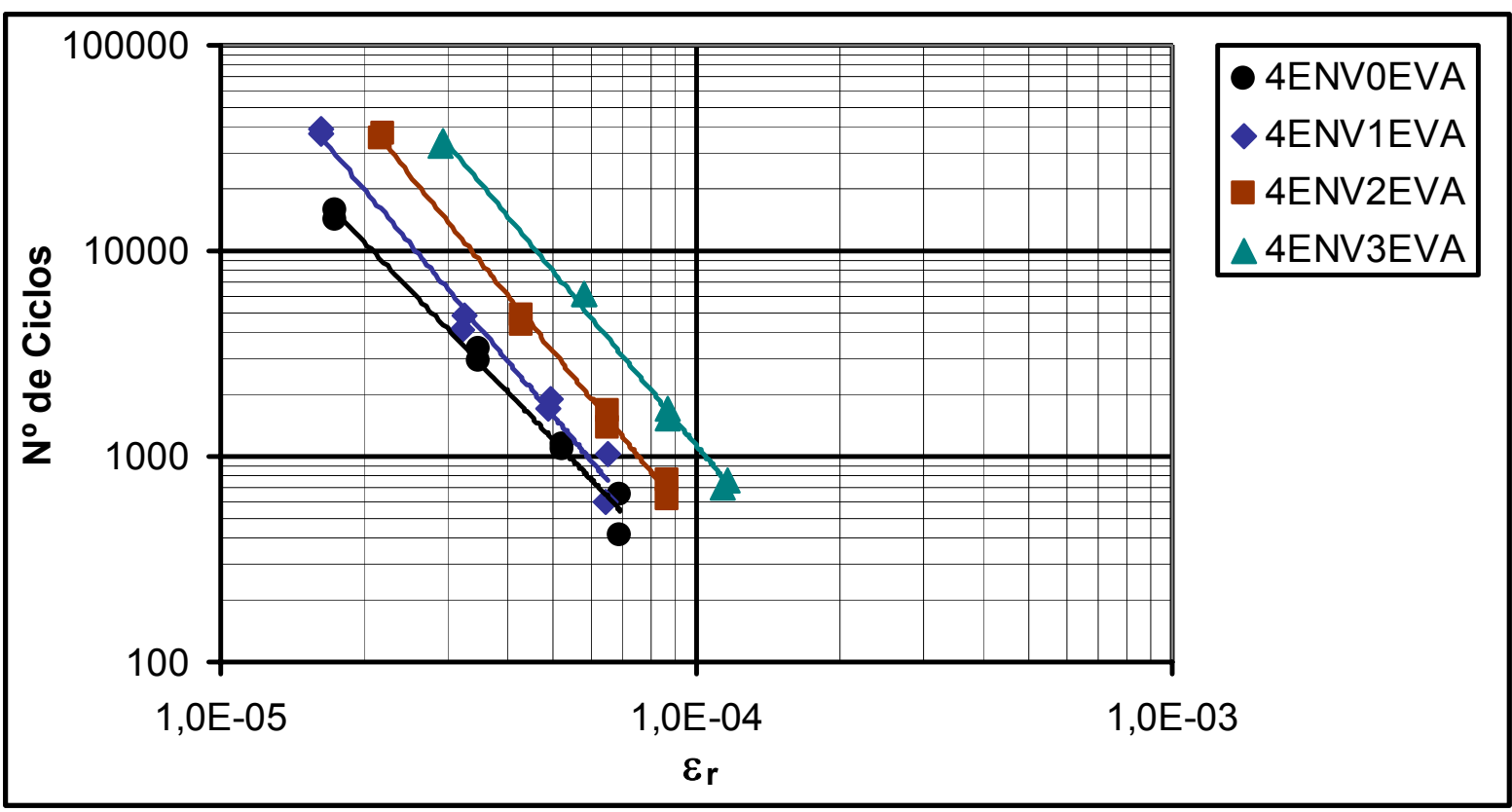

Figura 4.50. Programa experimental - Número de ciclos em função da deformação resiliente em corpos-de-prova com 4 horas de envelhecimento. 


\subsubsection{Simulação de tensões utilizando o programa ELSYM5}

Para a análise da vida de fadiga de misturas asfálticas, não basta apenas analisar as curvas de diferenças de tensões obtidas por regressão em laboratório, deve-se levar em conta o módulo de resiliência de cada material, pois este está diretamente ligado às características visco-elásticas do material e, portanto, à sua resistência à fadiga.

Com o auxílio do programa ELSYM5 e a partir de duas estruturas de pavimentos hipotéticas, foram determinadas as diferenças de tensões na fibra inferior da camada de revestimento asfáltico. Para a análise foram considerados dois carregamentos, com a finalidade de simular rodas duplas, separados por uma distância de $28,8 \mathrm{~cm}$ e com pressão de carregamento de $5,6 \mathrm{kgf} / \mathrm{cm}^{2}$, aplicada em uma área de $10,8 \mathrm{~cm}^{2}$. A Figura 4.51 mostra um desenho esquemático da estrutura hipotética do pavimento, em que os pontos $A, B$ e $C$ são os locais de análise de tensões e a origem do sistema $(0,0,0)$ se dá sob o carregamento à esquerda. As características das camadas estão descritas na Tabela 4.21. 


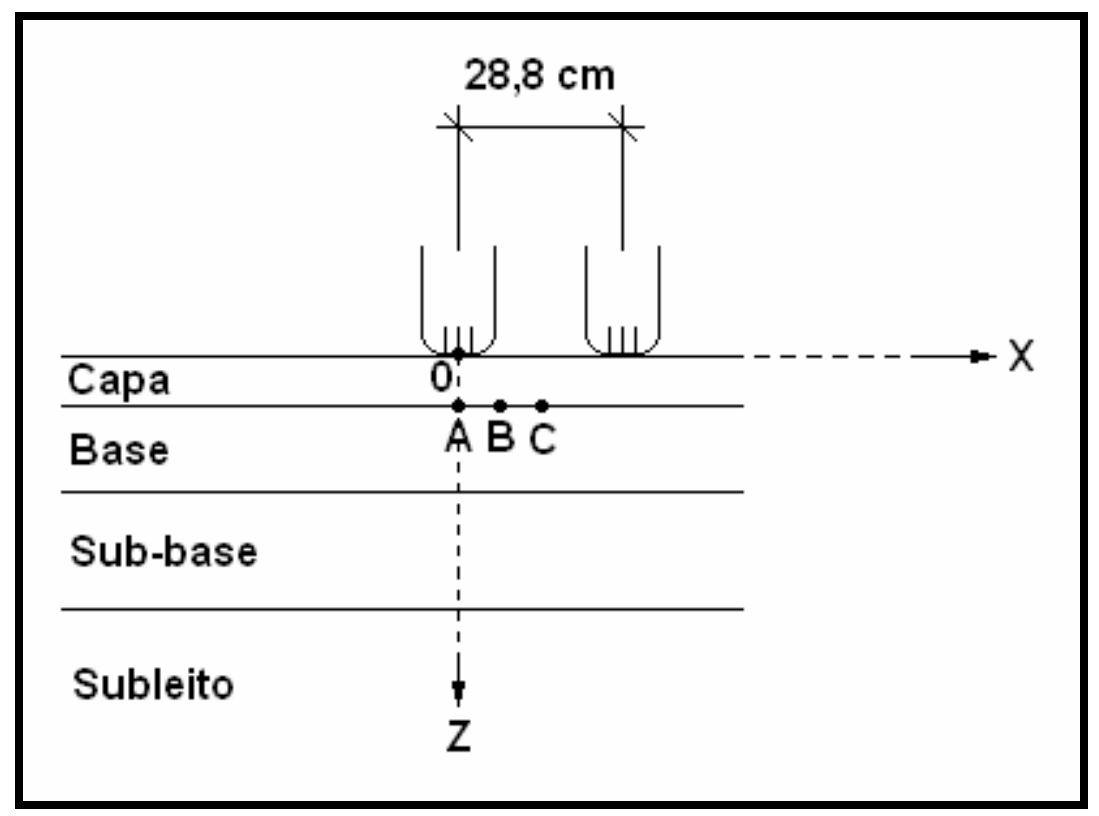

Figura 4.51. Esquema do pavimento hipotético.

O intuito de se analisar duas estruturas diferentes é verificar o comportamento à fadiga da mistura asfáltica quando de sua utilização em pavimentos esbeltos e mais flexíveis ou espessos e menos flexíveis.

Tabela 4.21 - Estruturas hipotéticas para análise das tensões através do programa ELSYM5.

\begin{tabular}{ccccc}
\hline Estrutura & Camada & $\begin{array}{c}\text { Espessura } \\
(\mathbf{c m})\end{array}$ & $\begin{array}{c}\text { Coeficiente de } \\
\text { Poisson }\end{array}$ & $\begin{array}{c}\text { Módulo de } \\
\text { resiliência (kgf) }\end{array}$ \\
\hline \multirow{2}{*}{1} & Capa & 15 & 0,35 & Variável \\
& Base & 25 & 0,40 & 3000 \\
& Sub-base & 30 & 0,40 & 2000 \\
& Subleito & Semi-infinito & 0,45 & 500 \\
\hline \multirow{2}{*}{2} & Capa & 10 & 0,35 & Variável \\
& Base & 15 & 0,40 & 2000 \\
& Sub-base & 20 & 0,40 & 1500 \\
& Subleito & Semi-infinito & 0,45 & 500 \\
\hline
\end{tabular}


Para cada condição experimental foi feito uma simulação e as tensões geradas pelo programa foram utilizadas nos modelos de cada material (Equação 4.6) e, assim, determinado o número de ciclos correspondente. Nas Tabelas 4.22 e 4.23 encontram-se as tensões nos pontos mais críticos e o número de ciclos correspondente e as Figuras 4.52 e 4.53 representam graficamente esses valores.

$$
N=k_{1} \times\left(\frac{1}{\Delta \sigma}\right)^{k_{2}}
$$

$\mathrm{Na}$ estrutura 1, o ponto com as diferenças de tensões mais críticas foi o ponto $\mathrm{B}$, já na estrutura 2 , as diferenças de tensões mais críticas se deu no ponto $A$.

Tabela 4.22 - Vida de fadiga para cada condição experimental de acordo com as tensões geradas pelo programa ELSYM5 para a estrutura 1.

\begin{tabular}{|c|c|c|c|c|c|c|c|}
\hline \multirow{2}{*}{$\begin{array}{c}\text { Env. } \\
\text { (h) }\end{array}$} & \multirow{2}{*}{$\begin{array}{l}\text { EVA } \\
(\%) \\
\end{array}$} & \multirow{2}{*}{$\begin{array}{c}\sigma_{\mathrm{t}} \\
(\mathrm{MPa})\end{array}$} & \multirow{2}{*}{$\begin{array}{c}\sigma_{\mathrm{c}} \\
(\mathrm{MPa})\end{array}$} & \multirow{2}{*}{$\begin{array}{c}\Delta \sigma \\
(\mathrm{MPa})\end{array}$} & \multicolumn{2}{|c|}{ Modelo } & \multirow{2}{*}{$\mathbf{N}$} \\
\hline & & & & & $k_{1}$ & $\mathbf{k}_{2}$ & \\
\hline \multirow{4}{*}{0} & 0 & 1,02700 & $-0,07941$ & 1,10641 & 2626,6 & 2,4746 & 2045 \\
\hline & 1 & 0,90230 & $-0,09810$ & 1,00040 & 3261,7 & 2,7464 & 3258 \\
\hline & 2 & 0,85040 & $-0,09597$ & 0,94637 & 2760,7 & 2,8459 & 3230 \\
\hline & 3 & 0,64880 & $-0,11850$ & 0,76730 & 1530,6 & 2,5810 & 3032 \\
\hline \multirow{4}{*}{2} & 0 & 1,03800 & $-0,07846$ & 1,11646 & 3939,5 & 2,3486 & 3041 \\
\hline & 1 & 0,93060 & $-0,08810$ & 1,01870 & 4814,2 & 2,7800 & 4573 \\
\hline & 2 & 0,99080 & $-0,08257$ & 1,07337 & 4654,5 & 2,7913 & 3820 \\
\hline & 3 & 0,78900 & $-0,10240$ & 0,89140 & 3130,8 & 2,7033 & 4272 \\
\hline \multirow{4}{*}{4} & 0 & 1,03500 & $-0,07868$ & 1,11368 & 3221,1 & 2,4216 & 2482 \\
\hline & 1 & 1,06900 & $-0,07582$ & 1,14482 & 5907,1 & 2,7713 & 4061 \\
\hline & 2 & 0,92870 & $-0,08828$ & 1,01698 & 4901,7 & 2,8432 & 4673 \\
\hline & 3 & 0,79030 & $-0,10230$ & 0,89260 & 5637,4 & 2,8104 & 7758 \\
\hline
\end{tabular}




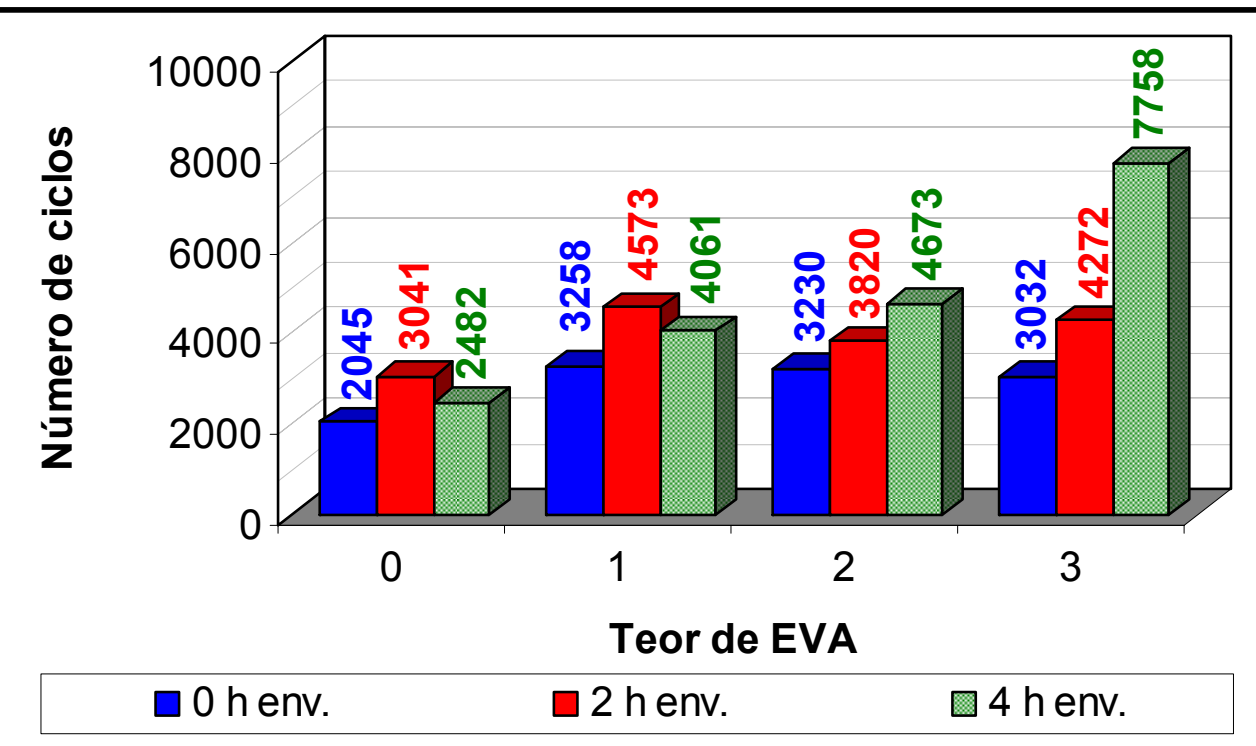

Figura 4.52. Vida de fadiga para cada condição experimental de acordo com as tensões geradas pelo programa ELSYM5 para a estrutura 1.

Tabela 4.23 - Vida de fadiga para cada condição experimental de acordo com as tensões geradas pelo programa ELSYM5 para a estrutura 2.

\begin{tabular}{|c|c|c|c|c|c|c|c|}
\hline \multirow{2}{*}{$\begin{array}{c}\text { Env. } \\
\text { (h) }\end{array}$} & \multirow{2}{*}{$\begin{array}{c}\text { EVA } \\
(\%)\end{array}$} & \multirow{2}{*}{$\begin{array}{c}\sigma_{\mathrm{t}} \\
(\mathrm{MPa})\end{array}$} & \multirow{2}{*}{$\begin{array}{c}\sigma_{\mathrm{c}} \\
(\mathrm{MPa})\end{array}$} & \multirow{2}{*}{$\begin{array}{c}\Delta \sigma \\
(\mathrm{MPa})\end{array}$} & \multicolumn{2}{|c|}{ Modelo } & \multirow{2}{*}{$\mathbf{N}$} \\
\hline & & & & & $k_{1}$ & $\mathbf{k}_{2}$ & \\
\hline \multirow{4}{*}{0} & 0 & 1,89000 & $-0,10920$ & 1,99920 & 2626,6 & 2,4746 & 473 \\
\hline & 1 & 1,66500 & $-0,12440$ & 1,78940 & 3261,7 & 2,7464 & 660 \\
\hline & 2 & 1,57200 & $-0,13130$ & 1,70330 & 2760,7 & 2,8459 & 606 \\
\hline & 3 & 1,21400 & $-0,16220$ & 1,37620 & 1530,6 & 2,5810 & 671 \\
\hline \multirow{4}{*}{2} & 0 & 1,91000 & $-0,10790$ & 2,01790 & 3939,5 & 2,3486 & 757 \\
\hline & 1 & 1,71600 & $-0,12080$ & 1,83680 & 4814,2 & 2,7800 & 888 \\
\hline & 2 & 1,82400 & $-0,11340$ & 1,93740 & 4654,5 & 2,7913 & 735 \\
\hline & 3 & 1,46200 & $-0,14000$ & 1,60200 & 3130,8 & 2,7033 & 876 \\
\hline \multirow{4}{*}{4} & 0 & 1,90500 & $-0,10820$ & 2,01320 & 3221,1 & 2,4216 & 592 \\
\hline & 1 & 1,96700 & $-0,10440$ & 2,07140 & 5907,1 & 2,7713 & 785 \\
\hline & 2 & 1,71200 & $-0,12100$ & 1,83300 & 4901,7 & 2,8432 & 875 \\
\hline & 3 & 1,46400 & $-0,13980$ & 1,60380 & 5637,4 & 2,8104 & 1495 \\
\hline
\end{tabular}




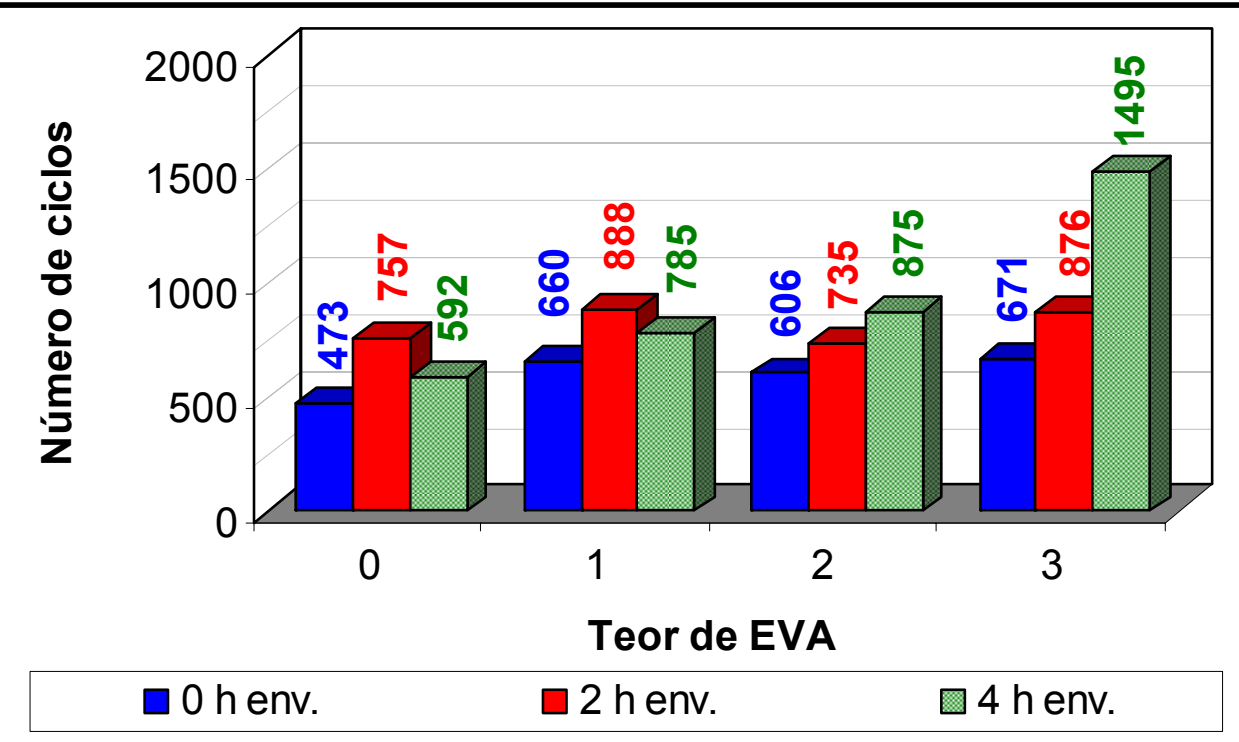

Figura 4.53. Vida de fadiga para cada condição experimental de acordo com as tensões geradas pelo programa ELSYM5 para a estrutura 2.

No geral, as misturas envelhecidas apresentaram maior resistência à ruptura por fadiga que as misturas sem envelhecimento. A vida de fadiga das misturas modificadas com EVA nas duas estruturas de pavimento propostas foram maiores que a das misturas de controle, salvo a mistura de controle com 2 horas de envelhecimento, que apresentou valor intermediário.

A inclinação das curvas das misturas modificadas foram praticamente as mesmas, diferentemente das misturas de controle, para um mesmo tempo de envelhecimento. O comportamento das misturas nos dois pavimentos simulados foi semelhante, sendo que o segundo pavimento apresenta número de ciclos que varia entre $20 \%$ e $25 \%$ do número de ciclos do primeiro. Os gráficos de deformação resiliente mostram que as misturas modificadas apresentam melhores resultados que as misturas de controle, principalmente quando a deformação é menor. 


\subsubsection{Fluência por compressão uniaxial estática}

O ensaio de fluência por compressão uniaxial estática foi realizado com tensão média de aproximadamente $4 \mathrm{kgf} / \mathrm{cm}^{2}$, aplicada estaticamente no plano axial dos corpos-de-prova, com o intuito de analisar a susceptibilidade das misturas à deformação permanente. Foram verificados os dados referentes à deformação total, deformação recuperável, deformação permanente, recuperação, módulo de fluência aos 3600 segundos, que é a relação entre a tensão média aplicada e a deformação total, módulo de fluência aos 4500 segundos, que é a relação entre a tensão aplicada e a deformação não recuperável, e as inclinações das curvas no estágio secundário de deformação.

Os resultados médios dos ensaios são apresentados na Tabela 4.24, enquanto as Figuras 4.54 a 4.60 mostram graficamente os resultados obtidos nos ensaios em função do tempo de envelhecimento e do teor de EVA. Os dados completos são encontrados no Apêndice $\mathrm{H}$. 
Tabela 4.24 - Programa experimental - Resultados dos ensaios de fluência por compressão uniaxial estática.

\begin{tabular}{|c|c|c|c|c|c|c|c|c|}
\hline $\begin{array}{l}\text { Env. } \\
\text { (h) }\end{array}$ & $\begin{array}{c}\text { EVA } \\
(\%)\end{array}$ & $\begin{array}{c}\text { Def. } \\
\text { total } \\
(\%)\end{array}$ & $\begin{array}{l}\text { Def. } \\
\text { recup. } \\
(\%)\end{array}$ & $\begin{array}{l}\text { Def. } \\
\text { perm. } \\
(\%)\end{array}$ & $\begin{array}{c}\text { Recup. } \\
\text { (\%) }\end{array}$ & $\begin{array}{c}\text { Módulo } \\
\text { fluência } \\
3600 \mathrm{~s} \\
(\mathrm{MPa})\end{array}$ & $\begin{array}{l}\text { Módulo } \\
\text { fluência } \\
4500 \mathrm{~s} \\
(\mathrm{MPa})\end{array}$ & Inclin. \\
\hline \multirow{4}{*}{0} & 0 & 0,209 & 0,176 & 0,034 & 84,9 & 194 & 1975 & 0,0395 \\
\hline & 1 & 0,489 & 0,421 & 0,069 & 85,8 & 86 & 657 & 0,0430 \\
\hline & 2 & 0,801 & 0,706 & 0,095 & 88,2 & 49 & 536 & 0,0598 \\
\hline & 3 & 1,171 & 1,029 & 0,142 & 86,7 & 35 & 303 & 0,0787 \\
\hline \multirow{4}{*}{2} & 0 & 0,224 & 0,186 & 0,038 & 82,6 & 186 & 1156 & 0,0340 \\
\hline & 1 & 0,448 & 0,381 & 0,067 & 84,6 & 103 & 690 & 0,0382 \\
\hline & 2 & 0,765 & 0,671 & 0,095 & 87,4 & 60 & 484 & 0,0454 \\
\hline & 3 & 1,052 & 0,903 & 0,149 & 86,1 & 41 & 281 & 0,0606 \\
\hline \multirow{4}{*}{4} & 0 & 0,248 & 0,200 & 0,048 & 80,8 & 163 & 983 & 0,0338 \\
\hline & 1 & 0,343 & 0,287 & 0,057 & 83,6 & 117 & 848 & 0,0368 \\
\hline & 2 & 0,671 & 0,577 & 0,095 & 85,5 & 63 & 436 & 0,0424 \\
\hline & 3 & 0,947 & 0,796 & 0,151 & 84,3 & 42 & 281 & 0,0535 \\
\hline
\end{tabular}

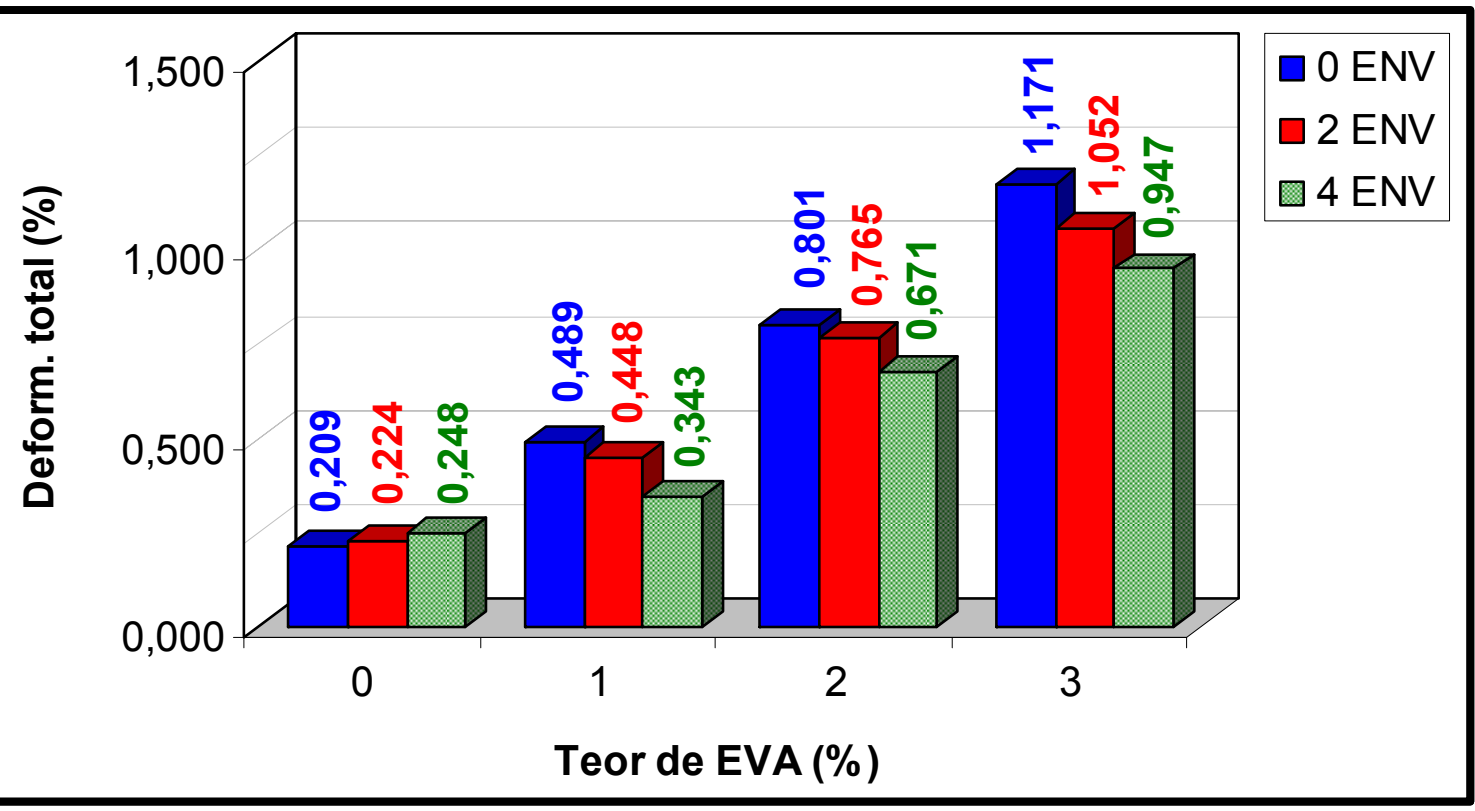

Figura 4.54. Programa experimental - Deformações totais medidas no ensaio de fluência por compressão uniaxial estática. 


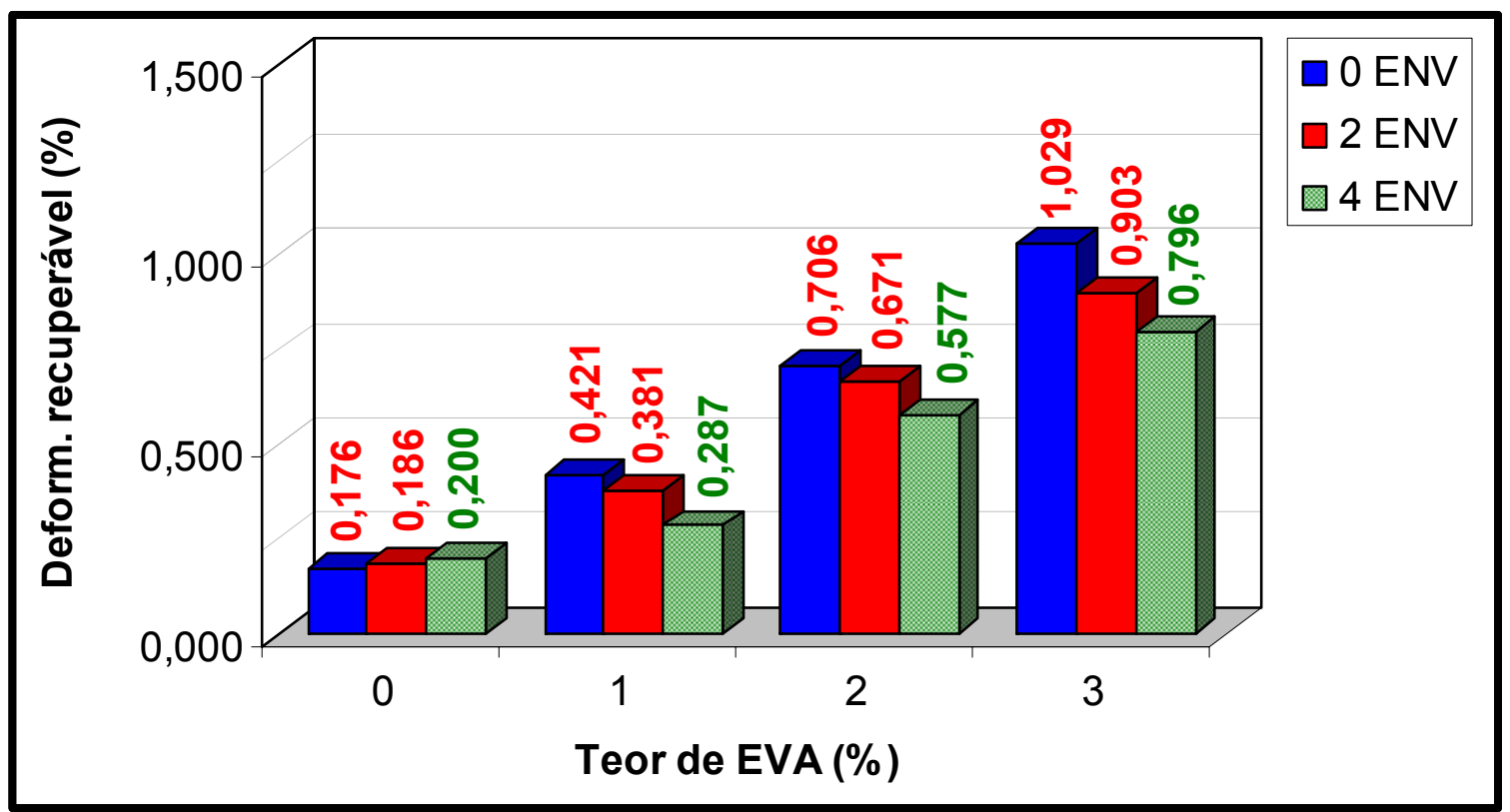

Figura 4.55. Programa experimental - Deformações recuperáveis medidas no ensaio de fluência por compressão uniaxial estática.

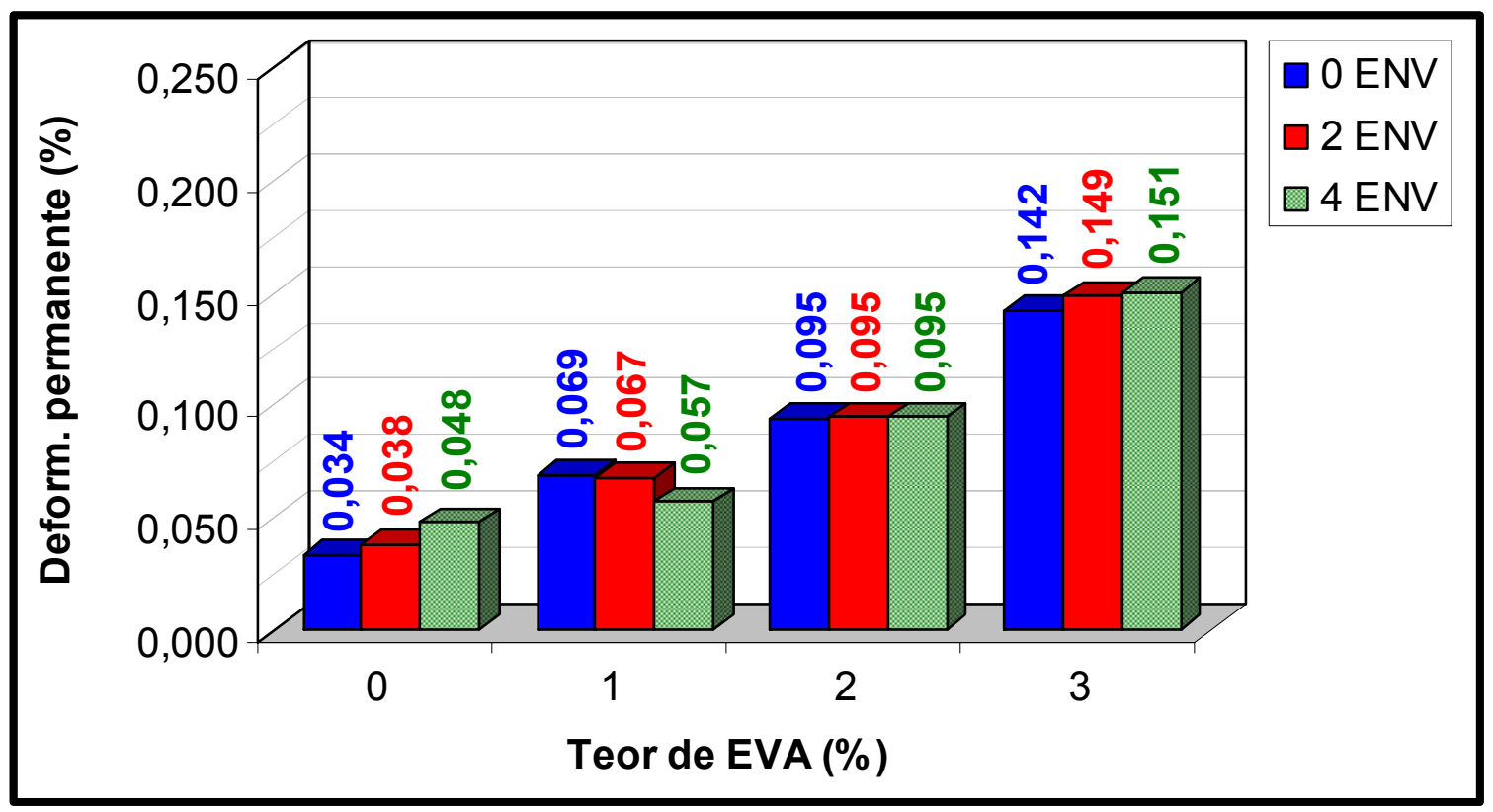

Figura 4.56. Programa experimental - Deformações permanentes medidas no ensaio de fluência por compressão uniaxial estática. 


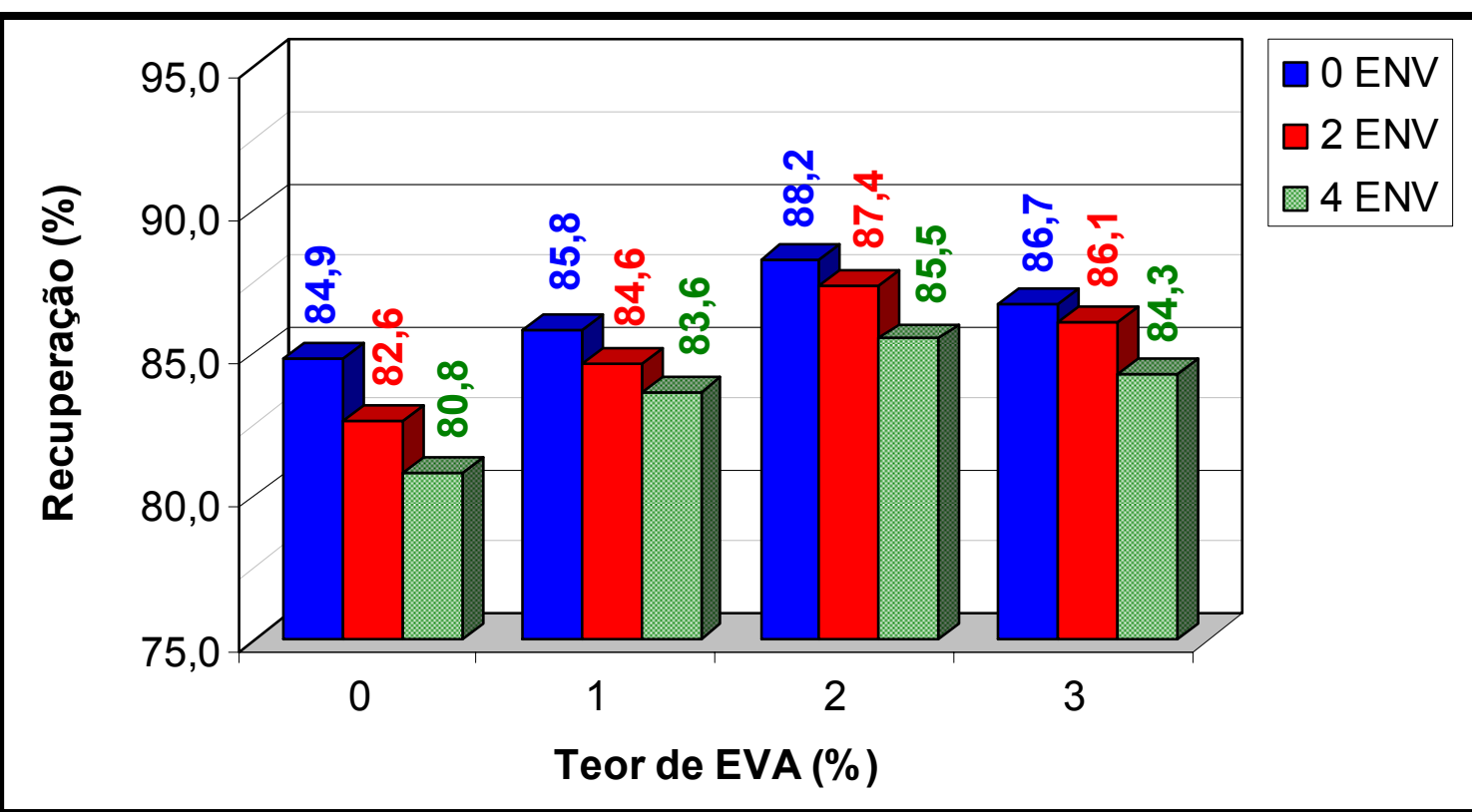

Figura 4.57. Programa experimental - Recuperações medidas no ensaio de fluência por compressão uniaxial estática.

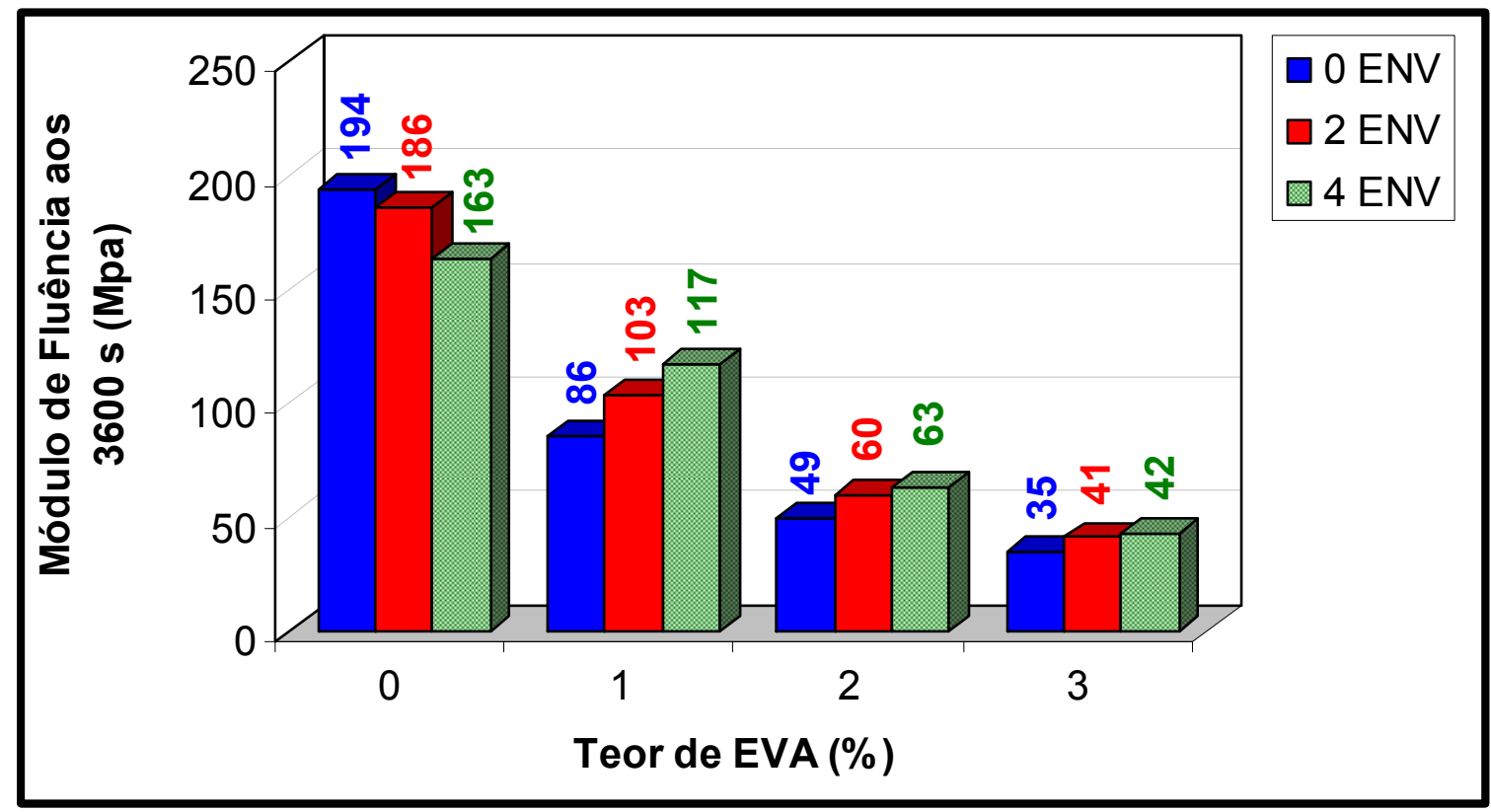

Figura 4.58. Programa experimental - Módulos de fluência medidos aos 3600 segundos no ensaio de fluência por compressão uniaxial estática. 


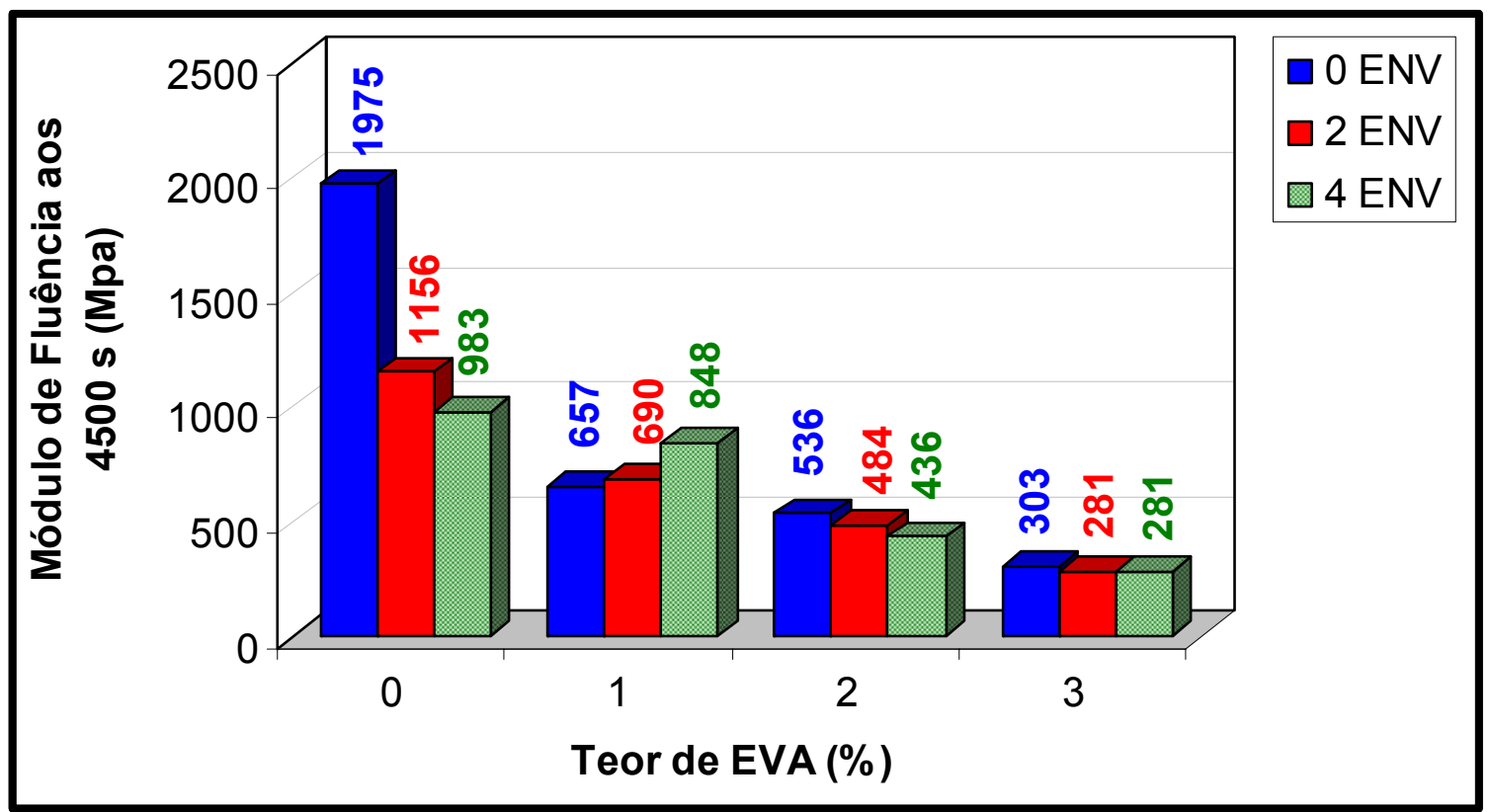

Figura 4.59. Programa experimental - Módulos de fluência medidos aos 4500 segundos no ensaio de fluência por compressão uniaxial estática.

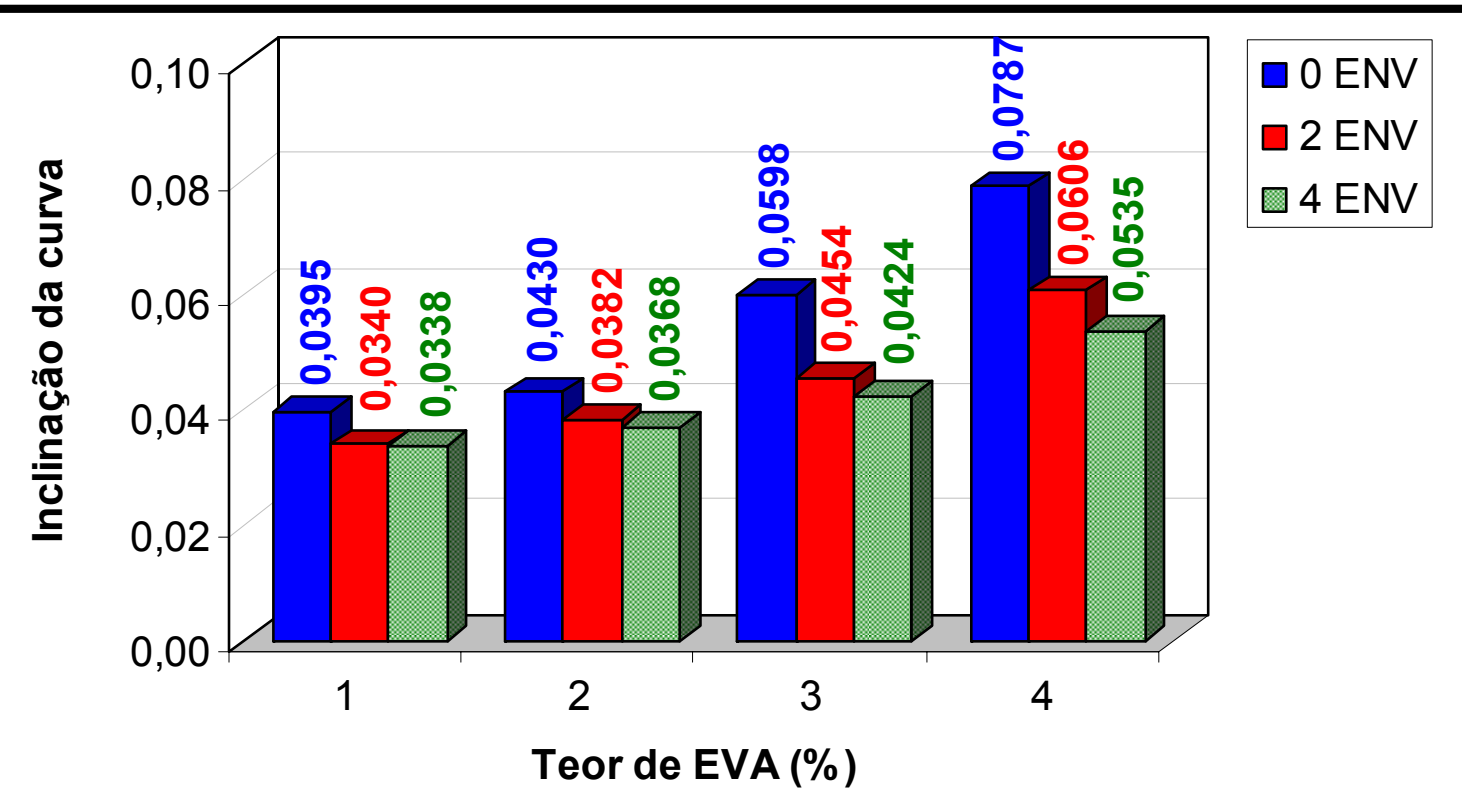

Figura 4.60. Programa experimental - Inclinações das curvas no ensaio de fluência por compressão uniaxial estática. 
As deformações totais, recuperáveis e permanentes aumentaram com o aumento do teor de resíduo nas misturas. Para as misturas modificadas, a deformação total e a deformação recuperável diminuíram com o envelhecimento, enquanto que para a mistura de controle aumentaram. A recuperação das misturas foi menor quanto maior o envelhecimento, para mesmos teores de EVA.

Os valores dos módulos de fluência medidos aos 3600 segundos decresceram com o incremento de resíduo, para mesmos tempos de envelhecimento. As misturas modificadas apresentaram módulo de fluência aos 3600 segundos maior conforme o envelhecimento, ao contrário das misturas de controle. Em todos os casos o módulo de fluência aos 3600 segundos foi menor conforme o incremento de EVA. Os módulos de fluência após a recuperação foram menores conforme o aumento no teor de EVA das misturas. As inclinações no trecho secundário da curva de fluência foram maiores quanto maiores os teores de EVA nas misturas e menores quanto maior o tempo de envelhecimento.

\subsubsection{Análise da variância no ensaio de fluência por compressão uniaxial estática}

O teste $F$ foi utilizado para verificar a influência de cada fator, bem como suas interações, nos resultados do ensaio de fluência por compressão uniaxial estática. As Tabelas 4.25 a 4.30 mostram os resultados para cada parâmetro do ensaio e os seus respectivos modelos estatísticos. As Figuras 4.61 a 4.66 apresentam esses modelos graficamente. 
Tabela 4.25 - Análise da variância da deformação total medida no ensaio de fluência por compressão uniaxial estática, para significância de $5 \%$.

\begin{tabular}{cccccccc}
\hline Parâmetro & $\mathbf{G L}$ & $\mathbf{S Q}$ & $\mathbf{Q M}$ & Coeficiente & $\mathbf{F}_{\mathbf{0}}$ & $\mathbf{F}_{\text {critico }}$ & Significativo? \\
\hline Total & 26 & 2,4422 & 0,0939 & 0,73930 & 3,02 & 2,13 & Sim \\
$\mathrm{T}_{1}$ & 1 & 1,7217 & 1,7217 & 0,30928 & 55,38 & 4,41 & Sim \\
$\mathrm{T}_{\mathrm{q}}$ & 1 & 0,0006 & 0,0006 & $-0,00324$ & 0,02 & 4,41 & Não \\
$\mathrm{E}_{1}$ & 1 & 0,1419 & 0,1419 & $-0,08878$ & 4,56 & 4,41 & Sim \\
$\mathrm{E}_{\mathrm{q}}$ & 1 & 0,0033 & 0,0033 & $-0,00780$ & 0,11 & 4,41 & Não \\
$\mathrm{T}_{1} \mathrm{E}_{1}$ & 1 & 0,0093 & 0,0093 & $-0,02788$ & 0,30 & 4,41 & Não \\
$\mathrm{T}_{1} \mathrm{E}_{\mathrm{q}}$ & 1 & 0,0005 & 0,0005 & 0,00368 & 0,02 & 4,41 & Não \\
$\mathrm{T}_{\mathrm{q}} \mathrm{E}_{1}$ & 1 & 0,0052 & 0,0052 & $-0,01201$ & 0,17 & 4,41 & Não \\
$\mathrm{T}_{\mathrm{q}} \mathrm{E}_{\mathrm{q}}$ & 1 & 0,0001 & 0,0001 & 0,00095 & 0,00 & 4,41 & Não \\
Resíduo & 18 & 0,5596 & 0,0311 & - & - & - & - \\
\hline Modelo & $D T_{C E}(\%)=0,73930+0,30928 \times P_{l}(T)-0,08878 \times P_{l}(E)$ & $\mathrm{R}^{2}=0,7631$ \\
\hline \multicolumn{7}{c}{}
\end{tabular}

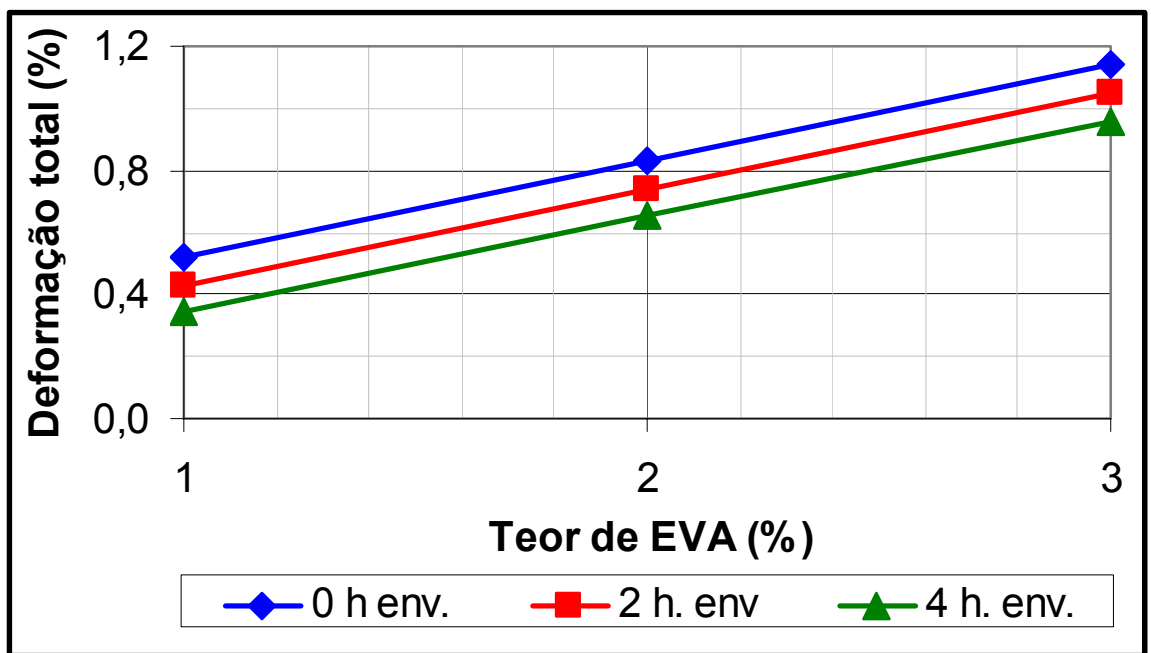

Figura 4.61. Programa Experimental - Modelo de deformação total do ensaio de fluência por compressão uniaxial estática em função do teor de EVA e do tempo de envelhecimento, para significância de $5 \%$. 
Tabela 4.26 - Análise da variância da deformação recuperável medida no ensaio de fluência por compressão uniaxial estática, para significância de 2,5\%.

\begin{tabular}{|c|c|c|c|c|c|c|c|}
\hline Parâmetro & $\mathbf{G L}$ & SQ & QM & Coeficiente & $F_{0}$ & $F_{\text {crítico }}$ & Significativo? \\
\hline Total & 26 & 1,8471 & 0,0710 & 0,63456 & 3,06 & 2,48 & Sim \\
\hline $\mathrm{T}_{1}$ & 1 & 1,2522 & 1,2522 & 0,26375 & 54,01 & 5,98 & Sim \\
\hline $\mathrm{T}_{\mathrm{q}}$ & 1 & 0,0037 & 0,0037 & $-0,00831$ & 0,16 & 5,98 & Não \\
\hline $\mathrm{E}_{1}$ & 1 & 0,1484 & 0,1484 & $-0,09081$ & 6,40 & 5,98 & Sim \\
\hline $\mathrm{E}_{\mathrm{q}}$ & 1 & 0,0025 & 0,0025 & $-0,00675$ & 0,11 & 5,98 & Não \\
\hline $\mathrm{T}_{1} \mathrm{E}_{1}$ & 1 & 0,0162 & 0,0162 & $-0,03679$ & 0,70 & 5,98 & Não \\
\hline $\mathrm{T}_{1} \mathrm{E}_{\mathrm{q}}$ & 1 & 0,0005 & 0,0005 & 0,00371 & 0,02 & 5,98 & Não \\
\hline $\mathrm{T}_{\mathrm{q}} \mathrm{E}_{\mathrm{l}}$ & 1 & 0,0061 & 0,0061 & $-0,01299$ & 0,26 & 5,98 & Não \\
\hline $\mathrm{T}_{\mathrm{q}} \mathrm{E}_{\mathrm{q}}$ & 1 & 0,0002 & 0,0002 & 0,00146 & 0,01 & 5,98 & Não \\
\hline Resíduo & 18 & 0,4173 & 0,0232 & - & - & - & - \\
\hline Modelo & \multicolumn{6}{|c|}{$D R_{C E}(\%)=0,63456+0,26375 \times P_{l}(T)-0,09081 \times P_{l}(E)$} & $\mathrm{R}^{2}=0,7583$ \\
\hline
\end{tabular}

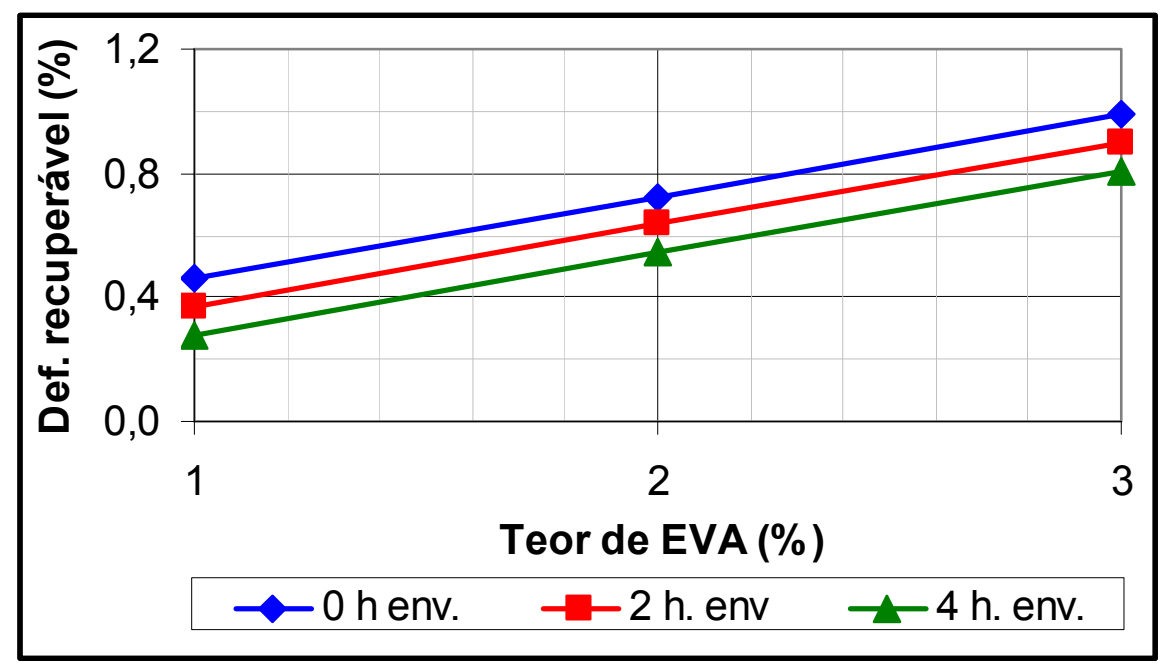

Figura 4.62. Programa Experimental - Modelo de deformação recuperável do ensaio de fluência por compressão uniaxial estática em função do teor de EVA e do tempo de envelhecimento, para significância de $5 \%$. 
Tabela 4.27 - Análise da variância da deformação permanente medida no ensaio de fluência por compressão uniaxial estática, para significância de 1\%.

\begin{tabular}{|c|c|c|c|c|c|c|c|}
\hline Parâmetro & $\mathbf{G L}$ & SQ & QM & Coeficiente & $F_{0}$ & $\mathbf{F}_{\text {critico }}$ & Significativo? \\
\hline Total & 26 & 0,04051 & 0,00156 & 0,10196 & 3,26 & 2,97 & Sim \\
\hline$T_{1}$ & 1 & 0,03079 & 0,03079 & 0,04136 & 64,42 & 8,29 & Sim \\
\hline$T_{q}$ & 1 & 0,00073 & 0,00073 & 0,00368 & 1,53 & 8,29 & Não \\
\hline $\mathrm{E}_{1}$ & 1 & 0,00000 & 0,00000 & $-0,00047$ & 0,01 & 8,29 & Sim \\
\hline$E_{q}$ & 1 & 0,00003 & 0,00003 & $-0,00077$ & 0,07 & 8,29 & Não \\
\hline $\mathrm{T}_{1} \mathrm{E}_{1}$ & 1 & 0,00032 & 0,00032 & 0,00517 & 0,67 & 8,29 & Não \\
\hline $\mathrm{T}_{1} \mathrm{E}_{\mathrm{q}}$ & 1 & 0,00001 & 0,00001 & 0,00039 & 0,01 & 8,29 & Não \\
\hline $\mathrm{T}_{\mathrm{q}} \mathrm{E}_{\mathrm{l}}$ & 1 & 0,00000 & 0,00000 & $-0,00028$ & 0,01 & 8,29 & Não \\
\hline $\mathrm{T}_{\mathrm{q}} \mathrm{E}_{\mathrm{q}}$ & 1 & 0,00001 & 0,00001 & $-0,00037$ & 0,03 & 8,29 & Não \\
\hline Resíduo & 18 & 0,00860 & 0,00048 & & & 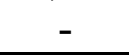 & \\
\hline Modelo & \multicolumn{6}{|c|}{$D P_{C E}(\%)=0,10196+0,04136 \times P_{l}(T)$} & $R^{2}=0,7602$ \\
\hline
\end{tabular}

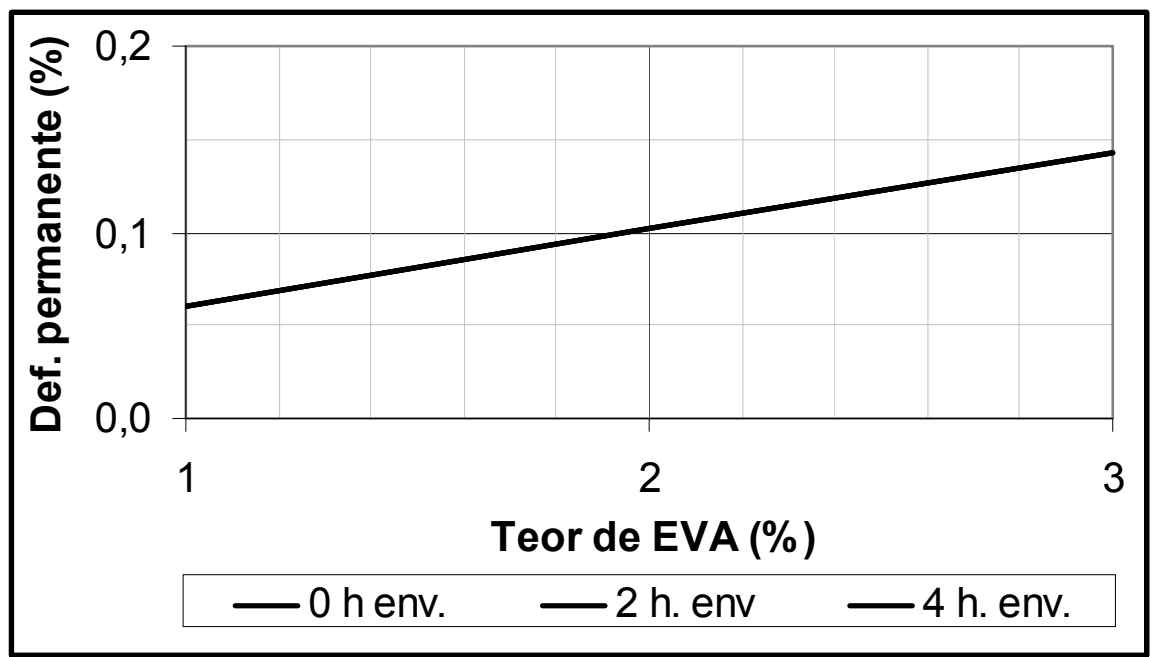

Figura 4.63. Programa Experimental - Modelo de deformação recuperável do ensaio de fluência por compressão uniaxial estática em função do teor de EVA e do tempo de envelhecimento, para significância de $5 \%$. 
Tabela 4.28 - Análise da variância do módulo de fluência medido aos 3600 s no ensaio de fluência por compressão uniaxial estática, para significância de $5 \%$.

\begin{tabular}{cccccccc}
\hline Parâm. & $\mathbf{G L}$ & $\mathbf{S Q}$ & $\mathbf{Q M}$ & Coefic. & $\mathbf{F}_{\mathbf{0}}$ & $\mathbf{F}_{\text {crítico }}$ & Signif.? \\
\hline Total & 26 & 23771,85 & 914,30 & 66,25 & 5,07 & 2,13 & Sim \\
$\mathrm{T}_{\mathrm{I}}$ & 1 & 17612,88 & 17612,88 & $-31,28$ & 97,59 & 4,41 & $\mathrm{Sim}$ \\
$\mathrm{T}_{\mathrm{q}}$ & 1 & 1072,49 & 1072,49 & 4,46 & 5,94 & 4,41 & $\mathrm{Sim}$ \\
$\mathrm{E}_{\mathrm{l}}$ & 1 & 1345,25 & 1345,25 & 8,65 & 7,45 & 4,41 & $\mathrm{Sim}$ \\
$\mathrm{E}_{\mathrm{q}}$ & 1 & 37,86 & 37,86 & $-0,84$ & 0,21 & 4,41 & Não \\
$\mathrm{T}_{\mathrm{l}} \mathrm{E}_{\mathrm{l}}$ & 1 & 421,26 & 421,26 & $-5,92$ & 2,33 & 4,41 & Não \\
$\mathrm{T}_{\mathrm{I}} \mathrm{E}_{\mathrm{q}}$ & 1 & 0,03 & 0,03 & $-0,03$ & 0,00 & 4,41 & Não \\
$\mathrm{T}_{\mathrm{q}} \mathrm{E}_{\mathrm{l}}$ & 1 & 31,72 & 31,72 & 0,94 & 0,18 & 4,41 & Não \\
$\mathrm{T}_{\mathrm{q}} \mathrm{E}_{\mathrm{q}}$ & 1 & 1,64 & 1,64 & 0,12 & 0,01 & 4,41 & Não \\
Resíduo & 18 & 3248,71 & 180,48 & - & - & - & - \\
\hline Modelo & $M F_{3600}(M P a)=66,3-31,3 \times P_{l}(T)+4,5 \times P_{q}(T)+8,6 \times P_{l}(E)$ & $\mathrm{R}^{2}=0,843$ \\
\hline
\end{tabular}

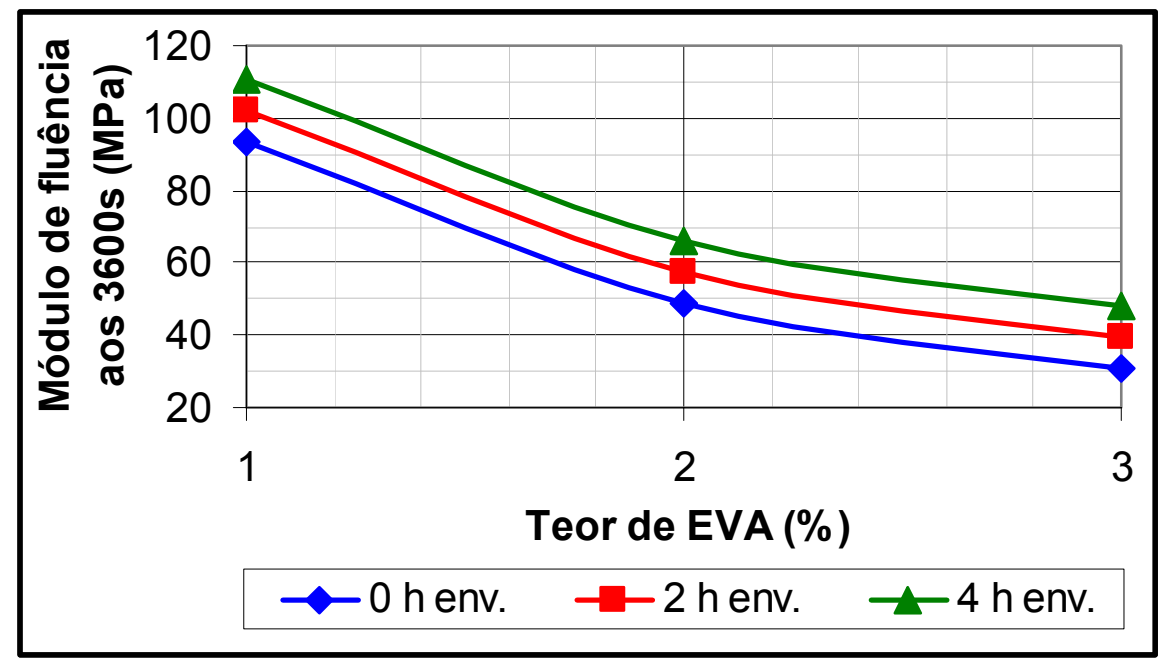

Figura 4.64. Programa Experimental - Modelo de módulo de fluência aos $3600 \mathrm{~s}$ do ensaio de fluência por compressão uniaxial estática em função do teor de EVA e do tempo de envelhecimento, para significância de $5 \%$. 
Tabela 4.29 - Análise da variância do módulo de fluência medido aos 4500 s no ensaio de fluência por compressão uniaxial estática, para significância de 1\%.

\begin{tabular}{|c|c|c|c|c|c|c|c|}
\hline Parâmetro & GL & SQ & QM & Coeficiente & $F_{0}$ & $\mathbf{F}_{\text {critico }}$ & Significativo? \\
\hline Total & 26 & 1184671 & 45564 & 506,48 & 3,04 & 2,97 & Sim \\
\hline$T_{1}$ & 1 & 829165 & 829165 & $-214,63$ & 55,34 & 8,29 & Sim \\
\hline $\mathrm{T}_{\mathrm{q}}$ & 1 & 5846 & 5846 & 10,40 & 0,39 & 8,29 & Não \\
\hline $\mathrm{E}_{1}$ & 1 & 2351 & 2351 & 11,43 & 0,16 & 8,29 & Não \\
\hline$E_{q}$ & 1 & 734 & 734 & 3,69 & 0,05 & 8,29 & Não \\
\hline $\mathrm{T}_{1} \mathrm{E}_{1}$ & 1 & 34027 & 34027 & $-53,25$ & 2,27 & 8,29 & Não \\
\hline $\mathrm{T}_{1} \mathrm{E}_{\mathrm{q}}$ & 1 & 8767 & 8767 & $-15,61$ & 0,59 & 8,29 & Não \\
\hline $\mathrm{T}_{\mathrm{q}} \mathrm{E}_{\mathrm{l}}$ & 1 & 33838 & 33838 & 30,66 & 2,26 & 8,29 & Não \\
\hline $\mathrm{T}_{\mathrm{q}} \mathrm{E}_{\mathrm{q}}$ & 1 & 257 & 257 & 1,54 & 0,02 & 8,29 & Não \\
\hline Resíduo & 18 & 269687 & 14983 & - & - & - & - \\
\hline Modelo & \multicolumn{6}{|c|}{$M F_{4500}(M P a)=506,48-214,63 \times P_{l}(T)$} & $R^{2}=0,6999$ \\
\hline
\end{tabular}

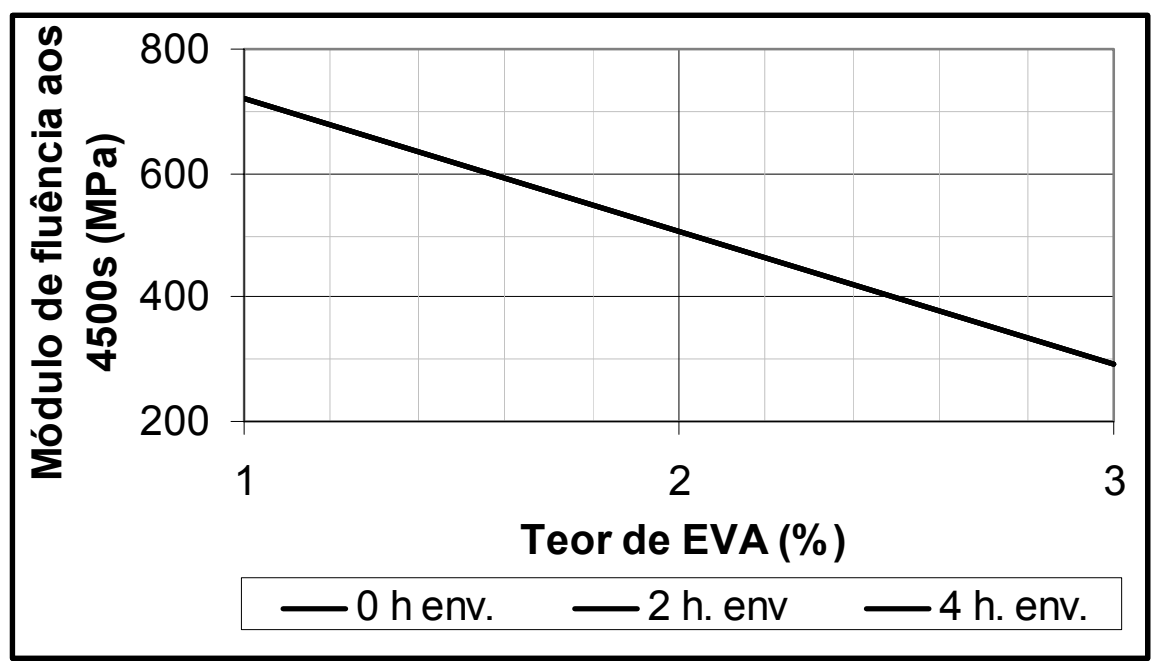

Figura 4.65. Programa Experimental - Modelo de módulo de fluência aos $4500 \mathrm{~s}$ do ensaio de fluência por compressão uniaxial estática em função do teor de EVA e do tempo de envelhecimento, para significância de $5 \%$. 
Tabela 4.30 - Análise da variância da inclinação da curva medida no estágio secundário do ensaio de fluência por compressão uniaxial estática, para significância de $2,5 \%$.

\begin{tabular}{cccccccc}
\hline Parâm. & GL & SQ & QM & Coefic. & $\mathbf{F}_{\mathbf{0}}$ & $\mathbf{F}_{\text {crítico }}$ & Signif.? \\
\hline Total & 26 & 0,005211 & 0,000200 & 0,05096 & 4,66 & 2,48 & Sim \\
$\mathrm{T}_{\mathrm{l}}$ & 1 & 0,002802 & 0,002802 & 0,01248 & 65,09 & 5,98 & $\mathrm{Sim}$ \\
$\mathrm{T}_{\mathrm{q}}$ & 1 & 0,000040 & 0,000040 & 0,00086 & 0,93 & 5,98 & $\mathrm{Não}$ \\
$\mathrm{E}_{\mathrm{l}}$ & 1 & 0,001193 & 0,001193 & $-0,00814$ & 27,72 & 5,98 & $\mathrm{Sim}$ \\
$\mathrm{E}_{\mathrm{q}}$ & 1 & 0,000110 & 0,000110 & 0,00143 & 2,57 & 5,98 & $\mathrm{Não}$ \\
$\mathrm{T}_{1} \mathrm{E}_{1}$ & 1 & 0,000268 & 0,000268 & $-0,00472$ & 6,21 & 5,98 & $\mathrm{Sim}$ \\
$\mathrm{T}_{1} \mathrm{E}_{\mathrm{q}}$ & 1 & 0,000014 & 0,000014 & 0,00063 & 0,33 & 5,98 & $\mathrm{Não}$ \\
$\mathrm{T}_{\mathrm{q}} \mathrm{E}_{\mathrm{l}}$ & 1 & 0,000003 & 0,000003 & 0,00028 & 0,06 & 5,98 & $\mathrm{Não}$ \\
$\mathrm{T}_{\mathrm{q}} \mathrm{E}_{\mathrm{q}}$ & 1 & 0,000006 & 0,000006 & $-0,00023$ & 0,14 & 5,98 & Não \\
Resíduo & 18 & 0,000775 & 0,000043 & - & - & - & - \\
\hline Modelo & $I_{C E}=0,051-0,012 \times P_{l}(T)-0,008 \times P_{l}(E)-0,005 \times P_{l}(T) \times P_{l}(E)$ & $\mathrm{R}^{2}=0,818$ \\
\hline
\end{tabular}

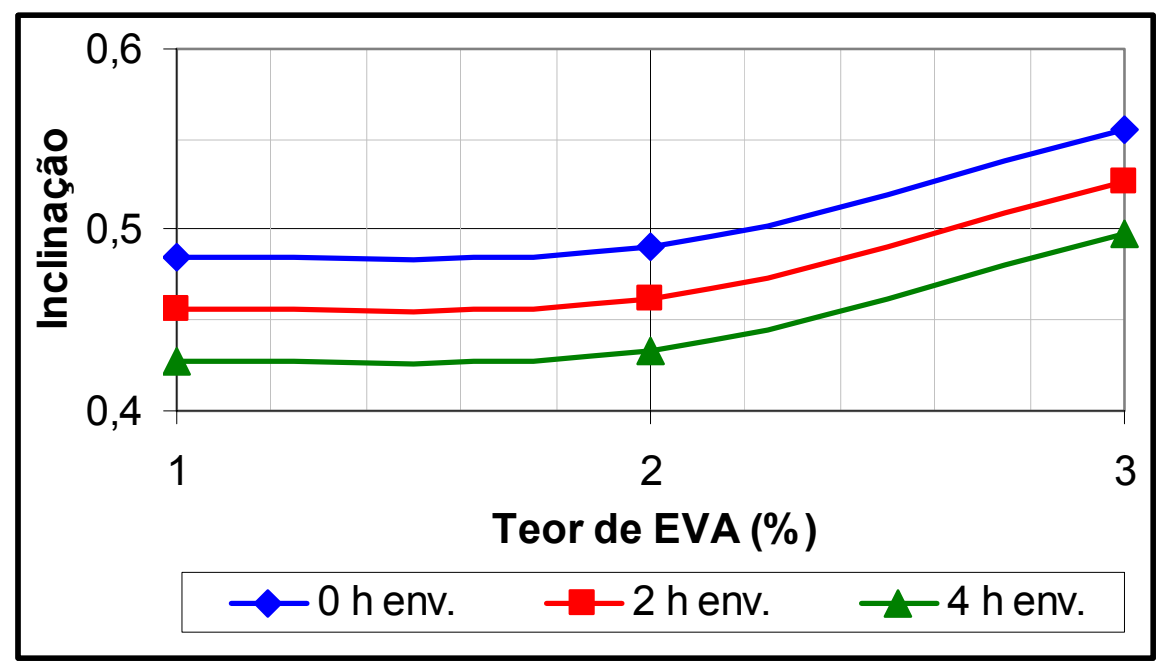

Figura 4.66. Programa Experimental - Modelo de inclinação da curva no estágio secundário do ensaio de fluência por compressão uniaxial estática em função do teor de EVA e do tempo de envelhecimento, para significância de 2,5\%. 


\subsubsection{Fluência por compressão uniaxial dinâmica}

O ensaio de fluência por compressão uniaxial dinâmica também foi realizado com a aplicação de uma tensão de $4 \mathrm{kgf} / \mathrm{cm}^{2}$, em um total de 5000 pulsos com 0,1 segundo de carregamento e 0,9 segundo de recuperação. Foram verificados a deformação total, o módulo de fluência (relação entre tensão aplicada e deformação total) e a inclinação da curva entre os pulsos 100 e 5000. Na Tabela 4.31 encontram-se as médias aritméticas dos corpos-de-prova utilizados para cada condição experimental e nas Figuras 4.67 a 4.69 estão representadas as médias graficamente. Os resultados completos encontram-se no Apêndice I.

Tabela 4.31 - Programa experimental - Resultados dos ensaios de fluência por compressão uniaxial dinâmica.

\begin{tabular}{ccccc}
\hline Env. (h) & EVA (\%) & Def. total (\%) & Módulo de fluência (MPa) & Inclinação \\
\hline \multirow{3}{*}{0} & 0 & 0,71883 & 59,72 & 0,3870434 \\
& 1 & 1,49417 & 27,34 & 0,4858157 \\
& 2 & 2,02583 & 20,61 & 0,4920284 \\
& 3 & 2,26650 & 17,97 & 0,5566220 \\
\hline \multirow{2}{*}{2} & 0 & 1,13550 & 38,48 & 0,5073219 \\
& 1 & 1,21150 & 34,76 & 0,4592940 \\
& 2 & 1,76067 & 27,19 & 0,4656871 \\
& 3 & 2,12000 & 19,30 & 0,5191717 \\
\hline \multirow{3}{*}{4} & 0 & 0,96567 & 45,85 & 0,5142071 \\
& 1 & 1,17617 & 35,45 & 0,4220246 \\
& 2 & 1,46967 & 31,52 & 0,4320727 \\
& 3 & 1,86300 & 25,15 & 0,5036688 \\
\hline
\end{tabular}




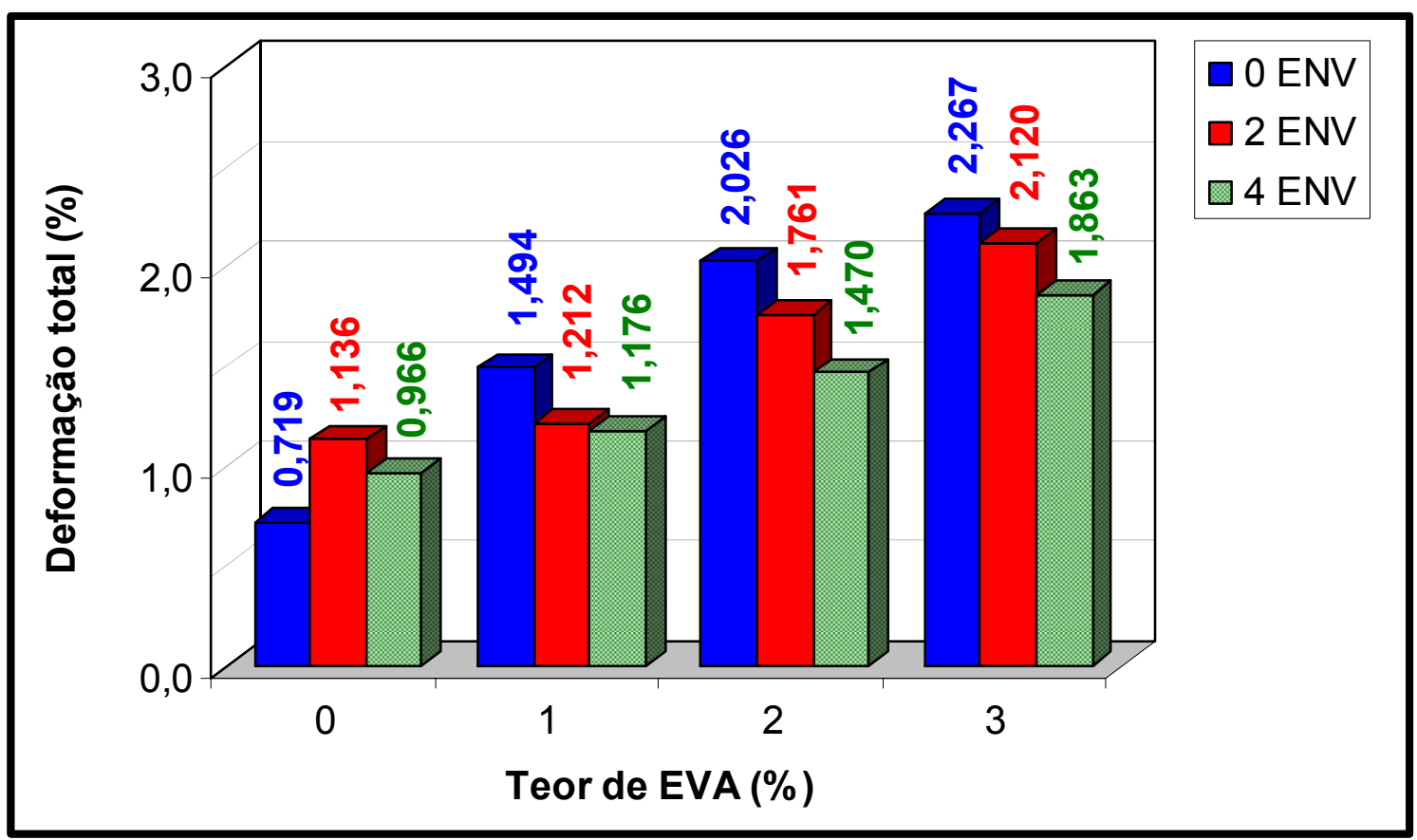

Figura 4.67. Programa experimental - Deformações totais medidas no ensaio de fluência por compressão uniaxial dinâmica.

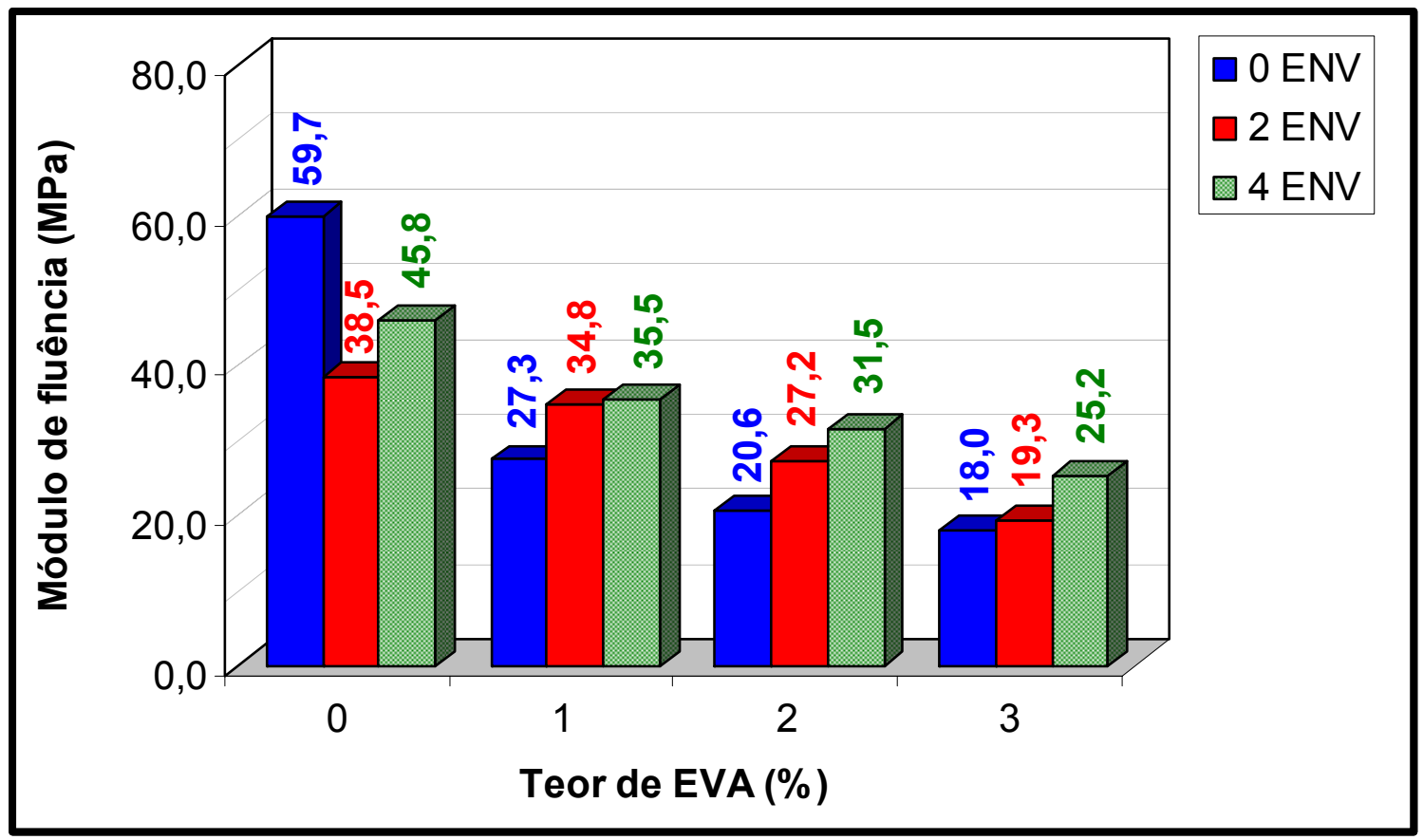

Figura 4.68. Programa experimental - Módulos de fluência medidos no ensaio de fluência por compressão uniaxial dinâmica. 


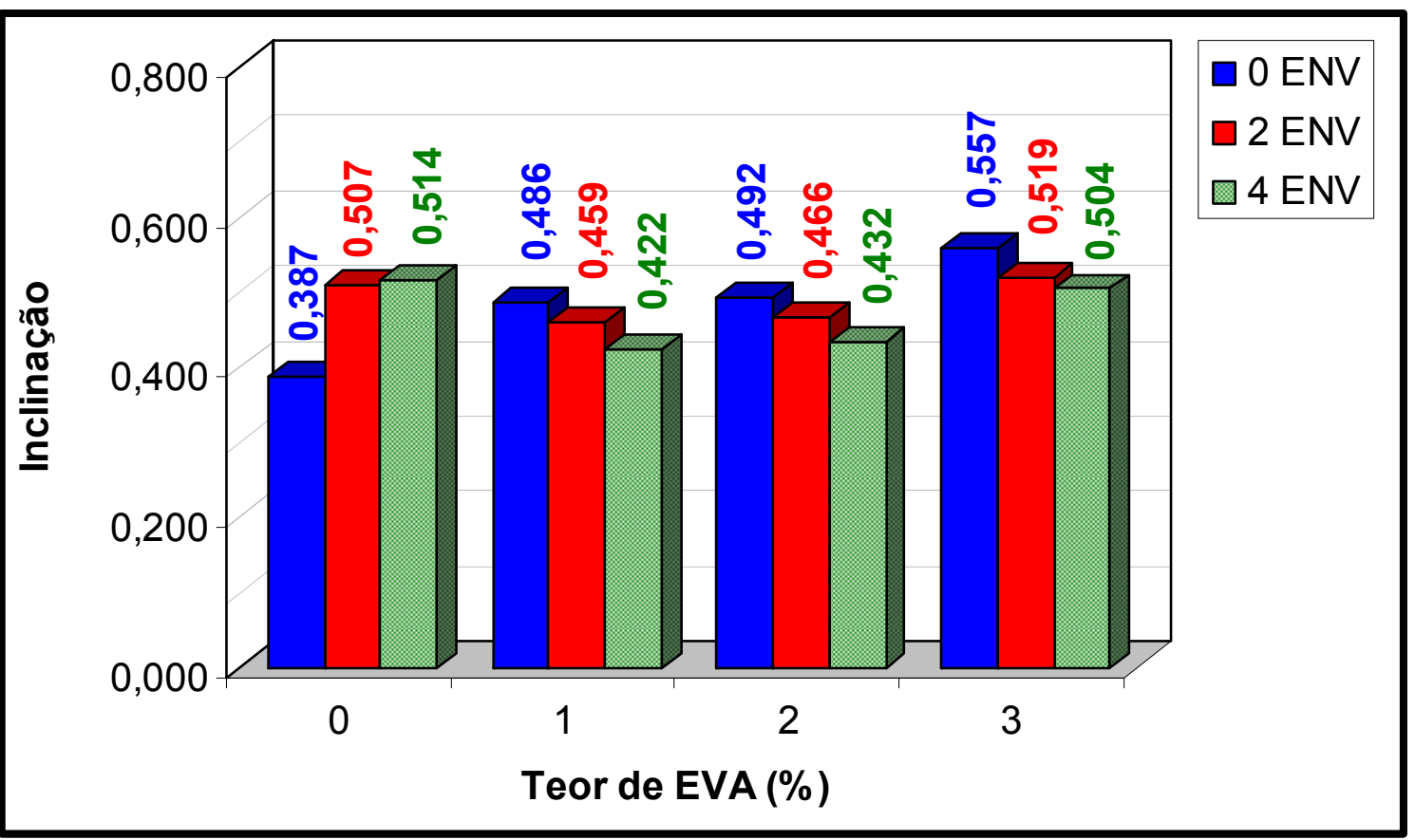

Figura 4.69. Programa experimental - Inclinações das curvas no ensaio de fluência por compressão uniaxial dinâmica.

A deformação total das misturas aumentou com o aumento do teor de EVA, para os mesmos tempos de envelhecimento, com as misturas modificadas apresentando menor deformação total para maiores tempos de envelhecimento. $\mathrm{Na}$ condição 0 hora de envelhecimento e $3 \%$ de teor de EVA, romperam-se 2 dos três corpos-deprova ensaiados, por deformação excessiva.

Os valores dos módulos de fluências das misturas foram menores quanto maior o teor de EVA nas misturas, para envelhecimentos semelhantes. A mistura de controle apresentou maior valor de módulo de fluência na condição 0 hora de envelhecimento, enquanto as misturas modificadas apresentaram maior valor com 4 horas de envelhecimento. As inclinações das curvas aumentaram conforme o aumento do tempo de envelhecimento para as misturas de controle e diminuíram 
para as misturas modificadas. O envelhecimento aumentou a resistência à deformação total e o módulo de fluência e diminui a inclinação da curva, nas misturas modificadas.

\subsubsection{Análise da variância e modelos estatísticos para os parâmetros do ensaio de fluência por compressão uniaxial dinâmica}

Os resultados foram submetidos ao teste $F$ para análise da variância, sendo os modelos apresentados nas Tabelas 4.32 a 4.34 , bem como o coeficiente de regressão de cada modelo e a significância do teste F. Nas Figuras 4.70 a 4.72 são apresentadas as curvas geradas com os modelos estatísticos.

Tabela 4.32 - Análise da variância da deformação total medida no ensaio de fluência por compressão uniaxial dinâmica, para significância de 5\%.

\begin{tabular}{cccccccc}
\hline Parâmetro & $\mathbf{G L}$ & $\mathbf{S Q}$ & $\mathbf{Q M}$ & Coeficiente & $\mathbf{F}_{\mathbf{0}}$ & $\mathbf{F}_{\text {crítico }}$ & Signif.? \\
\hline Total & 26 & 6,36533 & 0,24482 & 1,76731 & 2,85 & 2,13 & Sim \\
$\mathrm{T}_{1}$ & 1 & 4,16450 & 4,16450 & 0,48100 & 48,41 & 4,41 & Sim \\
$\mathrm{T}_{\mathrm{q}}$ & 1 & 0,00314 & 0,00314 & 0,00763 & 0,04 & 4,41 & Não \\
$\mathrm{E}_{\mid}$ & 1 & 0,37903 & 0,37903 & $-0,14511$ & 4,41 & 4,41 & Sim \\
$\mathrm{E}_{\mathrm{q}}$ & 1 & 0,01454 & 0,01454 & 0,01641 & 0,17 & 4,41 & Não \\
$\mathrm{T}_{\mid} \mathrm{E}_{\mid}$ & 1 & 0,07752 & 0,07752 & 0,08037 & 0,90 & 4,41 & Não \\
$\mathrm{T}_{\mid} \mathrm{E}_{\mathrm{q}}$ & 1 & 0,00753 & 0,00753 & $-0,01446$ & 0,09 & 4,41 & Não \\
$\mathrm{T}_{\mathrm{q}} \mathrm{E}_{\mid}$ & 1 & 0,15913 & 0,15913 & 0,06649 & 1,85 & 4,41 & Não \\
$\mathrm{T}_{\mathrm{q}} \mathrm{E}_{\mathrm{q}}$ & 1 & 0,01158 & 0,01158 & 0,01036 & 0,13 & 4,41 & Não \\
Resíduo & 18 & 1,54835 & 0,08602 & - & - & - & - \\
\hline Modelo & $D T_{C D}(\%)=1,76731+0,48100 \times P_{l}(T)-0,14511 \times P_{l}(E)$ & $\mathrm{R}^{2}=0,713$ \\
\hline
\end{tabular}




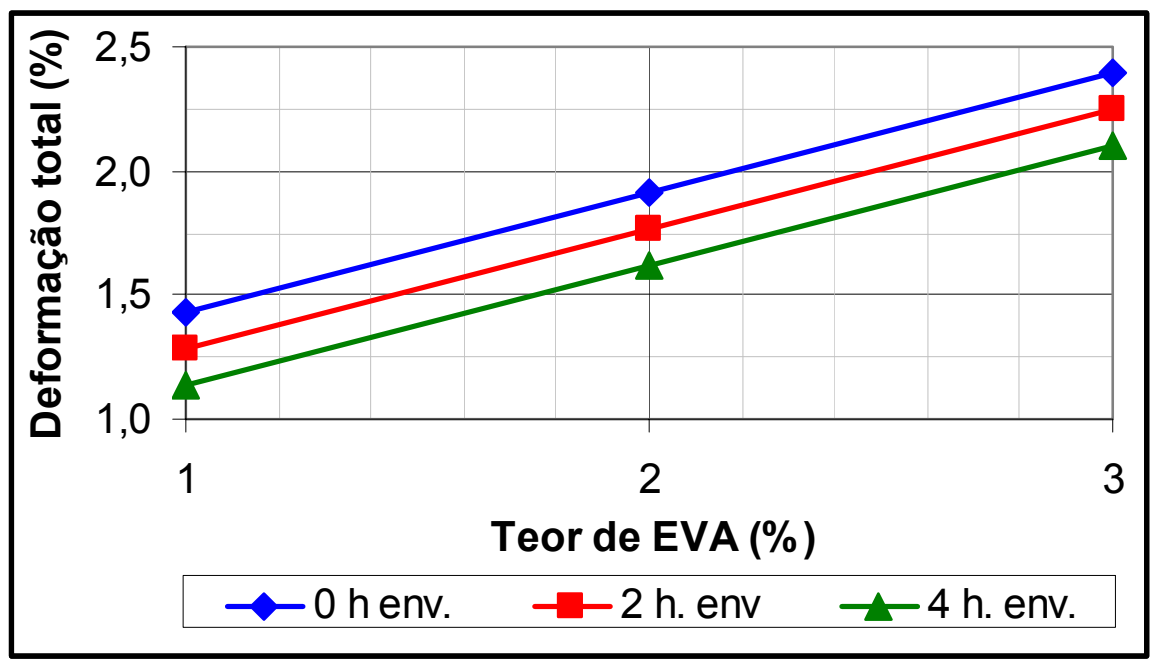

Figura 4.70 - Programa Experimental - Modelo de deformação total do ensaio de fluência por compressão uniaxial dinâmica em função do teor de EVA e do tempo de envelhecimento, para significância de 5\%.

Tabela 4.33 - Análise da variância do módulo de fluência medido no ensaio de fluência por compressão uniaxial dinâmica, para significância de 2,5\%.

\begin{tabular}{|c|c|c|c|c|c|c|c|}
\hline Parâmetro & GL & SQ & QM & Coeficiente & $F_{0}$ & $F_{\text {crítico }}$ & Signif.? \\
\hline Total & 26 & 1589,43 & 61,13 & 25,81 & 2,81 & 2,48 & Sim \\
\hline $\mathrm{T}_{1}$ & 1 & 887,86 & 887,86 & $-7,02$ & 40,77 & 5,98 & Sim \\
\hline $\mathrm{T}_{\mathrm{q}}$ & 1 & 5,35 & 5,35 & $-0,31$ & 0,25 & 5,98 & Não \\
\hline$E_{l}$ & 1 & 203,18 & 203,18 & 3,36 & 9,33 & 5,98 & Sim \\
\hline $\mathrm{E}_{\mathrm{q}}$ & 1 & 12,16 & 12,16 & $-0,47$ & 0,56 & 5,98 & Não \\
\hline $\mathrm{T}_{1} \mathrm{E}_{1}$ & 1 & 36,43 & 36,43 & $-1,74$ & 1,67 & 5,98 & Não \\
\hline$T_{1} E_{q}$ & 1 & 12,77 & 12,77 & 0,60 & 0,59 & 5,98 & Não \\
\hline$T_{q} E_{l}$ & 1 & 39,41 & 39,41 & $-1,05$ & 1,81 & 5,98 & Não \\
\hline $\mathrm{T}_{\mathrm{q}} \mathrm{E}_{\mathrm{q}}$ & 1 & 0,28 & 0,28 & $-0,05$ & 0,01 & 5,98 & Não \\
\hline Resíduo & 18 & 392,00 & 21,78 & - & - & - & - \\
\hline Modelo & \multicolumn{6}{|c|}{$M F_{C D}=25,81-7,02 \times P_{l}(T)-3,36 \times P_{l}(E)$} & $R^{2}=0,713$ \\
\hline
\end{tabular}




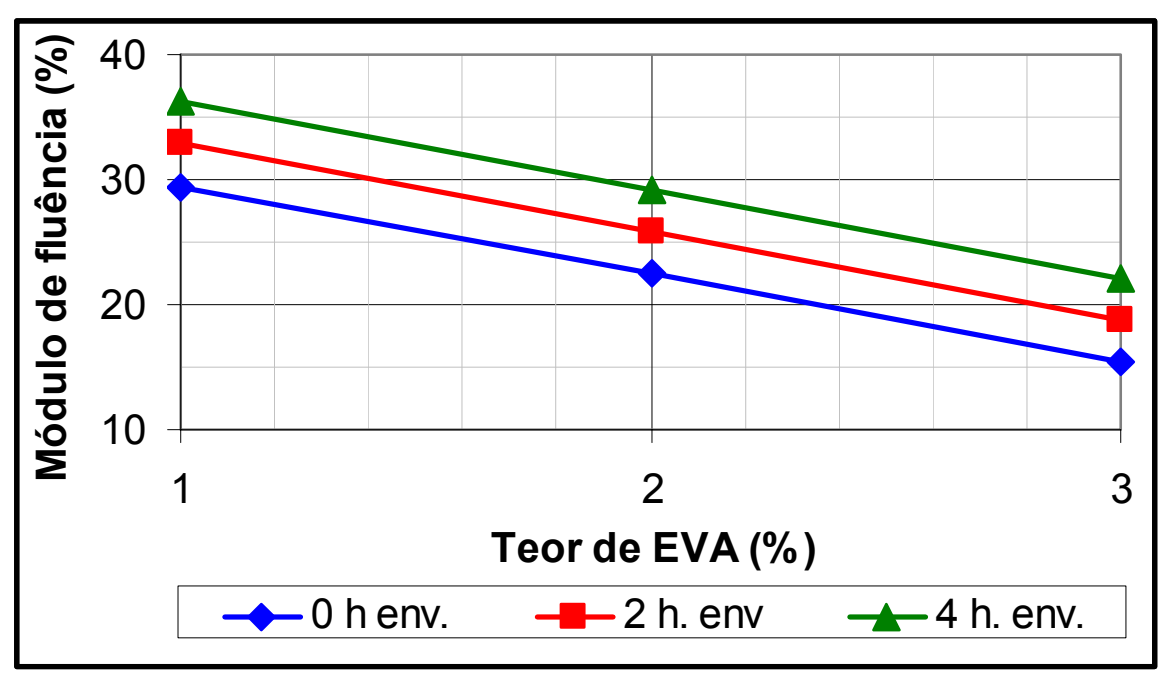

Figura 4.71. Programa Experimental - Modelo de módulo de fluência do ensaio de fluência por compressão uniaxial dinâmica em função do teor de EVA e do tempo de envelhecimento, para significância de 2,5\%.

Tabela 4.34 - Análise da variância da inclinação da curva medida no estágio secundário do ensaio de fluência por compressão uniaxial dinâmica, para significância de $2,5 \%$.

\begin{tabular}{cccccccc}
\hline Parâm. & GL & SQ & QM & Coef. & $\mathbf{F}_{\mathbf{0}}$ & $\mathbf{F}_{\text {crítico }}$ & Signif.? \\
\hline Total & 26 & 0,05692 & 0,00219 & 0,48140 & 2,84 & 2,48 & Sim \\
$\mathrm{T}_{\mid}$ & 1 & 0,02254 & 0,02254 & 0,03539 & 29,21 & 5,98 & Sim \\
$\mathrm{T}_{\mathrm{q}}$ & 1 & 0,00508 & 0,00508 & 0,00970 & 6,59 & 5,98 & $\mathrm{Sim}$ \\
$\mathrm{E}_{\mid}$ & 1 & 0,01494 & 0,01494 & $-0,02881$ & 19,36 & 5,98 & Sim \\
$\mathrm{E}_{\mathrm{q}}$ & 1 & 0,00000 & 0,00000 & 0,00001 & 0,00 & 5,98 & Não \\
$\mathrm{T}_{1} \mathrm{E}_{\mid}$ & 1 & 0,00009 & 0,00009 & 0,00271 & 0,11 & 5,98 & Não \\
$\mathrm{T}_{1} \mathrm{E}_{\mathrm{q}}$ & 1 & 0,00027 & 0,00027 & 0,00272 & 0,35 & 5,98 & Não \\
$\mathrm{T}_{\mathrm{q}} \mathrm{E}_{\mid}$ & 1 & 0,00001 & 0,00001 & $-0,00037$ & 0,01 & 5,98 & Não \\
$\mathrm{T}_{\mathrm{q}} \mathrm{E}_{\mathrm{q}}$ & 1 & 0,00009 & 0,00009 & 0,00093 & 0,12 & 5,98 & Não \\
Resíduo & 18 & 0,01389 & 0,00077 & - & - & - & - \\
\hline Modelo & $I_{C D}=0,4814+0,0354 \times P_{l}(T)+0,0097 \times P_{q}(T)-0,0228 \times P_{l}(E)$ & $\mathrm{R}^{2}=0,748$ \\
\hline
\end{tabular}




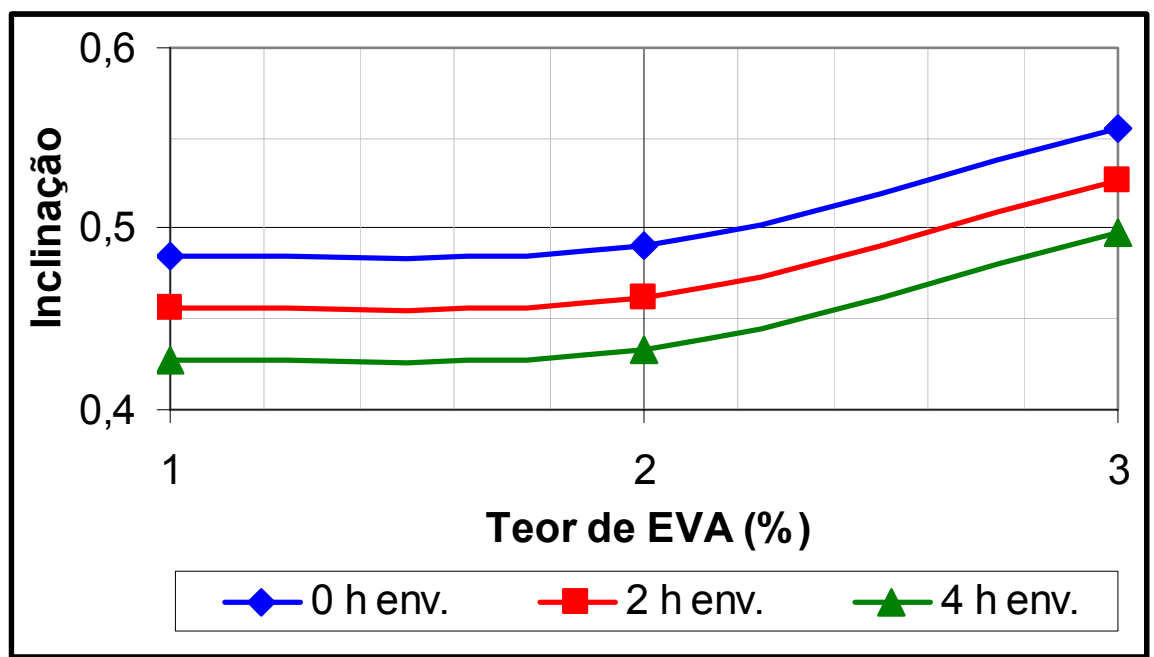

Figura 4.72. Programa Experimental - Modelo de inclinação da curva no estágio secundário do ensaio de fluência por compressão uniaxial dinâmica em função do teor de EVA e do tempo de envelhecimento, para significância de 2,5\%.

\subsubsection{Desgaste por abrasão (Cantabro)}

O ensaio Cantabro foi realizado em três corpos-de-prova por condição experimental e os resultados médios encontram-se na Tabela 4.35 e na Figura 4.73. Os resultados completos encontram-se no Apêndice J. Embora a norma recomende que o resultado seja expresso sem casas decimais, optou-se por utilizar uma casa decimal para ressaltar a diferença nos resultados. 
Tabela 4.35 - Desgaste médio por abrasão das misturas asfálticas em função do tempo de envelhecimento e do teor de EVA.

\begin{tabular}{ccc}
\hline Envelhecimento (h) & Teor de EVA (\%) & Desgaste médio (\%) \\
\hline \multirow{2}{*}{0} & 0 & 4,2 \\
& 1 & 3,1 \\
2 & 2,1 \\
3 & 1,4 \\
\hline \multirow{2}{*}{2} & 0 & 4,3 \\
& 1 & 3,3 \\
& 2 & 2,4 \\
3 & 1,9 \\
\hline \multirow{2}{*}{4} & 0 & 4,4 \\
& 1 & 3,8 \\
& 2 & 2,7 \\
& 3 & 2,4 \\
\hline
\end{tabular}

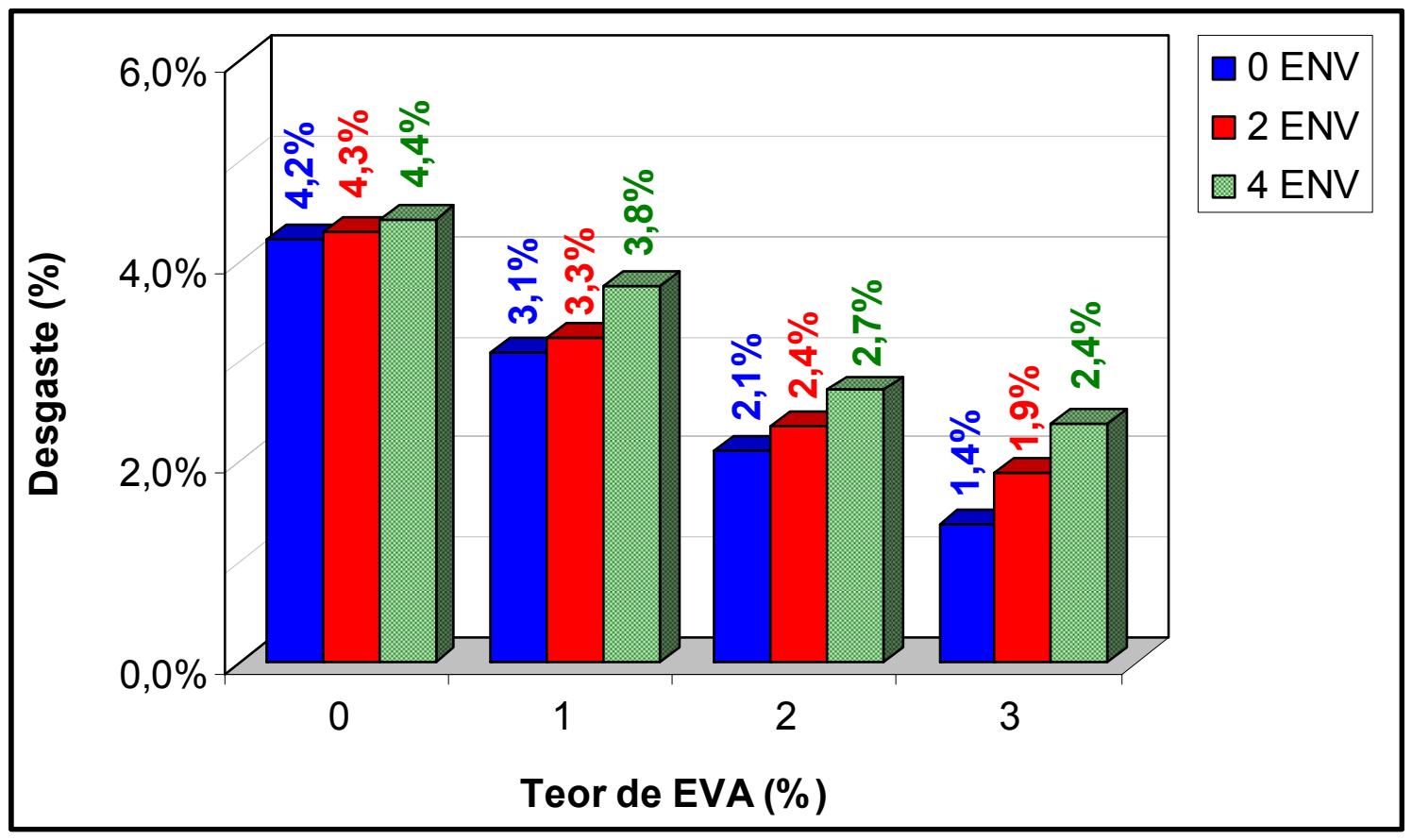

Figura 4.73. Desgaste por abrasão em função do teor de EVA e do tempo de envelhecimento.

O desgaste por abrasão diminuiu com o incremento de resíduo nas misturas e aumentou com o envelhecimento, para todas as condições experimentais. 


\subsubsection{Análise da variância e modelo estatístico do desgaste por abrasão}

A Tabela 4.36 apresenta a análise de variância realizada com os resultados do ensaio Cantabro e o modelo estatístico proposto, para significância de $1 \%$ do teste F. A Figura 4.74 apresenta o modelo proposto.

Tabela 4.36 - Análise da variância dos resultados do ensaio de desgaste, para significância de $1 \%$.

\begin{tabular}{|c|c|c|c|c|c|c|c|}
\hline Parâmetro & GL & SQ & $\mathbf{Q M}$ & Coef. & $\mathbf{F}_{0}$ & $\mathbf{F}_{\text {crítico }}$ & Signif.? \\
\hline Total & 26 & 14,61 & 0,56 & 2,55 & 6,22 & 2,96 & Sim \\
\hline $\mathrm{T}_{1}$ & 1 & 9,89 & 9,89 & $-0,74$ & 109,45 & 8,29 & Sim \\
\hline $\mathrm{T}_{\mathrm{q}}$ & 1 & 0,34 & 0,34 & 0,08 & 3,76 & 8,29 & Não \\
\hline$E_{l}$ & 1 & 2,55 & 2,55 & 0,38 & 28,27 & 8,29 & Sim \\
\hline $\mathrm{E}_{\mathrm{q}}$ & 1 & 0,03 & 0,03 & 0,02 & 0,34 & 8,29 & Não \\
\hline $\mathrm{T}_{1} \mathrm{E}_{1}$ & 1 & 0,09 & 0,09 & 0,09 & 1,02 & 8,29 & Não \\
\hline $\mathrm{T}_{\mathrm{j}} \mathrm{E}_{\mathrm{q}}$ & 1 & 0,04 & 0,04 & $-0,03$ & 0,44 & 8,29 & Não \\
\hline $\mathrm{T}_{\mathrm{q}} \mathrm{E}_{\mathrm{l}}^{\prime}$ & 1 & 0,05 & 0,05 & 0,04 & 0,51 & 8,29 & Não \\
\hline $\mathrm{T}_{\mathrm{q}} \mathrm{E}_{\mathrm{q}}$ & 1 & 0,00 & 0,00 & 0,00 & 0,00 & 8,29 & Não \\
\hline Resíduo & 18 & 1,63 & 0,09 & - & - & - & - \\
\hline Modelo & \multicolumn{6}{|c|}{$A(\%)=2,55-0,74 \times P_{l}(T)-0,38 \times P_{l}(E)$} & $\mathrm{R}^{2}=0,85$ \\
\hline
\end{tabular}

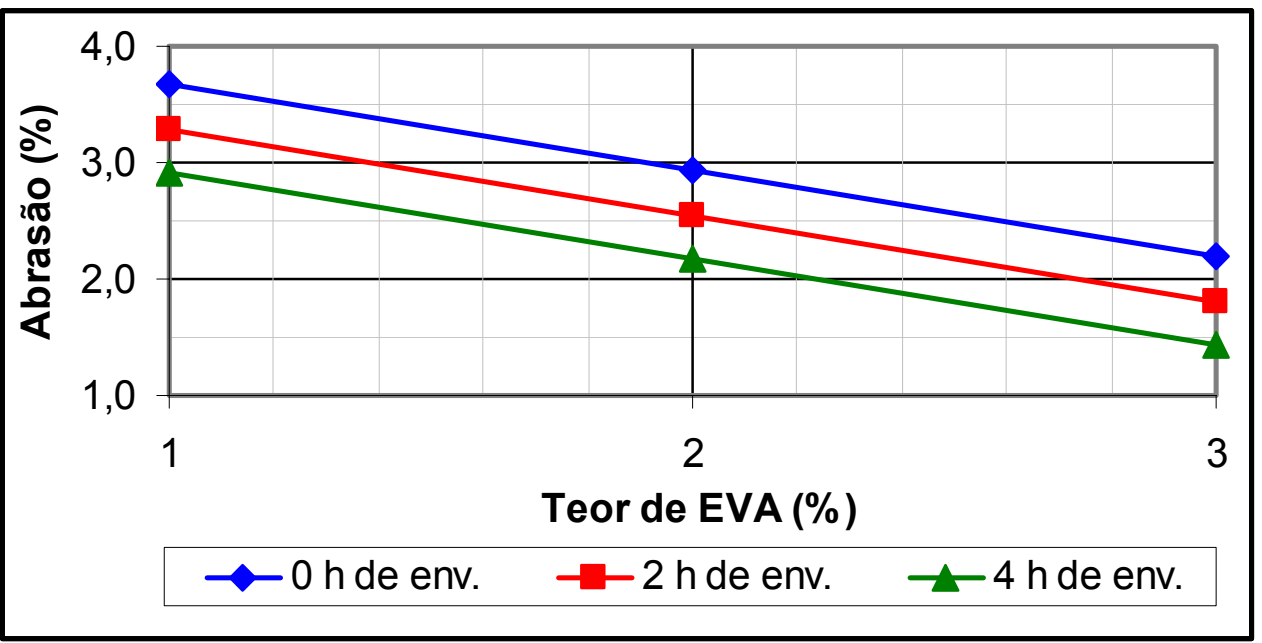

Figura 4.74. Programa Experimental - Modelo de desgaste por abrasão do ensaio

Cantabro em função do teor de EVA e do tempo de envelhecimento, para significância de 2,5\%. 
O rio atinge os seus objetivos porque aprendeu a contornar obstáculos.

(Lao-Tsé)

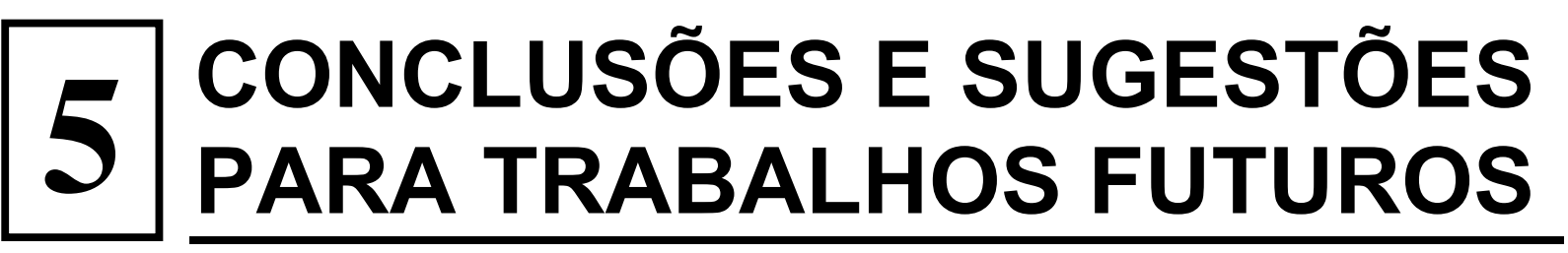

\subsection{CONSIDERAÇÕES INICIAIS}

Este trabalho teve por intuito verificar a possibilidade de inserção de etileno acetato de vinila (EVA), proveniente de resíduos de placas expandidas utilizadas pela indústria calçadista na confecção de palmilhas, em misturas asfálticas, através do processo seco.

Os fatores selecionados para a pesquisa foram o teor de resíduo incorporado $(0 \%$, $1 \%, 2 \%$ e $3 \%)$ e o tempo de envelhecimento de curto prazo (0, 2 e 4 horas). 0 primeiro fator foi escolhido com a finalidade de se determinar a maior quantidade de EVA passível de substituir os agregados, tentando, assim, minimizar o impacto ambiental gerado por esse resíduo e melhorar as características mecânicas e de 
resistência ao desgaste das misturas asfálticas. O segundo fator foi escolhido visando determinar melhoras no comportamento de misturas asfálticas com resíduos de placas expandidas de EVA em função do tempo de digestão.

A escolha de 2 fatores, um com 3 níveis e outro com 4 níveis, levou a um total de 12 condições experimentais. Para cada condição experimental foram realizados ensaios de módulo de resiliência por compressão diametral, ensaio de resistência à tração por compressão diametral estática, fluência por compressão uniaxial estática, fluência por compressão uniaxial dinâmica, desgaste e vida de fadiga. Além desses corpos-de-prova, foram moldados mais 18 para a determinação do teor ótimo de ligante através da dosagem Marshall, 6 corpos-de-prova para determinação da absorção de ligante pelo agregado e 16 corpos-de-prova para os ensaios preliminares (RT e MR), totalizando 208 corpos-de-prova para a realização da pesquisa.

\subsection{MÓDULO DE RESILIÊNCIA POR COMPRESSÃO DIAMETRAL}

Os ensaios de módulo de resiliência foram realizados em cada um dos 14 corposde-prova de cada condição experimental, totalizando168 ensaios. O desvio padrão dos resultados dos ensaios não foi significativo. Com exceção das misturas com 1\% de EVA e envelhecidas 4 horas, as misturas modificadas apresentaram valores mais baixos do que as misturas de controle, para mesmos tempos de envelhecimento.

Dentre as misturas modificadas, excetuando-se a mistura com $2 \%$ de EVA e 2 horas de envelhecimento, as misturas apresentaram maiores módulos com o aumento do 
tempo de envelhecimento, conforme esperado. As misturas de controle mostraramse praticamente não susceptíveis ao envelhecimento, tanto para 2 horas como para 4 horas.

Com relação aos resultados gerados pelo modelo estatístico, a análise de variância mostrou que tanto o teor de EVA quanto o tempo de envelhecimento e a interação entre eles foram significativos.

\subsection{RESISTÊNCIA À TRAÇÃO POR COMPRESSÃO DIAMETRAL ESTÁTICA}

Foram moldados 3 corpos-de-prova para este ensaio, em cada condição experimental, totalizando 36 corpos-de-prova. O desvio padrão dos resultados foi relativamente baixo, indicando boa repetibilidade. As misturas apresentaram menores resistências conforme o aumento do teor de resíduo incorporado e a queda foi menos perceptível para maiores tempos de envelhecimento, demonstrando que a resistência das misturas modificadas é mais susceptível ao envelhecimento do que as misturas de controle. A análise da variância confirmou que o teor de resíduo e o tempo de envelhecimento afetam significantemente a resistência à tração das misturas.

\subsection{VIDA DE FADIGA}

Foram moldados 96 corpos-de-prova, divididos em 8 corpos-de-prova semelhantes para cada condição experimental. Os 8 corpos-de-prova foram escolhidos 
aleatoriamente para serem ensaiados, em pares, com $10 \%, 20 \%, 30 \%$ e $40 \%$ da resistência à tração das misturas de controle com o mesmo tempo de envelhecimento.

Analisando-se o coeficiente de regressão dos modelos gerados por cada condição experimental, pode-se concluir que os ensaios apresentaram desvio padrão muito baixo. As curvas das misturas de controle são menos inclinadas que as curvas das misturas modificadas, indicando menores resistências para maiores deformações.

As tensões geradas pelo programa ELSYM5 e aplicadas nos modelos calibrados a partir dos ensaios mostraram que as misturas modificadas tiveram uma vida de fadiga muito maior que as misturas de controle, tanto em pavimento mais esbelto e flexível, quanto em pavimento mais espesso e rígido, com exceção da mistura com 2\% de EVA e 2 horas de envelhecimento, simulada na estrutura de pavimento mais esbelta.

\subsection{FLUÊNCIA POR COMPRESSÃO UNIAXIAL ESTÁTICA}

Foram moldados 3 corpos-de-prova por condição experimental, totalizando 36 corpos-de-prova, que também foram utilizados para os ensaios de fluência por compressão uniaxial dinâmica e desgaste por abrasão. As misturas de controle são resistentes a tráfegos de muito alta intensidade $\left(\mathrm{N}>10^{6}\right)$. As misturas com $1 \%$ de EVA e as misturas com $2 \%$ de EVA envelhecidas 2 e 4 horas são resistentes a tráfegos de alta intensidade $\left(5 \times 10^{5} \leq \mathrm{N} \leq 10^{6}\right)$. As misturas com $2 \%$ de EVA sem 
envelhecimento e as misturas com 3\% de EVA são resistentes a tráfegos de baixa intensidade $\left(\mathrm{N}<10^{5}\right)$.

As misturas modificadas apresentaram deformações totais, recuperáveis e permanentes muito acima das misturas de controle, indicando que com o aumento do teor de EVA as misturas se tornam mais susceptíveis à deformação permanente. As misturas de controle sofreram maiores deformações totais e permanentes com maiores tempo de envelhecimento, enquanto que as misturas modificadas apresentaram menores valores de deformação total com o envelhecimento, porém as deformações permanentes não apresentaram mudança significativa com o envelhecimento de curto prazo. A recuperação das misturas foi menor para maiores tempos de envelhecimento, indicando o enrijecimento das mesmas.

Enquanto os valores do módulo de fluência para as misturas de controle diminuíram, para as misturas modificadas aumentaram, com o aumento do tempo de envelhecimento. Quanto maior o tempo de envelhecimento, menores foram as inclinações no trecho secundário das curvas de fluência, indicando menores deformações ao longo do tempo com o aumento do envelhecimento da mistura.

As análises de variância realizadas com cada parâmetro do ensaio mostraram que as deformações permanentes e o módulo de fluência após recuperação foram sensíveis apenas ao teor de EVA. As deformações totais, recuperáveis e o módulo de fluência mostraram-se sensíveis às variações no teor de EVA e ao tempo de envelhecimento e as inclinações da curva mostraram-se sensíveis ao teor de EVA, ao tempo de envelhecimento e à interação entre eles. 


\subsection{FLUÊNCIA POR COMPRESSÃO UNIAXIAL DINÂMICA}

As deformações totais diminuíram com o aumento do tempo de envelhecimento, mas aumentaram com o aumento do teor de EVA. O módulo de fluência das misturas modificadas aumentou, enquanto que as respectivas inclinações diminuíram com o envelhecimento, ou seja, indicando que as misturas modificadas são menos susceptíveis às deformações permanentes com o envelhecimento. Em contrapartida, os módulos de fluência diminuíram e as inclinações aumentaram com o aumento do teor de EVA. De acordo com a análise da variância, todos os parâmetros do ensaio mostraram-se sensíveis ao teor de EVA e ao tempo de envelhecimento.

\subsection{DESGASTE POR ABRASÃO NO ENSAIO CANTABRO}

Todas as misturas apresentaram maiores desgastes com maiores tempos de envelhecimento e menores desgastes com maiores teores de EVA. A análise da variância mostrou que as misturas são sensíveis tanto ao teor de EVA quanto ao tempo de envelhecimento.

\subsection{CONCLUSÕES GERAIS}

Como resposta aos objetivos propostos concluiu-se que:

- As misturas mostraram-se sensíveis ao teor de EVA incorporado e, segundo os resultados deste trabalho, o teor não pode exceder $3 \%$ do volume de 
agregados, seja pela desagregação da mistura quando da compactação, seja pelo alto valor de deformação permanente;

- As misturas modificadas apresentam maior resistência à fadiga e ao desgaste, porém menor resistência à deformação permanente;

- O tempo de envelhecimento de curto prazo mostrou-se importante, melhorando as características mecânicas das misturas modificadas e, embora tenha aumentado o desgaste das misturas, não foi um aumento significativo;

- A utilização do resíduo das placas expandidas de EVA em misturas asfálticas contribui para a diminuição do passivo ambiental gerado pela fabricação de palmilhas, pois grande parte deste resíduo pode ser utilizado como parte do agregado da capa asfáltica.

Conclui-se, por fim, que a utilização do resíduo oriundo das placas expandidas de EVA em misturas asfálticas é viável, porém fica a ressalva que melhorias devem ser feitas com relação à susceptibilidade das misturas modificadas à deformação permanente.

\subsection{SUGESTÕES PARA TRABALHOS FUTUROS}

As pesquisas sobre incorporação de resíduos sólidos em misturas asfálticas, através do processo seco, têm um longo caminho a percorrer. No caso deste trabalho, que estudou resíduos de placas expandidas de EVA, descartados pela indústria 
calçadista, sugere-se o estudo de outras granulometrias de resíduo, os efeitos da absorção de ligante por parte do resíduo e as conseqüências do envelhecimento de longo prazo.

Sugere-se, também, que sejam estudadas a adesão do ligante ao resíduo e a possível interação entre eles, ou seja, se o resíduo passa a trabalhar, em parte, pelo processo úmido. Finalmente, sugerem-se os ensaios de sensibilidade das misturas modificadas à umidade e o ensaio de "trilha de rodas" (simulador de tráfego LCPC), pois os ensaios de fluência por compressão uniaxial apresentam resultados muito dispersos. 


\section{REFERÊNCIAS BIBLIOGRÁFICAS}

AASHTO (1997). Unit weight and voids in aggregate. Edição publicada sob a designação AASHTO T-19/T 19M. American Association of State Highway and Transportation Officials. 1997.

AASHTO (2001). Standard practice for mixture conditioning of hot mix asphalt (HMA). Edição publicada sob a designação PP2-00. American Association of State Highway and Transportation Officials. 3p., 2001.

ABICALÇADOS (2005). Associação Brasileira das Indústrias de Calçados. Site da internet: www.abicalcados.com.br.

ABNT (1993). Dosagem de misturas betuminosas pelo método Marshall. NBR 12891/93. Associação Brasileira de Normas Técnicas. Rio de Janeiro, 1993.

ABNT (2004). Resíduos Sólidos. NBR 10004/04. Associação Brasileira de Normas Técnicas. Rio de Janeiro, 2004.

AMARAL, S.C. (2000). Estudos de misturas asfálticas densas com agregados do estado do Pará, utilizando asfalto convencional (CAP-40) e asfalto modificado com polímero SBS (BETUFLEX B 65/60). Dissertação (Mestrado) Escola de Engenharia de São Carlos, Universidade de São Paulo. 147p. São Carlos, 2000.

ASSINTECAL (1999). Associação Brasileira de Empresas de Componentes para Couros, Calçados e Artefatos. Site da internet: www.assintecal.org.br. 
ASTM (1993). Edição publicada sob a designação ASTM C 128-93. Standard test method for specific gravity and absorption of fine aggregate. American Society for Testing and Materials. Philadelphia, 1993.

BALBO, J.T. (2000). Fatos, mitos e falácias sobre os modelos experimentais de fadiga. In: 32ª Reunião de Pavimentação, ABPv. Brasília, 2000.

BELL, C.A. (1989). Summary report on aging of asphalt-aggregate systems. Strategic Highway Research Program (SHRP) - SR-OSU-A-003A-89-02. Oregon State University. Corvallis, 1989. 121p.

BELL, C.A.; WIEDER, A.J.; FELLIN, M.J. (1994). Laboratory aging of asphaltaggregate mixtures: field validation. Publicação SHRP-A-390 do Strategic Highway Research Program. National Research Council. Washington, D.C., 1994. $204 p$.

BENEVIDES, S.A.S. (2000). Análise comparativa dos métodos de dimensionamento de pavimentos asfálticos: empírico do DNER e da resiliência da COPPE/UFRJ em rodovias do estado do Ceará. Dissertação (Mestrado). COPPE, Universidade Federal do Rio de Janeiro. 192p. Rio de Janeiro, 2000.

BROWN, E.R.; KANDHAL, P.S.; ZHANG, J. (2001). Performance testing for hot mix asphalt. National Center for Asphalt Tecnology. Auburn University. 79p. Aubourn, 2001.

BUTTON, J.W.; PERDOMO, D.; LYTTON, R.L. (1990). Influence of aggregate on rutting of asphalt concrete pavements. Transportation Research Record, n. 1259, p.141-152.

CHADBOURNE, B.A.; SKOK JR., E.L.; NEWCOMB, D.E.; CROW, B.L.; SPINDLER, S. (2000). The effects of voids in mineral aggregate (VMA) on hot-mix asphalt pavements. Final report. University of Minnesota. 131p. Minneapolis, 2000. 
CHANDA, M.; ROY, S.K. (1998). Plastic Technology Handbook. $3^{a}$ ed., 1195p. Marcel Dekker. New York, 1998.

COELHO, V. (1996). Contribuição ao estudo das deformações permanentes, nas condições do Brasil, em camadas de concreto asfáltico de pavimentação. Tese (Doutorado) - Escola de Engenharia de São Carlos, Universidade de São Paulo. 281p. São Carlos, 2004.

COMINSKY, R.J.; KILLINGSWORTH, B.M; ANDERSON, R.M.; ANDERSON, D.A.; CROCKFORD, W.W. (1998). Quality control and acceptance of SUPERPAVE designed hot mix asphalt. National Cooperative Highway Research Program, report 409, p. 1-26.

CUNHA, M.B. (2004). Avaliação do Método Bailey de seleção granulométrica de agregados para misturas asfálticas. Dissertação (Mestrado) - Escola de Engenharia de São Carlos, Universidade de São Paulo. 105p. São Carlos, 2004.

DNER (1987). Método de ensaio DNER-ME 117/87. Misturas betuminosas Determinação da densidade aparente. Departamento Nacional de Estradas de Rodagem. Rio de Janeiro, 1987.

DNER (1994a). Método de ensaio DNER-ME 138/94. Misturas betuminosas Determinação da resistência à tração por compressão diametral. Departamento Nacional de Estradas de Rodagem. Rio de Janeiro, 1994.

DNER (1994b). Método de ensaio DNER-ME 133/94. Misturas betuminosas Determinação do módulo de resiliência. Departamento Nacional de Estradas de Rodagem. Rio de Janeiro, 1994.

DNER (1997). Especificação de serviço DNER-ES 313/97. Pavimentação Concreto betuminoso - Norma rodoviária. Departamento Nacional de Estradas de Rodagem. Rio de Janeiro, 1997. 
DNER (1998a). Especificação de serviço DNER-ME 081/98. Agregados Determinação da absorção e da densidade de agregado miúdo. Departamento Nacional de Estradas de Rodagem. Rio de Janeiro, 1998.

DNER (1998b). Especificação de serviço DNER-ME 035/98. Agregados Determinação da abrasão “Los Angeles". Departamento Nacional de Estradas de Rodagem. Rio de Janeiro, 1998.

DNER (1999). Método de ensaio DNER-ME 383/99. Desgaste por abrasão de misturas betuminosas com asfalto polímero - ensaio Cantabro. Departamento Nacional de Estradas de Rodagem. Rio de Janeiro, 1999.

DNIT (2004). Especificação de serviço DNIT 031/2004-ES. Pavimentos flexíveis concreto asfáltico. 13p. Departamento Nacional de Infra-estrutura de Transportes. Rio de Janeiro, 2004.

FAXINA, A.L. (2002). Estudo em laboratório do desempenho de concreto asfáltico usinado a quente empregando ligante tipo asfalto-borracha. Dissertação (Mestrado) - Escola de Engenharia de São Carlos, Universidade de São Paulo. 274p. São Carlos, 2002.

FERNANDES JR., J.L. (1994). Investigação dos defeitos das solicitações do tráfego sobre o desempenho de pavimentos. Tese (Doutorado) - Escola de Engenharia de São Carlos, Universidade de São Paulo. São Carlos, 1994.

FERREIRA, J.G.H.M. (2002). Elaboração e análise da base de dados de ensaios triaxiais dinâmicos da COPPE/UFRJ. Dissertação (Mestrado). COPPE, Universidade Federal do Rio de Janeiro. 263p. Rio de Janeiro, 2002.

FORETTI, A.C. (1999). Estudo de misturas preparadas com asfalto convencional e asfalto modificado com polímeros. Dissertação (Mestrado) Escola de Engenharia de São Carlos, Universidade de São Paulo. 81p. São Carlos, 1999. 
FWHA (2003). Distress identification manual for the long-term pavement performance program. Federal Highway Administration. U.S. Department of Transportation $4^{\circ}$ Edition Revised. 154 p. McLean, 2003.

GHILE, D.B. (2006). Effects of nanoclay modification on rheology of bitumen and on performance of asphalt mixtures. Dissertação (Mestrado). Delft University of Technology. 115p. Delft, The Netherlands, 2006.

GOMES, F.P. (1973). Estatística experimental. 5a Edição. Editora Nobel. 430p. São Paulo, 1973.

GOUVEIA, L.T. (2002). Avaliação do ensaio de angularidade do agregado fino (FAA) da especificação superpave. Dissertação (Mestrado) - Escola de Engenharia de São Carlos, Universidade de São Paulo. 165p. São Carlos, 2002.

KANDHAL, P.S.; CHAKRABORTY, S. (1996). Effect of asphalt film thickness on short- and long-term aging of asphalt paving mixtures. Transportation Research Record, n. 1535, p.83-90.

KANDHAL, P.S.; FOO, K.Y.; MALLICK, R.B. (2001). Critical review of voids in mineral aggregate requirements in SUPERPAVE. Transportation Research Record, n. 1609, p.21-27.

KANDHAL, P.S.; MALLICK, R.B. (2001). Effect of mix gradation on rutting potential of dense-graded asphalt mixtures. Transportation Research Record, $\mathrm{n}$. 1767, p.146-151.

KHATTAK, M.J. e BALADI, G.Y. (2001). Fatigue and permanent deformation models for polymer-modified asphalt mixtures. Transportation Research Record, n. 1767, p.135-145.

KIM, Y.R.; KIM, N.; KHOSLA, N.P. (1992). Effects of aggregate type and graduation on fatigue and permanent deformation of asphalt concrete. In: MEININGER, R.C. (ed.) Effects of aggregate and mineral fillers on asphalt 
mixture performance. American Society for Testing and Materials (ASTM), Philadefia, 1992.

KIM, Y.R.; LITTLE, D.N.; SONG, I. (2003). Effect of mineral fillers on fatigue resistance and fundamental material characteristics - Mechanistic evaluation. Transportation Research Record, n.1832, p.1-8.

LEABO, D.A. (1972). Basic Statistics. $4^{\circ}$ Edição. Richard D. Irwin, Inc. 668p. Georgetown, Ontario, 1972.

LITTLE, D.N.; BUTTON, J.W.; YOUSSEF, H. (1993). Development of criteria to evaluate uniaxial creep data and asphalt concrete permanent deformation potential. Transportation Research Record, n.1417, p.49-57.

MAGALÃES, S.T. (2004). Misturas asfálticas de módulo elevado para pavimentos de alto desempenho. Dissertação (Mestrado). COPPE, Universidade Federal do Rio de Janeiro. 201p. Rio de Janeiro, 2004.

MAHBOUB, K. e LITTLE, D.N. (1988). Improved asphalt concrete design procedure. Resarch Report 474-1F, Texas Transportatios Institute, 1998.

MANO, E.B. (1998). Introdução a polímeros. Ed. Edgard Blücher Ltd. 111p. São Paulo, 1988.

MEDINA, J. (1997). Mecânica dos pavimentos. $1^{\text {a }}$ ed. Rio de Janeiro, UFRJ.

MEDINA, J.; MOTTA, L.MG. (2005). Mecânica dos pavimentos. $2^{a}$ ed. 574p. Rio de Janeiro, UFRJ, 2005.

MOTTA, L.M.G; PINTO, S. (1994). O uso de ensaios estáticos na definição de parâmetros de comportamento das misturas asfálticas. $12^{\circ}$ Encontro de Asfalto, p.152-178. 
MOTTA, L.M.G; LEITE, F.L.M.; CONSTANTINO, R.S.; TONIAL, I.A. (1996). Curso sobre o programa SHRP: Aplicação a ligantes, agregados e misturas betuminosas. Instituto Brasileiro de Petróleo. Rio de Janeiro, 1996.

MUGAYAR, A.N. (2004). Avaliação dos efeitos do tipo de asfalto e da distribuição granulométrica do agregado nas fluências estática e dinâmica de misturas asfálticas densas. Dissertação (Mestrado) - Escola de Engenharia de São Carlos, Universidade de São Paulo. 118p. São Carlos, 2004.

PEREIRA, A.S. (2002). Utilização de geotêxtil em reforço de pavimentos aplicado em um trecho experimental. Tese (Doutorado). COPPE, Universidade Federal do Rio de Janeiro. 198p. Rio de Janeiro, 2002.

PINTO, S. (1991). Estudo do comportamento à fadiga de misturas betuminosas e aplicação na avaliação estrutural de pavimentos. Tese (Doutorado). COPPE, Universidade Federal do Rio de Janeiro. Rio de Janeiro, 1991.

ROBERTS, F.L.; KANDHAL, P.S.; BROWN, E.R.; LEE, D.Y.; KENNEDY, T.W. (1991). Hot mix asphalt materials, mixture design, and construction. $1^{\text {a }}$ ed. Napa Education Foundation. Lenham, Maryland, 1991.

SANTANNA-GRECO, J.A (2004). Avaliação da influência de alguns fatores nas propriedades mecânicas de misturas asfálticas densas, à luz da técnica de planejamento e análise de experimentos fatoriais fracionários assimétricos. Tese (Doutorado) - Escola de Engenharia de São Carlos, Universidade de São Paulo. 340p. São Carlos, 2004.

SANTOS, C.R.G. (2005). Avaliação das influências do tipo de ligante e do volume de vazios na vida de fadiga de algumas misturas asfálticas. Dissertação (Mestrado) - Escola de Engenharia de São Carlos, Universidade de São Paulo. 123p. São Carlos, 2005. 
SI, Z. LITTLE, D.N.; LYTTON, R.L. (2002). Evaluation of fatigue healing effect of asphalt concrete by pseudostiffness. Transportation Research Record, n.1789, p.73-79.

SILVEIRA, M.A. (1999). Efeito da adição de polímero em areia-asfalto a frio. Dissertação (Mestrado) - Escola de Engenharia de São Carlos, Universidade de São Paulo. 103p. São Carlos, 1999.

SOUZA, J.B.; CRAUS, J.; MONISMITH, C.L. (1991). Summary report on permanent deformation in asphalt concrete. Publicação SHRP-A/IR-91-104 do Strategic Highway Research Program. National Research Council. Washington, D.C., 1991. 120p. 1991.

TAIRA, C. (2001). Avaliação do desempenho em laboratório de misturas asfálticas densas utilizando asfalto convencional (CAP-20) e asfalto modificado com polímero SBS (BETUFLEX B 65/60). Dissertação (Mestrado) Escola de Engenharia de São Carlos, Universidade de São Paulo. 153p. São Carlos, 2001.

TANGELLA S.C.S.R.; CRAUS, J.; DEACON, J.A.; MONISMITH, C.L. (1990). Summary report on fatigue response on asphalt mixture. TM-UCB-A-003A-89-3, Strategic Highway Research Program (SHRP) - Project A-003-A. Institute os Transportation Studies. University of California. Berkley, California, 1990.

THIESSEN, M.; SHALABY, A.; KAVANAGH, L. (2000). Strength testing of inservice asphalt pavements in Manitoba and correlations to rutting. Proceedings of the Canadian Technical Asphalt Association. p.205. Manitoba, 2000.

TONIAL, I.A. (2001). Influência do envelhecimento do revestimento asfáltico na vida de fadiga de pavimentos. Dissertação (mestrado). COPPE, Universidade Federal do Rio de Janeiro. 151p. Rio de Janeiro, 2001. 
VAN DE LOO, P.J. (1974). Creep testing, a simple tool to judge asphalt mix stability. The Association os Asphalt Paving Technologists, v. 43, p. 253-284.

VAN DE LOO, P.J. (1976). A Practical approach to the prediction of rutting in asphalt pavements: the Shell Method. Transportation Research Record, n.616, p.15-21.

VAVRIK, W.R.; HUBER, G.A.; PINE, W.J.; CARPENTER, SH.; BAYLEY, R. (2002). Bailey method for gradation selection in HMA mixture design. Transportation Research Record, Circular n E-C044. 2002.

WEN, H. e KIM, Y.R. (2002). Simple performance test for fatigue cracking and validation with westrak mixtures. Transportation Research Record, n.1789, p.6672.

WITCZAC, M.W.; KALOUSH, K.; PELLINEN, T.; EL-BASYOUNY, M.; VON QUINTUS, H. (2002). Simple performance test for Superpave mix design. Transportation Research Board (TRB) - National Cooperative Highway Research Program (NCHRP), report 465. 114 p. Washington, D.C. 2002.

ZHU, L.Y.; LIU, Y.; FWA, T.F. (2002). Rutting potential evaluation of asphalt mixtures by repeated-load creep test. Transportation Research Record, 2002 
APÊNDICE A

Método Bailey 


\section{A.1. CARACTERIZAÇÃO DOS AGREGADOS}

A Tabela A.1 apresenta a porcentagem retida acumulada de cada agregado utilizado na pesquisa nas peneiras recomendadas pelo SUPERPAVE. As Tabelas A.2, A.3, A.4 e A.5 mostram respectivamente os resultados dos ensaios de massa específica compactada do pó de pedra, massa específica solta e compactada do pedrisco e massa específica solta da pedra 1, como também os valores adotados para cada agregado.

Tabela A.1 - Granulometria dos agregados utilizados na pesquisa.

\begin{tabular}{c|c|c|c}
\hline $\begin{array}{c}\text { Peneiras } \\
\text { (mm) }\end{array}$ & Pedra 1 & Pedrisco & $\begin{array}{c}\text { Pó de } \\
\text { pedra }\end{array}$ \\
\hline $\mathbf{1 9 , 1}$ & 0,00 & 0,00 & 0,00 \\
$\mathbf{1 2 , 5}$ & 21,33 & 0,00 & 0,00 \\
$\mathbf{9 , 5}$ & 72,62 & 0,99 & 0,00 \\
$\mathbf{4 , 7 5}$ & 100,00 & 62,95 & 0,14 \\
$\mathbf{2 , 3 6}$ & - & 93,89 & 10,67 \\
$\mathbf{1 , 1 8}$ & - & 98,31 & 33,40 \\
$\mathbf{0 , 6 0}$ & - & 99,74 & 51,86 \\
$\mathbf{0 , 3 0}$ & - & 99,80 & 66,10 \\
$\mathbf{0 , 1 5}$ & - & 99,87 & 79,88 \\
$\mathbf{0 , 0 7 5}$ & - & 99,89 & 90,09 \\
Fundo & - & 100,00 & 100,00 \\
\hline
\end{tabular}

Tabela A.2 - Massa específica compactada do pó de pedra.

\begin{tabular}{|c|c|c|c|c|c|}
\hline \multirow{2}{*}{ Amostra } & \multirow{2}{*}{$\begin{array}{l}\mathbf{M c}_{\mathrm{f}} \\
(\mathbf{k g})\end{array}$} & \multirow{2}{*}{$\begin{array}{r}M c_{i} \\
(\mathbf{k g})\end{array}$} & \multirow{2}{*}{$\begin{array}{c}\mathrm{Vc} \\
\left(\mathrm{m}^{3}\right)\end{array}$} & \multicolumn{2}{|c|}{$\operatorname{MEC}\left(\mathrm{kg} / \mathrm{m}^{3}\right)$} \\
\hline & & & & Unitária & Média \\
\hline 1 & 8,975 & 3,230 & 0,003 & 1915 & \\
\hline & 8,96 & 3,23 & 0,00 & 1912 & 1914 \\
\hline Q & 8,980 & 3,230 & 0,003 & 1917 & \\
\hline
\end{tabular}


Tabela A.3 - Massa específica solta do pedrisco.

\begin{tabular}{c|c|c|c|c|c}
\hline \multirow{2}{*}{ Amostra } & \multirow{2}{*}{$\begin{array}{c}\text { Mcc } \\
\mathbf{( k g )}\end{array}$} & $\begin{array}{c}\text { Mcv } \\
\mathbf{( k g})\end{array}$ & $\begin{array}{c}\text { Vc } \\
\mathbf{( m}^{\mathbf{3}} \mathbf{)}\end{array}$ & \multicolumn{2}{|c}{ MES $\mathbf{( k g / \mathbf { m } ^ { 3 } )}$} \\
\hline $\mathbf{1}$ & 7,330 & 3,230 & 0,003 & 1367 & \\
$\mathbf{2}$ & 7,390 & 3,230 & 0,003 & 1387 & 1380 \\
$\mathbf{3}$ & 7,390 & 3,230 & 0,003 & 1387 & \\
\hline
\end{tabular}

Tabela A.4 - Massa específica compactada do pedrisco.

\begin{tabular}{c|c|c|c|c|c}
\hline \multirow{2}{*}{ Amostra } & $\mathbf{M c}_{\mathbf{f}}$ & $\mathbf{M c}_{\mathbf{i}}$ & $\mathbf{V} \mathbf{V}$ & \multicolumn{2}{|c}{ MEC (kg/m $\mathbf{3})$} \\
\cline { 5 - 6 } & $\mathbf{( k g )}$ & $\mathbf{( k g )}$ & $\left.\mathbf{( m}^{\mathbf{3}}\right)$ & Unitária & Média \\
\hline $\mathbf{1}$ & 7,685 & 3,230 & 0,003 & 1485 & \\
$\mathbf{2}$ & 7,720 & 3,230 & 0,003 & 1497 & 1492 \\
$\mathbf{3}$ & 7,710 & 3,230 & 0,003 & 1493 & \\
\hline
\end{tabular}

Tabela A.5. Massa específica solta do pedrisco.

\begin{tabular}{c|c|c|c|c|c}
\hline \multirow{2}{*}{ Amostra } & Mcc & Mcv & Vc & \multicolumn{2}{|c}{ MEC } \\
\cline { 5 - 6 } & $\mathbf{( k g )}$ & $\mathbf{( k g )}$ & $\left.\mathbf{( m}^{\mathbf{3}}\right)$ & Unitária & Média \\
\hline $\mathbf{1}$ & 7,130 & 3,230 & 0,003 & 1300 & \\
$\mathbf{2}$ & 7,140 & 3,230 & 0,003 & 1303 & \\
$\mathbf{3}$ & 7,150 & 3,230 & 0,003 & 1307 & \\
$\mathbf{4}^{*}$ & 7,250 & 3,230 & 0,003 & 1340 & \\
$\mathbf{5}$ & 7,125 & 3,230 & 0,003 & 1298 & 1306 \\
$\mathbf{6}$ & 7,160 & 3,230 & 0,003 & 1310 & \\
$\mathbf{7}$ & 7,180 & 3,230 & 0,003 & 1317 & \\
$\mathbf{8}$ & 7,185 & 3,230 & 0,003 & 1318 & \\
$\mathbf{9}$ & 7,125 & 3,230 & 0,003 & 1298 & \\
\hline
\end{tabular}

* Fora do desvio padrão.

\section{A.2. MÉTODO BAILEY}

\section{A.2.1. Massas específicas escolhidas}

$M E E_{\text {pedra1 }}=M E S_{\text {pedra1 }} \times M E S_{d, p e d r a 1}=1306 \times 0,95$

$M E E_{\text {pedra1 }}=1241^{\mathrm{kg}} / \mathrm{m}^{3}$ 
$M E E_{\text {pedrisco }}=M E S_{\text {pedrisco }} \times M E S_{d, \text { pedrisco }}=1380 \times 0,95$

$M E E_{\text {pedrisco }}=1311 \mathrm{~kg} / \mathrm{m}^{3}$

\section{A.2.2. Contribuição inicial dos agregados}

$C A G=M E E_{\text {pedra } 1} \times A G_{d p e d r a}+M E E_{\text {pedrisco }} \times A G_{d, \text { pedrisco }}=1241 \times 0,1+1311 \times 0,9$

$C A G=1304 \mathrm{~kg} / \mathrm{m}^{3}$

$V A G=100 \times\left[\left(1-\frac{M E E_{\text {pedra1 }}}{\rho_{\text {pedra1 }}}\right) \times A G_{\text {pedra1 }}+\left(1-\frac{M E E_{\text {pedrisco }}}{\rho_{\text {pedrisco }}}\right) \times A G_{\text {pedirsco }}\right]$

$V A G=100 \times\left[\left(1-\frac{1241}{2865}\right) \times 0,1+\left(1-\frac{1311}{2835}\right) \times 0,9\right]$

$V A G=54 \%$

$C A F=M E E_{p o ́} \times A F_{p o ́} \times V A G=1914 \times 1 \times 0,54$

$C A F=1035 \mathrm{~kg} / \mathrm{m}^{3}$

$M E M=C A G+C A F=1304+1035$

$M E M=2339 \mathrm{~kg} / \mathrm{m}^{3}$

$A G i_{p e d r a 1}=\frac{C A G_{p e d r a 1}}{M E M} \times 100=\frac{124,1}{2339} \times 100$

$A G i_{\text {pedra } 1}=5,3 \%$ 


$$
\begin{aligned}
& A G i_{\text {pedrisco }}=\frac{C A G_{\text {pedrisco }}}{M E M} \times 100=\frac{1179,9}{2339} \times 100 \\
& A G i_{\text {pedrisco }}=50,5 \%
\end{aligned}
$$

$$
A F i_{p o ́}=\frac{C A F_{p o ́}}{M E M} \times 100=\frac{1035}{2339} \times 100
$$

$$
A F i_{p o ́}=44,2 \%
$$

\section{A.2.3. Peneiras de controle}

$$
\begin{aligned}
& P M \approx \frac{D M N}{2}=\frac{12,5}{2}=6,25 \\
& P M=4,76 \mathrm{~mm} \\
& P C P \approx D M N \times F C=12,5 \times 0,22=2,75 \\
& P C P=2,38 \mathrm{~mm} \\
& P C S \approx P C P \times F C=2,36 \times 0,22=0,52 \\
& P C S=0,59 \mathrm{~mm} \\
& P C T \approx P C S \times F C=0,60 \times 0,22=0,132 \\
& P C T=0,149 \mathrm{~mm}
\end{aligned}
$$




\section{A.2.4. Contribuição final dos agregados}

$$
\begin{aligned}
& P F G_{\text {pedra1 }}=A G i_{\text {pedra } 1} \times Q A G_{\text {pedra1 }}=5,3 \times 0 \\
& P F G_{\text {pedra1 }}=0 \% \\
& P F G_{\text {pedrisco }}=A G i_{\text {pedrisco }} \times Q A G_{\text {pedrisco }}=50,5 \% \times 6,11 \\
& P F G_{\text {pedrisco }}=3,1 \%
\end{aligned}
$$$$
P G F=A F i_{p o ́} \times Q A F_{p o ́}=44,2 \% \times\left(\frac{100-89,3}{100}\right)
$$$$
P G F=4,7 \%
$$$$
A G f_{\text {pedra1 }}=A G i_{\text {pedra1 }}+P F G_{\text {pedra1 }}-\left(\frac{A G i_{p e d r a 1} \times P G F}{A G}\right)=5,3+0-\left(\frac{5,3 \times 4,7}{55,8}\right)
$$$$
A G f_{\text {pedra } 1}=4,86 \%
$$

$$
A G f_{\text {pedrisco }}=A G i_{\text {pedrisco }}+P F G_{\text {pedrisco }}-\left(\frac{A G i_{\text {pedrisco }} \times P G F}{A G}\right)=50,5+3,1-\left(\frac{50,5 \times 4,7}{55,8}\right)
$$

$$
A G f_{\text {pedrisco }}=49,26 \%
$$

$$
A F f_{p o ́}=A F i_{p o ́}+P G F-\left(\frac{A F i_{p o ́} \times P F G}{A F}\right)=44,2+4,7-\left(\frac{44,2 \times 3,1}{44,2}\right)
$$

$A F f_{p o ́}=45,88 \%$ 
Tabela A.6 - Massa específica média da mistura.

\begin{tabular}{c|c|c|c|c|c}
\hline Massas & \multirow{2}{*}{$\%$} & \multicolumn{2}{|c|}{ Real $\left(\mathbf{g} / \mathbf{c m}^{3}\right)$} & \multicolumn{2}{c}{ Aparente $\left(\mathbf{g} / \mathbf{c m}^{3}\right)$} \\
\cline { 3 - 6 } Específicas & & Individual & Composição & Individual & Composição \\
\hline Pedra 1 & 4,86 & 2,865 & & 2,746 & \\
Pedrisco & 49,26 & 2,839 & 2,866 & 2,730 & 2,775 \\
Pó & 45,88 & 2,895 & & 2,826 & \\
\hline
\end{tabular}

\section{A.2.5. Curva granulométrica}

A curva granulométrica demonstrada na Tabela B.7 e na Figura B.1, foi composta utilizando-se as porcentagens de cada agregado apresentadas no item B.2.4

Tabela A.7 - Curva granulométrica determinada através do método Bailey.

\begin{tabular}{c|c|c}
\hline Peneiras (mm) & $\begin{array}{c}\text { Quantidade } \\
\text { Passada } \\
\text { Acumulada (\%) }\end{array}$ & $\begin{array}{c}\text { Quantidade } \\
\text { Retida (\%) }\end{array}$ \\
\hline $\mathbf{1 9 , 1}$ & 100,00 & 0,00 \\
$\mathbf{1 2 , 5}$ & 98,96 & 1,04 \\
$\mathbf{9 , 5}$ & 95,98 & 2,98 \\
$\mathbf{4 , 7 5}$ & 64,07 & 31,92 \\
$\mathbf{2 , 3 6}$ & 44,00 & 20,07 \\
$\mathbf{1 , 1 8}$ & 31,39 & 12,61 \\
$\mathbf{0 , 6 0}$ & 22,22 & 9,17 \\
$\mathbf{0 , 3 0}$ & 15,65 & 6,56 \\
$\mathbf{0 , 1 5}$ & 9,30 & 6,35 \\
$\mathbf{0 , 0 7 5}$ & 4,60 & 4,70 \\
Fundo & 0,00 & 4,60 \\
\hline
\end{tabular}




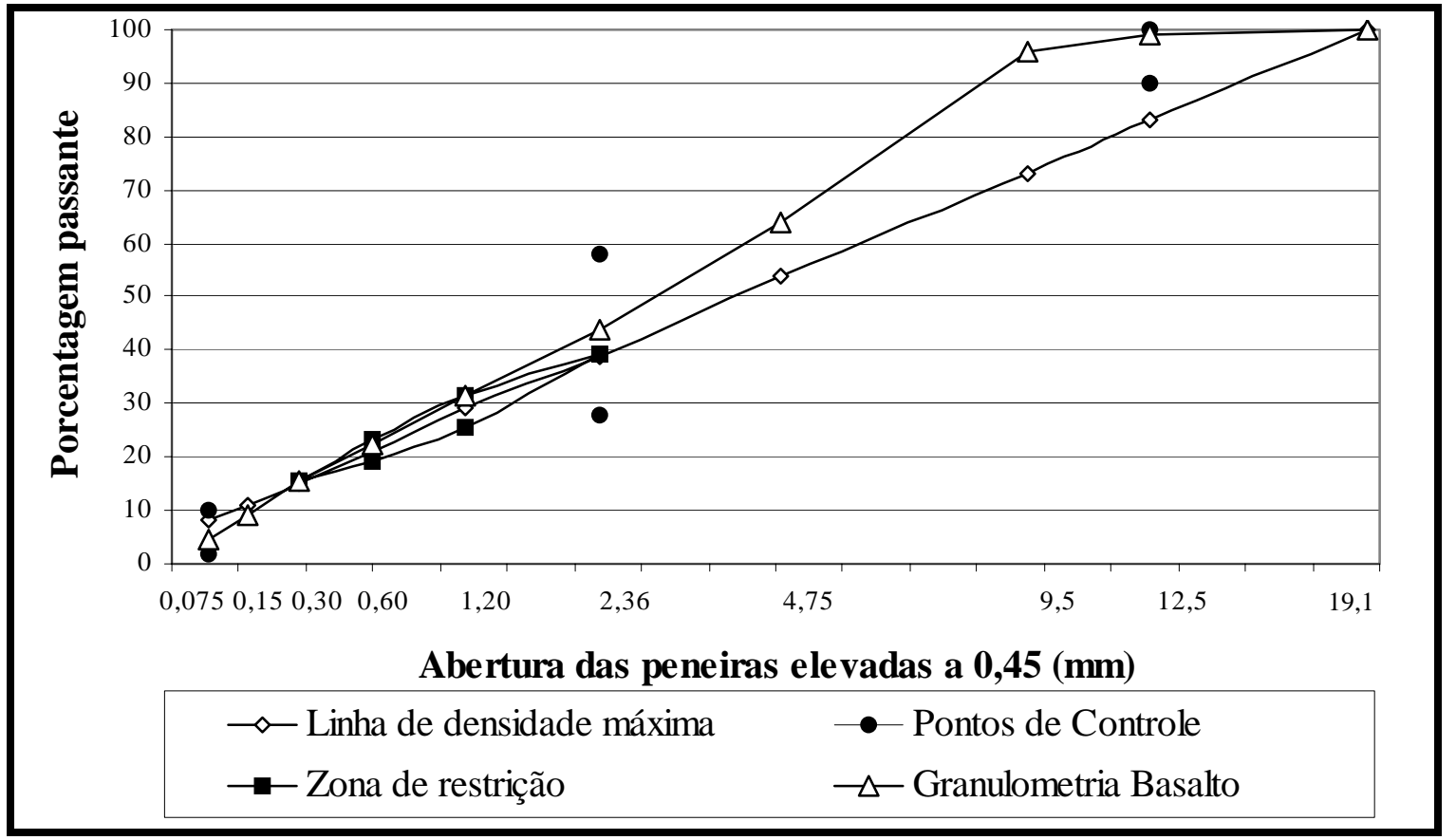

Figura A.1. Curva granulométrica determinada através do método Bailey.

\section{A.2.6. Parâmetros de controle}

$$
P A G=\frac{P M-P C P}{1-P M}=\frac{64,07 \%-44,00 \%}{1-64,07 \%}
$$

$P A G=0,56$

$$
P G A F=\frac{P C S}{P C P}=\frac{22,22}{44,00}
$$

$P G A F=0,50$

$$
P F A F=\frac{P C T}{P C S}=\frac{9,30}{22,22}
$$

$$
P F A F=0,42
$$


APÊNDICE B

\section{Dosagem Marshall}




\section{B.1. COMPOSIÇÃO DOS CORPOS-DE-PROVA}

A partir da curva granulométrica determinada através do método Bailey, definiu-se a superfície específica da composição dos agregados, seguida pela porcentagem provável de ligante na mistura.

$$
\begin{aligned}
& S=\frac{0,17 \times G+0,33 \times g+2,30 \times A+12,00 \times a+135,00 \times f}{100} \\
& S=\frac{0,17 \times 2,98+0,33 \times 31,92+2,30 \times(48,41)+12,00 \times(11,05)+135,00 \times 4,60}{100} \\
& S=8,757 \mathrm{~m}^{2} / \mathrm{kg}
\end{aligned}
$$

$T_{c a}=m \times \sqrt[5]{S}=3,75 \times \sqrt[5]{8,757}=5,79 \%$

$$
T_{c a}=5,79 \%
$$

$$
T^{\prime}{ }_{c a}=\frac{2,65 \times T_{c a}}{\delta_{a m}}=\frac{2,65 \times 5,79}{2,866}
$$

$$
T_{c a}^{\prime}=5,35 \%
$$

$$
P_{c a}=\frac{100 \times T_{c a}^{\prime}}{100+T_{c a}^{\prime}}=\frac{100 \times 5,35 \%}{100+5,35 \%}
$$

$$
P_{c a}=5,47 \%
$$


As respostas fornecidas pelas equações, no exemplo, foram calculadas com mais casas decimais do que apresentado, por esse motivo há discrepância entre os valores apresentados nas equações e as respostas obtidas.

De posse do teor provável de ligante, definiram-se os demais teores para a dosagem Marshall com intervalo de $0,5 \%$. Os dados para a composição dos corpos-de-prova com massa de $1200 \mathrm{~g}$ encontram-se na Tabela B.1.

Tabela B.1 - Composição dos corpos-de-prova para a dosagem Marshall.

\begin{tabular}{|c|c|c|c|c|c|c|c|}
\hline $\begin{array}{c}\text { Teor de Ligante } \\
(\%)\end{array}$ & $4,50 \%$ & $5,00 \%$ & $5,50 \%$ & $6,00 \%$ & $6,50 \%$ & $7,00 \%$ & \multirow{2}{*}{$\begin{array}{c}\text { Peneira } \\
(\mathrm{mm})\end{array}$} \\
\hline $\begin{array}{l}\text { Quantidade de } \\
\text { Ligante }(g)\end{array}$ & 54,00 & 60,00 & 66,00 & 72,00 & 78,00 & 84,00 & \\
\hline \multirow{11}{*}{$\begin{array}{c}\text { Quantidade de } \\
\text { Agregado Retido } \\
\text { em Cada Peneira } \\
\text { (g) }\end{array}$} & 0,00 & 0,00 & 0,00 & 0,00 & 0,00 & 0,00 & 19,1 \\
\hline & 11,87 & 11,81 & 11,75 & 11,69 & 11,62 & 11,56 & 12,5 \\
\hline & 34,15 & 33,98 & 33,80 & 33,62 & 33,44 & 33,26 & 9,5 \\
\hline & 365,76 & 363,84 & 361,93 & 360,01 & 358,10 & 356,18 & 4,75 \\
\hline & 230,02 & 228,82 & 227,61 & 226,41 & 225,21 & 224,00 & 2,36 \\
\hline & 144,50 & 143,74 & 142,99 & 142,23 & 141,48 & 140,72 & 1,18 \\
\hline & 105,08 & 104,53 & 103,98 & 103,43 & 102,88 & 102,33 & 0,60 \\
\hline & 75,23 & 74,84 & 74,44 & 74,05 & 73,65 & 73,26 & 0,30 \\
\hline & 72,83 & 72,45 & 72,07 & 71,68 & 71,30 & 70,92 & 0,15 \\
\hline & 53,87 & 53,58 & 53,30 & 53,02 & 52,74 & 52,46 & 0,075 \\
\hline & 52,69 & 52,41 & 52,14 & 51,86 & 51,58 & 51,31 & Fundo \\
\hline Total (g) & \multicolumn{7}{|c|}{\begin{tabular}{|l|l|l|l|l|l|l|l|l|}
1146,00 & 1140,00 & 1134,00 & 1128,00 & 1122,00 & 1116,00 \\
\end{tabular}} \\
\hline
\end{tabular}




\section{B.2. TEMPERATURAS DE ENSAIO}

Com os dados das viscosidades Saybolt-Furol do ligante nas temperaturas de $135^{\circ} \mathrm{C}, 150^{\circ} \mathrm{C}$ e $177^{\circ} \mathrm{C}$, traçou-se a curva $\log _{10}$ viscosidade versus temperatura, como mostra a Figura B.1.

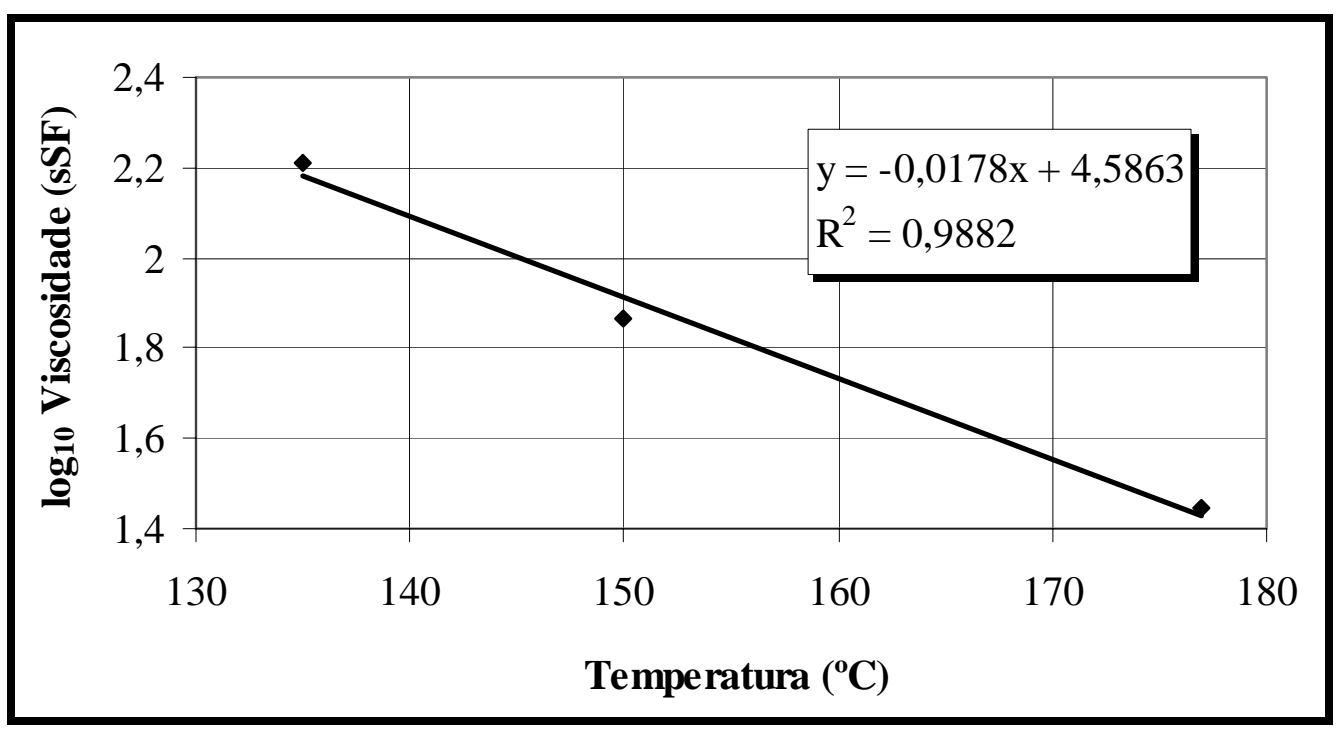

Figura B.1. Curva viscosidade versus temperatura do ligante asfáltico.

As temperaturas de mistura do CAP, de compactação e de aquecimento dos agregados foram calculadas como se segue.

$$
\begin{aligned}
& T_{\text {compactas } \tilde{\omega}}=T_{125}+\left(\frac{T_{155}-T_{125}}{2}\right)=139,85+\left(\frac{134,61-139,85}{2}\right) \\
& T_{\text {compactą } \tilde{\omega}}=137^{\circ} \mathrm{C}
\end{aligned}
$$$$
T_{\text {cap }}=T_{75}+\left(\frac{T_{95}-T_{75}}{2}\right)=152,32+\left(\frac{146,55-152,32}{2}\right)
$$ 


$$
\begin{aligned}
& T_{\text {cap }}=149^{\circ} \mathrm{C} \\
& T_{\text {agregado }}=T_{\text {cap }}+13=149+13 \\
& T_{\text {agregado }}=162^{\circ} \mathrm{C}
\end{aligned}
$$

\section{B.3. PARÂMETROS DA DOSAGEM MARSHALL}

A compactação dos corpos-de-prova deu-se pela aplicação de 75 golpes com o soquete Marshall em cada face e após serem desmoldados, calcularam-se os parâmetros Marshall como mostram as equações a seguir.

$$
\begin{aligned}
& V C P_{J S I 1}=M A-M I=1167,8-685,7 \\
& V C P_{J S I 1}=482,1 \mathrm{~cm}^{3} \\
& D A P=\frac{M A}{M A-M I}=\frac{1167,8}{1167,8-685,7} \\
& D A P=2,422
\end{aligned}
$$

$$
D M T=\frac{1}{\frac{C A P_{p}}{\rho_{C A P}}+\frac{A G_{p}}{\rho_{A G}}}=\frac{1}{\frac{0,045}{1,008}+\frac{0,955}{2,866}}
$$

$D M T=2,646$ 
$V v=\left(1-\frac{D A P}{D M T}\right) \times 100=\left(1-\frac{2,422}{2,646}\right)$

$V v=8,47 \%$

$$
\begin{aligned}
& V_{\text {сар }}=\frac{D A P \times C A P_{p}}{\rho_{\text {CAP }}} \times \rho_{\text {água }}=\frac{2,422 \times 0,045}{1,008} \times 1=10,81 \% \\
& V_{\text {cap }}=10,81 \%
\end{aligned}
$$

$V A M=V v+V_{c a}=8,47+10,81$

$V A M=19,28 \%$

$R B V=\frac{V_{C A P}}{V A M}=\frac{0,1081}{0,1928}$

$R B V=56,08 \%$

Os demais corpos-de-prova da dosagem foram calculados analogamente ao JSI001 e os resultados encontram-se na Tabela B.2, que também apresenta as médias dos valores de cada parâmetro da dosagem. 


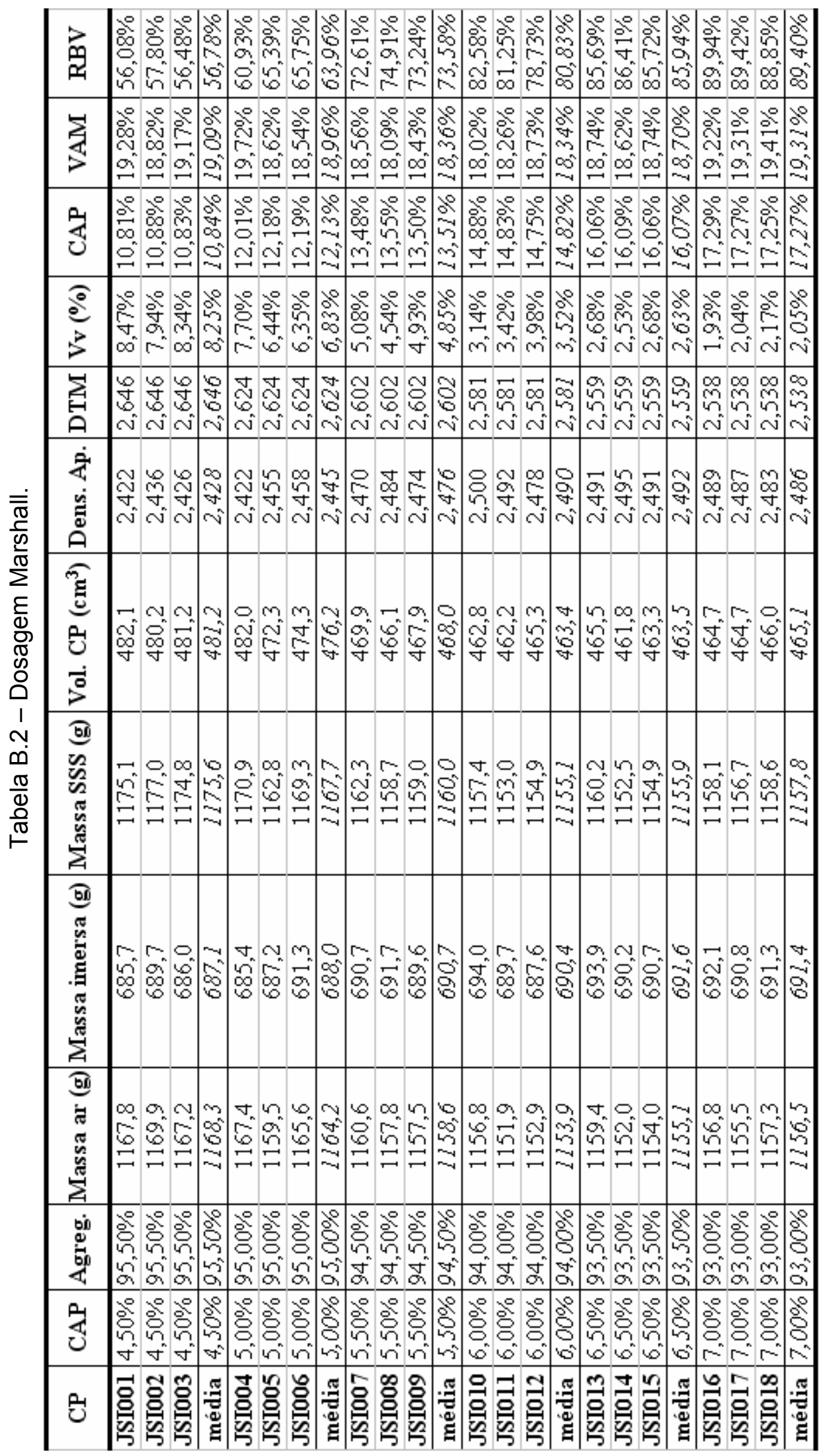


APÊNDICE C

Absorção de Asfalto 
A densidade máxima medida da mistura foi determina para a mistura dosada com o teor ótimo de ligante através da equação:

$D M M_{J S I 19}=\frac{A}{A+D-E}=\frac{1172,2}{1172,2+3601,9-4308,9}$

$D M M_{J S I 19}=2,520$

$\rho_{e f}=\frac{1-C A P_{p}}{\frac{1}{D M M}-\frac{C A P_{p}}{\rho_{c a p}}}=\frac{1-0,0578}{\frac{1}{2,520}-\frac{0,0578}{1,008}}$

$\rho_{\text {ef }}=2,7751 \mathrm{~g} / \mathrm{cm}^{3}$

$A b s=\left(\frac{\rho_{e f}-\rho_{a p}}{\rho_{e f} \times \rho_{a p}} \times \rho_{c a p}\right) \times 100=\left(\frac{2,7751-2,775}{2,7751 \times 2,775} \times 1,008\right) \times 100=0,001 \%$

Abs $=0,001 \%$

Os valores apresentados nas expressões anteriores estão omitindo muitas casas decimais, por esse motivo há diferença no resultado do cálculo apresentado com o os dados usados nas equações.

Os demais corpos-de-prova foram calculados analogamente ao JSI019 e os resultados se encontram na Tabela C.1. 
Tabela C.1 - Absorção de asfalto para as diferentes etapas de envelhecimento.

\begin{tabular}{|c|c|c|c|c|c|c|c|c|c|}
\hline$C P n^{\circ}$ & $\begin{array}{c}\text { Env. } \\
\text { (h) }\end{array}$ & $\begin{array}{c}\text { Massa } \\
\text { amostra } \\
\text { (g) }\end{array}$ & $\begin{array}{c}\text { Massa } \\
\text { amostra } \\
+ \\
\text { kitassato } \\
\text { cheio }(g)\end{array}$ & $\begin{array}{l}\text { Temp. } \\
\left({ }^{\circ} \mathrm{C}\right)\end{array}$ & $\begin{array}{c}\text { Massa } \\
\text { kitassato } \\
\text { calibração } \\
\text { (g) }\end{array}$ & DMM & $\begin{array}{c}\text { } \rho_{\text {ef do }} \\
\text { agregado } \\
\left(\mathrm{g} / \mathrm{cm}^{3}\right)\end{array}$ & $\begin{array}{c}\text { Abs. } \\
(\%)\end{array}$ & $\begin{array}{l}\text { Abs. } \\
\text { média } \\
(\%)\end{array}$ \\
\hline JSI019 & \multirow{2}{*}{0} & 1172,2 & 4308,9 & 24,3 & 3601,9 & 2,520 & 2,775 & 0,001 & \multirow{2}{*}{0,001} \\
\hline JSI020 & & 1168,9 & 4306,9 & 24,3 & 3601,9 & 2,520 & 2,775 & 0,000 & \\
\hline JSI021 & \multirow{2}{*}{2} & 1172,0 & 4308,7 & 24,9 & 3601,6 & 2,521 & 2,777 & 0,021 & \multirow{2}{*}{0,023} \\
\hline JSI022 & & 1165,0 & 4304,7 & 24,4 & 3601,8 & 2,521 & 2,777 & 0,024 & \\
\hline JSI023 & \multirow{2}{*}{ 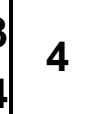 } & 1171,4 & 4309,8 & 24,4 & 3601,8 & 2,528 & 2,785 & $0,137 \mid$ & \multirow{2}{*}{0,123} \\
\hline JSI024 & & 1171,9 & 4309,9 & 24,3 & 3601,9 & 2,526 & 2,783 & 0,109 & \\
\hline
\end{tabular}


APÊNDICE D

\section{Características}

Volumétricas dos Corposde-prova 


\section{D.1. DOSAGEM MARSHALL}

Tabela D.1 - Dosagem Marshall - Diâmetro e altura dos corpos-de-prova.

\begin{tabular}{|c|c|c|c|c|c|c|c|c|c|c|c|}
\hline \multirow{2}{*}{$C P n^{\circ}$} & \multirow{2}{*}{$\begin{array}{l}\text { CAP } \\
(\%)\end{array}$} & \multicolumn{5}{|c|}{ Diâmetro $(\mathrm{mm})$} & \multicolumn{5}{|c|}{ Altura (mm) } \\
\hline & & D1 & D2 & D3 & D4 & $D_{\text {médio }}$ & H1 & $\mathrm{H} 2$ & H3 & H4 & $H_{\text {média }}$ \\
\hline 001 & & 101,7 & 101,7 & 101,7 & 101,7 & 101,7 & 60,8 & 61,0 & 60,9 & 61,0 & 60,9 \\
\hline & 4,5 & & & 101,8 & 1,8 & 101,8 & 60,8 & 60,9 & & 60,6 & 09 \\
\hline 1003 & & 101,9 & 101,9 & 101,9 & 101,9 & 101,9 & 60,7 & 60,7 & 60,9 & 60,6 & 60,7 \\
\hline JSI004 & & 101,9 & 102,2 & 102,0 & 102,1 & 102,1 & 60,2 & 60,2 & 59,9 & 60,6 & 60,2 \\
\hline 005 & 5,0 & 101,7 & 101,8 & 10 & 101,8 & 101,8 & 59,6 & 59,1 & 59,3 & 59,6 & 59,4 \\
\hline 1006 & & 101,7 & 101,6 & 101,6 & 101,7 & 101,7 & 60,0 & 59,7 & 59,6 & 59,7 & 59,8 \\
\hline JSI007 & & 101,7 & 101,7 & 101,7 & 101,8 & 101,7 & 58,8 & 58,9 & 59,1 & 59,2 & 59,0 \\
\hline & 5,5 & 101,7 & 101,7 & & 101,7 & & 58,5 & 58,9 & & 58,4 & 58,7 \\
\hline & & 101,6 & 101,7 & 101,7 & 101,7 & 101,7 & 59,0 & 59,1 & 58,9 & 59,0 & 59,0 \\
\hline JSI010 & & 101,7 & 101,7 & 101,8 & 101,6 & 101,7 & 58,1 & 58,1 & 58,1 & 58,1 & 58,1 \\
\hline JSI011 & 6,0 & 101,5 & 101,6 & 101,7 & 101,6 & 101,6 & 57,9 & 58,1 & 58,3 & 58,1 & 58,1 \\
\hline & & 101,6 & 101,8 & & 101,6 & & 58,5 & 58,8 & & 58,5 & 58,6 \\
\hline & & 101,7 & 101 & & 101,7 & 101 & 58,6 & 58,1 & 58,4 & 58,4 & 58,4 \\
\hline JSI014 & 6,5 & 101,5 & 101,6 & 101,8 & 101,6 & 101,6 & 58,8 & 58,3 & 58,9 & 58,1 & 58,5 \\
\hline JSI015 & & 101,4 & 101,5 & 101,8 & 101,8 & 101,6 & 58,6 & 58,6 & 58,5 & 58,5 & 58,6 \\
\hline JSI016 & & 101,5 & 101,5 & $10^{\prime}$ & 101,8 & $10^{\prime}$ & 58,3 & 58,1 & 58 & 58,3 & 58,3 \\
\hline & 7,0 & 101 & 101,6 & & 101,5 & & 58,5 & 58,1 & 58,2 & 58,3 & 58,3 \\
\hline JSI018 & & 101,7 & 101,9 & 101,9 & 102,0 & 101,9 & 58,2 & 58,5 & 58,3 & 58,4 & 58,4 \\
\hline
\end{tabular}


Tabela D.2 - Dosagem Marshall - Massas, volumes, densidades e volume de vazios dos corpos-de-prova.

\begin{tabular}{|c|c|c|c|c|c|c|c|}
\hline$C P n^{\circ}$ & $\begin{array}{l}\text { CAP } \\
(\%)\end{array}$ & $\begin{array}{c}\text { Massa ao ar } \\
\text { (g) }\end{array}$ & $\begin{array}{c}\text { Massa } \\
\text { imersa (g) }\end{array}$ & $\begin{array}{c}\text { Volume } \\
\left(\mathrm{cm}^{3}\right)\end{array}$ & DTM & Dap & $\begin{array}{l}\text { Vv } \\
(\%) \\
\end{array}$ \\
\hline JSI001 & & 1167,8 & 685,7 & 494,9 & & 2,422 & 8,47 \\
\hline JSI002 & 4,5 & 1169,9 & 689,7 & 494,8 & 2,646 & 2,436 & 7,94 \\
\hline JSI003 & & 1167,2 & 686,0 & 495,2 & & 2,426 & 8,34 \\
\hline JSI004 & & 1167,4 & 685,4 & 492,6 & & 2,422 & 7,70 \\
\hline JSI005 & 5,0 & 1159,5 & 687,2 & 483,5 & 2,624 & 2,455 & 6,44 \\
\hline JSI006 & & 1165,6 & 691,3 & 484,9 & & 2,458 & 6,35 \\
\hline JSI007 & & 1160,6 & 690,7 & 479,5 & & 2,470 & 5,08 \\
\hline JSI008 & 5,5 & 1157,8 & 691,7 & 477,3 & 2,602 & 2,484 & 4,54 \\
\hline JSI009 & & 1157,5 & 689,6 & 479,0 & & 2,474 & 4,93 \\
\hline JSI010 & & 1156,8 & 694,0 & 472,0 & & 2,500 & 3,14 \\
\hline JSI011 & 6,0 & 1151,9 & 689,7 & 471,0 & 2,581 & 2,492 & 3,42 \\
\hline JSI012 & & 1152,9 & 687,6 & 475,8 & & 2,478 & 3,98 \\
\hline JSI013 & & 1159,4 & 693,9 & 474,9 & & 2,491 & 2,68 \\
\hline JSI014 & 6,5 & 1152,0 & 690,2 & 474,7 & 2,559 & 2,495 & 2,53 \\
\hline JSI015 & & 1154,0 & 690,7 & 474,9 & & 2,491 & 2,68 \\
\hline JSI016 & & 1156,8 & 692,1 & 472,7 & & 2,489 & 1,93 \\
\hline JSI017 & 7,0 & 1155,5 & 690,8 & 472,7 & 2,538 & 2,487 & 2,04 \\
\hline JSI018 & & 1157,3 & 691,3 & 475,6 & & 2,483 & 2,17 \\
\hline
\end{tabular}




\section{D.2. ENSAIOS EXPLORATÓRIOS}

Tabela D.3 - Ensaios Exploratórios - Diâmetro e altura dos corpos-de-prova.

\begin{tabular}{|c|c|c|c|c|c|c|c|c|c|c|c|}
\hline \multirow{2}{*}{$C P n^{\circ}$} & \multirow{2}{*}{$\begin{array}{c}\text { EVA } \\
(\%) \\
\# 4,76\end{array}$} & \multicolumn{5}{|c|}{ Diâmetro (mm) } & \multicolumn{5}{|c|}{ Altura $(\mathrm{mm})$} \\
\hline & & D1 & D2 & D3 & D4 & $D_{\text {médio }}$ & H1 & $\mathrm{H} 2$ & H3 & H4 & $H_{\text {média }}$ \\
\hline JSI025 & & 101,7 & 101,7 & 101,7 & 101,7 & 101,7 & 59,6 & 60,1 & 59,9 & 59,6 & 59,8 \\
\hline JSI026 & & 101,5 & 101,6 & 101,6 & 101,6 & 101,6 & 60,5 & 60,7 & 60,7 & 60,6 & 60,6 \\
\hline JSI027 & & 101,9 & 101,7 & 101,8 & 101,8 & 101,8 & 60,3 & 60,5 & 60,4 & 60,5 & 60,4 \\
\hline JSI028 & & 101,8 & 101,8 & 101,8 & 101,8 & 101,8 & 59,6 & 60,0 & 60,0 & 59,7 & 59,8 \\
\hline JSI029 & & 101,6 & 101,8 & 101,7 & 101,8 & 101,7 & 60,8 & 60,8 & 60,9 & 60,9 & 60,9 \\
\hline JSI030 & & 101,7 & 101,8 & 101,7 & 101,7 & 101,7 & 60,7 & 60,6 & 60,7 & 60,7 & 60,7 \\
\hline JSI031 & 0,0 & 101,7 & 101,7 & 101,8 & 101,7 & 101,7 & 61,3 & 61,0 & 61,0 & 61,0 & 61,1 \\
\hline JSI032 & & 101,5 & 101,7 & 101,7 & 101,7 & 101,7 & 60,5 & 61,0 & 60,9 & 60,6 & 60,8 \\
\hline JSI033 & & 101,6 & 101,7 & 101,6 & 101,7 & 101,7 & 61,2 & 61,5 & 61,5 & 61,6 & 61,5 \\
\hline JSI034 & & 101,7 & 101,6 & 101,8 & 101,7 & 101,7 & 60,8 & 60,7 & 60,6 & 60,7 & 60,7 \\
\hline JSI035 & 1,0 & 101,8 & 101,9 & 101,8 & 101,7 & 101,8 & 60,7 & 60,4 & 60,6 & 60,2 & 60,5 \\
\hline JSI036 & & 101,7 & 101,8 & 101,8 & 101,7 & 101,8 & 60,6 & 60,4 & 60,2 & 60,5 & 60,4 \\
\hline JSI037 & & 101,6 & 101,8 & 101,9 & 101,8 & 101,8 & 62,0 & 62,0 & 62,1 & 61,6 & 61,9 \\
\hline JSI038 & & 101,8 & 101,7 & 101,6 & 101,7 & 101,7 & 62,3 & 62,1 & 62,5 & 62,4 & 62,3 \\
\hline JSI039 & 10,0 & 101,7 & 101,7 & 101,8 & 101,7 & 101,7 & 62,5 & 62,2 & 62,3 & 62,3 & 62,3 \\
\hline JSI040 & & 101,7 & 101,7 & 101,7 & 101,7 & 101,7 & 63,1 & 63,2 & 62,6 & 63,6 & 63,1 \\
\hline
\end{tabular}


Tabela D.4 - Ensaios exploratórios - Massas, volumes, densidades e volume de vazios dos corpos-de-prova.

\begin{tabular}{|c|c|c|c|c|c|c|c|}
\hline$C P n^{\circ}$ & $\begin{array}{r}\text { EVA (\%) } \\
\# 4,76 \mathrm{~mm}\end{array}$ & $\begin{array}{c}\text { Massa ao ar } \\
\text { (g) }\end{array}$ & $\begin{array}{c}\text { Massa } \\
\text { imersa }(\mathrm{g})\end{array}$ & $\begin{array}{c}\text { Volume } \\
\left(\mathrm{cm}^{3}\right)\end{array}$ & DTM & Dap & $\begin{array}{l}\text { Vv } \\
(\%)\end{array}$ \\
\hline JSI025 & \multirow{4}{*}{2,5} & 1161,0 & 684,8 & 485,8 & \multirow{4}{*}{2,551} & 2,438 & $4,38 \%$ \\
\hline JSI026 & & 1171,7 & 694,9 & 491,3 & & 2,457 & $3,62 \%$ \\
\hline JSI027 & & 1175,5 & 698,0 & 491,8 & & 2,462 & $3,45 \%$ \\
\hline JSI028 & & 1164,4 & 687,2 & 486,9 & & 2,440 & $4,30 \%$ \\
\hline JSI029 & \multirow{4}{*}{5,0} & 1156,1 & 675,4 & 494,5 & \multirow{4}{*}{2,512} & 2,405 & $4,24 \%$ \\
\hline JSI030 & & 1157,8 & 676,5 & 493,1 & & 2,406 & $4,22 \%$ \\
\hline JSI031 & & 1151,0 & 671,7 & 496,4 & & 2,401 & $4,38 \%$ \\
\hline JSI032 & & 1157,4 & 676,3 & 493,0 & & 2,406 & $4,21 \%$ \\
\hline JSI033 & \multirow{4}{*}{7,5} & 1158,7 & 676,2 & 498,7 & \multirow{4}{*}{2,475} & 2,401 & $4,38 \%$ \\
\hline JSI034 & & 1158,6 & 679,2 & 493,1 & & 2,417 & $3,77 \%$ \\
\hline JSI035 & & 1158,3 & 676,8 & 492,2 & & 2,406 & $4,22 \%$ \\
\hline JSI036 & & 1158,4 & 677,5 & 491,3 & & 2,409 & $4,09 \%$ \\
\hline JSI037 & \multirow{4}{*}{10,0} & 1145,0 & 655,5 & 503,8 & \multirow{4}{*}{2,439} & 2,339 & $4,07 \%$ \\
\hline JSI038 & & 1149,6 & 656,8 & 506,3 & & 2,333 & $4,33 \%$ \\
\hline JSI039 & & 1149,4 & 657,6 & 506,5 & & 2,337 & $4,15 \%$ \\
\hline JSI040 & & 1150,4 & 658,9 & 512,8 & & 2,341 & $4,01 \%$ \\
\hline
\end{tabular}




\section{D.3. PROGRAMA EXPERIMENTAL}

Tabela D.5 - Programa Experimental - Diâmetro e altura dos CPs com 0\% de EVA.

\begin{tabular}{|c|c|c|c|c|c|c|c|c|c|c|c|}
\hline \multirow{2}{*}{$C P n^{\circ}$} & \multirow{2}{*}{$\begin{array}{c}\text { Env. } \\
\text { (h) }\end{array}$} & \multicolumn{5}{|c|}{ Diâmetro (mm) } & \multicolumn{5}{|c|}{ Altura $(\mathrm{mm})$} \\
\hline & & D1 & D2 & D3 & D4 & $D_{\text {médio }}$ & H1 & $\mathrm{H} 2$ & $\mathrm{H} 3$ & H4 & $H_{\text {média }}$ \\
\hline JSI041 & & 101,5 & 101,7 & 101,7 & 101,7 & 101,7 & 59,6 & 59,4 & 59,6 & 59,5 & 59,5 \\
\hline JSI042 & & 101,5 & 101,6 & 101,7 & 101,6 & 101,6 & 58,7 & 58,5 & 58,7 & 58,5 & 58,6 \\
\hline JSI043 & & 101,6 & 101,6 & 101,5 & 101,6 & 101,6 & 58,8 & 58,6 & 59,1 & 58,6 & 58,8 \\
\hline JSI044 & & 101,8 & 101,8 & 101,9 & 101,9 & 101,9 & 59,5 & 59,5 & 59,1 & 59,2 & 59,3 \\
\hline JSI045 & & 102,3 & 101,7 & 102,6 & 101,7 & 102,1 & 59,2 & 58,7 & 58,9 & 58,6 & 58,9 \\
\hline JSI046 & & 101,7 & 101,7 & 101,7 & 101,7 & 101,7 & 59,5 & 59,0 & 58,9 & 59,1 & 59,1 \\
\hline JSI047 & 0 & 101,5 & 101,6 & 101,5 & 101,7 & 101,6 & 58,6 & 59,1 & 59,1 & 58,9 & 58,9 \\
\hline JSI048 & 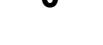 & 101,5 & 101,8 & 101,7 & 101,6 & 101,7 & 59,5 & 59,2 & 59,0 & 59,4 & 59,3 \\
\hline JSI049 & & 101,5 & 101,5 & 101,5 & 101,5 & 101,5 & 59,1 & 59,1 & 59,2 & 59,2 & 59,2 \\
\hline JSI050 & & 101,7 & 101,8 & 101,8 & 101,6 & 101,7 & 59,4 & 59,0 & 58,9 & 59,3 & 59,2 \\
\hline JSI051 & & 101,8 & 101,9 & 101,9 & 101,8 & 101,9 & 57,0 & 57,3 & 57,1 & 57,2 & 57,2 \\
\hline JSI052 & & 101,5 & 101,5 & 101,7 & 101,7 & 101,6 & 59,5 & 59,7 & 59,1 & 58,9 & 59,3 \\
\hline JSI053 & & 101,6 & 101,7 & 101,6 & 101,7 & 101,7 & 59,7 & 59,4 & 59,6 & 59,5 & 59,6 \\
\hline JSI054 & & 101,6 & 101,7 & 101,7 & 101,6 & 101,7 & 58,9 & 59,0 & 59,0 & 58,9 & 59,0 \\
\hline JSI055 & & 101,6 & 101,8 & 101,7 & 101,8 & 101,7 & 60,2 & 60,2 & 60,2 & 60,2 & 60,2 \\
\hline JSI056 & & 101,6 & 101,7 & 101,7 & 101,8 & 101,7 & 60,0 & 59,7 & 59,6 & 60,0 & 59,8 \\
\hline JSI057 & & 101,7 & 101,8 & 101,7 & 101,7 & 101,7 & 59,4 & 59,2 & 59,4 & 59,2 & 59,3 \\
\hline JSI058 & & 101,5 & 101,5 & 101,5 & 101,7 & 101,6 & 60,3 & 60,5 & 60,3 & 60,5 & 60,4 \\
\hline 059 & & 101,7 & 101,8 & 101,8 & 101,9 & 101,8 & 59,5 & 59,9 & 59,6 & 59,8 & 59,7 \\
\hline JSI060 & & 101,9 & 102,0 & 102,0 & 101,8 & 101,9 & 59,7 & 60,1 & 60,0 & 59,9 & 59,9 \\
\hline JSI061 & 2 & 101,6 & 101,6 & 101,5 & 101,5 & 101,6 & 59,8 & 59,9 & 59,9 & 60,0 & 59,9 \\
\hline JSI062 & & 101,6 & 101,7 & 101,8 & 101,6 & 101,7 & 59,8 & 59,8 & 59,8 & 59,8 & 59,8 \\
\hline 063 & & 101,6 & 101,7 & 101,7 & 101,6 & 101,7 & 59,6 & 60,0 & 59,5 & 59,8 & 59,7 \\
\hline 64 & & 101,6 & 101,7 & 101,7 & 101,7 & 101,7 & 59,7 & 60,1 & 60,0 & 60,1 & 60,0 \\
\hline & & 101,3 & 101,5 & 101,5 & 101,5 & 101,5 & 0,1 & 60,1 & 60,1 & 60,1 & 60,1 \\
\hline 066 & & 101,6 & 101,8 & 101,7 & 101,8 & 101,7 & 60,0 & 59,6 & 59,8 & 59,6 & 59,8 \\
\hline 067 & & 101,7 & 101,7 & 101,7 & 101,6 & 101,7 & 59,8 & 59,9 & 59,8 & 59,7 & 59,8 \\
\hline JS & & 101,7 & 101,7 & 101,8 & 101,7 & 101,7 & 60,1 & 60,2 & 60,2 & 60,1 & 60,2 \\
\hline & & 101,7 & 101,7 & 101,6 & 101,7 & 101,7 & 60,1 & 60,1 & 60 & 60,1 & 60,1 \\
\hline & & 101,7 & 101,7 & 101,8 & 101,7 & 101,7 & 59,6 & 59,8 & 59,6 & 59,7 & 59,7 \\
\hline 071 & & 101,8 & 101,9 & 101,9 & 101,9 & 101,9 & 60,2 & 60,0 & 60,1 & 60,1 & 60,1 \\
\hline 072 & & 101,7 & 101,7 & 101,7 & 101,8 & 101,7 & 59,8 & 59,4 & 59,5 & 59,6 & 59,6 \\
\hline 073 & & 101,7 & 101,8 & 101,7 & 101,7 & 101,7 & 60,8 & 60,8 & 60,8 & 60,7 & 60,8 \\
\hline JSI074 & & 101,6 & 101,7 & 101,7 & 101,6 & 101,7 & 60,1 & 60,1 & 60,1 & 60,1 & 60,1 \\
\hline JSI075 & 4 & 101,5 & 101,6 & 101,6 & 101,6 & 101,6 & 60,6 & 60,7 & 60,2 & 60,2 & 60,4 \\
\hline JSI076 & & 101,7 & 101,8 & 101,7 & 101,7 & 101,7 & 59,5 & 59,2 & 59,6 & 59,3 & 59,4 \\
\hline JSI077 & & 101,7 & 101,7 & 101,7 & 101,7 & 101,7 & 60,0 & 60,0 & 59,6 & 60,0 & 59,9 \\
\hline JSI078 & & 101,5 & 101,7 & 101,7 & 101,5 & 101,6 & 59,5 & 59,8 & 59,7 & 59,4 & 59,6 \\
\hline JSI079 & & 101,7 & 101,7 & 101,7 & 101,8 & 101,7 & 60,0 & 59,8 & 59,8 & 60,1 & 59,9 \\
\hline JSI080 & & 101,7 & 101,8 & 101,8 & 101,7 & 101,8 & 59,7 & 60,0 & 60,0 & 59,7 & 59,9 \\
\hline JSI081 & & 101,7 & 101,8 & 101,7 & 101,7 & 101,7 & 60,1 & 59,9 & 60,0 & 60,1 & 60,0 \\
\hline JSI082 & & 101,6 & 101,7 & 101,6 & 101,7 & 101,7 & 60,4 & 60,3 & 60,5 & 60,2 & 60,4 \\
\hline
\end{tabular}


Tabela D.6 - Programa Experimental - Diâmetro e altura dos CPs com 1\% de EVA.

\begin{tabular}{|c|c|c|c|c|c|c|c|c|c|c|c|}
\hline \multirow{2}{*}{$C P n^{\circ}$} & \multirow{2}{*}{$\begin{array}{c}\text { Env. } \\
\text { (h) }\end{array}$} & \multicolumn{5}{|c|}{ Diâmetro (mm) } & \multicolumn{5}{|c|}{ Altura (mm) } \\
\hline & & D1 & D2 & D3 & D4 & $D_{\text {médio }}$ & H1 & $\mathrm{H} 2$ & H3 & H4 & $\mathrm{H}_{\text {média }}$ \\
\hline JSI083 & & 101,6 & 101,6 & 101,9 & 101,8 & 101,7 & 59,5 & 59,3 & 59,5 & 59,6 & 59,5 \\
\hline & & 01,5 & 101,6 & 101,8 & 101,8 & 101,7 & 59,5 & 59,6 & 59,7 & 59,5 & 59,6 \\
\hline JSI085 & & 01,6 & 101,6 & 101,7 & 101,8 & 101,7 & 59,4 & 59,2 & 59,2 & 58,8 & 59,2 \\
\hline JSI086 & & 101,8 & 101,7 & 101,7 & 101,7 & 101,7 & 58,4 & 58,5 & 58,1 & 58,1 & 58,3 \\
\hline JSI087 & & 101,6 & 101,8 & 101,8 & 101,8 & 101,8 & 58,7 & 58,2 & 58,4 & 58,1 & 58,4 \\
\hline JSI088 & & 101,7 & 101,7 & 101,8 & 101,8 & 101,8 & 58,3 & 58,0 & 58,1 & 58,2 & 58,2 \\
\hline JSI089 & 0 & 101,7 & 101,5 & 101,7 & 101,8 & 101,7 & 58,9 & 58,8 & 58,7 & 58,3 & 58,7 \\
\hline JSI090 & 0 & 101,6 & 101,7 & 101,9 & 101,9 & 101,8 & 58,6 & 58,5 & 58,5 & 58,3 & 58,5 \\
\hline JSI091 & & 101,9 & 101,6 & 101,7 & 101,7 & 101,7 & 58,7 & 58,1 & 58,0 & 58,5 & 58,3 \\
\hline JSI092 & & 101,7 & 101,7 & 101,9 & 101,9 & 101,8 & 59,3 & 59,5 & 58,7 & 58,7 & 59,1 \\
\hline 093 & & 101,6 & 101,7 & 101,6 & 101,7 & 101,7 & 59,4 & 59,2 & 59,3 & 59,2 & 59,3 \\
\hline 094 & & 101,8 & 101,8 & 101,7 & 101,7 & & 59,2 & 59,1 & 59,1 & 59,3 & 59,2 \\
\hline 1095 & & 101,7 & 101,8 & 101,8 & 101,8 & 101,8 & 58,9 & 59,1 & 58,5 & 58,7 & 58,8 \\
\hline JSI096 & & 101,8 & 102,0 & 101,9 & 102,1 & 102,0 & 59,4 & 59,6 & 58,8 & 58,9 & 59,2 \\
\hline JSI097 & & 101,7 & 101,6 & 101,6 & 101,6 & 1,6 & 60,5 & 60,3 & 60,6 & 60,3 & 60,4 \\
\hline 1098 & & 101,7 & 101,7 & 101,8 & 101,7 & 101,7 & 59,8 & 59,7 & 60,0 & 59,6 & 59,8 \\
\hline 099 & & 101,8 & 101,9 & 101,9 & 101,8 & 1,9 & 60,7 & 60,5 & 60,5 & 60,6 & 60,6 \\
\hline JSI100 & & 101,7 & 101,9 & 101,8 & 101,8 & 101,8 & 59,1 & 59,1 & 59,2 & 58,9 & 59,1 \\
\hline JSI101 & & 101,6 & 101,7 & 101,7 & 101,8 & 101,7 & 59,2 & 59,4 & 59,4 & 59,3 & 59,3 \\
\hline 102 & & 101,7 & 101,8 & 101,8 & 101,8 & 101,8 & 59,2 & 59,4 & 59,3 & 59,0 & 59,2 \\
\hline JSI103 & $?$ & 101,7 & 101,7 & 101,8 & 101,8 & 101,8 & 59,6 & 59,4 & 59,0 & 59,0 & 59,3 \\
\hline JSI104 & 2 & 101,7 & 101,7 & 101,8 & 101,7 & 101,7 & 59,3 & 58,9 & 59,4 & 59,4 & 59,3 \\
\hline 105 & & 101,7 & 101,6 & 101,7 & 101,7 & 101,7 & 59,2 & 59,7 & 59,1 & 59,4 & 59,4 \\
\hline 106 & & 101,7 & 101,7 & 101,6 & 101,8 & 101,7 & 59,0 & 59,1 & 59,1 & 59,1 & 59,1 \\
\hline 107 & & 101,7 & 101,7 & 101,7 & 101,7 & 101,7 & 59,4 & 59,5 & 59,4 & 59,5 & 59,5 \\
\hline 108 & & 101,6 & 101,6 & 101,7 & 101,7 & 101,7 & 59,6 & 59,6 & 59,5 & 59,7 & 59,6 \\
\hline & & 101,6 & 101,6 & 101,8 & 101,8 & 101,7 & 58,6 & 58,5 & 58,5 & 59,2 & 58,7 \\
\hline 1110 & & 101,7 & 101,7 & 101,9 & 101,9 & 101,8 & 59,3 & 59,0 & 59,7 & 59,2 & 59,3 \\
\hline $\mid 111$ & & 101,7 & 101,7 & 101,7 & 101,7 & 101,7 & 60,3 & 59,9 & 60,2 & 60,1 & 60,1 \\
\hline $\mid 112$ & & 101,7 & 101,8 & 101,8 & 101,9 & 101,8 & 60,3 & 60,2 & 60,2 & 60,2 & 60,2 \\
\hline 1113 & & 101,6 & 101,6 & 101,6 & 101,6 & 101,6 & 60,2 & 60,0 & 60,0 & 60,2 & 60,1 \\
\hline & & 101,7 & 101,7 & 101,7 & 101,7 & 101,7 & 60,0 & 59,8 & 59,7 & 60,0 & 59,9 \\
\hline $\mid 115$ & & 101,6 & 101,7 & 101,8 & 101,8 & 101,7 & 60,2 & 59,8 & 59,9 & 59,5 & 59,9 \\
\hline JSI116 & & 101,6 & 101,8 & 101,7 & 101,8 & 101,7 & 60,0 & 59,8 & 59,9 & 59,9 & 59,9 \\
\hline 1117 & 1 & 101,8 & 101,9 & 101,9 & 101,9 & 101,9 & 59,6 & 59,3 & 59,7 & 59,4 & 59,5 \\
\hline JSI118 & 4 & 101,6 & 101,8 & 101,9 & 101,7 & 101,8 & 59,9 & 59,5 & 59,8 & 59,6 & 59,7 \\
\hline JSI119 & & 101,8 & 101,8 & 101,8 & 101,8 & 101,8 & 59,3 & 58,9 & 59,0 & 58,8 & 59,0 \\
\hline JSI120 & & 101,7 & 101,8 & 101,8 & 101,8 & 101,8 & 59,4 & 59,6 & 59,2 & 59,5 & 59,4 \\
\hline JSI121 & & 101,8 & 101,7 & 101,8 & 101,9 & 101,8 & 59,8 & 59,7 & 59,6 & 59,7 & 59,7 \\
\hline JSI122 & & 101,7 & 101,7 & 101,8 & 101,7 & 101,7 & 59,4 & 59,6 & 59,5 & 59,5 & 59,5 \\
\hline JSI123 & & 101,8 & 101,9 & 101,9 & 101,8 & 101,9 & 59,3 & 59,5 & 59,2 & 59,3 & 59,3 \\
\hline JSI124 & & 101,8 & 101,7 & 101,7 & 101,7 & 101,7 & 59,5 & 59,6 & 59,5 & 59,2 & 59,5 \\
\hline
\end{tabular}


Tabela D.7 - Programa Experimental - Diâmetro e altura dos CPs com 2\% de EVA.

\begin{tabular}{|c|c|c|c|c|c|c|c|c|c|c|c|}
\hline \multirow{2}{*}{$C P n^{\circ}$} & \multirow{2}{*}{$\begin{array}{c}\text { Env. } \\
\text { (h) }\end{array}$} & \multicolumn{5}{|c|}{ Diâmetro (mm) } & \multicolumn{5}{|c|}{ Altura (mm) } \\
\hline & & D1 & D2 & D3 & D4 & $D_{\text {médio }}$ & H1 & $\mathrm{H} 2$ & H3 & H4 & $\mathrm{H}_{\text {média }}$ \\
\hline JSI125 & & 101,8 & 101,9 & 101,9 & 102,0 & 101,9 & 60,7 & 60,2 & 60,2 & 59,7 & 60,2 \\
\hline JSI126 & & 101,8 & 101,9 & 101,8 & 101,9 & 101,9 & 60,9 & 60,4 & 60,8 & 60,6 & 60,7 \\
\hline JSI127 & & 101,4 & 101,6 & 101,7 & 101,7 & 101,6 & 61,1 & 59,8 & 60,8 & 60,1 & 60,5 \\
\hline JSI128 & & 101,6 & 101,6 & 101,6 & 101,8 & 101,7 & 60,6 & 59,7 & 60,2 & 60,8 & 60,3 \\
\hline JSI129 & & 101,9 & 101,8 & 102,0 & 102,0 & 101,9 & 59,2 & 60,0 & 60,0 & 59,9 & 59,8 \\
\hline JSI130 & & 101,8 & 101,7 & 101,9 & 101,9 & 101,8 & 59,6 & 59,3 & 59,3 & 59,3 & 59,4 \\
\hline JSI131 & 0 & 101,5 & 101,5 & 101,5 & 101,6 & 101,5 & 59,9 & 59,9 & 59,6 & 59,9 & 59,8 \\
\hline JSI132 & 0 & 101,8 & 101,6 & 101,7 & 101,7 & 101,7 & 60,7 & 59,9 & 59,6 & 61,5 & 60,4 \\
\hline JSI133 & & 101,8 & 101,8 & 101,8 & 101,9 & 101,8 & 59,6 & 59,7 & 59,8 & 59,8 & 59,7 \\
\hline JSI134 & & 101,9 & 101,9 & 101,9 & 102,0 & 101,9 & 59,5 & 59,1 & 59,4 & 59,0 & 59,3 \\
\hline JSI135 & & 101,8 & 101,8 & 101,9 & 101,7 & 101,8 & 60,1 & 60,0 & 60,3 & 60,1 & 60,1 \\
\hline JSI136 & & 101,9 & 101,8 & 101,7 & 101,9 & 101,8 & 59,9 & 60,2 & 59,8 & 59,9 & 60,0 \\
\hline JSI137 & & 101,8 & 101,8 & 101,9 & 101,9 & 101,9 & 59,1 & 58,5 & 59,2 & 58,8 & 58,9 \\
\hline JSI138 & & 101,7 & 101,7 & 101,8 & 101,7 & 101,7 & 59,3 & 58,6 & 58,9 & 58,8 & 58,9 \\
\hline JSI139 & & 101,7 & 101,7 & 101,7 & 101,8 & 101,7 & 59,5 & 59,4 & 59,1 & 59,4 & 59,4 \\
\hline JSI140 & & 101,9 & 101,7 & 101,8 & 101,9 & 101,8 & 60,7 & 60,0 & 60,5 & 60,0 & 60,3 \\
\hline JSI141 & & 101,7 & 101,6 & 101,6 & 101,8 & 101,7 & 60,0 & 59,6 & 60,0 & 59,5 & 59,8 \\
\hline JSI142 & & 101,6 & 101,6 & 101,7 & 101,6 & 101,6 & 60,2 & 59,7 & 59,9 & 60,1 & 60,0 \\
\hline JSI143 & & 101,8 & 101,8 & 101,8 & 101,7 & 101,8 & 60,2 & 60,6 & 60,7 & 60,1 & 60,4 \\
\hline JSI144 & & 101,9 & 101,8 & 101,8 & 101,9 & 101,9 & 60,5 & 59,7 & 60,2 & 60,3 & 60,2 \\
\hline JSI145 & $?$ & 101,8 & 101,7 & 101,7 & 101,9 & 101,8 & 59,7 & 60,3 & 60,2 & 60,2 & 60,1 \\
\hline JSI146 & 2 & 101,7 & 101,6 & 101,7 & 101,7 & 101,7 & 60,2 & 60,0 & 59,8 & 59,8 & 60,0 \\
\hline JSI147 & & 101,9 & 101,8 & 102,0 & 101,9 & 101,9 & 58,8 & 59,2 & 59,2 & 59,3 & 59,1 \\
\hline JSI148 & & 101,7 & 101,7 & 101,6 & 101,7 & 101,7 & 60,1 & 60,0 & 59,8 & 59,9 & 60,0 \\
\hline JSI149 & & 101,7 & 101,8 & 101,8 & 101,7 & 101,8 & 59,9 & 59,9 & 60,0 & 59,8 & 59,9 \\
\hline JSI150 & & 101,7 & 101,7 & 101,8 & 101,8 & 101,8 & 59,7 & 59,4 & 60,0 & 59,7 & 59,7 \\
\hline JSI151 & & 101,8 & 101,8 & 101,8 & 101,8 & 101,8 & 61,2 & 60,1 & 60,5 & 60,5 & 60,6 \\
\hline JSI152 & & 101,6 & 101,8 & 101,8 & 101,7 & 101,7 & 60,1 & 60,3 & 59,7 & 59,9 & 60,0 \\
\hline JSI153 & & 101,7 & 101,8 & 101,7 & 101,9 & 101,8 & 59,7 & 60,5 & 60,1 & 60,3 & 60,2 \\
\hline JSI154 & & 101,6 & 101,6 & 101,7 & 101,5 & 101,6 & 60,7 & 60,6 & 60,7 & 60,5 & 60,6 \\
\hline JSI155 & & 101,7 & 101,8 & 101,7 & 101,7 & 101,7 & 60,3 & 60,6 & 60,5 & 60,1 & 60,4 \\
\hline JSI156 & & 101,5 & 101,6 & 101,6 & 101,5 & 101,6 & 60,0 & 60,0 & 59,8 & 60,1 & 60,0 \\
\hline JSI157 & & 102,0 & 102,1 & 102,0 & 102,0 & 102,0 & 60,1 & 60,2 & 60,2 & 60,1 & 60,2 \\
\hline JSI158 & & 101,8 & 101,7 & 101,7 & 101,8 & 101,8 & 59,9 & 60,0 & 60,1 & 59,8 & 60,0 \\
\hline JSI159 & 4 & 101,9 & 101,8 & 101,9 & 101,8 & 101,9 & 59,7 & 59,6 & 59,3 & 59,6 & 59,6 \\
\hline JSI160 & 4 & 101,6 & 101,6 & 101,6 & 101,6 & 101,6 & 59,8 & 59,5 & 60,0 & 60,0 & 59,8 \\
\hline JSI161 & & 101,8 & 101,8 & 101,8 & 101,7 & 101,8 & 59,5 & 59,5 & 59,4 & 59,4 & 59,5 \\
\hline JSI162 & & 101,7 & 101,8 & 101,7 & 101,8 & 101,8 & 59,7 & 59,4 & 59,4 & 59,9 & 59,6 \\
\hline JSI163 & & 101,6 & 101,7 & 101,7 & 101,8 & 101,7 & 60,4 & 59,6 & 59,9 & 60,1 & 60,0 \\
\hline JSI164 & & 101,5 & 101,6 & 101,6 & 101,6 & 101,6 & 59,9 & 59,8 & 60,0 & 59,8 & 59,9 \\
\hline JSI165 & & 101,6 & 101,5 & 101,6 & 101,5 & 101,6 & 59,9 & 60,2 & 60,5 & 60,0 & 60,2 \\
\hline JSI166 & & 101,6 & 101,5 & 101,7 & 101,6 & 101,6 & 60,5 & 60,4 & 60,6 & 60,5 & 60,5 \\
\hline
\end{tabular}


Tabela D.8 - Programa Experimental - Diâmetro e altura dos CPs com 3\% de EVA.

\begin{tabular}{|c|c|c|c|c|c|c|c|c|c|c|c|}
\hline \multirow{2}{*}{$C P n^{\circ}$} & \multirow{2}{*}{$\begin{array}{c}\text { Env. } \\
\text { (h) }\end{array}$} & \multicolumn{5}{|c|}{ Diâmetro (mm) } & \multicolumn{5}{|c|}{ Altura (mm) } \\
\hline & & D1 & D2 & D3 & D4 & $D_{\text {médio }}$ & H1 & $\mathrm{H} 2$ & H3 & $\mathrm{H4}$ & $H_{\text {média }}$ \\
\hline JSI167 & & 101,8 & 101,8 & 101,8 & 101,7 & 101,8 & 60,4 & 60,6 & 60,9 & 60,6 & 60,6 \\
\hline JSI168 & & 101,6 & 101,6 & 101,7 & 101,8 & 101,7 & 62,5 & 63,2 & 62,8 & 63,3 & 63,0 \\
\hline JSI169 & & 101,6 & 101,7 & 101,9 & 101,8 & 101,8 & 62,1 & 61,3 & 61,9 & 60,6 & 61,5 \\
\hline JSI170 & & 101,8 & 101,9 & 101,8 & 101,9 & 101,9 & 63,4 & 62,6 & 62,6 & 62,7 & 62,8 \\
\hline JSI171 & & 101,8 & 101,8 & 101,9 & 102,0 & 101,9 & 62,1 & 62,4 & 62,7 & 61,6 & 62,2 \\
\hline JSI172 & & 101,5 & 101,6 & 101,7 & 101,7 & 101,6 & 61,4 & 61,7 & 61,5 & 62,2 & 61,7 \\
\hline JSI173 & & 101,8 & 101,6 & 101,7 & 101,6 & 101,7 & 61,8 & 62,0 & 62,1 & 61,2 & 61,8 \\
\hline JSI174 & 0 & 101,8 & 101,8 & 101,8 & 101,9 & 101,8 & 59,4 & 60,1 & 60,5 & 60,2 & 60,1 \\
\hline JSI175 & & 101,7 & 101,5 & 101,7 & 101,8 & 101,7 & 60,9 & 60,9 & 60,8 & 60,9 & 60,9 \\
\hline JSI176 & & 102,0 & 101,8 & 101,9 & 101,8 & 101,9 & 62,1 & 62,2 & 62,5 & 61,8 & 62,2 \\
\hline JSI177 & & 101,8 & 101,8 & 101,7 & 101,8 & 101,8 & 61,9 & 62,0 & 62,1 & 62,1 & 62,0 \\
\hline JSI178 & & 101,9 & 101,7 & 101,8 & 101,9 & 101,8 & 62,1 & 61,8 & 61,9 & 62,1 & 62,0 \\
\hline & & 101,5 & 101,6 & 101,8 & 101,6 & 101,6 & 61,1 & 60,3 & 60,2 & 61,6 & 60,8 \\
\hline JSI180 & & 101,8 & 101,8 & 101,9 & 102,1 & 101,9 & 62,8 & 63,1 & 63,1 & 61,5 & 62,6 \\
\hline JSI181 & & 101,8 & 101,6 & 101,7 & 101,6 & 101,7 & 60,6 & 60,0 & 60,4 & 60,4 & 60,4 \\
\hline JSI182 & & 101,7 & 101,8 & 101,8 & 101,8 & 101,8 & 60,9 & 60,1 & 60,1 & 60,1 & 60,3 \\
\hline JSI183 & & 102,0 & 101,9 & 101,8 & 101,8 & 101,9 & 60,4 & 61,0 & 60,5 & 60,2 & 60,5 \\
\hline JSI184 & & 101,7 & 101,7 & 101,9 & 101,8 & 101,8 & 61,0 & 60,9 & 60,6 & 60,5 & 60,8 \\
\hline JSI185 & & 101,5 & 101,6 & 101,7 & 101,7 & 101,6 & 60,5 & 61,0 & 61,7 & 61,8 & 61,3 \\
\hline JSI186 & & 101,7 & 101,6 & 101,8 & 101,6 & 101,7 & 60,1 & 61,3 & 60,3 & 60,6 & 60,6 \\
\hline JSI187 & & 101,6 & 101,7 & 101,8 & 101,8 & 101,7 & 59,7 & 59,7 & 59,8 & 60,0 & 59,8 \\
\hline JSI188 & 2 & 102,0 & 102,0 & 102,0 & 101,9 & 102,0 & 60,6 & 60,8 & 60,6 & 60,4 & 60,6 \\
\hline JSI189 & & 101,8 & 102,0 & 101,9 & 101,9 & 101,9 & 60,3 & 60,0 & 60,1 & 59,9 & 60,1 \\
\hline JSI190 & & 101,5 & 101,7 & 101,7 & 101,8 & 101,7 & 60,9 & 60,9 & 61,0 & 60,9 & 60,9 \\
\hline 191 & & 101,6 & 101,7 & 101,7 & 101,6 & 101,7 & 60,8 & 60,7 & 60,5 & 60,8 & 60,7 \\
\hline JSI192 & & 101,7 & 101,8 & 101,8 & 101,7 & 101,8 & 60,5 & 60,3 & 60,4 & 60,7 & 60,5 \\
\hline & & 101,8 & 101,6 & 101,8 & 101,6 & 101,7 & 60,7 & 60,5 & 61,0 & 60,1 & 60,6 \\
\hline JSI194 & & 101,8 & 101,5 & 101,7 & 101,6 & 101,7 & 61,3 & 61,7 & 61,4 & 61,6 & 61,5 \\
\hline JSI195 & & 101,8 & 101,8 & 101,6 & 101,6 & 101,7 & 60,9 & 60,7 & 60,9 & 60,6 & 60,8 \\
\hline JSI196 & & 101,7 & 101,7 & 101,7 & 101,7 & 101,7 & 60,8 & 60,9 & 60,3 & 60,9 & 60,7 \\
\hline JSI197 & & 101,7 & 101,7 & 101,5 & 101,7 & 101,7 & 60,1 & 60,3 & 60,0 & 60,2 & 60,2 \\
\hline JSI198 & & 101,7 & 101,8 & 101,8 & 101,7 & 101,8 & 60,8 & 60,5 & 60,8 & 60,9 & 60,8 \\
\hline JSI199 & & 101,7 & 101,7 & 101,8 & 101,7 & 101,7 & 60,8 & 60,7 & 60,5 & 60,7 & 60,7 \\
\hline JSI200 & & 101,7 & 101,8 & 101,8 & 101,7 & 101,8 & 60,2 & 60,8 & 61,1 & 61,0 & 60,8 \\
\hline JSI201 & & 102,0 & 101,9 & 101,8 & 101,7 & 101,9 & 61,8 & 62,0 & 61,8 & 61,8 & 61,9 \\
\hline JSI202 & 4 & 101,6 & 101,6 & 101,7 & 101,6 & 101,6 & 63,0 & 63,1 & 63,1 & 63,3 & 63,1 \\
\hline JSI203 & & 101,8 & 101,8 & 101,9 & 101,8 & 101,8 & 60,4 & 60,8 & 60,8 & 61,0 & 60,8 \\
\hline JSI204 & & 101,6 & 101,6 & 101,6 & 101,6 & 101,6 & 60,7 & 60,8 & 61,0 & 60,8 & 60,8 \\
\hline JSI205 & & 101,8 & 101,8 & 101,7 & 101,7 & 101,8 & 60,5 & 60,6 & 60,5 & 60,7 & 60,6 \\
\hline JSI206 & & 101,7 & 101,8 & 101,7 & 101,8 & 101,8 & 60,7 & 60,6 & 60,6 & 60,8 & 60,7 \\
\hline JSI207 & & 101,6 & 101,6 & 101,6 & 101,6 & 101,6 & 60,7 & 60,7 & 60,6 & 60,8 & 60,7 \\
\hline JSI208 & & 101,7 & 101,6 & 101,7 & 101,8 & 101,7 & 60,9 & 60,8 & 60,9 & 61,0 & 60,9 \\
\hline
\end{tabular}


Tabela D.9 - Programa Experimental - Massas, volumes, densidades e Vv dos corpos-de-prova com $0 \%$ de EVA.

\begin{tabular}{|c|c|c|c|c|c|c|}
\hline$C P n^{\circ}$ & Env. (h) & $\begin{array}{c}\text { Massa ao ar } \\
(\mathrm{g})\end{array}$ & Massa imersa (g) & $\begin{array}{c}\text { Volume } \\
\left(\mathrm{cm}^{3}\right)\end{array}$ & Dap & $\begin{array}{l}\text { Vv } \\
(\%)\end{array}$ \\
\hline JSI041 & \multirow{14}{*}{0} & 1165,2 & 695,5 & 469,7 & 2,481 & 4,19 \\
\hline JSI042 & & 1160,1 & 696,1 & 464,0 & 2,500 & 3,43 \\
\hline JSI043 & & 1164,4 & 698,7 & 465,7 & 2,500 & 3,43 \\
\hline JSI044 & & 1164,4 & 695,5 & 468,9 & 2,483 & 4,09 \\
\hline JSI045 & & 1162,0 & 696,5 & 465,5 & 2,496 & 3,59 \\
\hline JSI046 & & 1162,3 & 694,8 & 467,5 & 2,486 & 3,97 \\
\hline JSI047 & & 1164,3 & 699,3 & 465,0 & 2,504 & 3,29 \\
\hline JSI048 & & 1161,3 & 693,9 & 467,4 & 2,485 & 4,04 \\
\hline JSI049 & & 1152,6 & 688,3 & 464,3 & 2,482 & 4,12 \\
\hline JSI050 & & 1161,2 & 692,4 & 468,8 & 2,477 & 4,33 \\
\hline JSI051 & & 1144,1 & 685,8 & 458,3 & 2,496 & 3,58 \\
\hline JSI052 & & 1164,1 & 698,2 & 465,9 & 2,499 & 3,50 \\
\hline JSI053 & & 1165,3 & 695,3 & 470,0 & 2,479 & 4,24 \\
\hline JSI054 & & 1163,5 & 698,3 & 465,2 & 2,501 & 3,40 \\
\hline JSI055 & \multirow{14}{*}{2} & 1165,2 & 696,5 & 468,7 & 2,486 & 3,98 \\
\hline JSI056 & & 1163,1 & 692,3 & 470,8 & 2,470 & 4,58 \\
\hline JSI057 & & 1162,7 & 693,2 & 469,5 & 2,476 & 4,35 \\
\hline JSI058 & & 1164,8 & 695,4 & 469,4 & 2,481 & 4,16 \\
\hline JSI059 & & 1166,4 & 696,1 & 470,3 & 2,480 & 4,21 \\
\hline JSI060 & & 1181,3 & 704,2 & 477,1 & 2,476 & 4,37 \\
\hline JSI061 & & 1170,3 & 698,0 & 472,3 & 2,478 & 4,30 \\
\hline JSI062 & & 1167,3 & 697,7 & 469,6 & 2,486 & 3,99 \\
\hline JSI063 & & 1163,3 & 694,1 & 469,2 & 2,479 & 4,24 \\
\hline JSI064 & & 1163,5 & 695,2 & 468,3 & 2,485 & 4,04 \\
\hline JSI065 & & 1167,5 & 697,2 & 470,3 & 2,482 & 4,12 \\
\hline JSI066 & & 1161,1 & 692,9 & 468,2 & 2,480 & 4,22 \\
\hline JSI067 & & 1168,1 & 695,2 & 472,9 & 2,470 & 4,60 \\
\hline JSI068 & & 1163,3 & 693,2 & 470,1 & 2,475 & 4,42 \\
\hline JSI069 & \multirow{14}{*}{4} & 1167,9 & 689,0 & 478,9 & 2,439 & 5,81 \\
\hline JSI070 & & 1168,5 & 691,4 & 477,1 & 2,449 & 5,40 \\
\hline JSI071 & & 1168,5 & 687,9 & 480,6 & 2,431 & 6,09 \\
\hline JSI072 & & 1166,9 & 689,9 & 477,0 & 2,446 & 5,51 \\
\hline JSI073 & & 1171,9 & 688,3 & 483,6 & 2,423 & 6,40 \\
\hline JSI074 & & 1168,6 & 689,8 & 478,8 & 2,441 & 5,73 \\
\hline JSI075 & & 1163,6 & 684,1 & 479,5 & 2,427 & 6,27 \\
\hline JSI076 & & 1171,5 & 697,4 & 474,1 & 2,471 & 4,56 \\
\hline JSI077 & & 1166,0 & 689,9 & 476,1 & 2,449 & 5,41 \\
\hline JSI078 & & 1161,6 & 686,1 & 475,5 & 2,443 & 5,65 \\
\hline JSI079 & & 1171,0 & 691,9 & 479,1 & 2,444 & 5,60 \\
\hline JSI080 & & 1165,8 & 688,5 & 477,3 & 2,442 & 5,66 \\
\hline JSI081 & & 1170,8 & 689,4 & 481,4 & 2,432 & 6,06 \\
\hline JSI082 & & 1168,3 & 688,9 & 479,4 & 2,437 & 5,87 \\
\hline
\end{tabular}


Tabela D.10 - Programa Experimental - Massas, volumes, densidades e Vv dos corpos-de-prova com $1 \%$ de EVA.

\begin{tabular}{|c|c|c|c|c|c|c|}
\hline$C P n^{\circ}$ & $\begin{array}{c}\text { Env. } \\
\text { (h) }\end{array}$ & Massa ao ar (g) & Massa imersa (g) & $\begin{array}{c}\text { Volume } \\
\left(\mathrm{cm}^{3}\right) \\
\end{array}$ & Dap & $\begin{array}{l}\text { Vv } \\
(\%) \\
\end{array}$ \\
\hline JSI083 & \multirow{14}{*}{0} & 1159,7 & 682,3 & 477,4 & 2,429 & 4,44 \\
\hline JSI084 & & 1160,7 & 685,9 & 474,8 & 2,445 & 3,83 \\
\hline JSI085 & & 1153,9 & 681,7 & 472,2 & 2,444 & 3,87 \\
\hline JSI086 & & 1146,1 & 679,7 & 466,4 & 2,457 & 3,33 \\
\hline JSI087 & & 1147,6 & 680,1 & 467,5 & 2,455 & 3,43 \\
\hline JSI088 & & 1145,6 & 680,0 & 465,6 & 2,460 & 3,21 \\
\hline JSI089 & & 1150,4 & 682,4 & 468,0 & 2,458 & 3,30 \\
\hline JSI090 & & 1152,1 & 681,4 & 470,7 & 2,448 & 3,71 \\
\hline JSI091 & & 1150,1 & 685,7 & 464,4 & 2,477 & 2,57 \\
\hline JSI092 & & 1147,9 & 676,3 & 471,6 & 2,434 & 4,25 \\
\hline JSI093 & & 1158,7 & 681,2 & 477,5 & 2,427 & 4,54 \\
\hline JSI094 & & 1156,4 & 682,4 & 474,0 & 2,440 & 4,02 \\
\hline JSI095 & & 1149,0 & 677,4 & 471,6 & 2,436 & 4,15 \\
\hline JSI096 & & 1156,1 & 682,4 & 473,7 & 2,441 & 3,99 \\
\hline JSI097 & \multirow{14}{*}{2} & 1160,8 & 680,1 & 480,7 & 2,415 & 5,00 \\
\hline JSI098 & & 1161,7 & 684,3 & 477,4 & 2,433 & 4,27 \\
\hline JSI099 & & 1158,9 & 679,3 & 479,6 & 2,416 & 4,94 \\
\hline JSI100 & & 1159,2 & 687,1 & 472,1 & 2,455 & 3,41 \\
\hline JSI101 & & 1157,9 & 684,0 & 473,9 & 2,443 & 3,88 \\
\hline JSI102 & & 1159,3 & 686,4 & 472,9 & 2,451 & 3,56 \\
\hline JSI103 & & 1156,9 & 685,2 & 471,7 & 2,453 & 3,52 \\
\hline JSI104 & & 1155,9 & 681,5 & 474,4 & 2,437 & 4,15 \\
\hline JSI105 & & 1160,7 & 687,7 & 473,0 & 2,454 & 3,46 \\
\hline JSI106 & & 1160,1 & 687,5 & 472,6 & 2,455 & 3,43 \\
\hline JSI107 & & 1157,9 & 684,3 & 473,6 & 2,445 & 3,82 \\
\hline JSI108 & & 1158,6 & 681,4 & 477,2 & 2,428 & 4,49 \\
\hline JSI109 & & 1158,2 & 684,9 & 473,3 & 2,447 & 3,73 \\
\hline JSI110 & & 1168,2 & 691,5 & 476,7 & 2,451 & 3,59 \\
\hline JSI111 & \multirow{14}{*}{4} & 1165,5 & 686,3 & 479,2 & 2,432 & 4,32 \\
\hline JSI112 & & 1160,2 & 678,9 & 481,3 & 2,411 & 5,17 \\
\hline JSI113 & & 1157,9 & 680,1 & 477,8 & 2,423 & 4,66 \\
\hline JSI114 & & 1159,4 & 681,2 & 478,2 & 2,425 & 4,62 \\
\hline JSI115 & & 1165,5 & 689,2 & 476,3 & 2,447 & 3,74 \\
\hline JSI116 & & 1162,2 & 685,0 & 477,2 & 2,435 & 4,19 \\
\hline JSI117 & & 1162,2 & 687,7 & 474,5 & 2,449 & 3,64 \\
\hline JSI118 & & 1157,5 & 681,7 & 475,8 & 2,433 & 4,30 \\
\hline JSI119 & & 1162,4 & 690,9 & 471,5 & 2,465 & 3,02 \\
\hline JSI120 & & 1161,9 & 686,0 & 475,9 & 2,441 & 3,95 \\
\hline JSI121 & & 1162,8 & 687,6 & 475,2 & 2,447 & 3,74 \\
\hline JSI122 & & 1164,7 & 688,5 & 476,2 & 2,446 & 3,78 \\
\hline JSI123 & & 1163,8 & 689,3 & 474,5 & 2,453 & 3,51 \\
\hline JSI124 & & 1170,4 & 691,0 & 479,4 & 2,441 & 3,96 \\
\hline
\end{tabular}


Tabela D.11 - Programa Experimental - Massas, volumes, densidades e Vv dos corpos-de-prova com $2 \%$ de EVA.

\begin{tabular}{|c|c|c|c|c|c|c|}
\hline$C P n^{\circ}$ & Env. (h) & $\begin{array}{c}\text { Massa ao ar } \\
\text { (g) }\end{array}$ & Massa imersa $(g)$ & $\begin{array}{c}\text { Volume } \\
\left(\mathrm{cm}^{3}\right)\end{array}$ & Dap & $\begin{array}{l}\text { Vv } \\
(\%)\end{array}$ \\
\hline JSI125 & \multirow{14}{*}{0} & 1142,3 & 667,2 & 475,1 & 2,404 & 3,69 \\
\hline JSI126 & & 1152,6 & 675,1 & 477,5 & 2,414 & 3,31 \\
\hline JSI127 & & 1151,5 & 672,4 & 479,1 & 2,403 & 3,73 \\
\hline JSI128 & & 1145,5 & 669,0 & 476,5 & 2,404 & 3,71 \\
\hline JSI129 & & 1143,8 & 668,0 & 475,8 & 2,404 & 3,71 \\
\hline JSI130 & & 1144,4 & 668,5 & 475,9 & 2,405 & 3,68 \\
\hline JSI131 & & 1141,7 & 667,6 & 474,1 & 2,408 & 3,54 \\
\hline JSI132 & & 1146,7 & 664,8 & 481,9 & 2,380 & 4,69 \\
\hline JSI133 & & 1140,9 & 664,5 & 476,4 & 2,395 & 4,07 \\
\hline JSI134 & & 1144,0 & 666,9 & 477,1 & 2,398 & 3,95 \\
\hline JSI135 & & 1145,6 & 667,9 & 477,7 & 2,398 & 3,94 \\
\hline JSI136 & & 1143,2 & 665,3 & 477,9 & 2,392 & 4,18 \\
\hline JSI137 & & 1142,7 & 668,8 & 473,9 & 2,411 & 3,42 \\
\hline JSI138 & & 1140,0 & 667,9 & 472,1 & 2,415 & 3,28 \\
\hline JSI139 & \multirow{14}{*}{2} & 1150,1 & 670,7 & 479,4 & 2,399 & 3,90 \\
\hline JSI140 & & 1157,8 & 675,6 & 482,2 & 2,401 & 3,82 \\
\hline JSI141 & & 1152,0 & 672,2 & 479,8 & 2,401 & 3,83 \\
\hline JSI142 & & 1159,9 & 676,6 & 483,3 & 2,400 & 3,87 \\
\hline JSI143 & & 1152,1 & 671,2 & 480,9 & 2,396 & 4,04 \\
\hline JSI144 & & 1151,4 & 670,5 & 480,9 & 2,394 & 4,10 \\
\hline JSI145 & & 1148,3 & 669,7 & 478,6 & 2,399 & 3,89 \\
\hline JSI146 & & 1158,2 & 675,9 & 482,3 & 2,401 & 3,81 \\
\hline JSI147 & & 1155,2 & 673,9 & 481,3 & 2,400 & 3,86 \\
\hline JSI148 & & 1151,6 & 671,5 & 480,1 & 2,399 & 3,92 \\
\hline JSI149 & & 1152,4 & 670,2 & 482,2 & 2,390 & 4,27 \\
\hline JSI150 & & 1146,8 & 669,7 & 477,1 & 2,404 & 3,72 \\
\hline JSI151 & & 1147,6 & 667,5 & 480,1 & 2,390 & 4,25 \\
\hline JSI152 & & 1152,7 & 672,9 & 479,8 & 2,402 & 3,77 \\
\hline JSI153 & \multirow{14}{*}{4} & 1152,3 & 670,9 & 481,4 & 2,394 & 4,12 \\
\hline JSI154 & & 1150,9 & 669,1 & 481,8 & 2,389 & 4,32 \\
\hline JSI155 & & 1151,9 & 670,2 & 481,7 & 2,391 & 4,21 \\
\hline JSI156 & & 1155,9 & 673,4 & 482,5 & 2,396 & 4,04 \\
\hline JSI157 & & 1146,4 & 665,3 & 481,1 & 2,383 & 4,55 \\
\hline JSI158 & & 1147,4 & 668,4 & 479,0 & 2,395 & 4,05 \\
\hline JSI159 & & 1156,6 & 674,4 & 482,2 & 2,399 & 3,92 \\
\hline JSI160 & & 1153,1 & 671,7 & 481,4 & 2,395 & 4,05 \\
\hline JSI161 & & 1153,1 & 672,6 & 480,5 & 2,400 & 3,87 \\
\hline JSI162 & & 1148,8 & 666,3 & 482,5 & 2,381 & 4,63 \\
\hline JSI163 & & 1153,8 & 672,5 & 481,3 & 2,397 & 3,98 \\
\hline JSI164 & & 1152,6 & 672,5 & 480,1 & 2,401 & 3,84 \\
\hline JSI165 & & 1153,4 & 671,4 & 482,0 & 2,393 & 4,15 \\
\hline JSI166 & & 1145,4 & 665,5 & 479,9 & 2,387 & 4,40 \\
\hline
\end{tabular}


Tabela D.12 - Programa Experimental - Massas, volumes, densidades e Vv dos corpos-de-prova com 3\% de EVA.

\begin{tabular}{|c|c|c|c|c|c|c|}
\hline$C P n^{\circ}$ & $\begin{array}{c}\text { Env. } \\
\text { (h) }\end{array}$ & Massa ao ar (g) & Massa imersa $(\mathbf{g})$ & $\begin{array}{c}\text { Volume } \\
\left(\mathrm{cm}^{3}\right)\end{array}$ & Dap & Vv (\%) \\
\hline JSI167 & & 1141,3 & 657,4 & 483,9 & 2,359 & 3,84 \\
\hline JSI168 & & 1142,0 & 657,5 & 484,5 & 2,357 & 3,90 \\
\hline JSI169 & & 1119,7 & 644,3 & 475,4 & 2,355 & 3,97 \\
\hline JSI170 & & 1133,3 & 653,0 & 480,3 & 2,360 & 3,80 \\
\hline JSI171 & & 1131,3 & 651,2 & 480,1 & 2,356 & 3,93 \\
\hline JSI172 & & 1134,3 & 650,5 & 483,8 & 2,345 & 4,41 \\
\hline JSI173 & 0 & 1131,8 & 653,4 & 478,4 & 2,366 & 3,54 \\
\hline JSI174 & 0 & 1119,4 & 642,1 & 477,3 & 2,345 & 4,38 \\
\hline JSI175 & & 1129,2 & 648,9 & 480,3 & 2,351 & 4,14 \\
\hline JSI176 & & 1133,3 & 654,7 & 478,6 & 2,368 & 3,45 \\
\hline JSI177 & & 1132,1 & 654,2 & 477,9 & 2,369 & 3,42 \\
\hline JSI178 & & 1133,5 & 655,1 & 478,4 & 2,369 & 3,40 \\
\hline JSI179 & & 1127,9 & 648,2 & 479,7 & 2,351 & 4,14 \\
\hline JSI180 & & 1135,9 & 657,5 & 478,4 & 2,374 & 3,19 \\
\hline JSI181 & & 1153,4 & 664,8 & 488,6 & 2,361 & 3,75 \\
\hline JSI182 & & 1149,2 & 661,9 & 487,3 & 2,358 & 3,85 \\
\hline JSI183 & & 1151,8 & 662,1 & 489,7 & 2,352 & 4,10 \\
\hline JSI184 & & 1154,2 & 664,4 & 489,8 & 2,356 & 3,92 \\
\hline JSI185 & & 1154,1 & 664,8 & 489,3 & 2,359 & 3,83 \\
\hline JSI186 & & 1148,0 & 661,4 & 486,6 & 2,359 & 3,81 \\
\hline JSI187 & 2 & 1147,3 & 662,0 & 485,3 & 2,364 & 3,61 \\
\hline JSI188 & 2 & 1148,3 & 660,5 & 487,8 & 2,354 & 4,02 \\
\hline JSI189 & & 1147,2 & 660,3 & 486,9 & 2,356 & 3,94 \\
\hline JSI190 & & 1150,4 & 661,4 & 489,0 & 2,353 & 4,08 \\
\hline JSI191 & & 1150,3 & 662,5 & 487,8 & 2,358 & 3,85 \\
\hline JSI192 & & 1149,9 & 662,6 & 487,3 & 2,360 & 3,79 \\
\hline JSI193 & & 1154,8 & 663,5 & 491,3 & 2,350 & 4,17 \\
\hline JSI194 & & 1149,6 & 663,1 & 486,5 & 2,363 & 3,66 \\
\hline JSI195 & & 1153,7 & 661,5 & 492,2 & 2,344 & 4,43 \\
\hline JSI196 & & 1153,5 & 661,5 & 492,0 & 2,345 & 4,41 \\
\hline JSI197 & & 1151,1 & 663,6 & 487,5 & 2,361 & 3,73 \\
\hline JSI198 & & 1151,1 & 660,1 & 491,0 & 2,344 & 4,41 \\
\hline JSI199 & & 1154,5 & 662,0 & 492,5 & 2,344 & 4,42 \\
\hline JSI200 & & 1158,2 & 665,7 & 492,5 & 2,352 & 4,12 \\
\hline JSI201 & 4 & 1153,5 & 663,9 & 489,6 & 2,356 & 3,94 \\
\hline JSI202 & 4 & 1158,4 & 658,8 & 499,6 & 2,319 & 5,46 \\
\hline JSI203 & & 1154,0 & 660,4 & 493,6 & 2,338 & 4,68 \\
\hline JSI204 & & 1154,7 & 662,1 & 492,6 & 2,344 & 4,43 \\
\hline JSI205 & & 1154,2 & 662,1 & 492,1 & 2,345 & 4,37 \\
\hline JSI206 & & 1154,7 & 661,9 & 492,8 & 2,343 & 4,47 \\
\hline JSI207 & & 1154,0 & 662,6 & 491,4 & 2,348 & 4,25 \\
\hline JSI208 & & 1154,3 & 667,3 & 487,0 & 2,370 & 3,36 \\
\hline
\end{tabular}




\section{APÊNDICE E}

\section{Ensaios Exploratórios}


A seguir são apresentados os cálculos de resistência à tração para o corpo-de-prova JSI025 como exemplo. Os demais corpos-de-prova ensaiados foram calculados analogamente.

Leitura no anel de carga $\quad: 25,70$

Constante de anel de carga $\quad: 45,50 \mathrm{kgf}$

Diâmetro do corpo-de-prova $\quad: 10,17 \mathrm{~cm}$

Altura de corpo-de-prova $\quad: 5,98 \mathrm{~cm}$

Carga aplicada $=25,70 \times 45,50=1169,35 \mathrm{kgf}$

$R T=\frac{2 \times F}{\pi \times D \times H}=\frac{2 \times 1169,35}{3,14 \times 10,17 \times 5,98}$

$R T=12,25 \mathrm{~kg} / \mathrm{cm}^{2}=1,225 \mathrm{MPa}$

Os módulos de resiliência foram calculados através da média do módulo total de cada pulso do ensaio. A Tabela E1 apresenta os resultados dos ensaios exploratórios. 
Tabela E.1 - Ensaios Exploratórios - Resultado dos ensaios.

\begin{tabular}{|c|c|c|c|c|c|c|c|}
\hline$C P n^{\circ}$ & $\begin{array}{l}\text { Teor de } \\
\text { EVA (\%) }\end{array}$ & $\begin{array}{c}R T \\
(\mathrm{MPa})\end{array}$ & $\begin{array}{c}\text { RT } \\
\text { médio } \\
\text { (MPa) }\end{array}$ & $\begin{array}{c}\text { MR } \\
(\mathrm{MPa})\end{array}$ & $\begin{array}{c}\text { MR } \\
\text { médio } \\
\text { (MPa) }\end{array}$ & MR/RT & $\begin{array}{l}\text { MR/RT } \\
\text { médio }\end{array}$ \\
\hline JSI025 & \multirow{4}{*}{2,5} & 1,225 & \multirow{4}{*}{1,228} & 6067 & \multirow{4}{*}{6033} & 4953 & \multirow{4}{*}{4914} \\
\hline JSI026 & & 1,228 & & 5985 & & 4874 & \\
\hline JSI027 & & 1,239 & & 6184 & & 4991 & \\
\hline JSI028 & & 1,218 & & 5895 & & 4840 & \\
\hline JSI029 & \multirow{4}{*}{5,0} & 1,142 & \multirow{4}{*}{1,142} & 6708 & \multirow{4}{*}{6686} & 5874 & \multirow{4}{*}{5856} \\
\hline JSI030 & & 1,150 & & 6838 & & 5946 & \\
\hline JSI031 & & 1,138 & & 6540 & & 5747 & \\
\hline JSI032 & & 1,136 & & 6658 & & 5861 & \\
\hline JSI033 & \multirow{4}{*}{7,5} & 1,039 & \multirow{4}{*}{1,066} & 6494 & \multirow{4}{*}{6585} & 6250 & \multirow{4}{*}{6180} \\
\hline JSI034 & & 1,075 & & 6594 & & 6134 & \\
\hline JSI035 & & 1,078 & & 6682 & & 6199 & \\
\hline JSI036 & & 1,070 & & 6568 & & 6138 & \\
\hline JSI037 & \multirow{4}{*}{10,0} & 0,980 & \multirow{4}{*}{0,972} & 2956 & \multirow{4}{*}{3013} & 3016 & \multirow{4}{*}{3102} \\
\hline JSI038 & & 0,988 & & 2977 & & 3013 & \\
\hline JSI039 & & 0,965 & & 3019 & & 3128 & \\
\hline JSI040 & & 0,953 & & 3098 & & 3251 & \\
\hline
\end{tabular}




\section{APÊNDICE F}

\section{Módulos de Resiliência por Compressão Diametral}




\section{F.1. APRESENTAÇÃO DOS RESULTADOS}

O ensaio de módulo de resiliência por compressão diametral foi realizado nos 184 corpos-de-prova que correspondem aos ensaios exploratórios e ao programa experimental. As Tabelas F.1 a F.12 apresentam os dados dos ensaios de módulo de resiliência total, ensaios de módulo de resiliência instantâneo, carga de ensaio e desvios padrão de cada ensaio do programa experimental.

Tabela F.1 - Programa experimental - Dados do ensaio de MR para 0\% de EVA e 0 hora de envelhecimento.

\begin{tabular}{|c|c|c|c|c|c|c|}
\hline$C P n^{\circ}$ & $\begin{array}{l}\text { MR total } \\
\text { (MPa) }\end{array}$ & $\begin{array}{c}\text { Desvio } \\
\text { Padrão MR total } \\
\text { (MPa) }\end{array}$ & $\begin{array}{c}\text { MR }_{\text {inst. }} \\
\text { (MPa) }\end{array}$ & $\begin{array}{c}\text { Desvio } \\
\text { Padrão } \\
M_{\text {inst. }}(\mathrm{MPa})\end{array}$ & $\begin{array}{c}\text { Carga } \\
\text { (kgf) }\end{array}$ & $\begin{array}{c}\text { Desvio } \\
\text { Padrão } \\
\text { Carga (kgf) }\end{array}$ \\
\hline JSI041 & 7983,08 & 346,94 & 8509,36 & 270,09 & 114,70 & 1,67 \\
\hline JSI042 & 7136,42 & 153,38 & 7772,41 & 170,24 & 144,82 & 1,94 \\
\hline JSI043 & 6815,77 & 279,09 & 7228,96 & 226,12 & 122,90 & 1,50 \\
\hline JSI044 & 8210,82 & 205,04 & 9154,93 & 253,61 & 154,75 & 1,62 \\
\hline JSI045 & 8690,82 & 378,28 & 9429,07 & 324,84 & 150,87 & 1,35 \\
\hline JSI046 & 7529,12 & 239,74 & 8353,22 & 226,75 & 147,09 & 1,20 \\
\hline JSI047 & 7115,35 & 188,89 & 7698,05 & 335,61 & 148,85 & 1,53 \\
\hline JSI048 & 6737,09 & 166,21 & 7449,72 & 153,51 & 123,71 & 1,81 \\
\hline JSI049 & 7266,03 & 260,02 & 7970,07 & 419,38 & 127,34 & 1,32 \\
\hline JSI050 & 6218,98 & 205,52 & 6763,08 & 354,13 & 119,63 & 1,81 \\
\hline JSI051 & 7678,24 & 219,84 & 8275,09 & 270,18 & 143,92 & 1,93 \\
\hline JSI052 & 7375,87 & 175,65 & 7929,48 & 249,96 & 140,75 & 1,44 \\
\hline JSI053 & 7856,94 & 278,09 & 8459,67 & 215,28 & 145,23 & 1,51 \\
\hline JSI054 & 7438,56 & 197,45 & 8098,43 & 310,97 & 141,55 & 1,49 \\
\hline
\end{tabular}


Tabela F.2 - Programa experimental - Dados do ensaio de MR para 0\% de EVA e 2 horas de envelhecimento.

\begin{tabular}{|c|c|c|c|c|c|c|}
\hline$C P n^{\circ}$ & $\begin{array}{c}M R_{\text {total }} \\
(\mathrm{MPa})\end{array}$ & $\begin{array}{c}\text { Desvio } \\
\text { Padrão MR } \\
\text { (MPa) }\end{array}$ & $\begin{array}{l}M R_{\text {inst. }} \\
(\mathrm{MPa})\end{array}$ & $\begin{array}{c}\text { Desvio } \\
\text { Padrão } \\
\text { MR }_{\text {inst. }}(\mathrm{MPa})\end{array}$ & $\begin{array}{c}\text { Carga } \\
\text { (kgf) }\end{array}$ & $\begin{array}{c}\text { Desvio } \\
\text { Padrão } \\
\text { Carga (kgf) }\end{array}$ \\
\hline JSI055 & 6814,85 & 315,91 & 7658,16 & 255,34 & 153,46 & 1,57 \\
\hline JSI056 & 7582,34 & 289,67 & 8561,74 & 310,77 & 150,73 & 1,43 \\
\hline JSI057 & 7209,43 & 364,38 & 8001,46 & 351,28 & 155,64 & 1,87 \\
\hline JSI058 & 6706,48 & 199,99 & 7754,25 & 329,12 & 147,33 & 2,01 \\
\hline JSI059 & 8238,39 & 377,86 & 9218,09 & 270,29 & 140,98 & 1,38 \\
\hline JSI060 & 7401,27 & 180,25 & 7898,59 & 710,28 & 141,71 & 1,56 \\
\hline JSI061 & 8694,67 & 485,41 & 9663,49 & 671,85 & 157,26 & 1,45 \\
\hline JSI062 & 6801,36 & 252,95 & 7512,64 & 403,30 & 114,34 & 1,78 \\
\hline JSI063 & 7699,62 & 326,57 & 8782,94 & 417,57 & 158,84 & 2,42 \\
\hline JSI064 & 8090,71 & 269,94 & 8986,45 & 335,52 & 154,1 & 1,22 \\
\hline JSI065 & 8111,07 & 343,94 & 9288,50 & 308,26 & 159,42 & 1,35 \\
\hline JSI066 & 6847,83 & 252,12 & 7462,05 & 366,23 & 148,54 & 2,26 \\
\hline JSI067 & 7759,83 & 247,87 & 8421,84 & 357,18 & 156,37 & 2,10 \\
\hline JSI068 & 7550,12 & 269,54 & 8291,75 & 452,68 & 154,78 & 1,67 \\
\hline
\end{tabular}

Tabela F.3 - Programa experimental - Dados do ensaio de MR para 0\% de EVA e 4 horas de envelhecimento.

\begin{tabular}{|c|c|c|c|c|c|c|}
\hline$C P n^{\circ}$ & $\begin{array}{l}\text { MR total } \\
\text { (MPa) }\end{array}$ & $\begin{array}{c}\text { Desvio } \\
\text { Padrão MR } \text { total } \\
\text { (MPa) }\end{array}$ & $\begin{array}{l}\mathrm{MR}_{\text {inst. }} \\
(\mathrm{MPa})\end{array}$ & $\begin{array}{c}\text { Desvio } \\
\text { Padrão } \\
\text { MR }_{\text {inst. }}(\mathrm{MPa})\end{array}$ & $\begin{array}{c}\text { Carga } \\
\text { (kgf) }\end{array}$ & $\begin{array}{c}\text { Desvio } \\
\text { Padrão } \\
\text { Carga (kgf) }\end{array}$ \\
\hline JSI069 & 9168,62 & 410,80 & 9669,77 & 306,27 & 167,13 & 1,55 \\
\hline JSI070 & 7206,69 & 143,11 & 7773,93 & 206,21 & 151,63 & 3,18 \\
\hline JSI071 & 7877,04 & 283,48 & 8491,19 & 252,14 & 130,17 & 1,18 \\
\hline JSI072 & 8299,10 & 294,75 & 9129,58 & 231,25 & 167,15 & 3,37 \\
\hline JSI073 & 6694,08 & 173,79 & 7365,62 & 205,47 & 158,95 & 4,24 \\
\hline JSI074 & 7551,57 & 561,78 & 8254,02 & 343,36 & 145,59 & 4,21 \\
\hline JSI075 & 7423,76 & 298,15 & 8549,29 & 296,48 & 132,26 & 1,34 \\
\hline JSI076 & 7274,30 & 324,53 & 8415,89 & 252,09 & 143,53 & 1,47 \\
\hline JSI077 & 6959,68 & 229,47 & 7650,35 & 171,25 & 172,61 & 3,23 \\
\hline JSI078 & 7921,10 & 328,32 & 8614,33 & 228,06 & 136,29 & 2,18 \\
\hline JSI079 & 7276,69 & 350,48 & 8366,28 & 288,10 & 160,53 & 2,52 \\
\hline JSI080 & 8623,24 & 339,31 & 9330,44 & 240,78 & 149,28 & 2,08 \\
\hline JSI081 & 7354,87 & 326,48 & 7948,37 & 254,86 & 154,58 & 1,98 \\
\hline JSI082 & 7265,42 & 314,95 & 7898,14 & 247,24 & 152,73 & 2,45 \\
\hline
\end{tabular}


Tabela F.4 - Programa experimental - Dados do ensaio de MR para 1\% de EVA e 0 hora de envelhecimento.

\begin{tabular}{|c|c|c|c|c|c|c|}
\hline$C P n^{\circ}$ & $\begin{array}{l}M R_{\text {total }} \\
(\mathrm{MPa})\end{array}$ & $\begin{array}{c}\text { Desvio } \\
\text { Padrão MR } \\
\text { (MPa) }\end{array}$ & $\begin{array}{l}M R_{\text {inst. }} \\
(\mathrm{MPa})\end{array}$ & $\begin{array}{c}\text { Desvio } \\
\text { Padrão } \\
M_{\text {inst. }}(\mathrm{MPa})\end{array}$ & $\begin{array}{c}\text { Carga } \\
\text { (kgf) }\end{array}$ & $\begin{array}{c}\text { Desvio } \\
\text { Padrão } \\
\text { Carga (kgf) }\end{array}$ \\
\hline JSI083 & 4988,99 & 214,07 & 5218,44 & 187,07 & 93,52 & 1,47 \\
\hline JSI084 & 5503,03 & 199,91 & 5758,13 & 176,40 & 105,86 & 1,09 \\
\hline JSI085 & 5225,54 & 164,28 & 5224,76 & 353,89 & 99,17 & 1,46 \\
\hline JSI086 & 5659,53 & 185,60 & 5877,35 & 408,98 & 92,50 & 1,58 \\
\hline JSI087 & 6151,32 & 118,72 & 6473,54 & 146,03 & 122,25 & 1,29 \\
\hline JSI088 & 5741,24 & 197,52 & 5748,62 & 615,30 & 96,16 & 1,65 \\
\hline JSI089 & 4967,35 & 193,04 & 5219,17 & 266,62 & 85,68 & 2,94 \\
\hline JSI090 & 4974,33 & 190,92 & 5236,77 & 428,09 & 89,28 & 2,96 \\
\hline JSI091 & 7020,52 & 207,55 & 7072,07 & 587,16 & 102,23 & 1,21 \\
\hline JSI092 & 6815,60 & 247,57 & 7052,69 & 156,01 & 105,88 & 2,24 \\
\hline JSI093 & 5968,77 & 184,57 & 6128,67 & 257,94 & 115,27 & 1,47 \\
\hline JSI094 & 5425,80 & 187,29 & 5682,31 & 310,75 & 110,43 & 1,68 \\
\hline JSI095 & 4789,57 & 190,96 & 5121,62 & 338,28 & 96,48 & 1,60 \\
\hline JSI096 & 6219,38 & 228,41 & 7770,22 & 473,27 & 125,01 & 1,55 \\
\hline
\end{tabular}

Tabela F.5 - Programa experimental - Dados do ensaio de MR para 1\% de EVA e 2 horas de envelhecimento.

\begin{tabular}{|c|c|c|c|c|c|c|}
\hline$C P n^{\circ}$ & $\begin{array}{l}\text { MR total } \\
\text { (MPa) }\end{array}$ & $\begin{array}{c}\text { Desvio } \\
\text { Padrão MR } \\
\text { (MPa) }\end{array}$ & $\begin{array}{l}\text { MR }_{\text {inst. }} \\
\text { (MPa) }\end{array}$ & $\begin{array}{c}\text { Desvio Padrão } \\
M_{\text {inst. }}(\mathrm{MPa})\end{array}$ & $\begin{array}{c}\text { Carga } \\
\text { (kgf) }\end{array}$ & $\begin{array}{c}\text { Desvio } \\
\text { Padrão } \\
\text { Carga (kgf) }\end{array}$ \\
\hline JSI097 & 5856,50 & 249,18 & 6421,06 & 329,74 & 105,59 & 1,33 \\
\hline JSI098 & 6058,54 & 174,55 & 6339,28 & 377,50 & 118,78 & 2,34 \\
\hline JSI099 & 5496,46 & 127,98 & 5963,62 & 306,88 & 90,55 & 1,79 \\
\hline JSI100 & 5930,70 & 258,49 & 6332,82 & 179,10 & 109,18 & 1,22 \\
\hline JSI101 & 5489,99 & 173,35 & 5935,68 & 151,37 & 112,69 & 2,02 \\
\hline JSI102 & 6220,88 & 218,65 & 6266,61 & 403,99 & 115,79 & 1,65 \\
\hline JSI103 & 5256,21 & 175,70 & 5699,20 & 202,67 & 119,25 & 1,41 \\
\hline JSI104 & 6151,49 & 258,27 & 6548,58 & 642,58 & 122,35 & 1,50 \\
\hline JSI105 & 5055,10 & 141,30 & 5592,05 & 117,92 & 101,21 & 1,26 \\
\hline JSI106 & 6106,79 & 183,95 & 6447,38 & 243,32 & 120,04 & 1,25 \\
\hline JSI107 & 6138,50 & 194,37 & 6473,18 & 348,29 & 98,54 & 1,54 \\
\hline JSI108 & 6015,78 & 181,51 & 6391,74 & 405,37 & 124,36 & 1,66 \\
\hline JSI109 & 6117,63 & 172,13 & 6442,06 & 449,64 & 122,71 & 1,93 \\
\hline JSI110 & 6615,52 & 253,82 & 7269,78 & 279,95 & 128,45 & 2,25 \\
\hline
\end{tabular}


Tabela F.6 - Programa experimental - Dados do ensaio de MR para 1\% de EVA e 4 horas de envelhecimento.

\begin{tabular}{|c|c|c|c|c|c|c|}
\hline$C P n^{\circ}$ & $\begin{array}{c}M R_{\text {total }} \\
(\mathrm{MPa})\end{array}$ & $\begin{array}{c}\text { Desvio } \\
\text { Padrão MR } \\
\text { (MPa) }\end{array}$ & $\begin{array}{l}M R_{\text {inst. }} \\
(\mathrm{MPa})\end{array}$ & $\begin{array}{c}\text { Desvio } \\
\text { Padrão } \\
M_{\text {inst. }}(\mathrm{MPa})\end{array}$ & $\begin{array}{c}\text { Carga } \\
\text { (kgf) }\end{array}$ & $\begin{array}{c}\text { Desvio } \\
\text { Padrão } \\
\text { Carga (kgf) }\end{array}$ \\
\hline JSI111 & 6776,01 & 718,28 & 7315,81 & 647,29 & 114,71 & 2,05 \\
\hline JSI112 & 9686,47 & 518,09 & 10272,13 & 767,66 & 141,79 & 1,33 \\
\hline JSI113 & 8219,36 & 246,80 & 8899,86 & 734,20 & 155,16 & 2,33 \\
\hline JSI114 & 6282,27 & 322,07 & 7007,41 & 202,48 & 127,63 & 1,41 \\
\hline JSI115 & 8458,92 & 222,74 & 9000,65 & 596,36 & 145,36 & 3,39 \\
\hline JSI116 & 7330,63 & 474,35 & 8222,51 & 323,86 & 131,67 & 2,03 \\
\hline JSI117 & 7442,12 & 261,27 & 8077,48 & 609,68 & 140,97 & 1,73 \\
\hline JSI118 & 8606,01 & 249,40 & 9592,43 & 743,99 & 182,32 & 3,01 \\
\hline JSI119 & 7677,23 & 414,69 & 8614,34 & 240,79 & 173,18 & 1,17 \\
\hline JSI120 & 9184,20 & 417,01 & 9751,43 & 759,41 & 169,45 & 1,55 \\
\hline JSI121 & 8167,33 & 387,46 & 8739,41 & 455,98 & 179,36 & 1,46 \\
\hline JSI122 & 8859,47 & 284,39 & 9455,29 & 331,99 & 141,85 & 1,20 \\
\hline JSI123 & 8249,08 & 325,78 & 9201,26 & 229,66 & 145,55 & 1,27 \\
\hline JSI124 & 6799,48 & 311,54 & 7476,90 & 204,53 & 144,49 & 1,50 \\
\hline
\end{tabular}

Tabela F.7 - Programa experimental - Dados do ensaio de MR para 2\% de EVA e 0 hora de envelhecimento.

\begin{tabular}{|c|c|c|c|c|c|c|}
\hline$C P n^{\circ}$ & $\begin{array}{l}\text { MR total } \\
\text { (MPa) }\end{array}$ & $\begin{array}{c}\text { Desvio } \\
\text { Padrão MR } \text { total } \\
\text { (MPa) }\end{array}$ & $\begin{array}{l}\mathrm{MR}_{\text {inst. }} \\
(\mathrm{MPa})\end{array}$ & $\begin{array}{c}\text { Desvio } \\
\text { Padrão } \\
\text { MR }_{\text {inst. }}(\mathrm{MPa})\end{array}$ & $\begin{array}{c}\text { Carga } \\
\text { (kgf) }\end{array}$ & $\begin{array}{c}\text { Desvio } \\
\text { Padrão } \\
\text { Carga (kgf) }\end{array}$ \\
\hline JSI125 & 4588,05 & 181,66 & 4894,35 & 359,92 & 82,18 & 1,43 \\
\hline JSI126 & 5357,41 & 218,73 & 5842,70 & 450,05 & 83,87 & 1,38 \\
\hline JSI127 & 5508,68 & 308,44 & 6177,34 & 554,61 & 99,15 & 1,37 \\
\hline JSI128 & 5045,96 & 209,16 & 5360,79 & 346,15 & 95,70 & 1,60 \\
\hline JSI129 & 5412,25 & 219,67 & 5880,52 & 147,18 & 94,85 & 1,28 \\
\hline JSI130 & 4513,82 & 231,35 & 4605,46 & 255,41 & 95,96 & 2,36 \\
\hline JSI131 & 5519,21 & 176,07 & 5643,44 & 225,97 & 94,03 & 1,70 \\
\hline JSI132 & 4912,39 & 176,41 & 5587,47 & 264,00 & 97,36 & 1,61 \\
\hline JSI133 & 4687,41 & 212,96 & 5032,56 & 320,06 & 99,28 & 2,03 \\
\hline JSI134 & 4352,27 & 179,43 & 4848,23 & 440,06 & 82,43 & 1,32 \\
\hline JSI135 & 5212,87 & 205,37 & 5739,01 & 146,76 & 100,77 & 2,98 \\
\hline JSI136 & 4587,63 & 217,18 & 5095,96 & 325,88 & 96,79 & 1,62 \\
\hline JSI137 & 5570,95 & 210,10 & 5968,31 & 264,12 & 84,65 & 1,54 \\
\hline JSI138 & 5720,41 & 215,51 & 5932,97 & 475,71 & 99,68 & 1,63 \\
\hline
\end{tabular}


Tabela F.8 - Programa experimental - Dados do ensaio de MR para 2\% de EVA e 2 horas de envelhecimento.

\begin{tabular}{l|c|c|c|c|c|c}
\hline CP n' & $\begin{array}{c}\mathbf{M R}_{\text {total }} \\
\text { (MPa) }\end{array}$ & $\begin{array}{c}\text { Desvio } \\
\text { Padrão MR } \\
\text { (MPa) }\end{array}$ & $\begin{array}{c}\mathbf{M R}_{\text {inst. }} \\
\text { (MPa) }\end{array}$ & $\begin{array}{c}\text { Desvio } \\
\text { Padrão } \\
\text { MR }_{\text {inst. }}(\mathbf{M P a})\end{array}$ & $\begin{array}{c}\text { Carga } \\
\text { (kgf) }\end{array}$ & $\begin{array}{c}\text { Desvio } \\
\text { Padrão } \\
\text { Carga (kgf) }\end{array}$ \\
\hline JSI139 & 6525,70 & 221,00 & 6851,63 & 371,57 & 96,27 & 1,38 \\
JSI140 & 7049,11 & 166,61 & 7644,09 & 524,45 & 118,80 & 1,42 \\
JSI141 & 6814,57 & 271,60 & 7063,29 & 496,28 & 102,91 & 1,41 \\
JSI142 & 6141,43 & 236,57 & 6848,41 & 414,95 & 107,41 & 1,79 \\
JSI143 & 6887,16 & 196,17 & 7284,82 & 683,60 & 119,35 & 1,19 \\
JSI144 & 7185,04 & 348,44 & 7993,82 & 385,28 & 129,16 & 1,48 \\
JSI145 & 6113,41 & 185,78 & 6443,88 & 530,57 & 120,69 & 1,51 \\
JSI146 & 7160,08 & 180,57 & 7996,83 & 424,99 & 146,17 & 1,41 \\
JSI147 & 6668,71 & 199,30 & 6749,10 & 358,95 & 133,52 & 1,40 \\
JSI148 & 6954,76 & 210,87 & 7329,68 & 394,71 & 116,84 & 1,25 \\
JSI149 & 7084,69 & 178,34 & 7445,92 & 388,52 & 119,36 & 1,57 \\
JSI150 & 7084,56 & 169,44 & 7494,36 & 410,75 & 142,57 & 1,37 \\
JSI151 & 6123,25 & 213,44 & 6712,84 & 417,23 & 126,02 & 1,42 \\
JSI152 & 7166,80 & 283,92 & 7834,09 & 610,06 & 127,47 & 1,38 \\
\hline
\end{tabular}

Tabela F.9 - Programa experimental - Dados do ensaio de MR para $2 \%$ de EVA e 4 horas de envelhecimento.

\begin{tabular}{c|c|c|c|c|c|c}
\hline CP no $^{\mathbf{0}}$ & $\begin{array}{c}\mathbf{M R}_{\text {total }} \\
\text { (MPa) }\end{array}$ & $\begin{array}{c}\text { Desvio } \\
\text { Padrão MR } \\
\text { (MPa) }\end{array}$ & $\begin{array}{c}\mathbf{M R}_{\text {total }} \\
\text { (MPa) }\end{array}$ & $\begin{array}{c}\text { Desvio } \\
\text { Padrão } \\
\text { MR }_{\text {inst. }}(\mathbf{M P a})\end{array}$ & $\begin{array}{c}\text { Carga } \\
\text { (kgf) }\end{array}$ & $\begin{array}{c}\text { Desvio } \\
\text { Padrão } \\
\text { Carga (kgf) }\end{array}$ \\
\hline JSI153 & 5893,35 & 203,41 & 6320,20 & 399,36 & 121,77 & 1,45 \\
JSI154 & 5876,50 & 241,82 & 6430,53 & 416,71 & 112,76 & 1,65 \\
JSI155 & 6112,04 & 133,99 & 6772,98 & 308,73 & 122,01 & 1,01 \\
JSI156 & 6319,54 & 250,23 & 6719,60 & 221,80 & 114,52 & 1,41 \\
JSI157 & 5897,76 & 208,17 & 6365,16 & 303,51 & 120,53 & 1,81 \\
JSI158 & 6975,31 & 218,59 & 7205,12 & 472,19 & 137,41 & 1,52 \\
JSI159 & 5897,78 & 199,98 & 6521,70 & 317,45 & 124,65 & 1,63 \\
JSI160 & 5641,20 & 272,03 & 6346,39 & 218,06 & 126,35 & 1,32 \\
JSI161 & 7371,94 & 244,05 & 7802,68 & 417,32 & 122,36 & 1,72 \\
JSI162 & 6648,93 & 235,16 & 7017,77 & 229,69 & 142,74 & 3,63 \\
JSI163 & 4843,56 & 66,12 & 5508,66 & 89,73 & 216,07 & 2,01 \\
JSI164 & 5963,78 & 199,64 & 6381,29 & 267,91 & 115,35 & 1,59 \\
JSI165 & 5958,56 & 238,33 & 6495,19 & 400,89 & 113,48 & 1,44 \\
JSI166 & 5361,56 & 254,19 & 6123,53 & 191,28 & 102,67 & 1,73 \\
\hline
\end{tabular}


Tabela F.10 - Programa experimental - Dados do ensaio de MR para 3\% de EVA e 0 hora de envelhecimento.

\begin{tabular}{|c|c|c|c|c|c|c|}
\hline$C P n^{\circ}$ & $\begin{array}{l}M R_{\text {total }} \\
\text { (MPa) }\end{array}$ & $\begin{array}{c}\text { Desvio } \\
\text { Padrão MR total } \\
\text { (MPa) }\end{array}$ & $\begin{array}{l}\text { MR } \text { inst. }_{\text {ins }} \\
(\mathrm{MPa})\end{array}$ & $\begin{array}{c}\text { Desvio } \\
\text { Padrão } \\
\text { MR }_{\text {inst. }}(\mathrm{MPa})\end{array}$ & $\begin{array}{c}\text { Carga } \\
\text { (kgf) }\end{array}$ & $\begin{array}{c}\text { Desvio } \\
\text { Padrão } \\
\text { Carga (kgf) }\end{array}$ \\
\hline JSI167 & 3742,45 & 160,09 & 4185,47 & 359,92 & 60,63 & 1,00 \\
\hline JSI168 & 2321,16 & 73,65 & 2487,58 & 162,04 & 56,52 & 1,43 \\
\hline JSI169 & 2991,90 & 110,50 & 3109,46 & 223,50 & 58,35 & 1,32 \\
\hline JSI170 & 2515,70 & 91,23 & 2637,31 & 154,09 & 50,56 & 1,22 \\
\hline JSI171 & 3288,75 & 132,40 & 3488,21 & 333,77 & 53,91 & 1,82 \\
\hline JSI172 & 3050,21 & 85,48 & 3343,18 & 84,66 & 79,82 & 1,60 \\
\hline JSI173 & 3296,17 & 505,99 & 3421,74 & 191,24 & 57,72 & 1,24 \\
\hline JSI174 & 3613,22 & 245,55 & 3628,40 & 290,43 & 77,02 & 1,91 \\
\hline JSI175 & 3569,09 & 139,80 & 3768,88 & 193,38 & 65,97 & 1,56 \\
\hline JSI176 & 2668,47 & 77,75 & 2819,18 & 145,44 & 55,66 & 1,29 \\
\hline JSI177 & 3126,54 & 89,64 & 3368,37 & 154,67 & 71,25 & 1,11 \\
\hline JSI178 & 3265,45 & 76,17 & 3599,75 & 147,59 & 58,69 & 1,36 \\
\hline JSI179 & 3156,56 & 78,27 & 3303,38 & 111,09 & 70,56 & 1,08 \\
\hline JSI180 & 3350,76 & 157,74 & 3482,47 & 190,56 & 74,45 & 1,65 \\
\hline
\end{tabular}

Tabela F.11 - Programa experimental - Dados do ensaio de MR para 3\% de EVA e 2 horas de envelhecimento.

\begin{tabular}{|c|c|c|c|c|c|c|}
\hline$C P n^{\circ}$ & $\begin{array}{l}\text { MR total } \\
\text { (MPa) }\end{array}$ & $\begin{array}{c}\text { Desvio } \\
\text { Padrão MR } \text { total } \\
\text { (MPa) }\end{array}$ & $\begin{array}{l}\mathrm{MR}_{\text {inst. }} \\
(\mathrm{MPa})\end{array}$ & $\begin{array}{c}\text { Desvio } \\
\text { Padrão } \\
\text { MR }_{\text {inst. }}(\mathrm{MPa})\end{array}$ & $\begin{array}{c}\text { Carga } \\
\text { (kgf) }\end{array}$ & $\begin{array}{c}\text { Desvio } \\
\text { Padrão } \\
\text { Carga (kgf) }\end{array}$ \\
\hline JSI181 & 4943,30 & 288,35 & 5078,02 & 357,81 & 85,55 & 1,18 \\
\hline JSI182 & 3504,18 & 115,21 & 3735,06 & 231,58 & 73,60 & 1,31 \\
\hline JSI183 & 4362,17 & 108,93 & 4562,50 & 202,77 & 78,87 & 1,17 \\
\hline JSI184 & 3730,53 & 105,33 & 4035,52 & 328,84 & 83,99 & 1,36 \\
\hline JSI185 & 3511,39 & 101,15 & 3860,97 & 97,11 & 77,15 & 1,26 \\
\hline JSI186 & 4525,08 & 135,13 & 4827,16 & 349,12 & 81,79 & 1,09 \\
\hline JSI187 & 4043,87 & 115,80 & 4243,39 & 253,37 & 81,53 & 1,32 \\
\hline JSI188 & 4922,90 & 159,77 & 5319,73 & 373,95 & 89,67 & 1,47 \\
\hline JSI189 & 4429,00 & 72,86 & 4551,39 & 303,03 & 88,11 & 1,18 \\
\hline JSI190 & 5128,96 & 135,61 & 5788,56 & 337,02 & 85,69 & 1,33 \\
\hline JSI191 & 4459,86 & 141,74 & 4667,28 & 348,15 & 76,21 & 1,21 \\
\hline JSI192 & 4654,89 & 158,32 & 4900,01 & 391,46 & 80,46 & 1,15 \\
\hline JSI193 & 4423,85 & 336,01 & 4941,82 & 555,09 & 81,73 & 1,41 \\
\hline JSI194 & 4280,69 & 99,76 & 4631,42 & 229,85 & 79,76 & 1,30 \\
\hline
\end{tabular}


Tabela F.12 - Programa experimental - Dados do ensaio de MR para 3\% de EVA e 4 horas de envelhecimento.

\begin{tabular}{l|c|c|c|c|c|c}
\hline CP n' & $\begin{array}{c}\text { MR } \\
\text { (MPa) }\end{array}$ & $\begin{array}{c}\text { Desvio } \\
\text { Padrão MR } \\
\text { (MPa) }\end{array}$ & $\begin{array}{c}\mathbf{M R}_{\text {inst. }} \\
\text { (MPa) }\end{array}$ & $\begin{array}{c}\text { Desvio } \\
\text { Padrão } \\
\text { MR }_{\text {inst. }} \text { (MPa) }\end{array}$ & $\begin{array}{c}\text { Carga } \\
\text { (kgf) }\end{array}$ & $\begin{array}{c}\text { Desvio } \\
\text { Padrão } \\
\text { Carga (kgf) }\end{array}$ \\
\hline JSI195 & 4439,78 & 179,41 & 4757,80 & 293,26 & 97,58 & 1,06 \\
JSI196 & 5256,30 & 133,67 & 5512,93 & 450,37 & 101,43 & 0,98 \\
JSI197 & 4793,53 & 131,62 & 5159,14 & 364,27 & 88,75 & 1,15 \\
JSI198 & 3960,27 & 157,51 & 4496,03 & 130,88 & 85,67 & 0,98 \\
JSI199 & 4205,17 & 165,15 & 4712,30 & 195,24 & 85,80 & 1,36 \\
JSI200 & 4012,23 & 101,99 & 4352,23 & 203,84 & 77,19 & 1,37 \\
JSI201 & 3869,30 & 108,35 & 4400,04 & 292,97 & 83,43 & 1,12 \\
JSI202 & 3700,25 & 107,93 & 3951,06 & 477,60 & 86,23 & 1,17 \\
JSI203 & 5099,74 & 196,16 & 5554,87 & 386,78 & 99,79 & 1,19 \\
JSI204 & 4804,84 & 215,70 & 5362,91 & 361,32 & 99,18 & 0,94 \\
JSI205 & 4354,83 & 146,82 & 4875,14 & 268,43 & 95,61 & 0,99 \\
JSI206 & 4651,29 & 137,43 & 5029,84 & 218,49 & 96,22 & 1,11 \\
JSI207 & 4279,16 & 121,12 & 4621,02 & 338,24 & 88,40 & 1,24 \\
JSI208 & 4625,24 & 248,35 & 5193,47 & 404,62 & 96,58 & 0,98 \\
\hline
\end{tabular}

\section{F.2. TRATAMENTO ESTATÍSTICO}

Os dados relativos aos módulos totais do programa experimental são apresentados nas Tabelas F.13 a F.24, estas que apresentam, também, as médias e os desvios padrão antes e depois de ser aplicado o teste t com significância de 0,95.

Número de amostras para cada condição experimental: 14

Intervalo de confiança: 0,95

$$
t=2,16
$$


Após a Tabela F.13 estão apresentados os cálculos para a condição $0 \%$ de EVA e 0 hora de envelhecimento, e para as outras condições experimentais os cálculos foram análogos.

Tabela F.13 - Programa experimental - Tratamento estatístico para o ensaio de MR em corpos-de-prova com $0 \%$ de EVA e 0 hora de envelhecimento.

\begin{tabular}{|c|c|c|c|c|c|c|}
\hline \multirow{3}{*}{$C P n^{\circ}$} & \multirow{3}{*}{$\begin{array}{c}\mathrm{MR}_{\mathrm{i}} \\
(\mathrm{MPa})\end{array}$} & \multirow{3}{*}{$\begin{array}{c}\mathbf{M R}_{\mathrm{i}, \text { médio }} \\
\text { (MPa) }\end{array}$} & \multirow{3}{*}{$\begin{array}{c}\text { Desvio } \\
\text { Padrão Inicial } \\
\text { da Média } \\
(\mathrm{MPa})\end{array}$} & \multicolumn{3}{|c|}{ Intervalo Significante } \\
\hline & & & & \multicolumn{3}{|c|}{$7064 \longleftrightarrow 7801$} \\
\hline & & & & $\begin{array}{l}\mathrm{MR}_{\mathrm{f}} \\
(\mathrm{MPa})\end{array}$ & $\begin{array}{c}\text { MR }_{\text {f,médio }} \\
\text { (Mpa) }\end{array}$ & $\begin{array}{c}\text { Desvio Padrão } \\
\text { Final (MPa) }\end{array}$ \\
\hline JSI041 & 7983 & & & - & & \\
\hline JSI042 & 7136 & & & 7136 & & \\
\hline JSI043 & 6816 & & & - & & \\
\hline JSI044 & 8211 & & & - & & \\
\hline JSI045 & 8691 & & & - & & \\
\hline JSI046 & 7529 & & & 7529 & & \\
\hline JSI047 & 7115 & 7432 & 638 & 7115 & 7363 & 206 \\
\hline JSI048 & 6737 & & & - & & \\
\hline JSI049 & 7266 & & & 7266 & & \\
\hline JSI050 & 6219 & & & - & & \\
\hline JSI051 & 7678 & & & 7678 & & \\
\hline JSI052 & 7376 & & & 7376 & & \\
\hline JSI053 & 7857 & & & - & & \\
\hline JSI054 & 7439 & & & 7439 & & \\
\hline
\end{tabular}

A seguir é apresentado o método utilizado para determinar o intervalo de confiança para a condição experimental 0\% de EVA e 0 horas de envelhecimento.

$$
\begin{aligned}
& E E_{D P, 0-0}=\frac{D P_{i}}{\sqrt{n}}=\frac{638}{\sqrt{14}} \\
& E E_{D P, 0-0}=171
\end{aligned}
$$


Intervalo de confiança:

Lmenor $_{0-0}=M R_{i, \text { médio }}-t \times E E_{D P, 0-0}=7432-2,16 \times 171$

Lmenor $_{0-0}=7064 \mathrm{MPa}$

Lmaior $_{0-0}=M R_{i, \text { médio }}+t \times E E_{D P, 0-0}=7432+2,16 \times 171$

Lmenor $_{0-0}=7801 \mathrm{MPa}$

em que:

$E E_{D P, 0-0}$ : estimativa de erro do desvio padrão (MPa);

$D P_{i} \quad$ : desvio padrão inicial (MPa);

n $\quad$ : número de amostras analisadas;

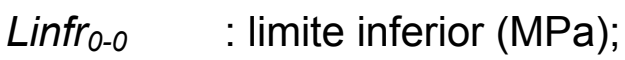

Lsup $_{0-0} \quad$ : limite superior (MPa);

$M R_{i, \text { médio }} \quad$ : MR médio antes do tratamento estatístico (MPa);

$M R_{f, \text { médio }} \quad$ : MR médio após o tratamento estatístico (MPa);

$t \quad$ : fator multiplicativo tabelado. 
Tabela F.14 - Programa experimental - Tratamento estatístico para o ensaio de MR em corpos-de-prova com $0 \%$ de EVA e 2 horas de envelhecimento.

\begin{tabular}{|c|c|c|c|c|c|c|}
\hline \multirow{3}{*}{$C P n^{\circ}$} & \multirow{3}{*}{$\begin{array}{l}\mathrm{MR}_{\mathrm{i}} \\
(\mathrm{MPa})\end{array}$} & \multirow{3}{*}{$\begin{array}{c}\text { MR }_{\mathrm{i}, \text { médio }} \\
\text { (MPa) }\end{array}$} & \multirow{3}{*}{$\begin{array}{c}\text { Desvio } \\
\text { Padrão Inicial } \\
\text { da Média } \\
\text { (MPa) }\end{array}$} & \multicolumn{3}{|c|}{ Intervalo Significante } \\
\hline & & & & \multicolumn{3}{|c|}{$7182 \longleftrightarrow 7891$} \\
\hline & & & & $\begin{array}{l}\mathrm{MR}_{\mathrm{f}} \\
(\mathrm{MPa})\end{array}$ & $\begin{array}{c}\text { MR } R_{\text {f,médio }} \\
\text { (MPa) }\end{array}$ & $\begin{array}{c}\text { Desvio Padrão } \\
\text { Final (MPa) }\end{array}$ \\
\hline JSI055 & 6815 & & & - & & \\
\hline JSI056 & 7582 & & & 7582 & & \\
\hline JSI057 & 7209 & & & 7209 & & \\
\hline JSI058 & 6706 & & & - & & \\
\hline JSI059 & 8238 & & & - & & \\
\hline JSI060 & 7401 & & & 7401 & & \\
\hline JSI061 & 8695 & 7536 & 614 & - & 7534 & 202 \\
\hline JSI062 & 6801 & 1500 & 014 & - & 1534 & $\angle U \angle$ \\
\hline JSI063 & 7700 & & & 7700 & & \\
\hline JSI064 & 8091 & & & - & & \\
\hline JSI065 & 8111 & & & - & & \\
\hline JSI066 & 6848 & & & - & & \\
\hline JSI067 & 7760 & & & 7760 & & \\
\hline JSI068 & 7550 & & & 7550 & & \\
\hline
\end{tabular}

Tabela F.15 - Programa experimental - Tratamento estatístico para o ensaio de MR em corpos-de-prova com $0 \%$ de EVA e 4 horas de envelhecimento.

\begin{tabular}{|c|c|c|c|c|c|c|}
\hline \multirow{3}{*}{$C P n^{\circ}$} & \multirow{3}{*}{$\begin{array}{c}\mathrm{MR}_{\mathrm{i}} \\
(\mathrm{MPa})\end{array}$} & \multirow{3}{*}{$\begin{array}{c}\mathbf{M R}_{\mathrm{i}, \text { médio }} \\
\text { (MPa) }\end{array}$} & \multirow{3}{*}{$\begin{array}{l}\text { Desvio } \\
\text { Padrão Inicial } \\
\text { da Média } \\
\text { (MPa) }\end{array}$} & \multicolumn{3}{|c|}{ Intervalo Significante } \\
\hline & & & & \multicolumn{3}{|c|}{$7245 \longleftrightarrow 8026$} \\
\hline & & & & $\begin{array}{c}\mathrm{MR}_{\mathrm{f}} \\
(\mathrm{MPa})\end{array}$ & $\begin{array}{l}\text { MR }_{\text {f,médio }} \\
\text { (MPa) }\end{array}$ & $\begin{array}{c}\text { Desvio Padrão } \\
\text { Final (MPa) }\end{array}$ \\
\hline JSI069 & 9169 & & & - & & \\
\hline JSI070 & 7207 & & & - & & \\
\hline JSI071 & 7877 & & & 7877 & & \\
\hline JSI072 & 8299 & & & - & & \\
\hline JSI073 & 6694 & & & - & & \\
\hline JSI074 & 7552 & & & 7552 & & \\
\hline JSI075 & 7424 & 7635 & 677 & 7424 & 7493 & \\
\hline JSI076 & 7274 & 1030 & 071 & 7274 & 1493 & 268 \\
\hline JSI077 & 6960 & & & - & & \\
\hline JSI078 & 7921 & & & 7921 & & \\
\hline JSI079 & 7277 & & & 7277 & & \\
\hline JSI080 & 8623 & & & - & & \\
\hline JSI081 & 7355 & & & 7355 & & \\
\hline JSI082 & 7265 & & & 7265 & & \\
\hline
\end{tabular}


Tabela F.16 - Programa experimental - Tratamento estatístico para o ensaio de MR em corpos-de-prova com $1 \%$ de EVA e 0 hora de envelhecimento.

\begin{tabular}{|c|c|c|c|c|c|c|}
\hline \multirow{3}{*}{$C P n^{\circ}$} & \multirow{3}{*}{$\begin{array}{c}\mathrm{MR}_{\mathrm{i}} \\
(\mathrm{MPa})\end{array}$} & \multirow{3}{*}{$\begin{array}{l}\mathrm{MR}_{\mathrm{i}, \text { médio }} \\
\text { (MPa) }\end{array}$} & \multirow{3}{*}{$\begin{array}{c}\text { Desvio } \\
\text { Padrão Inicial } \\
\text { da Média } \\
(\mathrm{MPa})\end{array}$} & \multicolumn{3}{|c|}{ Intervalo Significante } \\
\hline & & & & \multicolumn{3}{|c|}{$5274 \stackrel{\longleftrightarrow}{\longleftrightarrow} 6076$} \\
\hline & & & & $\begin{array}{c}\mathrm{MR}_{\mathrm{f}} \\
(\mathrm{MPa})\end{array}$ & $\begin{array}{c}\text { MR }_{\mathrm{f} \text {,médio }} \\
\text { (MPa) }\end{array}$ & $\begin{array}{c}\text { Desvio Padrão } \\
\text { Final (MPa) }\end{array}$ \\
\hline JSI083 & 4989 & & & & & \\
\hline JSI084 & 5503 & & & 5503 & & \\
\hline JSI085 & 5226 & & & & & \\
\hline JSI086 & 5660 & & & 5660 & & \\
\hline JSI087 & 6151 & & & - & & \\
\hline JSI088 & 5741 & & & 5741 & & \\
\hline JSI089 & 4967 & 5675 & 694 & - & 5660 & 213 \\
\hline JSI090 & 4974 & & & & & \\
\hline JSI091 & 7021 & & & - & & \\
\hline JSI092 & 6816 & & & - & & \\
\hline JSI093 & 5969 & & & 5969 & & \\
\hline JSI094 & 5426 & & & 5426 & & \\
\hline JSI095 & 4790 & & & - & & \\
\hline JSI096 & 6219 & & & - & & \\
\hline
\end{tabular}

Tabela F.17 - Programa experimental - Tratamento estatístico para o ensaio de MR em corpos-de-prova com $1 \%$ de EVA e 2 horas de envelhecimento.

\begin{tabular}{|c|c|c|c|c|c|c|}
\hline \multirow{3}{*}{$\mathrm{CP} \mathrm{n}^{\circ}$} & \multirow{3}{*}{$\begin{array}{c}\mathbf{M R}_{\mathrm{i}} \\
(\mathrm{MPa})\end{array}$} & \multirow{3}{*}{$\begin{array}{l}\mathrm{MR}_{\mathrm{i}, \text { médio }} \\
(\mathrm{MPa})\end{array}$} & \multirow{3}{*}{$\begin{array}{c}\text { Desvio } \\
\text { Padrão Inicial } \\
\text { da Média } \\
\text { (MPa) }\end{array}$} & \multicolumn{3}{|c|}{ Intervalo Significante } \\
\hline & & & & \multicolumn{3}{|c|}{$5649 \longleftrightarrow 6138$} \\
\hline & & & & $\begin{array}{c}\begin{array}{c}M R_{\mathrm{f}} \\
(\mathrm{MPa})\end{array} \\
\end{array}$ & $\begin{array}{c}\text { MR }_{\text {f,médio }} \\
(\mathrm{MPa}) \\
\end{array}$ & $\begin{array}{c}\text { Desvio Padrão } \\
\text { Final (MPa) } \\
\end{array}$ \\
\hline JSI097 & 5856 & & & 5856 & & \\
\hline JSI098 & 6059 & & & 6059 & & \\
\hline JSI099 & 5496 & & & - & & \\
\hline JSI100 & 5931 & & & 5931 & & \\
\hline JSI101 & 5490 & & & - & & \\
\hline JSI102 & 6221 & & & - & & \\
\hline JSI103 & 5256 & 5894 & 423 & - & 6014 & 103 \\
\hline JSI104 & 6151 & דטסט & $T<U$ & & 0014 & 100 \\
\hline JSI105 & 5055 & & & - & & \\
\hline JSI106 & 6107 & & & 6107 & & \\
\hline JSI107 & 6138 & & & - & & \\
\hline JSI108 & 6016 & & & 6016 & & \\
\hline JSI109 & 6118 & & & 6118 & & \\
\hline JSI110 & 6616 & & & 5856 & & \\
\hline
\end{tabular}


Tabela F.18 - Programa experimental - Tratamento estatístico para o ensaio de MR em corpos-de-prova com 1\% de EVA e 4 horas de envelhecimento.

\begin{tabular}{|c|c|c|c|c|c|c|}
\hline \multirow{3}{*}{$C P n^{\circ}$} & \multirow{3}{*}{$\begin{array}{l}\mathrm{MR}_{\mathrm{i}} \\
(\mathrm{MPa})\end{array}$} & \multirow{3}{*}{$\begin{array}{c}\text { MR }_{\mathrm{i}, \text { médio }} \\
\text { (MPa) }\end{array}$} & \multirow{3}{*}{$\begin{array}{c}\text { Desvio } \\
\text { Padrão Inicial } \\
\text { da Média } \\
\text { (MPa) }\end{array}$} & \multicolumn{3}{|c|}{ Intervalo Significante } \\
\hline & & & & \multicolumn{3}{|c|}{$7416 \longleftrightarrow 8546$} \\
\hline & & & & $\begin{array}{c}\mathrm{MR}_{\mathrm{f}} \\
(\mathrm{MPa})\end{array}$ & $\begin{array}{l}\text { MR }_{\text {f,médio }} \\
\text { (MPa) }\end{array}$ & $\begin{array}{c}\text { Desvio Padrão } \\
\text { Final (MPa) }\end{array}$ \\
\hline JSI111 & 6776 & & & - & & \\
\hline JSI112 & 9686 & & & - & & \\
\hline JSI113 & 8219 & & & 8219 & & \\
\hline JSI114 & 6282 & & & - & & \\
\hline JSI115 & 8459 & & & 8459 & & \\
\hline JSI116 & 7331 & & & - & & \\
\hline JSI117 & 7442 & 7982 & 079 & 7442 & 8036 & 380 \\
\hline JSI118 & 8606 & 1902 & 918 & - & 0030 & 309 \\
\hline JSI119 & 7677 & & & 7677 & & \\
\hline JSI120 & 9184 & & & - & & \\
\hline JSI121 & 8167 & & & 8167 & & \\
\hline JSI122 & 8859 & & & - & & \\
\hline JSI123 & 8249 & & & 8249 & & \\
\hline JSI124 & 6799 & & & - & & \\
\hline
\end{tabular}

Tabela F.19 - Programa experimental - Tratamento estatístico para o ensaio de MR em corpos-de-prova com $2 \%$ de EVA e 0 hora de envelhecimento.

\begin{tabular}{|c|c|c|c|c|c|c|}
\hline \multirow{3}{*}{$C P n^{\circ}$} & \multirow{3}{*}{$\begin{array}{c}\mathrm{MR}_{\mathrm{i}} \\
(\mathrm{MPa})\end{array}$} & \multirow{3}{*}{$\begin{array}{c}\mathbf{M R}_{\mathrm{i}, \text { médio }} \\
\text { (MPa) }\end{array}$} & \multirow{3}{*}{$\begin{array}{l}\text { Desvio } \\
\text { Padrão Inicial } \\
\text { da Média } \\
\text { (MPa) }\end{array}$} & \multicolumn{3}{|c|}{ Intervalo Significante } \\
\hline & & & & \multicolumn{3}{|c|}{$4805 \longleftrightarrow 5336$} \\
\hline & & & & $\begin{array}{l}\mathrm{MR}_{\mathrm{f}} \\
(\mathrm{MPa})\end{array}$ & $\begin{array}{l}\text { MR }_{\text {f,médio }} \\
\text { (MPa) }\end{array}$ & $\begin{array}{c}\text { Desvio Padrão } \\
\text { Final (MPa) }\end{array}$ \\
\hline JSI125 & 4588 & & & - & & \\
\hline JSI126 & 5357 & & & - & & \\
\hline JSI127 & 5509 & & & - & & \\
\hline JSI128 & 5046 & & & 5046 & & \\
\hline JSI129 & 5412 & & & - & & \\
\hline JSI130 & 4514 & & & - & & \\
\hline JSI131 & 5519 & 5071 & 460 & - & 5057 & 151 \\
\hline JSI132 & 4912 & 5011 & 400 & 4912 & זטכ & 101 \\
\hline JSI133 & 4687 & & & & & \\
\hline JSI134 & 4352 & & & - & & \\
\hline JSI135 & 5213 & & & 5213 & & \\
\hline JSI136 & 4588 & & & - & & \\
\hline JSI137 & 5571 & & & - & & \\
\hline JSI138 & 5720 & & & - & & \\
\hline
\end{tabular}


Tabela F.20 - Programa experimental - Tratamento estatístico para o ensaio de MR em corpos-de-prova com $2 \%$ de EVA e 2 horas de envelhecimento.

\begin{tabular}{|c|c|c|c|c|c|c|}
\hline \multirow{3}{*}{$\mathrm{CP} \mathrm{n}^{\circ}$} & \multirow{3}{*}{$\begin{array}{c}\mathrm{MR}_{\mathrm{i}} \\
(\mathrm{MPa})\end{array}$} & \multirow{3}{*}{$\begin{array}{c}\text { MR }_{\text {i,médio }} \\
\text { (MPa) }\end{array}$} & \multirow{3}{*}{$\begin{array}{c}\text { Desvio } \\
\text { Padrão Inicial } \\
\text { da Média } \\
\text { (MPa) }\end{array}$} & \multicolumn{3}{|c|}{ Intervalo Significante } \\
\hline & & & & \multicolumn{3}{|c|}{$6550 \longleftrightarrow 7016$} \\
\hline & & & & $\begin{array}{c}\mathrm{MR}_{\mathrm{f}} \\
(\mathrm{MPa})\end{array}$ & $\begin{array}{l}\text { MR }_{\text {f,médio }} \\
\text { (MPa) }\end{array}$ & $\begin{array}{l}\text { Desvio Padrão } \\
\text { Final (MPa) }\end{array}$ \\
\hline JSI139 & 6526 & & & - & & \\
\hline JSI140 & 7049 & & & - & & \\
\hline JSI141 & 6815 & & & 6815 & & \\
\hline JSI142 & 6141 & & & - & & \\
\hline JSI143 & 6887 & & & 6887 & & \\
\hline JSI144 & 7185 & & & - & & \\
\hline JSI145 & 6113 & 6783 & 404 & - & 6831 & 123 \\
\hline JSI146 & 7160 & & & & & \\
\hline JSI147 & 6669 & & & 6669 & & \\
\hline JSI148 & 6955 & & & 6955 & & \\
\hline JSI149 & 7085 & & & - & & \\
\hline JSI150 & 7085 & & & - & & \\
\hline JSI151 & 6123 & & & - & & \\
\hline JSI152 & 7167 & & & - & & \\
\hline
\end{tabular}

Tabela F.21 - Programa experimental - Tratamento estatístico para o ensaio de MR em corpos-de-prova com $2 \%$ de EVA e 4 horas de envelhecimento.

\begin{tabular}{|c|c|c|c|c|c|c|}
\hline \multirow{3}{*}{$C P n^{\circ}$} & \multirow{3}{*}{$\begin{array}{c}\mathbf{M R}_{\mathbf{i}} \\
(\mathrm{MPa})\end{array}$} & \multirow{3}{*}{$\begin{array}{l}\mathrm{MR}_{\mathrm{i}, \text { médio }} \\
(\mathrm{MPa})\end{array}$} & \multirow{3}{*}{$\begin{array}{c}\text { Desvio } \\
\text { Padrão Inicial } \\
\text { da Média } \\
\text { (MPa) }\end{array}$} & \multicolumn{3}{|c|}{ Intervalo Significante } \\
\hline & & & & \multicolumn{3}{|c|}{$5689 \longleftrightarrow 6421$} \\
\hline & & & & $\begin{array}{c}\begin{array}{c}M R_{\mathrm{f}} \\
(\mathrm{MPa})\end{array} \\
\end{array}$ & $\begin{array}{c}\text { MR }_{\text {f,médio }} \\
(\mathrm{MPa}) \\
\end{array}$ & $\begin{array}{c}\text { Desvio Padrão } \\
\text { Final (MPa) } \\
\end{array}$ \\
\hline JSI153 & 5893 & & & 5893 & & \\
\hline JSI154 & 5877 & & & 5877 & & \\
\hline JSI155 & 6112 & & & 6112 & & \\
\hline JSI156 & 6320 & & & 6320 & & \\
\hline JSI157 & 5898 & & & 5898 & & \\
\hline JSI158 & 6975 & & & & & \\
\hline JSI159 & 5898 & 6054 & 636 & 5898 & 5990 & 153 \\
\hline JSI160 & 5641 & 0004 & 000 & 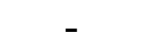 & 0950 & 100 \\
\hline JSI161 & 7372 & & & - & & \\
\hline JSI162 & 6649 & & & - & & \\
\hline JSI163 & 4844 & & & - & & \\
\hline JSI164 & 5964 & & & 5964 & & \\
\hline JSI165 & 5959 & & & 5959 & & \\
\hline JSI166 & 5362 & & & 5893 & & \\
\hline
\end{tabular}


Tabela F.22 - Programa experimental - Tratamento estatístico para o ensaio de MR em corpos-de-prova com $3 \%$ de EVA e 0 hora de envelhecimento.

\begin{tabular}{|c|c|c|c|c|c|c|}
\hline \multirow{3}{*}{$C P n^{\circ}$} & \multirow{3}{*}{$\begin{array}{l}\mathrm{MR}_{\mathrm{i}} \\
(\mathrm{MPa})\end{array}$} & \multirow{3}{*}{$\begin{array}{c}\text { MR }_{\mathrm{i}, \text { médio }} \\
\text { (MPa) }\end{array}$} & \multirow{3}{*}{$\begin{array}{c}\text { Desvio } \\
\text { Padrão Inicial } \\
\text { da Média } \\
\text { (MPa) }\end{array}$} & \multicolumn{3}{|c|}{ Intervalo Significante } \\
\hline & & & & \multicolumn{3}{|c|}{$2903 \longleftrightarrow 3377$} \\
\hline & & & & $\begin{array}{l}\mathrm{MR}_{\mathrm{f}} \\
(\mathrm{MPa})\end{array}$ & $\begin{array}{c}\text { MR } R_{\text {f,médio }} \\
\text { (MPa) }\end{array}$ & $\begin{array}{c}\text { Desvio Padrão } \\
\text { Final (MPa) }\end{array}$ \\
\hline JSI167 & 3742 & & & - & & \\
\hline JSI168 & 2321 & & & - & & \\
\hline JSI169 & 2992 & & & 2992 & & \\
\hline JSI170 & 2516 & & & - & & \\
\hline JSI171 & 3289 & & & 3289 & & \\
\hline JSI172 & 3050 & & & 3050 & & \\
\hline JSI173 & 3296 & 3140 & 411 & 3296 & 3191 & 129 \\
\hline JSI174 & 3613 & 3140 & 411 & - & ובונ & $1<9$ \\
\hline JSI175 & 3569 & & & - & & \\
\hline JSI176 & 2668 & & & - & & \\
\hline JSI177 & 3127 & & & 3127 & & \\
\hline JSI178 & 3265 & & & 3265 & & \\
\hline JSI179 & 3157 & & & 3157 & & \\
\hline JSI180 & 3351 & & & 3351 & & \\
\hline
\end{tabular}

Tabela F.23 - Programa experimental - Tratamento estatístico para o ensaio de MR em corpos-de-prova com 3\% de EVA e 2 horas de envelhecimento.

\begin{tabular}{|c|c|c|c|c|c|c|}
\hline \multirow{3}{*}{$C P n^{\circ}$} & \multirow{3}{*}{$\begin{array}{c}\mathrm{MR}_{\mathrm{i}} \\
(\mathrm{MPa})\end{array}$} & \multirow{3}{*}{$\begin{array}{c}\mathbf{M R}_{\mathrm{i}, \text { médio }} \\
(\mathrm{MPa})\end{array}$} & \multirow{3}{*}{$\begin{array}{l}\text { Desvio } \\
\text { Padrão Inicial } \\
\text { da Média } \\
\text { (MPa) }\end{array}$} & \multicolumn{3}{|c|}{ Intervalo Significante } \\
\hline & & & & \multicolumn{3}{|c|}{$4059 \longleftrightarrow 4644$} \\
\hline & & & & $\begin{array}{l}\mathrm{MR}_{\mathrm{f}} \\
(\mathrm{MPa})\end{array}$ & $\begin{array}{l}\text { MR }_{\text {f,médio }} \\
\text { (MPa) }\end{array}$ & $\begin{array}{c}\text { Desvio Padrão } \\
\text { Final (MPa) }\end{array}$ \\
\hline JSI181 & 4943 & & & - & & \\
\hline JSI182 & 3504 & & & - & & \\
\hline JSI183 & 4362 & & & 4362 & & \\
\hline JSI184 & 3731 & & & - & & \\
\hline JSI185 & 3511 & & & - & & \\
\hline JSI186 & 4525 & & & 4525 & & \\
\hline JSI187 & 4044 & 4351 & 507 & - & 4413 & 84 \\
\hline JSI188 & 4923 & 4351 & 501 & - & 4413 & 04 \\
\hline JSI189 & 4429 & & & 4429 & & \\
\hline JSI190 & 5129 & & & - & & \\
\hline JSI191 & 4460 & & & 4460 & & \\
\hline JSI192 & 4655 & & & - & & \\
\hline JSI193 & 4424 & & & 4424 & & \\
\hline JSI194 & 4281 & & & 4281 & & \\
\hline
\end{tabular}


Tabela F.24 - Programa experimental - Tratamento estatístico para o ensaio de MR em corpos-de-prova com 3\% de EVA e 4 horas de envelhecimento.

\begin{tabular}{|c|c|c|c|c|c|c|}
\hline \multirow{3}{*}{$C P n^{\circ}$} & \multirow{3}{*}{$\begin{array}{l}\mathrm{MR}_{\mathrm{i}} \\
(\mathrm{MPa})\end{array}$} & \multirow{3}{*}{$\begin{array}{l}\text { MR }_{\mathrm{i}, \text { médio }} \\
(\mathrm{MPa})\end{array}$} & \multirow{3}{*}{$\begin{array}{c}\text { Desvio } \\
\text { Padrão Inicial } \\
\text { da Média } \\
\text { (MPa) }\end{array}$} & \multicolumn{3}{|c|}{ Intervalo Significante } \\
\hline & & & & \multicolumn{3}{|c|}{$4164 \longleftrightarrow 4701$} \\
\hline & & & & $\begin{array}{l}\mathrm{MR}_{\mathrm{f}} \\
(\mathrm{MPa})\end{array}$ & $\begin{array}{c}\text { MR }_{\mathrm{f} \text {,médio }} \\
\text { (MPa) }\end{array}$ & $\begin{array}{c}\text { Desvio Padrão } \\
\text { Final (MPa) }\end{array}$ \\
\hline JSI195 & 4440 & & & 4440 & & \\
\hline JSI196 & 5256 & & & - & & \\
\hline JSI197 & 4794 & & & - & & \\
\hline JSI198 & 3960 & & & - & & \\
\hline JSI199 & 4205 & & & 4205 & & \\
\hline JSI200 & 4012 & & & - & & \\
\hline JSI201 & 3869 & 4432 & 465 & - & 1426 & 182 \\
\hline JSI202 & 3700 & 4432 & 405 & - & 4426 & 182 \\
\hline JSI203 & 5100 & & & - & & \\
\hline JSI204 & 4805 & & & - & & \\
\hline JSI205 & 4355 & & & 4355 & & \\
\hline JSI206 & 4651 & & & 4651 & & \\
\hline JSI207 & 4279 & & & 4279 & & \\
\hline JSI208 & 4625 & & & 4625 & & \\
\hline
\end{tabular}




\section{APÊNDICE G}

\section{Resistência à Tração por Compressão Diametral} Estática 
Na Tabela G.1 estão apresentados os dados referentes aos ensaios de resistência à tração por compressão diametral. A Leitura no Anel refere-se aos valores lidos na célula de carga, que tem uma constante de carga de 45,5 kg. Após a tabela estão demonstrados como foram feitos os cálculos através de um exemplo com os dados do corpo-de-prova JSI043.

Diâmetro do corpo-de-prova $\quad: 10,16 \mathrm{~cm}$

Altura de corpo-de-prova $\quad: 5,88 \mathrm{~cm}$

Leitura no anel de carga $\quad: 25,40$

Constante de anel de carga $\quad: 45,50 \mathrm{kgf}$

Carga real aplicada $=25,40 \times 45,50=1155,70 \mathrm{kgf}$

$$
R T_{\text {JSI } 043}=\frac{2 \times F}{\pi \times D \times H}=\frac{2 \times 1155,70}{3,14 \times 10,16 \times 5,88}
$$

$R T_{\text {JSI } 043}=12,33 \mathrm{~kg} / \mathrm{cm}^{2}=1,233 \mathrm{MPa}$

Para os demais corpos-de-prova os cálculos foram análogos. 
Tabela G.1 - Programa Experimental - Dados do ensaio de RT.

\begin{tabular}{|c|c|c|c|c|c|c|c|c|}
\hline \multirow{2}{*}{$\mathrm{CP} \mathrm{n}^{\circ}$} & \multirow{2}{*}{$\begin{array}{l}\text { EVA } \\
(\%)\end{array}$} & \multirow{2}{*}{$\begin{array}{c}\text { Env. } \\
\text { (h) }\end{array}$} & \multirow{2}{*}{$\begin{array}{l}\text { Leitura } \\
\text { no Anel }\end{array}$} & \multirow{2}{*}{$\begin{array}{c}\text { Carga } \\
\text { Real (kgf) }\end{array}$} & \multirow{2}{*}{$\begin{array}{c}\mathrm{RT} \\
(\mathrm{MPa}) \\
\end{array}$} & \multirow{2}{*}{$\begin{array}{c}\text { RT média } \\
(\mathrm{MPa})\end{array}$} & \multicolumn{2}{|c|}{ Desvio Padrão } \\
\hline & & & & & & & (MPa) & $(\%)$ \\
\hline JSI043 & \multirow{9}{*}{0} & \multirow{3}{*}{0} & 25,40 & 1155,70 & 1,233 & \multirow{3}{*}{1,234} & \multirow{3}{*}{0,001} & \multirow{3}{*}{0,09} \\
\hline JSI045 & & & 25,60 & 1164,80 & 1,235 & & & \\
\hline JSI054 & & & 25,50 & 1160,25 & 1,233 & & & \\
\hline JSI057 & & \multirow{3}{*}{2} & 26,10 & 1187,55 & 1,254 & \multirow{3}{*}{1,255} & \multirow{3}{*}{0,010} & \multirow{3}{*}{0,83} \\
\hline JSI058 & & & 26,80 & 1219,40 & 1,266 & & & \\
\hline JSI068 & & & 26,30 & 1196,65 & 1,246 & & & \\
\hline JSI073 & & \multirow{3}{*}{4} & 26,20 & 1192,10 & 1,228 & \multirow{3}{*}{1,289} & \multirow{3}{*}{0,055} & \multirow{3}{*}{4,30} \\
\hline JSI075 & & & 28,30 & 1287,65 & 1,336 & & & \\
\hline JSI082 & & & 27,60 & 1255,80 & 1,304 & & & \\
\hline JSI085 & \multirow{9}{*}{1} & \multirow{3}{*}{0} & 20,50 & 932,75 & 0,988 & \multirow{3}{*}{1,036} & \multirow{3}{*}{0,047} & \multirow{3}{*}{4,50} \\
\hline JSI094 & & & 21,60 & 982,80 & 1,040 & & & \\
\hline JSI096 & & & 22,50 & 1023,75 & 1,081 & & & \\
\hline JSI104 & & & 25,60 & 1164,80 & 1,231 & & & \\
\hline JSI107 & & 2 & 25,10 & 1142,05 & 1,203 & 1,211 & 0,017 & 1,43 \\
\hline JSI109 & & & 24,70 & 1123,85 & 1,199 & & & \\
\hline JSI115 & & & 25,40 & 1155,70 & 1,209 & & & \\
\hline JSI120 & & 4 & 27,70 & 1260,35 & 1,327 & 1,268 & 0,059 & 4,66 \\
\hline JSI122 & & & 26,50 & 1205,75 & 1,269 & & & \\
\hline JSI133 & & & 20,00 & 910,00 & 0,953 & & & \\
\hline JSI134 & & 0 & 19,60 & 891,80 & 0,941 & 0,946 & 0,006 & 0,67 \\
\hline JSI136 & & & 19,90 & 905,45 & 0,945 & & & \\
\hline JSI142 & & & 22,70 & 1032,85 & 1,079 & & & \\
\hline JSI144 & 2 & 2 & 23,80 & 1082,90 & 1,125 & 1,103 & 0,023 & 2,09 \\
\hline JSI148 & & & 23,20 & 1055,60 & 1,103 & & & \\
\hline JSI159 & & & 25,60 & 1164,80 & 1,223 & & & \\
\hline JSI164 & & 4 & 26,30 & 1196,65 & 1,253 & 1,240 & 0,015 & 1,23 \\
\hline JSI165 & & & 26,20 & 1192,10 & 1,243 & & & \\
\hline JSI168 & & & 17,20 & 782,60 & 0,779 & & & \\
\hline JSI175 & & 0 & 18,90 & 859,95 & 0,885 & 0,825 & 0,054 & 6,57 \\
\hline JSI177 & & & 17,70 & 805,35 & 0,813 & & & \\
\hline JSI187 & & & 21,50 & 978,25 & 1,024 & & & \\
\hline JSI191 & 3 & 2 & 22,60 & 1028,30 & 1,062 & 1,048 & 0,021 & 1,97 \\
\hline JSI193 & & & 22,50 & 1023,75 & 1,058 & & & \\
\hline JSI200 & & & 23,10 & 1051,05 & 1,083 & & & \\
\hline JSI203 & & 4 & 24,80 & 1128,40 & 1,162 & 1,119 & 0,040 & 3,58 \\
\hline JSI206 & & & 23,70 & 1078,35 & 1,113 & & & \\
\hline
\end{tabular}




\section{APÊNDICE H}

\section{Fluência por Compressão Uniaxial Estática}


A deformação total $\left(\varepsilon_{\text {total }}\right)$, a deformação recuperável $\left(\varepsilon_{\text {recuperável }}\right)$, a inclinação da curva e a tensão (T) são parâmetros lidos no ensaio. A seguir são demonstrados os cálculos para a determinação da deformação permanente, da recuperação, do módulo de fluência aos 3600 segundos e aos 4500 segundos. Os dados estão com aproximação, por esse motivo podem diferir em algum momento.

$M F(M P a)=\frac{T}{10 \times \varepsilon_{\text {permanente }}}=\frac{3,98}{10 \times 0,00017}$

$M F=2249,46 M P a$

O ensaio de fluência por compressão uniaxial estática foi realizado em 36 corpos-deprova, sendo 3 corpos-de-prova por condição experimental e as Tabelas H.1 a H.7 apresentam os dados dos ensaios. 
Tabela H.1 - Programa experimental - Deformações totais medidas no ensaio de fluência por compressão uniaxial estática.

\begin{tabular}{|c|c|c|c|c|}
\hline \multirow{2}{*}{$\begin{array}{l}\text { EVA } \\
\text { (\%) }\end{array}$} & \multirow{2}{*}{$\begin{array}{l}\text { Env. } \\
\text { (h) }\end{array}$} & \multirow{2}{*}{$\begin{array}{l}\text { CP } \\
n^{\circ}\end{array}$} & \multicolumn{2}{|c|}{ Canal } \\
\hline & & & 1 & 2 \\
\hline \multirow{9}{*}{0} & \multirow{3}{*}{0} & JSI049 & 0,00214 & 0,00284 \\
\hline & & JSI051 & 0,00182 & 0,00158 \\
\hline & & JSI053 & 0,00203 & 0,00215 \\
\hline & \multirow{3}{*}{2} & JSI055 & 0,00187 & 0,00259 \\
\hline & & JSI056 & 0,00164 & 0,00289 \\
\hline & & JSI067 & 0,00172 & 0,00271 \\
\hline & \multirow{3}{*}{4} & JSI069 & 0,00252 & 0,00233 \\
\hline & & JSI074 & 0,00226 & 0,00272 \\
\hline & & JSI081 & 0,00229 & 0,00274 \\
\hline \multirow{9}{*}{1} & \multirow{3}{*}{0} & JSI084 & 0,00500 & 0,00592 \\
\hline & & JSI090 & 0,00655 & 0,00328 \\
\hline & & JSI093 & 0,00490 & 0,00370 \\
\hline & \multirow{4}{*}{2} & JSI099 & 0,00496 & 0,00570 \\
\hline & & JSI106 & 0,00245 & 0,00745 \\
\hline & & JSI108 & 0,00366 & 0,00265 \\
\hline & & JSI112 & 0,00328 & 0,00321 \\
\hline & \multirow[t]{2}{*}{4} & JSI121 & 0,00377 & 0,00315 \\
\hline & & JSI123 & 0,00387 & 0,00332 \\
\hline \multirow{9}{*}{2} & \multirow{3}{*}{0} & JSI128 & 0,00808 & 0,00830 \\
\hline & & JSI135 & 0,00780 & 0,00657 \\
\hline & & JSI138 & 0,00860 & 0,00870 \\
\hline & \multirow{3}{*}{2} & JSI139 & 0,00903 & 0,00450 \\
\hline & & JSI149 & 0,01029 & 0,00425 \\
\hline & & JSI151 & 0,00698 & 0,01086 \\
\hline & \multirow{3}{*}{4} & JSI154 & 0,00545 & 0,00458 \\
\hline & & JSI157 & 0,00955 & 0,00647 \\
\hline & & JSI163 & 0,00936 & 0,00487 \\
\hline \multirow{9}{*}{3} & \multirow{3}{*}{0} & JSI167 & 0,00824 & 0,00808 \\
\hline & & JSI170 & 0,01400 & 0,01250 \\
\hline & & JSI178 & 0,01370 & 0,01373 \\
\hline & \multirow{3}{*}{2} & JSI182 & 0,01068 & 0,00519 \\
\hline & & JSI188 & 0,01036 & 0,01300 \\
\hline & & JSI192 & 0,01279 & 0,01108 \\
\hline & \multirow{3}{*}{4} & JSI196 & 0,01105 & 0,00932 \\
\hline & & JSI202 & 0,00915 & 0,00744 \\
\hline & & JSI205 & 0,01010 & 0,00975 \\
\hline
\end{tabular}


Tabela H.2 - Programa experimental - Deformações recuperáveis medidas no ensaio de fluência por compressão uniaxial estática.

\begin{tabular}{|c|c|c|c|c|}
\hline \multirow{2}{*}{$\begin{array}{l}\text { EVA } \\
(\%)\end{array}$} & \multirow{2}{*}{$\begin{array}{l}\text { Env. } \\
\text { (h) }\end{array}$} & \multirow{2}{*}{$\begin{array}{l}\text { CP } \\
n^{\circ}\end{array}$} & \multicolumn{2}{|c|}{ Canal } \\
\hline & & & 1 & 2 \\
\hline \multirow{9}{*}{0} & \multirow{3}{*}{0} & JSI049 & 0,00174 & 0,00207 \\
\hline & & JSI051 & 0,00164 & 0,00141 \\
\hline & & JSI053 & 0,00161 & 0,00207 \\
\hline & \multirow{3}{*}{2} & JSI055 & 0,00156 & 0,00198 \\
\hline & & JSI056 & 0,00134 & 0,00270 \\
\hline & & JSI067 & 0,00138 & 0,00218 \\
\hline & \multirow{3}{*}{4} & JSI069 & 0,00227 & 0,00174 \\
\hline & & JSI074 & 0,00197 & 0,00194 \\
\hline & & JSI081 & 0,00184 & 0,00223 \\
\hline \multirow{9}{*}{1} & \multirow{3}{*}{0} & JSI084 & 0,00386 & 0,00537 \\
\hline & & JSI090 & 0,00580 & 0,00278 \\
\hline & & JSI093 & 0,00409 & 0,00333 \\
\hline & \multirow{3}{*}{2} & JSI099 & 0,00454 & 0,00478 \\
\hline & & JSI106 & 0,00205 & 0,00628 \\
\hline & & JSI108 & 0,00299 & 0,00219 \\
\hline & \multirow{3}{*}{4} & JSI112 & 0,00275 & 0,00292 \\
\hline & & JSI121 & 0,00310 & 0,00240 \\
\hline & & JSI123 & 0,00299 & 0,00303 \\
\hline \multirow{9}{*}{2} & \multirow{3}{*}{0} & JSI128 & 0,00689 & 0,00780 \\
\hline & & JSI135 & 0,00649 & 0,00599 \\
\hline & & JSI138 & 0,00695 & 0,00826 \\
\hline & \multirow{3}{*}{2} & JSI139 & 0,00810 & 0,00397 \\
\hline & & JSI149 & 0,00904 & 0,00373 \\
\hline & & JSI151 & 0,00564 & 0,00975 \\
\hline & \multirow{3}{*}{4} & JSI154 & 0,00455 & 0,00376 \\
\hline & & JSI157 & 0,00826 & 0,00546 \\
\hline & & JSI163 & 0,00828 & 0,00429 \\
\hline \multirow{9}{*}{3} & \multirow{3}{*}{0} & JSI167 & 0,00649 & 0,00650 \\
\hline & & JSI170 & 0,01312 & 0,01046 \\
\hline & & JSI178 & 0,01283 & 0,01234 \\
\hline & \multirow{3}{*}{2} & JSI182 & 0,00822 & 0,00463 \\
\hline & & JSI188 & 0,00922 & 0,01144 \\
\hline & & JSI192 & 0,01116 & 0,00952 \\
\hline & \multirow{3}{*}{4} & JSI196 & 0,00902 & 0,00764 \\
\hline & & JSI202 & 0,00808 & 0,00645 \\
\hline & & JSI205 & 0,00857 & 0,00801 \\
\hline
\end{tabular}


Tabela H.3 - Programa experimental - Deformações permanente medidas no ensaio de fluência por compressão uniaxial estática.

\begin{tabular}{|c|c|c|c|c|}
\hline \multirow{2}{*}{$\begin{array}{l}\text { EVA } \\
(\%)\end{array}$} & \multirow{2}{*}{$\begin{array}{l}\text { Env. } \\
\text { (h) }\end{array}$} & \multirow{2}{*}{$\begin{array}{l}\text { CP } \\
n^{\circ}\end{array}$} & \multicolumn{2}{|c|}{ Canal } \\
\hline & & & 1 & 2 \\
\hline \multirow{9}{*}{0} & \multirow{3}{*}{0} & JSI049 & 0,00040 & 0,00077 \\
\hline & & JSI051 & 0,00018 & 0,00016 \\
\hline & & JSI053 & 0,00042 & 0,00008 \\
\hline & \multirow{3}{*}{2} & JSI055 & 0,00031 & 0,00061 \\
\hline & & JSI056 & 0,00030 & 0,00018 \\
\hline & & JS1067 & 0,00034 & 0,00053 \\
\hline & \multirow{3}{*}{4} & JSI069 & 0,00025 & 0,00059 \\
\hline & & JSI074 & 0,00029 & 0,00078 \\
\hline & & JSI081 & 0,00044 & 0,00051 \\
\hline \multirow{9}{*}{1} & \multirow{3}{*}{0} & JSI084 & 0,00114 & 0,00055 \\
\hline & & JSI090 & 0,00075 & 0,00050 \\
\hline & & JSI093 & 0,00081 & 0,00037 \\
\hline & \multirow{3}{*}{2} & JSI099 & 0,00042 & 0,00092 \\
\hline & & JSI106 & 0,00040 & 0,00117 \\
\hline & & JSI108 & 0,00067 & 0,00046 \\
\hline & \multirow{3}{*}{4} & JSI112 & 0,00053 & 0,00029 \\
\hline & & JSI121 & 0,00067 & 0,00075 \\
\hline & & JSI123 & 0,00088 & 0,00029 \\
\hline \multirow{9}{*}{2} & \multirow{3}{*}{0} & JSI128 & 0,00119 & 0,00050 \\
\hline & & JSI135 & 0,00131 & 0,00058 \\
\hline & & JSI138 & 0,00165 & 0,00044 \\
\hline & \multirow{3}{*}{2} & JSI139 & 0,00093 & 0,00053 \\
\hline & & JSI149 & 0,00125 & 0,00052 \\
\hline & & JSI151 & 0,00134 & 0,00111 \\
\hline & \multirow{3}{*}{4} & JSI154 & 0,00090 & 0,00082 \\
\hline & & JSI157 & 0,00129 & 0,00101 \\
\hline & & JSI163 & 0,00108 & 0,00058 \\
\hline \multirow{9}{*}{3} & \multirow{3}{*}{0} & JSI167 & 0,00175 & 0,00158 \\
\hline & & JSI170 & 0,00088 & 0,00204 \\
\hline & & JSI178 & 0,00087 & 0,00139 \\
\hline & \multirow{3}{*}{2} & JSI182 & 0,00246 & 0,00056 \\
\hline & & JSI188 & 0,00114 & 0,00156 \\
\hline & & JSI192 & 0,00163 & 0,00156 \\
\hline & \multirow{3}{*}{4} & JSI196 & 0,00203 & 0,00168 \\
\hline & & JSI202 & 0,00107 & 0,00099 \\
\hline & & JSI205 & 0,00153 & 0,00174 \\
\hline
\end{tabular}


Tabela H.4 - Programa experimental - Recuperações medidas no ensaio de fluência por compressão uniaxial estática.

\begin{tabular}{|c|c|c|c|c|}
\hline \multirow{2}{*}{$\begin{array}{l}\text { EVA } \\
\text { (\%) }\end{array}$} & \multirow{2}{*}{$\begin{array}{l}\text { Env. } \\
\text { (h) }\end{array}$} & \multirow{2}{*}{$\begin{array}{l}\text { CP } \\
n^{\circ}\end{array}$} & \multicolumn{2}{|c|}{ Canal } \\
\hline & & & 1 & 2 \\
\hline \multirow{9}{*}{0} & \multirow{3}{*}{0} & JSI049 & $81,31 \%$ & $72,89 \%$ \\
\hline & & JSI051 & $90,11 \%$ & $89,24 \%$ \\
\hline & & JSI053 & $79,31 \%$ & $96,28 \%$ \\
\hline & \multirow{3}{*}{2} & JSI055 & $83,42 \%$ & $76,45 \%$ \\
\hline & & JSI056 & $81,71 \%$ & $93,43 \%$ \\
\hline & & JSI067 & $80,23 \%$ & $80,44 \%$ \\
\hline & \multirow{3}{*}{4} & JSI069 & $90,08 \%$ & $74,68 \%$ \\
\hline & & JSI074 & $87,17 \%$ & $71,32 \%$ \\
\hline & & JSI081 & $80,35 \%$ & $81,39 \%$ \\
\hline \multirow{9}{*}{1} & \multirow{3}{*}{0} & JSI084 & $77,20 \%$ & $90,71 \%$ \\
\hline & & JSI090 & $88,55 \%$ & $84,76 \%$ \\
\hline & & JSI093 & $83,47 \%$ & $90,00 \%$ \\
\hline & \multirow{3}{*}{2} & JSI099 & $91,53 \%$ & $83,86 \%$ \\
\hline & & JSI106 & $83,67 \%$ & $84,30 \%$ \\
\hline & & JSI108 & $81,69 \%$ & $82,64 \%$ \\
\hline & \multirow{3}{*}{4} & JSI112 & $83,84 \%$ & $90,97 \%$ \\
\hline & & JSI121 & $82,23 \%$ & $76,19 \%$ \\
\hline & & JSI123 & $77,26 \%$ & $91,27 \%$ \\
\hline \multirow{9}{*}{2} & \multirow{3}{*}{0} & JSI128 & $85,27 \%$ & $93,98 \%$ \\
\hline & & JSI135 & $83,21 \%$ & $91,17 \%$ \\
\hline & & JSI138 & $80,81 \%$ & $94,94 \%$ \\
\hline & \multirow{3}{*}{2} & JSI139 & $89,71 \%$ & $88,22 \%$ \\
\hline & & JSI149 & $87,85 \%$ & $87,76 \%$ \\
\hline & & JSI151 & $80,80 \%$ & $89,78 \%$ \\
\hline & \multirow{3}{*}{4} & JSI154 & $83,49 \%$ & $82,10 \%$ \\
\hline & & JSI157 & $86,49 \%$ & $84,39 \%$ \\
\hline & & JSI163 & $88,46 \%$ & $88,09 \%$ \\
\hline \multirow{9}{*}{3} & \multirow{3}{*}{0} & JSI167 & $78,76 \%$ & $80,45 \%$ \\
\hline & & JSI170 & $93,71 \%$ & $83,68 \%$ \\
\hline & & JSI178 & $93,65 \%$ & $89,88 \%$ \\
\hline & \multirow{3}{*}{2} & JSI182 & $76,97 \%$ & $89,21 \%$ \\
\hline & & JSI188 & $89,00 \%$ & $88,00 \%$ \\
\hline & & JSI192 & $87,26 \%$ & $85,92 \%$ \\
\hline & \multirow{3}{*}{4} & JSI196 & $81,63 \%$ & $81,97 \%$ \\
\hline & & JSI202 & $88,31 \%$ & $86,69 \%$ \\
\hline & & JSI205 & $84,85 \%$ & $82,15 \%$ \\
\hline
\end{tabular}


Tabela H.5 - Programa experimental - Módulo de fluência em MPa medidos aos 3600 segundos no ensaio de fluência por compressão uniaxial estática.

\begin{tabular}{|c|c|c|c|c|}
\hline \multirow{2}{*}{$\begin{array}{c}\text { EVA } \\
(\%)\end{array}$} & \multirow{2}{*}{$\begin{array}{c}\text { Env. } \\
\text { (h) }\end{array}$} & \multirow{2}{*}{$\begin{array}{l}C P \\
n^{\circ}\end{array}$} & \multicolumn{2}{|c|}{ Canal } \\
\hline & & & 1 & 2 \\
\hline \multirow{9}{*}{0} & \multirow{3}{*}{0} & JSI049 & 185,83 & 140,04 \\
\hline & & JSI051 & 211,80 & 243,65 \\
\hline & & JSI053 & 197,72 & 186,32 \\
\hline & \multirow{3}{*}{2} & JSI055 & 214,25 & 154,74 \\
\hline & & JSI056 & 235,06 & 133,89 \\
\hline & & JSI067 & 231,40 & 146,86 \\
\hline & \multirow{3}{*}{4} & JSI069 & 164,85 & 177,80 \\
\hline & & JSI074 & 170,95 & 142,37 \\
\hline & & JSI081 & 175,57 & 146,59 \\
\hline \multirow{9}{*}{1} & \multirow{3}{*}{0} & JSI084 & 78,80 & 66,55 \\
\hline & & JSI090 & 61,22 & 122,26 \\
\hline & & JSI093 & 80,00 & 105,95 \\
\hline & \multirow{3}{*}{2} & JSI099 & 78,83 & 68,60 \\
\hline & & JSI106 & 162,86 & 53,56 \\
\hline & & JSI108 & 107,65 & 148,68 \\
\hline & \multirow{3}{*}{4} & JSI112 & 123,48 & 126,17 \\
\hline & & JSI121 & 105,04 & 125,71 \\
\hline & & JSI123 & 101,81 & 118,67 \\
\hline \multirow{9}{*}{2} & \multirow{3}{*}{0} & JSI128 & 49,01 & 47,71 \\
\hline & & JSI135 & 51,15 & 60,73 \\
\hline & & JSI138 & 44,42 & 43,91 \\
\hline & \multirow{3}{*}{2} & JSI139 & 43,85 & 88,00 \\
\hline & & JSI149 & 38,58 & 93,41 \\
\hline & & JSI151 & 56,73 & 36,46 \\
\hline & \multirow{3}{*}{4} & JSI154 & 71,19 & 84,72 \\
\hline & & JSI157 & 41,47 & 61,21 \\
\hline & & JSI163 & 40,92 & 78,64 \\
\hline \multirow{9}{*}{3} & \multirow{3}{*}{0} & JSI167 & 47,33 & 48,27 \\
\hline & & JSI170 & 27,21 & 30,48 \\
\hline & & JSI178 & 28,47 & 28,40 \\
\hline & \multirow{3}{*}{2} & JSI182 & 37,08 & 76,30 \\
\hline & & JSI188 & 36,68 & 29,23 \\
\hline & & JSI192 & 30,73 & 35,47 \\
\hline & \multirow{3}{*}{4} & JSI196 & 35,38 & 41,95 \\
\hline & & JSI202 & 43,28 & 53,23 \\
\hline & & JSI205 & 39,41 & 40,82 \\
\hline
\end{tabular}


Tabela H.6 - Programa experimental - Módulo de fluência em MPa medidos aos 4500 segundos no ensaio de fluência por compressão uniaxial estática.

\begin{tabular}{|c|c|c|c|c|}
\hline \multirow{2}{*}{$\begin{array}{l}\text { EVA } \\
(\%)\end{array}$} & \multirow{2}{*}{$\begin{array}{l}\text { Env. } \\
\text { (h) }\end{array}$} & \multirow{2}{*}{$\begin{array}{l}\text { CP } \\
n^{0}\end{array}$} & \multicolumn{2}{|c|}{ Canal } \\
\hline & & & 1 & 2 \\
\hline \multirow{9}{*}{0} & \multirow{3}{*}{0} & JSI049 & 986,16 & 140,04 \\
\hline & & JSI051 & 2160,37 & 243,65 \\
\hline & & JSI053 & 960,45 & 186,32 \\
\hline & \multirow{3}{*}{2} & JSI055 & 1301,82 & 154,74 \\
\hline & & JSI056 & 1273,43 & 133,89 \\
\hline & & JSI067 & 1170,59 & 146,86 \\
\hline & \multirow{3}{*}{4} & JSI069 & 1681,93 & 177,80 \\
\hline & & JSI074 & 1328,56 & 142,37 \\
\hline & & JSI081 & 904,90 & 146,59 \\
\hline \multirow{9}{*}{1} & \multirow{3}{*}{0} & JSI084 & 345,61 & 716,36 \\
\hline & & JSI090 & 534,67 & 802,00 \\
\hline & & JSI093 & 483,95 & 1059,46 \\
\hline & \multirow{3}{*}{2} & JSI099 & 930,95 & 425,00 \\
\hline & & JSI106 & 997,50 & 341,03 \\
\hline & & JSI108 & 588,06 & 856,52 \\
\hline & \multirow{3}{*}{4} & JSI112 & 764,15 & 1396,55 \\
\hline & & JSI121 & 591,04 & 528,00 \\
\hline & & JSI123 & 447,73 & 1358,62 \\
\hline \multirow{9}{*}{2} & \multirow{3}{*}{0} & JSI128 & 332,77 & 792,00 \\
\hline & & JSI135 & 304,58 & 687,93 \\
\hline & & JSI138 & 231,52 & 868,18 \\
\hline & \multirow{3}{*}{2} & JSI139 & 426,26 & 747,17 \\
\hline & & JSI149 & 317,60 & 763,46 \\
\hline & & JSI151 & 295,52 & 356,76 \\
\hline & \multirow{3}{*}{4} & JSI154 & 431,11 & 473,17 \\
\hline & & JSI157 & 306,98 & 392,08 \\
\hline & & JSI163 & 354,63 & 660,34 \\
\hline \multirow{9}{*}{3} & \multirow{3}{*}{0} & JSI167 & 222,86 & 246,84 \\
\hline & & JSI170 & 432,95 & 186,76 \\
\hline & & JSI178 & 448,28 & 280,58 \\
\hline & \multirow{3}{*}{2} & JSI182 & 160,98 & 707,14 \\
\hline & & JSI188 & 333,33 & 243,59 \\
\hline & & JSI192 & 241,10 & 251,92 \\
\hline & \multirow{3}{*}{4} & JSI196 & 192,61 & 232,74 \\
\hline & & JSI202 & 370,09 & 400,00 \\
\hline & & JSI205 & 260,13 & 228,74 \\
\hline
\end{tabular}


Tabela H.7 - Programa experimental - Inclinação das curvas medidas no estágio secundário no ensaio de fluência por compressão uniaxial estática.

\begin{tabular}{|c|c|c|c|c|}
\hline \multirow{2}{*}{$\begin{array}{l}\text { EVA } \\
(\%)\end{array}$} & \multirow{2}{*}{$\begin{array}{l}\text { Env. } \\
\text { (h) }\end{array}$} & \multirow{2}{*}{$\begin{array}{l}\text { CP } \\
n^{0}\end{array}$} & \multicolumn{2}{|c|}{ Canal } \\
\hline & & & 1 & 2 \\
\hline \multirow{9}{*}{0} & \multirow{3}{*}{0} & JSI049 & 0,0671318 & 0,0236098 \\
\hline & & JSI051 & 0,0359211 & 0,0284775 \\
\hline & & JSI053 & 0,0617616 & 0,0199706 \\
\hline & \multirow{3}{*}{2} & JSI055 & 0,0362215 & 0,0261207 \\
\hline & & JSI056 & 0,0351581 & 0,0260685 \\
\hline & & JSI067 & 0,0418545 & 0,0385846 \\
\hline & \multirow{3}{*}{4} & JSI069 & 0,0327564 & 0,0522735 \\
\hline & & JSI074 & 0,0217209 & 0,0337805 \\
\hline & & JSI081 & 0,0392745 & 0,0231666 \\
\hline \multirow{9}{*}{1} & \multirow{3}{*}{0} & JSI084 & 0,0602275 & 0,0113785 \\
\hline & & JSI090 & 0,0483572 & 0,0476273 \\
\hline & & JSI093 & 0,0604273 & 0,0302804 \\
\hline & \multirow{3}{*}{2} & JSI099 & 0,0425206 & 0,0389592 \\
\hline & & JSI106 & 0,0329158 & 0,0398239 \\
\hline & & JSI108 & 0,0261657 & 0,0489000 \\
\hline & \multirow{3}{*}{4} & JSI112 & 0,0411136 & 0,0332805 \\
\hline & & JSI121 & 0,0378857 & 0,0344466 \\
\hline & & JSI123 & 0,0386536 & 0,0352197 \\
\hline \multirow{9}{*}{2} & \multirow{3}{*}{0} & JSI128 & 0,0435576 & 0,0523550 \\
\hline & & JSI135 & 0,0543907 & 0,0798149 \\
\hline & & JSI138 & 0,0675716 & 0,0613071 \\
\hline & \multirow{3}{*}{2} & JSI139 & 0,0410886 & 0,0486978 \\
\hline & & JSI149 & 0,0472091 & 0,0439448 \\
\hline & & JSI151 & 0,0487740 & 0,0428968 \\
\hline & \multirow{3}{*}{4} & JSI154 & 0,0544968 & 0,0236741 \\
\hline & & JSI157 & 0,0422021 & 0,0481164 \\
\hline & & JSI163 & 0,0496250 & 0,0365000 \\
\hline \multirow{9}{*}{3} & \multirow{3}{*}{0} & JSI167 & 0,0835582 & 0,0769193 \\
\hline & & JSI170 & 0,0667452 & 0,0763328 \\
\hline & & JSI178 & 0,0875717 & 0,0811216 \\
\hline & \multirow{3}{*}{2} & JSI182 & 0,0822379 & 0,0456610 \\
\hline & & JSI188 & 0,0789477 & 0,0556735 \\
\hline & & JSI192 & 0,0573398 & 0,0439995 \\
\hline & \multirow{3}{*}{4} & JSI196 & 0,0671171 & 0,0462915 \\
\hline & & JSI202 & 0,0372504 & 0,0470780 \\
\hline & & JSI205 & 0,0663055 & 0,0571893 \\
\hline
\end{tabular}




\section{APÊNDICE I}

\section{Fluência por Compressão Uniaxial Dinâmica}


A deformação total $\left(\varepsilon_{\text {total }}\right)$, a inclinação da curva e a tensão $(\sigma)$ são parâmetros lidos no ensaio. A seguir são demonstrados os cálculos para a determinação da do módulo de fluência. Os dados estão com aproximação, por esse motivo podem diferir em algum momento.

$M F_{C D}(M P a)=\frac{\sigma}{10 \times \varepsilon_{\text {total }}}=\frac{4,06}{10 \times 0,00665}$

$M F_{C D}=62,59 M P a$

O ensaio de fluência por compressão uniaxial dinâmica foi realizado em 36 corposde-prova, sendo 3 corpos-de-prova por condição experimental e as Tabelas I.1 a I.3 apresentam os dados dos ensaios. 
Tabela I.1 - Programa experimental - Deformações totais medidas no ensaio de fluência por compressão uniaxial dinâmica.

\begin{tabular}{|c|c|c|c|c|}
\hline \multirow{2}{*}{$\begin{array}{l}\text { EVA } \\
\text { (\%) }\end{array}$} & \multirow{2}{*}{$\begin{array}{l}\text { Env. } \\
\text { (h) }\end{array}$} & \multirow{2}{*}{$\begin{array}{l}\text { CP } \\
n^{0}\end{array}$} & \multicolumn{2}{|c|}{ Canal } \\
\hline & & & 1 & 2 \\
\hline \multirow{9}{*}{0} & \multirow{3}{*}{0} & JSI049 & 0,00910 & 0,00651 \\
\hline & & JSI051 & 0,00645 & 0,00685 \\
\hline & & JSI053 & 0,00908 & 0,00514 \\
\hline & \multirow{3}{*}{2} & JSI055 & 0,00705 & 0,01394 \\
\hline & & JSI056 & 0,01196 & 0,01430 \\
\hline & & JSI067 & 0,01054 & 0,01034 \\
\hline & \multirow{3}{*}{4} & JSI069 & 0,01149 & 0,01197 \\
\hline & & JSI074 & 0,00539 & 0,00910 \\
\hline & & JSI081 & 0,01085 & 0,00914 \\
\hline \multirow{9}{*}{1} & \multirow{3}{*}{0} & JSI084 & 0,01660 & 0,01397 \\
\hline & & JSI090 & 0,01104 & 0,01721 \\
\hline & & JSI093 & 0,01644 & 0,01439 \\
\hline & \multirow{3}{*}{2} & JSI099 & 0,01548 & 0,01087 \\
\hline & & JSI106 & 0,00926 & 0,01416 \\
\hline & & JSI108 & 0,01086 & 0,01206 \\
\hline & \multirow{3}{*}{4} & JSI112 & 0,01399 & 0,01338 \\
\hline & & JSI121 & 0,01030 & 0,00967 \\
\hline & & JSI123 & 0,00948 & 0,01375 \\
\hline \multirow{9}{*}{2} & \multirow{3}{*}{0} & JSI128 & 0,02348 & 0,01787 \\
\hline & & JSI135 & 0,01468 & 0,02399 \\
\hline & & JSI138 & 0,02036 & 0,02117 \\
\hline & \multirow{3}{*}{2} & JSI139 & 0,01057 & 0,01114 \\
\hline & & JSI149 & 0,02584 & 0,02389 \\
\hline & & JSI151 & 0,01101 & 0,02319 \\
\hline & \multirow{3}{*}{4} & JSI154 & 0,02087 & 0,01018 \\
\hline & & JSI157 & 0,02027 & 0,01006 \\
\hline & & JSI163 & 0,00909 & 0,01771 \\
\hline \multirow{9}{*}{3} & \multirow{3}{*}{0} & JSI167 & 0,02203 & 0,02330 \\
\hline & & JSI170 & Rompeu & Rompeu \\
\hline & & JSI178 & Rompeu & Rompeu \\
\hline & \multirow{3}{*}{2} & JSI182 & 0,02455 & 0,01785 \\
\hline & & JSI188 & 0,02571 & 0,02376 \\
\hline & & JSI192 & 0,02003 & 0,01904 \\
\hline & \multirow{3}{*}{4} & JSI196 & 0,02552 & 0,01174 \\
\hline & & JSI202 & 0,02474 & 0,01691 \\
\hline & & JSI205 & 0,02473 & 0,01116 \\
\hline
\end{tabular}


Tabela I.2 - Programa experimental - Módulos de fluência, em MPa, medidos no ensaio de fluência por compressão uniaxial dinâmica.

\begin{tabular}{|c|c|c|c|c|}
\hline \multirow{2}{*}{$\begin{array}{c}\text { EVA } \\
(\%)\end{array}$} & \multirow{2}{*}{$\begin{array}{c}\text { Env. } \\
\text { (h) }\end{array}$} & \multirow{2}{*}{$\begin{array}{l}C P \\
n^{\circ}\end{array}$} & \multicolumn{2}{|c|}{ Canal } \\
\hline & & & 1 & 2 \\
\hline \multirow{9}{*}{0} & \multirow{3}{*}{0} & JSI049 & 44,73 & 62,52 \\
\hline & & JSI051 & 64,48 & 60,69 \\
\hline & & JSI053 & 44,82 & 81,07 \\
\hline & \multirow{3}{*}{2} & JSI055 & 59,48 & 30,09 \\
\hline & & JSI056 & 34,62 & 28,93 \\
\hline & & JSI067 & 38,52 & 39,26 \\
\hline & \multirow{3}{*}{4} & JSI069 & 36,15 & 34,71 \\
\hline & & JSI074 & 76,98 & 45,60 \\
\hline & & JSI081 & 37,33 & 44,31 \\
\hline \multirow{9}{*}{1} & \multirow{3}{*}{0} & JSI084 & 24,40 & 28,99 \\
\hline & & JSI090 & 36,05 & 23,13 \\
\hline & & JSI093 & 24,03 & 27,45 \\
\hline & \multirow{3}{*}{2} & JSI099 & 26,29 & 37,44 \\
\hline & & JSI106 & 43,74 & 28,60 \\
\hline & & JSI108 & 38,12 & 34,35 \\
\hline & \multirow{3}{*}{4} & JSI112 & 28,59 & 29,90 \\
\hline & & JSI121 & 39,13 & 41,68 \\
\hline & & JSI123 & 43,46 & 29,96 \\
\hline \multirow{9}{*}{2} & \multirow{3}{*}{0} & JSI128 & 17,07 & 22,43 \\
\hline & & JSI135 & 27,74 & 16,97 \\
\hline & & JSI138 & 20,12 & 19,35 \\
\hline & \multirow{3}{*}{2} & JSI139 & 38,58 & 36,62 \\
\hline & & JSI149 & 15,78 & 17,07 \\
\hline & & JSI151 & 37,33 & 17,73 \\
\hline & \multirow{3}{*}{4} & JSI154 & 19,26 & 39,49 \\
\hline & & JSI157 & 20,37 & 41,05 \\
\hline & & JSI163 & 45,54 & 23,38 \\
\hline \multirow{9}{*}{3} & \multirow{3}{*}{0} & JSI167 & 18,47 & 17,47 \\
\hline & & JSI170 & Rompeu & Rompeu \\
\hline & & JSI178 & Rompeu & Rompeu \\
\hline & \multirow{3}{*}{2} & JSI182 & 16,24 & 22,35 \\
\hline & & JSI188 & 15,92 & 17,23 \\
\hline & & JSI192 & 19,77 & 20,80 \\
\hline & \multirow{3}{*}{4} & JSI196 & 15,85 & 34,46 \\
\hline & & JSI202 & 16,52 & 24,17 \\
\hline & & JSI205 & 15,66 & 34,68 \\
\hline
\end{tabular}


Tabela I.3 - Programa experimental - Inclinação das curvas medidas no estágio secundário no ensaio de fluência por compressão uniaxial dinâmica.

\begin{tabular}{|c|c|c|c|c|}
\hline \multirow{2}{*}{$\begin{array}{l}\text { EVA } \\
(\%)\end{array}$} & \multirow{2}{*}{$\begin{array}{c}\text { Env. } \\
\text { (h) }\end{array}$} & \multirow{2}{*}{$\begin{array}{l}\text { CP } \\
n^{\circ}\end{array}$} & \multicolumn{2}{|c|}{ Canal } \\
\hline & & & 1 & 2 \\
\hline \multirow{9}{*}{0} & \multirow{3}{*}{0} & JSI049 & 0,4386049 & 0,4576827 \\
\hline & & JSI051 & 0,3351043 & 0,3842287 \\
\hline & & JSI053 & 0,3891336 & 0,3175060 \\
\hline & \multirow{3}{*}{2} & JSI055 & 0,4817249 & 0,5701201 \\
\hline & & JSI056 & 0,5955104 & 0,4047618 \\
\hline & & JSI067 & 0,5158468 & 0,4759671 \\
\hline & \multirow{3}{*}{4} & JSI069 & 0,6044564 & 0,5010597 \\
\hline & & JSI074 & 0,5763055 & 0,4291037 \\
\hline & & JSI081 & 0,5687414 & 0,4055761 \\
\hline \multirow{9}{*}{1} & \multirow{3}{*}{0} & JSI084 & 0,5379688 & 0,5011562 \\
\hline & & JSI090 & 0,4163040 & 0,4526530 \\
\hline & & JS1093 & 0,4669890 & 0,5398233 \\
\hline & \multirow{3}{*}{2} & JSI099 & 0,4703961 & 0,4421669 \\
\hline & & JSI106 & 0,4770621 & 0,4334543 \\
\hline & & JSI108 & 0,4503112 & 0,4823732 \\
\hline & \multirow{3}{*}{4} & JSI112 & 0,4219849 & 0,4370388 \\
\hline & & JSI121 & 0,4193721 & 0,4257924 \\
\hline & & JSI123 & 0,3966672 & 0,4312920 \\
\hline \multirow{9}{*}{2} & \multirow{3}{*}{0} & JSI128 & 0,6229066 & 0,3550153 \\
\hline & & JSI135 & 0,4332098 & 0,5401700 \\
\hline & & JSI138 & 0,4738944 & 0,5269741 \\
\hline & \multirow{3}{*}{2} & JSI139 & 0,4881334 & 0,3925524 \\
\hline & & JSI149 & 0,4536968 & 0,5251608 \\
\hline & & JSI151 & 0,5975039 & 0,3370750 \\
\hline & \multirow{3}{*}{4} & JSI154 & 0,5042920 & 0,4416574 \\
\hline & & JSI157 & 0,6031042 & 0,2112276 \\
\hline & & JSI163 & 0,3301656 & 0,5019895 \\
\hline \multirow{9}{*}{3} & \multirow{3}{*}{0} & JSI167 & 0,6360374 & 0,4772065 \\
\hline & & JSI170 & Rompeu & Rompeu \\
\hline & & JSI178 & Rompeu & Rompeu \\
\hline & \multirow{3}{*}{2} & JSI182 & 0,6051360 & 0,3628961 \\
\hline & & JSI188 & 0,5730907 & 0,3795538 \\
\hline & & JSI192 & 0,5004083 & 0,3994782 \\
\hline & \multirow{3}{*}{4} & JSI196 & 0,5926604 & 0,5926604 \\
\hline & & JSI202 & 0,4837655 & 0,4837655 \\
\hline & & JSI205 & 0,5331387 & 0,5331387 \\
\hline
\end{tabular}




\section{APÊNDICE J}

\section{Desgaste por Abrasão no Ensaio Cantabro}


O desgaste por abrasão medido no ensaio Cantabro foi realizado em 36 corpos-deprova, sendo 3 corpos-de-prova por condição experimental. A Tabela J.1 apresenta os dados dos ensaios. O valor da abrasão se dá da seguinte maneira:

$\operatorname{Abrasão}(\%)=\frac{M_{\text {iniacial }}-M_{\text {final }}}{M_{\text {inicial }}} \times 100=\frac{1152,6-1108,7}{1152,6} \times 100$

Abrasão $=3,8 \%$ 
Tabela J.1 - Programa experimental - Desgastes por abrasão medidos no ensaio Cantabro.

\begin{tabular}{|c|c|c|c|c|c|}
\hline \multirow{2}{*}{$\begin{array}{c}\text { EVA } \\
(\%)\end{array}$} & \multirow{2}{*}{$\begin{array}{c}\text { Env. } \\
\text { (h) }\end{array}$} & \multirow{2}{*}{$\begin{array}{l}C P \\
n^{\circ}\end{array}$} & \multicolumn{2}{|c|}{ Massa } & \multirow{2}{*}{$\begin{array}{c}\text { Abrasão } \\
(\%)\end{array}$} \\
\hline & & & Inicial & Final & \\
\hline \multirow{9}{*}{0} & \multirow{3}{*}{0} & JSI049 & 1152,6 & 1108,7 & $3,8 \%$ \\
\hline & & JSI051 & 1144,1 & 1095,3 & $4,3 \%$ \\
\hline & & JSI053 & 1165,3 & 1111,5 & $4,6 \%$ \\
\hline & \multirow{3}{*}{2} & JSI055 & 1165,2 & 1117,0 & $4,1 \%$ \\
\hline & & JSI056 & 1163,1 & 1112,3 & $4,4 \%$ \\
\hline & & JSI067 & 1168,1 & 1116,7 & $4,4 \%$ \\
\hline & \multirow{3}{*}{4} & JSI069 & 1167,9 & 1119,6 & $4,1 \%$ \\
\hline & & JSI074 & 1168,6 & 1112,9 & $4,8 \%$ \\
\hline & & JSI081 & 1170,8 & 1120,0 & $4,3 \%$ \\
\hline \multirow{9}{*}{1} & \multirow{3}{*}{0} & JSI084 & 1160,7 & 1121,6 & $3,4 \%$ \\
\hline & & JSI090 & 1152,1 & 1122,7 & $2,6 \%$ \\
\hline & & JSI093 & 1158,7 & 1119,3 & $3,4 \%$ \\
\hline & \multirow{3}{*}{2} & JSI099 & 1158,9 & 1125,4 & $2,9 \%$ \\
\hline & & JSI106 & 1160,1 & 1117,9 & $3,6 \%$ \\
\hline & & JSI108 & 1158,6 & 1121,1 & $3,2 \%$ \\
\hline & \multirow{3}{*}{4} & JSI112 & 1160,2 & 1119,7 & $3,5 \%$ \\
\hline & & JSI121 & 1162,8 & 1117,5 & $3,9 \%$ \\
\hline & & JSI123 & 1163,8 & 1118,7 & $3,9 \%$ \\
\hline \multirow{9}{*}{2} & \multirow{3}{*}{0} & JSI128 & 1145,5 & 1121,4 & $2,1 \%$ \\
\hline & & JSI135 & 1145,6 & 1117,3 & $2,5 \%$ \\
\hline & & JSI138 & 1140,0 & 1119,9 & $1,8 \%$ \\
\hline & \multirow{3}{*}{2} & JSI139 & 1150,1 & 1124,8 & $2,2 \%$ \\
\hline & & JSI149 & 1152,4 & 1125,4 & $2,3 \%$ \\
\hline & & JSI151 & 1147,6 & 1118,7 & $2,5 \%$ \\
\hline & \multirow{3}{*}{4} & JSI154 & 1150,9 & 1116,4 & $3,0 \%$ \\
\hline & & JSI157 & 1146,4 & 1118,1 & $2,5 \%$ \\
\hline & & JSI163 & 1153,8 & 1122,8 & $2,7 \%$ \\
\hline \multirow{9}{*}{3} & \multirow{3}{*}{0} & JSI167 & 1141,3 & 1120,6 & $1,8 \%$ \\
\hline & & JSI170 & 1133,3 & 1121,1 & $1,1 \%$ \\
\hline & & JSI178 & 1133,5 & 1119,2 & $1,3 \%$ \\
\hline & \multirow{3}{*}{2} & JSI182 & 1149,2 & 1128,1 & $1,8 \%$ \\
\hline & & JSI188 & 1148,3 & 1126,3 & $1,9 \%$ \\
\hline & & JSI192 & 1149,9 & 1127,4 & $2,0 \%$ \\
\hline & \multirow{3}{*}{4} & JSI196 & 1153,5 & 1127,5 & $2,3 \%$ \\
\hline & & JSI202 & 1158,4 & 1129,6 & $2,5 \%$ \\
\hline & & JSI205 & 1154,2 & 1126,4 & $2,4 \%$ \\
\hline
\end{tabular}

